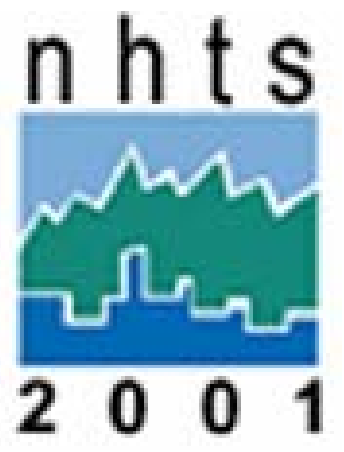

\title{
New York Household Travel Patterns: A Comparison Analysis
}

Based on 2001 National Household Travel Survey

April 2007 


\section{DOCUMENT AVAILABILITY}

Reports produced after January 1, 1996, are generally available free via the U.S. Department of Energy (DOE) Information Bridge.

Web site http://www.osti.gov/bridge

Reports produced before January 1, 1996, may be purchased by members of the public from the following source.

National Technical Information Service

5285 Port Royal Road

Springfield, VA 22161

Telephone 703-605-6000 (1-800-553-6847)

TDD 703-487-4639

Fax 703-605-6900

E-mail info@ntis.fedworld.gov

Web site http://www.ntis.gov/support/ordernowabout.htm

Reports are available to DOE employees, DOE contractors, Energy Technology Data Exchange (ETDE) representatives, and International Nuclear Information System (INIS) representatives from the following source.

Office of Scientific and Technical Information

P.O. Box 62

Oak Ridge, TN 37831

Telephone 865-576-8401

Fax 865-576-5728

E-mail reports@adonis.osti.gov

Web site http://www.osti.gov/contact.html

This report was prepared as an account of work sponsored by an agency of the United States Government. Neither the United States Government nor any agency thereof, nor any of their employees, makes any warranty, express or implied, or assumes any legal liability or responsibility for the accuracy, completeness, or usefulness of any information, apparatus, product, or process disclosed, or represents that its use would not infringe privately owned rights. Reference herein to any specific commercial product, process, or service by trade name, trademark, manufacturer, or otherwise, does not necessarily constitute or imply its endorsement, recommendation, or favoring by the United States Government or any agency thereof. The views and opinions of authors expressed herein do not necessarily state or reflect those of the United States Government or any agency thereof. 
ORNL/TM-2006/624

Engineering Science and Technology Division

\title{
New York Household Travel Patterns: A Comparison Analysis Based on 2001 National Household Travel Survey
}

Date published: April 2007

\author{
Pat S. Hu \\ Center for Transportation Analysis \\ Oak Ridge National Laboratory \\ Oak Ridge, Tennessee 37831 \\ Tim R. Reuscher \\ MacroSys Research and Technology \\ Washington, DC 20006
}

\author{
Prepared for \\ Office of Transportation Policy and Strategy \\ New York State Department of Transportation \\ Albany, New York 12232 \\ Prepared by \\ OAK RIDGE NATIONAL LABORATORY \\ Oak Ridge, Tennessee 37831-6285 \\ Managed by \\ UT-BATTELLE, LLC \\ for the \\ U.S. DEPARTMENT OF ENERGY \\ under contract DE-AC05-00OR22725
}


2001 New York NHTS: A Comparison Study 


\section{Table of Contents}

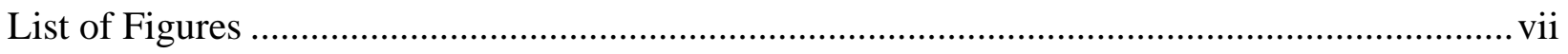

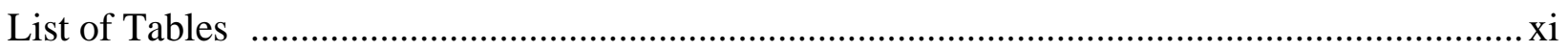

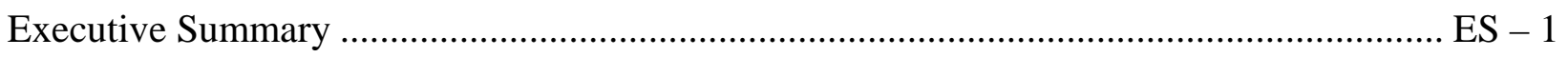

Chapter 1. Introduction ...................................................................................................... 1

1.1 Background and Objectives ....................................................................................... 1 - 1

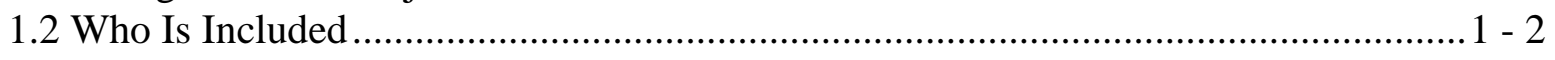

1.3 How the Data Were Collected ................................................................................. 1 - 2

1.4 Where the Data Were Collected .............................................................................. 1 - 3

1.5 Sample Sizes and Weighted Sums ............................................................................... 1 - 3

1.6 Travel Concepts ................................................................................................. 1 - 5

1.7 Differences Between the 1995 and 2001 Surveys and the Data Implications ............ 1 - 10

1.8 Report Organization.................................................................................................. 1 - 11

Chapter 2. Comparison of New York Data to the Rest of the United States ..............................2 - 1

2.1 Profile of New York Households................................................................................ 2 - 1

2.2 Personal Travel .............................................................................................. 2 - 5

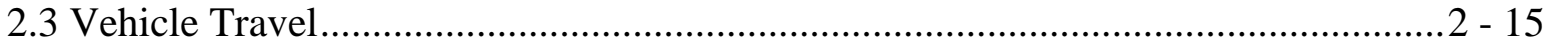

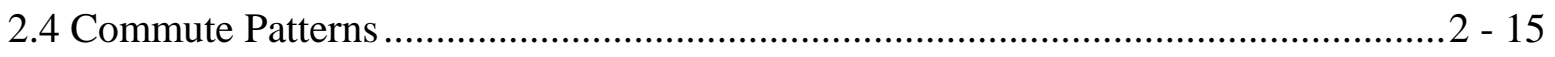

Chapter 3. Influence of NY Metropolitan Data on the Overall New York Travel Patterns ....... 3 - 1

3.1 Profile of New York City Households ........................................................................... 3 - 1

3.2 Personal Travel ................................................................................................. 3 - 5

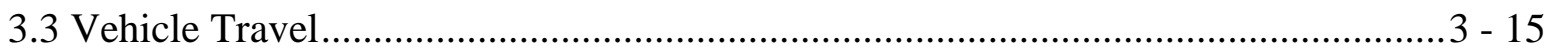

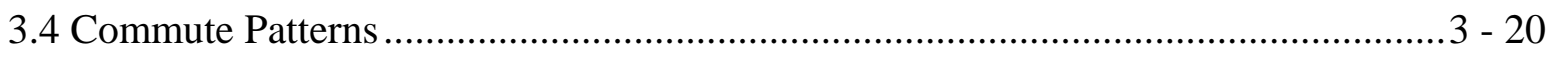

3.5 Summary ……………………….................................................................. 3 - 24

Chapter 4. Urban Travel and Population Density …………...................................................... 4 - 1

4.1 Profile of New York State Urban Households by Population Density ......................... 4 - 5

4.2 Personal Travel ...................................................................................................... 4 - 12

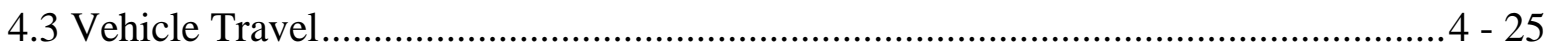

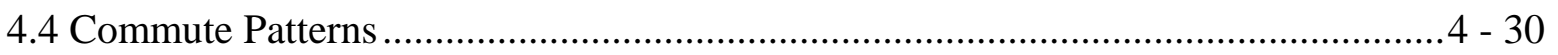

4.5 Travel by Manhattan Residents .............................................................................. 4 - 36

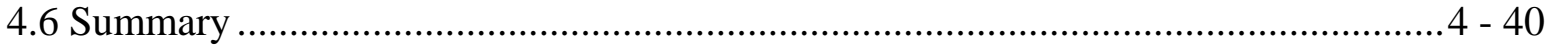


Chapter 5. Rural Travel..............................................................................................

5.1 Profile of Rural New York Households by Population Density ...................................... 5 - 3

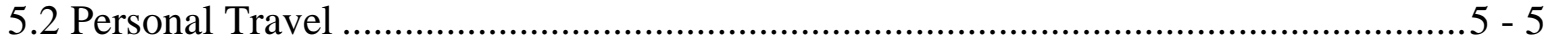

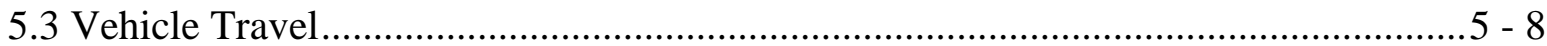

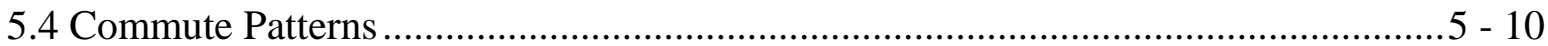

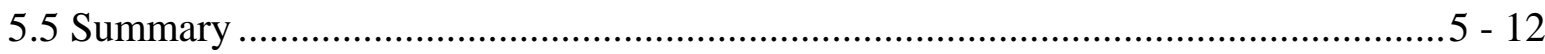

Chapter 6. Comparison of Travel Patterns Among New York State Metropolitan

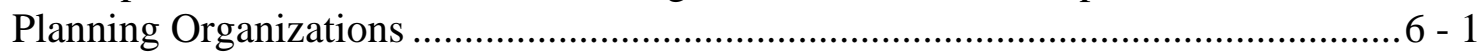

6.1 Profile of New York State MPO Households by MSA Size ………………………...... 6 - 4

6.2 Personal Travel ................................................................................................ 6 - 10

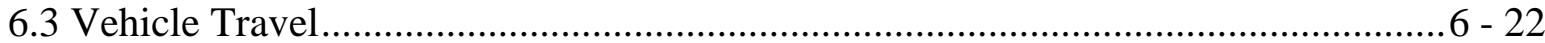

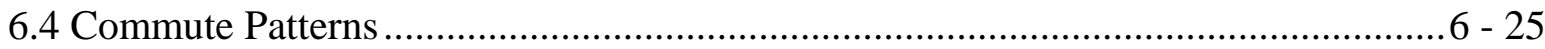

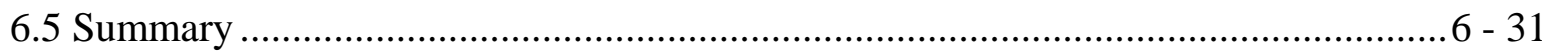

Appendix A Glossary of Terms …………………………............................................... A -

Appendix B Maps of New York State Area.......................................................................... B - 1

Appendix C Supplementary Travel Tables by Chapter ……………………………………..... C - 1

Appendix D Standard Errors for Selected Tables and Figures .................................................. D - 1 


\section{List of Figures}

\section{Figure}

ES.1 2001 Distribution of Households Owning Vehicles................................................ES - 2

ES.2 Personal Mobility Statistics New York State vs. Rest of the Country …....................ES - 2

ES.3 Personal Trip Statistics, New York City vs. New York State vs. Rest of the

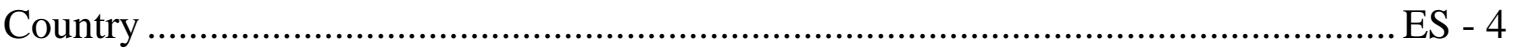

ES.4 Person Trip Distribution by Mode................................................................... ES - 4

ES.5 Percent Households Without a Vehicle .............................................................. ES - 5

ES.6 Percent Person Trips by Transit or Walking ......................................................... ES - 6

ES.7 Population Density of New York State ............................................................ ES - 6

ES.8 Daily Vehicle Trips by Population Density, New York State MPOs vs. MSAs

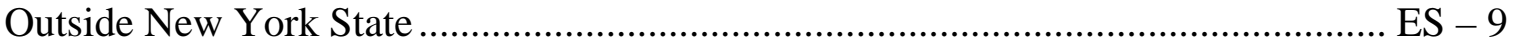

1.1 2001 NHTS New York Add-on Areas.................................................................... 1 - 4

1.2 Distinction Between Person Trip, Person Miles of Travel, Vehicle Trip, and Vehicle Miles of Travel.......................................................................................1- 7

1.3 Temporal Relationship Between Travel Day and Travel Period...................................1-9

$2.1 \quad$ Percent Difference from 1995 to 2001 ...................................................................2 - 1

2.22001 Distribution of Households Owning Vehicles, New York vs. Rest of the

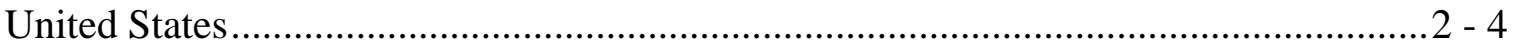

2.3 Daily Person Trips by Age, New York State vs. Rest of the United States ..................2 - 8

2.4 Daily Person Trips per Person by Trip Purpose, New York State vs. Rest of the United States........................................................................................................ 2 - 9

2.5 Daily Person Miles per Person by Trip Purpose, New York State vs. Rest of the United States........................................................................................................ 2 - 10

2.6 Person Trips Per Person by Vehicle Ownership, New York State vs. Rest of the

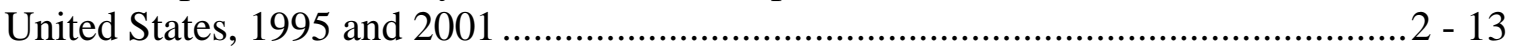

2.7 Distribution of Person Trips by Selected Mode and Vehicle Ownership New York State vs. Rest of the United States, 1995 vs. 2001 ............................................ 2 - 14

2.8 Daily Commute Trips per Worker by Mode, New York State vs. Rest of the

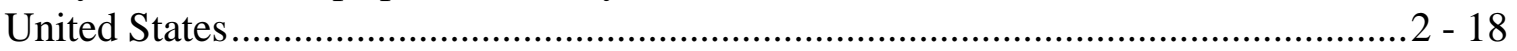

3.1 New York NHTS Primary Sampling Areas........................................................ 3 - 2

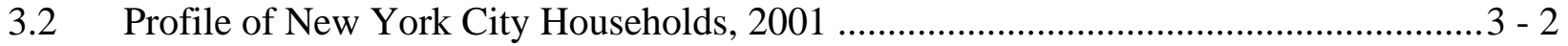

3.3 Distribution of Households with Vehicles by Number of Vehicles, New York City, Remainder of New York State, and Outside New York State............................... 3 - 4

3.4 Person Trip Distribution by Selected Mode, New York City, Remainder of New York State, and Outside New York State $3-8$

3.5 Daily Person Miles Traveled by Age, New York City, Remainder of New York State, and Outside New York State $3-10$ 
3.6 PMT by Selected Mode, New York City, Remainder of New York State, and Outside New York State

3.7 Distribution of Zero-Vehicle Households by Income, New York City,

Remainder of New York State, and Outside New York State. $3-12$

3.8 Difference in Daily Travel by Vehicle Ownership, New York City, Remainder of New York State, and Outside New York State $3-15$

3.9 Daily Driving by Driver Age, New York City, Remainder of New York State, and Outside New York State $3-16$

3.10 Daily Miles Driven by Driver Gender, New York City, Remainder of New York State, and Outside New York State....

3.11 Daily Commute by Mode, New York City, Remainder of New York State, and Outside New York State $3-21$

3.12 Commute Patterns on Privately-Owned Vehicles, New York City, Remainder of New York State, and Remainder of Unites States (U.S.). $3-23$

3.13 Commute Patterns on Public Transit, New York City, Remainder of New York State, and Remainder of United States (U.S.) $3-24$

4.1 Twelve New York MPOs Used in Urban Comparison Analysis ................................. 4 - 1

4.2 2001 Distribution of Households in New York MPOs and MPOs in Rest of the United States (U.S.) by Population Density .... $4-5$

4.3 New York Household Distribution by Population Density, 1995 and 2001 .................. 4 - 6

4.4 Percent Households Having Access to Rail, New York State MPOs vs. MSAs Outside New York State, 2001 $4-7$

4.5 Percent Households without a Vehicle and Population Density, New York MPOs vs. MSAs Outside New York State, 1995 and 2001 $4-10$

4.6 1995 and 2001 Driver Rates by Gender and Population Density, New York State MPOs vs. MSAs Outside New York State. $4-11$

4.7 Daily Person Trips by Population Density, New York MPOs vs. MSAs Outside New York State, 1995 and 2001 $4-12$

4.8 Percent Change from 1995 to 2001 in Number of Daily Person Trips, by Gender and Population Density, New York State MPOs vs. MSAs Outside New York State

4.9 Average Person Trip Length, New York State MPOs vs. MSAs Outside New York State, 1995 and 2001 $4-15$

4.10 Percent Difference in Trip Length between 1995 and 2001, New York State MPOs vs. MSAs Outside New York State. $4-16$

4.11 Person Trip Distribution by Trip Length and Population Density, New York MPOs 4 - 19

4.12 Percent Daily Person Trips by Public Transit and Walking, New York State MPOs vs. MSAs Outside New York State, 1995 and 2001 $4-20$

4.13 Average Daily Person Trips of Individuals Without a Vehicle, New York State MPOs vs. MSAs Outside New York State, 1995 and 2001 $4-22$ 
4.14 Percent of Transit Trips and Walking Trips Taken by Those Without a Vehicle, New York State MPOs vs. MSAs Outside New York State, 1995 and 20014 - 23

4.15 Trip Length, Population Density and Vehicle Ownership, New York State MPOs vs. MSAs Outside New York $4-25$

4.16 Percent Difference in Daily Vehicle Trips Between, New York State MPOs vs. MSAs Outside New York State, 1995 and 2001 ....................................................... 4 - 26

4.17 Commute Trips by Mode and Population Density, New York State MPOs and National Averages $4-30$

4.18 2001 Commute Patterns on Public Transit by New York State Workers, New York State MPOs and National Averages $4-31$

4.19 Percent Difference in Commute Time, Between Public Transit and Private Vehicles New York State MPOs vs. MSAs Outside New York State $4-34$

4.20 Commute Times by Public Transit, New York Urban Areas, 1995 and 2001 ............4 - 35

4.21 Percent Difference in Commute Patterns between 1995 and 2001, New York Urban Areas $4-36$

4.22 Driver Rates of Those Living in Extremely Densely Populated Areas, (More

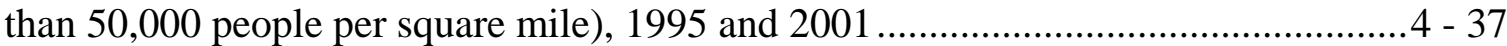

4.23 Mode Choices, By Those Living in Extremely Densely Populated Areas.................. 4 - 39

5.1 Average Annual Miles Driven per Rural Driver, (in census tracts with fewer than 500 people per square mile), New York State vs. Rest of United States ...................... 5 - 5

5.2 Average Daily Person Trips per Person, in Census Tracts with $<500$ Persons per Square Mile, New York State vs. Outside New York State.................................. 5 - 7

5.3 Distribution of Vehicle Trips in Rural Areas by Trip Length, New York State vs. Outside New York State $5-10$

5.4 Daily Commute Patterns in Rural Areas by Privately Owned Vehicles, New York State vs. Outside New York State .... $5-12$

6.1 Population Densities of Areas in New York State .................................................... 6 - 2

6.2 Distribution of Households in New York State MPOs by MSA Size ........................... 6 - 5

6.3 Percentage of Population Who Drive Categorized by Gender, New York State

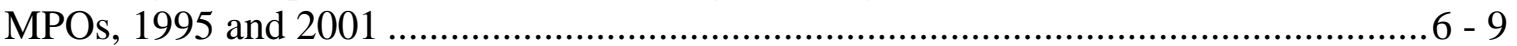

6.4 Daily Person Trips by New York MPOs, 1995 and 2001 ......................................... 13

6.5 Percent Change in Daily Person Trips from 1995 to 2001, New York MPOs............. 6 - 14

6.6 Daily Person Trips by Selected Modes, New York State MPOs, 1995 and 2001........6 - 15

6.7 Personal Travel Trends of Zero-Vehicle Households in New York MPOs ................6 - 18

6.8 Cumulative Frequency of Average Daily Trip Length of Zero-Vehicle Households Elmira vs. Glens Falls..................................................................... 6 - 21

6.9 Vehicle Travel Statistics by New York State MPOs..............................................6 - 24

6.10 Average Time Driving a Private Vehicle and Daily VMT, New York State MPO .....6 - 26

6.11 Average Commute Length and Commute Time, New York State MPO .................... 6 - 29

6.12 Percent Changes in Commute Travel Statistics from 1995 to 2001, New York MPOs $6-30$ 
2001 New York NHTS: A Comparison Study 


\section{List of Tables}

\section{Table}

1.1 Summary Statistics on Demographic Characteristics and Total Travel ....................... 1 - 6

2.1 Household Characteristics and Vehicle Ownership Patterns, New York State vs.

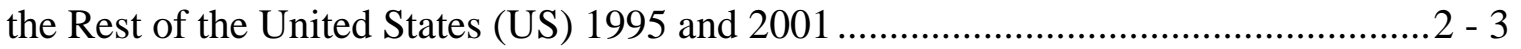

2.2 Personal Travel Statistics by Demographic Characteristics, New York State vs. Rest of the United States (US), 1995 and 2001 ......................................................... 2 - 6

2.3 Person Travel Rates by Mode of Transportation, New York State vs. Rest of the

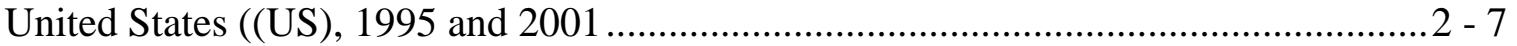

2.4 Person Travel of Households Without a Vehicle, New York State vs. Rest of the United States (US), 1995 and 2001 ...........................................................................2 - 12

2.5 Daily Vehicle Travel Statistics, New York State vs. Rest of the United States...........2 - 16

2.6 Commute Statistics, New York State vs. Rest of the United States (US) ..................2 - 17

3.1 Household Characteristics and Vehicle Ownership Patterns, New York City, Rest of New York State, and Rest of the United States (US), 1995 and 2001 ....................... 3 - 3

3.2a Person Trip Statistics by Mode of Transportation and Trip Purpose, New York City, Remainder of New York State, and Outside New York State.............................. 3 - 6

3.2b Person Miles Travel Statistics by Mode of Transportation and Trip Purpose, New York City, Remainder of New York State, and Outside New York State ...................... 3 - 7

3.3 Daily Personal Travel Statistics by Demographics, New York City, Remainder of New York State, and Outside New York State ............................................................. 3

3.4 Distribution of Zero-Vehicle Households and Their Personal Travel, New York City, Remainder of New York State, and Outside New York State.............................. 3 - 14

3.5 Daily Vehicle Travel Statistics, New York City, Remainder of New York State, and Outside New York State .................................................................................. 18

3.6 Daily Commute Statistics by Mode of Transportation, New York City, Remainder of New York State, and Outside New York State .................................................... 20

4.1a 2001 New York State Household Distribution by MPO and Population Density ......... 4 - 3

4.1b 1995 New York State Household Distribution by MPO and Population Density .........4 - 4

4.2a 2001 Household Characteristics and Vehicle Ownership Patterns by Population Density, New York State MPOs vs. MSAs Outside New York State............................ 4 - 8

4.2b 1995 Household Characteristics and Vehicle Ownership Patterns by Population Density, New York State MPOs vs. MSAs Outside New York State........................... 4 - 9

4.3a Personal Travel Statistics by Mode of Transportation and Population Density, New York State MPOs vs. MSAs Outside New York State, 2001 .....................................4 - 17

4.3b Personal Travel Statistics by Mode of Transportation and Population Density, New York State MPOs vs. MSAs Outside New York State, 1995.....................................4 - 18

4.4a Statistics on Daily Vehicle Travel by Population Density, New York State MPOs vs. MSAs Outside New York State, 2001 $4-28$ 
4.4b Statistics on Daily Vehicle Travel by Population Density, New York State MPOs vs. MSAs Outside New York State, 1995

4.5a Daily Commute Statistics by Population Density, New York State MPOs vs. MSAs Outside New York State, 2001 $4-32$

4.5b Daily Commute Statistics by Population Density, New York State MPOs vs. MSAs Outside New York State, 1995 $4-33$

4.6 Household Characteristics and Travel Profile of Those Living in Extremely Densely Populated Area $4-38$

5.1 Distribution of Rural Households by Block Group’s Population Density, New York State vs. Rest of the United States (U.S.)......................................................... 5 - 2

5.2 Rural Household Distribution by Census-Tract Population Density, 2001 NHTS ........ 5 - 3

5.3 Characteristics of Rural Households, New York State vs. Rest of the Country ............5 - 4

5.4 Personal Travel Statistics of Rural Households by Mode and Trip Purpose, New York State vs. Outside New York State $5-6$

5.5 Vehicle Travel Statistics by Drivers in Rural Areas, (In Census Tracts of Less than 500 People Per Square Mile), New York State vs. Rest of the United States. $5-9$

5.6 Daily Commute Statistics in Rural Areas by Mode of Transportation, New York State vs. Outside New York State $5-11$

6.1 New York State MPOs Categorized by Their MSA Size, 2001 NHTS and 1995 NPTS $6-3$

6.2a Household Characteristics and Vehicle Ownership Patterns New York State MPOs by MSA Size, 2001 NHTS $6-6$

6.2b Household Characteristics and Vehicle Ownership Patterns New York State MPOs by MSA Size, 1995 NPTS $6-7$

6.3a Personal Travel Statistics New York State MPOs by MSA Size, 1995 NPTS ........... 6 - 11

6.3b Personal Travel Statistics New York State MPOs by MSA Size, 2001 NHTS............6 - 12

6.4 Number of New York Households Interviewed in 2001 NHTS, by Number of Vehicles $6-17$

6.5a Person Travel for Zero-Vehicle Households by Mode of Transportation, New York State MPOs by MSA Size, 2001 NHTS

6.5b Person Travel for Zero-Vehicle Households by Mode of Transportation, New York State MPOs by MSA Size, 1995 NPTS $6-20$

6.6 Daily Vehicle Travel Statistics of New York State MPO Drivers by MSA Size, 2001 NHTS and 1995 NPTS

6.7a Commute Statistics by Mode of Transportation, New York State MPOs by MSA Size, 2001 NHTS $6-27$

6.7b Commute Statistics by Mode of Transportation, New York State MPOs by MSA Size, 1995 NPTS $6-28$ 


\section{EXECUTIVE SUMMARY}

In 1969, the U. S. Department of Transportation began collecting detailed data on personal travel to address various transportation planning issues. These issues range from assessing transportation investment programs to developing new technologies to alleviate congestion. This 1969 survey was the birth of the Nationwide Personal Transportation Survey (NPTS). The survey was conducted again in 1977, 1983, 1990 and 1995. Longer-distance travel was collected in 1977 and 1995. In 2001, the survey was renamed to the National Household Travel Survey (NHTS) and collected both daily and longer-distance trips in one survey.

In addition to the number of sample households that the national NPTS/NHTS survey allotted to New York State (NYS), the state procured an additional sample of households in both the 1995 and 2001 surveys. In the 1995 survey, NYS procured an addition sample of more than 9,000 households, increasing the final NY NPTS sample size to a total of 11,004 households. Again in 2001, NYS procured 12,000 additional sample households, increasing the final New York NHTS sample size to a total of 13,423 households with usable data. These additional sample households allowed NYS to address transportation planning issues pertinent to geographic areas significantly smaller than for what the national NPTS and NHTS data are intended. Specifically, these larger sample sizes enable detailed analysis of twelve individual Metropolitan Planning Organizations (MPOs). Furthermore, they allowed NYS to address trends in travel behavior over time.

In this report, travel data for the entire NYS were compared to those of the rest of the country with respect to personal travel behavior and key travel determinants. The influence of New York City (NYC) data on the comparisons of the state of New York to the rest of the country was also examined. Moreover, the analysis examined the relationship between population density and travel patterns, and the similarities and differences among New York MPOs. The 1995 and 
2001 survey data make it possible to examine and identify travel trends over time. This report does not address, however, the causes of the differences and/or trends.

Personal travel in NYS and the rest of the nation differ in four major ways:

- Vehicle ownership. While one in every fifteen households outside NYS is without a vehicle, one in every four New York households has no vehicle. Many NYS households do not own a vehicle largely by choice, whereas those elsewhere do not own a vehicle largely due to income constraints. Moreover, New York households are less likely to own more than one vehicle than households elsewhere (Figure ES.1). While $55 \%$ of vehicle-owning households in New York owned more than one vehicle, this

Figure ES.1 2001 Distribution of Households Owning Vehicles

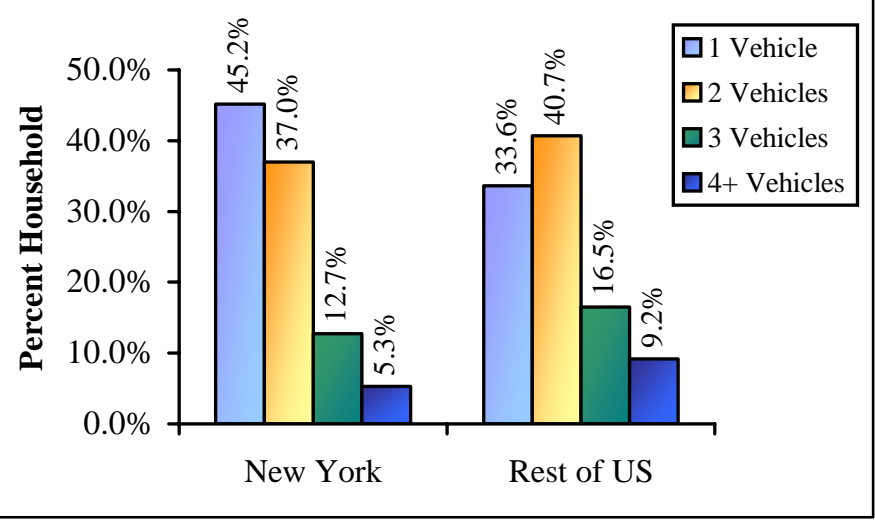
percentage elsewhere is $66 \%$.

- Personal mobility. Residents of NYS, on average, take fewer trips, shorter trips, and drive considerably less than those elsewhere. This was the same in both 1995 and 2001 (Figure ES.2). However, much of this difference is an artifact of NYC data. After excluding NYC data from the analysis, the differences in travel patterns between NYS and

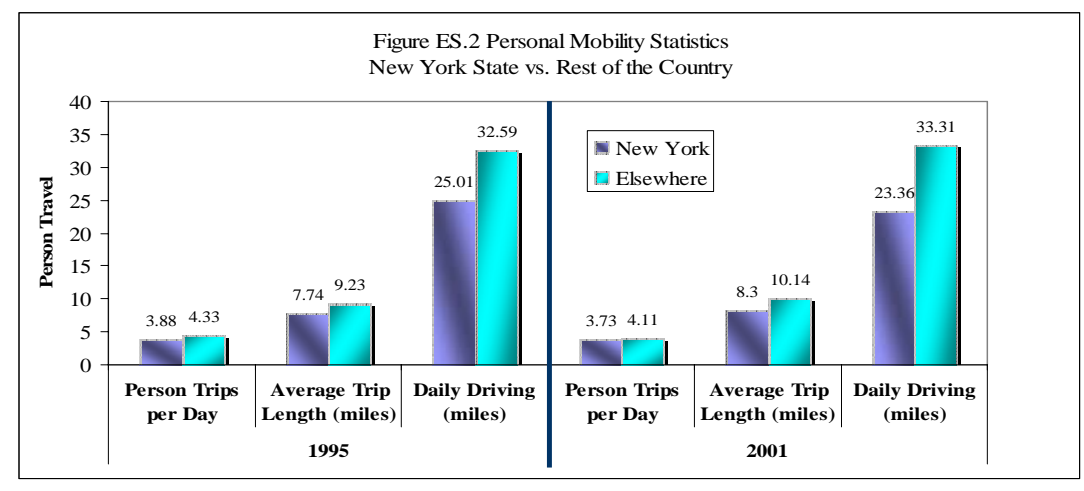

ES - 2 
the rest of the country narrow. However, New York residents outside NYC still take, on average, fewer trips, shorter trips and drive less than Americans elsewhere.

- Impact of not having a vehicle on mobility. While the proportion of New York households that do not own a vehicle is almost four times that in the rest of the country (27\% vs. 7\%), many New York households do not own a vehicle for reasons other than financial factors. Lacking a vehicle in NYS generally does not significantly deter personal mobility. Many households that are without a vehicle meet their daily mobility needs by using public transit or walking.

- Commute modes. Compared to workers elsewhere, workers in NYS as a whole are six times more likely to use public transit and three times more likely to walk to work. The proportion of commute trips by public transit and walking in New York is almost six times that elsewhere, $29 \%$ vs. $5 \%$.

How much of these differences are attributable to travel behavior in large metropolitan areas in the state, NYC in particular? Our results suggest that the travel behavior of NYC residents has a tremendous impact on the overall travel patterns of the entire state. Excluding NYC, the analysis indicates that residents of NYS are similar to those in the rest of the country with respect to personal travel characteristics, household vehicle ownership, and the proportion of individuals who consider themselves as a driver. However, only five in every ten NYC women consider themselves to be a driver while almost nine in every ten women elsewhere consider themselves to be a driver. Although the proportion of those who consider themselves as a driver among NYC men is closer to the national average than that of NYC women, it is still $20 \%$ less than the national average. 
New York City residents take not only fewer trips but also significantly shorter trips than other New York residents as well as those outside NYS (Figure ES.3). The distribution of trip purposes among NYC residents is about the same as that in the rest of the country. However, how NYC residents go to places is very different from residents elsewhere.

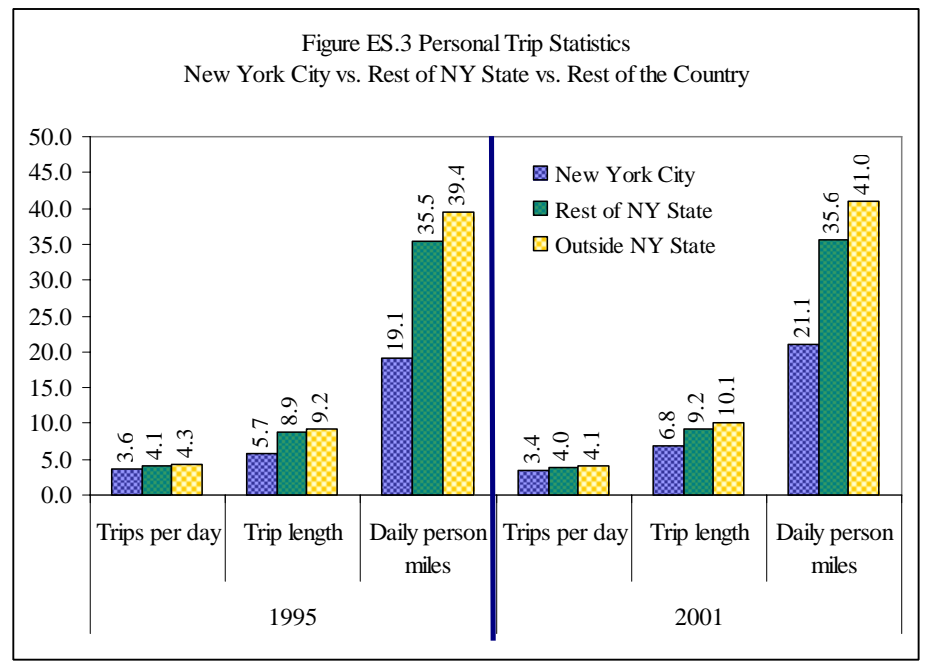
NYC residents are four times more likely to walk to places and fourteen times more likely to use public transit than other New York residents, as well as those outside NYS (Figure ES.4).

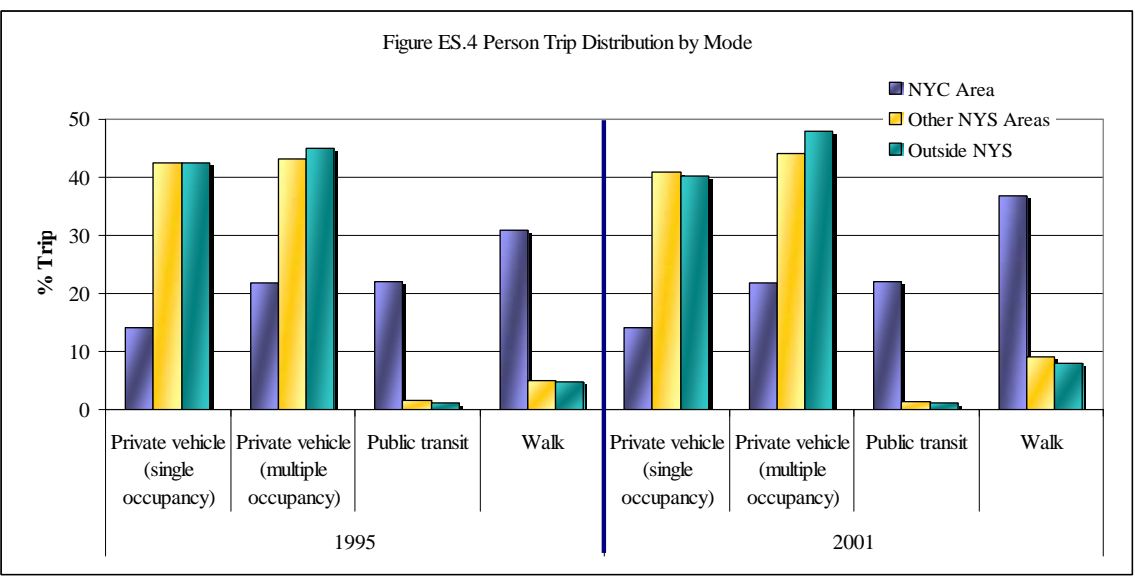

Travel by NYC households, that do not have a vehicle, is considerably different from those elsewhere. These NYC households are not typically low-income as commonly believed. The percentage of households earning more than \$70,000 a year in NYC and that do not own a vehicle is eight times that in other parts of NYS as well in other parts of the country. Almost one quarter of the zero-vehicle households in NYC earn below $\$ 10,000$. By comparison, this percentage is greater than $40 \%$ outside NYS. Lacking a vehicle does not curb the need or ability to travel for zero-vehicle households in NYC. They take on average almost 30\% more trips than households without a vehicle in other parts of NYS and 25\% more trips than households without a vehicle outside NYS. 
The percentage of households without a vehicle is positively correlated with population density (Figure ES.5). Although those without a vehicle are less mobile than those who own a vehicle, the difference in trip frequency narrows as population density increases. This implies that being without access to a vehicle in highly populated areas, which almost always have public transit available, is less of a mobility constraint than in less populated areas. Residents in highly densely populated areas are less likely to consider themselves to be a driver than those in less populated areas.

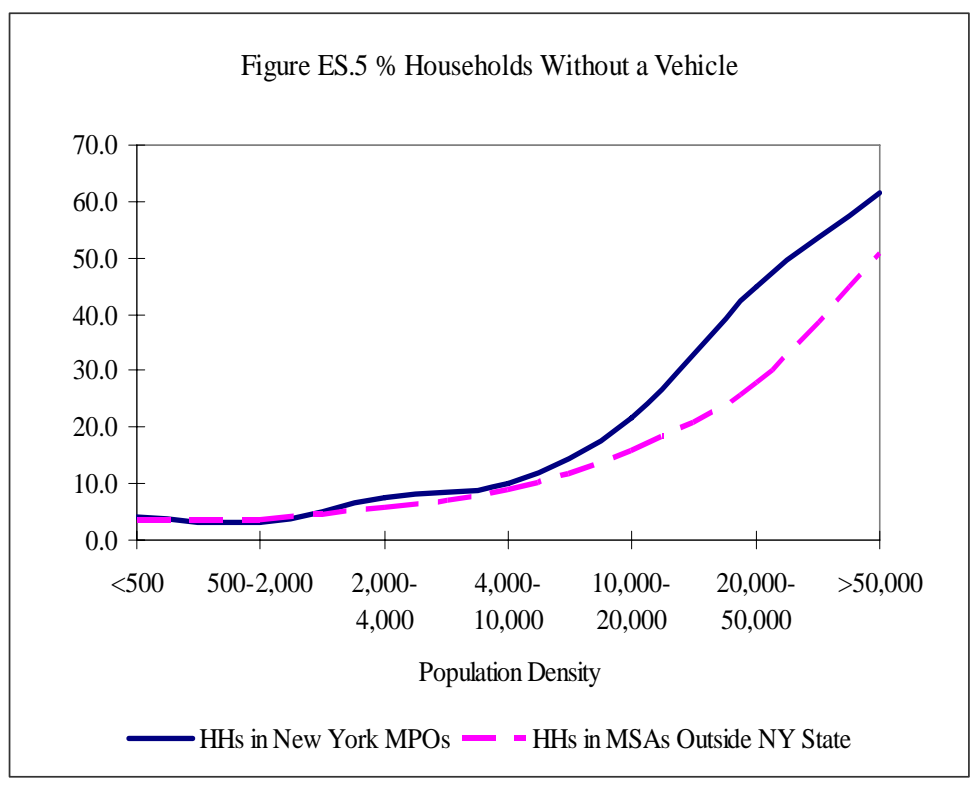
These patterns are true both inside and outside NYS.

It is obvious that population density has a significant bearing on how people travel. Since population density is highly correlated to the availability of public transit, density and public transit availability have overlapping effects on mode choice. The majority of the trips in the most populated areas are by using public transit or walking. The departures from average national travel characteristics increase with increasing population density. For example, a typical U.S. worker spends an average of 48 minutes and travels 12 miles a day to go to work on public transit ${ }^{1}$. However, depending on the residence of the worker and workplace location, the one-way commute on public transit can on average be as much as one hour and 46 minutes, and as long as 30 miles. Thus, analyzing travel characteristics without consideration to population density or public transit availability can be extremely misleading.

\footnotetext{
${ }^{1}$ Hu, P.S., Reuscher, T. “Summary of Travel Trends: 2001 National Household Travel Survey.” Oak Ridge National Laboratory. Oak Ridge, Tennessee. December 2004. 
An obvious difference between NYS urban data and other urban areas outside NYS is mode choice. Although it is true both inside and outside NYS that the proportion of person trips by public transit and walking increases with population density (measured by people per square mile), this pattern is more pronounced in NYS than elsewhere (Figure ES.6).

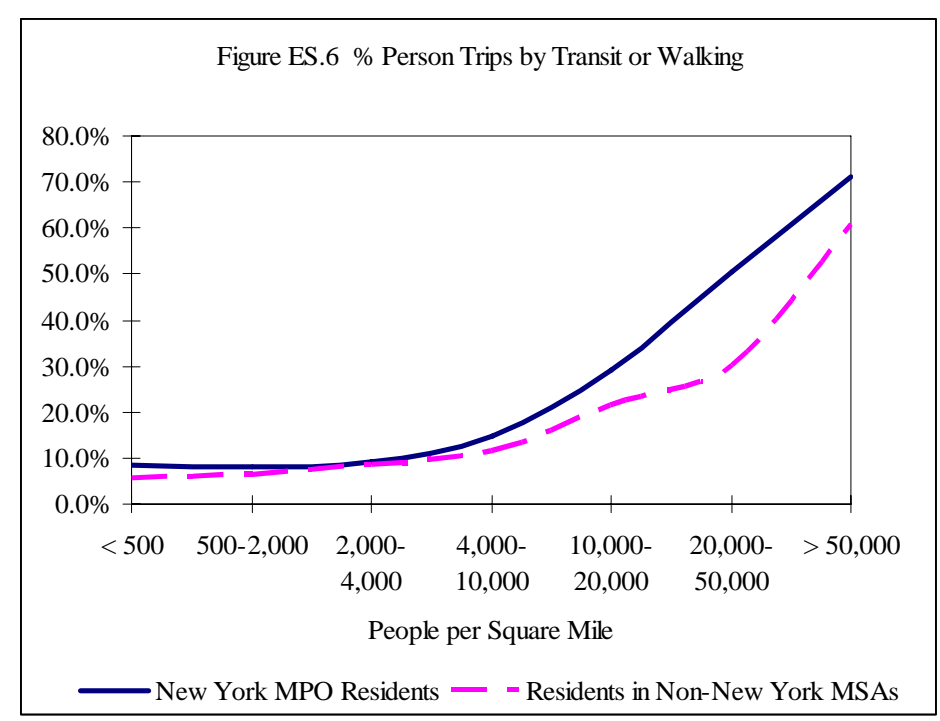

Urban daily vehicle travel patterns are similar inside and outside NYS. The number of vehicle trips per day increases with population density, reaches its peak in areas with between five hundred and four thousand people per square mile, then declines with increasing population

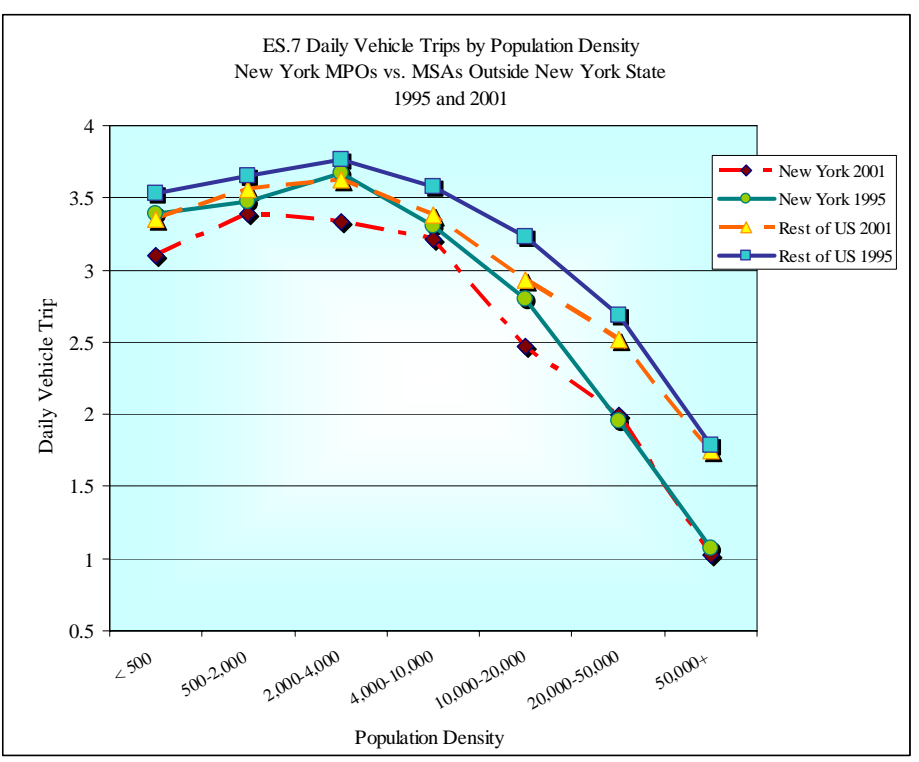
density (Figure ES.7). Although following a similar pattern, the difference between NYS and the rest of the country becomes more apparent as population density increases, ranging from a 5 to $8 \%$ difference in small to medium size urban areas (those with a population density of less than 10,000 people per square mile) to a $70 \%$ difference in the most populated areas.

With almost ninety percent of its residents living in extremely densely populated areas (more than 50,000 people per square mile), do Manhattan residents travel differently from those 
living in similarly densely populated areas? If so, does this different travel behavior affect the overall travel profile of the New York metropolitan areas?

Compared to households that are outside Manhattan, but in equally densely populated areas, more Manhattan households do not own a vehicle - almost seven in ten households do not own a vehicle. However, Manhattan residents are more likely to consider themselves to be a driver than their neighbors living in equally densely populated areas in NYC. Among those without a vehicle, Manhattan residents are more mobile than others living in equally densely populated areas - inside or outside NYS. Half of the time, Manhattan residents walk to places. About one-quarter of the time, they take public transit.

Rural travel patterns in NYS were compared to those in other rural areas. On a per household basis, rural New York households are similar to those elsewhere with respect to the number of workers and vehicle ownership patterns. Drivers in New York rural areas drive fewer, and shorter, trips than drivers in other rural areas. There is no noticeable difference between rural New York households and similar households elsewhere as to why driving takes place. Although not statistically significant, residents in New York rural areas take fewer, and shorter, trips than those in other rural areas. These observations slightly reverse the trends in 1995 when rural New York residents took fewer, but longer, trips than rural residents elsewhere.

Finally, we compared travel patterns among the twelve NYS MPOs: Albany; Binghamton; Buffalo; Elmira; Glens Falls; Ithaca; New York Metropolitan Transportation Council (NYMTC); Newburgh; Poughkeepsie; Rochester; Syracuse; and Utica-Rome (Figure ES.8). New York metropolitan area, under the jurisdiction of the NYMTC, was further disaggregated into:

- $\quad$ Nassau and Suffolk;

- $\quad$ the five counties of NYC: Bronx, Kings, Queens, New York (or Manhattan), and Richmond; and 
- $\quad$ Putnam, Rockland, and Westchester.

This further breakdown of the New York metropolitan area facilitated comparisons among areas. To make travel comparisons meaningful, the MPOs and the sub-components of an MPO (e.g., Manhattan) were grouped into Metropolitan Statistical Area (MSA) size categories. The grouping of the twelve MPOs is the same in 2001 as in 1995. The travel data of an MPO are compared to other MPOs with a similar MSA size. For example, the travel data of Elmira residents are compared to those of Glens Falls residents. While Ithaca is outside an MSA area, its population size of more than 85,000 in 2001 makes it reasonable to compare its travel patterns to those of other small MSAs such Elmira and Glens Falls.

From the standpoint of personal travel, there is little difference among New York MPOs when compared to other MPOs with similar population size. However, this is not true with respect to vehicle ownership, vehicle travel, and commutes. New York MPOs with fewer than 3 million people are fairly comparable in the percentage of households without a vehicle. Even the biggest difference of a little over 3\% between Albany and Syracuse is not statistically significant. The percentage of households without a vehicle in the largest metro areas (within the largest MSA size group) fluctuates widely, ranging from over 70\% in New York/Manhattan to a little less than $5 \%$ in Nassau and Suffolk. 


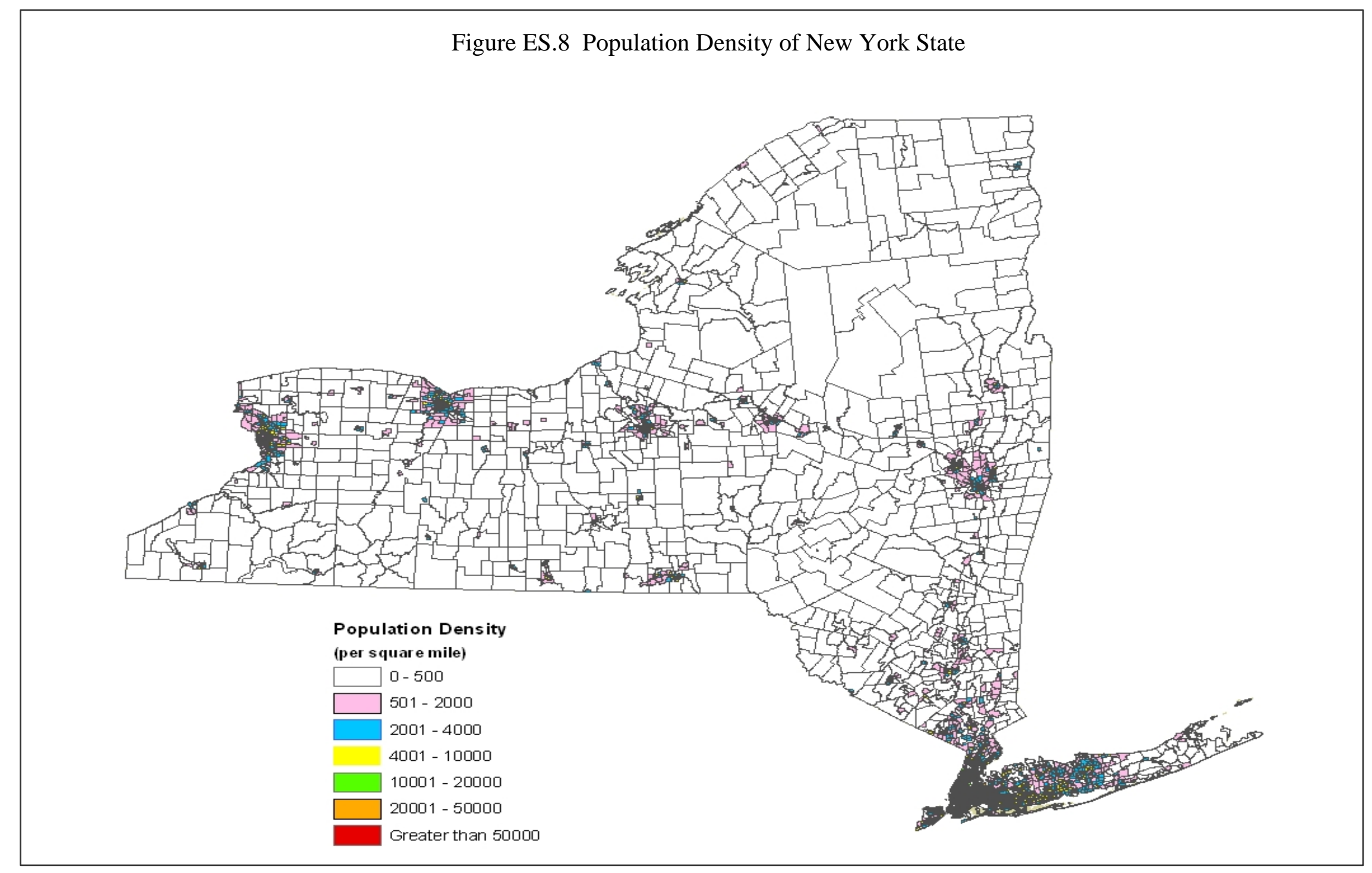

ES - 9 
Similar to 1995, seven out of every 10 households in New York/Manhattan do not own a vehicle in 2001. While households in MPOs outside NYC do not own a vehicle largely due to income constraints, many households in New York/Manhattan do not own a vehicle by choice. One in every four zero-vehicle households in New York/Manhattan are below the poverty line (with a household income less than \$20,000) whereas at least 2 in every 3 zero-vehicle households in some MPOs are in poverty. Our analysis results suggest that the mobility of zero-vehicle households in New York/Manhattan is by no means deterred by the lack of a vehicle. Most of their daily travel is met by walking or by public transit.

The vehicle travel characteristics show some distinct patterns among NYS MPOs. Almost all comparisons suggest that NYS MPOs can be categorized into three distinctive groups regardless of the size of the MSA within which an MPO is located. The first group consists of New York/Manhattan, the second group consists of the remaining four counties of NYC, and the last group consists of all of the remaining MPOs and the rest of the NYMTC area outside NYC (i.e., Nassau and Suffolk, and Putnam, Rockland, and Westchester). The second group has travel patterns somewhere between those of the first and the third groups.

All comparisons indicate that analysis of the 2001 New York NHTS should consider separating Manhattan data from the rest of NYS. When data for Manhattan residents are combined with those for the rest of NYC, the unique travel characteristics of Manhattan residents are obscured. Furthermore, consideration of population density in any analysis would make the results more definite. 


\section{Chapter 1. Introduction}

\subsection{Background and Objectives}

Policymakers rely on transportation statistics, including data on personal travel behavior, to formulate strategic transportation policies, and to improve the safety and efficiency of the U.S. transportation system. Data on personal travel trends are needed to examine the reliability, efficiency, capacity, and flexibility of the Nation's transportation system to meet current demands and accommodate future demands; to assess the feasibility and efficiency of alternative congestion-alleviating technologies (e.g., high-speed rail, magnetically levitated trains, intelligent vehicle and highway systems); to evaluate the merits of alternative transportation investment programs; and to assess the energy-use and air-quality impacts of various policies.

To address these data needs, the U.S. Department of Transportation (USDOT) initiated an effort in 1969 to collect detailed data on personal travel. The 1969 survey was the first Nationwide Personal Transportation Survey (NPTS). The survey was conducted again in 1977, 1983, 1990, 1995, and 2001. Data on daily travel were collected in 1969, 1977, 1983, 1990 and 1995. Longer-distance travel was collected in 1977 and 1995. The 2001, the survey was renamed to the National Household Travel Survey (NHTS) and it collected both daily and longer-distance trips in one survey.

The 2001 survey was sponsored by three USDOT agencies: Federal Highway Administration (FHWA), Bureau of Transportation Statistics (BTS), and National Highway Traffic Safety Administration (NHTSA). The primary objective of the survey was to collect tripbased data on the nature and characteristics of personal travel so that the relationships between the characteristics of personal travel and the demographics of the traveler can be established. Commercial and institutional travel was not part of the survey.

New York State (NYS) participated in the 2001 NHTS by procuring 12,000 additional sample households. These additional sample households allowed NYS to address transportation planning issues pertinent to geographic areas significantly smaller than what the national NHTS data are intended for. The final sample size for NYS was 13,423 usable households. 
As in the 1995 report $^{2}$, this report also addresses four key questions. First, are New York residents different from those elsewhere with respect to personal mobility? Second, to what extent do the travel patterns of New York City (NYC) residents skew the overall travel patterns in the state? If the impact is substantial, the next question is whether New York residents outside NYC travel differently from the rest of the nation. Finally, are there significant differences in travel patterns between 1995 and 2001? This report highlights the similarities and differences in daily travel patterns, but does not address the causes for the differences.

\subsection{Who Is Included}

The NHTS collected travel data from the civilian, non-institutionalized population of the United States. People living in college dormitories, nursing homes, other medical institutions, prisons, and military bases were excluded from the sample. All household members age 5 or older were eligible to be interviewed. For children ages 5 through 13, an adult member of the household reported for them. Unlike previous surveys, the 2001 survey enumerated travel taken by persons younger than five years old. In order to compare 2001 with 1995 numbers, this report only looks at travel by persons 5 and older.

Large metropolitan areas with subway or elevated rail transit systems were over-sampled in order to increase the number of in-sample transit trips. Furthermore, nine geographic areas (including NYS) purchased NHTS add-on contracts that increased the sample size within their planning areas. The increased sample sizes within these areas provided small-area data for more reliable transportation planning.

\subsection{How The Data Were Collected}

The NHTS was conducted as a telephone survey, using Computer-Assisted Telephone Interviewing technology. The sample was a list-assisted telephone number sample. Each household in the sample was assigned a specific 24-hour "Travel Day” and kept diaries to record all travel taken by all household members for the assigned day. Furthermore, a 28-day "Travel Period" was assigned to each household to collect longer-distance travel (over 50 miles from home) for each household member. Information collected for long-distance travel included

\footnotetext{
2 “1995 New York NPTS: A Comparison Study.” Hu and Young. Oak Ridge National Laboratory, Oak Ridge, TN. November 1999. http://www.dot.state.ny.us/ttss/1995npts/nynpts95_comparison_study.pdf
} 
information on long commutes, airport access, and overnight stays. The assigned travel day was the last day of the assigned travel period.

The households were contacted by an advance letter, followed by a telephone contact. For New York sample households, a five-dollar incentive was sent along with the letter requesting their participation. After the first telephone interview where household characteristics were collected, travel diaries were mailed to the household so that each household member could record their travel on the assigned Travel Day. Residents of the sampled households were contacted by telephone as soon as possible after the designated travel day to record their travel.

\subsection{When the Data Were Collected}

The 2001 NHTS was conducted over a period from March 2001 through June 2002, with the New York add-on covering April 2001 through May 2002. Travel data were collected for all seven days of the week, including all holidays. The survey was conducted over at least a 12month period so that data would account for seasonal variations in travel. To correct for this seasonal variation, sample weighting was developed to specifically address this issue. Each household and person weight were adjusted so that the weighted data reflect an equal number of household and person interviews for each month.

The tragic event of September 11, 2001 occurred six months into the 15-month data collection period, providing a unique opportunity to examine the impact of this event on daily travel behavior. The impacts of September 11 on travel behavior of New York residents will be discussed in a separate report.

\subsection{Sample Sizes and Weighted Sums}

For the state of New York, information was gathered for a total of 13,423 households, 30,268 persons, 23,732 vehicles, and 118,200 daily trips. More than ten thousands sample households in the New York NHTS sample (13,423 households) were the result of NYS acquiring additional samples for specific geographic areas (i.e., NHTS Add-ons). The added sample households were intended to increase the number of sample households in those areas so 
that trip rates and travel statistics can be reliably estimated at that geographic level. Figure 1.1 shows the New York add-on areas.

Figure 1.12001 NHTS New York Add-on Areas

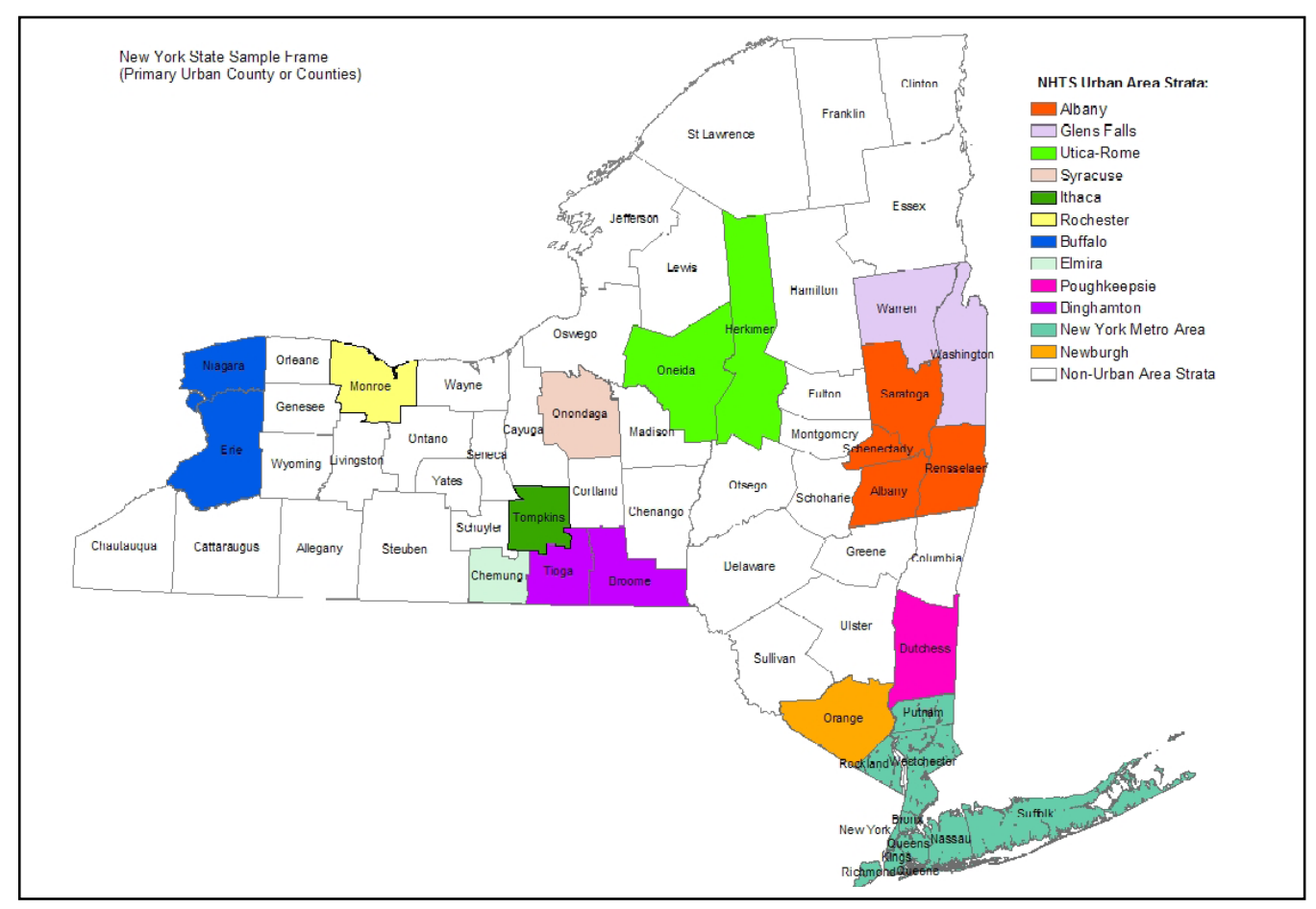

The NHTS uses weights to expand the sample data to estimates for the entire NYS population. The weights reflect the sample design and selection probabilities, over-sampling of certain strata, and adjustments to compensate for survey non-response and non-coverage. It is absolutely necessary to use the survey weights to properly account for the sample design used for the survey.

The weights are multiplicative factors that must be applied to the file variables in order to obtain valid estimates of population values. If the weights are not used, incorrect estimates will result. For example, the overall number of unweighted daily sample trips per household for the state of New York is 8.81, whereas the overall number of weighted daily trips per household is 9.5. Sample errors can be magnified and lead to serious inaccuracies when weights are not used in tabulating these data. 


\subsection{Travel Concepts}

Appendix A contains a full glossary of terms used in this report. However, a few basic terms and concepts need to be introduced before data are presented.

Person Trip - A trip by one person in any mode of transportation. This is the most basic and universal measure of personal travel. Each record in the Travel Day and Travel Period files in the NHTS dataset represents one person trip. An example of this is if two people are traveling together in one car, two person trips are counted. Based on 2001 NHTS data, residents of NYS made an estimated 24,899 million person-trips that year (Table 1.1).

Person Miles of Travel (PMT) - The number of miles traveled by each person on a trip. An example of this is two people taking a six-mile subway trip to the airport results in 12 person miles of travel. A four-mile van trip with a driver and three passengers counts as 16 person miles of travel.

Person-miles are often called passenger miles, particularly in the transit and airline industries. The state of New York had an estimated 194,513 million person-miles of travel during the 2001 NHTS period.

Vehicle Trip - A trip by a single privately operated vehicle (POV) regardless of the number of persons in the vehicle. For example, two people traveling together in a car would be counted as one vehicle trip. Four people going to a restaurant in a van are considered one vehicle trip. To be counted as a vehicle trip in the NHTS, a trip must be made in a POV and the driver must be a member of a household in the NHTS sample. A POV can be a householdbased car, van, sport utility vehicle, pickup truck, other truck, recreational vehicle, motorcycle or other POV. The vehicle does not need to belong to the household.

Trips made in other highway vehicles, such as buses, streetcars, taxis, and school buses are collected in the NHTS. However, these trips are not counted as vehicle trips because these vehicles are not privately operated vehicles. The state of New York had an estimated 10,886 million vehicle-trips during the 2001 NHTS period. 
Table 1.1 Summary Statistics on Demographic Characteristics and Total Travel Based on 1995 New York NPTS and 2001 New York NHTS

\begin{tabular}{|c|c|c|}
\hline & 1995 NPTS & 2001 NHTS \\
\hline Households & $6,848,091$ & $7,183,208$ \\
\hline Persons & - & $18,635,650$ \\
\hline $0-4$ & - & $1,241,257$ \\
\hline Persons 5 Years or Older & $16,806,988$ & $17,394,393$ \\
\hline $5-15$ & $3,001,540$ & $2,805,630$ \\
\hline $16-19$ & 878,870 & 992,404 \\
\hline $20-34$ & $2,562,132$ & $3,810,147$ \\
\hline $35-54$ & $3,278,947$ & $5,486,605$ \\
\hline 55-64 & 703,052 & $1,591,252$ \\
\hline 65 and over & $2,070,923$ & $2,305,198$ \\
\hline Not reported & - & 403,158 \\
\hline Persons including all ages & - & $18,635,650$ \\
\hline Male & - & $8,938,448$ \\
\hline Female & - & $9,697,202$ \\
\hline Persons 5 Years or Older & $16,806,988$ & $17,394,393$ \\
\hline Male & $8,135,143$ & $8,284,292$ \\
\hline Female & $8,671,845$ & $9,110,101$ \\
\hline Drivers & $10,469,256$ & $11,167,231$ \\
\hline Male & $5,513,627$ & $5,729,689$ \\
\hline Female & 4,955,629 & $5,437,541$ \\
\hline Workers & $\mathbf{8 , 7 7 4 , 6 3 5}$ & $9,645,253$ \\
\hline Male & 4,702,897 & $5,061,833$ \\
\hline Female & $4,071,739$ & $4,583,420$ \\
\hline Total Vehicle Trips $(000,000)$ & 11,023 & 10,886 \\
\hline Total Vehicle Miles of Travel $(000,000)$ & 95,571 & 95,209 \\
\hline Total Person Trips $(000,000)$ including all ages & - & 24,899 \\
\hline Total Person Miles of Travel $(000,000)$ including all ages & - & 194,513 \\
\hline Total Person Trips $(000,000)$ excluding $0-4$ year olds & 23,810 & 23,705 \\
\hline Total Person Miles of Travel $(000,000)$ excluding $0-4$ year olds & 177,072 & 186,685 \\
\hline
\end{tabular}


Vehicle Miles of Travel (VMT) - One vehicle mile of travel is the movement of one privately operated vehicle (POV) for one mile, regardless of the number of people in the vehicle. When one person drives her car 12 miles to work, 12 vehicle miles of travel have been made. If two people travel three miles in a pickup truck, three vehicle miles of travel have been made. The distinction among person trip, person miles of travel, vehicle trip and vehicle miles of travel is better illustrated in Figure 1.1. The state of New York had an estimated 95,209 million vehicle-miles of travel during the 2001 NHTS period.

Figure 1.2 Distinction Between Person Trip, Person Miles of Travel, Vehicle Trip, and Vehicle Miles of Travel

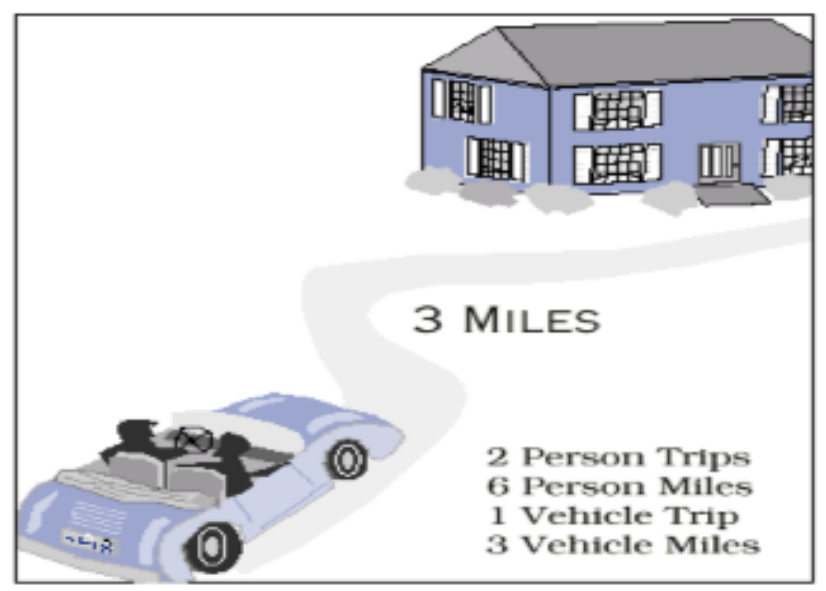

Vehicle Occupancy - For NHTS data, vehicle occupancy is generally computed as person miles of travel per vehicle mile (referred to as the travel method). Note that the other commonlyused definition of vehicle occupancy is persons per vehicle trip (referred to as the trip method).

Because longer trips often have higher occupancies, the travel method generally yields a higher vehicle occupancy rate than the trip method. For example, the average person-miles of travel per vehicle mile for the state of New York was 1.6 in 2001 compared to a vehicle occupancy of 1.5 persons per vehicle trip. The calculation of the travel method requires that trip miles be reported, thus it is calculated on a slightly smaller number of trips than the trip method. 
Daily Trip Rates - Rather than presenting total travel, much of the data presented in this report are in units of daily trip rate, such as the number of trips taken by an individual on a typical day. Daily trip rates are derived by dividing the total daily travel (e.g., total person trips) by the total number of entities (e.g., households, workers, drivers, persons). This method implies that even if one did not travel on the designated travel day, he/she is included in the calculation.

Average Daily Person Travel per Person - The average daily number of person trips or person miles of travel taken by a person. This includes persons who did not travel during the designated travel day. The estimated average daily person trips per person in the state of New York were 3.66. The estimated average daily person miles per person were 28.6 during the 2001 NHTS period.

Average Daily Vehicle Travel per Driver - The average number of daily vehicle trips or vehicle miles of travel driven by an individual driver in the state of New York. This includes drivers who did not drive during the designated travel day. On average, a New York driver drove 2.67 trips and 23.36 miles per day.

Average Daily Journey-to-Work Travel per Worker - The average number of daily journeys to or from work for any day of the week. This includes travel by workers who work at home and workers who did not go to work during the designated travel day. On average, a typical New York worker took 1.12 trips to work per day.

Average Daily Travel per Household - The average daily number of person trips, vehicle trips, person miles of travel, vehicle miles of travel, or journey-to-work trips taken by a typical household in the state of New York. This includes households that did not travel during the designated travel day. For the state of New York, the estimates are as follows: the average daily person trips per household was 9.5, the average daily person miles per household was 74.1, the average daily vehicle trips per household was 4.15 , the average daily vehicle miles per household was 36.31, and the average daily journey-to-work trips taken by a household was 1.5 during the 2001 NHTS period. 
Travel Day and Travel Period sections refer to two sections of the NHTS questionnaire designed to complement each other. In the travel day section, the respondent is asked to report all trips of any length by any mode of travel during a 24-hour period. This reporting provides data on the types of trips made on a daily basis, such as trips to work, or the store, running errands, and visiting friends. Because most people make out-of-town trips less frequently, respondents are asked to report any long trips (defined as 50 miles or more one way) for a 28-week period. This is known as the travel period and includes the travel day as well as the preceding 27 days (Figure 1.2).

Figure 1.3 Temporal Relationship Between

Travel Day and Travel Period

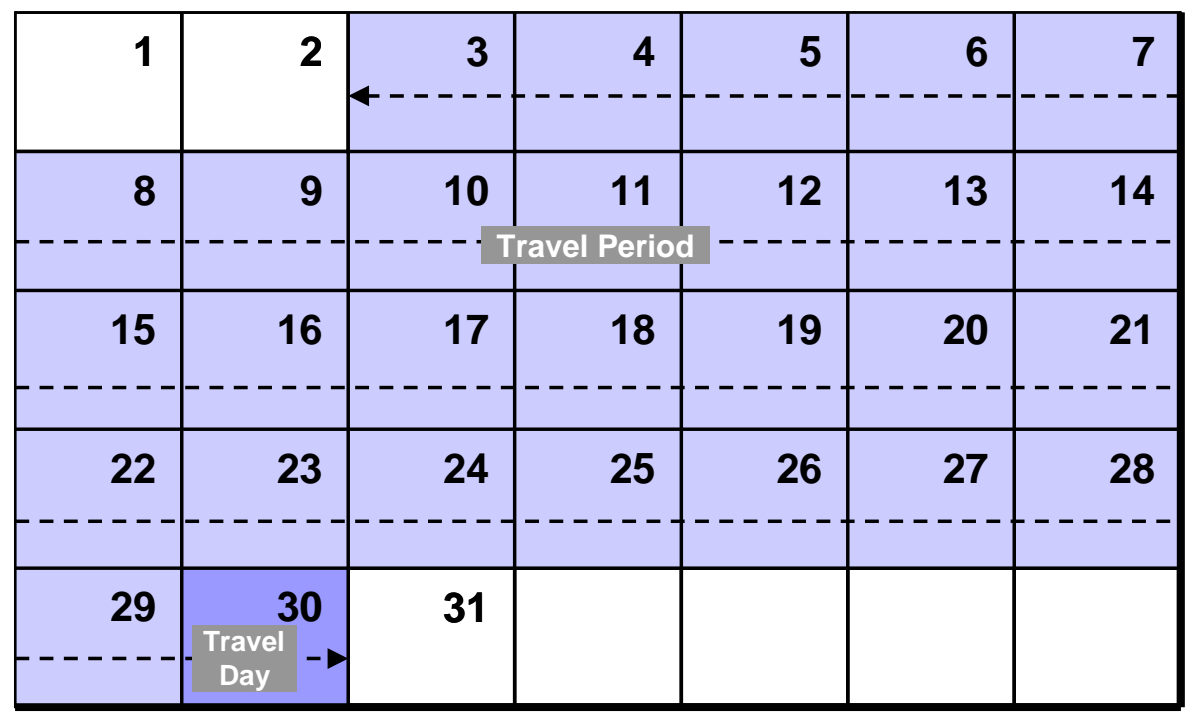

If the respondent took a trip of 50 miles or more and returned home on the Travel Day, that trip will be collected in both the travel day and the travel period sections of the questionnaire. Note that, for travel period trips, it does not matter when the outgoing portion of the trip took place, the return trip must be made during the 28-day travel period. A trip will be collected (and counted) twice only for the travel that took place on the travel day. A set of variables, TPOVRLAP in the Travel Day file and TDOVRLAP in the New York Travel Period file, were created to identify which travel day trips are part of the long trip reported in the travel period file so as to avoid double counting. 


\subsection{Differences Between the 1995 and 2001 Surveys and the Data Implications}

There are a number of improvements and changes in the 2001 NHTS:

1. Travel taken by persons younger than five years old are enumerated,

2. More emphasis on walk and bike trips by prompting specifically for these trips,

3. If one did not travel on the designated travel day, then information on the most recent trip was collected,

4. If one did not travel during the designated travel period (the 28-day period when data on long distance trips were collected), then information on the most recent long distance trip was collected,

5. Information on access and egress to the transit station was explicitly collected,

6. The travel period was a 28-day period in 2001 but a two-week period in 1995, and

7. Long distance trips in 2001 were those with the farthest destination 50 miles away from home while the criterion in 1995 was 75 miles.

In addition, a number of questions were added to the 2001 NHTS to cover emerging trends pertinent to personal travel behavior:

At the Household Level:

- Cell-phone ownership,

- Number of phone lines owned and how they were used (voice, fax, modem), and

- Vehicle fuel consumption and annual fuel cost.

At the Person level:

- Internet access and frequency and location of use,

- Travel disability and its effect on mobility,

- Primary activities during "last week,"

- Explicit coding of multiple jobs,

- Broad categories of occupation,

- Immigrant status (whether the person was born outside the U.S. and, if so, what year they arrived), and

- Frequency of walk \& bike trips during the week prior to the interview day. 
At the Individual Daily Trip Level.

- More detail on trip purpose, and

- Access and egress modes to transit stations.

At the Individual Long-distance Trip Level.

- Types of lodging used,

- Access and egress modes to airport, train station, etc.,

- Overnight stops \& purpose of stops, and

- All modes used at the final destination.

\subsection{Report Organization}

In the next chapter, New York travel data are compared to the rest of the nation with respect to personal travel behavior and key travel determinants. Chapter 3 addresses the question of whether travel patterns of NYC residents are so atypical that they alter the travel characteristics of NYS away from the national averages. Chapter 4 investigates whether travel patterns within New York Metropolitan Planning Organizations (MPOs) differ from those in other metro areas of similar population density. A similar comparison, but focused on rural areas, is reported in Chapter 5. A comparison among New York MPOs by MSA size is presented in Chapter 6. Chapter 7 concludes the report by summarizing key findings. Relevant comparisons between 1995 and 2001 travel patterns are highlighted in the appropriate chapters. Key travel concepts and a glossary of terms used in this report are included in Appendix A. The complete travel statistics for each chapter are presented in Appendix B. 
This page intentionally left blank.

$1-12$ 


\section{Chapter 2. Comparison of New York Data to the Rest of the United States}

This chapter examines how New York residents differ from the rest of the nation with respect to personal travel behavior and key travel determinants. For example, do New York residents travel more or less than the rest of the country? Do they take longer or shorter trips to work? Typically, households without a vehicle are low income. Is this true in the state of New York? Who are without a vehicle in New York? Are they as equally mobile as those with vehicles? And, how do they meet their transportation needs?

\subsection{Profile of New York Households}

Table 2.1 compares household characteristics and vehicle ownership patterns between the state of New York and the rest of the United States. Like the rest of the country, NYS experienced an increase in the total number of households - from 6.9 million households in 1995 to 7.2 millions in 2001. Instead of increasing by $8 \%$ like the rest of the country, the number of New York households increased at a lower rate of 5\% from 1995 to 2001 (Figure 2.1).

Figure 2.1 Percent Difference from 1995 to 2001

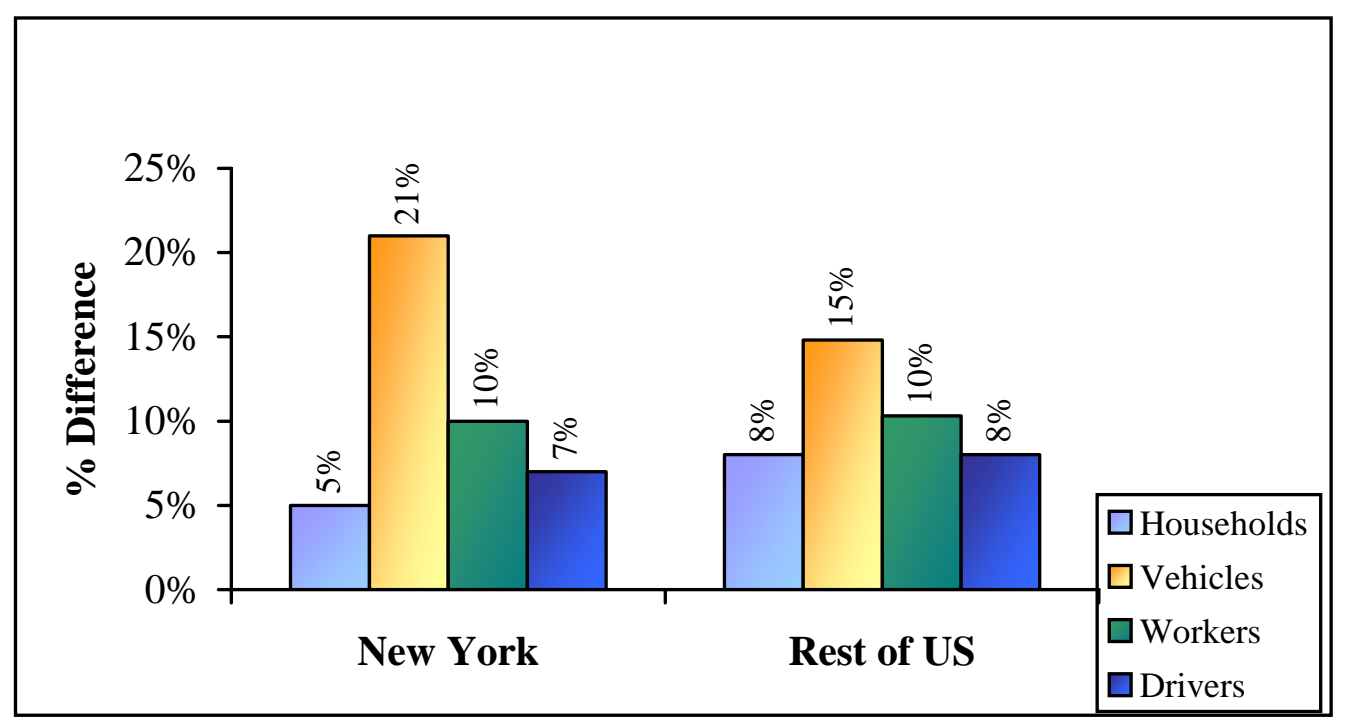


This increase in the number of households contributed to an increase in the number of household vehicles (Table 2.1 and Figure 2.1). Although the number of households increased at a slower rate than the rest of the country, New York had a significantly greater percentage increase in the number of household vehicles. Nonetheless, compared to the rest of the country, a typical New York household still owns fewer vehicles than a typical household elsewhere. And, the average number of vehicles per driver is less in New York. That said, the gap in household vehicle ownership between New York households and those elsewhere was narrowing.

A slightly greater proportion of New York households declined to provide information on their income, compared to the rest of the United States. Among households that did, those that earned more than \$70,000 in 2001 accounted for a somewhat greater proportion in New York than in other part of the country $(25.2 \%$ vs. $22.3 \%)$. Licensing rates were strikingly different between New York residents and other Americans. Slightly more than 70\% of New York women are reported as a driver whereas the comparable percentage for the rest of the United States is $88 \%$ (Table 2.1). The discrepancy in men's reporting as a driver is smaller but statistically significant $-84 \%$ in New York vs. $93 \%$ in the rest of the United States.

While one in every fifteen households outside NYS is without a vehicle, one in every four New York households has no vehicle. Moreover, New York households are less likely to own more than one vehicle than households elsewhere (Figure 2.2). While 55\% of vehicleowning households in New York owned more than one vehicle, this percentage elsewhere is 66\%. Little difference was observed between 1995 and 2001 in terms of household vehicle ownership. 
Table 2.1 Household Characteristics and Vehicle Ownership Patterns

New York State vs. the Rest of the United States (US)

1995 and 2001

\begin{tabular}{|c|c|c|c|c|}
\hline & \multicolumn{2}{|c|}{1995} & \multicolumn{2}{|c|}{2001} \\
\hline & New York & Rest of US & New York & Rest of US \\
\hline Households (000) & 6,848 & 92,858 & 7,183 & 100,182 \\
\hline Drivers $(000)$ & 10,469 & 165,861 & 11,167 & 179,258 \\
\hline Workers $(000)$ & 8,775 & 122,922 & 9,645 & 135,627 \\
\hline Household Vehicles (000) & 7,922 & 168,145 & 9,545 & 193,041 \\
\hline Workers per Household & 1.28 & 1.32 & 1.34 & 1.35 \\
\hline Vehicles per Household & 1.16 & 1.81 & 1.33 & 1.93 \\
\hline Vehicles per Driver & 0.76 & 1.01 & 0.85 & 1.08 \\
\hline \multicolumn{5}{|l|}{ Income $^{a}$} \\
\hline$\%<\$ 10,000$ Households & 7.1 & 6.5 & 9.2 & 8.7 \\
\hline$\% \$ 10$ to $\$ 20,000$ Households & 11.1 & 11.7 & 12.2 & 12.1 \\
\hline$\% \$ 20$ to $\$ 30,000$ Households & 11.5 & 12.7 & 12.2 & 13.3 \\
\hline$\% \$ 30$ to $\$ 40,000$ Households & 10.7 & 12.2 & 11.3 & 12.8 \\
\hline$\% \$ 40$ to $\$ 50,000$ Households & 9.2 & 10.5 & 9.2 & 10.3 \\
\hline$\% \$ 50$ to $\$ 60,000$ Households & 7.4 & 8.2 & 7.4 & 8.3 \\
\hline$\% \$ 60$ to $\$ 70,000$ Households & 5.6 & 5.9 & 5.6 & 6.0 \\
\hline$\% \$ 70$ to $\$ 80,000$ Households & 4.2 & 4.2 & 4.9 & 5.1 \\
\hline$\% \$ 80,000+$ Households & 13.7 & 11.7 & 17.7 & 15.4 \\
\hline \% Unreported Households & 19.5 & 16.5 & 10.3 & 8.1 \\
\hline \multicolumn{5}{|l|}{ Driver Rate R $^{\text {b }}$} \\
\hline \% Female Drivers/Female 16+ & $68.4 \%$ & $86.6 \%$ & $71.1 \%$ & $87.7 \%$ \\
\hline \% Male Drivers/Male 16+ & $84.1 \%$ & $93.2 \%$ & $83.5 \%$ & $93.3 \%$ \\
\hline \multicolumn{5}{|l|}{ Vehicle Ownership } \\
\hline \% 0 vehicles Households & 26.8 & 6.9 & 26.5 & 6.8 \\
\hline$\% 1$ vehicle Households & 32.9 & 32.4 & 33.2 & 31.3 \\
\hline \% 2 vehicles Households & 29.7 & 41.1 & 27.2 & 37.9 \\
\hline \% 3 vehicles Households & 7.8 & 14.4 & 9.3 & 15.4 \\
\hline \% 4+ vehicles Households & 2.9 & 5.3 & 3.9 & 8.6 \\
\hline
\end{tabular}

Note:

a 1995 income categories are adjusted to 2001 dollars.

b Driver rate is determined using the self-reported response to the question "Are you a driver?" in the NHTS survey. As such, this rate should not be compared to the official NYS Department of Transportation drivers' licensing statistics. 
Figure 2.2 2001 Distribution of Households Owning Vehicles New York vs. Rest of the United States (US)

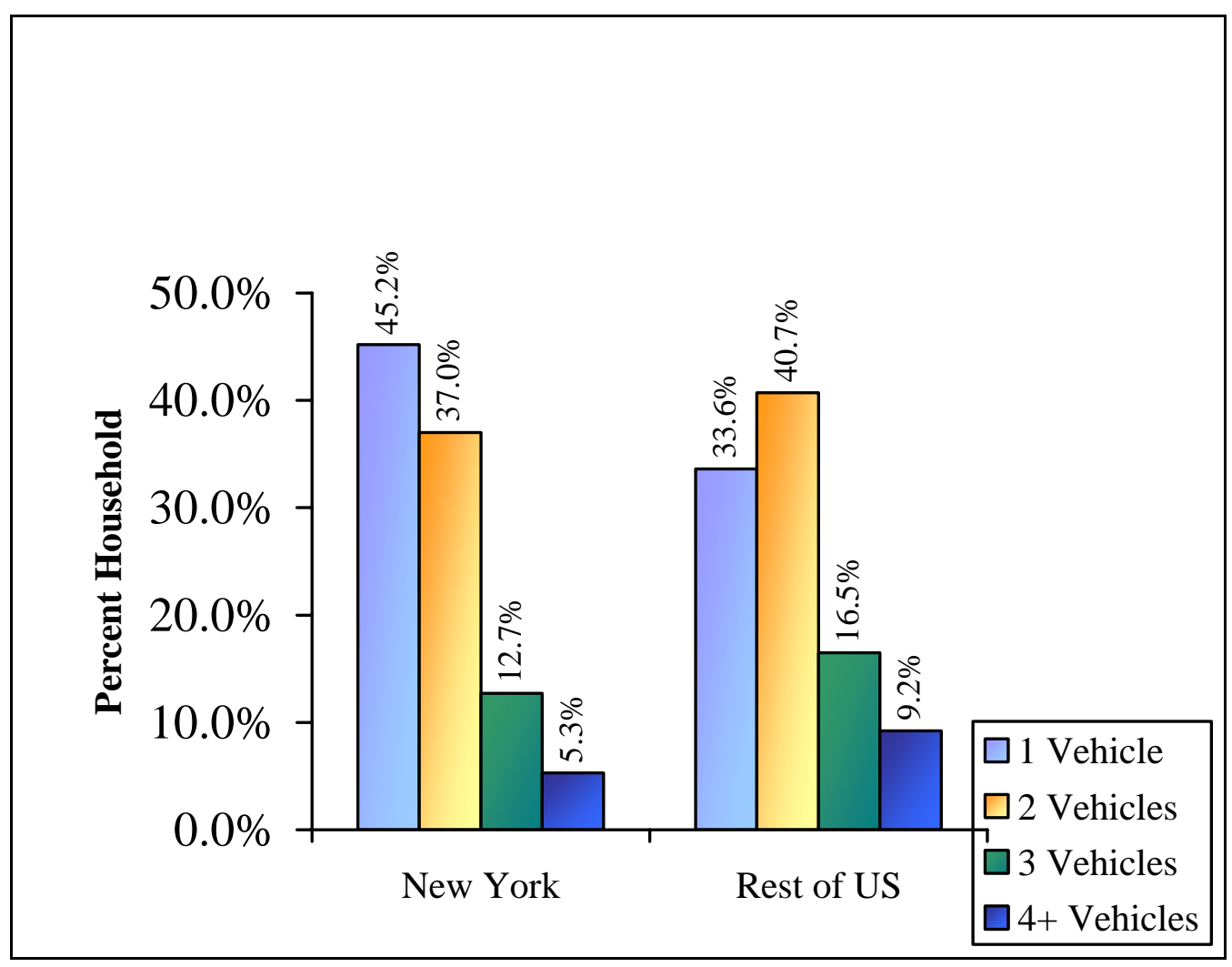




\subsection{Personal Travel}

Throughout the nation, Americans took fewer but longer trips in 2001 than in 1995 (Table 2.2). New York residents take almost 10\% fewer trips than others in the United States (Table 2.2). Their trips are also shorter. New York residents travel an average of 29 miles per day, compared to 41 miles elsewhere (Table 2.3). As in 1995, New York men took more trips in 2001 than women, on average. Although age appears to have a similar impact on personal travel regardless of the location, New York residents consistently took fewer trips than people elsewhere for every age category (Figure 2.3). The greatest change in travel propensity from 1995 to 2001 was observed among those between the ages of 16 and 19 living outside NYS (Figure 2.3). These teenagers took 10\% fewer trips in 2001 than in 1995 - a statistically significant decline. New York residents are not different from Americans elsewhere in that they take more trips on weekend days than on weekdays, and in that more affluent households are typically more mobile than less affluent households. Across the country, daily trip rates decreased from 1995 to 2001, both on weekend days and on weekdays, although the decreases on weekdays are not statistically significant (Table 2.2).

There is very little difference between New York residents and Americans elsewhere on why travel took place (Figures 2.4 and 2.5). Although family and personal business accounted for almost half of the trips, they only accounted for one-third of the total person miles traveled, suggesting that these trips were shorter compared to non-family and personal trip. While Americans elsewhere traveled, on average, 5\% more miles in 2001 than in 1995, the amount of travel by New York residents remained almost constant at 29 miles per day. The absence of any increase in travel among New York residents could be attributed to the economic recession, effects of the 9/11, or a combination of both. However, this report does not attempt to estimate the influence of each of these factors on personal travel.

As in 1995, New York residents rely considerably less on privately-owned vehicles, and use public transit and walk to places more often than people elsewhere. The proportion of walking trips by New York residents is striking (Table 2.3). Chapter 3 will address whether this high propensity to use public transit and walk was determined largely by the travel patterns of NYC residents. 
Table 2.2 Personal Travel Statistics by Demographic Characteristics New York State vs. Rest of the United States (US) 1995 and 2001

\begin{tabular}{|c|c|c|c|c|c|c|}
\hline & \multicolumn{2}{|c|}{$1995^{a}$} & \multicolumn{2}{|c|}{2001} & \multirow{2}{*}{$\begin{array}{c}\text { \% difference } \\
\text { in New York } \\
\text { between } 1995 \\
\text { and } 2001 \\
\end{array}$} & \multirow{2}{*}{$\begin{array}{c}\text { \% difference } \\
\text { Elsewhere } \\
\text { between } 1995 \\
\text { and } 2001 \\
\end{array}$} \\
\hline & $\begin{array}{l}\text { New } \\
\text { York } \\
\text { State } \\
\end{array}$ & $\begin{array}{c}\text { Rest of } \\
\text { US }\end{array}$ & $\begin{array}{l}\text { New } \\
\text { York } \\
\text { State } \\
\end{array}$ & $\begin{array}{c}\text { Rest of } \\
\text { US }\end{array}$ & & \\
\hline $\begin{array}{l}\text { Person Trips per } \\
\text { Person }\end{array}$ & 3.88 & 4.33 & 3.73 & 4.11 & $-3.9 \%{ }^{*}$ & $-5.1 \%{ }^{*}$ \\
\hline Male & 3.93 & 4.36 & 3.77 & 4.11 & $-4.1 \%^{*}$ & $-5.7 \%^{*}$ \\
\hline Female & 3.84 & 4.30 & 3.70 & 4.12 & $-3.6 \%^{*}$ & $-4.2 \%^{*}$ \\
\hline $\begin{array}{l}\text { Person Trips per } \\
\text { Person }\end{array}$ & 3.88 & 4.33 & 3.73 & 4.11 & $-3.9 \%{ }^{*}$ & $-5.1 \%{ }^{*}$ \\
\hline$<\$ 10,000$ & 3.12 & 3.28 & 2.98 & 3.22 & $-5.7 \%^{b}$ & $-4.2 \%^{b}$ \\
\hline$\$ 10$ to $\$ 20,000$ & 3.53 & 3.85 & 3.23 & 3.59 & $-9.8 \%^{b}$ & $-9.3 \%^{b}$ \\
\hline$\$ 20$ to $\$ 30,000$ & 3.79 & 4.28 & 3.57 & 3.93 & $-9.8 \%^{b}$ & $-10.5 \%{ }^{b}$ \\
\hline$\$ 30$ to $\$ 40,000$ & 3.95 & 4.50 & 3.73 & 4.14 & $-4.4 \%^{\mathrm{b}}$ & $-9.6 \%^{b}$ \\
\hline$\$ 40$ to $\$ 50,000$ & 4.05 & 4.60 & 3.80 & 4.27 & $-10.6 \%^{\mathrm{b}}$ & $-8.4 \%^{b}$ \\
\hline$\$ 50$ to $\$ 60,000$ & 4.14 & 4.64 & 4.06 & 4.38 & $-2.6 \%^{\mathrm{b}}$ & $-6.0 \%^{b}$ \\
\hline$\$ 60$ to $\$ 70,000$ & 4.25 & 4.65 & 4.00 & 4.46 & $-9.1 \%^{\mathrm{b}}$ & $-4.3 \%^{b}$ \\
\hline$\$ 70$ to $\$ 80,000$ & 4.39 & 4.70 & 3.98 & 4.44 & $-10.8 \%^{b}$ & $-4.7 \%^{b}$ \\
\hline$\$ 80,000+$ & 4.37 & 4.72 & 4.22 & 4.55 & $-2.5 \%^{\mathrm{b}}$ & $-4.6 \%^{b}$ \\
\hline $\begin{array}{l}\text { Weekday Person } \\
\text { Trips/Person }\end{array}$ & 3.75 & 4.25 & 3.66 & 4.00 & $-2.4 \%$ & $-5.9 \%$ \\
\hline $\begin{array}{l}\text { Weekend Person } \\
\text { Trips/Person }\end{array}$ & 4.24 & 4.55 & 3.95 & 4.44 & $-6.8 \%{ }^{*}$ & $-2.4 \%$ \\
\hline $\begin{array}{l}\text { Average Person } \\
\text { Trip Length }\end{array}$ & 7.74 & 9.23 & 8.30 & 10.14 & $7.2 \%$ & $9.9 \%{ }^{*}$ \\
\hline
\end{tabular}

Note:

a 1995 income categories are adjusted to 2001 dollars.

b Standard errors are not available for 1995 statistics where income was adjusted to 2001 dollars; thus, significant differences could not be determined.

* Indicates statistically significant difference. 
Table 2.3 Person Travel Rates by Mode of Transportation

New York State vs. Rest of the United States (US)

1995 and 2001

\begin{tabular}{|c|c|c|c|c|c|c|}
\hline & \multicolumn{2}{|c|}{1995} & \multicolumn{2}{|c|}{2001} & \multirow{2}{*}{$\begin{array}{c}\text { \% difference } \\
\text { in } \\
\text { New York } \\
\text { between } \\
1995 \text { and } \\
2001\end{array}$} & \multirow{2}{*}{$\begin{array}{c}\% \\
\text { difference } \\
\text { Elsewhere } \\
\text { between } \\
1995 \text { and } \\
2001 \\
\end{array}$} \\
\hline & $\begin{array}{l}\text { New } \\
\text { York } \\
\text { State }\end{array}$ & $\begin{array}{c}\text { Rest of } \\
\text { US }\end{array}$ & $\begin{array}{l}\text { New } \\
\text { York } \\
\text { State }\end{array}$ & $\begin{array}{c}\text { Rest of } \\
\text { US }\end{array}$ & & \\
\hline Person Trips per Person & 3.88 & 4.33 & 3.73 & 4.11 & $-3.9 \%$ & $-5.1 \%$ \\
\hline$\% \mathrm{SOV}$ & 31.7 & 42.5 & 30.3 & 40.3 & & \\
\hline$\% \mathrm{MOV}$ & 35.1 & 45.0 & 35.3 & 47.3 & & \\
\hline \% Other $\mathrm{POV}^{\mathrm{a}}$ & 0.0 & 0.0 & & & & \\
\hline$\%$ Amtrak & 0.0 & 0.0 & 0.2 & 0.0 & & \\
\hline \% Commuter Train & 1.3 & 0.0 & 0.4 & 0.1 & & \\
\hline \% Subway/Elevated Rail & 3.9 & 0.2 & 5.3 & 0.2 & & \\
\hline \% Other Public Transit & 4.1 & 0.9 & 3.8 & 0.8 & & \\
\hline \% Walk & 14.7 & 4.8 & 20.0 & 7.9 & & \\
\hline \% Other & 4.4 & 3.0 & 4.6 & 3.3 & & \\
\hline \% Unreported & 4.9 & 3.5 & 0.1 & 0.1 & & \\
\hline PMT per Person & 28.86 & 39.40 & 29.40 & 41.03 & $1.9 \%$ & $4.1 \%$ \\
\hline$\% \mathrm{SOV}$ & 34.5 & 40.4 & 31.8 & 37.6 & & \\
\hline$\% \mathrm{MOV}$ & 48.2 & 51.1 & 43.0 & 51.3 & & \\
\hline$\%$ Other $\mathrm{POV}^{\mathrm{a}}$ & 0.1 & 0.1 & & & & \\
\hline$\%$ Amtrak & 0.3 & 0.0 & 0.6 & 0.1 & & \\
\hline \% Commuter Train & 2.5 & 0.3 & 1.1 & 0.2 & & \\
\hline \% Subway/Elevated Rail & 4.2 & 0.2 & 4.7 & 0.1 & & \\
\hline \% Other Public Transit & 3.9 & 1.3 & 2.0 & 0.5 & & \\
\hline \% Walk & 1.2 & 0.3 & 1.8 & 0.6 & & \\
\hline$\%$ Other & 4.2 & 5.4 & 14.6 & 9.3 & & \\
\hline \% Unreported & 0.9 & 1.0 & 0.6 & 0.5 & & \\
\hline
\end{tabular}

Note:

a Other POV was not a "mode" available to the survey respondents in 2001. 
Figure 2.3 Daily Person Trips by Age New York State vs. Rest of the United States

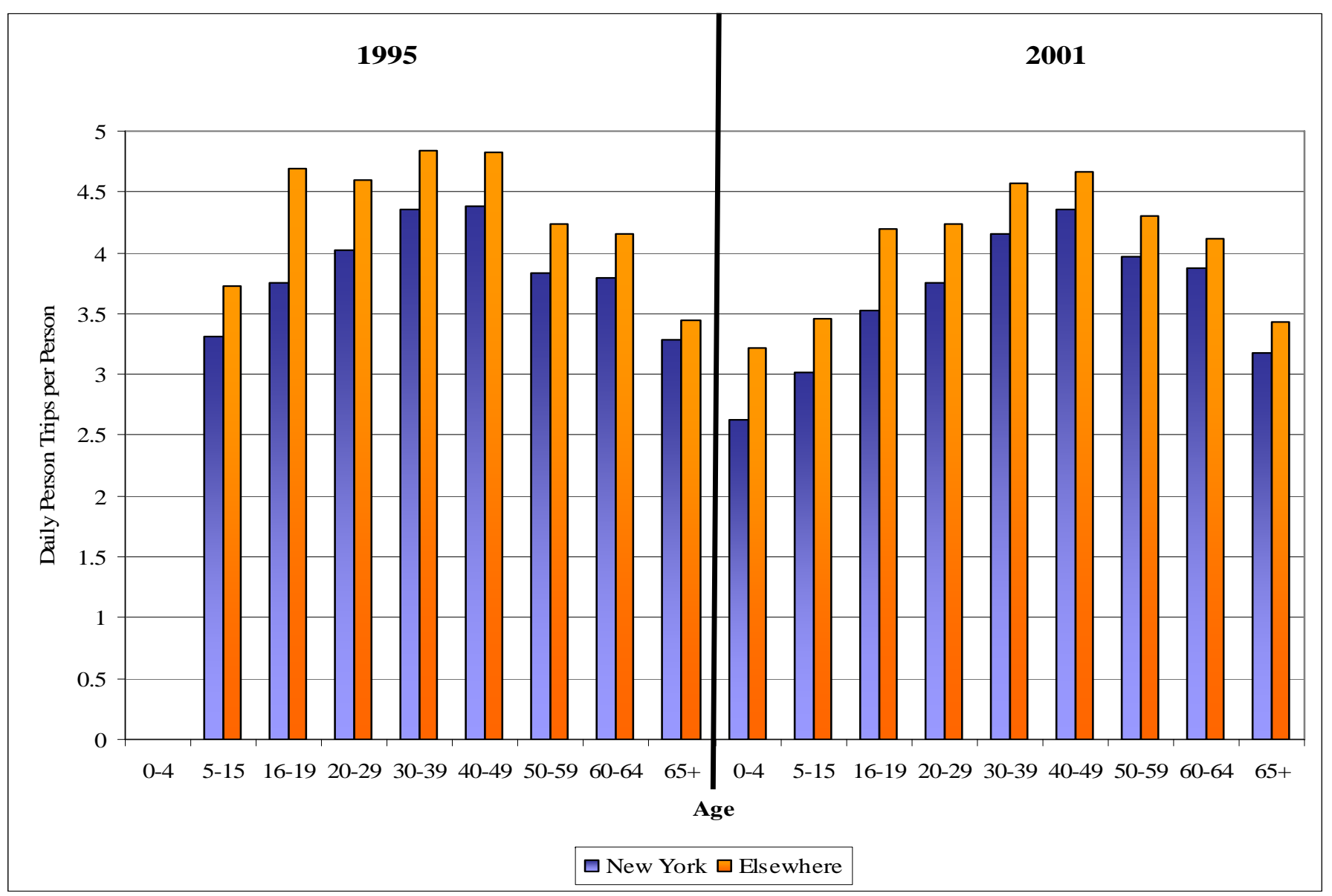


Figure 2.4 Daily Person Trips per Person by Trip Purpose

New York State vs. Rest of the United States

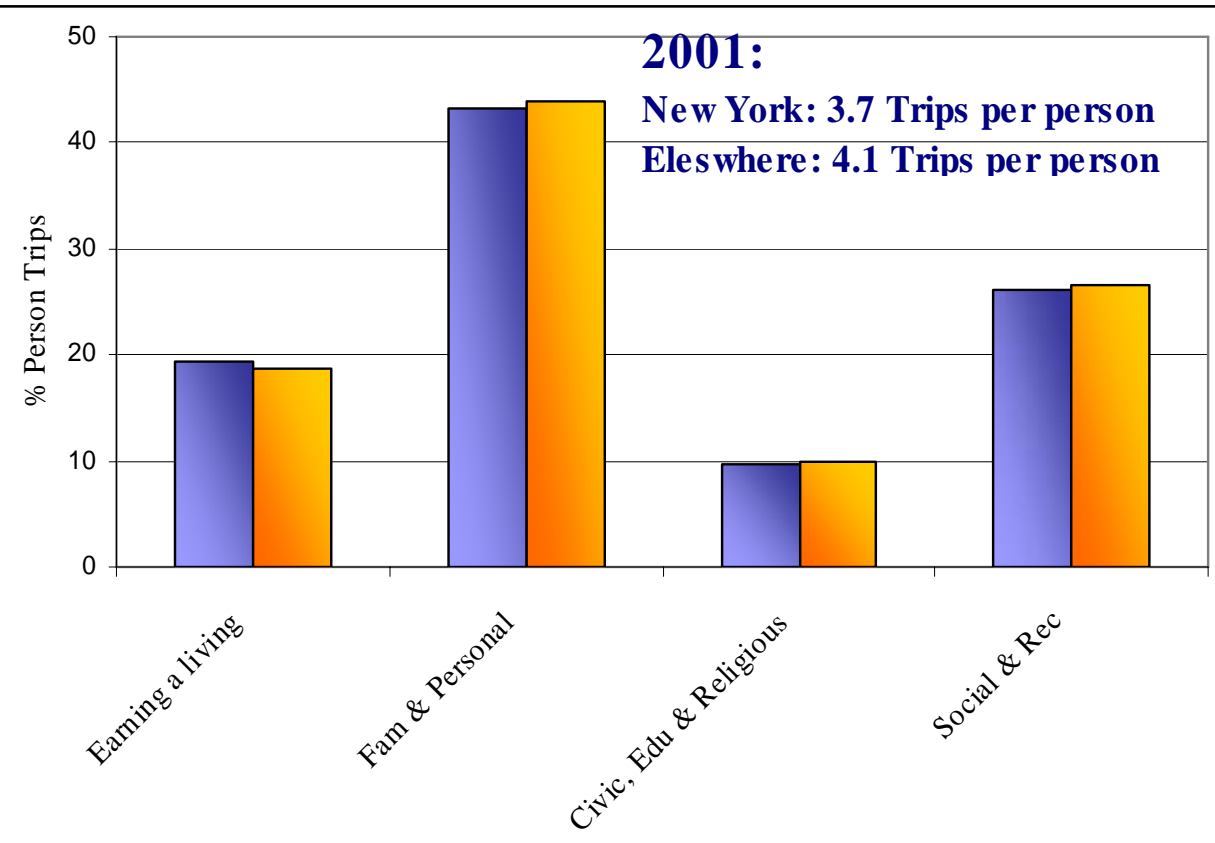

$\square$ New York $\square$ Elsewhere

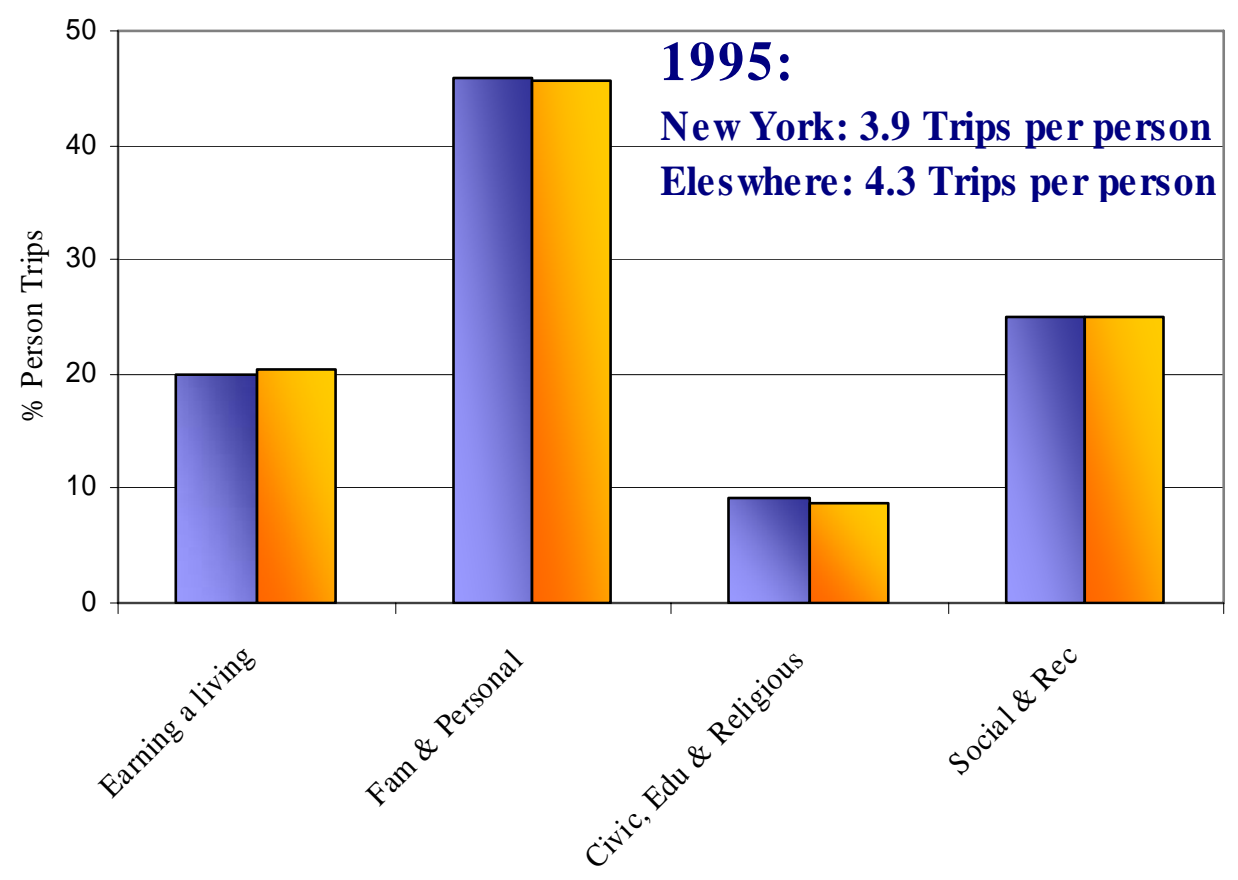


Figure 2.5 Daily Person Miles per Person by Trip Purpose New York State vs. Rest of the United States

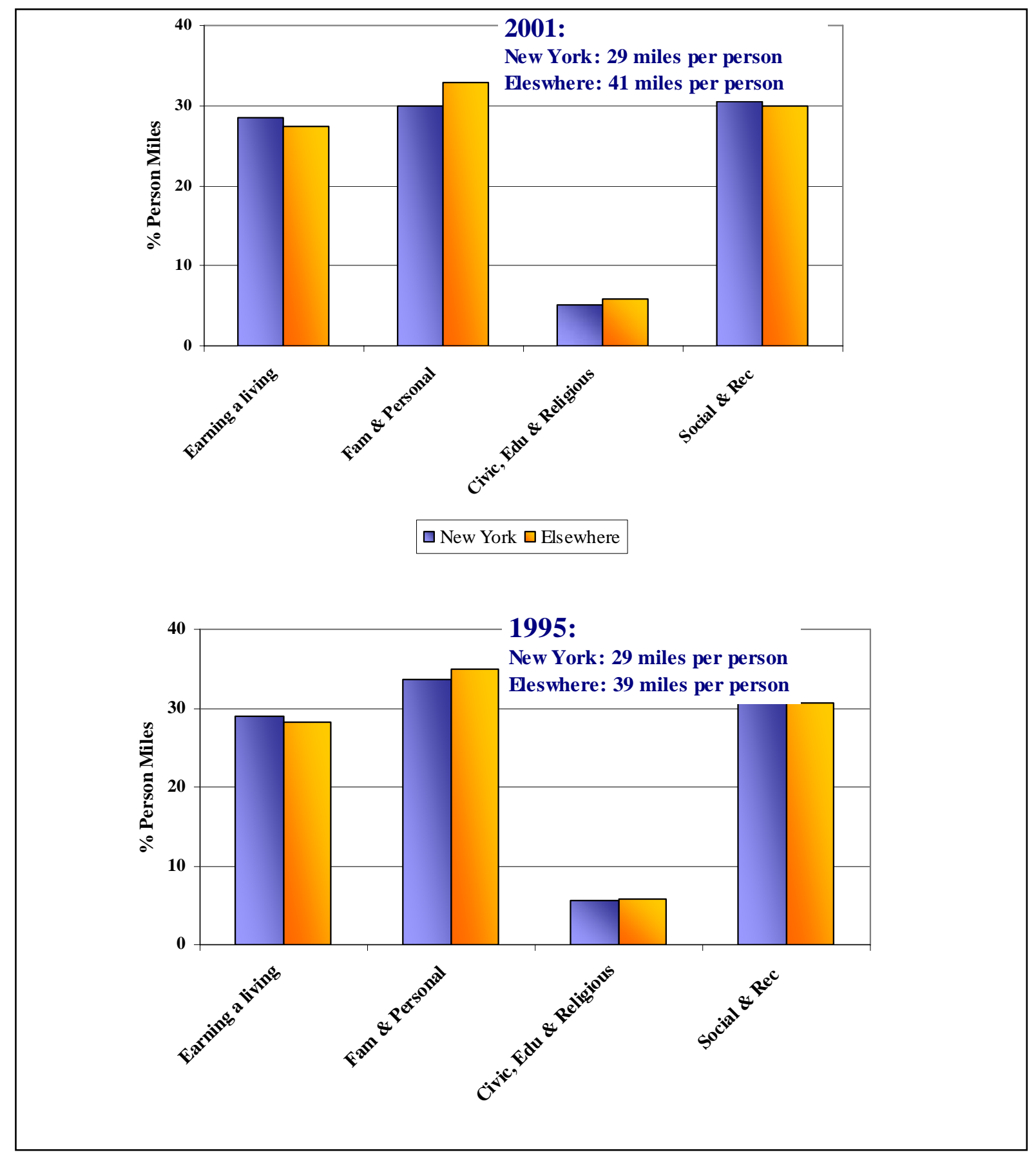




\section{Zero-Vehicle Households}

There is a distinct difference between New York households that do not own vehicles and those elsewhere (Table 2.4). In 2001, more than half of zero-vehicle households outside New York were low income (excluding households without income information), earning less than $\$ 10,000$. However, this was not true in New York. Of households without a vehicle in New York, only $26 \%$ were low income and close to $10 \%$ earned more than $\$ 80,000$ in 2001 . It is obvious that many New York households do not own a vehicle for reasons other than financial factors.

Like other parts of the country, individuals in New York households that do not own a vehicle take fewer trips than those in households that do own a vehicle, 3.21 trips vs. 3.87 trips (Figure 2.6). However, the lack of a vehicle has a greater impact on households outside NYS than those in the state. This observation is evident from the fact that among those without a vehicle, New York residents took 22\% more trips than those elsewhere, 3.21 vs. 2.63 trips, respectively. This is largely the "Manhattan effect" in that the socioeconomic profiles, and thereby the travel patterns, of Manhattan residents who do not own a vehicle are significantly different than those of non-Manhattan residents who do not own a vehicle (see Section 4.5).

Among New Yorkers without a vehicle, the trip propensity was essentially unchanged between 1995 and 2001 (Table 2.4). However, this was not the case elsewhere in the country. Outside NYS, those who did not own a vehicle took 11\% fewer trips in 2001 than in 1995, further deepening the mobility gap due to the lack of a vehicle (Table 2.4 and Figure 2.6).

The difference in mode choice between New York residents and those elsewhere when they do not own a vehicle is quite remarkable, partially reflecting differences in the availability of public transit. While those outside NYS who do not own a vehicle rely heavily on non-public modes to meet their transportation needs, New York residents generally used public transit or walked to places (Figure 2.7). Walking continues to be the most common mode in New York for those who do not own a vehicle, followed closely by public transit. The increased share of walk trips in 2001 is probably an artifact of the improvement in the 2001 survey where special prompting was carried out to better recall walk and bicycle trips. Other than walk trips, there are no noticeable differences between 1995 and 2001. 
Table 2.4 Person Travel of Households Without a Vehicle

New York State vs. Rest of the United States (US)

1995 and 2001

\begin{tabular}{|c|c|c|c|c|c|c|}
\hline & \multicolumn{2}{|c|}{1995} & \multicolumn{2}{|c|}{2001} & \multirow{2}{*}{$\begin{array}{c}\% \\
\text { difference } \\
\text { in NY } \\
\text { between } \\
1995 \text { and } \\
2001 \\
\end{array}$} & \multirow{2}{*}{$\begin{array}{c}\% \\
\text { different } \\
\text { elsewhere } \\
\text { between } \\
1995 \text { and } \\
2001 \\
\end{array}$} \\
\hline & $\begin{array}{l}\text { New York } \\
\text { State }\end{array}$ & $\begin{array}{l}\text { Rest of } \\
\text { US }\end{array}$ & $\begin{array}{l}\text { New } \\
\text { York } \\
\text { State }\end{array}$ & $\begin{array}{c}\text { Rest of } \\
\text { US }\end{array}$ & & \\
\hline $\begin{array}{l}\text { \% Zero-Vehicle HH } \\
\text { by Income }{ }^{\mathrm{a}}\end{array}$ & $26.8 \%$ & $6.9 \%$ & $26.5 \%$ & $6.8 \%$ & & \\
\hline$\%<\$ 10,000$ & 22.8 & 43.2 & 26.1 & 50.4 & & \\
\hline$\% \$ 10$ to $\$ 20,000$ & 23.9 & 32.8 & 23.1 & 26.9 & & \\
\hline$\% \$ 20$ to $\$ 30,000$ & 17.2 & 12.8 & 14.0 & 10.7 & & \\
\hline$\% \$ 30$ to $\$ 40,000$ & 12.2 & 5.2 & 10.3 & 5.3 & & \\
\hline$\% \$ 40$ to $\$ 50,000$ & 8.4 & 2.7 & 8.3 & 3.1 & & \\
\hline$\% \$ 50$ to $\$ 60,000$ & 5.4 & 1.7 & 3.9 & 1.0 & & \\
\hline$\% \$ 60$ to $\$ 70,000$ & 3.0 & 0.8 & 2.5 & 0.4 & & \\
\hline$\% \$ 70$ to $\$ 80,000$ & 1.5 & 0.1 & 2.1 & 0.2 & & \\
\hline$\% \$ 80,000+$ & 5.7 & 0.8 & 9.7 & 2.0 & & \\
\hline $\begin{array}{l}\text { Person Trips } \\
\text { per Person }\end{array}$ & 3.24 & 2.97 & 3.21 & 2.63 & $-0.9 \%$ & $-11.4 \%$ \\
\hline \% Private & 14.8 & 46.5 & 15.5 & 43.6 & & \\
\hline \% Public & 32.1 & 14.5 & 30.8 & 16.7 & & \\
\hline \% Walk & 39.2 & 24.6 & 46.1 & 31.9 & & \\
\hline \% Other & 6.8 & 6.7 & 7.3 & 7.6 & & \\
\hline \% Unreported & 7.1 & 7.7 & 0.2 & 0.1 & & \\
\hline $\begin{array}{l}\text { Person Trips } \\
\text { per Person }\end{array}$ & 3.24 & 2.97 & 3.21 & 2.63 & $-1.0 \%$ & $-11.3 \%$ \\
\hline$<\$ 10,000$ & 2.94 & 2.71 & 2.76 & 2.47 & $-6.2 \%$ & $-8.9 \%$ \\
\hline$\$ 10$ to $\$ 20,000$ & 3.23 & 3.29 & 3.06 & 2.66 & $-5.4 \%$ & $-19.2 \%$ \\
\hline$\$ 20$ to $\$ 30,000$ & 3.36 & 3.74 & 3.27 & 2.76 & $-2.6 \%$ & $-26.3 \%$ \\
\hline$\$ 30$ to $\$ 40,000$ & 3.46 & 3.40 & 3.17 & 3.01 & $-8.3 \%$ & $-11.5 \%$ \\
\hline$\$ 40$ to $\$ 50,000$ & 3.57 & 2.50 & 3.41 & 3.93 & $-4.6 \%$ & $57.2 \%$ \\
\hline$\$ 50$ to $\$ 60,000$ & 3.88 & 2.66 & 5.00 & 3.32 & $28.8 \%$ & $24.9 \%$ \\
\hline$\$ 60$ to $\$ 70,000$ & 4.73 & 4.75 & 3.25 & 4.20 & $-31.3 \%$ & $-11.6 \%$ \\
\hline$\$ 70$ to $\$ 80,000$ & 4.92 & $* *$ & 4.42 & 3.65 & $-10.1 \%$ & $* *$ \\
\hline$\$ 80,000+$ & 3.96 & 5.06 & 4.43 & 4.13 & $12.0 \%$ & $-18.4 \%$ \\
\hline
\end{tabular}

Note:

a 1995 income categories are adjusted to 2001 dollars. 
Figure 2.6 Person Trips Per Person by Vehicle Ownership

New York State vs. Rest of the United States

1995 and 2001

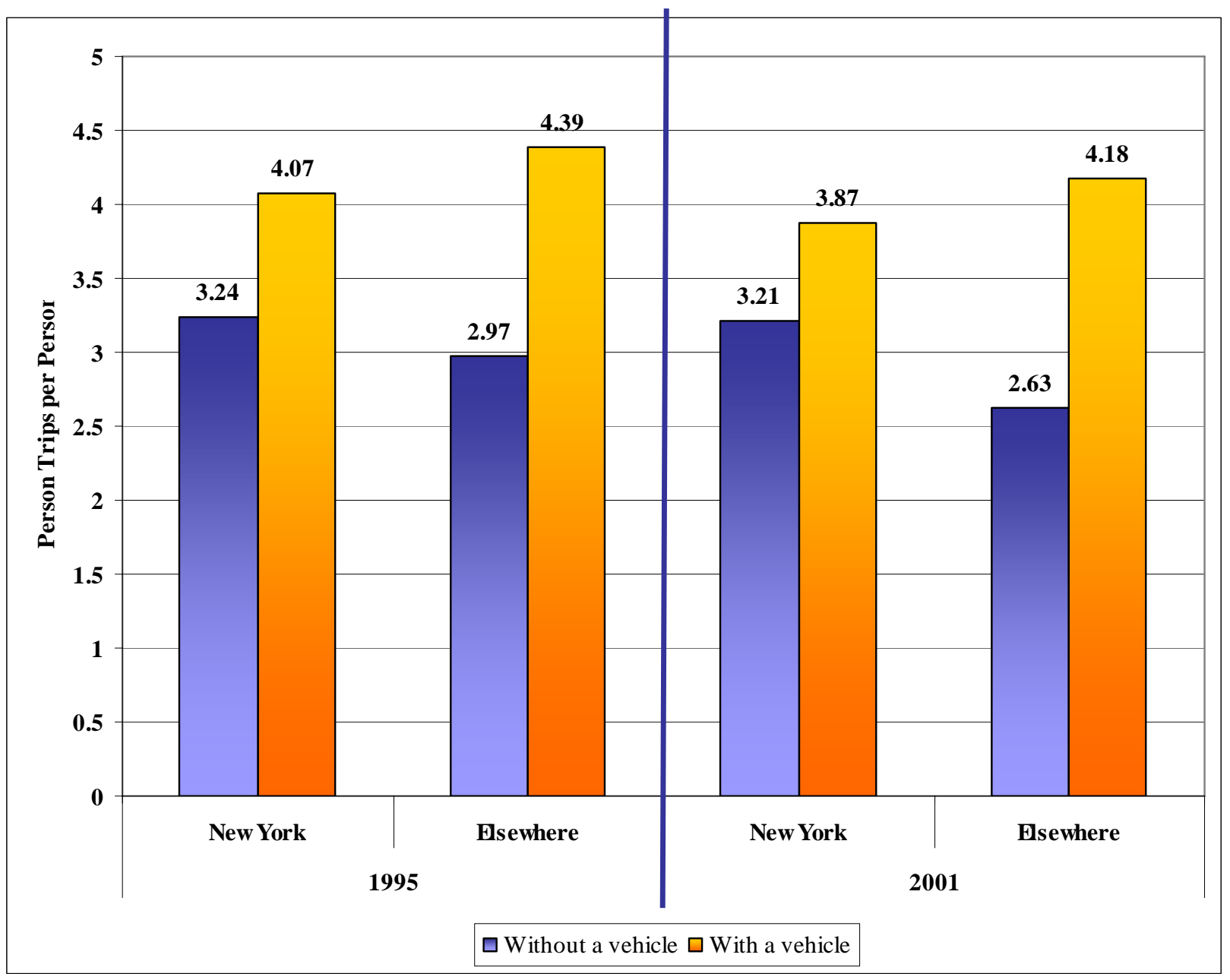


Figure 2.7 Distribution of Person Trips by Selected Mode and Vehicle Ownership New York State vs. Rest of the United States, 1995 vs. 2001
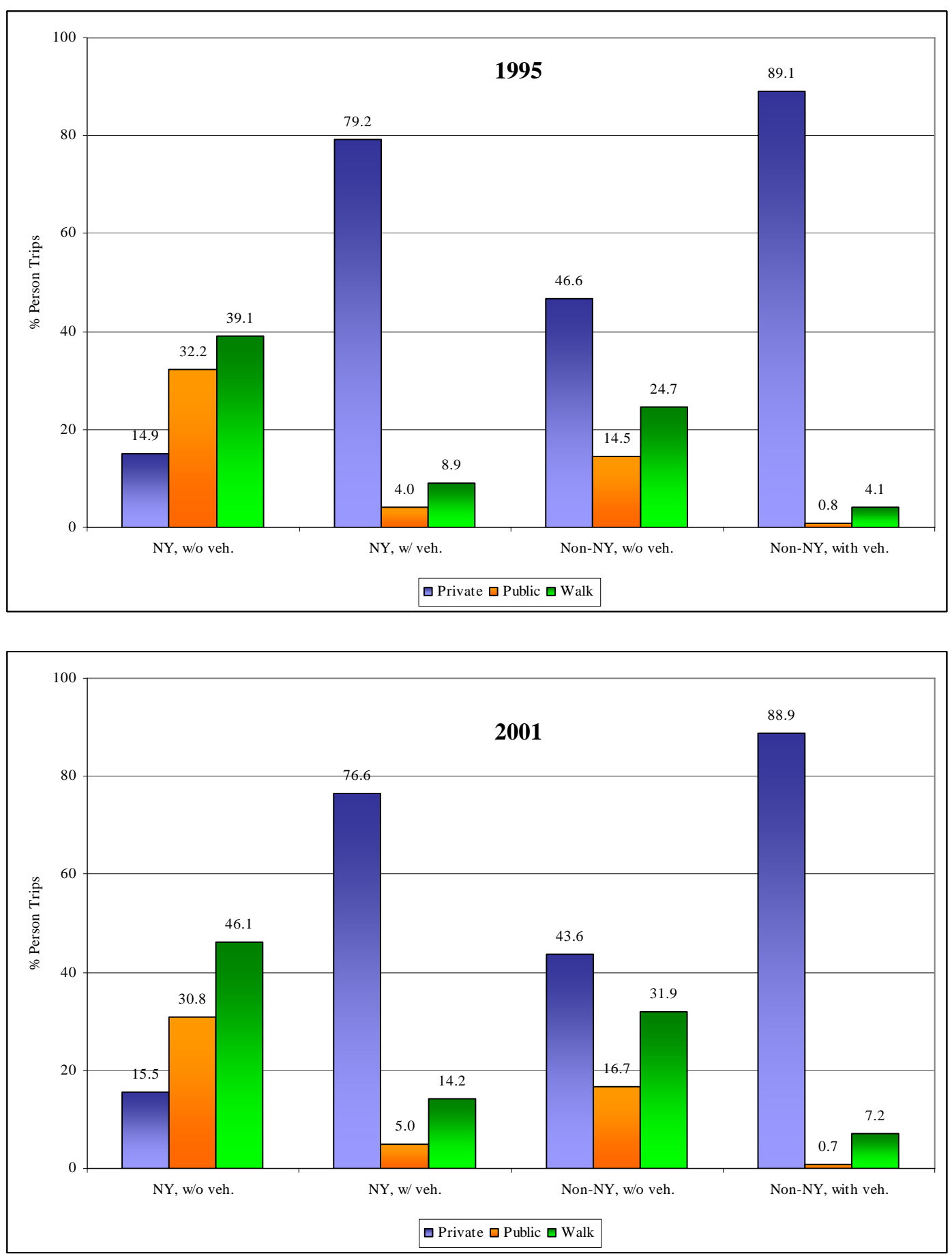

$2-14$ 


\subsection{Vehicle Travel}

Drivers drove fewer but longer trips in 2001 than in 1995. On a daily basis, a New York resident drove on average 20\% fewer trips and almost 10 miles less than others in the United States (Table 2.5). This trend was consistent throughout all age categories and for either gender. Regardless of the location, almost three quarters of the daily vehicle trips were non-work trips. Back in 1995, those in New York drove more on weekend days than on weekdays. However, this trend disappeared in 2001. The weekend driving among New York residents decreased by almost 11\% from 1995 to 2001 (Table 2.5). Consistent with the trends in personal travel, the proportion of travel driven in privately owned vehicles was smaller for those in New York than for others - 46\% vs. 62\%, respectively. This confirms that New York residents rely more heavily on non-private vehicle modes of travel than others do.

\subsection{Commute Patterns}

There is not a notable difference in commute frequency between New York residents and others (Table 2.6). However, how New York residents commute to and from work is significantly different from the rest of the country. The proportion of commute trips by public transit and walking in New York is almost six times that elsewhere, 29\% vs. 5\%. More than three quarters of the commutes in other parts of the country are in single-occupant vehicles while the comparable percentage in New York is 55\%. Regardless of the location, both New York workers and workers elsewhere take statistically fewer commute trips per day in 2001 than in 1995 (Figure 2.8). It is not clear if and how much the event on September 11, 2001 and/or the recession were part of the cause of these decreases.

Although commute distances are slightly shorter in New York than elsewhere, New York workers spent almost 7 minutes more in commuting than those elsewhere. Commute travel time on public transit is more than double that by privately-owned vehicles. This is true nationwide, and since 1995 as well. In 2001, a typical commute trip by public transit in NYS takes almost one hour - an increase of 30\% from 1995 (Table 2.6). Average commute speeds in New York continue to be less than elsewhere. 
Table 2.5 Daily Vehicle Travel Statistics

New York State vs. Rest of the United States (US)

\begin{tabular}{|c|c|c|c|c|c|c|}
\hline & \multicolumn{2}{|c|}{1995} & \multicolumn{2}{|c|}{2001} & \multirow{2}{*}{$\begin{array}{l}\text { \% difference in } \\
\text { New York } \\
\text { Between } 1995 \\
\text { and } 2001 \\
\end{array}$} & \multirow{2}{*}{$\begin{array}{c}\text { \% different } \\
\text { Elsewhere } \\
\text { Between } 1995 \\
\text { and } 2001 \\
\end{array}$} \\
\hline & $\begin{array}{l}\text { New } \\
\text { York } \\
\text { State } \\
\end{array}$ & $\begin{array}{c}\text { Rest of } \\
\text { US }\end{array}$ & $\begin{array}{l}\text { New } \\
\text { York } \\
\text { State } \\
\end{array}$ & $\begin{array}{c}\text { Rest of } \\
\text { US }\end{array}$ & & \\
\hline Vehicle Trips per Driver & 2.88 & 3.61 & 2.67 & 3.40 & $-7.3 \%$ & $-5.8 \%$ \\
\hline \% Earning a Living & 26.7 & 27.4 & 25.5 & 26.2 & & \\
\hline \% Family \& Personal Business & 51.0 & 49.9 & 49.0 & 48.0 & & \\
\hline \% Civic, Ed \& Religious & 3.8 & 4.2 & 4.1 & 4.9 & & \\
\hline \% Social/Recreational & 18.4 & 18.3 & 20.6 & 20.3 & & \\
\hline \% Other & 0.0 & 0.1 & 0.6 & 0.5 & & \\
\hline \% Unreported & & & 0.2 & 0.1 & & \\
\hline Vehicle Trips per Driver & 2.88 & 3.61 & 2.67 & 3.40 & $-7.3 \%$ & $-5.8 \%$ \\
\hline $16-19$ & 2.47 & 3.35 & 2.26 & 2.91 & & \\
\hline $20-34$ & 2.67 & 3.65 & 2.22 & 3.36 & & \\
\hline $35-54$ & 3.12 & 3.90 & 2.98 & 3.77 & & \\
\hline $55-64$ & 2.91 & 3.42 & 2.79 & 3.28 & & \\
\hline$>=65$ & 2.76 & 2.95 & 2.65 & 2.85 & & \\
\hline Vehicle Trips per Driver & 2.88 & 3.61 & 2.67 & 3.40 & $-7.3 \%$ & $-5.8 \%$ \\
\hline Male & 3.08 & 3.82 & 2.79 & 3.61 & $-9.4 \%$ & $-5.5 \%$ \\
\hline Female & 2.67 & 3.40 & 2.55 & 3.19 & $-4.5 \%$ & $-6.2 \%$ \\
\hline VMT per Driver & 25.01 & 32.59 & 23.36 & 33.31 & $-6.6 \%$ & $2.2 \%$ \\
\hline \% Earning a Living & 37.0 & 37.8 & 34.8 & 35.5 & & \\
\hline \% Family \& Personal Business & 35.1 & 35.5 & 34.8 & 35.3 & & \\
\hline \% Civic, Ed \& Religious & 3.8 & 4.2 & 3.3 & 3.8 & & \\
\hline \% Social/Recreational & 24.8 & 22.7 & 26.1 & 24.4 & & \\
\hline \% Other & 0.0 & 0.1 & 0.8 & 0.8 & & \\
\hline \% Unreported & & & 0.3 & 0.2 & & \\
\hline VMT per Driver & 25.01 & 32.59 & 23.36 & 33.31 & $-6.6 \%$ & $2.2 \%$ \\
\hline $16-19$ & 16.20 & 24.10 & 16.17 & 22.57 & $-0.2 \%$ & $-6.3 \%$ \\
\hline $20-34$ & 26.60 & 35.40 & 21.08 & 35.36 & $-20.8 \%$ & $-0.1 \%$ \\
\hline $35-54$ & 27.40 & 36.60 & 27.47 & 38.46 & $0.3 \%$ & $5.1 \%$ \\
\hline $55-64$ & 23.30 & 30.60 & 23.19 & 32.60 & $-0.5 \%$ & $6.5 \%$ \\
\hline$>=65$ & 17.40 & 19.70 & 17.82 & 21.34 & $2.4 \%$ & $8.3 \%$ \\
\hline VMT per Driver & 25.01 & 32.59 & 23.36 & 33.31 & $-6.6 \%$ & $2.2 \%$ \\
\hline Male & 30.80 & 40.60 & 28.58 & 41.63 & $-7.2 \%$ & $2.5 \%$ \\
\hline Female & 18.60 & 24.50 & 17.86 & 25.12 & $-4.0 \%$ & $2.5 \%$ \\
\hline Weekday Vehicle Trips/Driver & 2.85 & 3.70 & 2.68 & 3.46 & $-6.0 \%$ & $-6.5 \%$ \\
\hline Weekend Vehicle Trips/Driver & 3.00 & 3.43 & 2.68 & 3.26 & $-10.7 \%$ & $-5.0 \%$ \\
\hline Average Vehicle Trip Length & 8.78 & 9.07 & 8.92 & 9.91 & $1.6 \%$ & $9.3 \%$ \\
\hline \% Vehicle Trips/Person Trips & $46.3 \%$ & $61.6 \%$ & $45.9 \%$ & $61.6 \%$ & & \\
\hline \% VMT/PMT & $54.0 \%$ & $61.0 \%$ & $51.0 \%$ & $60.6 \%$ & & \\
\hline
\end{tabular}


Table 2.6 Commute Statistics

New York State vs. Rest of the United States (US)

\begin{tabular}{|c|c|c|c|c|c|c|}
\hline & \multicolumn{2}{|c|}{1995} & \multicolumn{2}{|c|}{2001} & \multirow{2}{*}{$\begin{array}{l}\text { \% difference } \\
\text { in New York } \\
\text { Between } 1995 \\
\text { and } 2001\end{array}$} & \multirow{2}{*}{$\begin{array}{l}\text { \% different } \\
\text { Elsewhere } \\
\text { Between } 1995 \\
\text { and } 2001\end{array}$} \\
\hline & $\begin{array}{l}\text { New } \\
\text { York } \\
\text { State }\end{array}$ & $\begin{array}{l}\text { Rest of } \\
\text { US }\end{array}$ & $\begin{array}{l}\text { New } \\
\text { York } \\
\text { State }\end{array}$ & $\begin{array}{l}\text { Rest of } \\
\text { US }\end{array}$ & & \\
\hline $\begin{array}{l}\text { Commute Person Trips per } \\
\text { Worker }\end{array}$ & 1.31 & 1.40 & 1.12 & 1.15 & $-14.5 \%$ & $-17.9 \%$ \\
\hline$\% \mathrm{SOV}$ & 56.5 & 75.7 & 55.3 & 77.7 & & \\
\hline$\% \mathrm{MOV}$ & 13.0 & 16.4 & 12.6 & 16.4 & & \\
\hline \% Other POV & 0.0 & 0.0 & & & & \\
\hline$\%$ Amtrak & 0.0 & 0.0 & 0.7 & 0.1 & & \\
\hline \% Commuter Train & 3.1 & 0.7 & 1.8 & 0.3 & & \\
\hline \% Subway/Elevated Rail & 9.9 & 0.7 & 12.8 & 0.5 & & \\
\hline \% Other Public & 5.3 & 1.4 & 5.5 & 1.6 & & \\
\hline \% Walk & 6.1 & 2.1 & 8.7 & 2.4 & & \\
\hline \% Other & 2.3 & 1.4 & 2.4 & 0.9 & & \\
\hline \% Unreported & 3.8 & 1.6 & 0.1 & 0.1 & & \\
\hline Commute PMT per Worker & 13.97 & 16.08 & 10.79 & 13.78 & $-22.8 \%$ & $-14.3 \%$ \\
\hline \% SOV & 62.5 & 76.8 & 64.7 & 77.7 & & \\
\hline$\% \mathrm{MOV}$ & 15.0 & 17.2 & 12.8 & 16.1 & & \\
\hline \% Other POV & 0.1 & 0.1 & & & & \\
\hline \% Amtrak & 0.0 & 0.1 & 1.0 & 0.3 & & \\
\hline \% Commuter Train & 5.9 & 0.7 & 4.5 & 0.7 & & \\
\hline \% Subway/Elevated Rail & 8.4 & 0.4 & 10.9 & 0.5 & & \\
\hline \% Other Public & 3.7 & 1.5 & 2.7 & 1.0 & & \\
\hline \% Walk & 0.6 & 0.1 & 1.1 & 0.2 & & \\
\hline \% Other & 3.1 & 2.2 & 2.1 & 3.5 & & \\
\hline \% Unreported & 0.7 & 0.9 & 0.2 & 0.1 & & \\
\hline $\begin{array}{l}\text { Commute Trip Distance } \\
\text { (miles) }\end{array}$ & 11.29 & 11.65 & 10.39 & 12.22 & $-8.0 \%$ & $4.9 \%$ \\
\hline POV & 12.15 & 11.82 & 11.31 & 12.13 & $-6.9 \%$ & $2.6 \%$ \\
\hline Public Transit & 12.6 & 13 & 11.32 & 11.94 & $-10.2 \%$ & $-8.2 \%$ \\
\hline $\begin{array}{l}\text { Commute Travel Time } \\
\text { (minutes) }^{a}\end{array}$ & 25.66 & 20.23 & 30.40 & 23.11 & $18.5 \%$ & $14.2 \%$ \\
\hline POV & 22.57 & 19.97 & 23.87 & 22.42 & $5.8 \%$ & $12.3 \%$ \\
\hline Public Transit & 44.32 & 39.94 & 57.79 & 54.18 & $30.4 \%$ & $35.7 \%$ \\
\hline Commute Trip Speed (mph) & 28.83 & 35.00 & 26.40 & 32.82 & $-8.4 \%$ & $-6.2 \%$ \\
\hline POV & 32.28 & 35.53 & 28.49 & 32.51 & $-11.7 \%$ & $-8.5 \%$ \\
\hline Public Transit $^{\mathrm{b}}$ & 15.82 & 21.1 & & & & \\
\hline
\end{tabular}

Note:

$\frac{\text { a } \text { The }}{2001}$ survey did not collect data on the time taken to wait for the transportation. Therefore, the 1995 statistics were recalculated to be compatible with the 2001 statistics.

b Average commute speeds do not include any segmented trips, which are defined in the 2001 survey as trips with public transit as a segment of the trip. 
Figure 2.8 Daily Commute Trips per Worker by Mode New York State vs. Rest of the United States

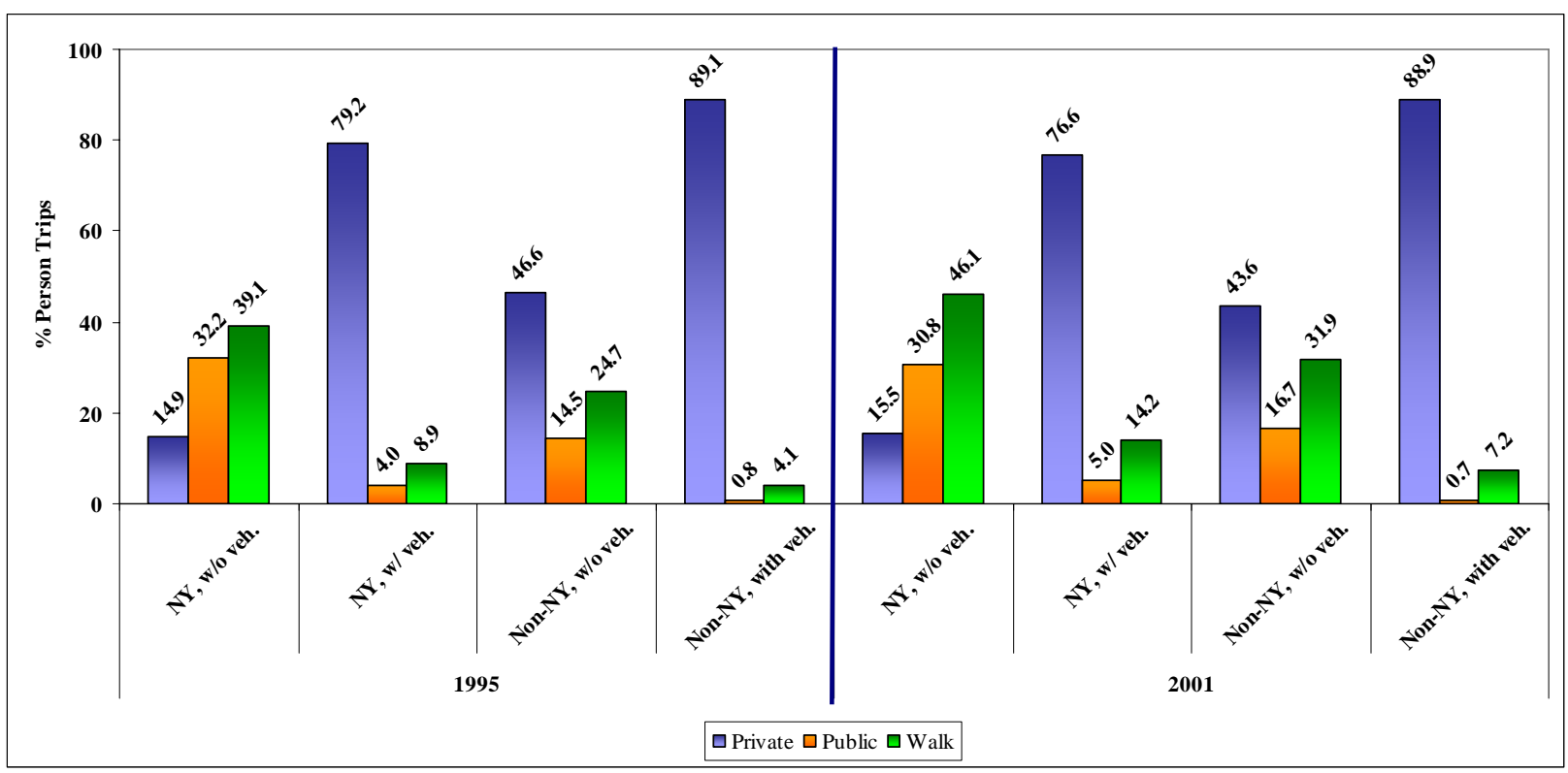




\section{Chapter 3. Influence of NY Metropolitan Data on the Overall New York Travel Patterns}

It is apparent from the analysis results in Chapter 2 that travel patterns of NYS residents are different from those elsewhere in the United States with respect to trip frequency, driving, and mode choice. The next logical question is whether travel patterns by residents in the New York metropolitan area are so atypical that they sway the travel characteristics of NYS away from the national averages. NYC is distinctly different from other areas of NYS in terms of public transit and land use, and accounts for a substantial share of NYS's population. This chapter examines the influence of NYC on the comparisons of the state of New York to the rest of the country.

\subsection{Profile of New York City Households}

The NYC consists of five boroughs: Bronx, Kings (Brooklyn), New York (Manhattan), Queens, and Richmond (Staten Island). Although small in land area (Figure 3.1), it accounts for 42\% (Appendix C, Chapter 3, Table 1) of the total population in NYS. However, $17 \%$ of the households interviewed for the 2001 NHTS New York add-on survey were residents of NYC. While NYC accounts from about $40 \%$ of the total households, total population, and total workers in NYS, it only accounts for 33\% of the total NYS drivers (Figure 3.2). Furthermore, eight out of ten New York households without a vehicle live in NYC (Figure 3.2).

A greater percentage of NYC households are below the poverty level than the rest of NYS households and households in other parts of the country (Table 3.1). Without the NYC households, the rest of NYS resembles households elsewhere in terms of vehicle ownership. More than nine-tenths of the households own at least one vehicle. By contrast, one in two households in NYC do not own a vehicle (Table 3.1). Even for households that own a vehicle, NYC households are far less likely to own more than one vehicle than other NYS households and households elsewhere (Figure 3.3). In general, vehicle ownership patterns among NYC households are quite different from those elsewhere. On the other hand, NYS households outside NYC are virtually identical to those in other parts of the country with respect to vehicle ownership patterns. 
Figure 3.1 New York NHTS Primary Sampling Areas

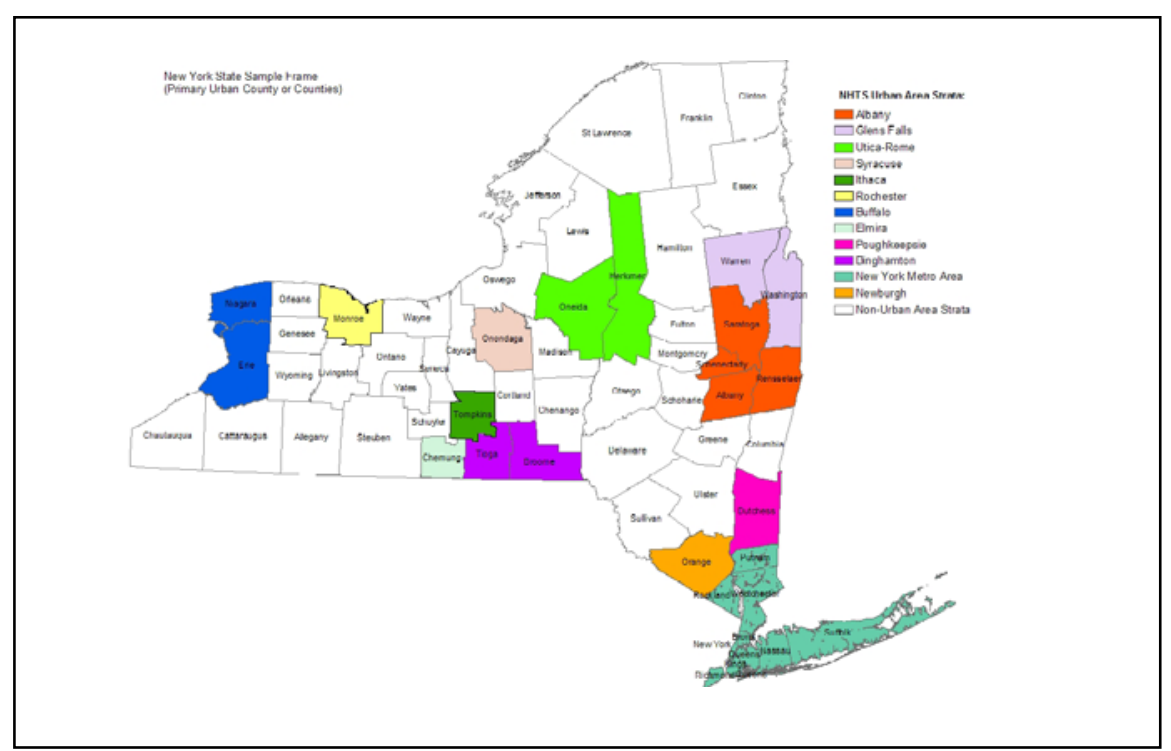

Figure 3.2 Profile of New York City Households, 2001

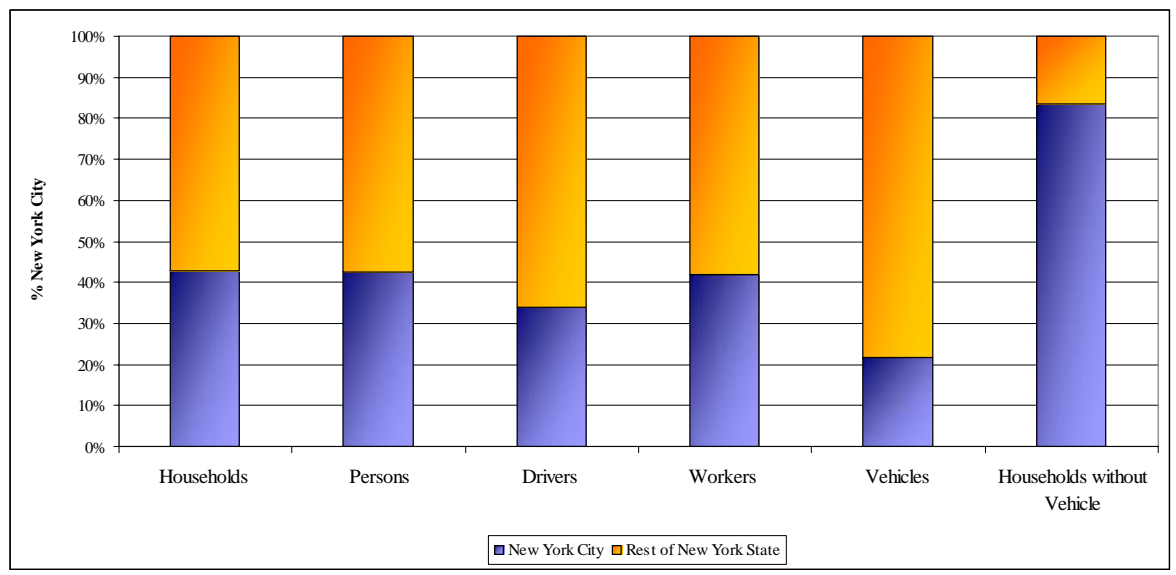

Source: Appendix C, Chapter 3, Table 1 
Table 3.1 Household Characteristics and Vehicle Ownership Patterns New York City, Rest of New York State, and Rest of the United States (US) 1995 and $2001^{a}$

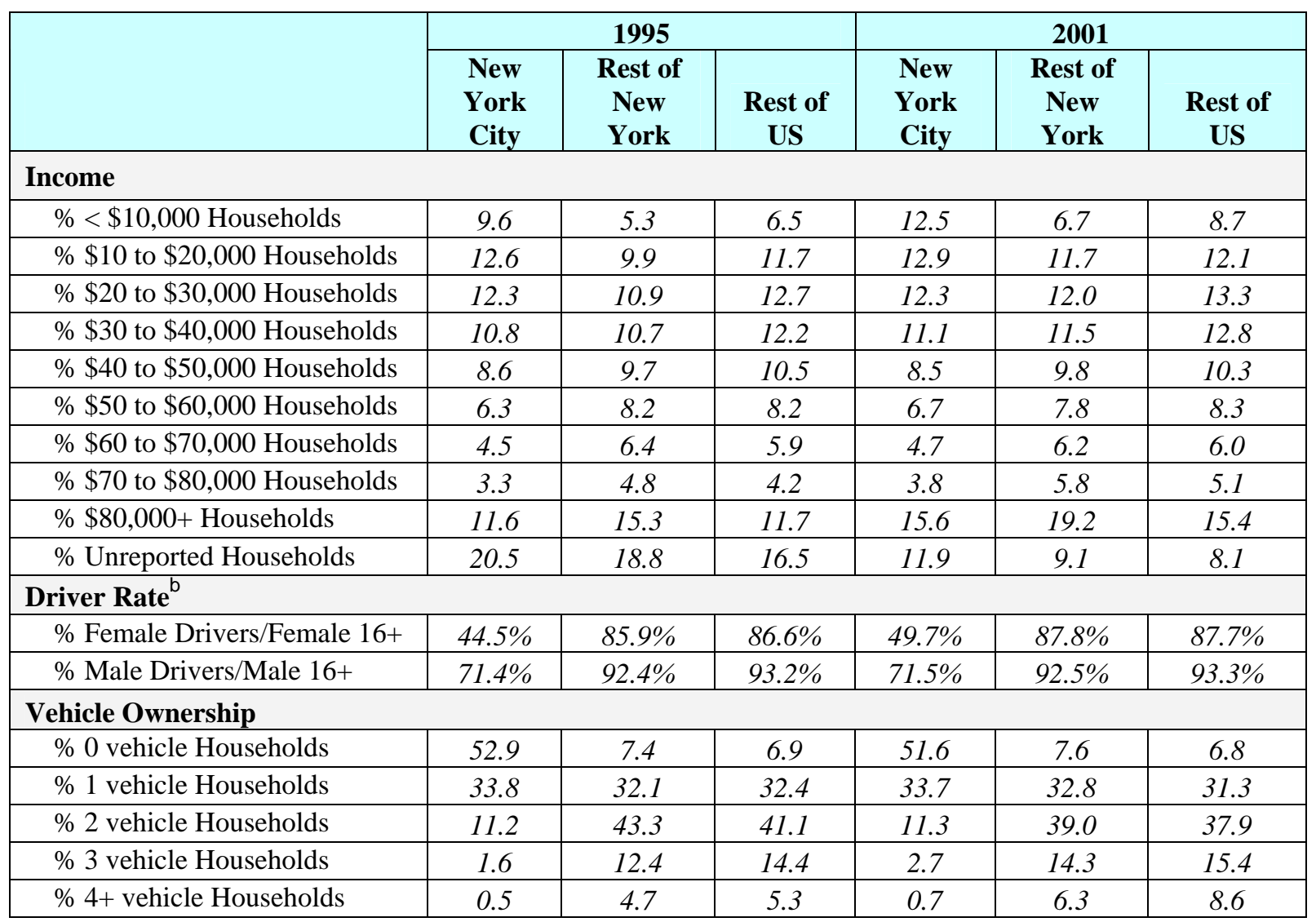

Note:

$\frac{1}{a}$ All percents may not add to $100 \%$ due to rounding.

b The driver rate is computed using the self-reported response to the survey question “Are you a driver?” and should not be compared to the NYS DOT licensing statistics. 
Figure 3.3 Distribution of Households with Vehicles by Number of Vehicles New York City, Remainder of New York State, and Outside New York State

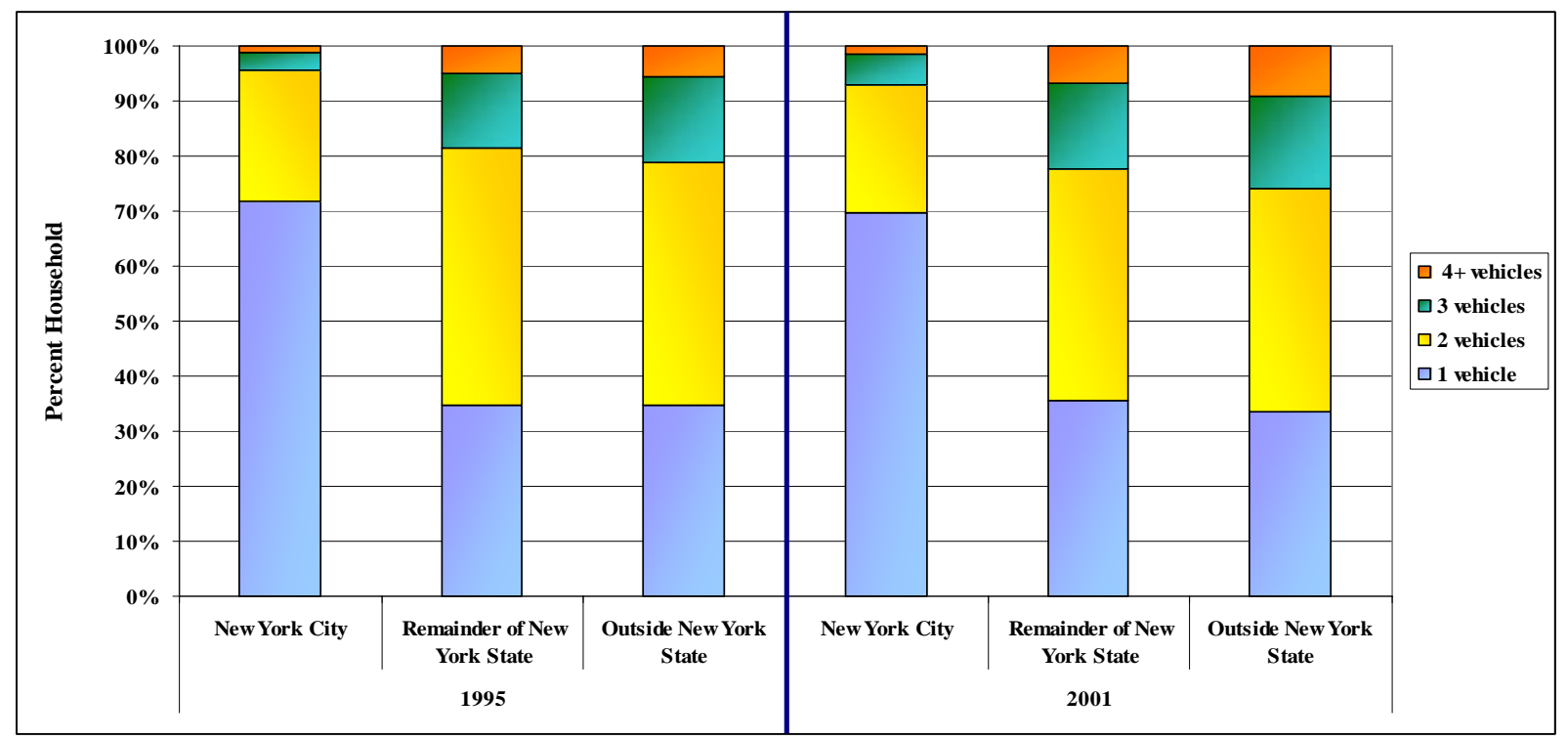

Source: Table 3.1 - Distribution computed for households with one or more vehicle only.

Similarly, without the NYC households, the percentage of the population that is reported as a driver is almost identical between the rest of the NYS and households outside NYS ${ }^{3}$. One in every two NYC women is reported as a driver while more than four in every five women elsewhere are reported as drivers. Although the driver rate of NYC men is closer to the national average than that of NYC women, it is still 20 percent less.

\footnotetext{
${ }^{3}$ In the NHTS survey, the respondents were asked for their driver status (i.e., “Are you a driver?”), rather than license status. Therefore, the driver rate reported in this report refers to the percentage of New York residents who state that they are drivers, and should not be compared to driver license rates maintained by New York Department of Motor Vehicles.
} 


\subsection{Personal Travel}

Although residents in NYS took on average fewer trips than others in the United States, the difference from the national average is more pronounced for NYC residents than for New Yorkers elsewhere (Tables 3.2a and 3.2b). Regardless of the location, people took fewer but longer trips in 2001 than in 1995 (Tables 3.2a and 3.2b). The reasons why people travel are relatively similar across geographic regions. However, how people in NYC get to places is very different from those elsewhere (Figure 3.4). The propensity to walk to places increased significantly from 1995 to 2001. However, it is important to point out that this increase could be an artifact of the improved survey approach in 2001. The similarity in mode choice among New York residents outside NYC and the rest of the country is obvious.

There were no documented changes in survey protocols that could explain the shift by NYC residents from commuter train to subway, from $2.5 \%$ of trips taken by commuter trains in 1995 to $0.4 \%$ in 2001 (Table 3.2a). However, this shift could be attributable to the transitfavorable changes in fare cards and transfer fees implemented between 1995 and 2001. 
Table 3.2a Person Trip Statistics by Mode of Transportation and Trip Purpose New York City, Remainder of New York State, and Outside New York State ${ }^{a}$

\begin{tabular}{|c|c|c|c|c|c|c|c|c|c|}
\hline & \multicolumn{3}{|c|}{1995} & \multicolumn{3}{|c|}{2001} & \multirow[b]{2}{*}{$\begin{array}{l}\text { \% difference } \\
\text { in New York } \\
\text { City between } \\
1995 \text { \& } 2001 \\
\end{array}$} & \multirow[b]{2}{*}{$\begin{array}{l}\text { \% difference } \\
\text { in Rest of } \\
\text { New York } \\
\text { State between } \\
1995 \text { \& } 2001 \\
\end{array}$} & \multirow[b]{2}{*}{$\begin{array}{c}\text { \% difference } \\
\text { in Elsewhere } \\
\text { between } \\
1995 \& 2001\end{array}$} \\
\hline & $\begin{array}{l}\text { New } \\
\text { York } \\
\text { City }\end{array}$ & $\begin{array}{c}\text { Remainder } \\
\text { of New } \\
\text { York State }\end{array}$ & $\begin{array}{c}\text { Outside } \\
\text { New } \\
\text { York } \\
\text { State }\end{array}$ & $\begin{array}{l}\text { New } \\
\text { York } \\
\text { City }\end{array}$ & $\begin{array}{c}\text { Remainder } \\
\text { of New } \\
\text { York State }\end{array}$ & $\begin{array}{c}\text { Outside } \\
\text { New } \\
\text { York } \\
\text { State }\end{array}$ & & & \\
\hline Person Trips per Person & 3.58 & 4.08 & 4.33 & 3.44 & 3.95 & 4.11 & $-3.9 \%$ & $-3.2 \%$ & $-5.1 \%$ \\
\hline \% SOV & 14.0 & 42.4 & 42.5 & 14.1 & 40.8 & 40.3 & & & \\
\hline$\% \mathrm{MOV}$ & 21.8 & 43.1 & 45.0 & 21.9 & 44.1 & 47.3 & & & \\
\hline \% Other POV & 0.0 & 0.0 & 0.0 & & & & & & \\
\hline \% Amtrak & 0.0 & 0.0 & 0.0 & 0.4 & 0.1 & 0.0 & & & \\
\hline \% Commuter Train & 2.5 & 0.5 & 0.0 & 0.4 & 0.4 & 0.1 & & & \\
\hline \% Subway & 10.3 & 0.2 & 0.2 & 13.0 & 0.3 & 0.2 & & & \\
\hline \% Other Public Transit & 9.2 & 1.0 & 0.9 & 8.7 & 0.6 & 0.8 & & & \\
\hline \% Walk & 31.0 & 4.9 & 4.8 & 36.8 & 9.1 & 7.9 & & & \\
\hline \% Other & 5.0 & 4.2 & 3.0 & 4.6 & 4.6 & 3.3 & & & \\
\hline \% Unreported & 6.1 & 3.7 & 3.5 & 0.1 & 0.1 & 0.1 & & & \\
\hline Person Trips per Person & 3.58 & 4.08 & 4.33 & 3.44 & 3.95 & 4.11 & & & \\
\hline \% Earning a Living & 19.6 & 20.0 & 20.3 & 20.1 & 18.8 & 18.8 & & & \\
\hline \% Family and Personal & 45.8 & 45.9 & 45.7 & 42.7 & 43.7 & 43.9 & & & \\
\hline \% Civic, Ed, and Religious & 10.6 & 8.5 & 8.8 & 11.1 & 8.8 & 9.8 & & & \\
\hline \% Social \& Recreational & 24.0 & 25.4 & 24.9 & 24.6 & 27.3 & 26.6 & & & \\
\hline \% Other & 0.0 & 0.2 & 0.2 & 1.3 & 1.1 & 0.8 & & & \\
\hline \% Unreported & & & & 0.3 & 0.3 & 0.1 & & & \\
\hline Weekday Person Trips/Person & 3.45 & 3.96 & 4.25 & 3.41 & 3.84 & 4.00 & $-1.2 \%$ & $-3.0 \%$ & $-5.9 \%$ \\
\hline Weekend Person Trips/Person & 3.94 & 4.44 & 4.55 & 3.53 & 4.26 & 4.44 & $-10.4 \%$ & $-4.1 \%$ & $-2.4 \%$ \\
\hline
\end{tabular}

Note:

a All percents may not add to $100 \%$ due to rounding. 
Table 3.2b Person Miles Travel Statistics by Mode of Transportation and Trip Purpose New York City, Remainder of New York State, and Outside New York State

\begin{tabular}{|c|c|c|c|c|c|c|c|c|c|}
\hline & \multicolumn{3}{|c|}{1995} & \multicolumn{3}{|c|}{2001} & \multirow[b]{2}{*}{$\begin{array}{l}\text { \% difference } \\
\text { in New York } \\
\text { City between } \\
1995 \text { \& } 2001\end{array}$} & \multirow{2}{*}{$\begin{array}{c}\text { \% difference } \\
\text { in Rest of } \\
\text { New York } \\
\text { State } \\
\text { between } \\
1995 \text { \& } 2001\end{array}$} & \multirow[b]{2}{*}{$\begin{array}{c}\text { \% difference } \\
\text { in Elsewhere } \\
\text { between } 1995 \\
\text { \& } 2001\end{array}$} \\
\hline & $\begin{array}{l}\text { New } \\
\text { York } \\
\text { City } \\
\end{array}$ & $\begin{array}{c}\text { Remainder } \\
\text { of New } \\
\text { York State }\end{array}$ & $\begin{array}{c}\text { Outside } \\
\text { New York } \\
\text { State }\end{array}$ & $\begin{array}{l}\text { New } \\
\text { York } \\
\text { City }\end{array}$ & $\begin{array}{c}\text { Remainder } \\
\text { of New } \\
\text { York State }\end{array}$ & $\begin{array}{c}\text { Outside } \\
\text { New } \\
\text { York } \\
\text { State } \\
\end{array}$ & & & \\
\hline PMT per Person & 19.08 & 35.50 & 39.40 & 21.11 & 35.60 & 41.03 & $10.6 \%$ & $0.3 \%$ & $4.1 \%$ \\
\hline$\% \mathrm{SOV}$ & 20.5 & 39.6 & 40.4 & 16.5 & 38.6 & 37.6 & & & \\
\hline$\% \mathrm{MOV}$ & 38.9 & 51.5 & 51.1 & 28.2 & 49.5 & 51.3 & & & \\
\hline \% Other POV & 0.3 & 0.0 & 0.1 & & & & & & \\
\hline \% Amtrak & 0.3 & 0.3 & 0.0 & 1.0 & 0.4 & 0.1 & & & \\
\hline \% Commuter Train & 5.0 & 1.6 & 0.3 & 0.6 & 1.3 & 0.2 & & & \\
\hline \% Subway & 14.8 & 0.3 & 0.2 & 14.2 & 0.4 & 0.1 & & & \\
\hline \% Other Public Transit & 9.2 & 2.0 & 1.3 & 5.4 & 0.4 & 0.5 & & & \\
\hline \% Walk & 3.5 & 0.3 & 0.3 & 3.9 & 0.8 & 0.6 & & & \\
\hline \% Other & 6.6 & 3.3 & 5.4 & 29.1 & 8.1 & 9.3 & & & \\
\hline \% Unreported & 0.8 & 1.0 & 1.0 & 0.9 & 0.4 & 0.5 & & & \\
\hline PMT per Person & 19.08 & 35.50 & 39.40 & 21.11 & 35.60 & 41.03 & & & \\
\hline \% Earning a Living & 31.2 & 28.2 & 28.2 & 34.2 & 25.9 & 27.5 & & & \\
\hline \% Family and Personal & 32.2 & 34.2 & 35.0 & 23.6 & 32.9 & 32.9 & & & \\
\hline \% Civic, Ed, and Religious & 6.7 & 5.1 & 5.7 & 5.3 & 5.1 & 5.9 & & & \\
\hline \% Social \& Recreational & 30.0 & 32.2 & 30.6 & 24.3 & 33.3 & 30.0 & & & \\
\hline \% Other & 0.0 & 0.3 & 0.4 & 9.1 & 2.4 & 3.4 & & & \\
\hline \% Unreported & & & & 3.6 & 0.5 & 0.3 & & & \\
\hline Average Person Trip Length ${ }^{a}$ & 5.74 & 8.86 & 9.23 & 6.82 & 9.18 & 10.14 & $18.8 \%$ & $3.6 \%$ & $9.9 \%$ \\
\hline
\end{tabular}

Note:

a Average trip length is calculated using only those records with trip mileage information present. 
Figure 3.4 Person Trip Distribution by Selected Mode, New York City, Remainder of New York State, and Outside New York State

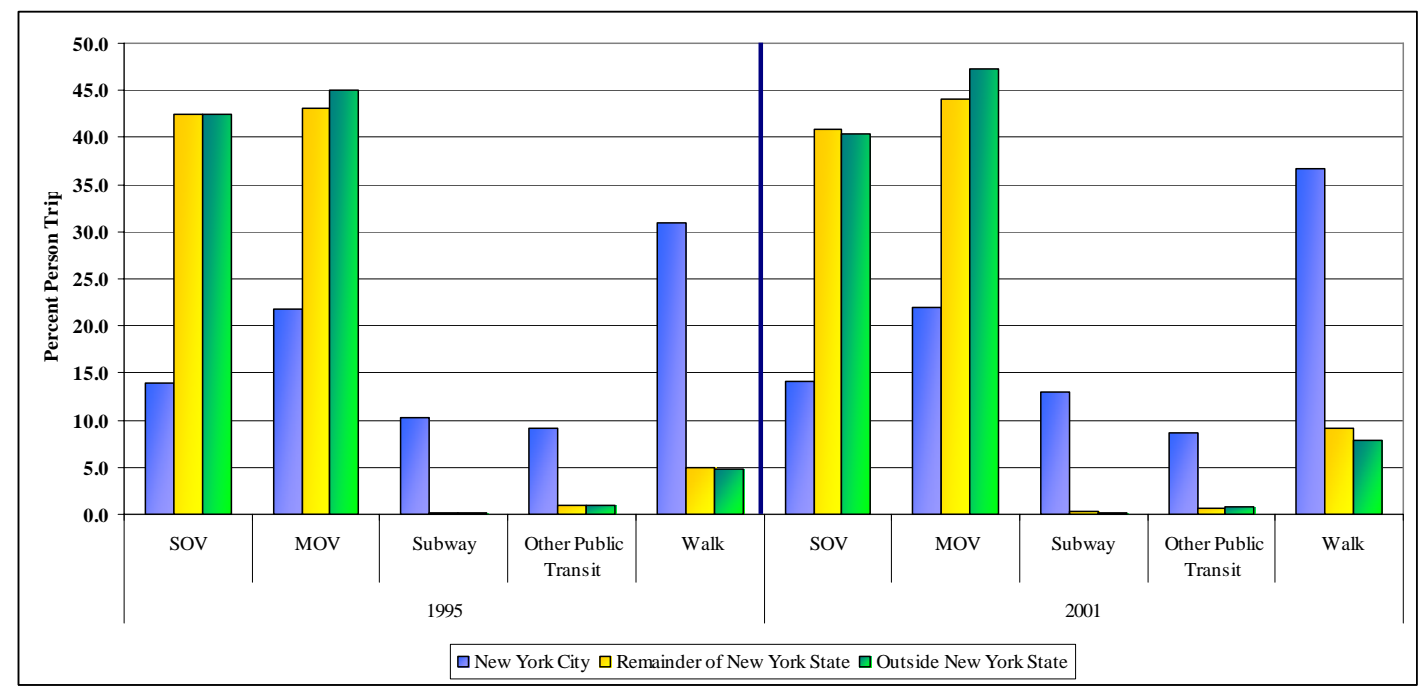

Source: Table 3.2a.

Residents in NYC not only take fewer trips, their trips are considerably shorter than others in other parts of NYS and in the rest of the United States The difference is more than 2 miles per trip on average (Tables 3.2a and 3.2b). This difference of two miles in trip length is largely due to the predominance of walking trips in NYC compared to the rest of NYS, 37\% vs. 9\%. Consequently, the average person-miles traveled per resident in NYC is at least $40 \%$ less than others. Although trips taken by NYC residents, on average, are still shorter than those taken by people elsewhere, NYC residents' trips are almost 20\% longer in 2001, increasing from 5.7 miles per trip on average in 1995 to 6.8 miles in 2001.

The gender differences in both trip frequency and travel distance are small across regions (Table 3.3). However, the age impact on the number of miles traveled is certainly noticeable. Across all age categories, residents in NYC traveled considerably fewer miles than their similarly aged counterparts elsewhere (Figure 3.5). The differences are particularly obvious in the younger and the older groups. However, the difference between those in NYC between the ages of 20 and 34 and those elsewhere narrowed in 2001. In 2001, NYC residents 65 years or older traveled on average only 10 miles per day, compared to 25 miles in other parts of NYS and 26 miles elsewhere of the country. These differences were unchanged from 1995. 
Table 3.3 Daily Personal Travel Statistics by Demographics

New York City, Remainder of New York State, and Outside New York State

\begin{tabular}{|c|c|c|c|c|c|c|c|c|c|}
\hline & \multicolumn{3}{|c|}{1995} & \multicolumn{3}{|c|}{2001} & \multirow[b]{2}{*}{$\begin{array}{c}\text { \% difference } \\
\text { in New York } \\
\text { City between } \\
1995 \text { and } \\
2001\end{array}$} & \multirow[b]{2}{*}{$\begin{array}{l}\text { \% difference in } \\
\text { Rest of New } \\
\text { York State } \\
\text { between } 1995 \\
\text { and } 2001\end{array}$} & \multirow[b]{2}{*}{$\begin{array}{c}\% \text { difference } \\
\text { in Elsewhere } \\
\text { between } 1995 \\
\text { and } 2001 \\
\end{array}$} \\
\hline & $\begin{array}{l}\text { New } \\
\text { York } \\
\text { City } \\
\end{array}$ & $\begin{array}{c}\text { Remainder } \\
\text { of New } \\
\text { York State }\end{array}$ & $\begin{array}{c}\text { Outside } \\
\text { New } \\
\text { York } \\
\text { State } \\
\end{array}$ & $\begin{array}{l}\text { New } \\
\text { York } \\
\text { City } \\
\end{array}$ & $\begin{array}{c}\text { Remainder } \\
\text { of New } \\
\text { York State }\end{array}$ & $\begin{array}{c}\text { Outside } \\
\text { New } \\
\text { York } \\
\text { State } \\
\end{array}$ & & & \\
\hline Person Trips per Person & 3.58 & 4.08 & 4.33 & 3.44 & 3.95 & 4.11 & $-3.9 \%$ & $-3.2 \%$ & $-5.1 \%$ \\
\hline Male & 3.63 & 4.12 & 4.36 & 3.54 & 3.93 & 4.11 & $-2.5 \%$ & $-4.6 \%$ & $-5.7 \%$ \\
\hline Female & 3.54 & 4.05 & 4.30 & 3.35 & 3.97 & 4.12 & $-5.4 \%$ & $-2.0 \%$ & $-4.2 \%$ \\
\hline Person Trips per Person & 3.58 & 4.08 & 4.33 & 3.44 & 3.95 & 4.11 & & & \\
\hline $0-4$ years & & & & 2.67 & 2.61 & 3.22 & & & \\
\hline $5-15$ years & 3.09 & 3.44 & 3.73 & 2.71 & 3.21 & 3.46 & & & \\
\hline 16-19 years & 3.18 & 4.22 & 4.69 & 3.08 & 3.97 & 4.19 & & & \\
\hline 20-34 years & 3.96 & 4.29 & 4.67 & 3.77 & 3.98 & 4.30 & & & \\
\hline $35-54$ years & 3.84 & 4.55 & 4.75 & 3.89 & 4.47 & 4.64 & & & \\
\hline $55-64$ years & 3.28 & 4.15 & 4.19 & 3.66 & 4.18 & 4.13 & & & \\
\hline $65+$ years & 2.95 & 3.46 & 3.44 & 2.57 & 3.56 & 3.43 & & & \\
\hline PMT per Person & 19.08 & 35.50 & 39.40 & 21.11 & 35.60 & 41.03 & & & \\
\hline Male & 21.54 & 39.69 & 44.70 & 25.92 & 39.66 & 45.84 & $20.3 \%$ & $-0.1 \%$ & $2.6 \%$ \\
\hline Female & 16.91 & 31.41 & 34.38 & 16.88 & 31.82 & 36.47 & $-0.2 \%$ & $1.3 \%$ & $6.1 \%$ \\
\hline PMT per Person & 19.08 & 35.50 & 39.40 & 21.11 & 35.60 & 41.03 & & & \\
\hline 0-4 years & & & & 13.75 & 19.58 & 26.96 & & & \\
\hline 5-15 years & 11.62 & 22.57 & 25.43 & 5.61 & 20.19 & 25.18 & & & \\
\hline 16-19 years & 15.97 & 28.61 & 36.91 & 10.87 & 30.99 & 37.58 & & & \\
\hline 20-34 years & 24.97 & 44.30 & 46.37 & 31.58 & 36.91 & 46.31 & & & \\
\hline $35-54$ years & 21.39 & 42.66 & 47.66 & 27.24 & 45.73 & 52.02 & & & \\
\hline 55-64 years & 15.51 & 35.58 & 41.93 & 19.71 & 41.15 & 42.62 & & & \\
\hline $65+$ years & 10.99 & 24.83 & 25.60 & 8.74 & 27.49 & 28.62 & & & \\
\hline
\end{tabular}


Figure 3.5 Daily Person Miles Traveled by Age

New York City, Remainder of New York State, and Outside New York State

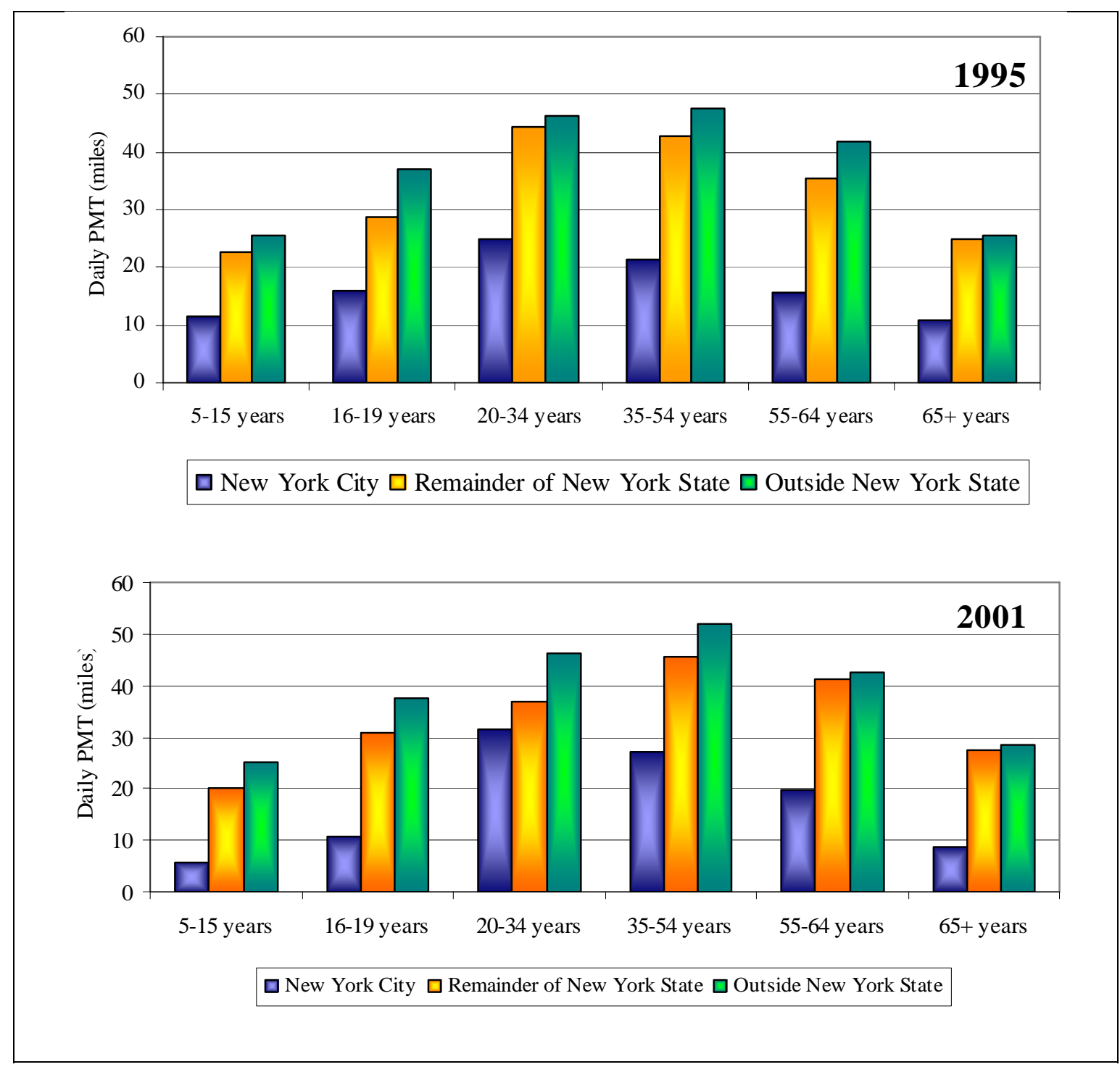

Source: Table 3.2a.

An average trip taken by residents in the NYC was 25\% shorter in distance than those taken by NYS residents elsewhere, and 33\% shorter than those by others outside NYS (Table 3.2b). Consequently, residents in the NYC traveled, on a daily basis, 14 miles less than others in NYS. One third of the total personal travel by residents in the NYC were by public transit modes and walking while this percentage decreases to $4.3 \%$ for NYS residents outside NYC and 
2.0\% for others outside NYS (Figure 3.6). Some evidence has suggested that the changes in fare cards and transfer fees implemented between 1995 and 2001 were favorable toward transit at the expense of the commuter train, leading to the PMT decrease in commuter trains.

Figure 3.6 PMT by Selected Mode

New York City, Remainder of New York State, and Outside New York State
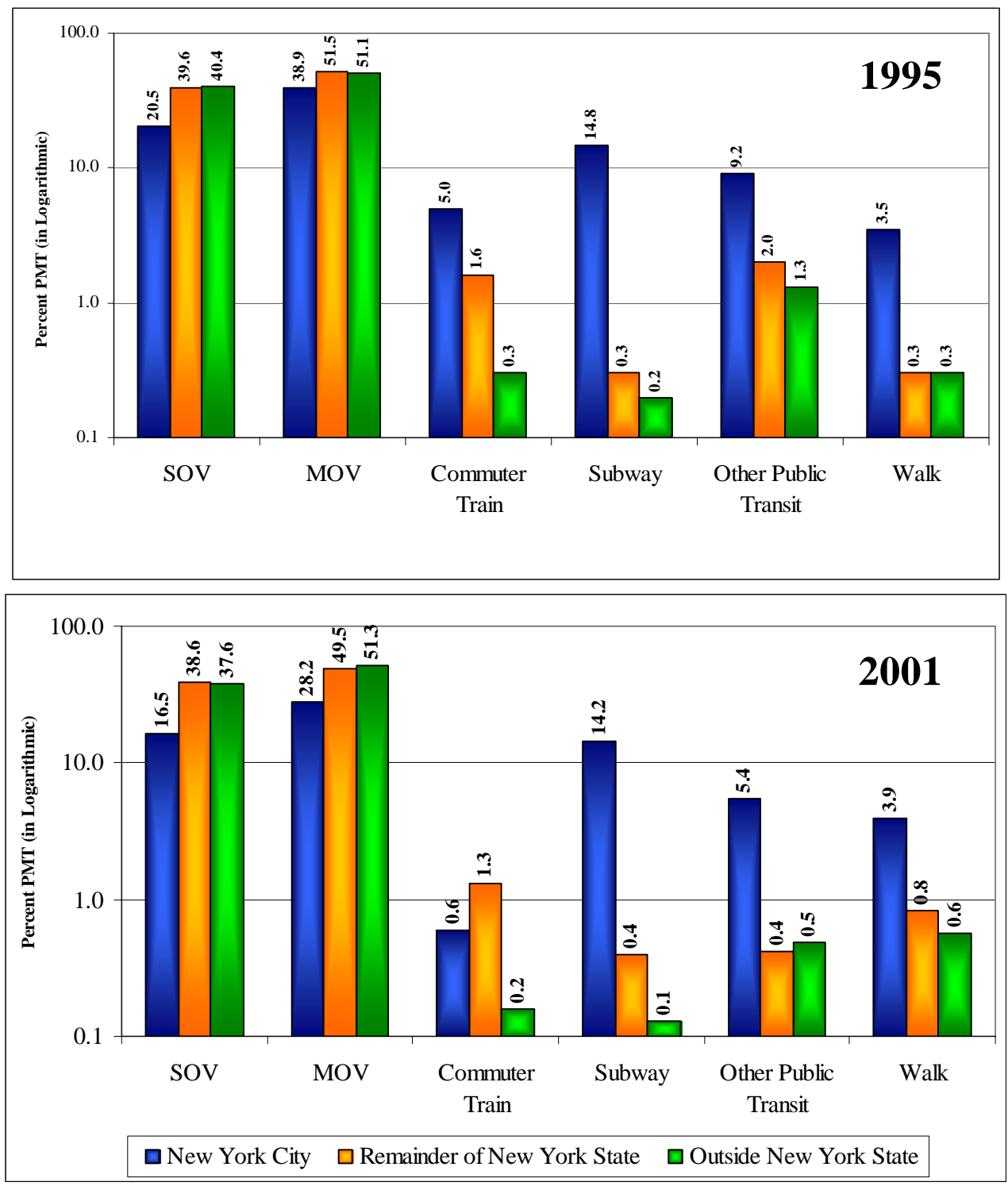

Source: Appendix C, Chapter 3, Table 3 


\section{Zero-Vehicle Households}

The fact that one out of every two households in NYC does not own a vehicle prompts the following questions: (1) are they demographically different from zero-vehicle households in other parts of the country? If so, how are they different? (2) How do these households meet their travel needs?

Households in NYC that do not own a vehicle are not typically low-income as commonly believed. Excluding households that did not provide income information, the percent of households earning more than $\$ 70,000$ per year in NYC and that do not own a vehicle is eight times that in other parts of NYS as well as that in other parts of the country (Figure 3.7). Almost one quarter of the zero-vehicle households in NYC are below the poverty level (below $\$ 10,000$ ). By comparison, this percentage is greater than $50 \%$ outside NYS.

Figure 3.7 Distribution of Zero-Vehicle Households by Income New York City, Remainder of New York State, and Outside New York State

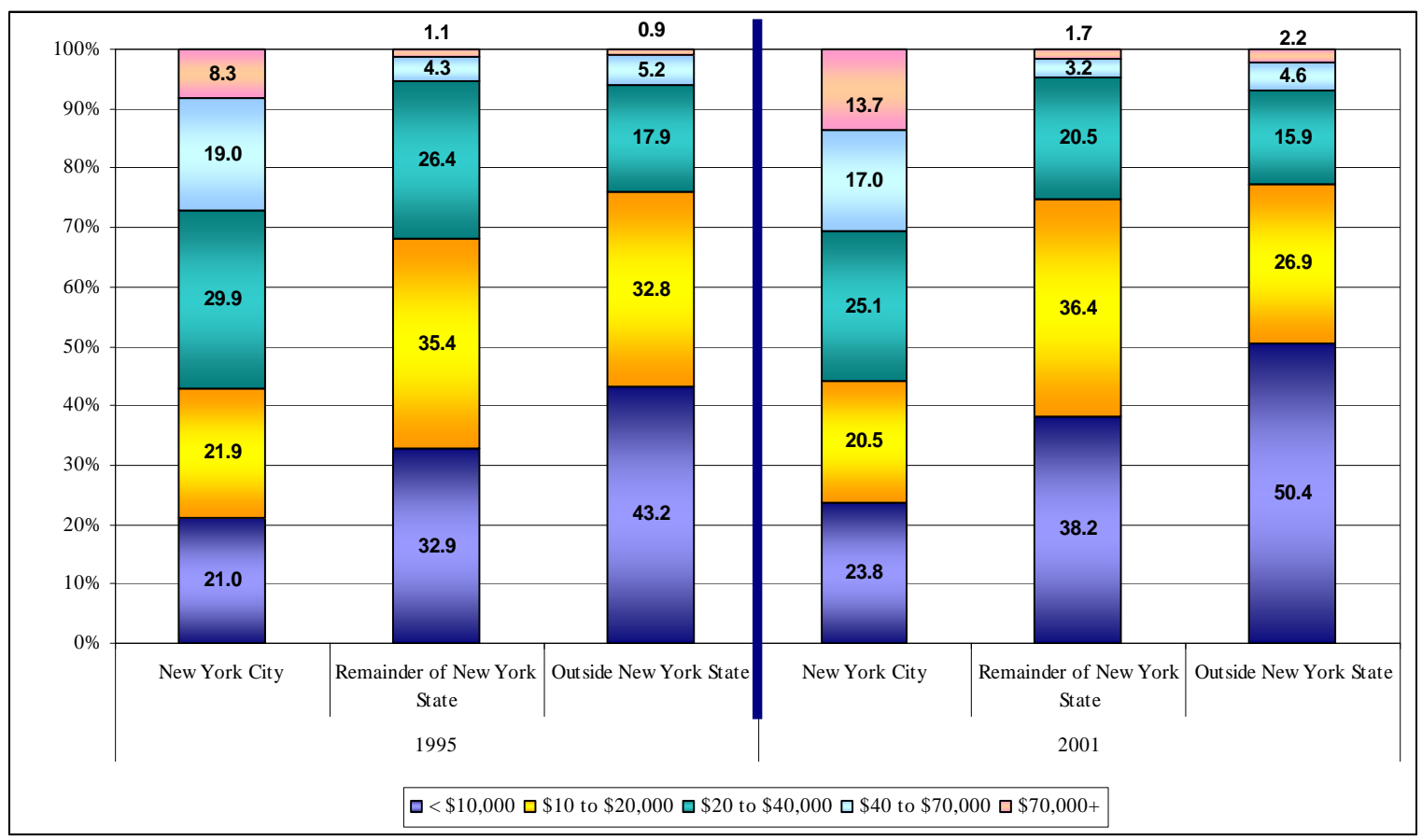

Source: Table 3.4 - Distribution computed for households with reported income information only. Household income was adjusted to the 2001 dollars. 
Lacking a vehicle does not seem to curb the need to travel for households in NYC as much as it does to similar households elsewhere. Zero-vehicle households in NYC take almost $30 \%$ more trips than zero-vehicle households in other parts of NYS and 25\% more than zerovehicle households outside NYS (Table 3.4). The impact on the overall mobility of not owning a vehicle in NYC is further illustrated by the small differences between those who owned a vehicle and those who did not in NYC (Figure 3.8). For example, NYC residents who own a vehicle take 8\% more trips and travel 32\% more miles than those who do not own a vehicle in NYC. Similar comparisons for those outside NYC show that owning a vehicle increases the number of daily trips by $50 \%$ and the amount of travel two-fold. 
Table 3.4 Distribution of Zero-Vehicle Households and Their Personal Travel New York City, Remainder of New York State, and Outside New York State ${ }^{a}$

\begin{tabular}{|c|c|c|c|c|c|c|}
\hline & \multicolumn{3}{|c|}{1995} & \multicolumn{3}{|c|}{2001} \\
\hline & $\begin{array}{l}\text { New } \\
\text { York } \\
\text { City }\end{array}$ & $\begin{array}{c}\text { Remainder of } \\
\text { New York } \\
\text { State } \\
\end{array}$ & $\begin{array}{c}\text { Outside } \\
\text { New York } \\
\text { State } \\
\end{array}$ & $\begin{array}{c}\text { New York } \\
\text { City }\end{array}$ & $\begin{array}{c}\text { Remainder } \\
\text { of New } \\
\text { York State }\end{array}$ & $\begin{array}{c}\text { Outside } \\
\text { New York } \\
\text { State } \\
\end{array}$ \\
\hline \% Zero Vehicle HHs & $52.9 \%$ & $7.4 \%$ & $6.9 \%$ & $51.6 \%$ & $7.6 \%$ & $6.8 \%$ \\
\hline \multicolumn{7}{|l|}{ Household Income } \\
\hline$\%<\$ 10,000$ & 16.5 & 24.6 & 34.2 & 20.3 & 32.4 & 43.1 \\
\hline$\% \$ 10$ to $\$ 20,000$ & 17.2 & 26.5 & 26.0 & 17.5 & 30.9 & 23.0 \\
\hline$\% \$ 20$ to $\$ 30,000$ & 13.4 & 13.9 & 10.1 & 11.9 & 12.1 & 9.1 \\
\hline$\% \$ 30$ to $\$ 40,000$ & 10.2 & 5.9 & 4.1 & 9.5 & 5.3 & 4.5 \\
\hline$\% \$ 40$ to $\$ 50,000$ & 7.4 & 1.9 & 2.2 & 8.2 & 1.4 & 2.6 \\
\hline$\% \$ 50$ to $\$ 60,000$ & 4.8 & 0.7 & 1.3 & 3.8 & 0.8 & 0.9 \\
\hline$\% \$ 60$ to $\$ 70,000$ & 2.7 & 0.6 & 0.6 & 2.5 & 0.5 & 0.4 \\
\hline$\% \$ 70$ to $\$ 80,000$ & 1.3 & 0.4 & 0.1 & 2.0 & 0.3 & 0.2 \\
\hline$\% \$ 80,000+$ & 5.2 & 0.5 & 0.6 & 9.7 & 1.1 & 1.7 \\
\hline \% Unreported & 21.3 & 25.2 & 20.8 & 14.5 & 15.2 & 14.4 \\
\hline $\begin{array}{l}\text { Person Trips per } \\
\text { Person }\end{array}$ & 3.32 & 2.78 & 2.97 & 3.30 & 2.53 & 2.63 \\
\hline \% Private & 11.4 & 39.2 & 46.5 & 13.3 & 36.8 & 43.6 \\
\hline$\%$ Public & 34.3 & 16.9 & 14.5 & 32.7 & 13.5 & 16.7 \\
\hline \% Walk & 41.6 & 21.2 & 24.6 & 47.2 & 35.8 & 31.9 \\
\hline$\%$ Other & 6.3 & 10.4 & 6.7 & 6.6 & 13.8 & 7.6 \\
\hline \% Unreported & 6.3 & 12.2 & 7.7 & 0.2 & 0.2 & 0.1 \\
\hline
\end{tabular}

Note:

$\overline{\mathrm{a}}$ All percents may not add to $100 \%$ due to rounding.

In 2001, the impact, on New York residents living outside NYC, of owning a vehicle was more than a four-fold increase in the number of daily trips. This difference could be attributable to the fact that a greater percentage - 5 percentage points greater than that in 1995 -- of those who do not own a vehicle did not travel on the designated travel day.

Walking seems to be more common in 2001 than in 1995 across all areas. This is true regardless of whether one owns a vehicle or not. However, it is uncertain how much of the 
increase was due to the special attention used in the 2001 survey to prompt the survey respondents about often-overlooked walk trips.

Figure 3.8 Difference in Daily Travel by Vehicle Ownership

New York City, Remainder of New York State, and Outside New York State

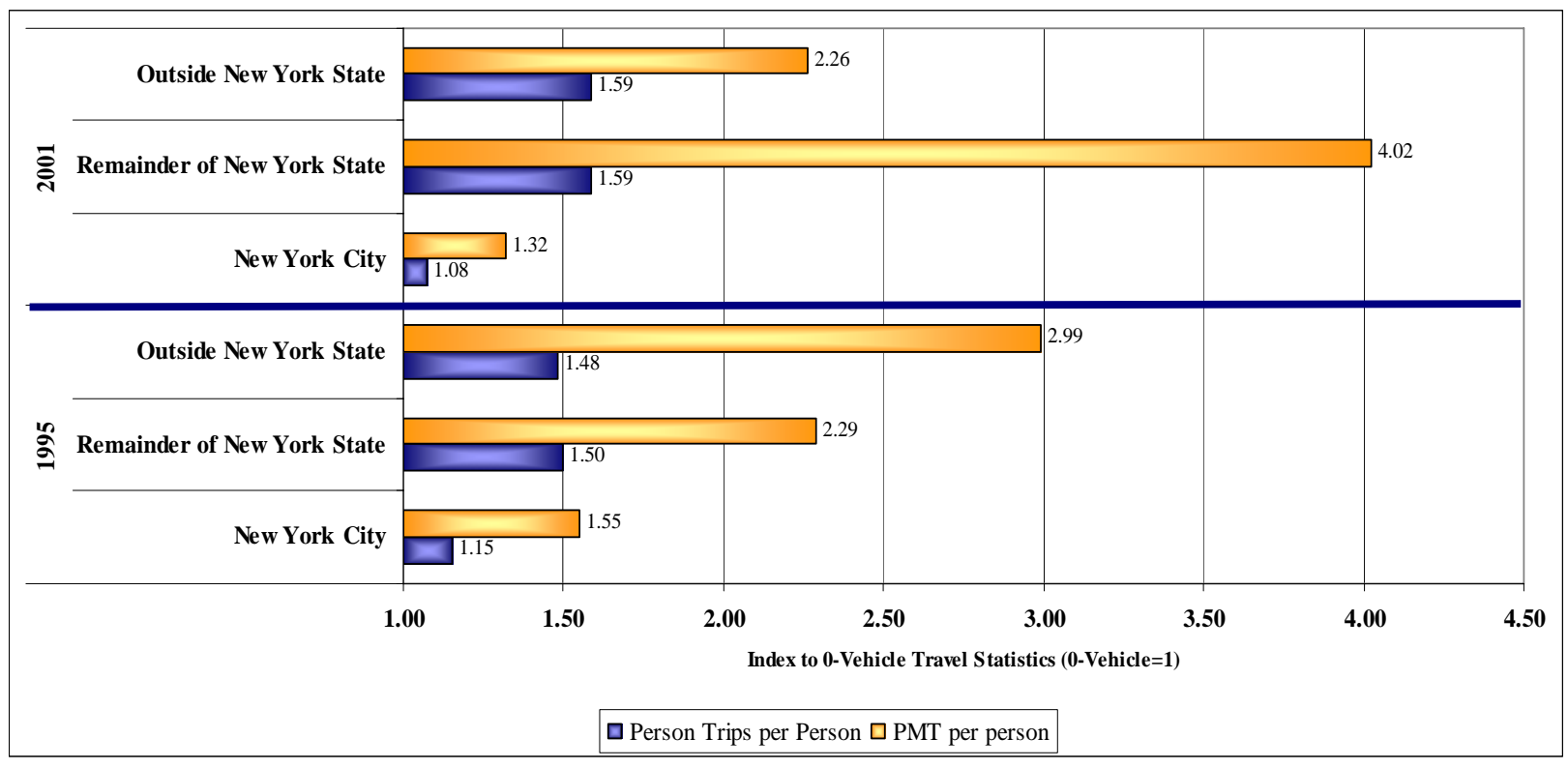

\subsection{Vehicle Travel}

On average, residents in NYC continued to take fewer than two vehicle-trips a day, compared to those elsewhere who take more than three vehicle-trips a day (Table 3.5). This is true for all age groups and for both genders. Not surprisingly, residents in NYC engaged in significantly less vehicle travel than others: at least $50 \%$ fewer trips and almost $60 \%$ fewer miles by privately-owned vehicles. This pattern is further confirmed by the fact that one in every four trips taken by residents in NYC was a vehicle trip, compared to one in every other trip elsewhere. Nonetheless, the breakdown of trip purposes in vehicle travel was similar across regions (Table 3.5). The majority of driving was for non-work trips. Typically, driving occurs more on weekdays than on weekend days. However, this was not true for residents in NYC weekend driving is slightly greater than the average (Table 3.5).

On average, residents in NYC drove about 12 miles a day, only a one-third of what others in the United States drove. This gap widened in 2001, compare to 1995. Age has a smaller

$$
3-15
$$


impact on driving of NYC drivers than drivers elsewhere, except for teenage drivers (Figure 3.9). However, the elderly in NYC drove significantly less in 2001 than in 1995, broadening the age impact on driving. Compared to New York drivers outside NYC, NYC drivers drive at least 50\% fewer miles. This is true for both men and women (Figure 3.10).

In 1995, residents in NYC drove significantly fewer miles per day than others in the United States. The average length of each trip was virtually the same, ranging from 8.5 miles to 9 miles. This was no longer true in 2001. Compared to 1995, trips in 2001 were shorter for residents in NYC while vehicle trips by those living elsewhere became longer (Table 3.5).

Figure 3.9 Daily Driving by Driver Age

New York City, Remainder of New York State, and Outside New York State

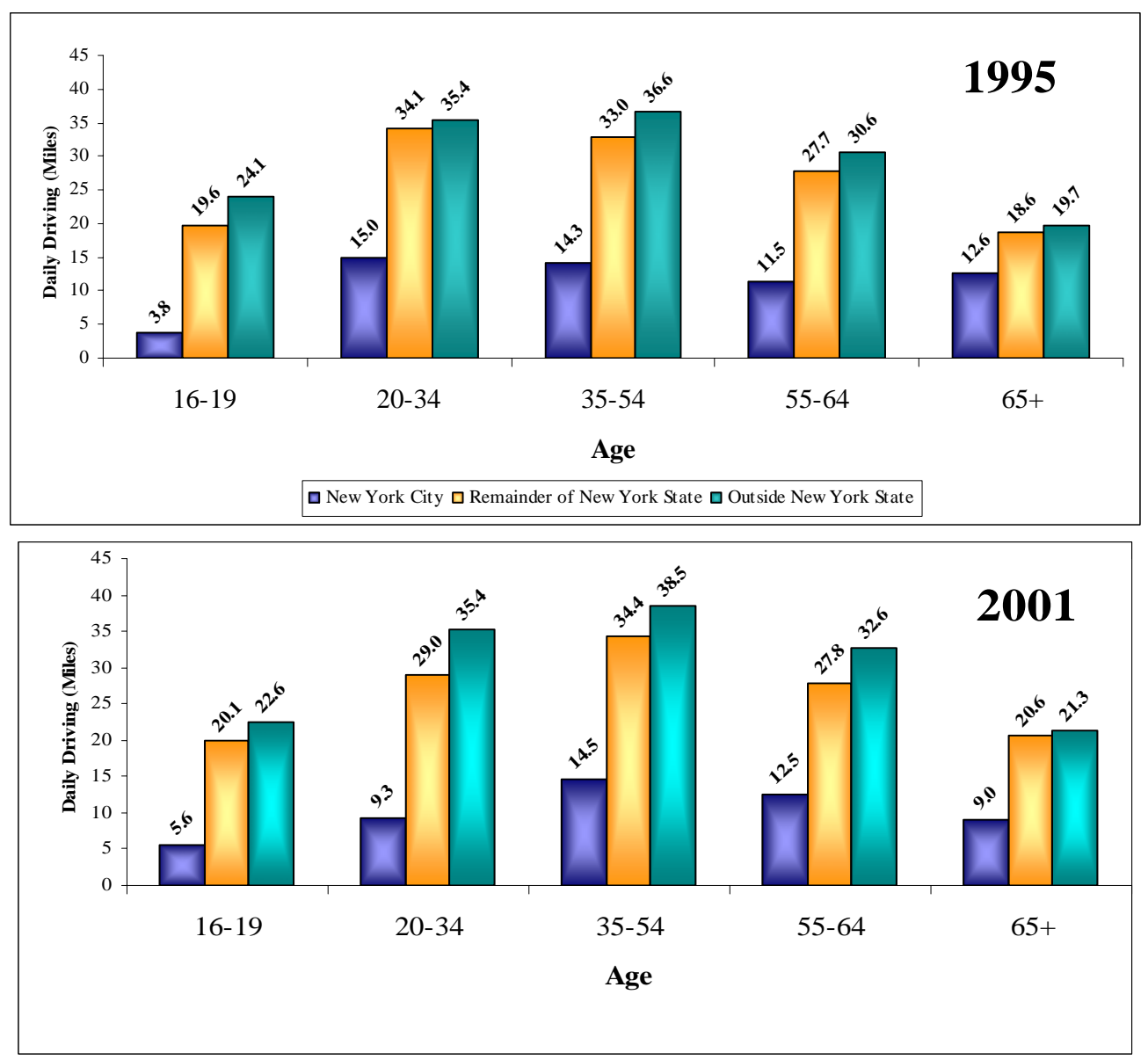

Source: Table 3.5 . 
Figure 3.10 Daily Miles Driven by Driver Gender

New York City, Remainder of New York State, and Outside New York State
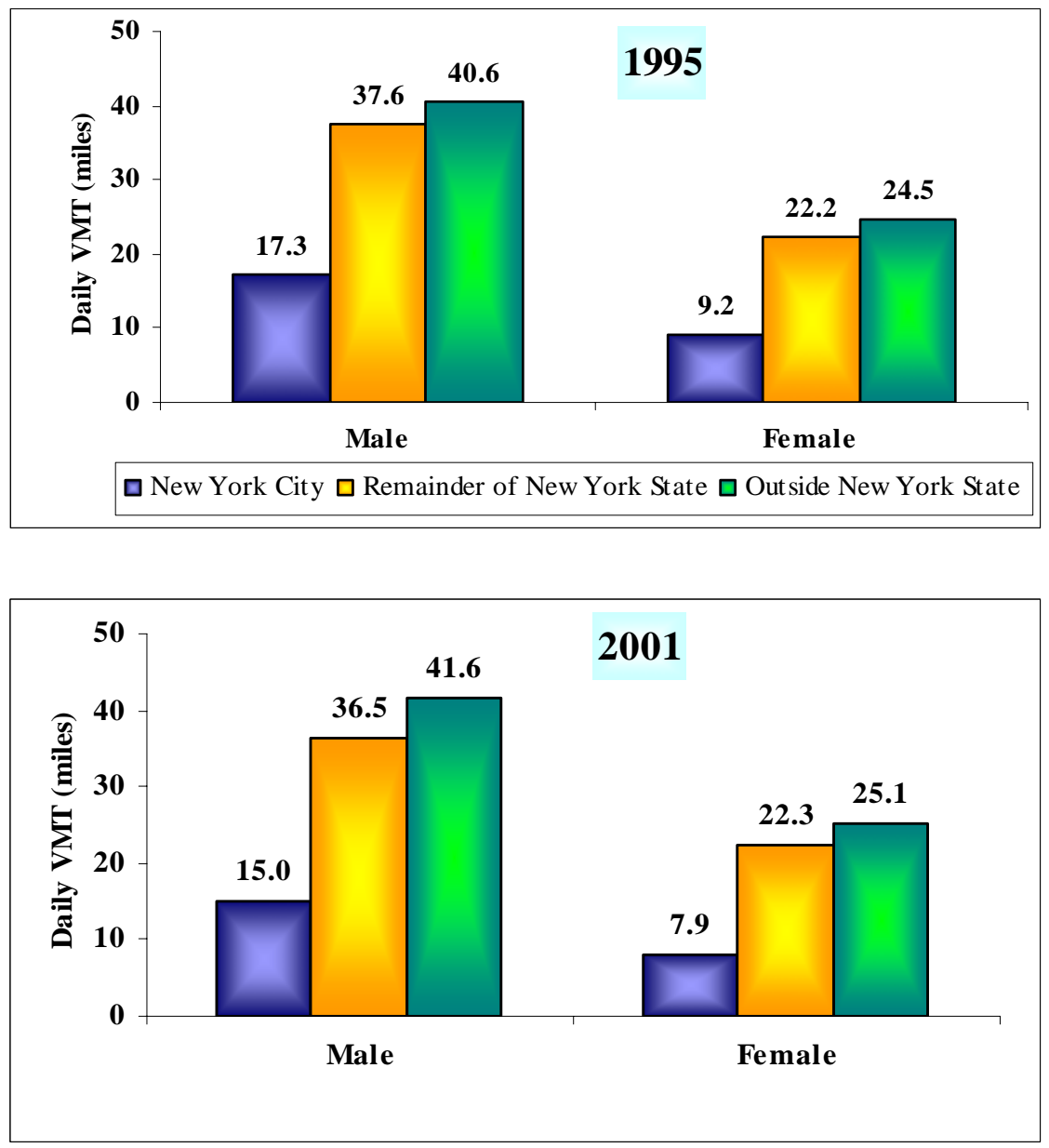
Table 3.5 Daily Vehicle Travel Statistics (Continued on Next Page)

New York City, Remainder of New York State, and Outside New York State ${ }^{a}$

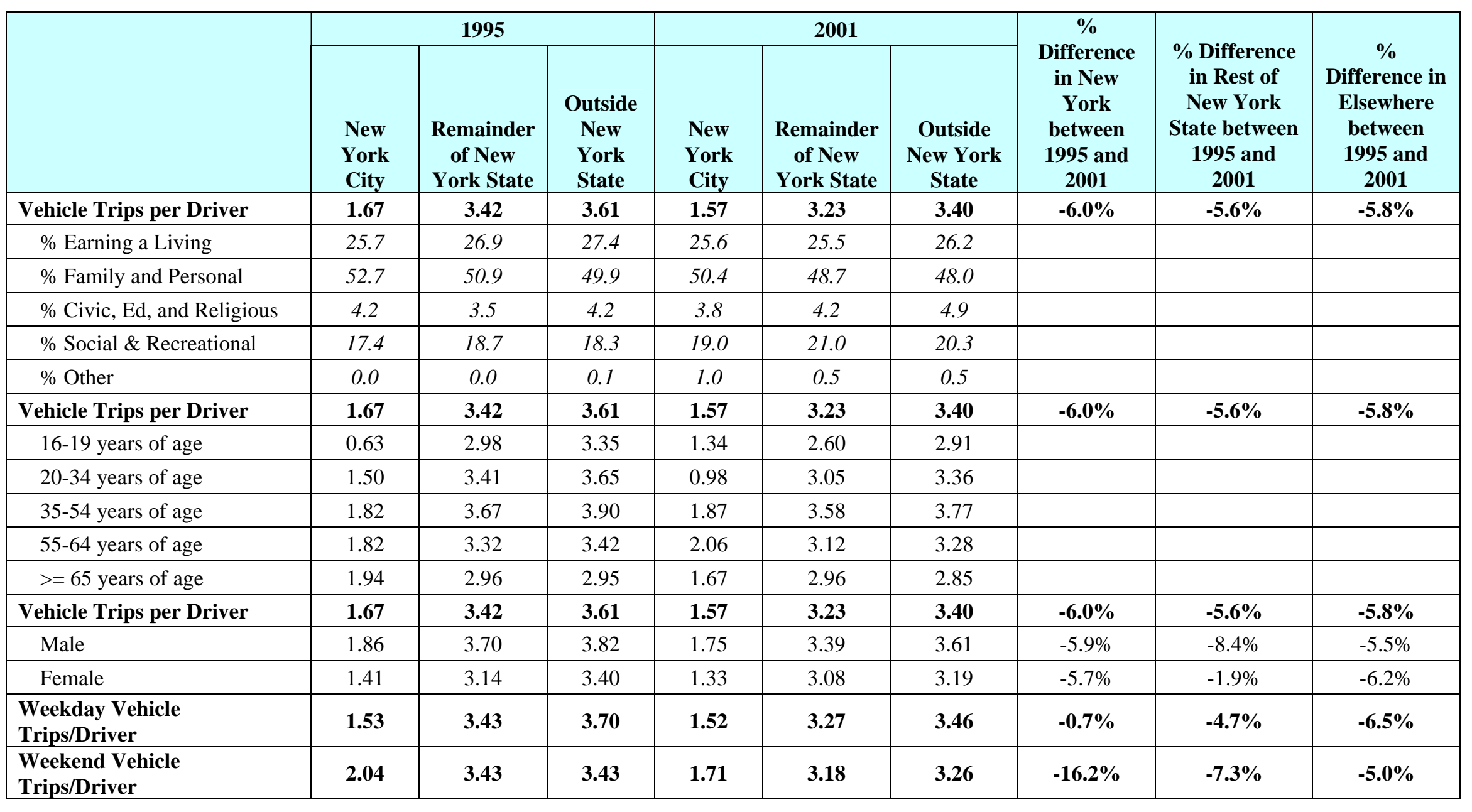




\begin{tabular}{|c|c|c|c|c|c|c|c|c|c|}
\hline & \multicolumn{3}{|c|}{1995} & \multicolumn{3}{|c|}{2001} & \multirow{2}{*}{$\begin{array}{c}\% \\
\text { Difference } \\
\text { in New } \\
\text { York } \\
\text { between } \\
1995 \text { and } \\
2001\end{array}$} & \multirow{2}{*}{$\begin{array}{l}\text { \% Difference } \\
\text { in Rest of } \\
\text { New York } \\
\text { State between } \\
1995 \text { and } \\
2001\end{array}$} & \multirow{2}{*}{$\begin{array}{c}\% \\
\text { Difference in } \\
\text { Elsewhere } \\
\text { between } \\
1995 \text { and } \\
2001\end{array}$} \\
\hline & $\begin{array}{l}\text { New } \\
\text { York } \\
\text { City }\end{array}$ & $\begin{array}{c}\text { Remainder } \\
\text { of New } \\
\text { York State }\end{array}$ & $\begin{array}{c}\text { Outside } \\
\text { New } \\
\text { York } \\
\text { State } \\
\end{array}$ & $\begin{array}{l}\text { New } \\
\text { York } \\
\text { City }\end{array}$ & $\begin{array}{c}\text { Remainder } \\
\text { of New } \\
\text { York State }\end{array}$ & $\begin{array}{c}\text { Outside } \\
\text { New York } \\
\text { State }\end{array}$ & & & \\
\hline VMT per Driver & 13.86 & 29.96 & 32.59 & 11.86 & 29.24 & 33.31 & $-14.4 \%$ & $-2.4 \%$ & $2.2 \%$ \\
\hline \% Earning a Living & 35.9 & 37.2 & 37.8 & 34.6 & 34.8 & 35.5 & & & \\
\hline \% Social \& Recreational & 29.1 & 24.0 & 22.7 & 25.1 & 26.3 & 24.4 & & & \\
\hline \% Other & 0.0 & 0.2 & 0.1 & 0.6 & 0.9 & 0.8 & & & \\
\hline VMT per Driver & 13.86 & 29.96 & 32.59 & 11.86 & 29.24 & 33.31 & $-14.4 \%$ & $-2.4 \%$ & $2.2 \%$ \\
\hline 16-19 years of age & 3.82 & 19.64 & 24.07 & 5.57 & 20.05 & 22.57 & & & \\
\hline 20-34 years of age & 14.95 & 34.06 & 35.43 & 9.28 & 29.02 & 35.36 & & & \\
\hline VMT per Driver & 13.86 & 29.96 & 32.59 & 11.86 & 29.24 & 33.31 & $-14.4 \%$ & $-2.4 \%$ & $2.2 \%$ \\
\hline Male & 17.28 & 37.62 & 40.64 & 15.02 & 36.47 & 41.63 & $-13.1 \%$ & $-3.1 \%$ & $2.4 \%$ \\
\hline Female & 9.22 & 22.15 & 24.53 & 7.88 & 22.28 & 25.12 & $-14.5 \%$ & $0.6 \%$ & $2.4 \%$ \\
\hline Average Vehicle Trip Length ${ }^{b}$ & 8.54 & 8.84 & 9.07 & 7.91 & 9.16 & 9.91 & $-7.4 \%$ & $3.6 \%$ & $9.3 \%$ \\
\hline \% Vehicle Trips/Person Trips & $22.1 \%$ & $60.7 \%$ & $61.6 \%$ & $23.2 \%$ & $60.7 \%$ & $61.6 \%$ & & & \\
\hline$\%$ VMT/PMT & $34.4 \%$ & $61.1 \%$ & $61.0 \%$ & $28.6 \%$ & $61.0 \%$ & $60.6 \%$ & & & \\
\hline
\end{tabular}
Note:

a All percents may not add to $100 \%$ due to rounding.

b Average trip length is calculated using only those records with trip mileage information present. 


\subsection{Commute Patterns}

There is virtually no difference in commute frequency between residents in NYC and others elsewhere (Table 3.6). However, trip distributions by mode show extraordinary differences (Figure 3.11). In 2001, almost one in every three commute trips in NYC was by subway while this percentage is less than $1 \%$ elsewhere (of course, most areas do not have a subway). Walking was the most common non-motorized mode in NYC for commutes. From the perspective of mode split, commutes in the rest of NYS were basically identical to the rest of the United States, except for the use of commuter trains, $2.1 \%$ versus $0.3 \%$, respectively.

Table 3.6 Daily Commute Statistics by Mode of Transportation New York City, Remainder of New York State, and Outside New York State ${ }^{a}$

\begin{tabular}{|c|c|c|c|c|c|c|}
\hline & \multicolumn{3}{|c|}{1995} & \multicolumn{3}{|c|}{2001} \\
\hline & $\begin{array}{l}\text { New } \\
\text { York } \\
\text { City }\end{array}$ & $\begin{array}{c}\text { Remainder } \\
\text { of New } \\
\text { York State }\end{array}$ & $\begin{array}{c}\text { Outside } \\
\text { New York } \\
\text { State }\end{array}$ & $\begin{array}{l}\text { New } \\
\text { York } \\
\text { City }\end{array}$ & $\begin{array}{c}\text { Remainder of } \\
\text { New York } \\
\text { State }\end{array}$ & $\begin{array}{c}\text { Outside } \\
\text { New York } \\
\text { State }\end{array}$ \\
\hline $\begin{array}{l}\text { Commute Person Trips } \\
\text { per Worker }\end{array}$ & 1.26 & 1.34 & 1.4 & 1.08 & 1.14 & 1.15 \\
\hline$\%$ SOV & 25.4 & 75.4 & 75.7 & 25.0 & 76.1 & 77.7 \\
\hline$\% \mathrm{MOV}$ & 9.5 & 14.9 & 16.4 & 9.7 & 14.7 & 16.4 \\
\hline$\%$ Amtrak & 0.0 & 0.0 & 0.0 & 1.2 & 0.4 & 0.1 \\
\hline \% Commuter Train & 5.6 & 2.2 & 0.7 & 1.4 & 2.1 & 0.3 \\
\hline \% Subway & 26.2 & 0.7 & 0.7 & 30.3 & 0.7 & 0.5 \\
\hline $\begin{array}{l}\text { \% Other Public } \\
\text { Transit }\end{array}$ & 11.9 & 1.5 & 1.4 & 12.2 & 1.0 & 1.6 \\
\hline$\%$ Walk & 13.5 & 2.2 & 2.1 & 16.0 & 3.8 & 2.4 \\
\hline \% Other & 5.6 & 1.5 & 1.4 & 4.2 & 1.2 & 0.9 \\
\hline $\begin{array}{l}\text { Commute PMT per } \\
\text { Worker }\end{array}$ & 10.70 & 16.04 & 16.08 & 7.48 & 13.18 & 13.78 \\
\hline$\% \mathrm{SOV}$ & 33.6 & 74.8 & 76.8 & 33.5 & 77.4 & 77.7 \\
\hline$\% \mathrm{MOV}$ & 13.7 & 15.5 & 17.2 & 13.0 & 12.8 & 16.1 \\
\hline \% Amtrak & 0.0 & 0.1 & 0.1 & 1.4 & 0.9 & 0.3 \\
\hline \% Commuter Train & 6.6 & 5.5 & 0.7 & 2.3 & 5.3 & 0.7 \\
\hline \% Subway & 26.2 & 0.9 & 0.4 & 35.1 & 1.0 & 0.5 \\
\hline $\begin{array}{l}\text { \% Other Public } \\
\text { Transit }\end{array}$ & 9.2 & 1.4 & 1.5 & 7.7 & 0.6 & 1.0 \\
\hline$\%$ Walk & 1.7 & 0.1 & 0.1 & 2.8 & 0.4 & 0.2 \\
\hline \% Other & 8.1 & 0.9 & 2.2 & 4.1 & 1.3 & 3.5 \\
\hline
\end{tabular}

Note:

${ }^{\mathrm{a}}$ All percents may not add to $100 \%$ due to rounding. 
Figure 3.11 Daily Commute by Mode

New York City, Remainder of New York State, and Outside New York State
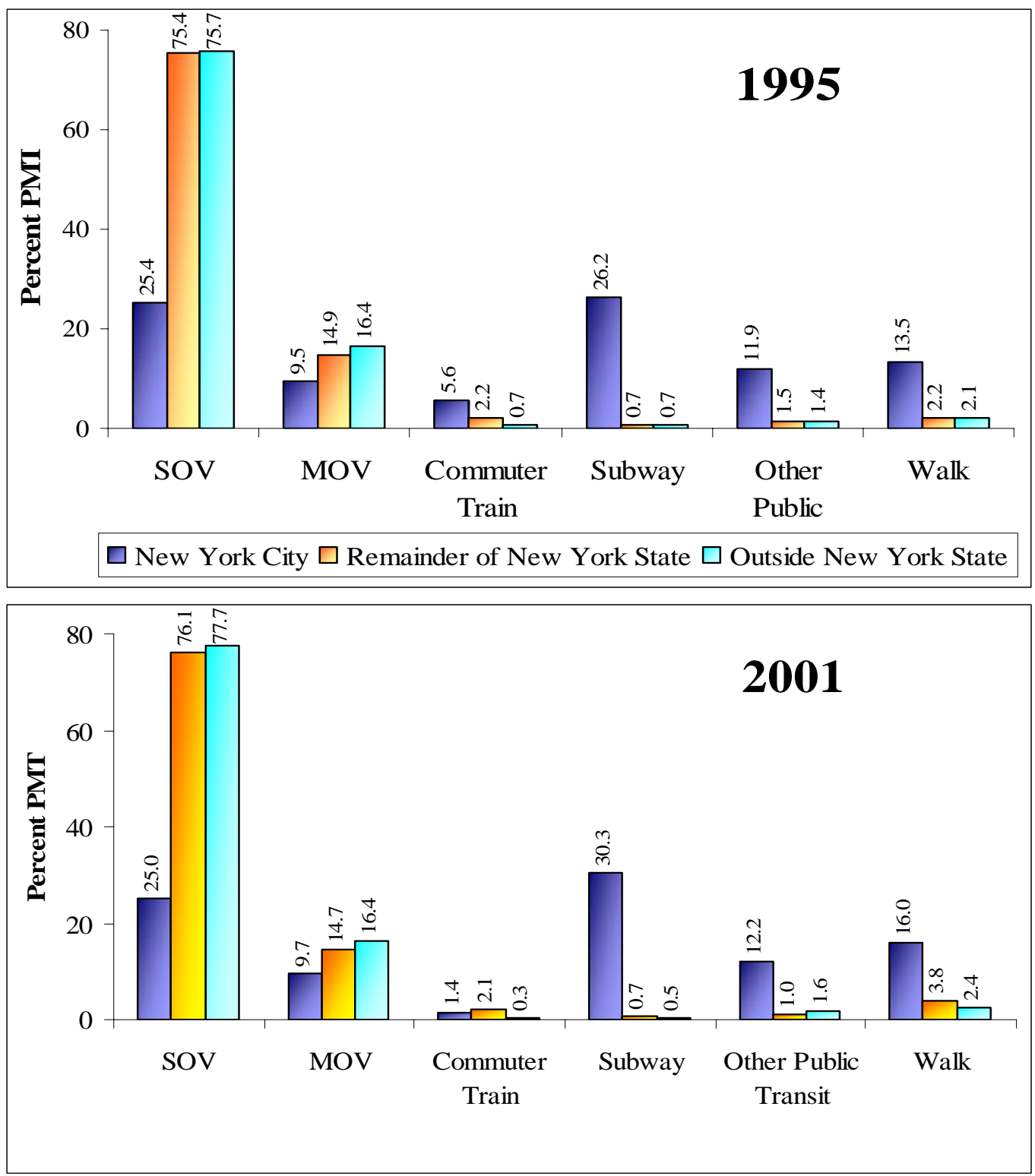

Source: Appendix C, Chapter 3, Table 7 
Given the large share of NYC trips on public transit modes, it is important to compare the use of public transit versus non-public transit modes in the commute patterns of NYC residents and those elsewhere. For commutes in privately-owned vehicles, the trip lengths are almost equal regardless of regions (Figure 3.12). However, it takes NYC residents 10 minutes more to commute an equal distance than others, reflecting more severely congested commute speeds. This pattern remains the same in 2001. The decrease in commute speed -- from 24.3 miles per hour in 1995 to 18.8 in 2001 - probably reflects the increases in congestion as reported by the Texas Transportation Institute (TTI). TTI's Urban Mobility Study 4 reported an increase in the number of annual hours delayed per passenger in NYC from 34 hours in 1993 to 50 hours in 2002.

$4 \underline{\text { http://mobility.tamu.edu/ums/congestion_data/tables/national/table_4.pdf }}$ 
Figure 3.12 Commute Patterns on Privately-Owned Vehicles

New York City, Remainder of New York State, and Remainder of Unites States (U.S.)
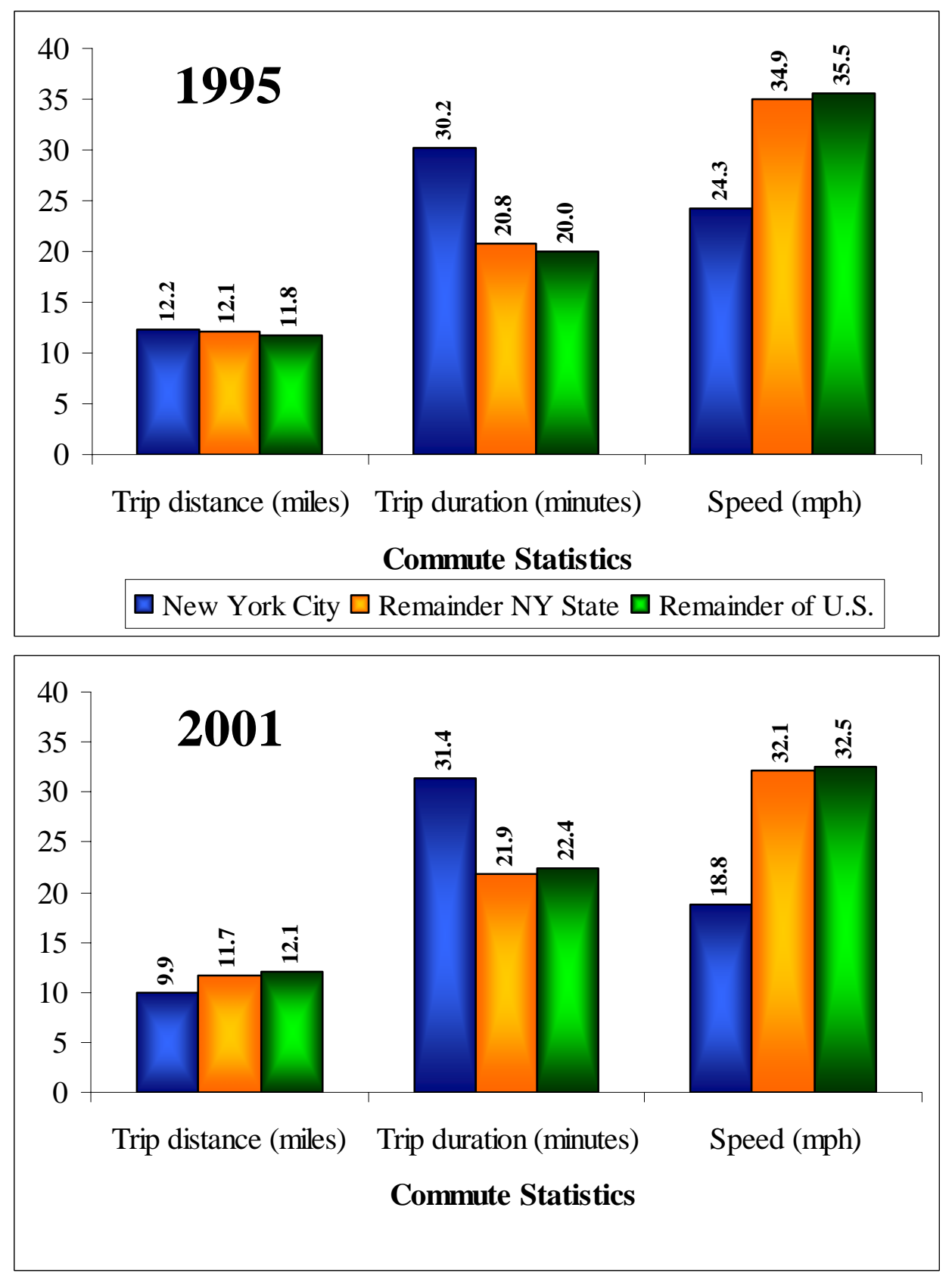

Source: Appendix C, Chapter 3, Table 7 
Although commute trips on public transit by NYC residents are slightly shorter than those by privately-owned vehicles, they take almost twice as long in duration (Figures 3.12 and 3.13). Commute distance remains relatively stable between 1995 and 2001. However, the time it takes to commute jumped by at least $25 \%$ during that period, perhaps reflecting the increase in congestion (Figure 3.13). This pattern was observed across all regions.

Figure 3.13 Commute Patterns on Public Transit

New York City, Remainder of New York State, and Remainder of United States (U.S.)

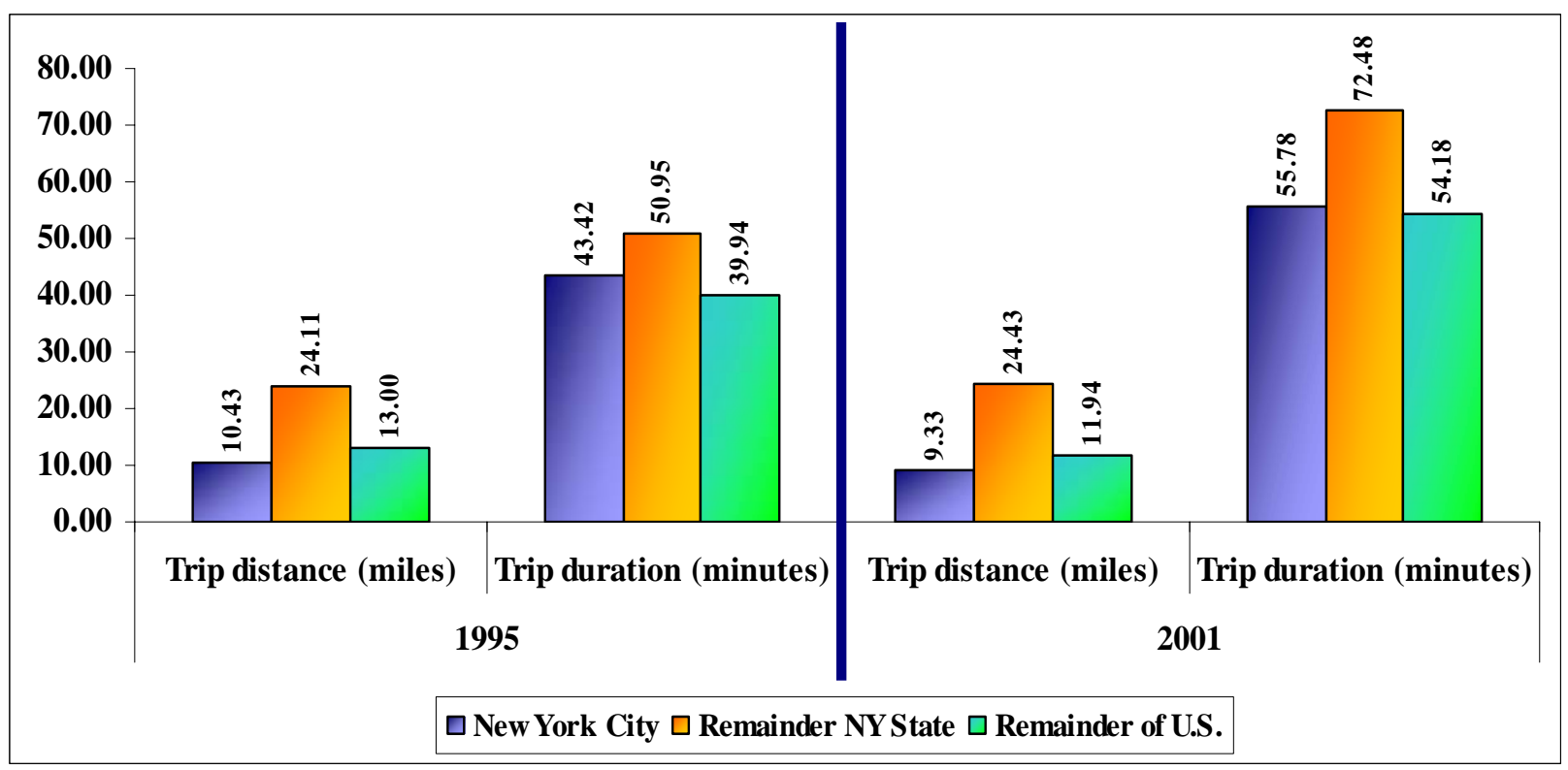

Source: Appendix C, Chapter 3, Table 7.

\subsection{Summary}

In sum, the travel behavior of NYC residents has a tremendous impact on the overall travel patterns of the entire state. Excluding NYC, NYS has travel characteristics very similar to the rest of the country. That said, do other urban areas in NYS resemble those in other parts of the nation? How different are rural communities in NYS from those elsewhere? The rest of this report addresses these questions. 


\section{Chapter 4. Urban Travel and Population Density}

Urban travel patterns are analyzed in this chapter with respect to population density (i.e., number of persons per square mile) which is measured on a census tract basis and which includes only land areas. Specifically, travel patterns (e.g. commuter distance, driving frequency, trip frequency, etc.) in twelve New York MPOs (Figure 4.1) are compared to those of Metropolitan Statistical Areas (MSAs) outside NYS. The reason that New York MPO data are compared to MSA data is because NHTS sample households outside NYS can not be identified by specific MPO, only by MSA. The twelve New York MPOs, by their common names, are: Albany; Binghamton; Buffalo; Elmira; Glens Falls; Ithaca; New York Metropolitan Transportation Council (NYMTC) (including Nassau, Suffolk, NYC (Bronx, Kings, Queens, New York, and

Figure 4.1 Twelve New York MPOs Used in Urban Comparison Analysis

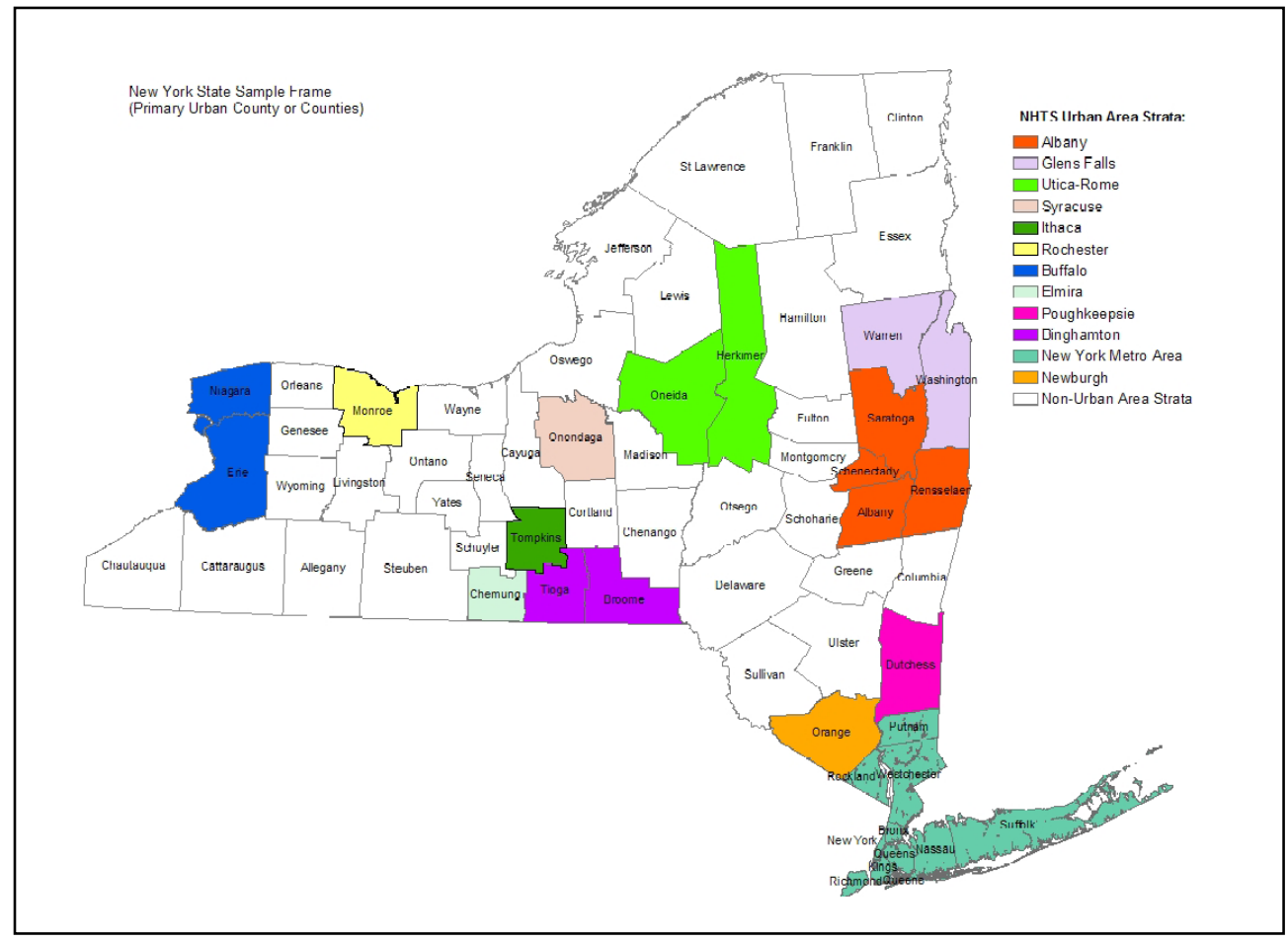

$4-1$ 
Richmond), Putnam, Rockland, and Westchester counties); Newburgh; Poughkeepsie; Rochester; Syracuse; and Utica-Rome. ${ }^{5}$ Note that although this chapter refers to these areas as MPOs, the NHTS sampling frame is comprised of the primary urban counties in which each MPO lies. Therefore, the entire MPO may not be represented by the survey.

Sampled households are grouped into appropriate population-density groups depending on the census tract in which the household is located. Census tracts within an MPO or an MSA vary greatly in population density. For example, more than half of the households in NYC (consisting of five New York Counties) are in areas of more than 50,000 people per square mile while less than one percent of the NYC households are in sparsely populated areas of less than 500 habitants per square mile (Table 4.1a). Thus, statistics in this chapter can no longer be MPO- or MSA-specific. Rather, they are characterized by population density.

Almost all households (99.9\%) in NYS's highest density areas (i.e., areas with more than 50,000 people per square mile) are in NYC (Table 4.1a). Comparisons between NYC data and data from other larger urban areas can be extremely misleading because NYC was significantly over-sampled compared to other large urban areas. Specifically, the national sample includes a total of 247 households located in an area with more than 50,000 people per square mile while the New York sample includes 838 such households. Thus, data on these highly dense areas should be compared with extreme caution.

\footnotetext{
${ }^{5}$ The 2000 Census identified 3 new "MPO” areas: Kingston, Saratoga Springs, and Middletown. Unfortunately, knowledge of these new areas was unknown at the time when the survey was conducted. Kingston, which was in Ulster County, was categorized as "rural." The remaining two were part of other MPO areas: Saratoga Springs was part of the Albany MPO, and Middletown was part of the Newburgh MPO.
} 
Table 4.1a 2001 New York State Household Distribution by MPO and Population Density (Population density of census tract)

\begin{tabular}{|c|c|c|c|c|c|c|c|c|c|}
\hline & \multicolumn{9}{|c|}{ Population Density (population per square mile) } \\
\hline & All & $<500$ & $500-2,000$ & $2,000-4,000$ & $4,000-10,000$ & $10,000-20,000$ & $20,000-50,000$ & $50,000+$ & Unreported \\
\hline ALL & $7,183,208$ & $1,186,731$ & 813,608 & 752,260 & $1,073,037$ & 635,381 & $1,001,682$ & $1,719,602$ & 906 \\
\hline Albany & 323,953 & 76,618 & 113,160 & 56,277 & 59,204 & 18,178 & 96 & & 420 \\
\hline Glen Falls & 49,047 & 33,958 & 6,500 & 4,608 & 3,980 & & & & \\
\hline Utica-Rome & 118,311 & 50,849 & 32,415 & 20,238 & 12,794 & 2,014 & & & \\
\hline Syracuse & 184,396 & 27,098 & 49,006 & 38,194 & 51,809 & 18,290 & & & \\
\hline Ithaca & 37,072 & 21,299 & 4,853 & 5,906 & 3,876 & & 1,138 & & \\
\hline Rochester & 291,642 & 23,949 & 89,634 & 70,432 & 66,215 & 41,412 & & & \\
\hline Buffalo & 477,111 & 65,689 & 94,217 & 88,470 & 174,441 & 54,294 & & & \\
\hline Elmira & 35,677 & 13,416 & 10,872 & 3,726 & 7,664 & & & & \\
\hline Poughkeepsie & 101,318 & 33,897 & 40,667 & 13,606 & 10,736 & 2,412 & & & \\
\hline Binghamton & 102,273 & 40,523 & 22,557 & 11,024 & 26,518 & 1,651 & & & \\
\hline Newburgh & 116,843 & 53,270 & 34,915 & 15,139 & 7,757 & 5,393 & & & 368 \\
\hline \multicolumn{10}{|l|}{ NYMTC } \\
\hline New York City & $3,075,688$ & 15,957 & 5,155 & 11,285 & 59,211 & 304,948 & 961,727 & $1,717,404$ & \\
\hline Bronx & 471,506 & 1,256 & & 370 & 6,983 & 25,615 & 151,096 & 286,185 & \\
\hline Brooklyn (Kings Cnty) & 896,496 & 780 & 3,335 & & 1,453 & 31,479 & 337,402 & 522,047 & \\
\hline Manhattan (NY County) & 751,869 & 9,521 & 265 & 1,704 & 1,329 & 11,035 & 54,347 & 673,667 & \\
\hline Queens & 796,677 & 2,485 & 385 & 4,243 & 17,462 & 146,039 & 391,161 & 234,902 & \\
\hline Staten Island (Richmond Cnty) & 159,140 & 1,914 & 1,169 & 4,968 & 31,984 & 90,780 & 27,722 & 604 & \\
\hline Nassau, Suffolk & 933,098 & 37,360 & 117,460 & 231,227 & 438,220 & 102,188 & 6,644 & & \\
\hline Putnam, Rockland, Westchester & 470,801 & 36,488 & 116,293 & 93,432 & 105,594 & 84,601 & 32,078 & 2,198 & 119 \\
\hline Rest of State & 865,978 & 656,360 & 75,905 & 88,696 & 45,017 & & & & \\
\hline
\end{tabular}


Table 4.1b 1995 New York State Household Distribution by MPO and Population Density (Population density of census tract)

\begin{tabular}{|c|c|c|c|c|c|c|c|c|c|}
\hline & \multicolumn{9}{|c|}{ Population Density (population per square mile) } \\
\hline & All & $<500$ & $500-2,000$ & $2,000-4,000$ & $4,000-10,000$ & $10,000-20,000$ & $20,000-50,000$ & $50,000+$ & Unreported \\
\hline ALL & $6,848,091$ & $1,178,102$ & 796,380 & 672,210 & $1,044,564$ & 616,582 & 977,772 & $1,528,190$ & 34,292 \\
\hline Albany & 325,710 & 86,937 & 105,054 & 50,287 & 60,411 & 15,419 & 3,118 & & 4,483 \\
\hline Glen Falls & 45,500 & 30,125 & 6,318 & 3,884 & 4,616 & & & & 557 \\
\hline Utica-Rome & 116,864 & 50,394 & 29,621 & 22,132 & 10,857 & 2,916 & & & 944 \\
\hline Syracuse & 179,526 & 29,249 & 62,101 & 37,977 & 37,442 & 12,756 & & & \\
\hline Ithaca & 34,879 & 22,054 & 5,237 & 2,276 & 3,946 & & 1,210 & & 156 \\
\hline Rochester & 279,228 & 27,475 & 94,749 & 63,057 & 65,087 & 28,859 & & & \\
\hline Buffalo & 465,261 & 72,505 & 87,032 & 74,691 & 147,188 & 78,153 & 3,892 & & 1,800 \\
\hline Elmira & 35,162 & 13,124 & 8,487 & 6,185 & 5,937 & 1,258 & & & 171 \\
\hline Poughkeepsie & 94,551 & 37,606 & 34,047 & 13,549 & 3,671 & 4,451 & & & 1,228 \\
\hline Binghamton & 100,577 & 43,560 & 23,832 & 10,000 & 21,642 & 1,380 & & & 165 \\
\hline Newburgh & 108,147 & 41,902 & 34,265 & 16,697 & 12,685 & 1,626 & & & 972 \\
\hline \multicolumn{10}{|l|}{ NYMTC } \\
\hline New York City & $2,920,494$ & 18,225 & 4,278 & 14,185 & 89,850 & 325,165 & 934,660 & $1,525,464$ & 8,669 \\
\hline Bronx & 443,662 & 1,969 & & 3,978 & 7,189 & 26,599 & 156,198 & 244,927 & 2,802 \\
\hline Brooklyn (Kings Cnty) & 854,463 & 1,942 & & 3,104 & 8,318 & 12,552 & 387,639 & 439,521 & 1,387 \\
\hline Manhattan (NY County) & 727,533 & 12,286 & & & 10,211 & 13,073 & 41,763 & 647,314 & 2,887 \\
\hline Queens & 751,406 & & 2,244 & 3,108 & 25,341 & 189,613 & 337,976 & 191,531 & 1,594 \\
\hline Staten Island (Richmond Cnty) & 143,430 & 2,028 & 2,034 & 3,995 & 38,790 & 83,328 & 11,084 & 2,171 & \\
\hline Nassau, Suffolk & 886,460 & 42,165 & 118,103 & 210,207 & 420,173 & 87,419 & 1,845 & & 6,549 \\
\hline Putnam, Rockland, Westchester & 447,759 & 53,206 & 113,463 & 75,643 & 110,708 & 57,179 & 33,048 & 2,726 & 1,785 \\
\hline Rest of State & 807,972 & 609,577 & 69,793 & 71,441 & 50,350 & & & & 6,812 \\
\hline
\end{tabular}




\subsection{Profile of New York State Urban Households by Population Density}

Eighty-eight percent of New York households are within the jurisdictions of the aforementioned twelve New York MPOs. One-quarter of these households are in highly populated areas of more than 50,000 people per square mile (Figure 4.2). Residents in these twelve MPOs account for $88.4 \%$ of the total New York population. Compared to the rest of the country, a significantly greater percentage of New York households are in extremely densely populated areas. For example, more than $40 \%$ of New York households are in areas with more than 20,000 people per square mile. By comparison, this percentage is only $3 \%$ elsewhere in the country.

Figure 4.2 2001 Distribution of Households in New York MPOs and MPOs in Rest of the United States (U.S.) by Population Density

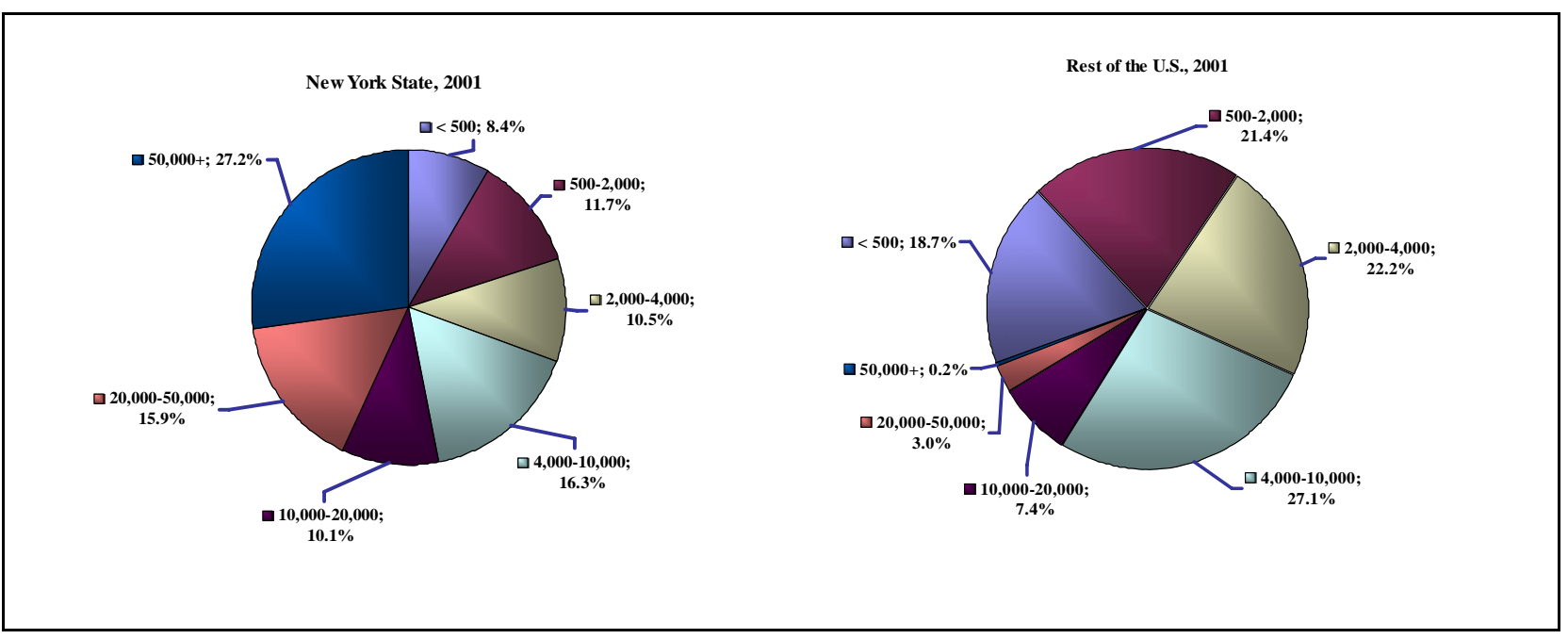

Source: Appendix C, Chapter 4, Table 1 
In 2001, more New York households are in the most densely populated area (with more than 50,000 people per square mile) than in 1995 - from 22\% of the households in 1995 to $27 \%$ in 2001 (Figure 4.3). In 1995, more than 17\% of the New York households lived in the least dense areas with less than 500 people per square mile; only 8.4\% lived in these areas in 2001. This shift is not observed outside NYS.

Figure 4.3 New York Household Distribution by Population Density 1995 and 2001

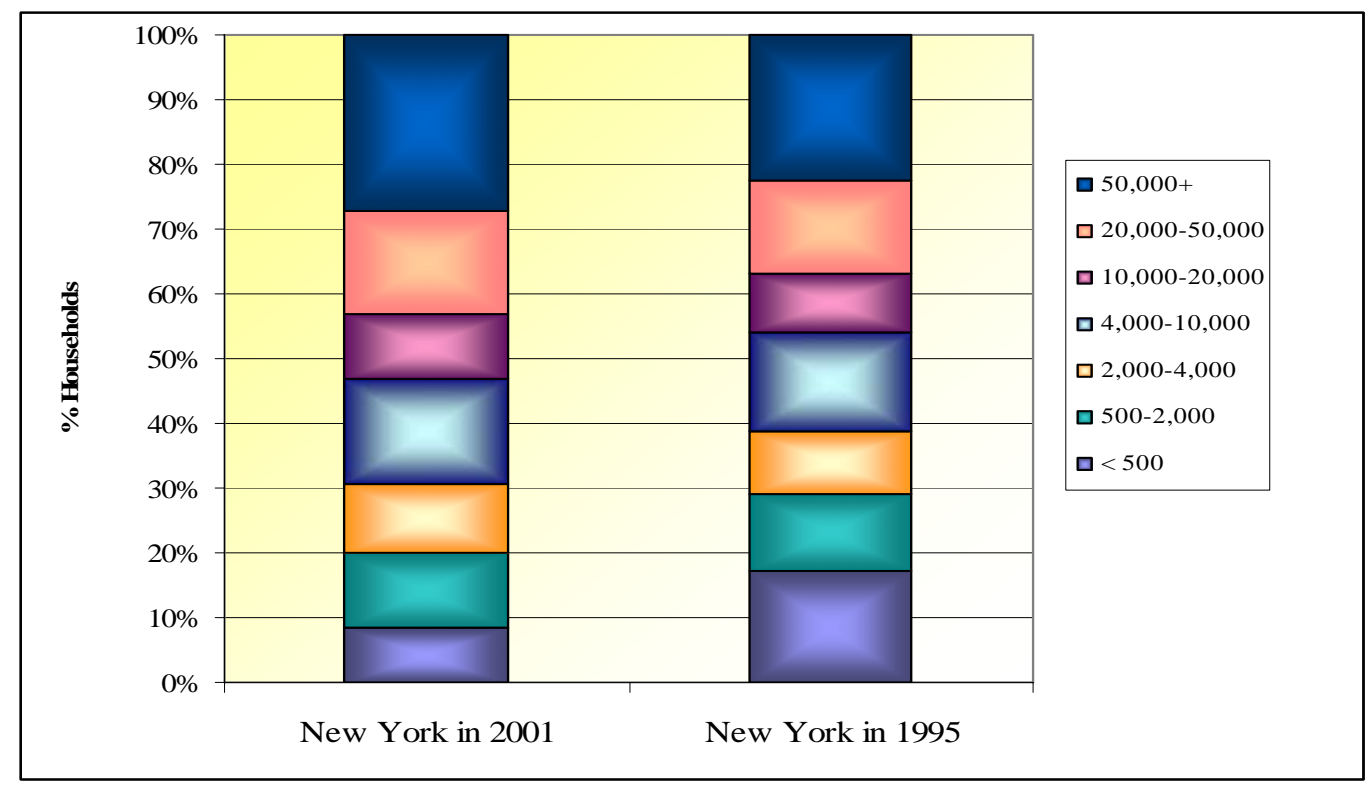

Source: Tables 4.1a and 4.1b

In general, the percentage of households that have access to rail is greater in New York urban areas than in urban areas outside NYS, especially in highly populated areas (Figure 4.4). On a per household basis, New York urban households have more workers than households in urban areas outside NYS. The number of workers per household typically declines with increasing population density. This is true for New York households as well as for households in other parts of the country (Table 4.2a). 
Figure 4.4 Percent Households Having Access to Rail New York State MPOs vs. MSAs outside New York State 2001

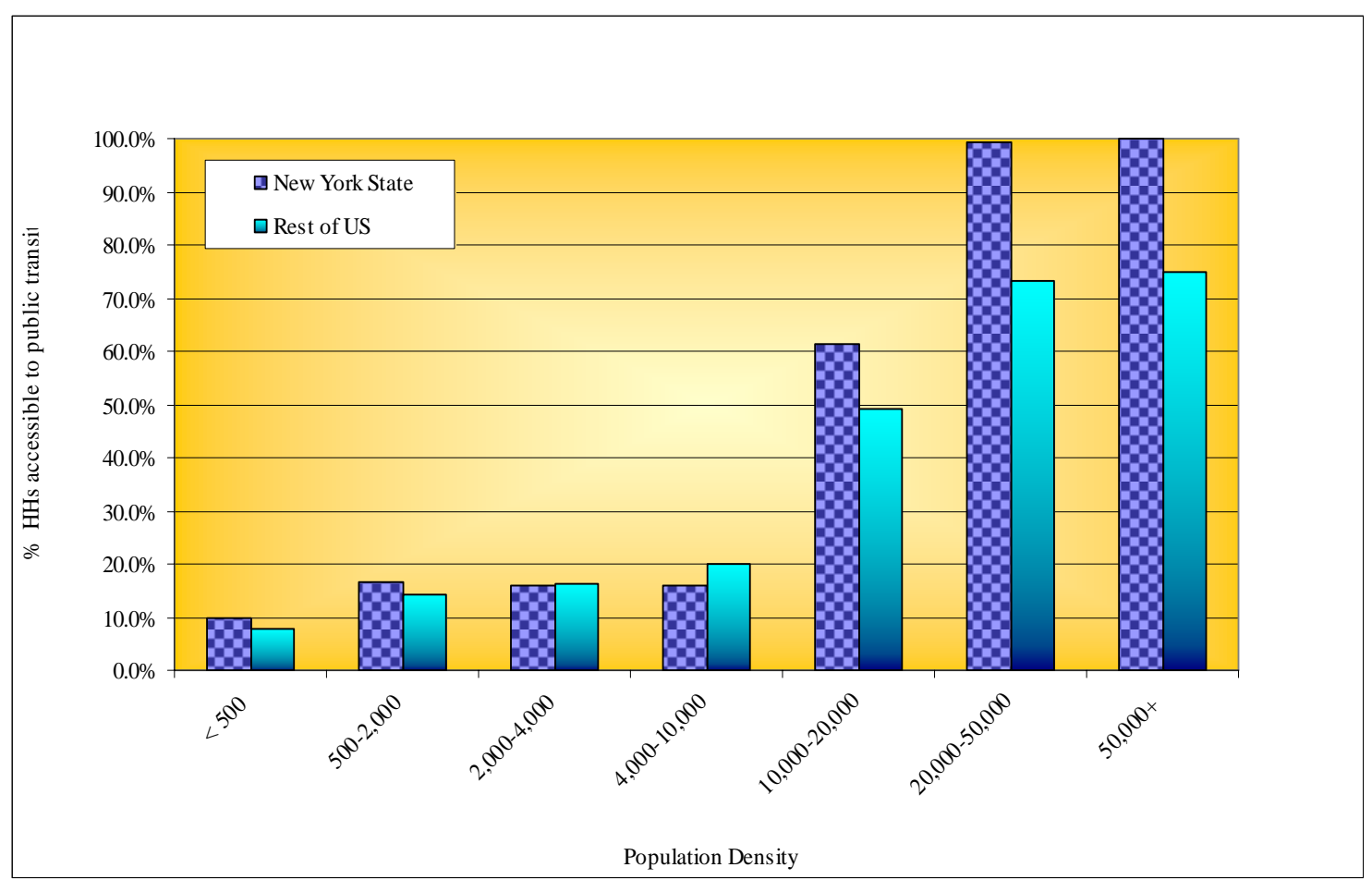

Source: Tables 4.2a and 4.2b

In general, New York urban households have fewer vehicles than those in other urban areas (Tables 4.2a and 4.2b). The disparity in vehicle ownership between New York households and those outside the state is the greatest in areas of 50,000 people per square mile. There is about one vehicle for every three drivers in highly dense areas in New York (with more than 50,000 people per square mile), while there are about two vehicles for every three drivers in other highly dense areas. These finding confirms those reported in Chapter 3. 
Table 4.2a 2001 Household Characteristics and Vehicle Ownership Patterns by Population Density New York State MPOs vs. MSAs Outside New York State

(Population density of census tract)

\begin{tabular}{|c|c|c|c|c|c|c|c|c|c|c|c|c|c|c|}
\hline & \multicolumn{14}{|c|}{ Population Density (population per square mile) } \\
\hline & \multicolumn{2}{|c|}{$<500$} & \multicolumn{2}{|c|}{$500-2,000$} & \multicolumn{2}{|c|}{$2,000-4,000$} & \multicolumn{2}{|c|}{$4,000-10,000$} & \multicolumn{2}{|c|}{$10,000-20,000$} & \multicolumn{2}{|c|}{$20,000-50,000$} & \multicolumn{2}{|c|}{$50,000+$} \\
\hline & NYS & U.S. $^{a}$ & NYS & U.S. & NYS & U.S. & NYS & U.S. & NYS & U.S. & NYS & U.S. & NYS & U.S. \\
\hline $\begin{array}{l}\text { Households } \\
(000)\end{array}$ & 530 & 14,802 & 738 & 16,937 & 664 & 17,589 & 1,028 & 21,471 & 635 & 5,839 & 1,002 & 2,337 & 1,720 & 188 \\
\hline $\begin{array}{l}\text { \% households } \\
\text { in an MSA } \\
\text { with rail }\end{array}$ & $9.9 \%$ & $7.9 \%$ & $16.5 \%$ & $14.1 \%$ & $15.8 \%$ & $16.2 \%$ & $16.0 \%$ & $19.9 \%$ & $61.3 \%$ & $49.2 \%$ & $99.2 \%$ & $73.2 \%$ & $100.0 \%$ & $75.0 \%$ \\
\hline $\begin{array}{l}\text { Workers per } \\
\text { Household }\end{array}$ & 1.42 & 1.46 & 1.42 & 1.41 & 1.33 & 1.32 & 1.39 & 1.35 & 1.50 & 1.40 & 1.28 & 1.27 & 1.26 & 1.10 \\
\hline $\begin{array}{l}\text { Vehicles per } \\
\text { Household }\end{array}$ & 2.08 & 2.28 & 1.96 & 2.02 & 1.77 & 1.85 & 1.66 & 1.71 & 1.37 & 1.45 & 0.78 & 1.11 & 0.47 & 0.55 \\
\hline $\begin{array}{l}\text { Vehicles per } \\
\text { Driver }\end{array}$ & 1.05 & 1.15 & 1.03 & 1.06 & 0.98 & 1.05 & 0.96 & 1.00 & 0.80 & 0.93 & 0.61 & 0.84 & 0.44 & 0.60 \\
\hline \multicolumn{15}{|c|}{ Distribution of Households by Number of Household Vehicles ${ }^{\text {b }}$} \\
\hline 0 vehicles & $3.98 \%$ & $3.30 \%$ & $3.24 \%$ & $3.52 \%$ & $7.47 \%$ & $5.61 \%$ & $10.16 \%$ & $8.67 \%$ & $21.76 \%$ & $15.61 \%$ & $44.96 \%$ & $28.09 \%$ & $61.46 \%$ & $50.73 \%$ \\
\hline 1 vehicle & $24.04 \%$ & $22.88 \%$ & $30.15 \%$ & $28.44 \%$ & $33.70 \%$ & $33.95 \%$ & $35.55 \%$ & $37.10 \%$ & $38.23 \%$ & $41.80 \%$ & $36.63 \%$ & $42.05 \%$ & $32.47 \%$ & $43.31 \%$ \\
\hline 2 vehicles & $45.02 \%$ & $39.91 \%$ & $44.09 \%$ & $43.11 \%$ & $40.72 \%$ & $39.19 \%$ & $37.38 \%$ & $36.56 \%$ & $26.46 \%$ & $30.09 \%$ & $15.15 \%$ & $22.52 \%$ & $5.17 \%$ & $5.96 \%$ \\
\hline 3 vehicles & $17.95 \%$ & $20.13 \%$ & $15.86 \%$ & $16.34 \%$ & $12.85 \%$ & $15.28 \%$ & $12.57 \%$ & $12.44 \%$ & $10.23 \%$ & $8.34 \%$ & $2.50 \%$ & $5.58 \%$ & $0.58 \%$ & \\
\hline $4+$ vehicles & $9.02 \%$ & $13.77 \%$ & $6.66 \%$ & $8.59 \%$ & $5.26 \%$ & $5.97 \%$ & $4.34 \%$ & $5.24 \%$ & $3.32 \%$ & $4.16 \%$ & $0.76 \%$ & $1.76 \%$ & $0.32 \%$ & \\
\hline ALL & $100 \%$ & $100 \%$ & $100 \%$ & $100 \%$ & $100 \%$ & $100 \%$ & $100 \%$ & $100 \%$ & $100 \%$ & $100 \%$ & $100 \%$ & $100 \%$ & $100 \%$ & $100 \%$ \\
\hline
\end{tabular}

Note:

a Columns labeled “U.S.” include data from outside New York State only.

b All percents may not add to $100 \%$ due to rounding. 
Table 4.2b 1995 Household Characteristics and Vehicle Ownership Patterns by Population Density New York State MPOs vs. MSAs Outside New York State

(Population density of census tract)

\begin{tabular}{|c|c|c|c|c|c|c|c|c|c|c|c|c|c|c|}
\hline & \multicolumn{14}{|c|}{ Population Density (population per square mile) } \\
\hline & \multicolumn{2}{|c|}{$<500$} & \multicolumn{2}{|c|}{$500-2,000$} & \multicolumn{2}{|c|}{$2,000-4,000$} & \multicolumn{2}{|c|}{$4,000-10,000$} & \multicolumn{2}{|c|}{$10,000-20,000$} & \multicolumn{2}{|c|}{$20,000-50,000$} & \multicolumn{2}{|c|}{$50,000+$} \\
\hline & NYS & U.S. $^{a}$ & NYS & U.S. & NYS & U.S. & NYS & U.S. & NYS & U.S. & NYS & U.S. & NYS & U.S. \\
\hline $\begin{array}{l}\text { Households } \\
(000)\end{array}$ & 568 & 14,723 & 727 & 15,721 & 601 & 15,126 & 994 & 19,726 & 617 & 5,230 & 978 & 1,962 & 1,528 & 83 \\
\hline $\begin{array}{l}\text { \% households } \\
\text { accessible to } \\
\text { public transit }\end{array}$ & $33.8 \%$ & $30.8 \%$ & $75.9 \%$ & $62.5 \%$ & $85.8 \%$ & $81.8 \%$ & $94.2 \%$ & $92.8 \%$ & $98.2 \%$ & $97.9 \%$ & $99.4 \%$ & $98.9 \%$ & $98.8 \%$ & $100.0 \%$ \\
\hline $\begin{array}{l}\text { Workers per } \\
\text { household }\end{array}$ & 1.40 & 1.38 & 1.39 & 1.40 & 1.39 & 1.36 & 1.41 & 1.32 & 1.28 & 1.18 & 1.16 & 1.19 & 1.12 & 1.18 \\
\hline $\begin{array}{l}\text { Vehicles per } \\
\text { household } \\
\end{array}$ & 1.75 & 2.08 & 1.76 & 1.95 & 1.62 & 1.79 & 1.45 & 1.64 & 1.08 & 1.29 & 0.69 & 0.90 & 0.32 & 0.66 \\
\hline $\begin{array}{l}\text { Vehicles per } \\
\text { driver }\end{array}$ & 0.92 & 1.09 & 0.90 & 1.03 & 0.85 & 0.99 & 0.81 & 0.95 & 0.73 & 0.87 & 0.58 & 0.74 & 0.35 & 0.60 \\
\hline \multicolumn{15}{|c|}{ Distribution of Households by Number of Household Vehicles ${ }^{b}$} \\
\hline 0 vehicles & $4.23 \%$ & $3.40 \%$ & $2.76 \%$ & $3.15 \%$ & $6.06 \%$ & $6.06 \%$ & $11.31 \%$ & $8.34 \%$ & $21.94 \%$ & $18.45 \%$ & $42.21 \%$ & $35.28 \%$ & $68.19 \%$ & $47.07 \%$ \\
\hline 1 vehicle & $26.84 \%$ & $23.12 \%$ & $28.08 \%$ & $28.80 \%$ & $32.13 \%$ & $33.70 \%$ & $36.06 \%$ & $38.64 \%$ & $43.01 \%$ & $45.05 \%$ & $39.16 \%$ & $43.89 \%$ & $27.21 \%$ & $40.39 \%$ \\
\hline 2 vehicles & $48.05 \%$ & $46.41 \%$ & $48.84 \%$ & $46.35 \%$ & $43.42 \%$ & $42.33 \%$ & $39.47 \%$ & $38.62 \%$ & $28.53 \%$ & $27.99 \%$ & $15.22 \%$ & $16.62 \%$ & $4.26 \%$ & $12.10 \%$ \\
\hline 3 vehicles & $15.52 \%$ & $19.57 \%$ & $14.08 \%$ & $16.00 \%$ & $13.77 \%$ & $12.76 \%$ & $8.79 \%$ & $10.95 \%$ & $5.40 \%$ & $6.43 \%$ & $2.86 \%$ & $3.93 \%$ & $0.25 \%$ & $0.44 \%$ \\
\hline 4+ vehicles & $5.36 \%$ & $7.50 \%$ & $6.25 \%$ & $5.69 \%$ & $4.62 \%$ & $5.14 \%$ & $4.37 \%$ & $3.45 \%$ & $1.11 \%$ & $2.08 \%$ & $0.55 \%$ & $0.28 \%$ & $0.08 \%$ & $0.00 \%$ \\
\hline$A L L$ & $100 \%$ & $100 \%$ & $100 \%$ & $100 \%$ & $100 \%$ & $100 \%$ & $100 \%$ & $100 \%$ & $100 \%$ & $100 \%$ & $100 \%$ & $100 \%$ & $100 \%$ & $100 \%$ \\
\hline
\end{tabular}

Note:

a Columns labeled “U.S.” include data from outside New York State only.

b All percents may not add to $100 \%$ due to rounding. 
The percentage of households without a vehicle is positively correlated with population density. This is true for New York MPO households as well as households in MSAs outside NYS. However, this relationship is particularly prominent in NYS (Figure 4.5). While two in every three households in the most densely populated areas in NYS are without a vehicle, the equivalent figure outside NYS is one in every two households (Table 4.2a). Compared to 2001, a slightly greater percentage of New York households living in the extremely densely populated areas did not own a vehicle in 1995.

Figure 4.5 Percent Households without a Vehicle and Population Density

New York MPOs vs. MSAs Outside New York State 1995 and 2001

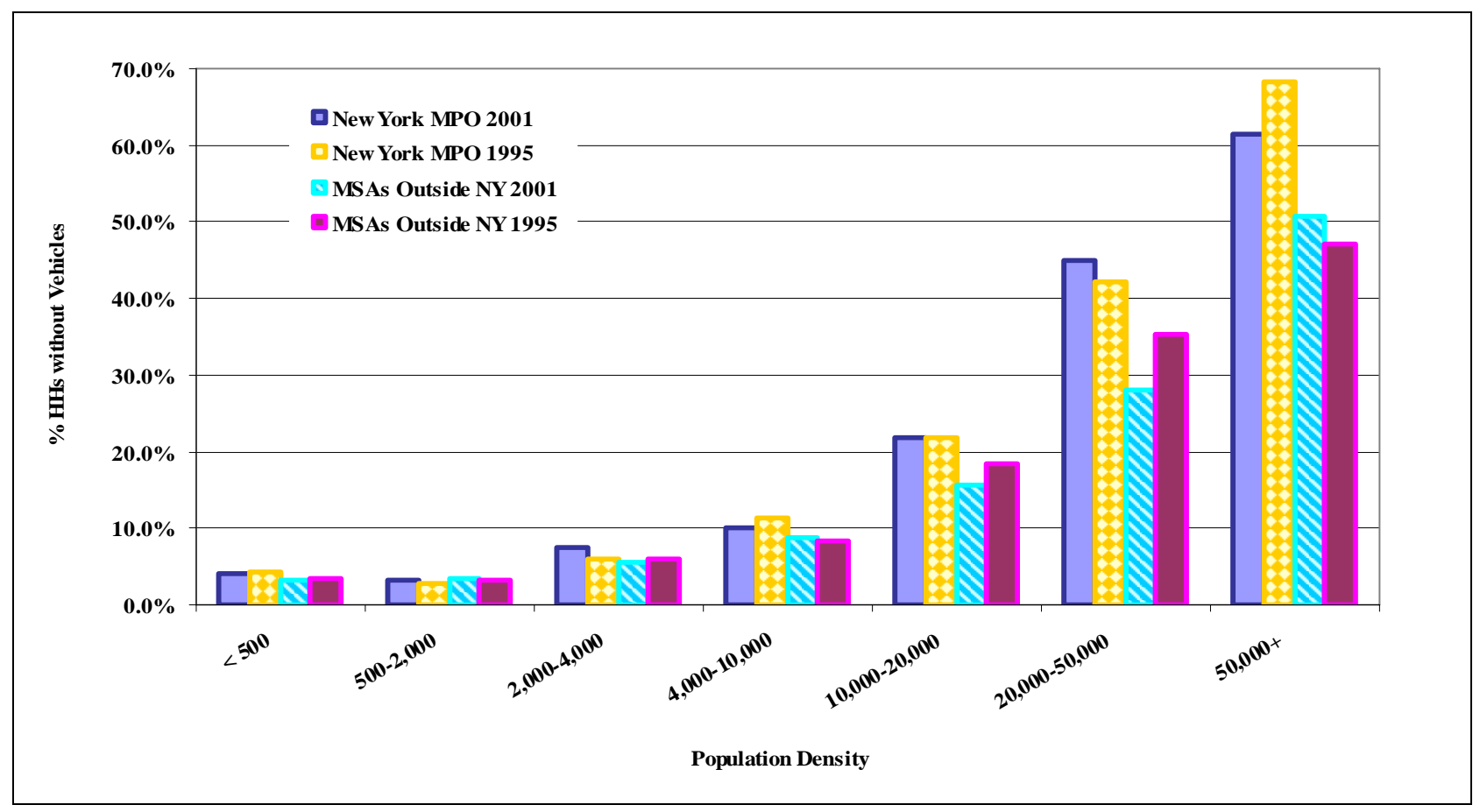

Source: Tables 4.2a and 4.2b

There is not a significant difference in driver rate between New York residents in MPOs and residents in MSAs outside NYS. Similar to vehicle ownership patterns, driver rates are clearly related to population density: residents in highly populated areas are less likely to drive 
(Figure 4.6). These statistics are different from those reported in Highway Statistics (Federal Highway Administration, 2002) for three reasons. First, Highway Statistics includes all residential population, while NHTS includes civilian population. Second, driver rates reported in Figure 4.6 are for urban population only. Finally, the NHTS asked the responder whether he/she was a driver regardless of her/her license status, while Highway Statistics reports licensing rates.

Figure 4.6 1995 and 2001 Driver Rates by Gender and Population Density New York State MPOs vs. MSAs Outside New York State

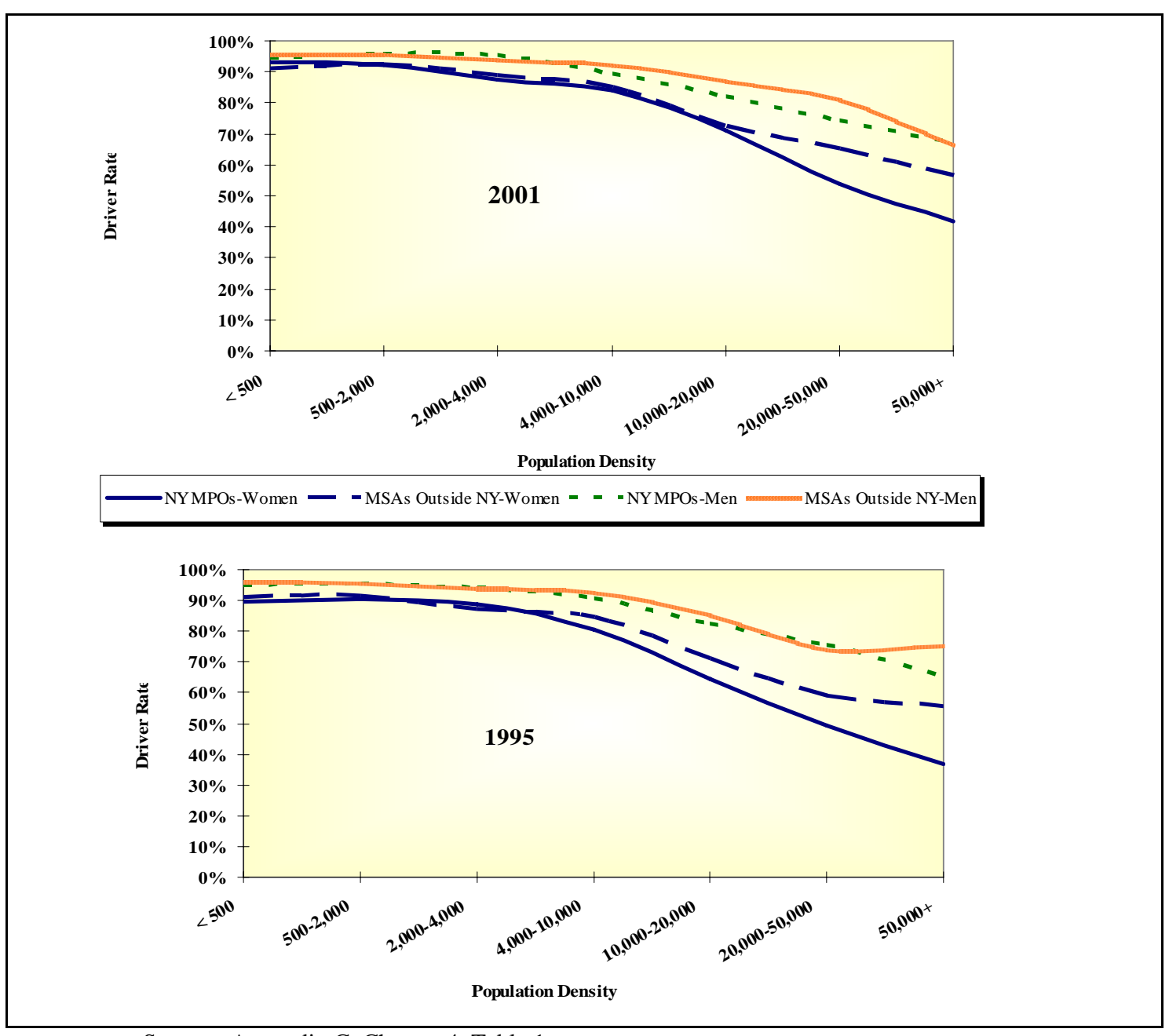

Source: Appendix C, Chapter 4, Table 1 


\subsection{Personal Travel}

In general, the differences in personal travel between New York urban areas and other urban areas are not prominent. However, the overall pattern seems to be that New York residents in urban areas take slightly fewer, and shorter, trips than those in other urban areas of similar density. Across almost all urban areas, the number of daily trips decreased from 1995 to 2001 (Figure 4.7). Consistent across the nation, the relationship between daily trip rate and population density is quasi bell-shaped - increasing with population density, and then declining with increasing population density. Residents in the densest populated areas take the fewest number of trips per day. Regardless of gender and location, almost everyone living in an urban area took fewer trips in 2001 than in 1995, exception for men living in the most populated areas in NYS (Figure 4.8). Excluded from Figure 4.8 are comparisons of extremely populated areas (population density greater than 50,000 per square mile). The small sample sizes for these areas preclude any meaningful comparisons.

Figure 4.7 Daily Person Trips by Population Density New York MPOs vs. MSAs Outside New York State 1995 and 2001

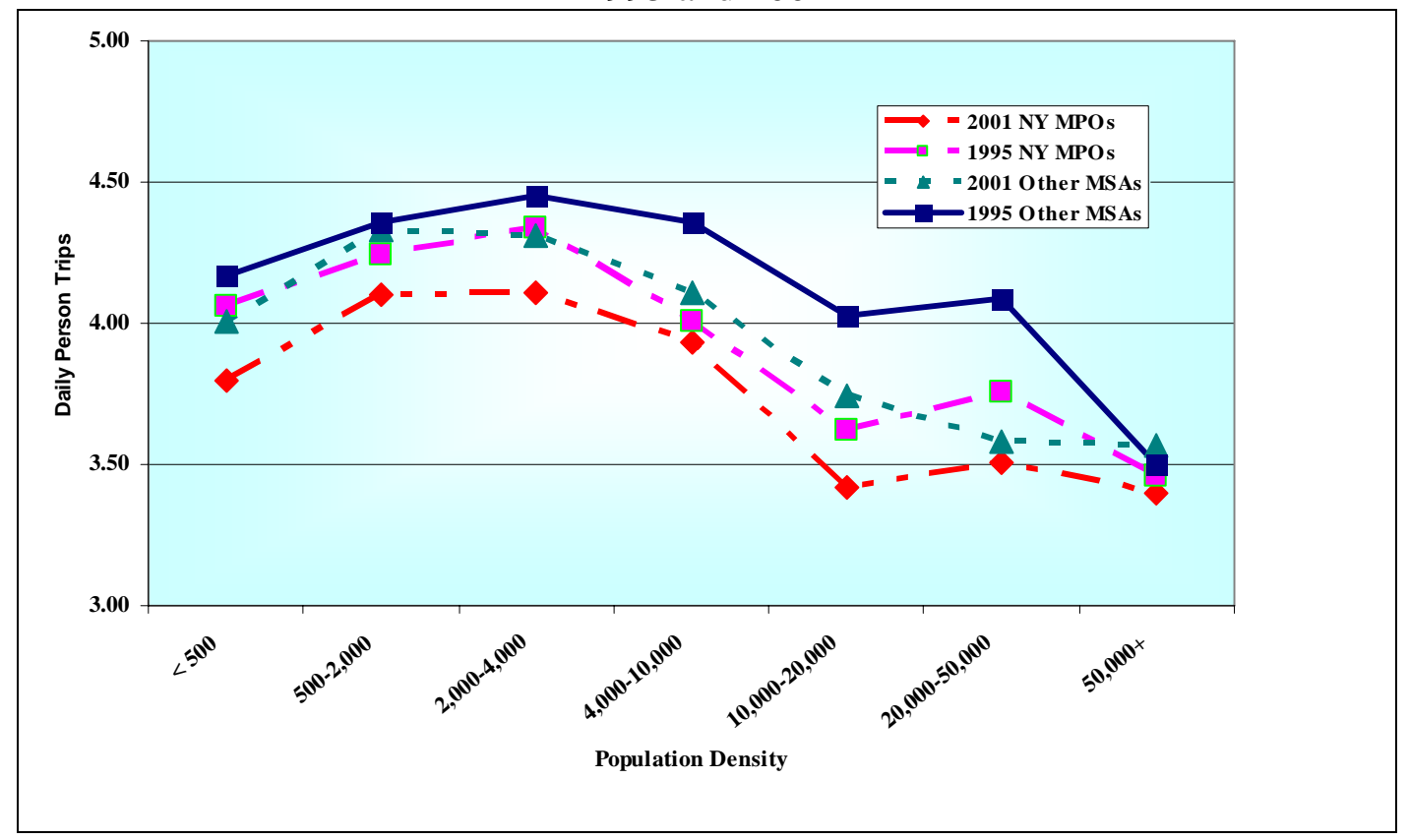

Source: Tables 4.3a and 4.3b 
Figure 4.8 Percent Change from 1995 to 2001 in Number of Daily Person Trips by Gender and Population Density

New York State MPOs vs. MSAs Outside New York State

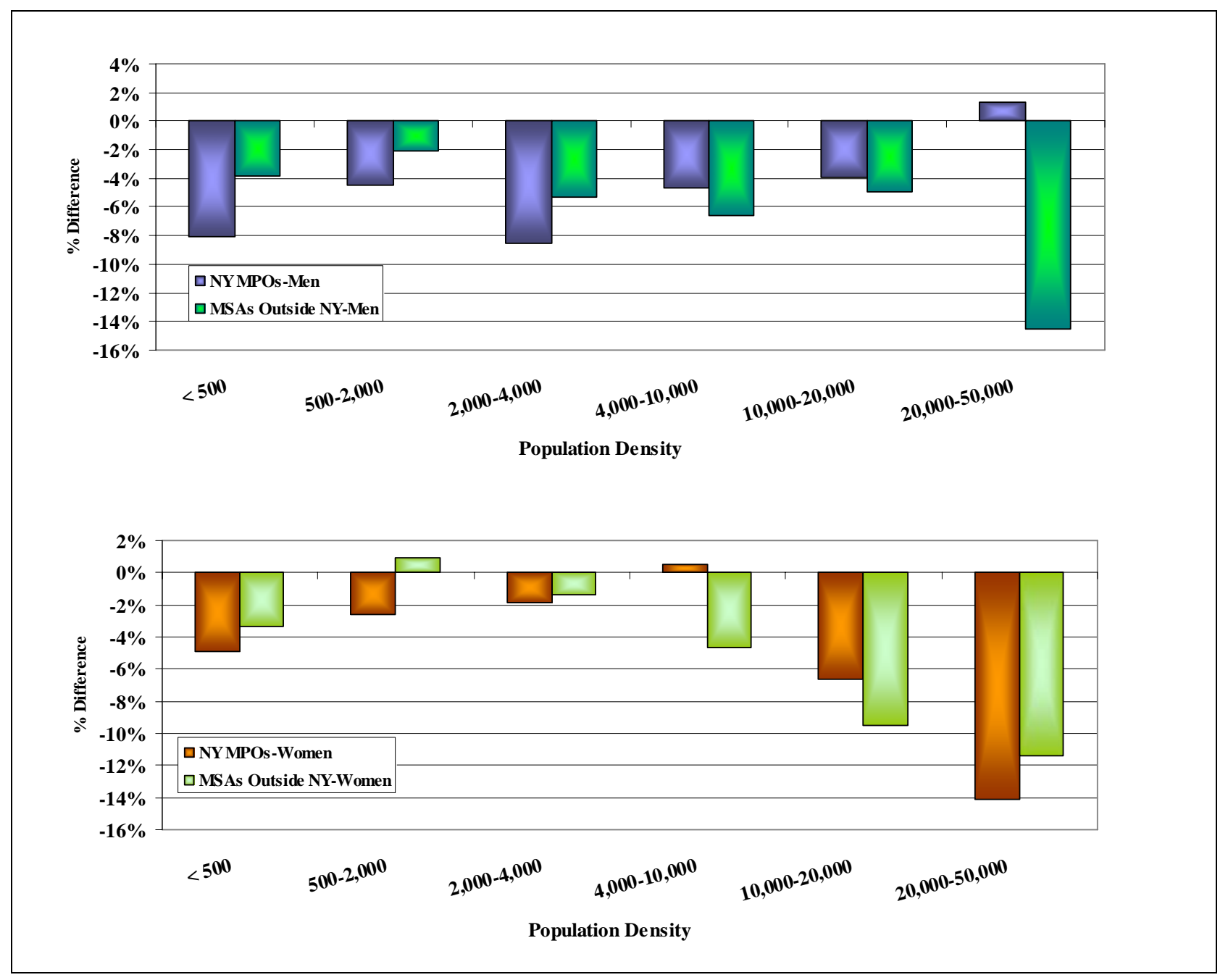

Source: Appendix C, Chapter 4, Table 2 
Outside NYS, the average trip length declines with increasing population density, ranging from about 11.5 miles per trip in the least populated areas to about 7 miles in the densest populated areas (Figure 4.9 and Table 4.3a). However, this is not the case in New York urban areas. The relationship between trip length and population density in New York urban areas seems to follow a reversed bell-shape - trips are the longest in the least populated urban areas, decline with increasing population density, then start to increase with increasing population density (Figure 4.8). The trends continue where residents in New York MPOs seem to take, on average, shorter trips than their counterparts in areas of similar density, except those in the densest New York urban areas (Figure 4.9). New York residents in the least populated urban areas travel on average about 40 miles per day, compared to 19 miles by residents in NYC (Table 4.3a). This is because residents in the sparsely populated areas take not only more, but also longer, trips than people in heavily-urbanized areas, who typically do not have to travel as far to reach their destinations (Table 4.3b). The differences in average trip length between 1995 and 2001 are quite pronounced in the extremely populated New York areas (Figure 4.10). Trips taken by New York residents living in areas with more than 20,000 people per square mile are more than 40\% longer in 2001 than in 1995. After 9/11, many workers commuted to new employment locations away from Manhattan. Only after two years after the attack did the NYC payroll employment begin to recover. 6

6 “Taking the Pulse of the New York City Economy,” Current Issues in Economics and Finance, Volume 12, Number 4. Federal Reserve Bank of New York, May/June 2006. 
Figure 4.9 Average Person Trip Length

New York State MPOs vs. MSAs Outside New York State 1995 and 2001

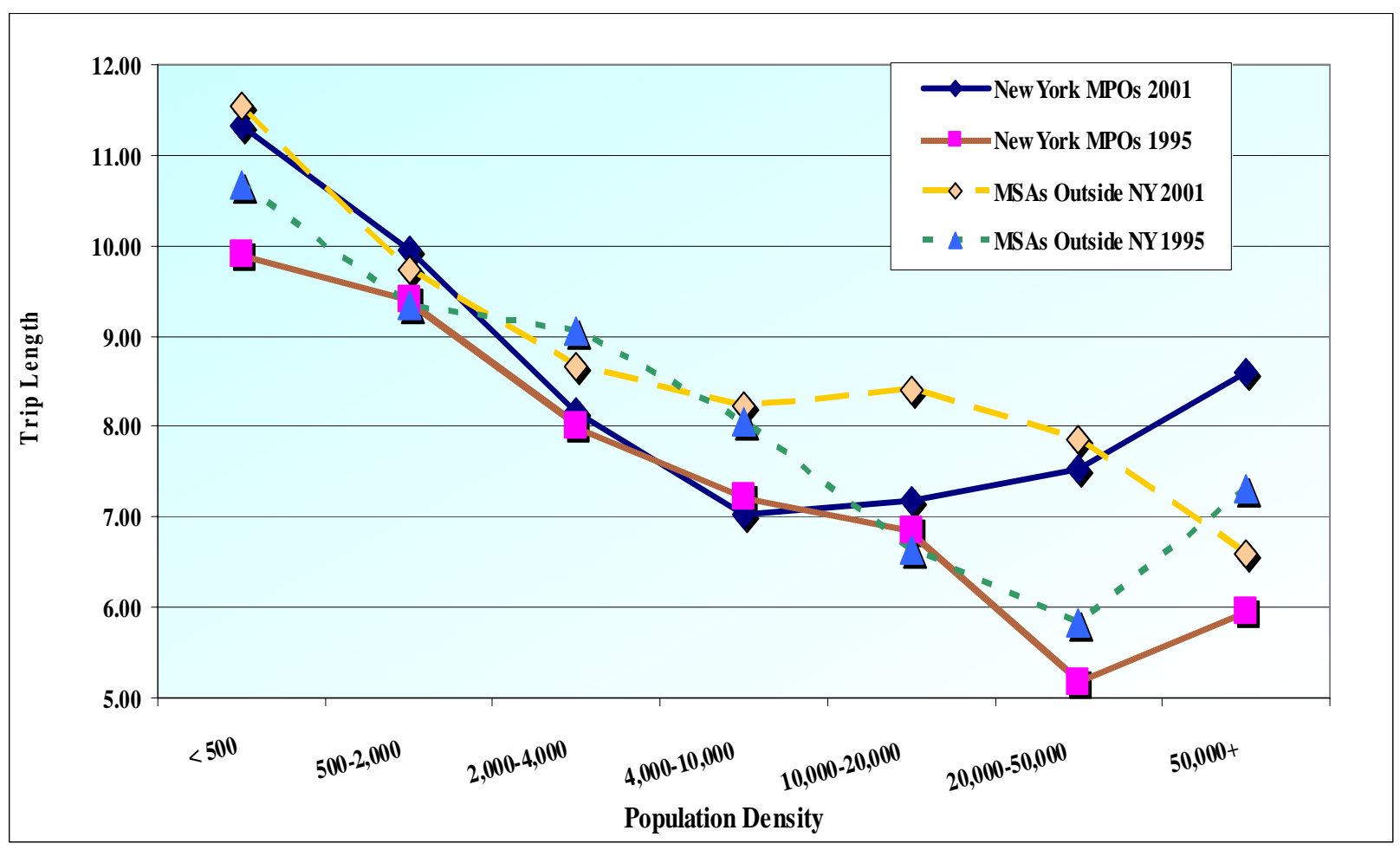

Source: Appendix C, Chapter 4, Table 2. 
Figure 4.10 Percent Difference in Trip Length between 1995 and 2001 New York State MPOs vs. MSAs Outside New York State

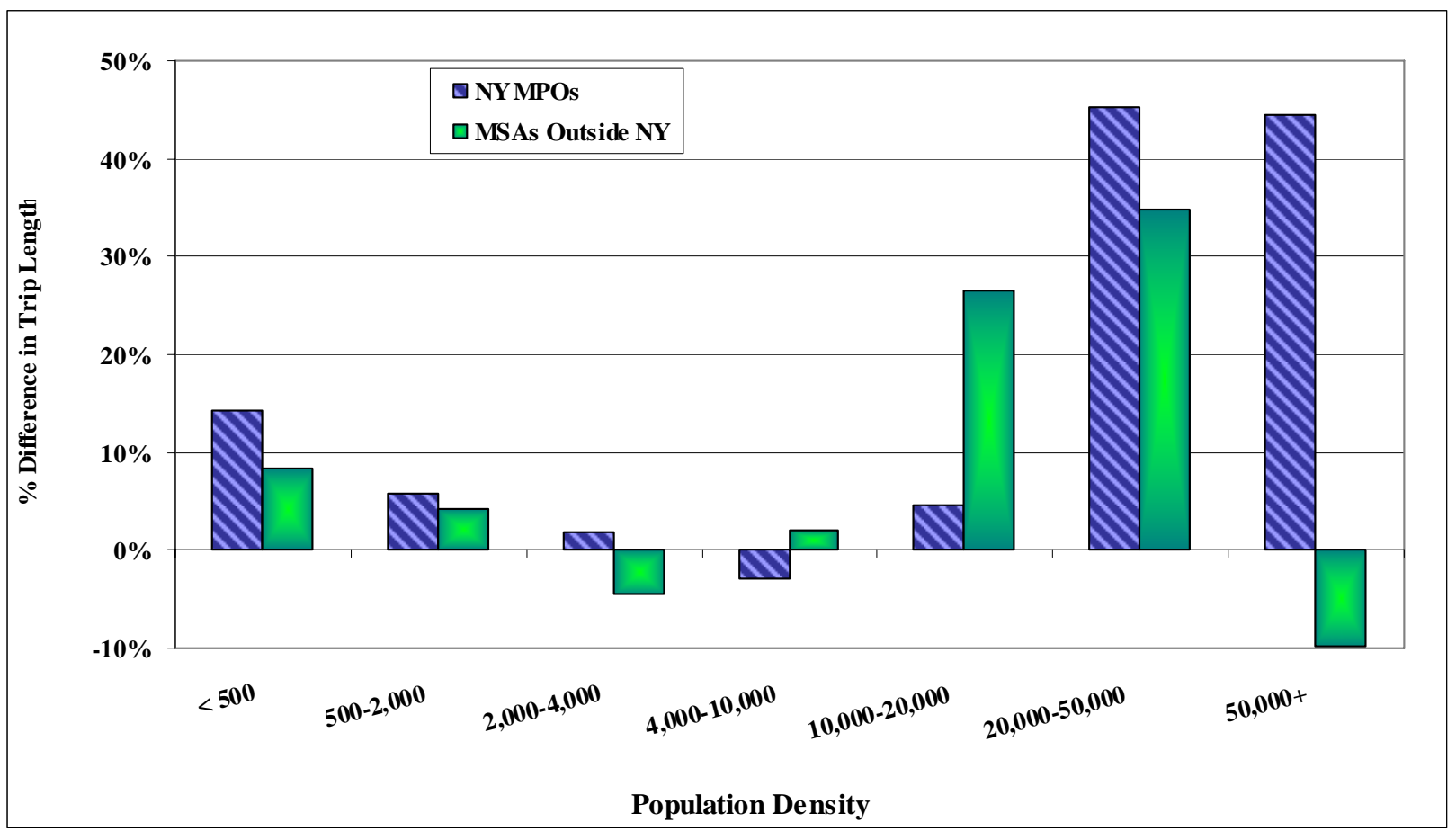

Source: Appendix C, Chapter 4, Table 2 
Table 4.3a Personal Travel Statistics by Mode of Transportation and Population Density New York State MPOs (NYS) vs. MSAs Outside New York State (U.S.), 2001

(Population density of census tract)

\begin{tabular}{|c|c|c|c|c|c|c|c|c|c|c|c|c|c|c|}
\hline & \multicolumn{14}{|c|}{ Population Density (population per square mile) $^{\mathrm{a}}$} \\
\hline & \multicolumn{2}{|c|}{$<500$} & \multicolumn{2}{|c|}{$500-2,000$} & \multicolumn{2}{|c|}{$2,000-4,000$} & \multicolumn{2}{|c|}{$4,000-10,000$} & \multicolumn{2}{|c|}{$10,000-20,000$} & \multicolumn{2}{|c|}{$20,000-50,000$} & \multicolumn{2}{|c|}{$50,000+$} \\
\hline & NYS & U.S. & NYS & U.S. & NYS & U.S. & NYS & U.S. & NYS & U.S. & NYS & U.S. & NYS & U.S. \\
\hline \multicolumn{15}{|c|}{ Person Trips per Person } \\
\hline TOTAL & 3.80 & 4.01 & 4.10 & 4.33 & 4.11 & 4.31 & 3.93 & 4.11 & 3.42 & 3.74 & 3.51 & 3.58 & 3.40 & 3.57 \\
\hline$\% S O V$ & 42.1 & 41.8 & 44.2 & 40.8 & 39.9 & 42.4 & 39.0 & 39.0 & 32.5 & 33.7 & 18.2 & 27.5 & 8.0 & 22.0 \\
\hline$\% M O V$ & 44.2 & 48.7 & 43.0 & 49.0 & 46.3 & 46.7 & 41.6 & 47.0 & 34.6 & 41.9 & 26.8 & 37.9 & 15.6 & 13.3 \\
\hline$\%$ Amtrak & 0.0 & 0.0 & 0.1 & 0.0 & 0.1 & 0.1 & 0.2 & 0.0 & 0.5 & 0.1 & 0.3 & & 0.4 & \\
\hline \% Commuter Train & 0.2 & 0.0 & 0.2 & 0.0 & 0.6 & 0.1 & 0.9 & 0.2 & 0.4 & 0.1 & 0.5 & 0.2 & 0.4 & \\
\hline \% Subway/El Rail & 0.4 & 0.0 & 0.3 & 0.1 & 0.5 & 0.1 & 0.8 & 0.2 & 4.8 & 0.8 & 10.0 & 1.7 & 16.1 & 5.3 \\
\hline \% Other Public & 0.7 & 0.1 & 0.1 & 0.2 & 0.5 & 0.5 & 1.2 & 1.3 & 4.0 & 3.9 & 7.4 & 7.7 & 10.3 & 20.4 \\
\hline$\%$ Walk $^{\mathrm{b}}$ & 7.2 & 5.5 & 7.3 & 5.9 & 7.7 & 7.5 & 11.6 & 9.7 & 19.3 & 16.3 & 32.4 & 20.5 & 43.9 & 35.2 \\
\hline$\%$ Other $^{\mathrm{c}}$ & 5.1 & 3.8 & 4.6 & 3.8 & 4.4 & 2.6 & 4.7 & 2.6 & 3.7 & 3.4 & 4.3 & 4.3 & 5.2 & 3.8 \\
\hline \% Unreported & 0.1 & 0.1 & 0.1 & 0.1 & 0.1 & 0.1 & 0.1 & 0.1 & 0.2 & 0.0 & 0.1 & 0.1 & 0.1 & \\
\hline \multicolumn{15}{|c|}{ Person Miles Traveled (PMT) per Person } \\
\hline TOTAL & 40.12 & 44.65 & 37.78 & 42.51 & 35.05 & 39.00 & 28.31 & 36.12 & 23.75 & 33.53 & 24.84 & 30.69 & 18.5 & 24.5 \\
\hline$\%$ SOV & 42.5 & 40.3 & 41.5 & 38.5 & 39.7 & 39.6 & 36.8 & 36.6 & 31.4 & 27.8 & 16.3 & 24.4 & 13.0 & 22.0 \\
\hline$\% M O V$ & 49.3 & 53.7 & 44.8 & 49.6 & 49.0 & 50.7 & 47.4 & 49.3 & 47.9 & 41.7 & 20.9 & 42.6 & 29.4 & 58.4 \\
\hline$\%$ Amtrak & 0.6 & 0.0 & 0.4 & 0.0 & 0.2 & 0.0 & 0.6 & 0.2 & 0.9 & 0.4 & 0.2 & & 1.7 & \\
\hline \% Commuter Train & 0.7 & 0.1 & 0.7 & 0.2 & 2.2 & 0.1 & 2.9 & 0.5 & 1.4 & 0.3 & 0.9 & 0.2 & 0.5 & \\
\hline \% Subway/El Rail & 0.5 & 0.0 & 0.3 & 0.2 & 0.5 & 0.1 & 1.5 & 0.2 & 6.9 & 0.7 & 9.8 & 1.1 & 18.2 & 3.7 \\
\hline$\%$ Other Public & 0.6 & 0.1 & 0.2 & 0.2 & 0.4 & 0.4 & 1.0 & 1.0 & 3.5 & 2.3 & 4.1 & 3.9 & 6.5 & 12.4 \\
\hline$\%$ Walk & 0.6 & 0.4 & 0.7 & 0.5 & 0.7 & 0.6 & 1.3 & 0.8 & 2.2 & 1.2 & 3.4 & 1.5 & 4.9 & 2.8 \\
\hline$\%$ Other & 5.2 & 5.4 & 11.4 & 10.7 & 7.1 & 6.2 & 6.8 & 11.6 & 5.7 & 25.5 & 44.5 & 26.3 & 24.1 & 0.7 \\
\hline \% Unreported & 0.0 & 0.2 & 0.1 & 0.1 & 0.2 & 2.2 & 1.8 & 0.1 & 0.2 & 0.0 & 0.0 & 0.0 & 1.9 & \\
\hline \multicolumn{15}{|c|}{ Person Trips per Person } \\
\hline Weekday & 3.71 & 3.95 & 4.01 & 4.27 & 4.01 & 4.17 & 3.78 & 3.92 & 3.34 & 3.48 & 3.50 & 3.53 & 3.30 & 4.08 \\
\hline Weekend & 4.06 & 4.20 & 4.36 & 4.54 & 4.40 & 4.68 & 4.32 & 4.62 & 3.66 & 4.43 & 3.56 & 3.73 & 3.68 & 2.34 \\
\hline \multicolumn{15}{|c|}{ Average Person Trip Length ${ }^{\mathrm{d}}$} \\
\hline & 11.32 & 11.55 & 9.95 & 9.73 & 8.16 & 8.66 & 7.02 & 8.22 & 7.17 & 8.40 & 7.52 & 7.86 & 8.60 & 6.60 \\
\hline $\begin{array}{ll}\text { Note: } \\
\text { a } \\
\text { b } & \text { All percents may not } \\
\text { c } & \text { Multiple prompts in } \\
\text { d } & \text { The mode "Other" in } \\
& \text { Average trip length i }\end{array}$ & $\begin{array}{l}\text { urvey fo } \\
\text { nmercial }\end{array}$ & $\begin{array}{l}\text { unding. } \\
\text { lk trips in } \\
\text { private a }\end{array}$ & $\begin{array}{l}\text { ed the } \\
\text { mmute }\end{array}$ & $\begin{array}{l}\text { ber of st } \\
\text { ool/cha }\end{array}$ & $\begin{array}{l}\text { rips cons } \\
\text { city to c }\end{array}$ & ably. & xi, li & $e, a$ & shuttl & ycle, a & n & ifies & & \\
\hline
\end{tabular}


Table 4.3b Personal Travel Statistics by Mode of Transportation and Population Density New York State MPOs (NYS) vs. MSAs Outside New York State (U.S.), 1995

(Population density of census tract)

\begin{tabular}{|c|c|c|c|c|c|c|c|c|c|c|c|c|c|c|}
\hline & \multicolumn{14}{|c|}{ Population Density (population per square mile) $^{\mathrm{a}}$} \\
\hline & \multicolumn{2}{|c|}{$<500$} & \multicolumn{2}{|c|}{$500-2,000$} & \multicolumn{2}{|c|}{$2,000-4,000$} & \multicolumn{2}{|c|}{$4,000-10,000$} & \multicolumn{2}{|c|}{$10,000-20,000$} & \multicolumn{2}{|c|}{$20,000-50,000$} & \multicolumn{2}{|c|}{$>50,000$} \\
\hline & NYS & U.S. & NYS & U.S. & NYS & U.S. & NYS & U.S. & NYS & U.S. & NYS & U.S. & NYS & U.S. \\
\hline \multicolumn{15}{|c|}{ Person Trips per Person } \\
\hline TOTAL & 4.06 & 4.17 & 4.24 & 4.36 & 4.34 & 4.45 & 4.01 & 4.36 & 3.62 & 4.03 & 3.76 & 4.09 & 3.46 & 3.50 \\
\hline$\% S O V$ & 43.1 & 43.4 & 41.7 & 42.9 & 46.8 & 44.3 & 39.7 & 42.0 & 32.0 & 36.7 & 18.4 & 23.2 & 7.2 & 25.4 \\
\hline$\% M O V$ & 44.6 & 47.0 & 45.0 & 46.8 & 39.4 & 44.3 & 42.1 & 44.0 & 37.0 & 38.5 & 23.1 & 34.0 & 16.2 & 20.0 \\
\hline \%Other POV & 0.0 & 0.2 & 0.0 & 0.0 & 0.2 & 0.0 & 0.0 & 0.0 & 0.0 & $n a$ & 0.3 & $n a$ & 0.0 &. \\
\hline$\% A m t r a k$ & $n a$ & $n a$ & $n a$ & $n a$ & $n a$ & $n a$ & $n a$ & 0.0 &. & $n a$ & $n a$ &. & $n a$ &. \\
\hline \%Commuter Train & 0.2 & 0.0 & 0.5 & 0.0 & 0.7 & 0.2 & 0.7 & 0.2 & 0.8 & 0.5 & 1.9 & 0.5 & 3.5 & 0.6 \\
\hline \%Subway/El Rail & 0.2 & 0.0 & 0.0 & 0.0 & 0.2 & 0.0 & 0.7 & 0.0 & 3.0 & 1.0 & 8.2 & 1.7 & 13.3 & 6.9 \\
\hline \%Other Public & 0.5 & 0.2 & 0.5 & 0.5 & 0.7 & 0.9 & 1.5 & 1.6 & 6.4 & 5.0 & 8.5 & 8.3 & 11.0 & 12.9 \\
\hline \%Walk & 3.9 & 2.4 & 4.5 & 3.0 & 4.1 & 4.7 & 7.2 & 6.2 & 12.4 & 11.7 & 30.3 & 22.7 & 36.1 & 28.9 \\
\hline \%Other ${ }^{\mathrm{b}}$ & 4.4 & 3.6 & 4.2 & 3.7 & 4.1 & 2.7 & 3.7 & 2.3 & 3.0 & 2.2 & 4.0 & 3.4 & 6.4 & 1.4 \\
\hline \%Unreported & 3.0 & 3.1 & 3.5 & 3.2 & 3.7 & 2.9 & 4.2 & 3.7 & 5.2 & 4.5 & 5.3 & 6.1 & 6.4 & 4.0 \\
\hline \multicolumn{15}{|c|}{ Person Miles Traveled (PMT) per Person } \\
\hline TOTAL & 39.75 & 43.90 & 39.25 & 40.28 & 34.31 & 39.89 & 28.12 & 34.49 & 23.60 & 26.13 & 18.05 & 22.84 & 18.93 & 25.59 \\
\hline$\% S O V$ & 42.4 & 42.7 & 37.1 & 41.4 & 43.7 & 38.4 & 38.9 & 41.1 & 34.1 & 40.1 & 26.1 & 31.8 & 12.8 & 16.0 \\
\hline$\% M O V$ & 48.3 & 52.0 & 55.6 & 51.0 & 47.4 & 49.4 & 48.3 & 49.0 & 48.9 & 44.4 & 36.4 & 47.0 & 38.4 & 68.4 \\
\hline \%Other POV & 0.0 & 0.1 & 0.0 & 0.0 & 0.3 & 0.4 & 0.0 & 0.1 & 0.0 & $n a$ & 0.4 & $n a$ & 0.1 & \\
\hline$\%$ Amtrak & na & na & na & na & na & na & na & 0.0 & & na & na & & na & \\
\hline \%Commuter Train & 0.7 & 0.1 & 1.5 & 0.2 & 2.7 & 0.5 & 3.3 & 0.4 & 2.2 & 0.7 & 3.0 & 0.6 & 7.4 & 1.5 \\
\hline \%Subway/El Rail & 0.2 & 0.0 & 0.1 & 0.1 & 0.1 & 0.2 & 1.4 & 0.1 & 3.9 & 1.2 & 16.1 & 1.9 & 16.6 & 6.5 \\
\hline \%Other Public & 1.3 & 0.3 & 0.9 & 0.4 & 1.1 & 2.1 & 2.9 & 1.4 & 6.9 & 8.3 & 9.3 & 8.8 & 10.7 & 3.7 \\
\hline \%Walk & 0.4 & 0.1 & 0.3 & 0.2 & 0.3 & 0.3 & 0.6 & 0.4 & 0.9 & 0.9 & 3.6 & 2.1 & 4.1 & 3.4 \\
\hline \%Other & 4.0 & 3.9 & 3.5 & 5.9 & 3.3 & 6.8 & 2.8 & 6.6 & 2.1 & 2.8 & 4.4 & 7.5 & 8.9 & 0.2 \\
\hline \%Unreported & 0.8 & 0.8 & 0.8 & 0.7 & 1.1 & 1.8 & 1.4 & 0.9 & 1.0 & 1.5 & 0.7 & 0.3 & 0.9 & 0.2 \\
\hline \multicolumn{15}{|c|}{ Person Trips per Person } \\
\hline Weekday & 3.97 & 4.12 & 4.30 & 4.25 & 4.13 & 4.44 & 3.74 & 4.25 & 3.31 & 3.75 & 3.48 & 3.87 & 3.47 & 3.81 \\
\hline Weekend & 4.34 & 4.32 & 4.13 & 4.70 & 4.90 & 4.54 & 4.70 & 4.67 & 4.42 & 4.79 & 4.50 & 4.66 & 3.46 & 2.75 \\
\hline \multicolumn{15}{|c|}{ Average Person Trip Length $^{\mathrm{C}}$} \\
\hline & 9.91 & 10.66 & 9.41 & 9.33 & 8.02 & 9.06 & 7.23 & 8.05 & 6.85 & 6.64 & 5.18 & 5.83 & 5.95 & 7.31 \\
\hline
\end{tabular}


After controlling for population density, the person-trip distribution by trip length is almost identical between New York urban areas and other urban areas, except for the slight differences in highly populated areas. The proportion of trips longer than 10 miles decreases with population density (Figure 4.11), reflecting the spatial proximity of places in the dense development in large urban areas. The patterns between average trip length and population density in New York urban areas remained stable from 1995 to 2001.

Figure 4.11 Person Trip Distribution by Trip Length and Population Density New York MPOs

(Population density of census tract)
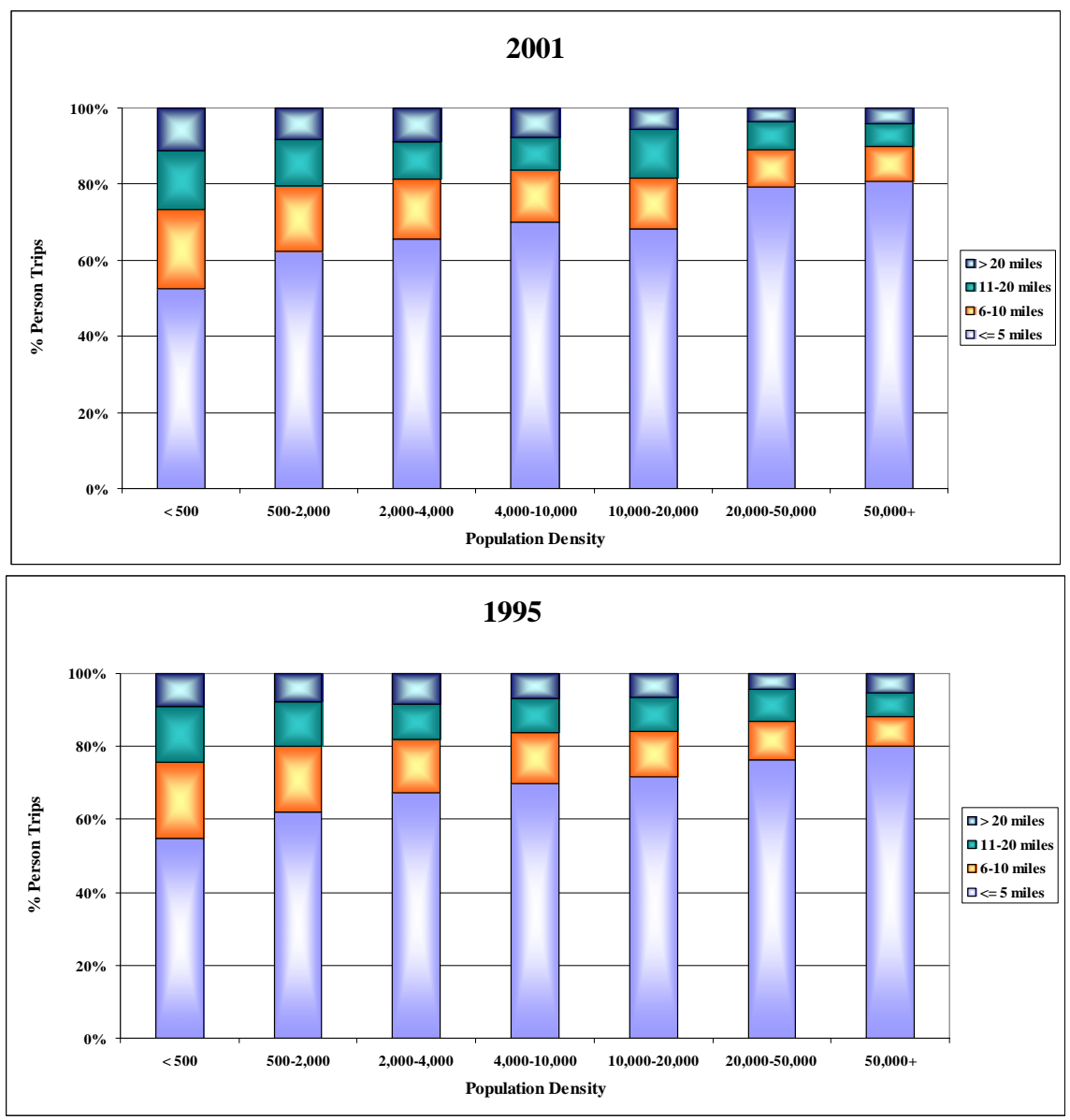

Source: Appendix C, Chapter 4, Table 3 
The percentage of trips taken in non-private vehicles (e.g., public transit, walking) increases with increasing population density (Table 4.3a and Table 4.3b), ranging from less than $10 \%$ in small urban areas (with population density $<4,000$ per square mile) in NYS to $76 \%$ in NYC. However, this rate of increase is more distinct to population density in NYS than in the rest of the country (Figure 4.12). This partially reflects the facts that more New York households have access to public transit than those in areas of similar size (Table 4.2) and that census tracts in NYC, particularly in Manhattan, are so much denser than 50,000 people per square mile. Residents living in the extremely dense populated areas are more likely to walk or taking public transit in 2001 than in 1995. This observation could be an artifact of the improvement in the 2001 survey where special prompting was carried out to better recall walk and bicycle trips.

Figure 4.12 Percent Daily Person Trips by Public Transit and Walking

New York State MPOs vs. MSAs Outside New York State

1995 and 2001

(Population density of census tract)

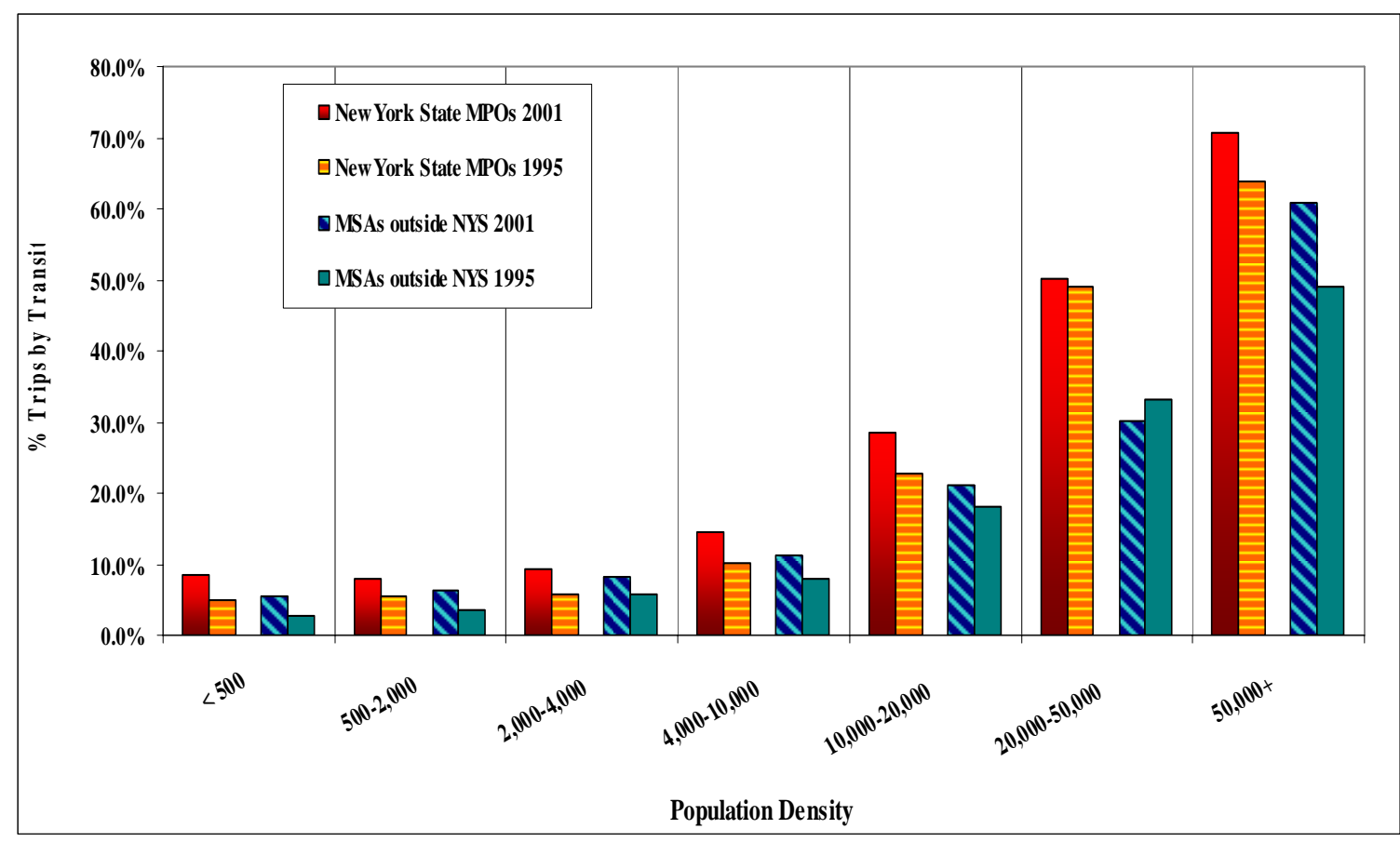

Source: Appendix C, Chapter 4, Table 3. 


\section{Zero-Vehicle Households}

In urban areas with more than 4,000 people per square mile, a greater proportion of New York households are without a vehicle than households elsewhere (Table 4.2a). Regardless of population density, those without a vehicle take fewer trips on average than those with a vehicle (Appendix D, Chapter 4, Tables 4 and 5). The difference in trip frequency narrows with population density, implying that having no access to a vehicle is less of a mobility constraint in highly populated areas than in less populated areas. This again reflects the spatial density and proximity of infrastructure and ready accessibility to public transit and taxis in densely populated areas.

Outside NYS, the effect on trip frequency of being without a vehicle is that those in densely populated areas are significantly more mobile than those in less dense areas, except in areas with more than 50,000 people per square mile. However, this trend is not apparent in New York where population density does not appear to bear any relationship to the trip frequency of those without a vehicle (Figure 4.13). The small sample sizes in NYS can be a contributing factor to this lack of a relationship. Compared to 1995, New York residents who live in small urban areas and who are without a vehicle take fewer trips in 2001. 
Figure 4.13 Average Daily Person Trips of Individuals Without a Vehicle New York State MPOs vs. MSAs Outside New York State 1995 and 2001

(Population density of census tract)

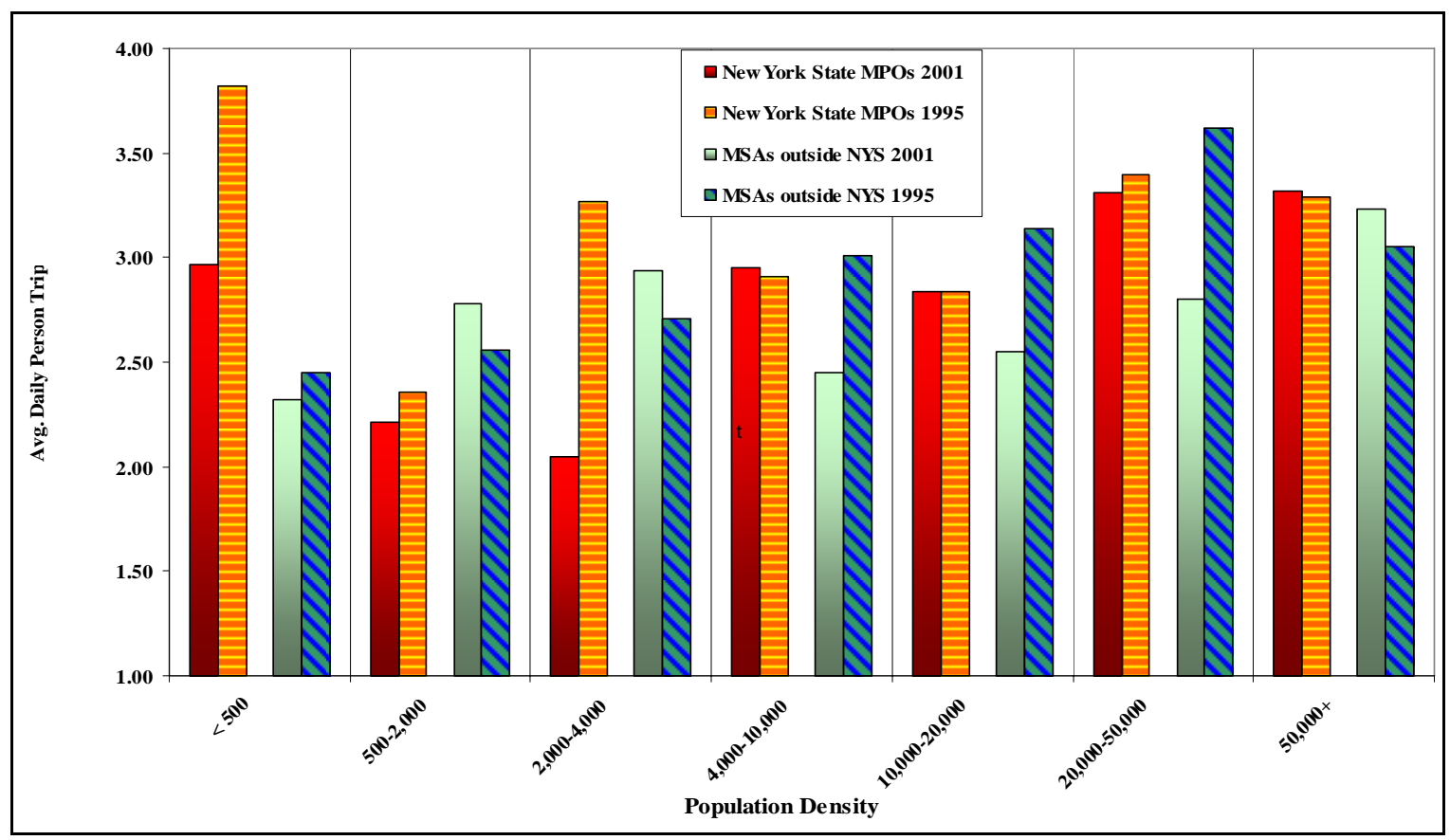

Source: Appendix C, Chapter 4, Table 4

As expected, individuals without a vehicle walk or use public transit more frequently than those with a vehicle (Appendix C, Chapter 4, Table 4). This is true both inside and outside NYS. However, NYS residents who are without a vehicle in small and medium size urban areas (those with a population density of less than 2,000 per square mile) rely significantly more on public transit and walking than those elsewhere (Figure 4.14). 
Figure 4.14 Percent of Transit Trips and Walking Trips Taken by Those Without a Vehicle New York State MPOs vs. MSAs Outside New York State 1995 and 2001

(Population density of census tract)
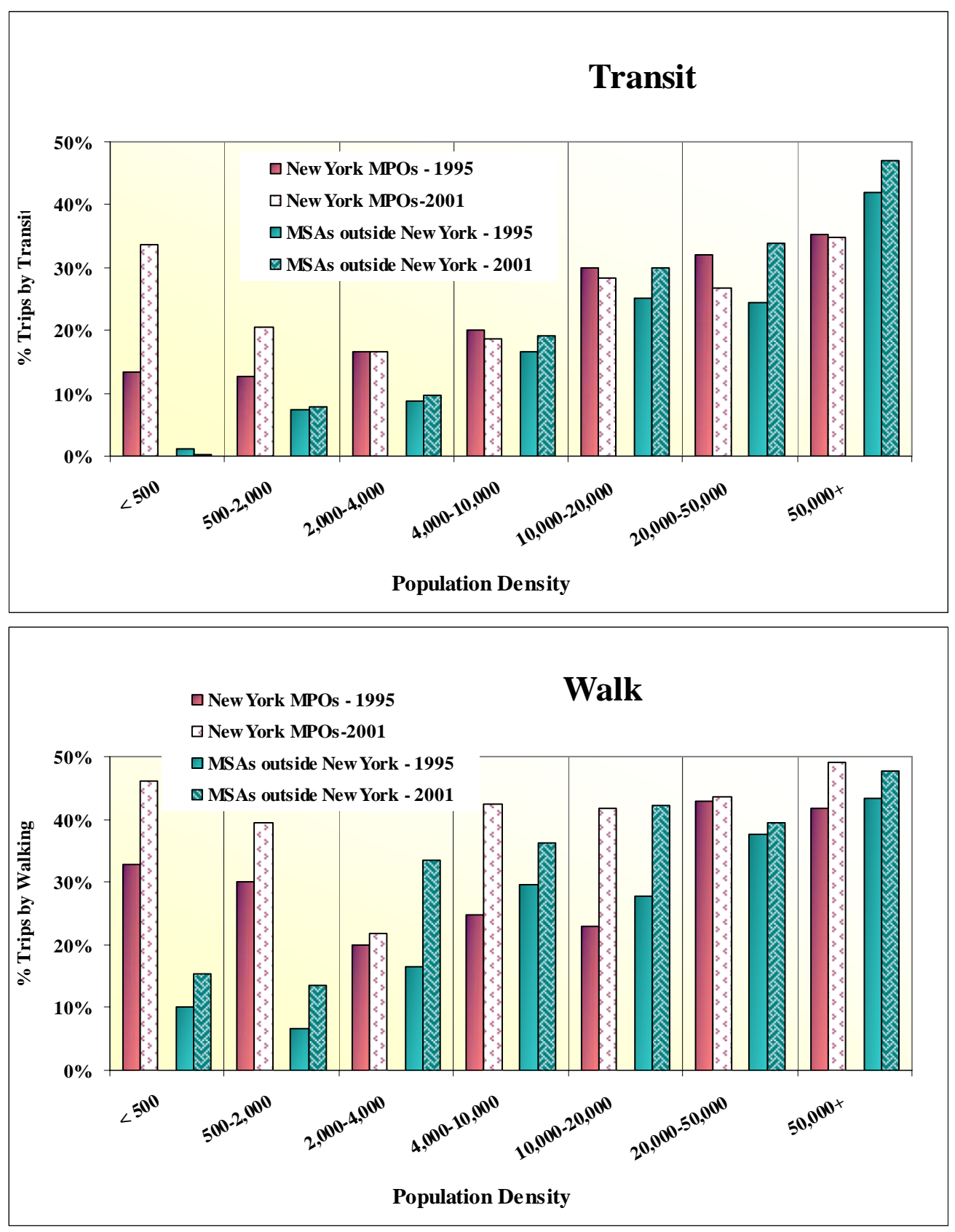

Source: Appendix C, Chapter 4, Table 4 
For example, at least three in five trips taken by New York residents in areas with less than 2,000 people per square mile are by public transit and/or walking, compared to one in five trips in areas outside NYS with similar density. For those without a vehicle, walking is the most common mode of transportation in areas with more than 10,000 residents per square mile, both inside and outside NYS. While a transit trip always implicitly includes walking, only a very small percentage of walking trips include public transit. The difference in the dominance of walking and taking public transit between urban areas in NYS and those outside the State disappears in areas with more than 10,000 residents per square mile.

Consistent with previous findings, those who do not own or have access to a vehicle take shorter trips than those who do (Figure 4.15). Among those who own a vehicle, the average trend is that trip length tends to decrease with increasing population density, except in the highest density areas. This reflects that places in urban areas are spread farther apart. In these areas, small sample sizes probably contribute to the unstable patterns. Moreover, the difference in trip distance between New Yorkers with vehicles and those outside NYS with vehicles is negligible (Figure 4.15). However, the relationship between population density and trip length for those without a vehicle is not as noticeable as that observed in those with vehicles. Trips taken by those in NYC (with more than 50,000 people per square mile) who do not have a vehicle are half as long as those taken by their neighbors who own a vehicle. 
Figure 4.15 Trip Length*, Population Density and Vehicle Ownership New York State MPOs vs. MSAs Outside New York

(Population density of census tract)

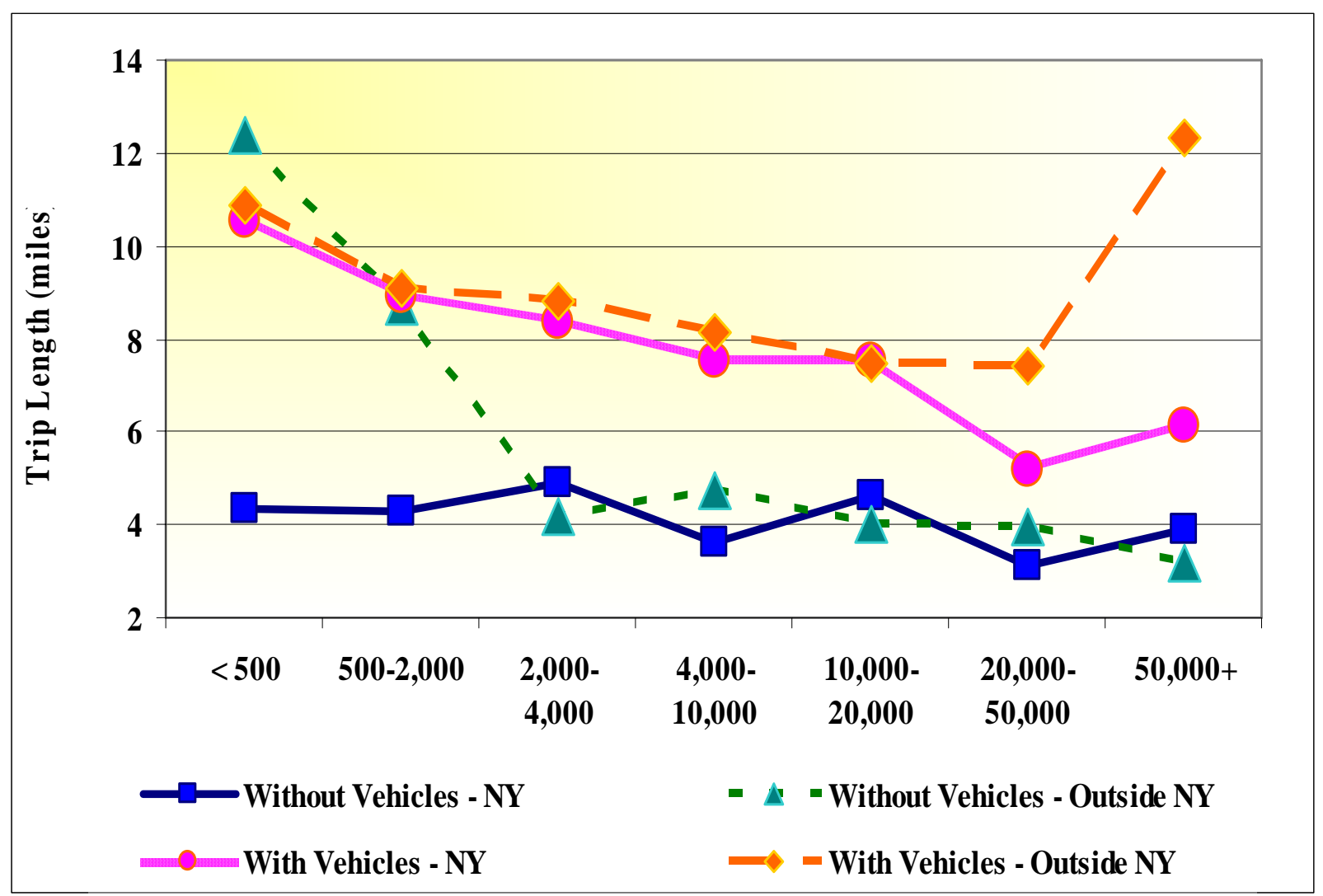

Source: Appendix C, Chapter 4, Table 5

* Excluding air trips.

\subsection{Vehicle Travel}

The trends in daily vehicle travel in urban areas are similar inside and outside NYS. The number of vehicle trips per day increases with population density, reaches its peak in areas with between two and four thousand people per square mile, then declines with increasing population density (Table 4.4a). Although following a similar trend, the difference between NYS and the rest of the country becomes more apparent as population density increases, ranging from a 5\% to $8 \%$ difference in small to medium size urban areas (those with a population density of less than 
10,000 people per square mile) to a 70\% difference in the most populated areas (Figure 4.16). The difference in daily vehicle trips between NYS and the rest of the country in areas between 20,000 and 50,000 people per square mile reduced from 38\% in 1995 to 27\% in 2001 (Figure 4.16).

Figure 4.16 Percent Difference in Daily Vehicle Trips Between

New York State MPOs vs. MSAs Outside New York State 1995 and 2001

(Population density of census tract)

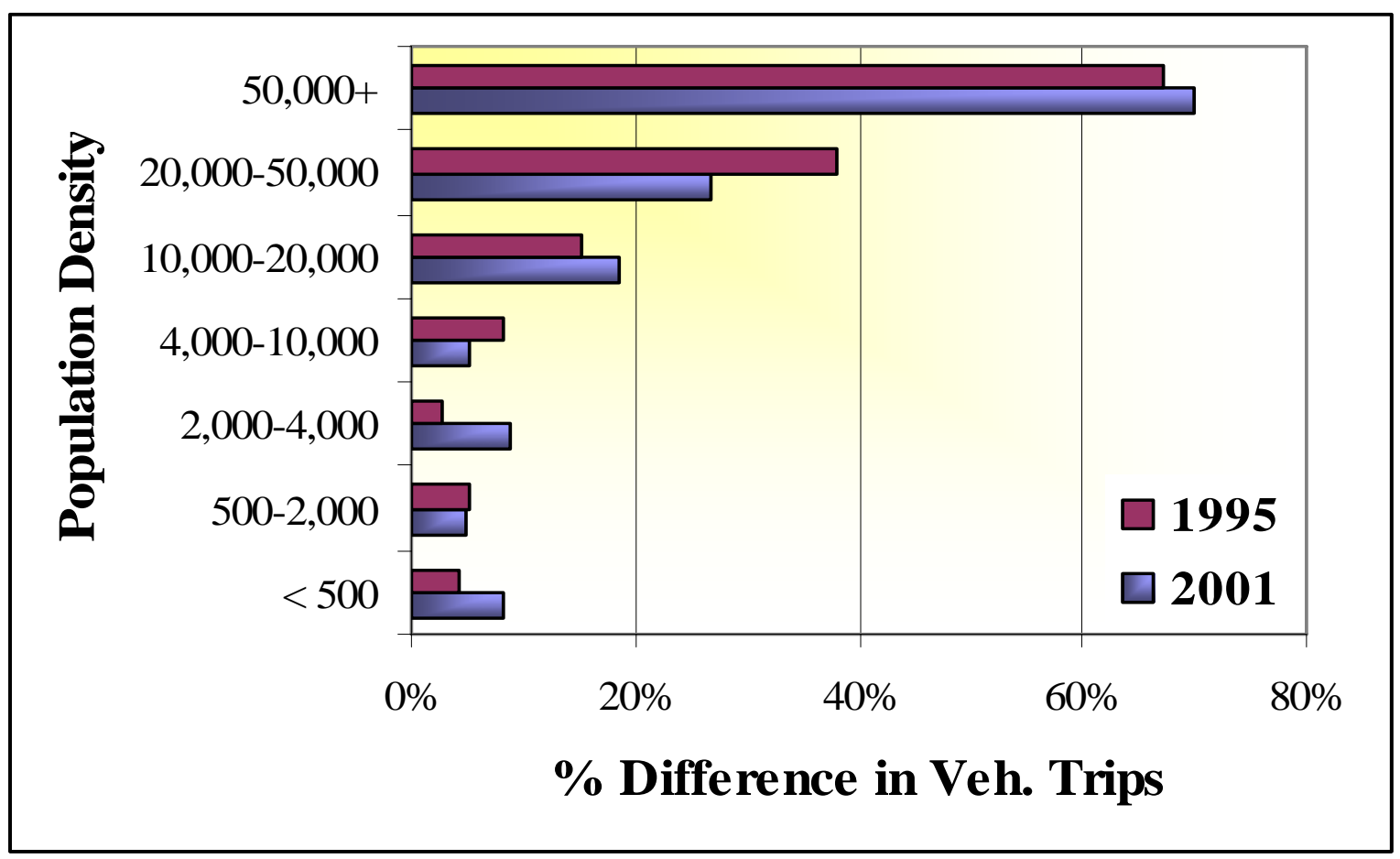

Source: Table 4.4

A typical NYS resident in the most populated areas takes about one vehicle trip a day (Table 4.4a). This trend by no means suggests that residents in highly populated areas are less mobile than those elsewhere. In fact, data in Table 4.3 suggest that NYS residents in the most populated areas are almost as mobile, from the perspective of overall personal travel, as those in 
areas with a population density between ten and twenty thousand people. The majority of the trips in the most populated areas are by public transit and walking.

On a daily basis, those in densely populated areas drive less than half the distance, but spend more time driving, as those in less dense areas. This observation reflects the traffic congestion in dense areas -- this is true for both inside and outside NYS. In the extremely dense populated areas, a driver typically spends one and one-half hours per day driving a distance of approximately 10 miles.

Consistently across the nation, half of all daily driving trips are for family and personal business, followed by $25 \%$ for commuting to and from work and $20 \%$ for social and recreational purposes (Table 4.4a). 
Table 4.4a Statistics on Daily Vehicle Travel by Population Density New York State MPOs (NYS) vs. MSAs Outside New York State (U.S.), 2001 (Population density of census tract)

\begin{tabular}{|c|c|c|c|c|c|c|c|c|c|c|c|c|c|c|}
\hline & \multicolumn{14}{|c|}{ Population Density (population per square mile) ${ }^{a}$} \\
\hline & \multicolumn{2}{|c|}{$<500$} & \multicolumn{2}{|c|}{$500-2,000$} & \multicolumn{2}{|c|}{$2,000-4,000$} & \multicolumn{2}{|c|}{ 4,000-10,000 } & \multicolumn{2}{|c|}{$10,000-20,000$} & \multicolumn{2}{|c|}{$20,000-50,000$} & \multicolumn{2}{|c|}{$50,000+$} \\
\hline & NYS & U.S. & NYS & U.S. & NYS & U.S. & NYS & U.S. & NYS & U.S. & NYS & U.S. & NYS & U.S. \\
\hline \multicolumn{15}{|l|}{ Vehicle Trips per Driver } \\
\hline TOTAL & 3.10 & 3.35 & 3.39 & 3.56 & 3.33 & 3.62 & 3.21 & 3.38 & 2.47 & 2.93 & 1.99 & 2.52 & 1.03 & 1.75 \\
\hline \% Earn a Living & 26.8 & 27.3 & 25.4 & 25.4 & 25.5 & 25.8 & 24.2 & 25.7 & 25.9 & 28.5 & 23.0 & 28.4 & 28.1 & 14.8 \\
\hline \% Family \& Personal Business & 47.4 & 47.5 & 48.9 & 48.5 & 48.5 & 48.2 & 49.6 & 48.9 & 47.9 & 45.8 & 55.1 & 43.8 & 44.9 & 61.3 \\
\hline \% Civic, Educational \& Religious & 3.9 & 4.9 & 4.2 & 4.7 & 3.5 & 5.0 & 5.0 & 4.7 & 5.6 & 4.0 & 3.8 & 4.9 & 2.6 & 0.1 \\
\hline \% Social \& Recreational & 21.2 & 19.7 & 20.8 & 20.9 & 22.1 & 20.4 & 20.4 & 20.3 & 20.0 & 21.1 & 16.2 & 22.5 & 23.7 & 20.7 \\
\hline \% Other & 0.5 & 0.5 & 0.6 & 0.5 & 0.4 & 0.5 & 0.7 & 0.5 & 0.6 & 0.5 & 1.7 & 0.4 & 0.6 & \\
\hline \% Unreported & 0.3 & 0.1 & 0.1 & 0.1 & 0.1 & 0.1 & 0.2 & 0.1 & 0.0 & 0.1 & 0.1 & 0.0 & 0.1 & 3.2 \\
\hline \multicolumn{15}{|c|}{ Vehicle Miles Traveled (VMT) per Driver } \\
\hline TOTAL & 33.70 & 37.92 & 30.22 & 33.80 & 28.76 & 32.01 & 23.12 & 29.30 & 19.46 & 23.22 & 12.21 & 20.37 & 10.08 & 11.88 \\
\hline \% Earn a Living & 36.2 & 37.7 & 36.2 & 34.8 & 38.3 & 34.4 & 35.6 & 36.2 & 32.7 & 37.3 & 32.8 & 31.9 & 32.2 & 38.7 \\
\hline \% Family \& Personal Business & 34.3 & 35.0 & 34.5 & 34.9 & 31.7 & 35.5 & 32.1 & 33.4 & 34.0 & 35.9 & 40.9 & 29.5 & 34.9 & 43.3 \\
\hline \% Civic, Educational \& Religious & 2.9 & 4.1 & 3.4 & 3.7 & 3.1 & 3.6 & 3.5 & 3.5 & 6.0 & 3.6 & 2.6 & 5.0 & 2.1 & 0.0 \\
\hline \% Social \& Recreational & 25.6 & 22.3 & 24.3 & 25.3 & 26.3 & 25.4 & 28.0 & 26.2 & 26.4 & 22.4 & 22.7 & 33.1 & 30.0 & 14.3 \\
\hline$\%$ Other & 0.9 & 0.6 & 0.9 & 1.2 & 0.5 & 1.1 & 0.7 & 0.6 & 0.9 & 0.6 & 0.8 & 0.5 & 0.5 & \\
\hline$\%$ Unreported & 0.2 & 0.3 & 0.6 & 0.1 & 0.1 & 0.1 & 0.1 & 0.2 & 0.1 & 0.1 & 0.2 & 0.0 & 0.3 & 3.7 \\
\hline \multicolumn{15}{|c|}{ Average Vehicle Trip Length (miles) ${ }^{\mathrm{b}}$} \\
\hline & 10.95 & 11.42 & 9.03 & 9.55 & 8.69 & 8.94 & 7.37 & 8.81 & 8.07 & 8.19 & 6.40 & 8.25 & 10.50 & 6.78 \\
\hline \multicolumn{15}{|c|}{ Average Time Spend Driving in a POV in a Typical Day ${ }^{c}$ (minutes) } \\
\hline & 78.76 & 84.74 & 76.13 & 81.31 & 79.37 & 79.32 & 74.22 & 80.43 & 81.01 & 77.64 & 84.66 & 81.51 & 97.22 & 113.02 \\
\hline $\begin{array}{l}\text { Note: } \\
\text { a } \\
\text { b All percents may not add to } 100 \% \\
\text { c Average trip length is calculated } \\
\text { Average time spent driving inclu } \\
\text { driving done in a trip where publi }\end{array}$ & $\begin{array}{l}\text { e to rou } \\
\text { g only } t\end{array}$ & $\begin{array}{l}\text { ding. } \\
\text { tose reco } \\
\text { who dro }\end{array}$ & ds with & $\begin{array}{l}\text { ip mile } \\
\text { el-day }\end{array}$ & $\begin{array}{l}\text { e infor } \\
y . \text { It do }\end{array}$ & $\begin{array}{l}\text { tion pr } \\
\text { not in }\end{array}$ & ent. & senger & did & 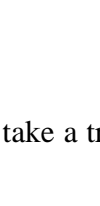 & tho & $\mathrm{d}$ & & anv \\
\hline
\end{tabular}


Table 4.4b Statistics on Daily Vehicle Travel by Population Density New York State MPOs (NYS) vs. MSAs Outside New York State (U.S.), 1995

(Population density of census tract)

\begin{tabular}{|c|c|c|c|c|c|c|c|c|c|c|c|c|c|c|}
\hline & \multicolumn{14}{|c|}{ Population Density (population per square mile) $^{a}$} \\
\hline & \multicolumn{2}{|c|}{$<500$} & \multicolumn{2}{|c|}{$500-2,000$} & \multicolumn{2}{|c|}{$2,000-4,000$} & \multicolumn{2}{|c|}{$4,000-10,000$} & \multicolumn{2}{|c|}{$10,000-20,000$} & \multicolumn{2}{|c|}{$20,000-50,000$} & \multicolumn{2}{|c|}{$>50,000$} \\
\hline & NYS & U.S. & NYS & U.S. & NYS & U.S. & NYS & U.S. & NYS & U.S. & NYS & U.S. & NYS & U.S. \\
\hline \multicolumn{15}{|l|}{ Vehicle Trips per Driver } \\
\hline TOTAL & 3.39 & 3.53 & 3.47 & 3.65 & 3.67 & 3.77 & 3.31 & 3.58 & 2.8 & 3.23 & 1.95 & 2.69 & 1.07 & 1.79 \\
\hline \% Earn a Living & 27.9 & 28.2 & 26.2 & 27.2 & 24.5 & 27.9 & 26.1 & 26.5 & 28.5 & 25.7 & 22.6 & 26.8 & 31.8 & 29.1 \\
\hline \% Family \& Personal Business & 50 & 49.9 & 51.3 & 50.8 & 52.2 & 49.6 & 51.8 & 51.1 & 50.5 & 49.2 & 54.4 & 47.2 & 47.7 & 48.6 \\
\hline \% Civic, Educational \& Religious & 2.9 & 4 & 4 & 3.8 & 3.8 & 4.5 & 3.6 & 3.9 & 3.9 & 5.3 & 5.1 & 5.2 & 3.7 & \\
\hline \% Social \& Recreational & 18.8 & 17.9 & 18.4 & 18.1 & 19.6 & 18 & 18.5 & 18.4 & 17.1 & 19.8 & 17.9 & 20.8 & 16.8 & 22.3 \\
\hline$\%$ Other & 0.3 & 0.0 & 0.0 & 0.0 & & 0.0 & 0.0 & 0.0 & & 0.0 & & & & \\
\hline \multicolumn{15}{|c|}{ Vehicle Miles Traveled (VMT) per Driver } \\
\hline TOTAL & 33.21 & 37.19 & 32.04 & 33.74 & 28.89 & 31.19 & 23.22 & 28.28 & 20.81 & 23.04 & 13.37 & 20.65 & 12.12 & 20.35 \\
\hline \% Earn a Living & 38.8 & 39.7 & 35.5 & 38.7 & 37.2 & 38.4 & 41.2 & 36.6 & 36.9 & 34.4 & 35.4 & 34.7 & 34.9 & 16.6 \\
\hline \% Family \& Personal Business & 34.2 & 36.1 & 37.1 & 35.7 & 34.5 & 34 & 33.6 & 35.6 & 34.2 & 34.6 & 37.1 & 32.6 & 24.2 & 48.2 \\
\hline \% Civic, Educational \& Religious & 2.3 & 4.0 & 2.9 & 3.7 & 2.5 & 3.9 & 3.1 & 2.9 & 2.1 & 5.4 & 5.9 & 4.3 & 1.5 & \\
\hline \% Social \& Recreational & 24.0 & 20.1 & 24.4 & 21.5 & 25.8 & 23.6 & 22.0 & 24.7 & 26.4 & 25.6 & 21.6 & 28.3 & 39.4 & 35.2 \\
\hline$\%$ Other & 0.8 & 0.1 & 0.1 & 0.3 & & 0.1 & 0.1 & 0.1 & & & & & & \\
\hline \%Unreported & 0.0 & 0.0 & 0.0 & 0.0 & 0.0 & 0.0 & 0.0 & 0.0 & 0.5 & & & & & \\
\hline \multicolumn{15}{|c|}{ Average Vehicle Trip Length (miles) ${ }^{b}$} \\
\hline & 9.85 & 10.61 & 9.35 & 9.29 & 7.9 & 8.32 & 7.12 & 7.97 & 7.58 & 7.24 & 7.11 & 7.86 & 11.68 & 11.34 \\
\hline \multicolumn{15}{|c|}{ Average Time Spent Driving in a POV in a Typical Day ${ }^{\mathrm{c}}$ (minutes) } \\
\hline & 69.85 & 77.11 & 71.47 & 74 & 70.84 & 71.46 & 67.94 & 70.63 & 69.79 & 71.46 & 72.28 & 79.4 & 89.71 & 86.19 \\
\hline
\end{tabular}

Note:

a All percents may not add to $100 \%$ due to rounding.

b Average trip length is calculated using only those records with trip mileage information present.

c Average time spent driving includes persons who drove on travel-day only. It does not include any persons who did not take a trip on their travel day, nor does it include any driving done in a trip where public transit was used in part of the trip. 


\subsection{Commute Patterns}

Residential location does not significantly affect commute frequency. However, it does influence how people go to work and how long daily commutes take. At the national level, less than $3 \%$ of commutes are usually by public transit. This pattern extends to urban areas with fewer than 4,000 people per square mile. Private vehicle continues to be the primary mode for commuting in urban areas with less than 20,000 people per square mile. However, in cities like NYC, public transit and walking reverse the usual dominance of autos in commuting (Figure 4.17). Commute patterns have generally remained the same since 1995.

Figure 4.17 Commute Trips by Mode and Population Density

New York State MPOs and National Averages

(Population density of census tract)
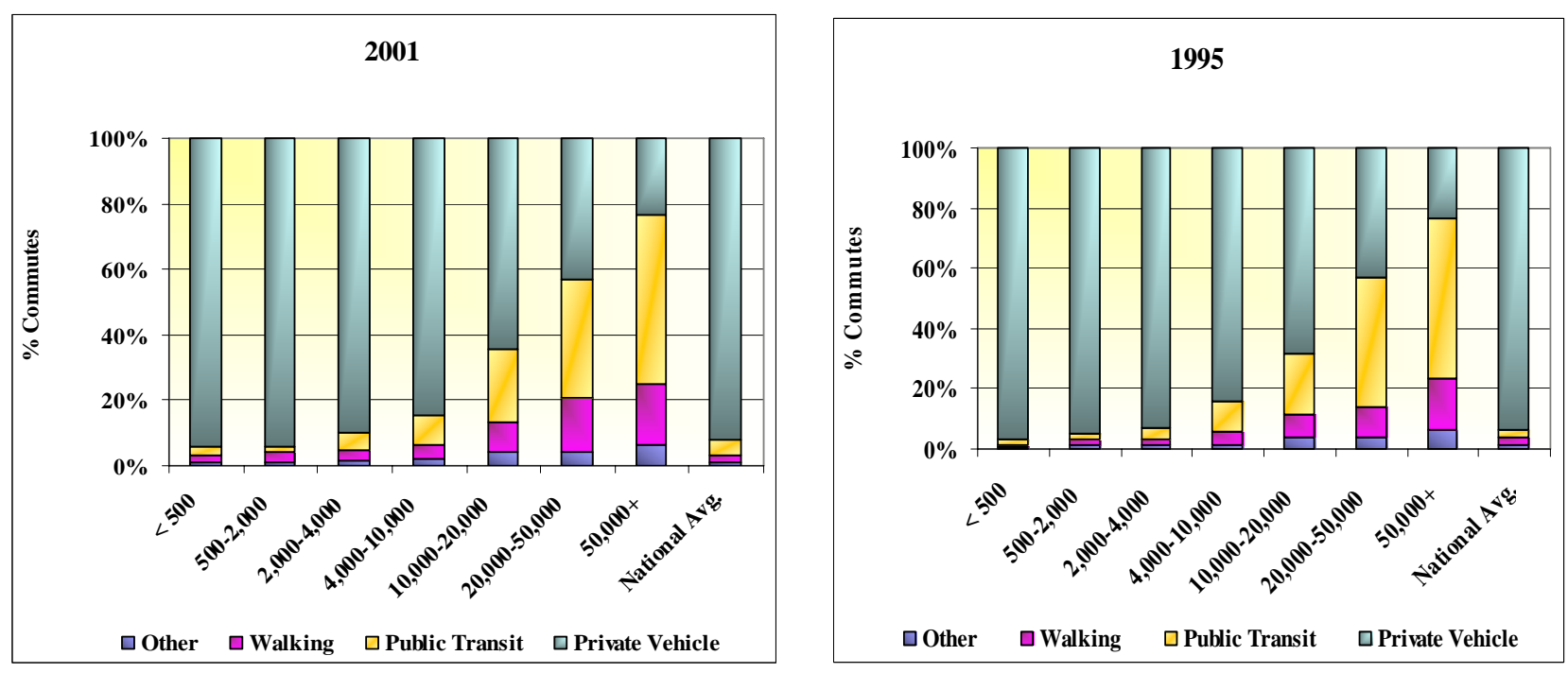

Source: Appendix C, Chapter 4, Table 7 
Commutes for workers in metropolitan areas are substantially shorter than for those in small urban areas (with population density less than 4,000 per square mile). The shorter commuter trips in medium-size urban areas (those with a population density between 4,000 and 20,000 per square mile) seem to support the hypothesis of the suburbanization of jobs where jobs move closer to workers (Table 4.5a). With both homes and workplaces geo-coded in the 1995 NPTS and 2001 NHTS, further examination on commuting flow characteristics is possible. The differences in commute distance between NYS and other states are negligible, except for the very densely populated areas. In areas with more than 50,000 people per square mile, commutes by public transit are the shortest (excluding walking trips); however, they take 55 minutes - an increase of 5 minutes from the typical 1995 commute (Figure 4.18 and Tables 4.5a and 4.5b).

Figure 4.18 2001 Commute Patterns on Public Transit by New York State Workers New York State MPOs and National Averages (Population density of census tract)

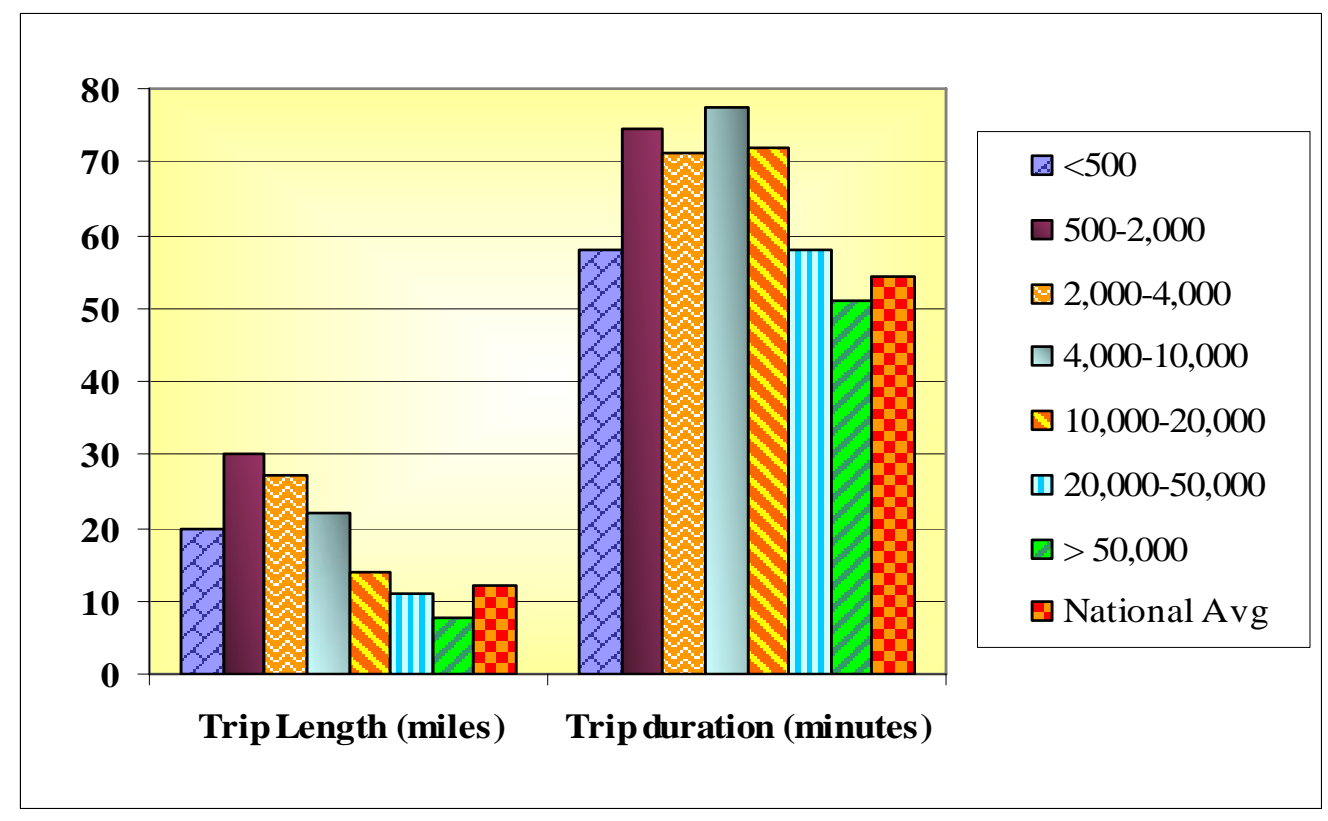

Source: Table 4.5a 
Table 4.5a Daily Commute Statistics by Population Density

New York State MPOs (NYS) vs. MSAs Outside New York State (U.S.), 2001

(Population density of census tract)

\begin{tabular}{|c|c|c|c|c|c|c|c|c|c|c|c|c|c|c|}
\hline & \multicolumn{14}{|c|}{ Population Density (population per square mile) } \\
\hline & \multicolumn{2}{|c|}{$<500$} & \multicolumn{2}{|c|}{$500-2,000$} & \multicolumn{2}{|c|}{$2,000-4,000$} & \multicolumn{2}{|c|}{$4,000-10,000$} & \multicolumn{2}{|c|}{$10,000-20,000$} & \multicolumn{2}{|c|}{$20,000-50,000$} & \multicolumn{2}{|c|}{$50,000+$} \\
\hline & NYS & U.S. & NYS & U.S. & NYS & U.S. & NYS & U.S. & NYS & U.S. & NYS & U.S. & NYS & U.S. \\
\hline \multicolumn{15}{|c|}{ Average Commute Length ${ }^{\mathrm{a}}$ (miles) } \\
\hline Private & 13.81 & 14.83 & 12.05 & 11.79 & 12.03 & 10.61 & 10.00 & 10.99 & 9.92 & 10.47 & 8.89 & 9.70 & 10.45 & 14.88 \\
\hline Public Transit & 19.98 & 22.56 & 29.95 & 23.30 & 27.01 & 14.76 & 21.93 & 12.83 & 13.95 & 9.22 & 11.04 & 6.17 & 7.76 & 9.22 \\
\hline Other $^{\mathrm{b}}$ & 47.27 & 104.50 & 24.74 & 102.39 & 12.69 & 80.81 & 14.08 & 73.82 & 11.04 & 31.86 & 7.43 & 3.02 & 6.80 & \\
\hline Walk & 2.91 & 0.83 & 0.93 & 0.78 & 0.91 & 1.11 & 1.94 & 0.87 & 1.26 & 0.89 & 1.25 & 0.83 & 1.22 & \\
\hline \multicolumn{15}{|c|}{ Commute Travel Time $^{\mathrm{c}}$ (minutes) } \\
\hline Private & 23.56 & 24.24 & 22.27 & 22.10 & 23.27 & 21.25 & 21.95 & 22.82 & 25.95 & 25.87 & 28.13 & 23.95 & 35.47 & 35.95 \\
\hline Public Transit & 57.97 & 106.73 & 74.46 & 61.94 & 71.18 & 56.26 & 77.46 & 59.47 & 71.98 & 48.46 & 58.02 & 43.97 & 51.16 & 55.11 \\
\hline Other & 67.52 & 74.73 & 52.86 & 57.97 & 32.74 & 56.35 & 53.63 & 39.13 & 42.48 & 40.71 & 32.43 & 32.13 & 37.50 & \\
\hline Walk & 12.59 & 8.91 & 33.23 & 15.15 & 14.52 & 13.02 & 12.90 & 13.18 & 17.70 & 14.54 & 20.27 & 15.28 & 19.76 & \\
\hline \multicolumn{15}{|c|}{ Average Commute Speed $^{\mathrm{d}}(\mathrm{mph})$} \\
\hline Private & 35.19 & 36.71 & 32.73 & 32.02 & 31.25 & 30.04 & 27.34 & 28.92 & 23.29 & 24.29 & 18.53 & 24.37 & 17.68 & 24.84 \\
\hline Other & 48.42 & 84.34 & 22.97 & 134.47 & 13.71 & 121.36 & 14.76 & 164.61 & 10.46 & 7.69 & 16.08 & 5.06 & 12.59 & \\
\hline Walk & 7.09 & 5.49 & 1.40 & 2.46 & 3.77 & 3.07 & 6.79 & 3.73 & 3.14 & 3.07 & 3.14 & 2.66 & 3.15 & \\
\hline
\end{tabular}

Note:

$\frac{\mathrm{N}}{\mathrm{a}}$ Average commute lengths are calculated using only those records with trip mileage information present.

b The mode "Other" includes commercial and private air, school/charter/city to city buses, Amtrak, water modes, taxi, limousine, shuttles, bicycle, and other nonspecified modes.

c Average commute travel times and average commute speeds do not include time spent waiting for transportation.

d Average commute speeds do not include any segmented trips, which are defined in the 2001 survey as trips with public transit as a segment of the trip. Thus, speeds for 2001 public transit trips are unavailable. The calculations for the mph are based on estimates of miles and minutes given by the respondent.

Therefore, any mph estimate for walking that is greater than 5 might be attributable to self-reporting bias. 
Table 4.5b Daily Commute Statistics by Population Density New York State MPOs (NYS) vs. MSAs Outside New York State (U.S.), 1995 (Population density of census tract)

\begin{tabular}{|c|c|c|c|c|c|c|c|c|c|c|c|c|c|c|}
\hline & \multicolumn{14}{|c|}{ Population Density (People per square mile) } \\
\hline & \multicolumn{2}{|c|}{$<500$} & \multicolumn{2}{|c|}{$500-2,000$} & \multicolumn{2}{|c|}{$2,000-4,000$} & \multicolumn{2}{|c|}{$4,000-10,000$} & \multicolumn{2}{|c|}{$10,000-20,000$} & \multicolumn{2}{|c|}{$20,000-50,000$} & \multicolumn{2}{|c|}{$>50,000$} \\
\hline & NYS & U.S. & NYS & U.S. & NYS & U.S. & NYS & U.S. & NYS & U.S. & NYS & U.S. & NYS & U.S. \\
\hline \multicolumn{15}{|c|}{ Average Commute Length ${ }^{\mathrm{a}}$ (miles) } \\
\hline Private & 13.44 & 14.73 & 12.80 & 12.71 & 12.29 & 10.67 & 10.74 & 10.41 & 9.57 & 10.02 & 12.96 & 10.61 & 11.88 & 6.18 \\
\hline Public Transit & 38.32 & 38.67 & 35.01 & 20.24 & 27.13 & 20.44 & 20.86 & 11.24 & 12.97 & 8.32 & 12.99 & 8.72 & 8.89 & 5.36 \\
\hline Other $^{b}$ & 41.18 & 17.50 & 11.32 & 22.61 & 2.82 & 71.95 & 7.51 & 8.49 & 4.67 & 5.39 & 10.17 & 4.16 & 16.61 & 1.00 \\
\hline Walk & 0.61 & 0.63 & 0.58 & 0.51 & 0.82 & 0.58 & 0.60 & 0.88 & 0.83 & 0.81 & 0.94 & 0.68 & 1.18 & 1.97 \\
\hline \multicolumn{15}{|c|}{ Commute Travel Time $^{c}$ (minutes) } \\
\hline Private & 21.25 & 22.77 & 21.71 & 20.90 & 22.02 & 19.12 & 21.60 & 19.83 & 22.70 & 21.01 & 29.63 & 26.13 & 30.76 & 18.07 \\
\hline Public Transit & 55.72 & 67.45 & 60.88 & 48.73 & 60.38 & 46.46 & 50.32 & 39.15 & 46.31 & 33.28 & 49.94 & 36.85 & 39.39 & 35.84 \\
\hline Other & 37.95 & 56.84 & 35.40 & 24.83 & 11.80 & 36.82 & 24.93 & 39.77 & 23.33 & 19.48 & 29.48 & 52.54 & 23.23 & 5.00 \\
\hline Walk & 6.81 & 7.51 & 11.15 & 8.51 & 12.43 & 11.76 & 8.87 & 11.92 & 9.34 & 10.49 & 10.82 & 12.22 & 16.53 & 20.25 \\
\hline \multicolumn{15}{|c|}{ Average Commute Speed ${ }^{\mathrm{d}}(\mathrm{mph})$} \\
\hline Private & 37.94 & 38.81 & 35.37 & 36.46 & 33.48 & 33.47 & 29.84 & 31.50 & 25.30 & 28.61 & 26.25 & 24.36 & 23.17 & 20.51 \\
\hline Public Transit & 30.71 & 39.65 & 37.73 & 27.07 & 30.72 & 34.98 & 21.85 & 17.09 & 14.99 & 15.51 & 17.63 & 11.42 & 12.32 & 10.98 \\
\hline Other & 65.10 & 18.42 & 19.19 & 55.04 & 13.76 & 117.25 & 15.75 & 11.16 & 12.35 & 16.59 & 20.70 & 4.75 & 42.90 & 12.00 \\
\hline Walk & 5.35 & 5.01 & 3.13 & 3.60 & 3.98 & 2.94 & 4.09 & 4.41 & 5.35 & 4.66 & 5.18 & 3.33 & 4.27 & 5.84 \\
\hline
\end{tabular}

Note:

Average commute lengths are calculated using only those records with trip mileage information present.

b The mode "Other" includes Amtrak, airplane, taxi, bicycle, school bus, and other non-POV.

c Average commute travel times and average commute speeds do not include time spent waiting for transportation.

d Average commute speeds do not include any segmented trips, which are defined in the 2001 survey as trips with public transit as a segment of the trip. Thus, speeds for 2001 public transit trips are unavailable. The calculations for the mph are based on estimates of miles and minutes given by the respondent. Therefore, any mph estimate for walking that is greater than 5 might be attributable to self-reporting bias. 
Commute times varies considerably by mode, with transit commute times being twice those of private vehicles. The disparity in commute times between private vehicles and public transit decreases as population density increases. Differences in commute travel times between private vehicles and public transit are almost always greater for New York State workers than for those elsewhere (Figure 4.19). Compared to 1995, commutes in 2001 by public transit take longer for New York State residents. The increase is more than fifty percent for those living in areas between 4,000 to 20,000 people per square mile (Figure 4.20). This increase is not unique to NYS. In other parts of the country, commutes by public transit take at least twenty percent longer in 2001 than in 1995.

Figure 4.19 Percent Difference in Commute Time

Between Public Transit and Private Vehicles

MPOs vs. MSAs Outside New York State

(Population density of census tract)
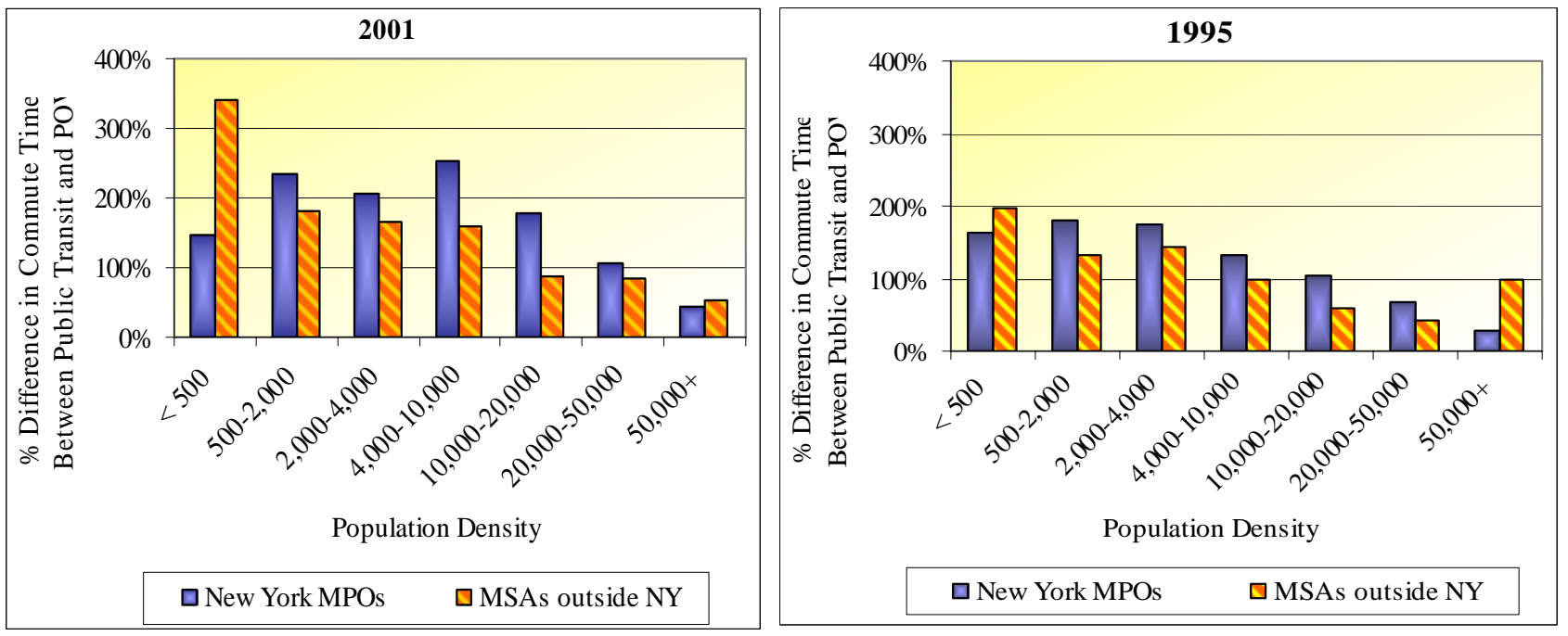

Source: Table 4.5a and 4.5b 
Figure 4.20 Commute Times by Public Transit

New York Urban Areas, 1995 and 2001

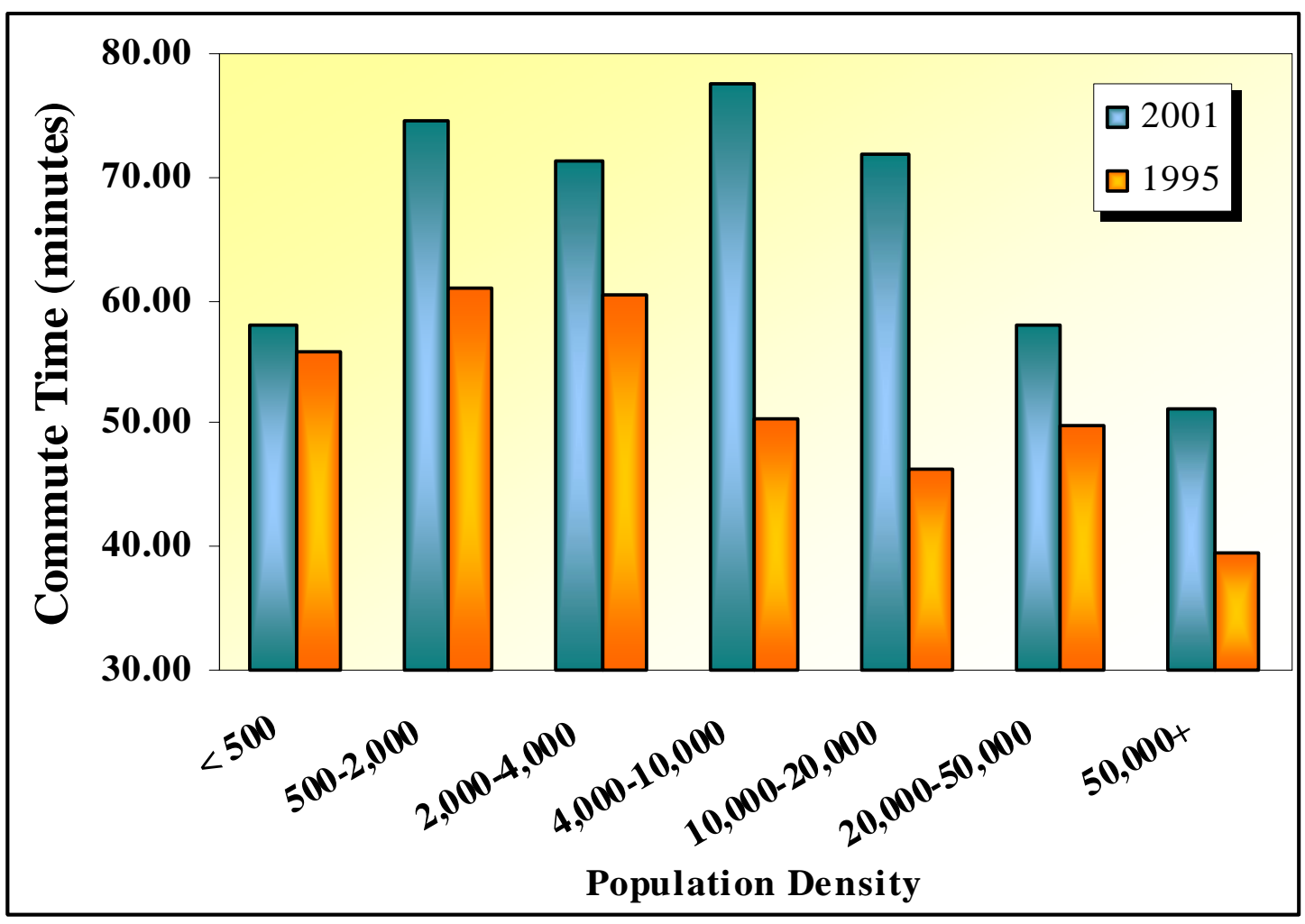

Source: Table 4.5a and Table 4.5b

New York residents in urban areas spent more time commuting in 2001 than in 1995 while commute distances remained relatively unchanged (Figure 4.21), except for commutes by residents in small New York urban areas with fewer than 500 people per square mile. The decrease in commute distance between 1995 and 2001 in New York urban areas with fewer than 500 people per square mile could be attributed to simply the small sample sizes. In 2001, the median commute distance was 9 miles each way for these areas -- significantly different from the 40-mile median based on the 1995 survey data. 
Figure 4.21 Percent Difference in Commute Patterns between 1995 and 2001, New York Urban Areas

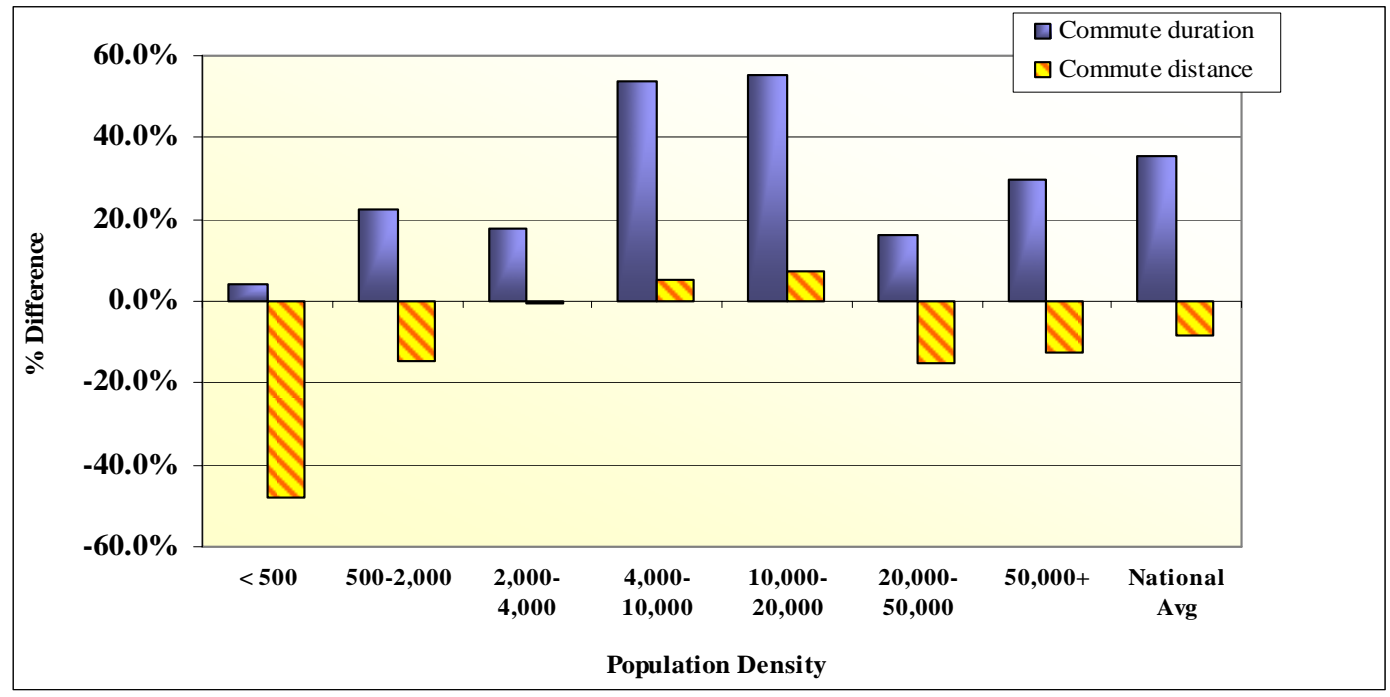

Source: Table 4.5a and Table 4.5b

\subsection{Travel by Manhattan Residents}

With almost ninety percent of its residents living in extremely densely populated areas (more than 50,000 people per square mile), do Manhattan residents travel differently from those living in similarly densely populated areas? If so, does this different travel behavior affect the overall travel profile of the New York metropolitan areas?

Compared to households that are outside Manhattan, but in areas with similar population densities, more Manhattan households do not own a vehicle - almost seven in ten households do not own a vehicle. However, Manhattan residents are more likely to consider themselves to be a driver than their neighbors living elsewhere with similar population densities in NYC (Figure 4.22). The driver rate for Manhattan residents increased slightly since 1995. In the surveys, the respondents were asked for their driver status (i.e., “Are you a driver?”), rather than license status. Therefore, the driver rate reported in this report refers to the percentage of New York residents who state that they are drivers, and should not be compared to driver license rates maintained by New York Department of Motor Vehicles.

$$
4-36
$$


Figure 4.22 Driver Rates of Those Living in Extremely Densely Populated Areas

(More than 50,000 people per square mile)

1995 and 2001

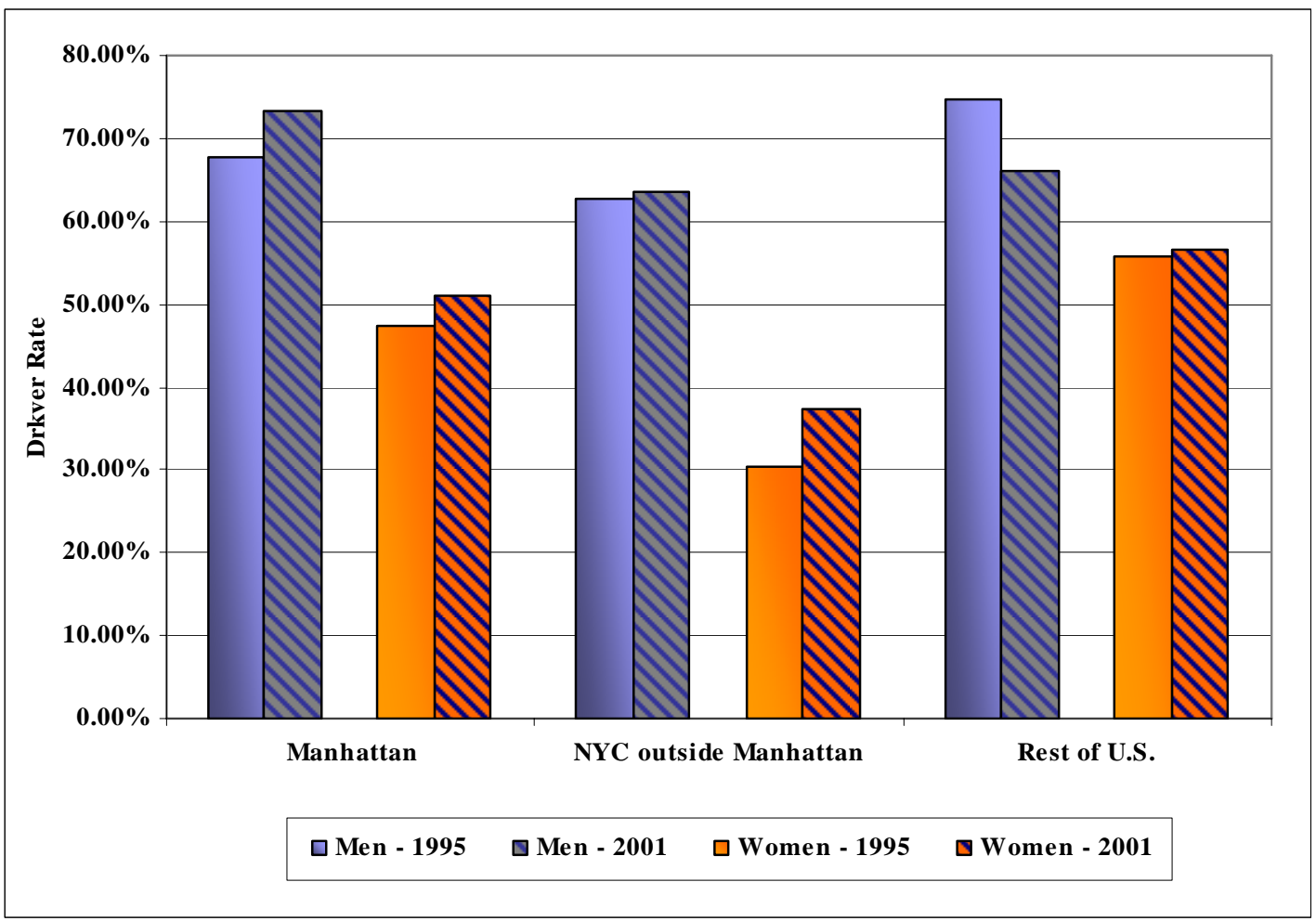

Source: Table 4.6

Among those without a vehicle, Manhattan residents are more mobile than others living in areas with similar population densities - inside or outside NYS (Table 4.6). Those who live in extremely densely populated areas apparently have less need to drive (or find it more difficult to drive due to congestion and lack of parking spaces) - as reflected in the percentages of those who are reported as a driver. Although this is true for both men and women, men seem to have more need to drive than women (Table 4.6). 
Table 4.6 Household Characteristics and Travel Profile of Those Living in Extremely Densely Populated Areas

\begin{tabular}{|c|c|c|c|c|c|c|}
\hline & \multicolumn{3}{|c|}{1995} & \multicolumn{3}{|c|}{2001} \\
\hline & Manhattan & $\begin{array}{l}\text { NYC Non- } \\
\text { Manhattan }\end{array}$ & Rest of U.S. & Manhattan & $\begin{array}{l}\text { NYC Non- } \\
\text { Manhattan }\end{array}$ & Rest of U.S. \\
\hline Workers per Household & 1.13 & 1.11 & 1.18 & 1.15 & 1.33 & 1.10 \\
\hline Vehicles per Household & 0.27 & 0.37 & 0.66 & 0.39 & 0.52 & 0.55 \\
\hline Vehicles per Driver & 0.27 & 0.41 & 0.60 & 0.39 & 0.48 & 0.60 \\
\hline \multicolumn{7}{|c|}{ Households by Household Vehicles } \\
\hline 0 vehicles & $73.48 \%$ & $64.41 \%$ & $47.07 \%$ & $68.73 \%$ & $56.76 \%$ & $50.73 \%$ \\
\hline 1 vehicle & $24.35 \%$ & $29.33 \%$ & $40.39 \%$ & $27.18 \%$ & $35.88 \%$ & $43.31 \%$ \\
\hline 2 vehicles & $2.06 \%$ & $5.77 \%$ & $12.10 \%$ & $3.11 \%$ & $6.51 \%$ & $5.96 \%$ \\
\hline 3 vehicles & $0.05 \%$ & $0.40 \%$ & $0.44 \%$ & $0.50 \%$ & $0.63 \%$ & \\
\hline 4+ vehicles & $0.06 \%$ & $0.09 \%$ & $0.00 \%$ & $0.47 \%$ & $0.22 \%$ & \\
\hline TOTAL & $100.00 \%$ & $100.00 \%$ & $100.00 \%$ & $100.00 \%$ & $100.00 \%$ & $100.00 \%$ \\
\hline \multicolumn{7}{|l|}{ Driver Rate } \\
\hline \% Male Drivers/Male 16+ & $67.75 \%$ & $62.69 \%$ & $74.71 \%$ & $73.32 \%$ & $63.44 \%$ & $66.03 \%$ \\
\hline \% Female Drivers/Female 16+ & $47.43 \%$ & $30.32 \%$ & $55.61 \%$ & $50.99 \%$ & $37.44 \%$ & $56.60 \%$ \\
\hline \multicolumn{7}{|l|}{ Person Trips per Person } \\
\hline Person Trips per Person & 3.72 & 3.31 & 3.50 & 3.91 & 3.15 & 3.57 \\
\hline$\% P O V$ & 16.13 & 28.40 & 45.43 & 17.75 & 27.10 & 35.22 \\
\hline$\%$ Public Transit & 28.23 & 27.19 & 20.29 & 24.69 & 28.02 & 25.70 \\
\hline \% Walk & 41.40 & 32.63 & 28.86 & 50.75 & 39.73 & 35.24 \\
\hline$\%$ Other & 8.87 & 4.83 & 1.43 & 6.74 & 4.96 & 3.84 \\
\hline$\%$ Unreported & 5.38 & 6.95 & 4.00 & 0.07 & 0.19 & \\
\hline \multicolumn{7}{|l|}{ Person Trips per Person } \\
\hline PMT per Person & 17.98 & 19.52 & 25.59 & 27.46 & 14.21 & 24.49 \\
\hline Average Trip Length & 5.10 & 6.54 & 7.31 & 10.33 & 7.22 & 6.60 \\
\hline \multicolumn{7}{|l|}{ Vehicle Trips per Driver } \\
\hline Vehicle Trips per Driver & 0.57 & 1.48 & 1.79 & 0.77 & 1.20 & 1.75 \\
\hline VMT per Driver & 7.11 & 16.29 & 20.35 & 11.66 & 9.12 & 11.88 \\
\hline
\end{tabular}


Half of the time, Manhattan residents walk to places. About one-quarter of the time, they take public transit (Figure 4.23). Manhattan residents are twice as mobile as those living in NYC outside Manhattan, and their trips average 40\% longer than those taken by others living in other extremely densely areas in NYC. Person trips taken by Manhattan residents in 2001 were twice as long as those in 1995. It is not clear how much of this increase was due to the 9/11 where employment centers in downtown Manhattan were relocated to outside Manhattan.

Manhattan households are less likely to drive to places than others who live in areas with similar population densities. However, when these households drive, they tend to drive to slightly farther-away destinations.

Figure 4.23 Mode Choices

By Those Living in Extremely Densely Populated Areas

(More than 50,000 people per square mile)

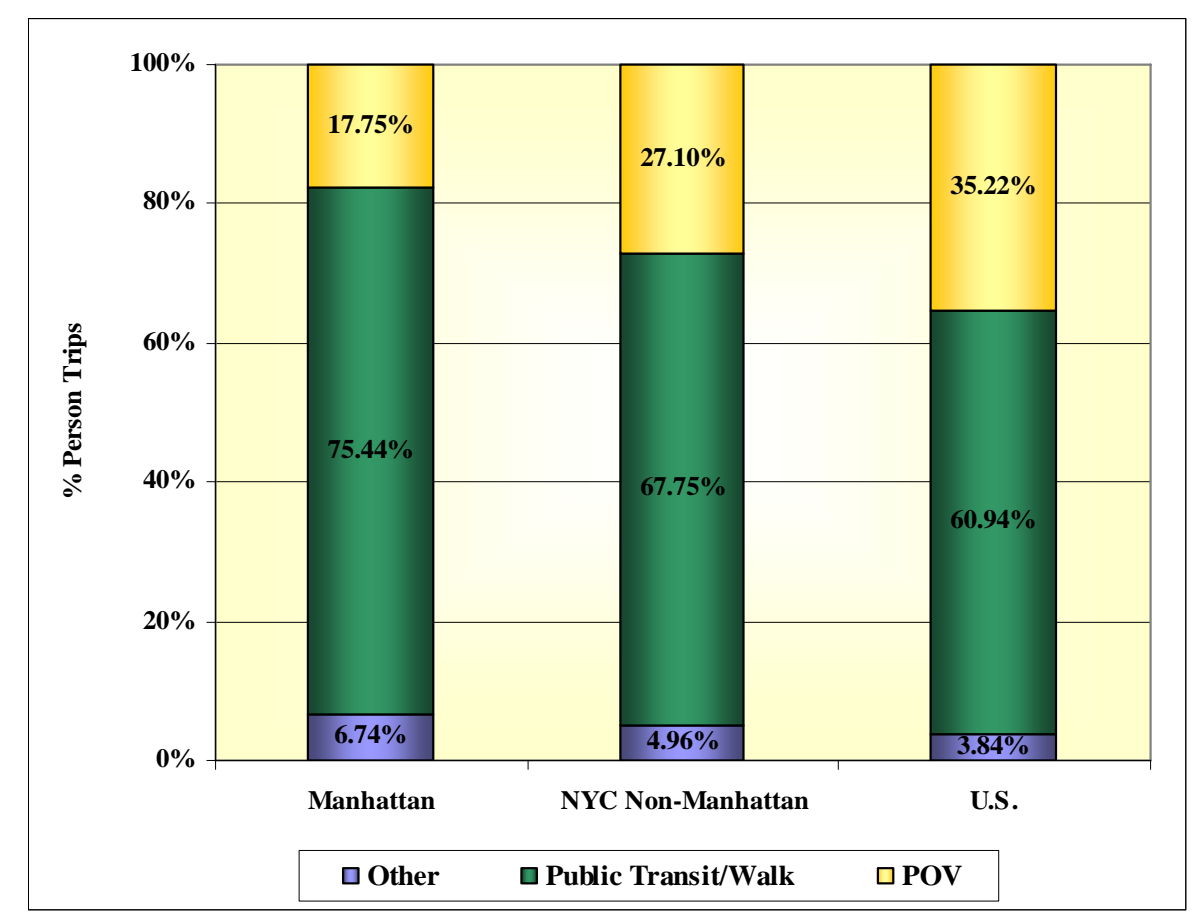

Source: Table 4.6 


\subsection{Summary}

Some travel characteristics in New York urban areas show noticeable differences from

other urban areas, and some do not. For example, the relationship between population density and daily trip rate is somewhat bell-shaped, both inside and outside NYS (Figure 4.7). Residents in the most densely populated areas take the fewest number of trips per day. Also, there is no significant difference in average trip length between New York MPOs and MSAs outside NYS. Nonetheless, NYS residents consistently take, on average, slightly shorter trips than their counterparts in areas of similar density (e.g., MSAs outside NYS), with one exception. New York residents who live in the extremely densely populated areas (i.e., more than 50,000 people per square mile, which contains areas throughout NYC, and not just Manhattan) take longer trips than those in areas of similar density elsewhere. This difference only occurred in 2001 but not in 1995. It is unclear whether $9 / 11$ had any impact on this change.

People who live in highly densely populated areas are less likely to be licensed to drive and to own a vehicle. This is true both inside and outside NYS. However, the difference in these aspects between New York residents and those elsewhere widens as population density increases. The most apparent difference is vehicle ownership. Comparing New York urban households to those outside the state, more New York households in very densely populated areas are likely to be without a vehicle than those elsewhere. Although those without a vehicle are less mobile than those with a vehicle, the difference in trip frequency narrows as population density increases. This implies that not having a vehicle in highly populated areas is less of a mobility constraint than in less populated areas.

An obvious difference between New York urban data and other urban areas outside NYS is mode choice. Although it is true both inside and outside NYS the proportion of trips by public transit and walking increases with population density, this rate of increase is much more pronounced in NYS than elsewhere. For example, while NYS residents in areas with less than 500 people per square mile walk or use public transit in $8.6 \%$ of their trips, NYS residents in the 
very densely populated areas walk or use public transit in $71 \%$ of their trips. The comparable figures for urban areas outside NYS with similar density are $5.6 \%$ and $61 \%$, respectively. These findings essentially echo those found in Chapter 3.

The difference in daily vehicle trips between New York urban data and those outside the state increases as population density increases, ranging from a 5 to $8 \%$ difference in small urban areas (with population density $<4,000$ per square mile) to a $70 \%$ difference in the very densely populated areas. The majority of the trips in the most populated areas are by public transit and walking.

It is obvious that population density has a significant bearing on how people travel. This is particularly true for those living in extremely densely populated areas. The differences from average national travel characteristics can be great as population density increases. For example, a typical worker spends an average of 48 minutes and travels 12 miles a day to go to work on public transit (Hu and Reuscher, 2004). However, depending on the residence of the worker and workplace location, the one-way commute on public transit can on average be as much as one hour and 46 minutes, and as long as 30 miles. Thus, analyzing travel characteristics without consideration of population density could be extremely misleading. 
This page intentionally left blank.

$4-42$ 


\section{Chapter 5. Rural Travel}

This chapter investigates whether rural travel in NYS differs from that outside the NYS, and whether population density has any bearing on travel patterns. In this report, MPO boundaries are used as a proxy to delineate urban areas from rural areas. Households in the twelve New York MPOs are the basis for the analysis in Chapter 4, which focuses on urban travel. However, comparing rural travel in New York to that elsewhere is not as straightforward as the comparison on urban travel. While New York households can be easily identified by the MPO boundary, households outside NYS can not be characterized by MPO boundary. Instead, they can only be characterized by the size of the MSA where the household is located. Thus, it is difficult to identify rural households outside NYS for comparison purposes.

The method used to determine which households were "rural" was developed for the 1995 report. To ensure compatible comparisons between 1995 and 2001, the same method is used in this report. In the previous report, two options were explored to identify "rural households" both inside and outside NYS in as comparable a way as possible. The first option used the MPO boundary to identify rural households in New York - those outside MPOs are "rural." An MSA was presumed to be comparable to an MPO in terms of separating urban from rural households. Under this assumption, the MSA boundary was used to identify rural households outside NYS. Specifically, households outside the State that were not in MSAs were considered "rural." Using this approach, however, the percentage of New York households outside the MPOs that was in MSAs of more than 500,000 people was 27\% in 1995 and 32\% in 2001. Of non-MPO households in New York, only 65\% in 1995 and 61\% in 2001 were not in MSAs. This distribution clearly suggests that households outside an MPO boundary are not always "rural."

The second option used the MPO boundary in conjunction with the NPTS//NHTS' definition of rural households. "Rural households" are defined in the 1995 NPTS as those in a 
block group, a subdivision of a census tract, with fewer than 1,000 persons per square mile. Using this criterion, in both 1995 and 2001 about three-quarters of NYS households that are outside MPOs are characterized as "rural households.” Using the same criterion on households elsewhere yields a somewhat similar distribution of households by population density at the individual block group level. Although a greater proportion of households outside NYS are in areas with fewer than 100 persons per square mile than New York households (Table 5.1), this option identifies rural households in as comparable a way as data can support both inside and outside NYS.

Table 5.1 Distribution of Rural Households by Block Group’s Population Density New York State vs. Rest of the United States (U.S.)

\begin{tabular}{|l|c|c|c|c|}
\hline \multirow{2}{*}{$\begin{array}{l}\text { Population Density } \\
\text { of Block Group }\end{array}$} & \multicolumn{2}{|c|}{ New York State $^{\mathbf{a}}$} & \multicolumn{2}{|c|}{ Rest of the U.S. $^{\text {b }}$} \\
\cline { 2 - 5 } $0-100$ & $\begin{array}{c}\text { Sample } \\
\text { Size }\end{array}$ & $\begin{array}{c}\text { Number of Households } \\
\text { (thousands) }\end{array}$ & $\begin{array}{c}\text { Sample } \\
\text { Size }\end{array}$ & $\begin{array}{c}\text { Number of Households } \\
\text { (thousands) }\end{array}$ \\
$100-500$ & 720 & $348(54.8 \%)$ & 5,096 & $9,003(56.5 \%)$ \\
$500-1,000$ & 471 & $225(35.5 \%)$ & 2,754 & $5,073(31.8 \%)$ \\
Total & 114 & $61(9.7 \%)$ & 1,273 & $1,854(11.6 \%)$ \\
\hline
\end{tabular}

Note:

a NYS households outside MPOs and in areas with fewer than 1,000 persons per square mile in an individual block group level.

b Non-New York households outside MSAs and in areas with fewer than 1,000 persons per square mile in an individual block group level.

c A block group is defined as a subdivision of a census tract that averages 1,000 to 1,100 people, and approximately 400-500 housing units.

In Chapter 4, urban New York households are compared to urban households outside NYS who reside in areas with similar population density. To facilitate comparing statistics across chapters, the analyses in this chapter will continue to be categorized by the population density of census tracts. Unfortunately, when identifying rural households based on population density of census tracts, only 34 New York households in 1995 and 52 households in 2001 were sampled from census tracts with more than 500 people per square mile (Table 5.2). Thus, this chapter only presents statistics based on survey data collected from 9,329 households (1,253 New York 
households, 8,076 households outside NYS). These households were sampled from census tracts that are with fewer than 500 people per square mile (Table 5.2).

Table 5.2 Rural Household Distribution by Census-Tract Population Density 2001 NHTS

\begin{tabular}{|l|r|c|c|c|}
\hline \multirow{2}{*}{$\begin{array}{l}\text { Population Density } \\
\text { of Census Tract }\end{array}$} & $\begin{array}{c}\text { Sample } \\
\text { Size }\end{array}$ & $\begin{array}{c}\text { Number of Households } \\
\text { (thousands) }\end{array}$ & $\begin{array}{c}\text { Sample } \\
\text { Size }\end{array}$ & $\begin{array}{c}\text { Number of Households } \\
\text { (thousands) }\end{array}$ \\
$0-500$ & 1,253 & $607(95.7 \%)$ & 8,076 & $14,503(91.1 \%)$ \\
$500-2,000$ & 50 & $27(4.2 \%)$ & 1,038 & $1,414(8.9 \%)$ \\
$2,000-4,000$ & 2 & $0.3(0.0 \%)$ & 9 & $12(0.1 \%)$ \\
Total & $\mathbf{1 , 3 0 5}$ & $\mathbf{6 3 4}(\mathbf{1 0 0 \% )}$ & $\mathbf{9 , 1 2 3}$ & $\mathbf{1 5 , 9 3 0 ( 1 0 0 \% )}$ \\
\hline
\end{tabular}

\subsection{Profile of Rural New York Households by Population Density}

On a per household basis, rural New York households are similar to those elsewhere with respect to the number of workers and vehicle ownership patterns (Table 5.3). In 2001, a typical rural household owns two vehicles, and has at least one vehicle available to each driver in the household. This is true both inside and outside New York. Across the country, rural households own more vehicles in 2001 than in 1995, with the increase in New York greater than that observed elsewhere (Table 5.3). Like households in small urban areas, about two-thirds of the rural households have at least two vehicles. Compared to urban households in areas of similar population density (fewer than 500 people per square mile), rural households tend to have slightly more vehicles (Tables 5.3 and 4.2a). 
Table 5.3 Characteristics of Rural Households

New York State vs. Rest of the Country

\begin{tabular}{|c|c|c|c|c|}
\hline & \multicolumn{4}{|c|}{$\begin{array}{l}\text { Population Density }^{a} \\
\text { (census tract) }<500\end{array}$} \\
\hline & \multicolumn{2}{|c|}{1995} & \multicolumn{2}{|c|}{2001} \\
\hline & NY & U.S. & NY & U.S. \\
\hline Workers per Household & 1.37 & 1.27 & 1.36 & 1.31 \\
\hline Drivers per Household & 1.94 & 1.83 & 1.89 & 1.85 \\
\hline Vehicles per Household & 1.80 & 2.01 & 2.08 & 2.25 \\
\hline Vehicles per Driver & 0.93 & 1.10 & 1.10 & 1.21 \\
\hline \multicolumn{5}{|c|}{ Distribution of Households by Household Vehicles } \\
\hline ALL & $100 \%$ & $100 \%$ & $100 \%$ & $100 \%$ \\
\hline 0 vehicles & $3.18 \%$ & $4.26 \%$ & $4.93 \%$ & $4.50 \%$ \\
\hline 1 vehicle & $30.65 \%$ & $27.73 \%$ & $27.56 \%$ & $24.43 \%$ \\
\hline 2 vehicles & $44.51 \%$ & $41.37 \%$ & $38.66 \%$ & $37.80 \%$ \\
\hline 3 vehicles & $16.43 \%$ & $19.21 \%$ & $18.39 \%$ & $18.78 \%$ \\
\hline 4+ vehicles & $5.22 \%$ & $7.43 \%$ & $10.45 \%$ & $14.49 \%$ \\
\hline \multicolumn{5}{|l|}{ Driver Rate } \\
\hline \% Male Drivers/Male 16+ & $94.30 \%$ & $94.50 \%$ & $95.77 \%$ & $95.68 \%$ \\
\hline \% Female Drivers/Female 16+ & $89.76 \%$ & $88.90 \%$ & $92.37 \%$ & $91.28 \%$ \\
\hline
\end{tabular}

In 2001, ninety-six percent of men 16 years or older in New York rural areas reported they drive, while about 92\% of women do (Table 5.3). This is true both inside and outside New York. For both men and women, rural New York residents drive less than their counterparts elsewhere (Figure 5.1). The difference in annual miles driven between men in New York rural areas and men outside the State widened from 8\% in 1995 to 16\% in 2001. 
Figure 5.1 Average Annual Miles Driven* per Rural Driver (in census tracts with fewer than 500 people per square mile)

New York State vs. Rest of United States (U.S.)

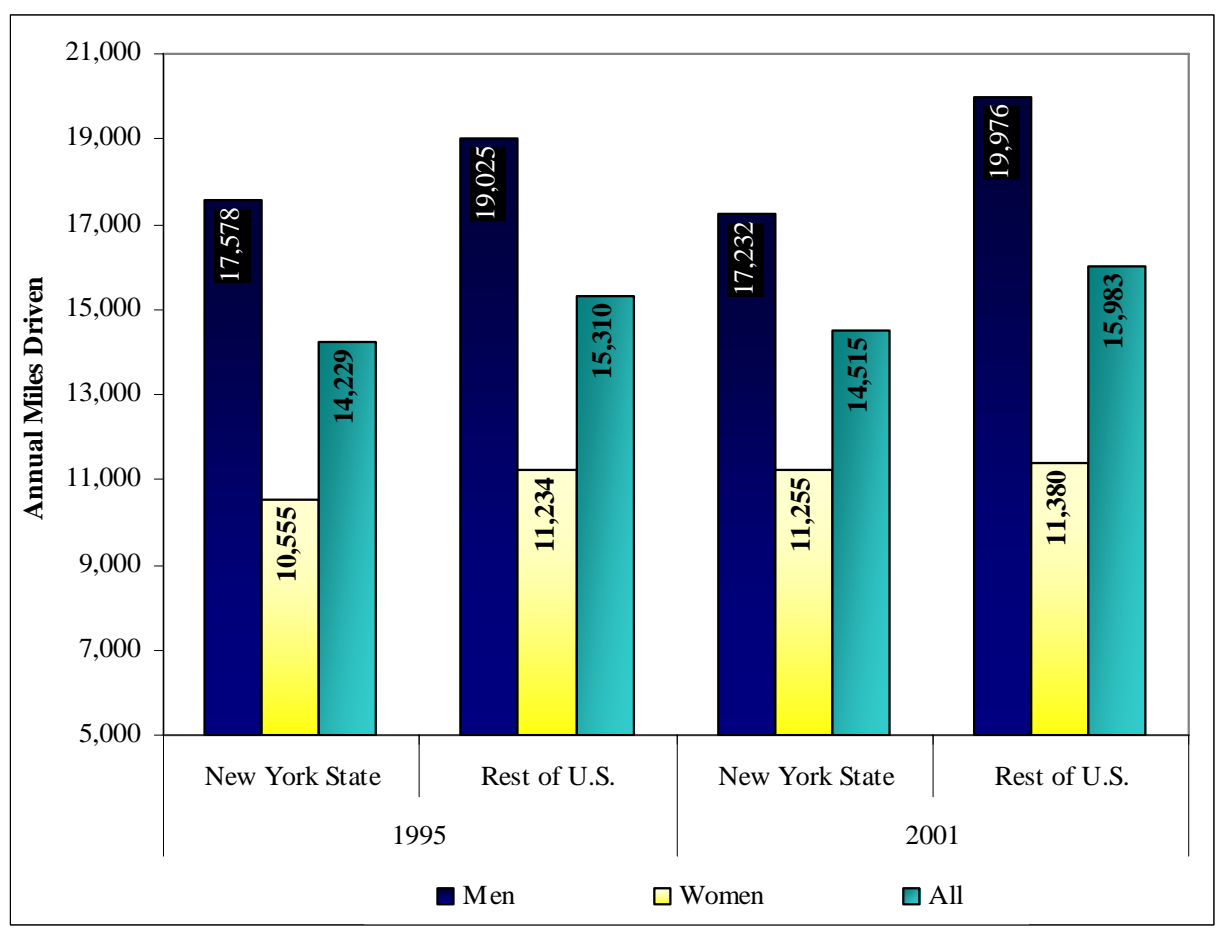

- Based on the self-reported VMT.

- Source: Appendix C, Chapter 5, Table 1.

\subsection{Personal Travel}

In 2001, rural New York residents tend to take fewer, and shorter, trips than rural residents elsewhere (Table 5.4). This observation slightly reverses the trends in 1995 when rural New York residents took fewer, but longer, trips than rural residents elsewhere. The distributions of personal trips by trip purpose and mode are similar between NYS and other rural areas (Table 5.4). The percentage of walk trips increases significantly from 1995 to 2001 due to the improved survey method used in 2001 when the responders were prompted multiple times to report walk trips. 
Table 5.4 Personal Travel Statistics of Rural Households by Mode and Trip Purpose New York State vs. Outside New York State

\begin{tabular}{|c|c|c|c|c|}
\hline & \multicolumn{4}{|c|}{$\begin{array}{c}\text { Fewer than } 500 \text { People Per Square } \\
\text { Mile }^{\mathrm{a}} \text { (census tract) }\end{array}$} \\
\hline & \multicolumn{2}{|c|}{1995} & \multicolumn{2}{|c|}{2001} \\
\hline & NYS & U.S. & NYS & U.S. \\
\hline \multicolumn{5}{|l|}{ Person Trips per Person } \\
\hline TOTAL & 3.91 & 4.25 & 3.88 & 3.93 \\
\hline Male & 3.92 & 4.27 & 3.85 & 3.92 \\
\hline Female & 3.91 & 4.23 & 3.92 & 3.94 \\
\hline TOTAL & 3.91 & 4.25 & 3.88 & 3.93 \\
\hline$\%$ SOV & 41.9 & 43.3 & 41.3 & 41.8 \\
\hline$\% M O V$ & 45.8 & 47.1 & 46.9 & 48.3 \\
\hline \% Other POV & 0.0 & 0.0 & & . \\
\hline$\%$ Commuter Train & . & . & 0.0 & . \\
\hline \% Subway/El Rail & . & . & 0.1 & 0.0 \\
\hline \% Other Public & 0.5 & 0.2 & 0.1 & 0.1 \\
\hline$\%$ Walk & 2.6 & 2.8 & 7.1 & 5.7 \\
\hline$\%$ Other & 5.1 & 4.0 & 4.5 & 4.0 \\
\hline \% Unreported & 4.1 & 2.6 & 0.0 & 0.1 \\
\hline TOTAL & 3.91 & 4.25 & 3.88 & 3.93 \\
\hline \% Earn a Living & 21.2 & 20.9 & 19.2 & 19.4 \\
\hline \% Family \& Personal Business & 44.8 & 44.2 & 43.9 & 44.1 \\
\hline$\%$ Civic, Educational \& Religious & 9.0 & 9.6 & 8.2 & 10.8 \\
\hline \% Social \& Recreational & 25.1 & 24.9 & 27.6 & 24.7 \\
\hline$\%$ Other & . & 0.2 & 0.7 & 0.7 \\
\hline \% Unreported & . & . & 0.4 & 0.2 \\
\hline \multicolumn{5}{|l|}{ Average Person Trip Length ${ }^{b}$} \\
\hline & 11.57 & 11.09 & 11.62 & 12.01 \\
\hline \multicolumn{5}{|l|}{ PMT per Person } \\
\hline TOTAL & 44.76 & 46.79 & 45.25 & 49.30 \\
\hline$\%$ SOV & 38.2 & 39.3 & 36.6 & 38.5 \\
\hline$\% M O V$ & 54.7 & 55.0 & 52.8 & 55.5 \\
\hline$\%$ Other POV & 0.0 & 0.0 & . & . \\
\hline \% Commuter Train & . & . & 0.0 & . \\
\hline \% Subway/El Rail & 0.0 & . & 0.0 & 0.0 \\
\hline \% Other Public & 2.2 & 0.4 & 0.1 & 0.1 \\
\hline \% Walk & 0.1 & 0.1 & 0.6 & 0.3 \\
\hline$\%$ Other & 3.8 & 4.3 & 9.9 & 5.5 \\
\hline \% Unreported & 0.8 & 0.7 & . & 0.2 \\
\hline TOTAL & 44.76 & 46.79 & 45.25 & 49.30 \\
\hline \% Earn a Living & 25.8 & 26.5 & 21.2 & 25.2 \\
\hline \% Family \& Personal Business & 35.9 & 38.1 & 37.0 & 38.2 \\
\hline \% Civic, Educational \& Religious & 6.5 & 7.1 & 5.1 & 7.1 \\
\hline \% Social \& Recreational & 31.5 & 28.2 & 35.2 & 27.9 \\
\hline$\%$ Other & 0.3 & 0.2 & 1.2 & 1.0 \\
\hline \% Unreported &. & & 0.4 & 0.7 \\
\hline
\end{tabular}

Note: $^{\text {a }} \quad$ All percents may not add to $100 \%$ due to rounding.

Average trip length is calculated using only those records with trip mileage information present. 
Compared to NYS residents in urban areas of similar density, residents in New York rural areas tend to take more trips in 2001 (Figure 5.2). Residents in New York rural areas take trips that are slightly longer than New York residents in urban areas of similar population density, 11.6 miles compared to 11.3 miles, respectively (Tables 5.4 and 4.3a). The differences in trip frequency and trip length contribute to rural New York residents traveling 13\% more miles a day than NYS small-urban residents in areas of similar density, 45 miles vs. 40 miles, respectively (Tables 5.4 and $4.3 a$ ).

Figure 5.2 Average Daily Person Trips per Person in Census Tracts with < 500 Persons per Square Mile

New York State vs. Outside New York State

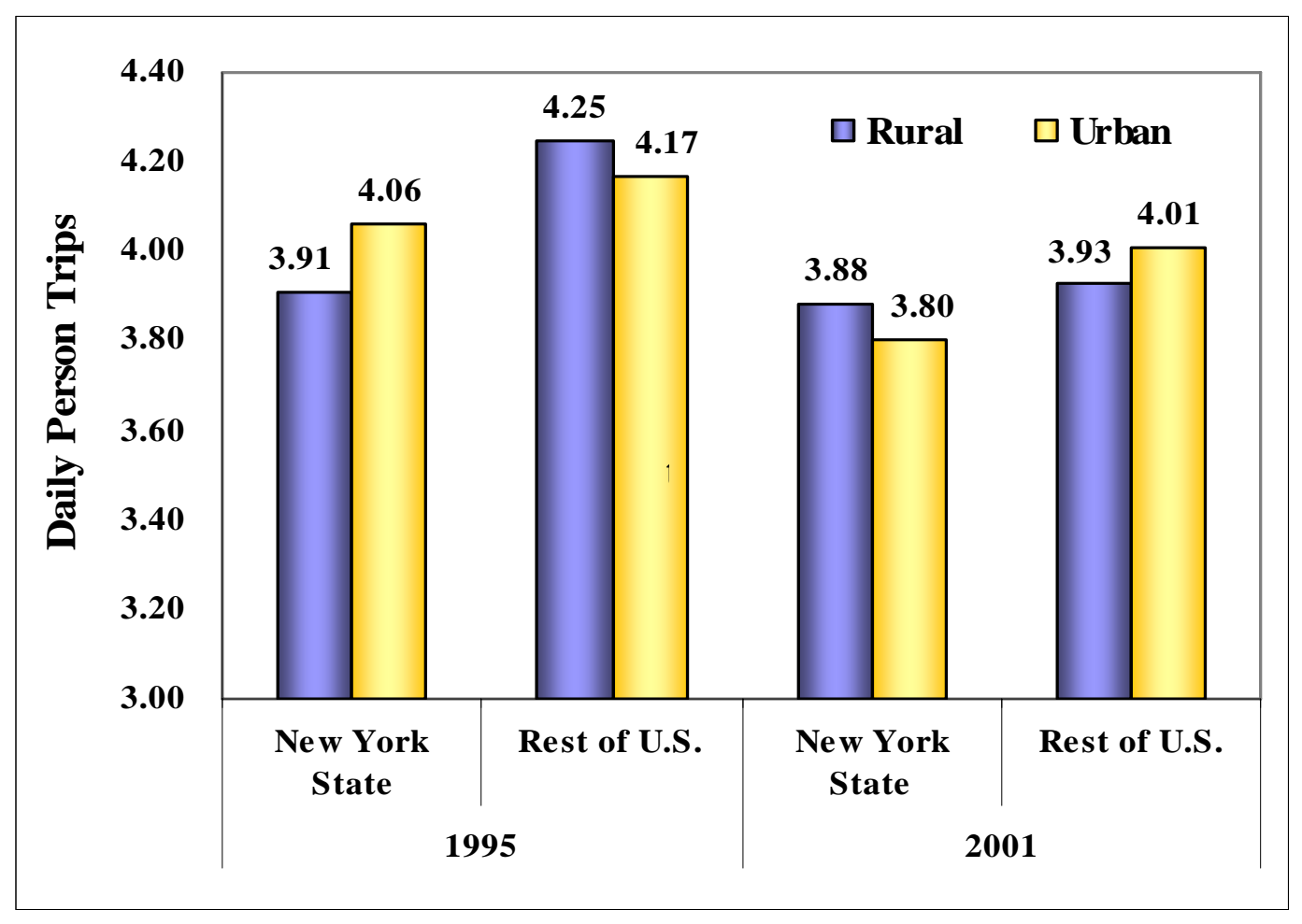

Source: Tables 5.4 and 4.3a and 4.3b 
$\underline{\text { Zero-Vehicle Households }}$

Small sample size limits our analysis of rural households that are without a vehicle. In fact, only 30 rural households in NYS that are without a vehicle were interviewed for the 2001 NPTS. This limitation affects the breadth of the analysis. For example, any comparison of trip rate by household income is impossible. The limitation on sample size also affects the conclusiveness of any comparison results.

\subsection{Vehicle Travel}

In 2001, rural drivers in NYS not only drive less frequently than their counterparts elsewhere, they also make shorter trips (Table 5.4). The average vehicle trip lengths are 11.3 and 12.5 miles for rural drivers within and outside NYS, respectively (Table 5.5). The trip length distributions shed more light on this difference in the average vehicle trip lengths (Figure 5.3). Almost nine percent of driving done by rural drivers outside NYS are to destinations more than 30 miles away, while the corresponding figure for rural New York drivers is slightly less than 7\%. There is no noticeable difference between rural New York households and similar households elsewhere as to why driving takes place. About half of the daily driving trips are for family and personal business, while less than one-third are for earning a living (Table 5.5). 
Table 5.5 Vehicle Travel Statistics by Drivers in Rural Areas New York State (NYS) vs. Rest of the United States (U.S.) ${ }^{a}$ (In Census Tracts of Less than 500 People Per Square Mile)

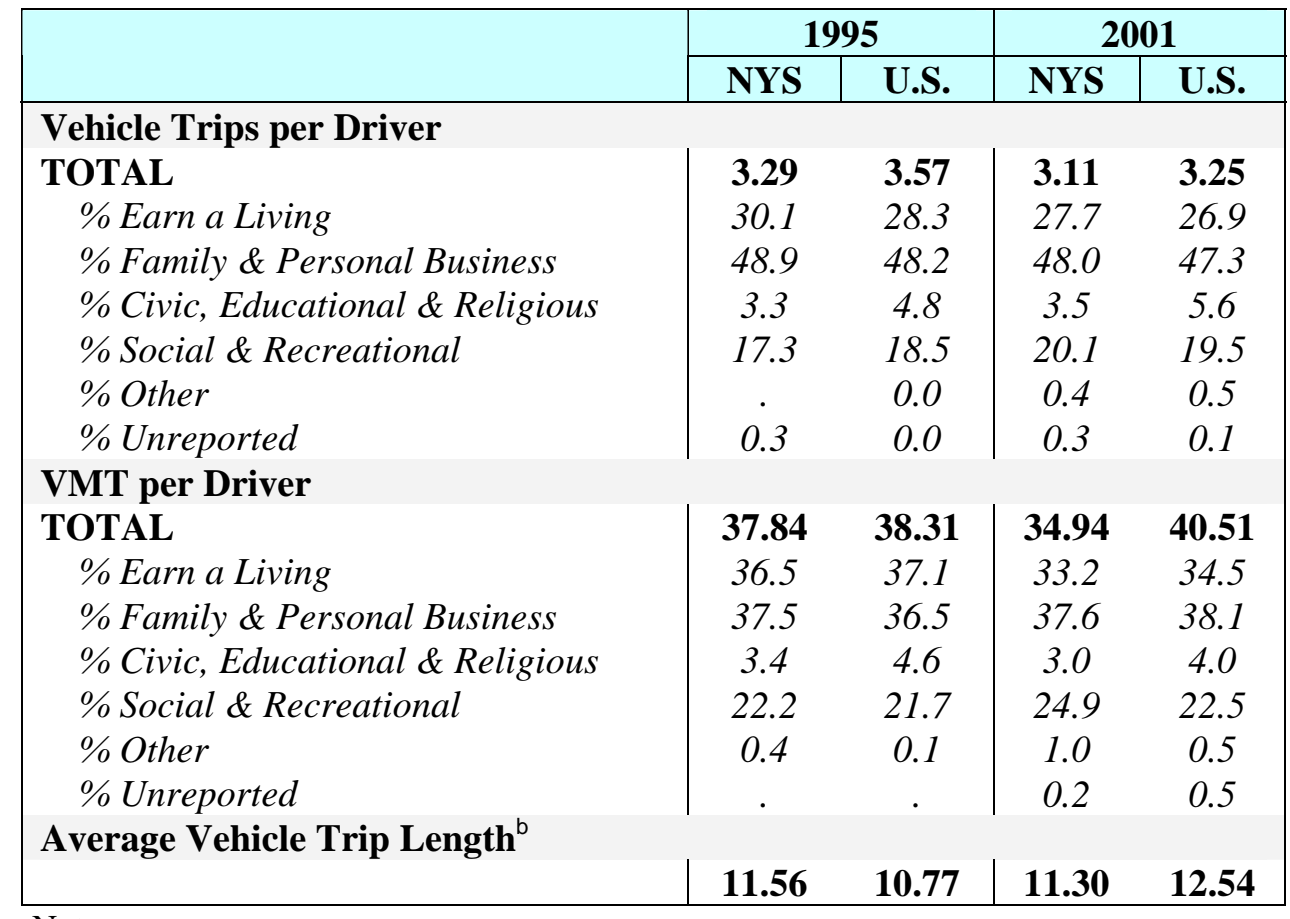

Note:

a All percents may not add to $100 \%$ due to rounding.

b Average trip length is calculated using only those records with trip mileage information present. 
Figure 5.3 Distribution of Vehicle Trips in Rural Areas by Trip Length New York State vs. Outside New York State

(In Census Tracts of Fewer than 500 People Per Square Mile)

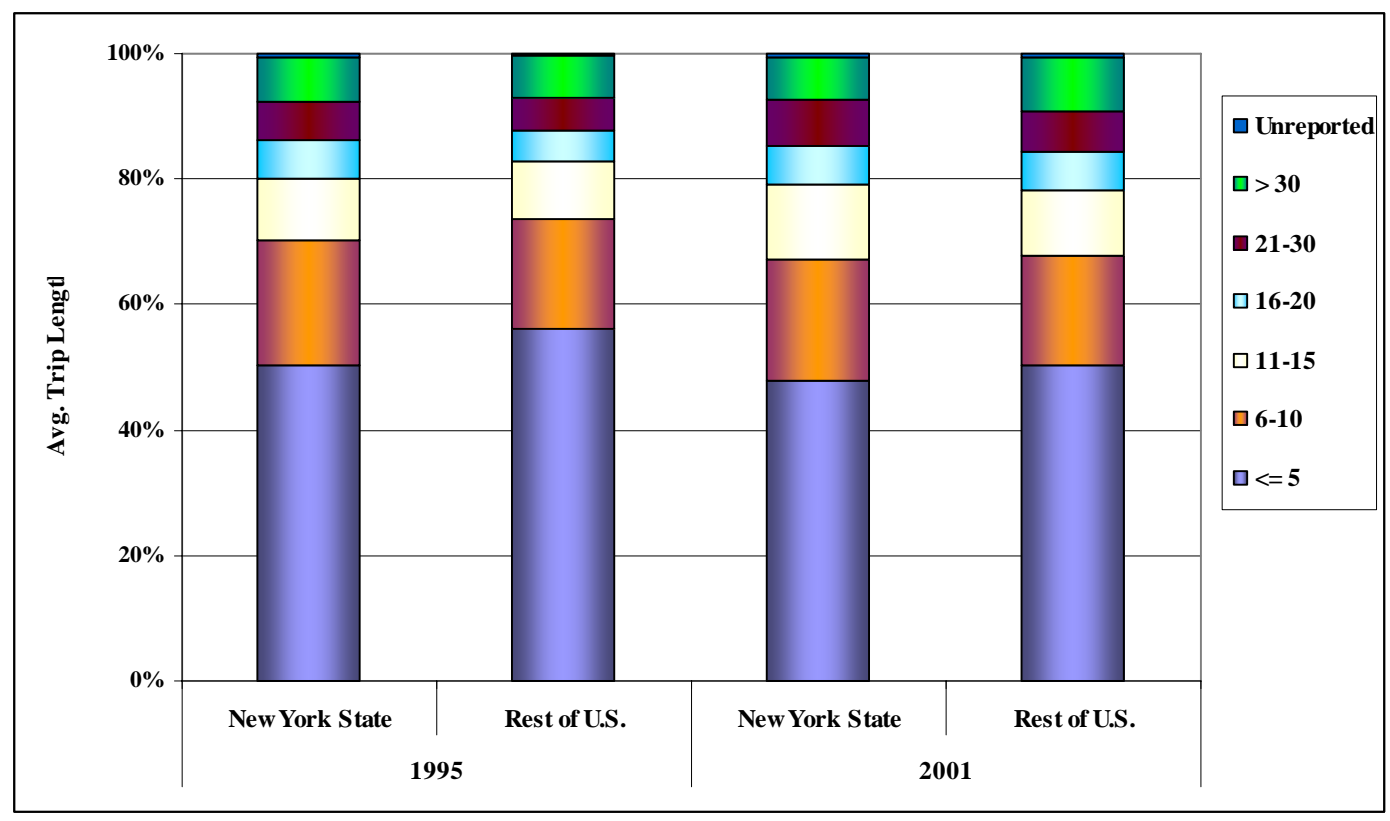

Source: Appendix C, Chapter 5, Table 5

\subsection{Commute Patterns}

Rural New York residents do not resemble their counterparts outside NYS in commuting patterns except for the likelihood of carpooling. Both inside and outside NYS, workers drive themselves to work without carpooling four out of every five work trips (Table 5.6). However, workers in rural New York areas are less likely to carpool in 2001 than in 1995. Compared to 1995, workers in rural areas take fewer work trips in 2001 - true both inside and outside NYS. On a daily basis, an average worker in New York rural areas takes 1.2 trips to and from work. One-way commutes by privately-owned vehicle in 2001 are shorter, with respect to both distance and time, for workers in New York rural areas than those outside NYS (Figure 5.4). 
Table 5.6 Daily Commute Statistics in Rural Areas by Mode of Transportation ${ }^{a}$ New York State (NYS) vs. Outside New York State (U.S.)

\begin{tabular}{|c|c|c|c|c|}
\hline & \multicolumn{2}{|c|}{1995} & \multicolumn{2}{|c|}{2001} \\
\hline & NYS & U.S. & NYS & U.S. \\
\hline \multicolumn{5}{|c|}{ Commute Person Trips per Worker } \\
\hline TOTAL & 1.39 & 1.48 & 1.16 & 1.14 \\
\hline$\%$ SOV & 78.4 & 77.0 & 82.0 & 79.6 \\
\hline$\% M O V$ & 18.0 & 17.6 & 14.2 & 17.1 \\
\hline$\%$ Other POV & 0.0 & 0.0 & . & . \\
\hline$\%$ Amtrak & 0.0 & 0.0 & . & . \\
\hline \% Commuter Train & 0.0 & 0.0 & . & . \\
\hline \% Subway/El Rail & 0.0 & 0.0 & . & . \\
\hline \% Other Public & 0.7 & 0.0 & 0.2 & 0.2 \\
\hline$\%$ Walk & 0.7 & 1.4 & 3.0 & 2.3 \\
\hline$\%$ Other & 0.7 & 1.4 & 0.6 & 0.8 \\
\hline \% Unreported & 1.4 & 2.7 & 0.1 & 0.1 \\
\hline \multicolumn{5}{|c|}{ Commute PMT per Worker } \\
\hline TOTAL & 19.56 & 18.68 & 14.63 & 15.74 \\
\hline$\%$ SOV & 77.5 & 76.0 & 88.6 & 80.1 \\
\hline$\% M O V$ & 19.7 & 21.2 & 10.4 & 19.1 \\
\hline$\%$ Other POV & 0.1 & 0.0 & . & . \\
\hline$\%$ Amtrak & 0.0 & 0.0 & . & . \\
\hline$\%$ Commuter Train & 0.0 & 0.0 & . & . \\
\hline \% Subway/El Rail & 0.1 & 0.0 & . & . \\
\hline$\%$ Other Public & 0.7 & 0.3 & 0.5 & 0.2 \\
\hline$\%$ Walk & 0.1 & 0.1 & 0.2 & 0.1 \\
\hline$\%$ Other & 0.7 & 1.6 & 0.4 & 0.5 \\
\hline \% Unreported & 1.1 & 0.9 & . & 0.1 \\
\hline
\end{tabular}

Note:

a All percents may not add to $100 \%$ due to rounding. 
Figure 5.4 Daily Commute Patterns in Rural Areas by Privately Owned Vehicles New York State vs. Outside New York State

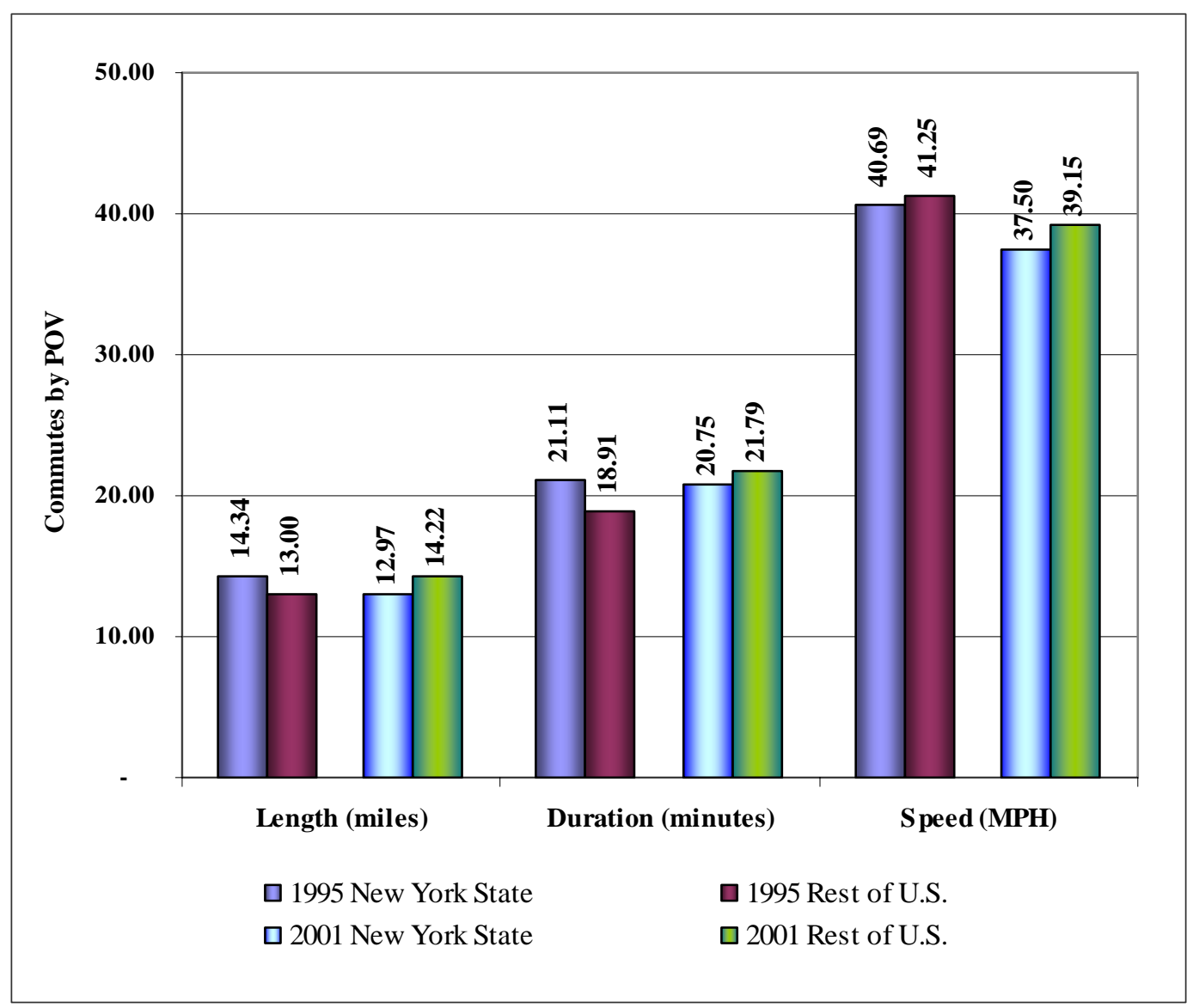

Source: Appendix C, Chapter 5, Table 7.

\subsection{Summary}

The small sample sizes contribute to some unstable results and preclude any definitive analyses. Furthermore, the small sample sizes demand special attention in interpreting the results in this chapter. On an individual household basis, the trends in 1995 continued in 2001 where households in rural New York areas own, on average, fewer vehicles than rural households outside NYS. Vehicle ownership patterns are somewhat different between rural New York households and households in rural areas outside NYS. Greater proportions of rural New York households are without a vehicle, or with one or two vehicles, than rural households 
outside NYS (Table 5.3). However, among rural households outside NYS a larger proportion continue to own more than four vehicles when compared to rural New York households. On average, drivers in New York rural areas drive fewer, and shorter, trips than those in rural areas elsewhere (Table 5.5). Similar patterns are observed from the standpoint of overall personal travel patterns. Residents in New York rural areas also take fewer, and shorter, trips than those in other rural areas (Table 5.4).

In rural NYS, households that do not own a vehicle walking to and from work accounts for almost one-quarter of the commutes. It is not clear whether this is an artifact of the improved survey methodology in 2001 when multiple prompts were used for the responders to better recollect the walking trips.

Changes in travel patterns were observed between 1995 and 2001. For example, the commute distance by rural New York workers increased more than 50\%, from an average of 17 miles in 1995 to 27 miles in 2001. Further research would be necessary to decipher the validity and causes of this apparent change. 
2001 New York NHTS: A Comparison Study

This page intentionally left blank.

$5-14$ 


\section{Chapter 6. Comparison of Travel Patterns Among New York State Metropolitan Planning Organizations}

Previous chapters compare the travel patterns of NYS residents to the rest of the nation. This chapter examines travel patterns among the twelve New York Metropolitan Planning Organizations (MPOs): Albany; Binghamton; Buffalo; Elmira; Glens Falls; Ithaca; NYMTC; Newburgh; Poughkeepsie; Rochester; Syracuse; and Utica-Rome (Figure 6.1). ${ }^{7}$ The travel patterns are compared among NYS MPOs of similar size.

The metropolitan area that is under the jurisdiction of the NYMTC is evaluated in terms of its three geographic components:

- Nassau and Suffolk;

- the five counties of NYC: Bronx, Kings, Queens, New York (or Manhattan), and Richmond; and

- Putnam, Rockland, and Westchester.

NYC is further broken down to New York/Manhattan and the rest of NYC.

To make travel comparisons meaningful, the MPOs and the sub-components of an MPO (e.g., New York/Manhattan) are grouped into Metropolitan Statistical Area (MSA) size categories (Table 6.1). The grouping of the twelve MPOs is the same in 2001 as in 1995 . The travel data of an MPO are compared to other NYS MPOs with a similar MSA size.

\footnotetext{
7 The 2000 Census identified 3 new “MPO” areas: Kingston, Saratoga Springs, and Middletown. Unfortunately, knowledge of these new areas was unknown at the time when the survey was conducted. Kingston, in Ulster County, was categorized as "rural." The remaining two were part of other MPO areas: Saratoga Springs is part of the Albany MPO, and Middletown is part of the Newburgh MPO.
}

$$
6-1
$$


Figure 6.1 Population Densities of Areas in New York State

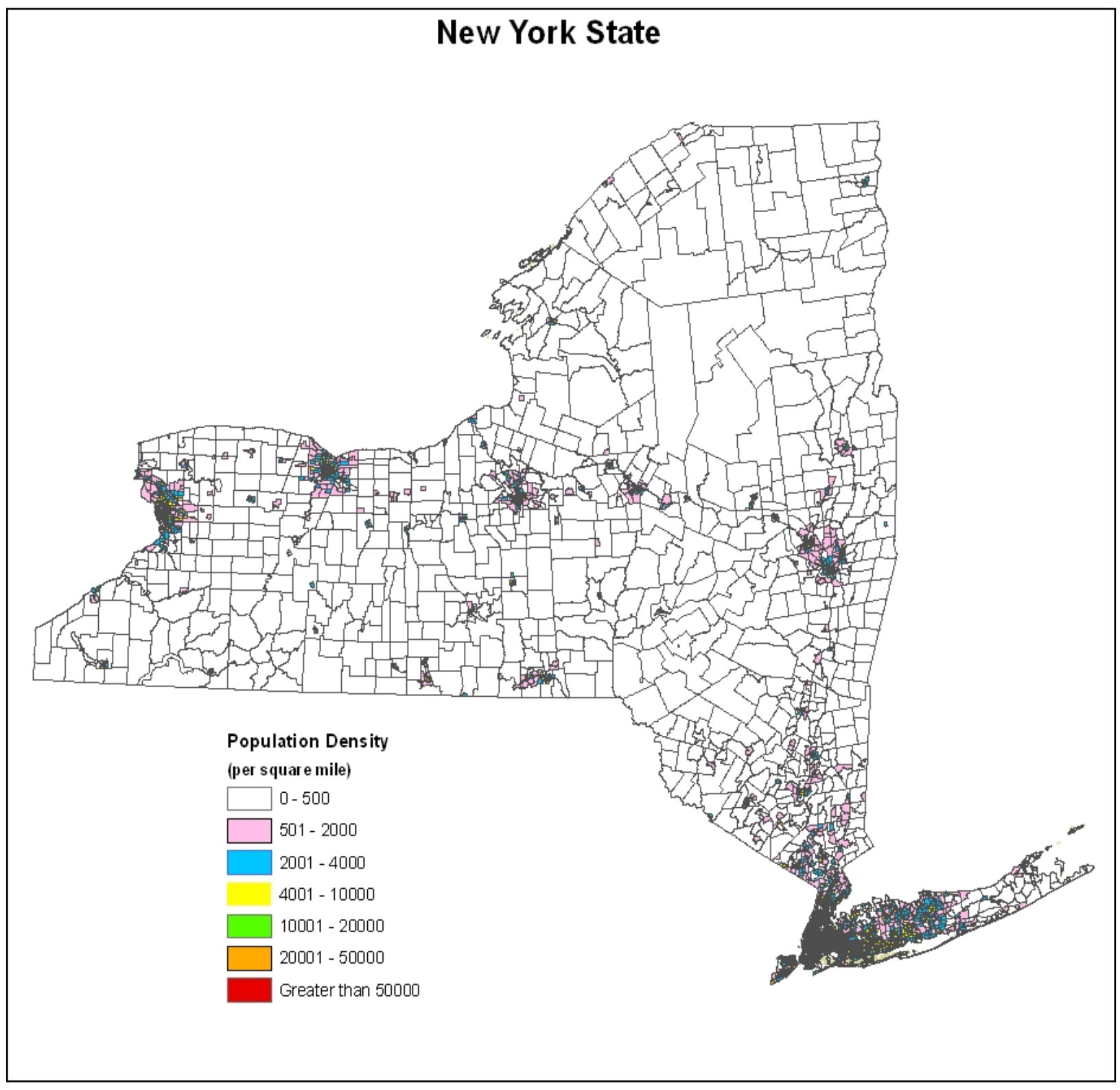

6 - 2 
For example, the travel data of Elmira residents are compared to those of Glens Falls residents. While Ithaca is outside an MSA area, its population size of more than 85,000 in 2001 makes it reasonable to compare its travel patterns to those of other small MSAs such Elmira and Glens Falls. The complete travel statistics of the Ithaca MPO can be found in Appendix C. Figure 6.1 shows the population densities of areas in NYS. Population density maps for individual add-on areas are in Appendix B.

Table 6.1 New York State MPOs Categorized by Their MSA Size 2001 NHTS and 1995 NPTS

\begin{tabular}{|c|c|}
\hline $\begin{array}{l}\text { MSA Size } \\
\text { Category }\end{array}$ & MPOs \\
\hline Not in an MSA & $\begin{array}{l}\text { - Ithaca (population of the MPO was 91,000 in 1995, 85,648 in } \\
\text { 2001) }\end{array}$ \\
\hline$<250,000$ & $\begin{array}{ll}\text { - } & \text { Elmira } \\
\text { - Glens Falls }\end{array}$ \\
\hline 250,000 - 499,999 & $\begin{array}{l}\text { - Binghamton; } \\
\text { - Utica-Rome }\end{array}$ \\
\hline 500,000 - 999,999 & $\begin{array}{l}\text { - Albany; } \\
\text { - Syracuse } \\
\end{array}$ \\
\hline 1 to 2.9 million & $\begin{array}{l}\text { - Buffalo; } \\
\text { - Rochester }\end{array}$ \\
\hline$>3$ million & $\begin{array}{l}\text { - } \quad \text { Newburgh; } \\
\text { - Poughkeepsie; } \\
\text { - Nassau/Suffolk; } \\
\text { - NYC (NYC's } 5 \text { counties: Bronx, Kings, Queens, New } \\
\text { - York/Manhattan, and Richmond); } \\
\text { - Putnam/Rockland/Westchester, }\end{array}$ \\
\hline
\end{tabular}




\subsection{Profile of New York State MPO Households by MSA Size}

Eight out of ten households within New York MPOs are located within an MSA with a population of 3 million or more, with only $0.4 \%$ of NY's MPO households located outside of an MSA (Figure 6.2). This distribution profile was extremely stable from 1995 to 2001 . Similar to 1995, the number of workers on a per household basis is not considerably different among MPOs of similar size (Tables 6.2a and 6.2b).

Vehicle ownership in small and medium-size MPOs (in MSAs with a population of less than 3 million) is fairly consistent. In 1995, there are about 9 vehicles for every ten drivers (Table 6.2b). However, there was, on average, more than one vehicle available to a driver in 2001 (Table 6.2a). In 2001, the percentage of households without a vehicle ranges widely among the small and medium-size MPOs, ranging from 7 to almost $13 \%$. Close to $13 \%$ of Syracuse households do not own a vehicle. The disparity in these percentages is greater in 2001 than in 1995. 
Figure 6.2 Distribution of Households In New York State MPOs by MSA Size

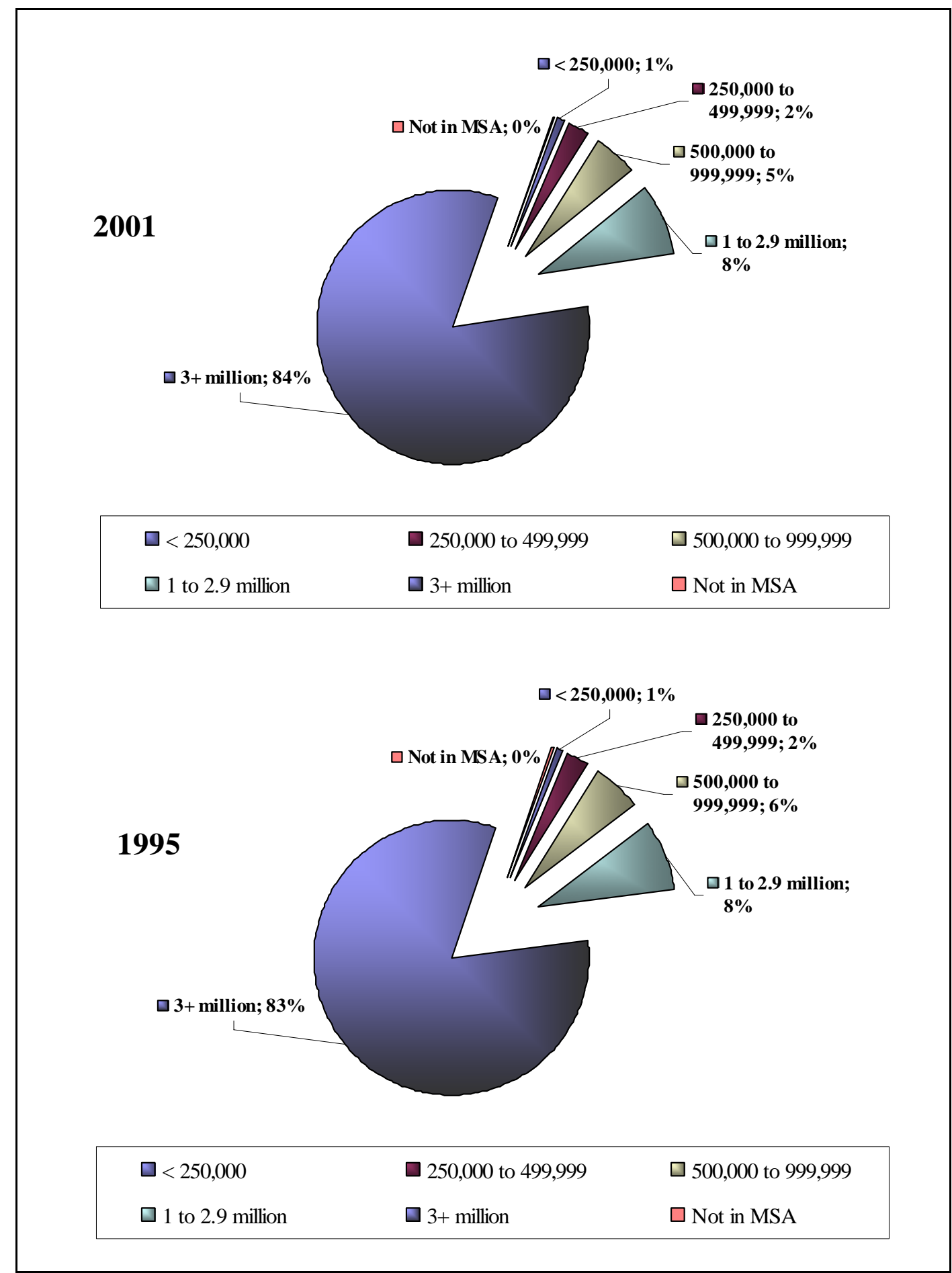

Source: Appendix C, Chapter 6: Table 1.

$$
6-5
$$


Table 6.2a Household Characteristics and Vehicle Ownership Patterns New York State MPOs by MSA Size 2001 NHTS

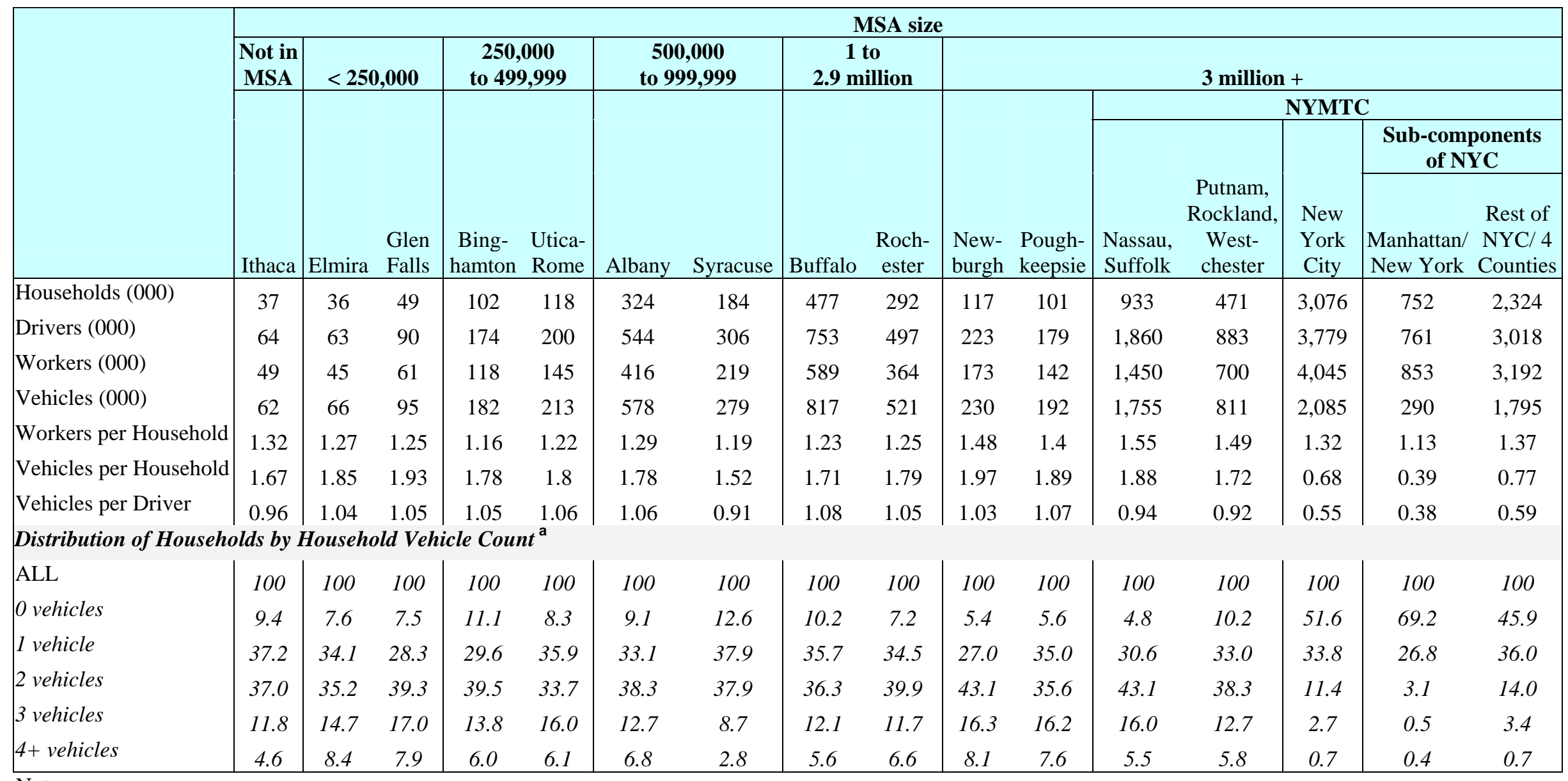

Note:

a All percents may not add to $100 \%$ due to rounding. 
Table 6.2b Household Characteristics and Vehicle Ownership Patterns New York State MPOs by MSA Size 1995 NPTS

\begin{tabular}{|c|c|c|c|c|c|c|c|c|c|c|c|c|c|c|c|c|}
\hline & \multicolumn{16}{|c|}{ MSA size } \\
\hline & \multirow{4}{*}{$\begin{array}{l}\begin{array}{c}\text { Not in } \\
\text { MSA }\end{array} \\
\\
\text { Ithaca }\end{array}$} & \multicolumn{2}{|c|}{$<250,000$} & \multicolumn{2}{|c|}{$\begin{array}{c}250,000 \\
\text { to } 499,999 \\
\end{array}$} & \multicolumn{2}{|c|}{$\begin{array}{c}500,000 \\
\text { to } 999,999 \\
\end{array}$} & \multicolumn{2}{|c|}{\begin{tabular}{|c|}
1 to \\
2.9 million \\
\end{tabular}} & \multicolumn{7}{|c|}{3 million +} \\
\hline & & \multirow{3}{*}{\multicolumn{2}{|c|}{$\begin{array}{ll} & \text { Glen } \\
\text { Elmira } & \text { Falls }\end{array}$}} & \multirow[b]{3}{*}{$\begin{array}{c}\text { Bing- } \\
\text { hamton }\end{array}$} & \multirow[b]{3}{*}{$\begin{array}{l}\text { Utica- } \\
\text { Rome }\end{array}$} & \multirow[b]{3}{*}{ Albany } & \multirow[b]{3}{*}{ Syracuse } & \multirow{3}{*}{\multicolumn{2}{|c|}{$\begin{array}{r}\text { Roch- } \\
\text { Buffalo } \\
\text { ester }\end{array}$}} & \multirow[b]{3}{*}{$\begin{array}{l}\text { New- } \\
\text { burgh }\end{array}$} & \multirow[b]{3}{*}{$\begin{array}{l}\text { Pough- } \\
\text { keepsie }\end{array}$} & \multicolumn{5}{|c|}{ NYMTC } \\
\hline & & & & & & & & & & & & & & & \begin{tabular}{|r|} 
Sub-compo \\
NY \\
\end{tabular} & $\begin{array}{l}\text { onents of } \\
\text { C }\end{array}$ \\
\hline & & & & & & & & & & & & \begin{tabular}{|l} 
\\
Nassau, \\
Suffolk
\end{tabular} & $\begin{array}{c}\text { Putnam, } \\
\text { Rockland, } \\
\text { West- } \\
\text { chester }\end{array}$ & $\begin{array}{l}\text { New } \\
\text { York } \\
\text { City }\end{array}$ & $\begin{array}{l}\text { Manhattan/ } \\
\text { New York }\end{array}$ & $\begin{array}{c}\text { Rest of } \\
\text { NYC/4 } \\
\text { Counties }\end{array}$ \\
\hline Households (000) & 35 & 35 & 45 & 101 & 117 & 326 & 180 & 465 & 279 & 108 & 95 & 886 & 448 & 2,920 & 728 & 2,193 \\
\hline Driver (000) & 70 & 61 & 77 & 174 & 209 & 555 & 313 & 787 & 491 & 204 & 180 & 1,783 & 837 & 3,218 & 730 & 2,489 \\
\hline Workers (000) & 50 & 41 & 59 & 115 & 151 & 410 & 244 & 562 & 366 & 158 & 136 & 1,374 & 632 & 3,404 & 846 & 2,559 \\
\hline Vehicles (000) & 50 & 55 & 73 & 158 & 189 & 508 & 283 & 667 & 452 & 176 & 161 & 1,464 & 724 & 1,600 & 201 & 1,399 \\
\hline Workers per Household & 1.42 & 1.16 & 1.31 & 1.14 & 1.29 & 1.26 & 1.36 & 1.21 & 1.31 & 1.46 & 1.44 & 1.55 & 1.41 & 1.17 & 1.16 & 1.17 \\
\hline Vehicles per household & 1.42 & 1.57 & 1.61 & 1.57 & 1.62 & 1.56 & 1.57 & 1.43 & 1.62 & 1.63 & 1.70 & 1.65 & 1.62 & 0.55 & 0.28 & 0.64 \\
\hline Vehicles per Driver & 0.71 & 0.90 & 0.94 & 0.91 & 0.91 & 0.91 & 0.90 & 0.85 & 0.92 & 0.86 & 0.89 & 0.82 & 0.86 & 0.50 & 0.28 & 0.56 \\
\hline \multicolumn{17}{|c|}{ Distribution of Households by Household Vehicle Count ${ }^{\text {a }}$} \\
\hline ALL & 100 & 100 & 100 & 100 & 100 & 100 & 100 & 100 & 100 & 100 & 100 & 100 & 100 & 100 & 100 & 100 \\
\hline 0 vehicles & 9.0 & 8.4 & 6.1 & 6.5 & 6.9 & 8.7 & 8.4 & 11.5 & 7.7 & 5.6 & 7.1 & 5.4 & 9.8 & 52.9 & 72.6 & 46.3 \\
\hline 1 vehicle & 42.0 & 37.4 & 29.6 & 36.4 & 34.4 & 32.2 & 33.3 & 37.8 & 31.9 & 31.0 & 26.5 & 29.1 & 30.0 & 33.8 & 24.8 & 36.8 \\
\hline 2 vehicles & 35.0 & 39.6 & 49.6 & 39.8 & 40.3 & 40.2 & 44.3 & 38.1 & 43.7 & 46.0 & 42.6 & 48.1 & 41.2 & 11.2 & 2.4 & 14.2 \\
\hline 3 vehicles & 11.3 & 10.1 & 12.1 & 12.6 & 13.0 & 13.4 & 10.5 & 10.2 & 11.7 & 11.5 & 16.0 & 12.2 & 13.8 & 1.6 & 0.1 & 2.1 \\
\hline $4+$ vehicles & 2.7 & 4.4 & 2.7 & 4.7 & 5.4 & 5.5 & 3.6 & 2.4 & 5.0 & 5.9 & 7.8 & 5.3 & 5.2 & 0.5 & 0.1 & 0.6 \\
\hline
\end{tabular}

Note:

${ }^{a}$ All percents may not add to $100 \%$ due to rounding. 
On the other hand, vehicle ownership and the percentage of households without a vehicle vary among households in different large metro areas (in MSAs with more than 3 million people). In fact, these households can be divided into three distinct groups with respect to vehicle ownership patterns. The first group encompasses households in Putnam, Rockland, and Westchester counties. Among these households, the percentage that does not own a vehicle is very similar to those in small and medium-size MPOs (in MSAs with a population of less than 3 million). The second group encompasses households outside the NYMTC area (i.e., Newburgh and Poughkeepsie), and households in Nassau and Suffolk counties. Significantly more likely to own a vehicle than households in other MPOs, only 5\% of the households in this group do not own a vehicle. This percentage is at least two percentage points lower than the percentage observed in small and medium-size MPOs (in MSAs with a population of less than 3 million).

The final group, encompassing households in NYC, is distinctively different from the other New York MPOs. Parallel to findings in Chapter 3, households in NYC have considerably different vehicle ownership patterns than other households. More than two-thirds of Manhattan households do not own a vehicle (Table 6.2a). No consistent patterns merge across all MPOs in terms of changes in vehicle ownership from 1995 to 2001 (Tables 6.2a and 6.2b).

More than nine out of ten NYS men who are sixteen years or older reportedly drive. This is true for all MPOs, except men living in NYC (Figure 6.3). Women are less likely to drive than men, regardless of where they live. The gender gap is the greatest in NYC. About 70\% of men and less than $50 \%$ of women in NYC reportedly drive, compared to over $90 \%$ and $80 \%$, respectively, elsewhere in the country. The percentage of women living in NYC who are reported as a driver increased from 1995 to 2001 (Figure 6.3). The increase is the greatest for women between the ages of 20 and 34. Although Ithaca is not characterized as an MSA, it has driver rates similar to those of other NY MPOs except for NYC (Figure 6.3). 
Figure 6.3 Percentage of Population Who Drive Categorized by Gender New York State MPOs 1995 and 2001

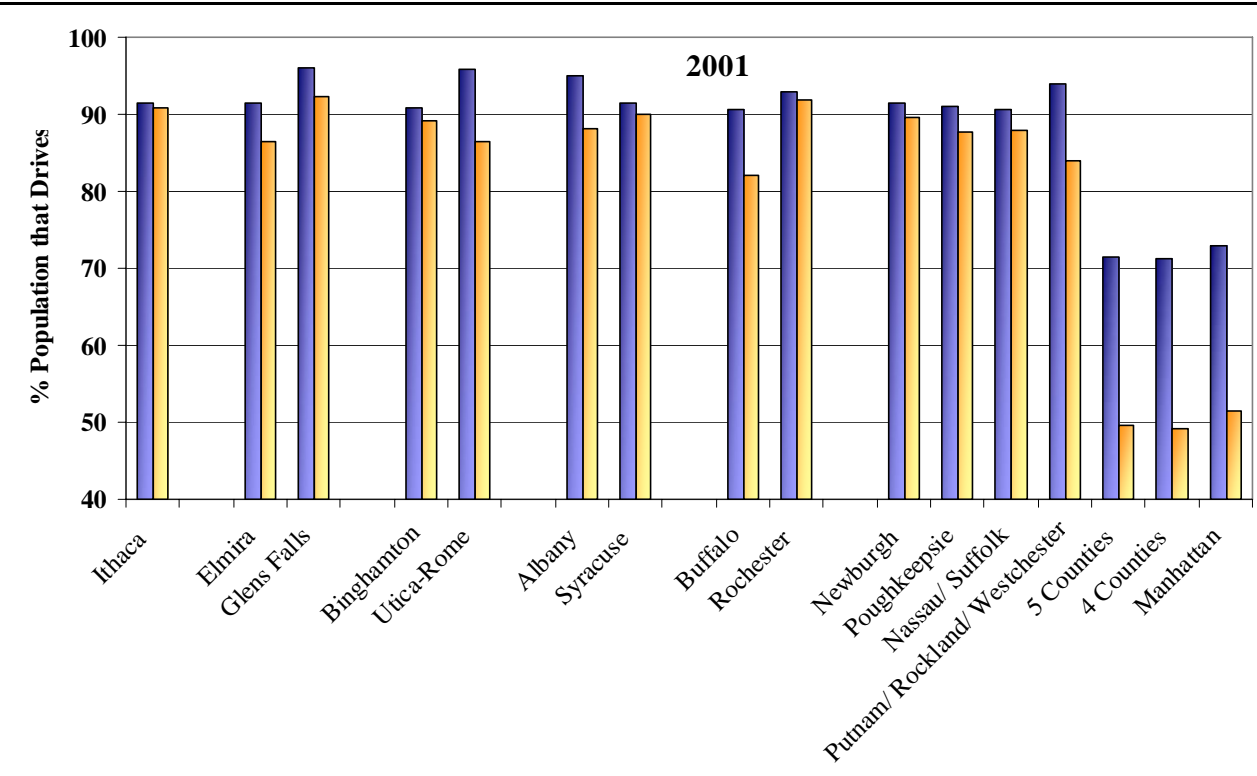

$\square \%$ Male Drivers/Male 16+ $\square \%$ Female Drivers/Female 16+

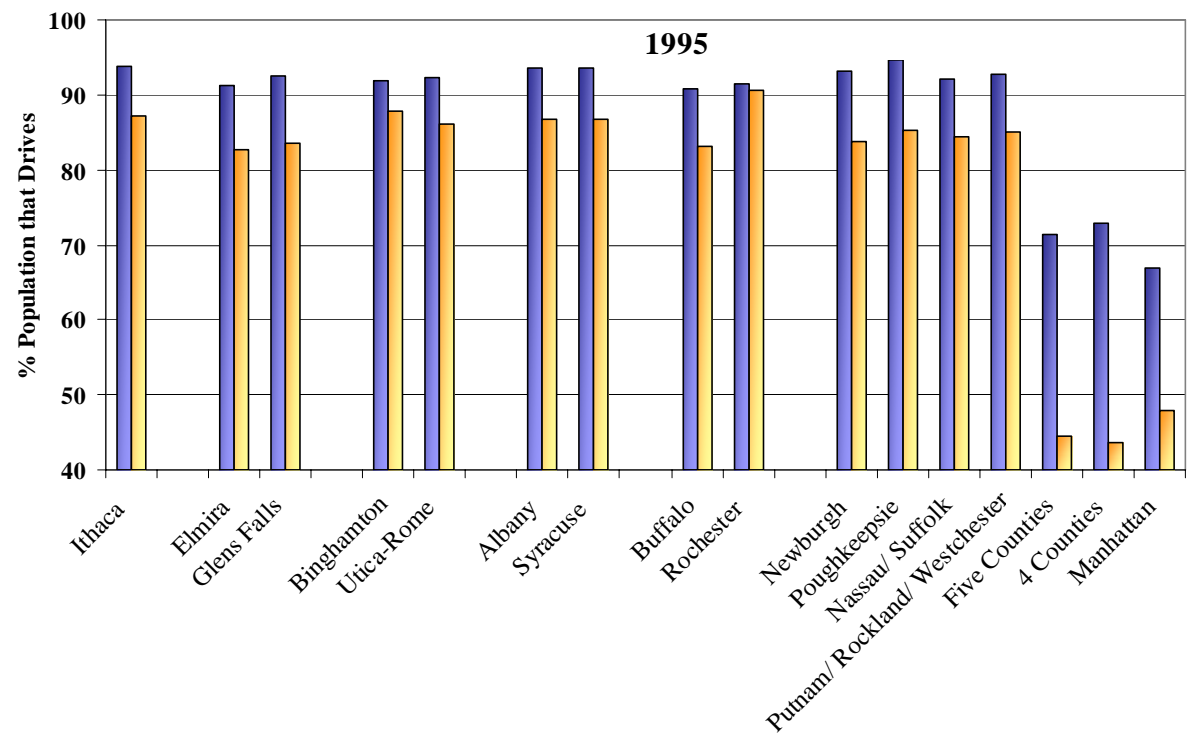

$\square \%$ Male Drivers/Male 16+ $\quad \square \%$ Female Drivers/Female 16+

Source: Appendix C, Chapter 6, Table 1

$$
6-9
$$




\subsection{Personal Travel}

On a per person basis, NYS residents in small and medium-size MSAs took more than four trips a day in 1995. In that year, residents in large metro areas (with more than 3 million people) took fewer than four trips per day, except for residents in Nassau and Suffolk counties. Nassau and Suffolk residents had daily mobility patterns similar to those in medium-size MSAs such as Buffalo (Table 6.3a and Figure 6.4). However, this difference no longer exists in 2001 (Table 6.3b and Figure 6.4). There is less disparity between small and medium-size MPOs and large urban areas in 2001. In general, residents in New York MPOs travel less frequently in 2001 than in 1995. It is unclear the extent to which 9/11 or recessionary impacts contributed to this decline. This is true across almost all of the MPOs, except for those living in Newburgh and in the five counties in NYC (Figure 6.5).

In 1995, residents in NYC not only took fewer trips (3.5 trips per day), but also shorter trips (6 miles per trip) than almost all of the residents in other large New York metro areas (Table 6.3a). Although this overall pattern continues in 2001, trips by residents in New York/Manhattan are 2.4 times longer, from 5 miles per trip in 1995 to 12 miles in 2001 (Tables 6.3a and 6.3b).

Men, for the most part, take slightly more trips per day than women (Tables 6.3a and 6.3b). Age appears to have a similar impact regardless of area size (Appendix C, Chapter 6, Table 2). Sample size limitations preclude an analysis of whether race is a factor in these differences. The distribution of person trips per person across trip purposes shows little variation between MPO areas within each MSA size category (Tables 6.3a and 6.3b). 
Table 6.3a Personal Travel Statistics New York State MPOs by MSA Size 1995 NPTS $^{a}$

\begin{tabular}{|c|c|c|c|c|c|c|c|c|c|c|c|c|c|c|c|c|}
\hline & \multicolumn{16}{|c|}{ MSA size } \\
\hline & $\begin{array}{l}\text { Not in } \\
\text { MSA }\end{array}$ & \multicolumn{2}{|c|}{$<250,000$} & \multicolumn{2}{|c|}{$\begin{array}{c}250,000 \\
\text { to } 499,999 \\
\end{array}$} & \multicolumn{2}{|c|}{$\begin{array}{c}500,000 \\
\text { to } 999,999 \\
\end{array}$} & \multicolumn{2}{|c|}{$\begin{array}{c}1 \text { to } \\
2.9 \text { million } \\
\end{array}$} & \multicolumn{7}{|c|}{3 million +} \\
\hline & \multirow[b]{3}{*}{ Ithaca } & \multirow[b]{3}{*}{ Elmira } & \multirow[b]{3}{*}{$\begin{array}{l}\text { Glen } \\
\text { Falls }\end{array}$} & \multirow[b]{3}{*}{$\begin{array}{l}\text { Bing- } \\
\text { hamton }\end{array}$} & \multirow[b]{3}{*}{$\begin{array}{l}\text { Utica- } \\
\text { Rome }\end{array}$} & \multirow[b]{3}{*}{ Albany } & \multirow[b]{3}{*}{ Syracuse } & \multirow[b]{3}{*}{$\begin{array}{c}\text { Buffal } \\
\text { o }\end{array}$} & \multirow[b]{3}{*}{$\begin{array}{l}\text { Roch- } \\
\text { ester }\end{array}$} & \multirow[b]{3}{*}{$\begin{array}{l}\text { New- } \\
\text { burgh }\end{array}$} & \multirow[b]{3}{*}{$\begin{array}{l}\text { Pough- } \\
\text { keepsie }\end{array}$} & \multicolumn{5}{|c|}{ NYMTC } \\
\hline & & & & & & & & & & & & \multirow[b]{2}{*}{$\begin{array}{l}\text { Nassau, } \\
\text { Suffolk }\end{array}$} & \multirow[b]{2}{*}{$\begin{array}{c}\text { Putnam, } \\
\text { Rockland, } \\
\text { Westchester }\end{array}$} & \multirow[b]{2}{*}{$\begin{array}{l}\text { New } \\
\text { York } \\
\text { City }\end{array}$} & \multicolumn{2}{|c|}{$\begin{array}{c}\text { Sub-components of } \\
\text { NYC }\end{array}$} \\
\hline & & & & & & & & & & & & & & & $\begin{array}{l}\text { Manhattan/ } \\
\text { New York }\end{array}$ & $\begin{array}{c}\text { Rest of } \\
\text { NYC/4 } \\
\text { Counties } \\
\end{array}$ \\
\hline \multicolumn{17}{|c|}{ Person Trips per Person } \\
\hline TOTAL & 4.38 & 4.33 & 4.45 & 4.30 & 4.24 & 4.13 & 4.24 & 4.17 & 4.25 & 3.73 & 3.94 & 4.12 & 3.86 & 3.58 & 3.78 & 3.53 \\
\hline Male & 4.34 & 4.40 & 4.42 & 4.40 & 4.37 & 4.18 & 4.32 & 4.25 & 4.26 & 3.66 & 4.01 & 4.18 & 3.76 & 3.63 & 3.91 & 3.56 \\
\hline Female & 4.41 & 4.27 & 4.47 & 4.20 & 4.12 & 4.07 & 4.16 & 4.09 & 4.25 & 3.80 & 3.86 & 4.07 & 3.95 & 3.54 & 3.66 & 3.50 \\
\hline \multicolumn{17}{|c|}{ Average Person Trip Length ${ }^{b}$} \\
\hline & 7.24 & 9.23 & 8.28 & 8.11 & 8.41 & 8.30 & 8.67 & 6.94 & 9.08 & 9.39 & 10.41 & 8.33 & 9.70 & 5.74 & 5.04 & 5.95 \\
\hline \multicolumn{17}{|c|}{ Person Trips per Person } \\
\hline TOTAL & 4.38 & 4.33 & 4.45 & 4.3 & 4.24 & 4.13 & 4.24 & 4.17 & 4.25 & 3.73 & 3.94 & 4.12 & 3.86 & 3.58 & 3.78 & 3.53 \\
\hline \%Earn a Living & 19.6 & 17.8 & 21.6 & 17.0 & 20.3 & 19.7 & 20.5 & 19.2 & 20.2 & 23.1 & 21.4 & 18.7 & 23.3 & 19.6 & 21.2 & 19.0 \\
\hline$\%$ Fam/ Per Bus & 44.5 & 49.0 & 44.8 & 46.7 & 46.0 & 45.5 & 47.5 & 47.4 & 46.0 & 45.3 & 47.8 & 47.6 & 41.3 & 45.8 & 42.4 & 46.9 \\
\hline$\%$ Civ, Ed, \& Rel & 11.4 & 7.9 & 9.5 & 9.1 & 8.7 & 7.5 & 7.5 & 7.2 & 8.0 & 9.1 & 7.6 & 9.0 & 9.3 & 10.6 & 7.4 & 11.4 \\
\hline$\%$ Soc and Rec & 24.2 & 24.9 & 23.9 & 27.2 & 25.0 & 27.3 & 24.2 & 26.2 & 25.8 & 22.3 & 22.9 & 24.5 & 25.8 & 24.0 & 28.9 & 22.7 \\
\hline \%Other & 0.2 & 0.5 & 0.2 & 0.0 & 0.0 & 0.0 & 0.2 & 0.0 & 0.0 & 0.3 & 0.3 & 0.2 & 0.3 & 0.0 & 0.0 & 0.0 \\
\hline
\end{tabular}

Note:

a All percents may not add to $100 \%$ due to rounding.

b Average trip length is calculated using only those records with trip mileage information present. 
Table 6.3b Personal Travel Statistics New York State MPOs by MSA Size 2001 NHTS $^{a}$

\begin{tabular}{|c|c|c|c|c|c|c|c|c|c|c|c|c|c|c|c|c|}
\hline & \multicolumn{16}{|c|}{ MSA size } \\
\hline & $\begin{array}{l}\text { Not in } \\
\text { MSA }\end{array}$ & \multicolumn{2}{|c|}{$<250,000$} & \multicolumn{2}{|c|}{$\begin{array}{c}250,000 \\
\text { to } 499,999 \\
\end{array}$} & \multicolumn{2}{|c|}{$\begin{array}{c}500,000 \\
\text { to } 999,999\end{array}$} & \multicolumn{2}{|c|}{$\begin{array}{c}1 \text { to } \\
2.9 \text { million }\end{array}$} & \multicolumn{7}{|c|}{3 million +} \\
\hline & & \multirow[b]{3}{*}{ Elmira } & \multirow[b]{3}{*}{$\begin{array}{l}\text { Glen } \\
\text { Falls }\end{array}$} & \multirow[b]{3}{*}{$\begin{array}{c}\text { Bing- } \\
\text { hamton }\end{array}$} & \multirow[b]{3}{*}{$\begin{array}{l}\text { Utica- } \\
\text { Rome }\end{array}$} & \multirow[b]{3}{*}{ Albany } & \multirow[b]{3}{*}{ Syracuse } & \multirow[b]{3}{*}{ Buffalo } & \multirow[b]{3}{*}{$\begin{array}{l}\text { Roch- } \\
\text { ester }\end{array}$} & \multirow[b]{3}{*}{$\begin{array}{l}\text { New- } \\
\text { burgh }\end{array}$} & \multirow[b]{3}{*}{$\begin{array}{l}\text { Pough- } \\
\text { keepsie }\end{array}$} & \multicolumn{5}{|c|}{ NYMTC } \\
\hline & & & & & & & & & & & & & & & \begin{tabular}{|r|} 
Sub-comp \\
$\mathbf{N Y}$ \\
\end{tabular} & $\begin{array}{l}\text { onents of } \\
\text { C }\end{array}$ \\
\hline & Ithaca & & & & & & & & & & & $\begin{array}{l}\text { Nassau, } \\
\text { Suffolk }\end{array}$ & $\begin{array}{c}\text { Putnam, } \\
\text { Rockland, } \\
\text { Westchester }\end{array}$ & $\begin{array}{l}\text { New } \\
\text { York } \\
\text { City }\end{array}$ & $\begin{array}{c}\text { Manhattan/ } \\
\text { New York }\end{array}$ & $\begin{array}{c}\text { Rest of } \\
\text { NYC/4 } \\
\text { Counties } \\
\end{array}$ \\
\hline \multicolumn{17}{|c|}{ Person Trips per Person } \\
\hline TOTAL & 4.38 & 4.08 & 4.02 & 4.21 & 4.19 & 3.96 & 3.94 & 4.03 & 4.00 & 3.94 & 3.83 & 3.79 & 3.97 & 3.44 & 3.86 & 3.34 \\
\hline Male & 4.41 & 4.10 & 3.92 & 4.26 & 4.30 & 3.95 & 4.09 & 3.81 & 3.93 & 3.80 & 3.85 & 3.79 & 4.05 & 3.54 & 3.71 & 3.50 \\
\hline Female & 4.35 & 4.07 & 4.11 & 4.16 & 4.09 & 3.98 & 3.81 & 4.23 & 4.07 & 4.08 & 3.81 & 3.80 & 3.91 & 3.35 & 3.99 & 3.20 \\
\hline \multicolumn{17}{|c|}{ Average Person Trip Length ${ }^{b}$} \\
\hline & 9.42 & 8.39 & 10.04 & 8.67 & 8.65 & 9.25 & 8.48 & 8.47 & 8.81 & 11.82 & 10.68 & 8.22 & 10.94 & 7.72 & 11.93 & 6.64 \\
\hline \multicolumn{17}{|c|}{ Person Trips per Person } \\
\hline TOTAL & 4.27 & 4.04 & 4.00 & 4.11 & 4.08 & 3.88 & 3.83 & 3.94 & 3.90 & 3.91 & 3.79 & 3.69 & 3.87 & 3.39 & 3.83 & 3.29 \\
\hline \%Earn a Living & 18.3 & 18.5 & 18.1 & 16.8 & 18.6 & 19.9 & 18.1 & 16.9 & 18.0 & 19.1 & 18.8 & 19.9 & 19.2 & 20.1 & 20.6 & 20.0 \\
\hline$\%$ Fam/Per Bus & 42.5 & 46.3 & 46.0 & 45.9 & 44.3 & 42.9 & 45.3 & 43.9 & 43.6 & 43.3 & 44.3 & 41.5 & 46.0 & 42.7 & 39.0 & 43.7 \\
\hline$\%$ Civ, Ed \& Rel & 11.5 & 8.0 & 7.6 & 7.8 & 7.5 & 9.3 & 8.7 & 9.4 & 9.8 & 9.5 & 10.5 & 8.9 & 7.9 & 11.1 & 9.6 & 11.5 \\
\hline \%Soc \& Rec & 26.4 & 26.2 & 27.2 & 28.7 & 28.5 & 26.4 & 26.9 & 28.6 & 27.3 & 26.4 & 25.1 & 28.0 & 25.2 & 24.6 & 28.9 & 23.4 \\
\hline$\%$ Other & 1.2 & 0.8 & 0.6 & 0.6 & 0.9 & 1.0 & 0.5 & 1.0 & 0.9 & 1.5 & 1.1 & 1.5 & 1.6 & 1.3 & 1.8 & 1.2 \\
\hline \% Unreported & 0.1 & 0.2 & 0.6 & 0.3 & 0.2 & 0.4 & 0.6 & 0.3 & 0.4 & 0.2 & 0.3 & 0.3 & 0.3 & 0.3 & 0.2 & 0.3 \\
\hline
\end{tabular}

Note:

a All percents may not add to $100 \%$ due to rounding.

b Average trip length is calculated using only those records with trip mileage information present. 
Figure 6.4 Daily Person Trips by New York MPOs 1995 and 2001

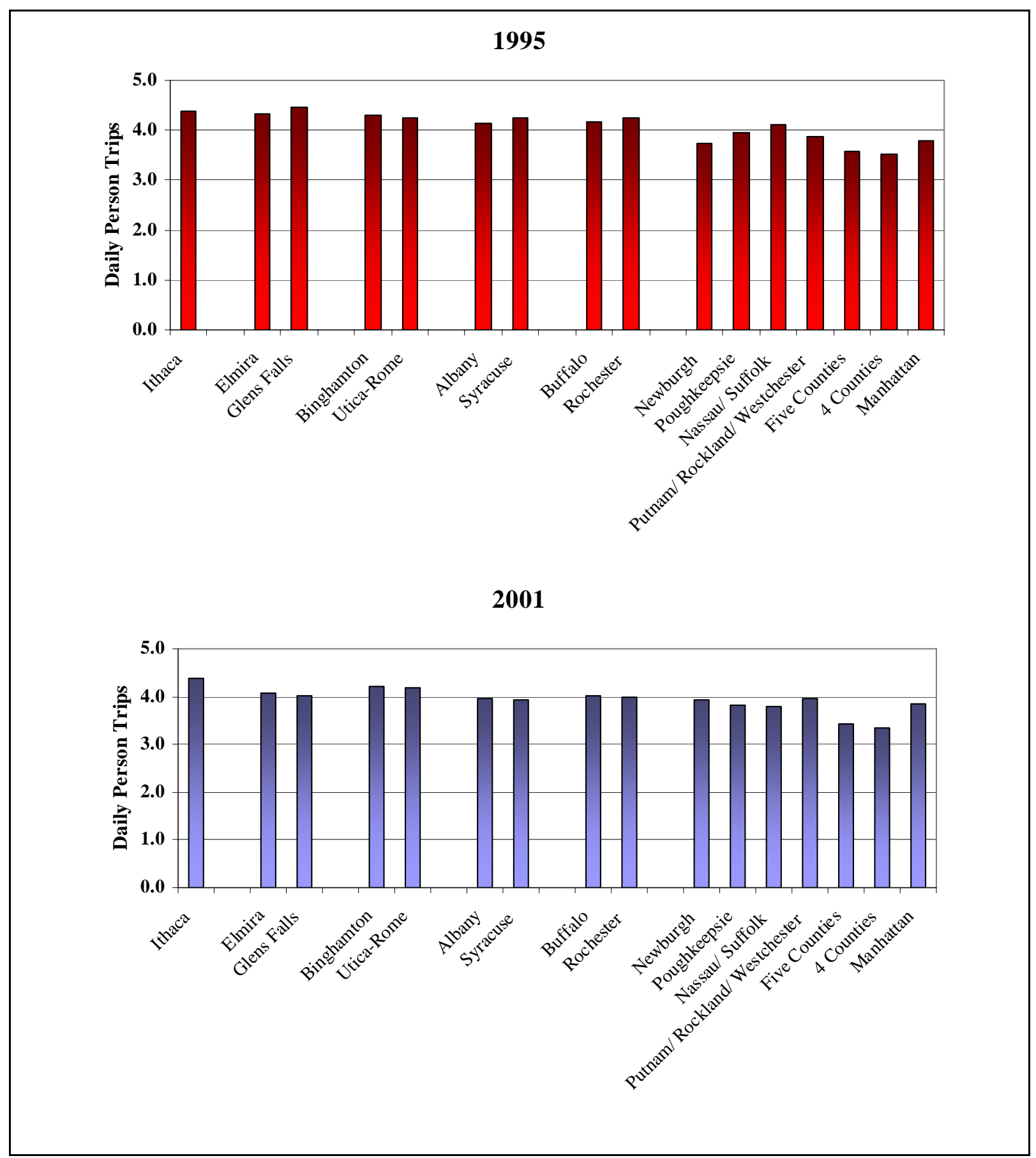

Source: Tables 6.3a and 6.3b 
Figure 6.5 Percent Change in Daily Person Trips from 1995 to 2001

New York MPOs

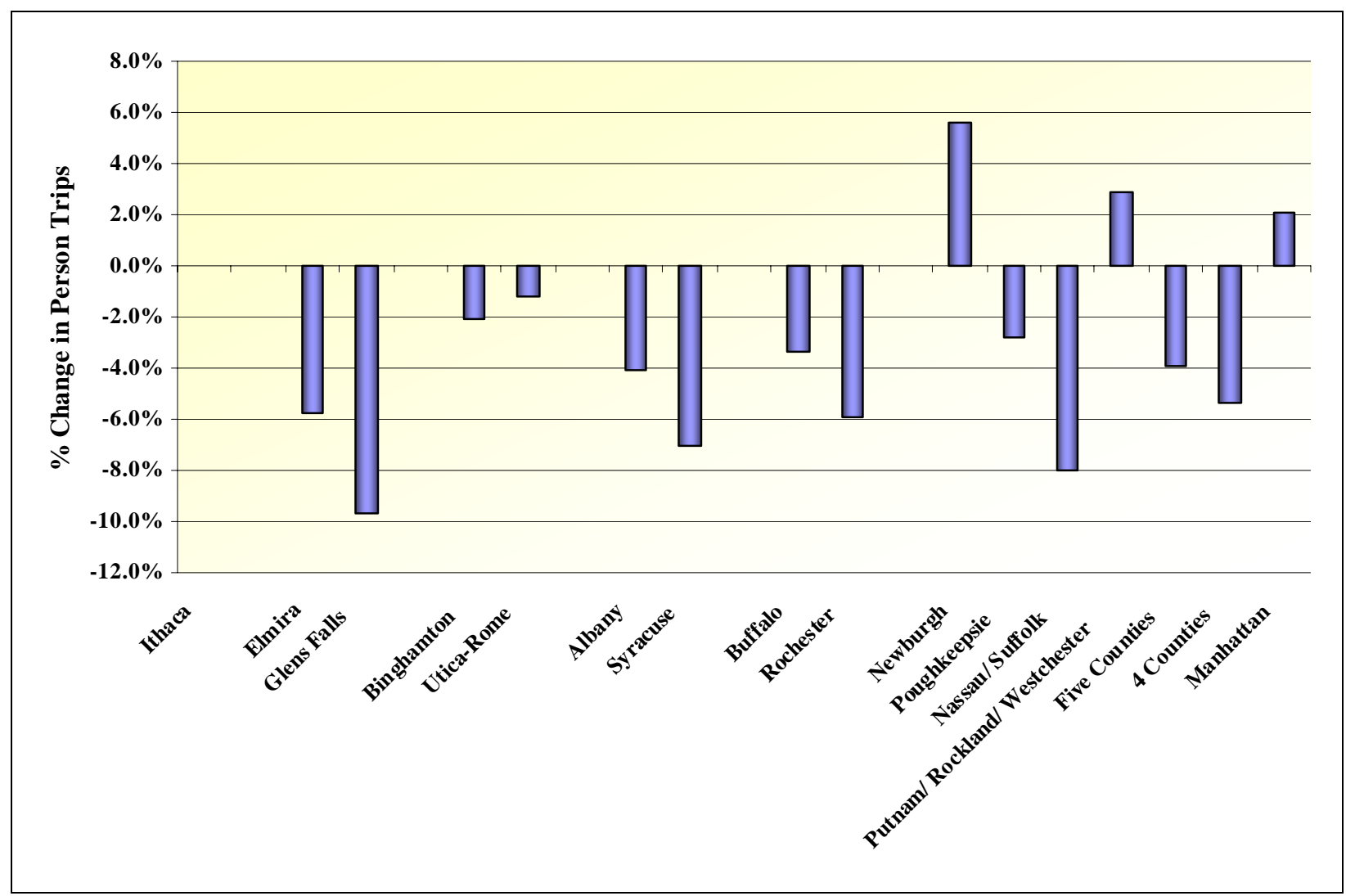

Source: Tables 6.3a and 6.3b

Note that the average person trips per person in Ithaca were the same for both 1995 and 2001 -- 4.38 person trips per person.

Figure 6.6 highlights patterns among the major modes of transportation used for personal travel. For small or medium-size MPOs (in MSAs less than 3 million people) or the MPO outside an MSA, mode choice is generally consistent. About two in every five trips are singleoccupant trips and two in every five trips are multi-occupant trips. The remaining one trip is either by walking, other modes, or public transit. Trips with more than one occupant account for almost one half of all the daily person miles traveled. These overall patterns remain relatively stable from 1995 to 2001. NYC residents’ propensity to walk is apparent in Figure 6.6. 
Figure 6.6 Daily Person Trips by Selected Modes

New York State MPOs

1995 and 2001

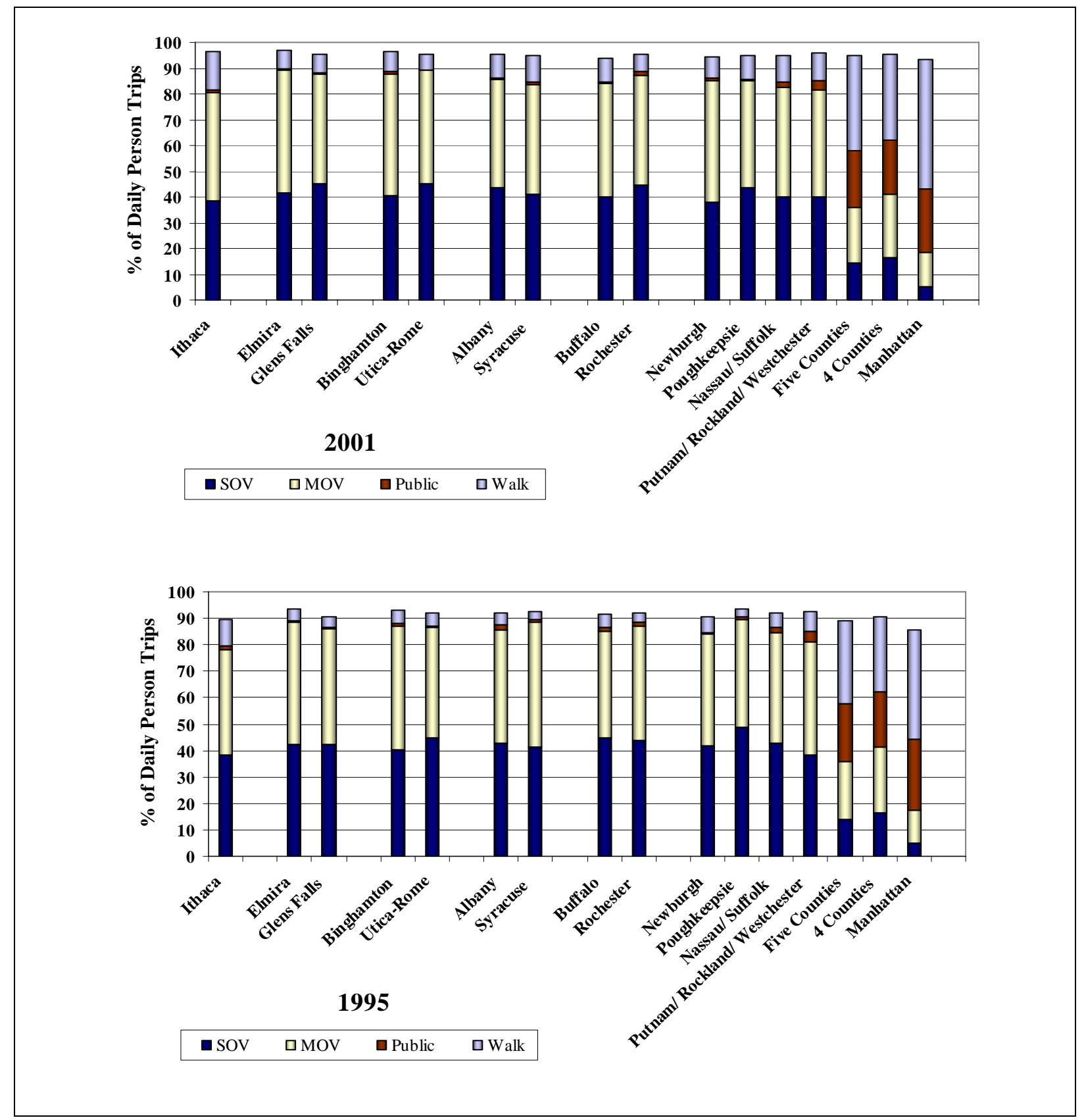

Source: Appendix C, Chapter 6, Tables 2 and 3

Note that numbers do not sum to $100 \%$ due to unreported characteristics.

$6-15$ 
Residents in large metro areas (in MSAs with more than 3 million people) can again be separated into two distinct groups: one group resembles those in small or medium-size MPOs, and the other group displays completely different patterns. The former encompasses Newburgh, Nassau/Suffolk, Putnam/Rockland/Westchester, and Poughkeepsie, while the latter encompasses NYC. Even within NYC, there appears to be two distinctive components: New York/Manhattan vs. the rest of NYC. Fifty percent of trips by New York/Manhattan residents are by walking, compared to $33 \%$ in the rest of NYC.

\section{Zero-Vehicle Households}

In evaluating the mobility of zero-vehicle households, there is a definite difference between small and large metro areas with respect to the percentage of households that do not own a vehicle (Table 6.2a). The MPOs in the MSA size categories of less than 3 million people are fairly comparable in the percentage of households without a vehicle -- with the biggest difference of a little over 3\% between Albany and Syracuse. The percentage of households without a vehicle in the largest metro areas (within the largest MSA size group) fluctuates widely, ranging from over $70 \%$ in New York/Manhattan to a little less than 5\% in Nassau and Suffolk.

The income distribution of households without a vehicle varies significantly among NYS MPOs (Appendix C, Chapter 6, Table 4). While 25\% of zero-vehicle households in New York/Manhattan earn less than \$20,000 a year, the corresponding numbers for MPOs outside New York/Manhattan range from 53\% in Albany to 82\% in Elmira. In contrast, more than 20\% of zero-vehicle households in New York/Manhattan have an annual income of more than \$80,000 while the comparable figures outside New York/Manhattan range from 4\% in Albany to 0\% in MPOs with less than 3 million people. Although Ithaca is not in an MSA, its vehicle ownership rates resemble those of small and medium-size MPOs. 
Comparisons of travel characteristics of zero-vehicle households are limited by small sample size. Although a little over 1,000 households without a vehicle were interviewed in the NYMTC area, only 22 such households were interviewed in Glens Falls and 25 in Rochester (Table 6.4). This disparity in sample sizes makes comparisons among MPOs less reliable.

Table 6.4 Number of New York Households Interviewed in 2001 NHTS, by Number of Vehicles

\begin{tabular}{|l|c|c|c|}
\hline MPO & $\begin{array}{c}\text { Zero-Vehicle } \\
\text { Households }\end{array}$ & $\begin{array}{c}\text { Non-Zero Vehicle } \\
\text { Households }\end{array}$ & All \\
\hline Ithaca & 35 & 464 & 499 \\
\hline Elmira & 31 & 516 & 547 \\
\hline Glens Falls & 22 & 455 & 477 \\
\hline Binghamton & 47 & 507 & 554 \\
\hline Utica-Rome & 29 & 482 & 511 \\
\hline Albany & 116 & 1,725 & 1,841 \\
\hline Syracuse & 45 & 476 & 521 \\
\hline Buffalo & 47 & 582 & 629 \\
\hline Rochester & 25 & 626 & 651 \\
\hline Newburgh & 21 & 498 & 519 \\
\hline Poughkeepsie & 20 & 518 & 538 \\
\hline New York City & 949 & 1,329 & 2,278 \\
\hline Nassau, Suffolk & 35 & 824 & 859 \\
\hline Putnam, Rockland, Westchester & 68 & 1,199 & 1,267 \\
\hline Remainder of State & 85 & 1,647 & 1,732 \\
\hline Total in New York State & $\mathbf{1 , 5 7 5}$ & $\mathbf{1 1 , 8 4 8}$ & $\mathbf{1 3 , 4 2 3}$ \\
\hline
\end{tabular}

The number of trips and miles traveled per day by people without a vehicle appear to vary considerably (Table 6.5a). They not only vary considerably across MPOs within similar MSA size categories, but also across the two survey years (Figure 6.7). For example, Elmira residents traveled almost five times more miles a day in 1995 than those in Glens Falls, an average of 20.8 miles vs. 4.7 miles, respectively, despite the fact that both MPOs are somewhat similar in size (Table 6.5b). This relationship was reversed in 2001, with Elmira residents traveled only one-third of the miles traveled by Glens Falls residents (Table 6.5a). That said, neither of these differences is highly statistically significant. 
Figure 6.7 Personal Travel Trends of Zero-Vehicle Households in New York MPOs

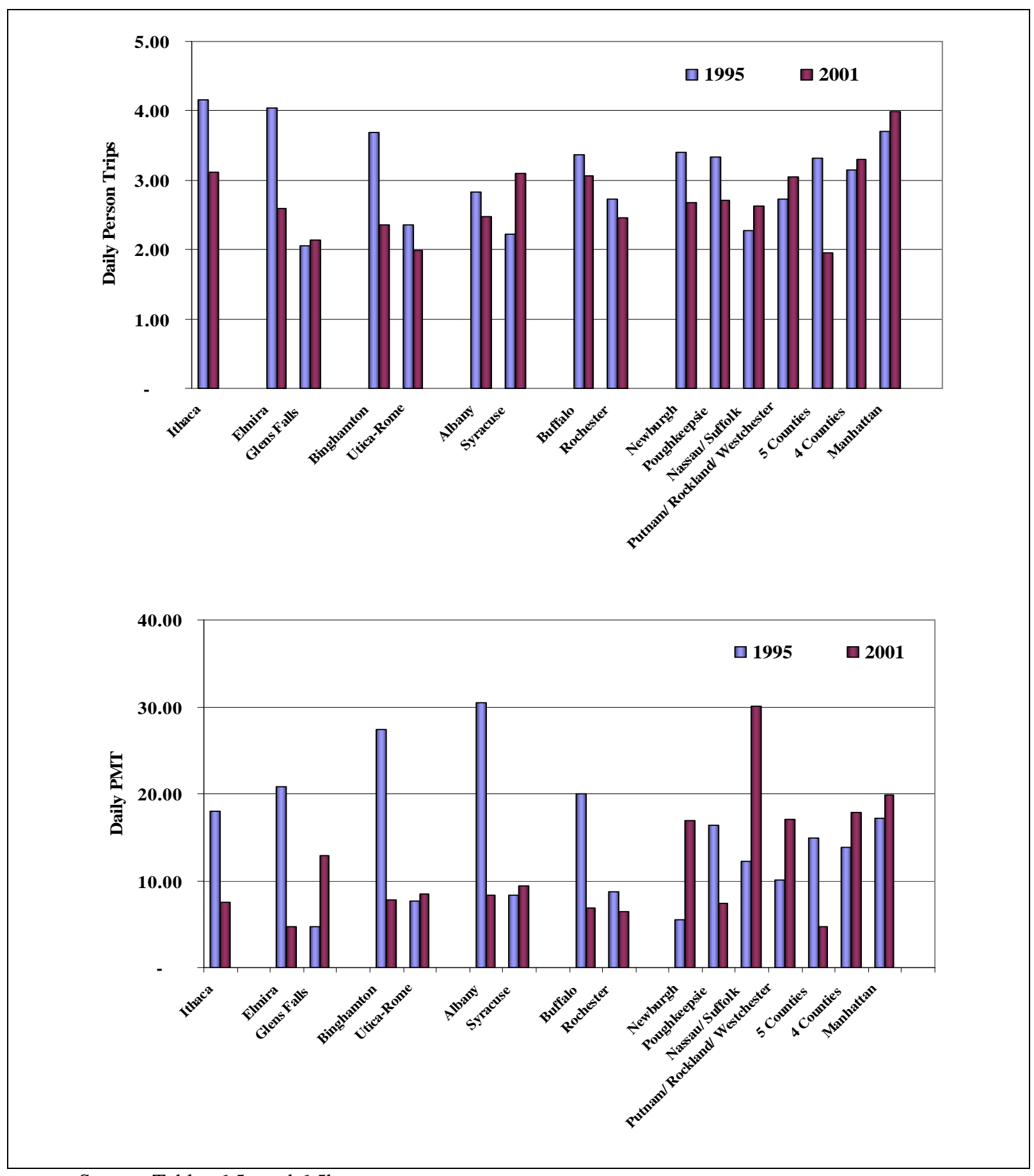

Source: Tables 6.5a and 6.5b 
Table 6.5a Person Travel for Zero-Vehicle Households by Mode of Transportation New York State MPOs by MSA Size 2001 NHTS $^{a}$

\begin{tabular}{|c|c|c|c|c|c|c|c|c|c|c|c|c|c|c|c|c|}
\hline & \multicolumn{16}{|c|}{ MSA size } \\
\hline & $\begin{array}{c}\text { Not in } \\
\text { MSA }\end{array}$ & \multicolumn{2}{|c|}{$<250,000$} & \multicolumn{2}{|c|}{$\begin{array}{c}250,000 \text { to } \\
499,999\end{array}$} & \multicolumn{2}{|c|}{$\begin{array}{c}500,000 \text { to } \\
999,999\end{array}$} & \multicolumn{2}{|c|}{$\begin{array}{c}1 \text { to } \\
2.9 \text { million }\end{array}$} & \multicolumn{7}{|c|}{3 million + } \\
\hline & \multirow[b]{3}{*}{ Ithaca } & \multirow[b]{3}{*}{ Elmira } & \multirow[b]{3}{*}{$\begin{array}{l}\text { Glen } \\
\text { Falls }\end{array}$} & \multirow[b]{3}{*}{$\begin{array}{l}\text { Bing- } \\
\text { hamton }\end{array}$} & \multirow[b]{3}{*}{$\begin{array}{l}\text { Utica- } \\
\text { Rome }\end{array}$} & \multirow[b]{3}{*}{ Albany } & \multirow[b]{3}{*}{ Syracuse } & \multirow[b]{3}{*}{ Buffalo } & \multirow[b]{3}{*}{$\begin{array}{l}\text { Roch- } \\
\text { ester }\end{array}$} & \multirow[b]{3}{*}{$\begin{array}{l}\text { New- } \\
\text { burgh }\end{array}$} & \multirow[b]{3}{*}{$\begin{array}{l}\text { Pough- } \\
\text { keepsie }\end{array}$} & \multicolumn{5}{|c|}{ NYMTC } \\
\hline & & & & & & & & & & & & & & & Sub-comp & ments of NYC \\
\hline & & & & & & & & & & & & $\begin{array}{l}\text { Nassau, } \\
\text { Suffolk }\end{array}$ & $\begin{array}{c}\text { Putnam, } \\
\text { Rockland, } \\
\text { Westchester }\end{array}$ & $\begin{array}{l}\text { New } \\
\text { York } \\
\text { City }\end{array}$ & $\begin{array}{l}\text { Manhattan/ } \\
\text { New York }\end{array}$ & $\begin{array}{c}\text { Rest of NYC/ } \\
4 \text { Counties }\end{array}$ \\
\hline \multicolumn{17}{|c|}{ Person Trips per Person } \\
\hline TOTAL & 3.12 & 2.60 & 2.14 & 2.36 & 1.99 & 2.48 & 3.10 & 3.07 & 2.45 & 2.68 & 2.63 & 1.96 & 2.71 & 3.30 & 3.99 & 3.04 \\
\hline$\%$ Private & 40.8 & 46.8 & 39.3 & 30.0 & 48.8 & 32.6 & 34.9 & 28.5 & 17.2 & 32.1 & 49.5 & 41.9 & 31.7 & 13.3 & 9.9 & 15.0 \\
\hline$\%$ Public & 3.9 & 15.3 & 14.2 & 14.8 & 11.4 & 17.1 & 14.4 & 11.9 & 38.6 & 6.5 & 3.1 & 1.4 & 24.0 & 32.7 & 27.5 & 35.2 \\
\hline$\%$ Walk & 53.6 & 31.7 & 43.5 & 45.1 & 39.8 & 42.3 & 38.3 & 33.8 & 40.3 & 47.0 & 36.9 & 37.7 & 35.4 & 47.2 & 55.4 & 43.2 \\
\hline$\%$ Other & 1.7 & 6.2 & 3.0 & 10.1 & & 7.9 & 12.5 & 25.8 & 3.9 & 14.4 & 10.5 & 19.0 & 7.9 & 6.6 & 7.0 & 6.4 \\
\hline \% Unreported & & & & & & & & & & & & & 0.9 & 0.2 & 0.1 & 0.2 \\
\hline \multicolumn{17}{|c|}{ PMT per Person } \\
\hline TOTAL & 7.56 & 4.74 & 12.84 & 7.73 & 8.50 & 8.27 & 9.37 & 6.85 & 6.42 & 16.90 & 30.03 & 4.64 & 7.35 & 17.87 & 19.87 & 17.11 \\
\hline$\%$ Private & 77.6 & 71.8 & 88.6 & 53.7 & 76.0 & 63.3 & 63.5 & 56.5 & 21.9 & 75.4 & 93.2 & 56.4 & 32.1 & 16.8 & 24.5 & 13.5 \\
\hline$\%$ Public & 11.3 & 6.3 & 7.3 & 22.1 & 13.2 & 22.5 & 17.2 & 13.4 & 69.6 & 7.7 & 0.1 & 1.6 & 55.1 & 31.5 & 27.1 & 33.4 \\
\hline$\%$ Walk & 9.7 & 14.8 & 3.9 & 13.3 & 10.8 & 6.5 & 6.2 & 8.2 & 6.3 & 4.1 & 1.7 & 17.2 & 8.4 & 5.7 & 7.6 & 4.9 \\
\hline \% Other & 1.4 & 7.1 & 0.2 & 10.9 & & 7.7 & 13.1 & 21.9 & 2.2 & 12.9 & 5.1 & 24.8 & 4.4 & 45.9 & 40.8 & 48.1 \\
\hline$\%$ Unreported & & & & & & & & & & & & 0.1 & & 0.0 & 0.1 & \\
\hline
\end{tabular}

Note:

All percents may not add to $100 \%$ due to rounding. 
Table 6.5b Person Travel for Zero-Vehicle Households by Mode of Transportation New York State MPOs by MSA Size

1995 NPTS $^{a}$

\begin{tabular}{|c|c|c|c|c|c|c|c|c|c|c|c|c|c|c|c|c|}
\hline & \multicolumn{16}{|c|}{ MSA size } \\
\hline & $\begin{array}{l}\text { Not in } \\
\text { MSA }\end{array}$ & \multicolumn{2}{|c|}{$<250,000$} & \multicolumn{2}{|c|}{$\begin{array}{c}250,000 \\
\text { to } 499,999 \\
\end{array}$} & \multicolumn{2}{|c|}{$\begin{array}{c}500,000 \\
\text { to } 999,999 \\
\end{array}$} & \multicolumn{2}{|c|}{$\begin{array}{c}1 \text { to } \\
2.9 \text { million } \\
\end{array}$} & \multicolumn{7}{|c|}{3 million +} \\
\hline & \multirow[b]{3}{*}{ Ithaca } & \multirow[b]{3}{*}{ Elmira } & \multirow[b]{3}{*}{$\begin{array}{l}\text { Glen } \\
\text { Falls }\end{array}$} & \multirow[b]{3}{*}{$\begin{array}{l}\text { Bing- } \\
\text { hamton }\end{array}$} & \multirow[b]{3}{*}{$\begin{array}{l}\text { Utica- } \\
\text { Rome }\end{array}$} & \multirow[b]{3}{*}{$\begin{array}{c}\text { Alban } \\
\mathrm{y}\end{array}$} & \multirow[b]{3}{*}{ Syracuse } & \multirow[b]{3}{*}{$\begin{array}{c}\text { Buffal } \\
0\end{array}$} & \multirow[b]{3}{*}{$\begin{array}{l}\text { Roch- } \\
\text { ester }\end{array}$} & \multirow[b]{3}{*}{$\begin{array}{l}\text { New- } \\
\text { burgh }\end{array}$} & \multirow[b]{3}{*}{$\begin{array}{l}\text { Pough- } \\
\text { keepsie }\end{array}$} & \multicolumn{5}{|c|}{ NYMTC } \\
\hline & & & & & & & & & & & & & & & Sub-compo & onents of NYC \\
\hline & & & & & & & & & & & & $\begin{array}{l}\text { Nassau, } \\
\text { Suffolk }\end{array}$ & $\begin{array}{c}\text { Putnam, } \\
\text { Rockland, } \\
\text { Westchester }\end{array}$ & $\begin{array}{l}\text { New } \\
\text { York } \\
\text { City }\end{array}$ & $\begin{array}{l}\text { Manhattan/ } \\
\text { New York }\end{array}$ & $\begin{array}{c}\text { Rest of NYC/ } \\
4 \text { Counties }\end{array}$ \\
\hline \multicolumn{17}{|c|}{ Person Trips per Person } \\
\hline TOTAL & 4.16 & 4.04 & 2.06 & 3.69 & 2.35 & 2.83 & 2.22 & 3.36 & 2.73 & 3.40 & 3.34 & 2.27 & 2.73 & 3.32 & 3.71 & 3.15 \\
\hline$\%$ Private & 28.8 & 57.7 & 32.5 & 43.6 & 36.2 & 48.1 & 52.7 & 40.8 & 35.2 & 26.5 & 52.4 & 37.4 & 21.2 & 11.4 & 8.6 & 13.0 \\
\hline$\%$ Public & 9.4 & 4.0 & 8.3 & 8.1 & 14.9 & 30.0 & 18.9 & 19.6 & 25.3 & 4.4 & 8.7 & 9.7 & 26.0 & 34.3 & 32.9 & 34.9 \\
\hline$\%$ Walk & 41.1 & 20.0 & 12.6 & 30.4 & 26.4 & 15.5 & 17.1 & 16.7 & 19.0 & 53.2 & 21.0 & 26.4 & 21.6 & 41.6 & 44.7 & 40.0 \\
\hline$\%$ Other & 10.8 & 10.4 & 41.3 & 11.4 & 12.8 & 3.5 & 2.3 & 6.5 & 11.0 & 10.6 & 15.9 & 11.5 & 17.6 & 6.3 & 8.1 & 5.1 \\
\hline \% Unreported & 9.9 & 7.9 & 5.3 & 6.5 & 9.8 & 2.8 & 9.0 & 16.4 & 9.5 & 5.3 & 2.1 & 15.0 & 13.6 & 6.3 & 5.7 & 7.0 \\
\hline \multicolumn{17}{|c|}{ PMT per Person } \\
\hline TOTAL & 18.02 & 20.83 & 4.71 & 27.42 & 7.66 & 30.53 & 8.28 & 19.97 & 8.71 & 5.57 & 16.32 & 12.25 & 10.06 & 14.86 & 17.21 & 13.86 \\
\hline$\%$ Private & 73.5 & 92.2 & 56.5 & 89.4 & 62.5 & 76.7 & 80.4 & 80.8 & 37.4 & 74.9 & 74.9 & 87.3 & 15.7 & 33.4 & 32.5 & 33.8 \\
\hline$\%$ Public & 15.7 & 1.7 & 10.2 & 5.0 & 8.6 & 22.0 & 14.4 & 14.2 & 17.3 & 5.6 & 15.7 & 3.8 & 75.8 & 50.2 & 37.5 & 56.9 \\
\hline$\%$ Walk & 6.3 & 2.4 & 1.9 & 1.9 & 5.4 & 0.6 & 2.9 & 2.0 & 2.2 & 14.9 & 4.1 & 3.1 & 3.0 & 5.8 & 6.7 & 5.3 \\
\hline$\%$ Other & 4.0 & 2.1 & 30.8 & 3.6 & 10.4 & 0.6 & 2.2 & 2.4 & 42.6 & 4.7 & 5.1 & 4.8 & 4.9 & 9.8 & 22.5 & 3.0 \\
\hline$\%$ Unreported & 0.6 & 1.7 & 0.6 & 0.1 & 13.1 & 0.1 & 0.1 & 0.7 & 0.5 & 0.0 & 0.1 & 1.0 & 0.6 & 0.9 & 0.9 & 0.9 \\
\hline
\end{tabular}

Note:

All percents may not add to $100 \%$ due to rounding. 
Figure 6.8 illustrates part of the reason for this extraordinary difference. In 1995, trips by Elmira residents were proportionally longer than those by Glens Falls. Although Elmira and Glens Falls were similar in that half of all trips by both Elmira and Glens Falls residents were less than or equal to 1 mile in length, the two communities diverged beyond this median point with respect to trip length. While $90 \%$ of the trips taken by Glens Falls' residents who are without a vehicle were less than 7 miles long, the corresponding figure for Elmira is 18 miles. For most trips, Elmira and Glens Falls are still similar in 2001 in that three-quarters of all trips by both Elmira and Glens Falls residents are less than or equal to 2 mile in length. For longer trips in 2001, five percent of the trips taken by Elmira residents are 10 miles or longer, whereas five percent of the trips taken by Glens Falls residents are 55 miles or longer. More research will be needed to test the validity of these differences, and to identify contributing factors to this disparity.

Figure 6.8 Cumulative Frequency of Average Daily Trip Length of Zero-Vehicle Households Elmira vs. Glens Falls

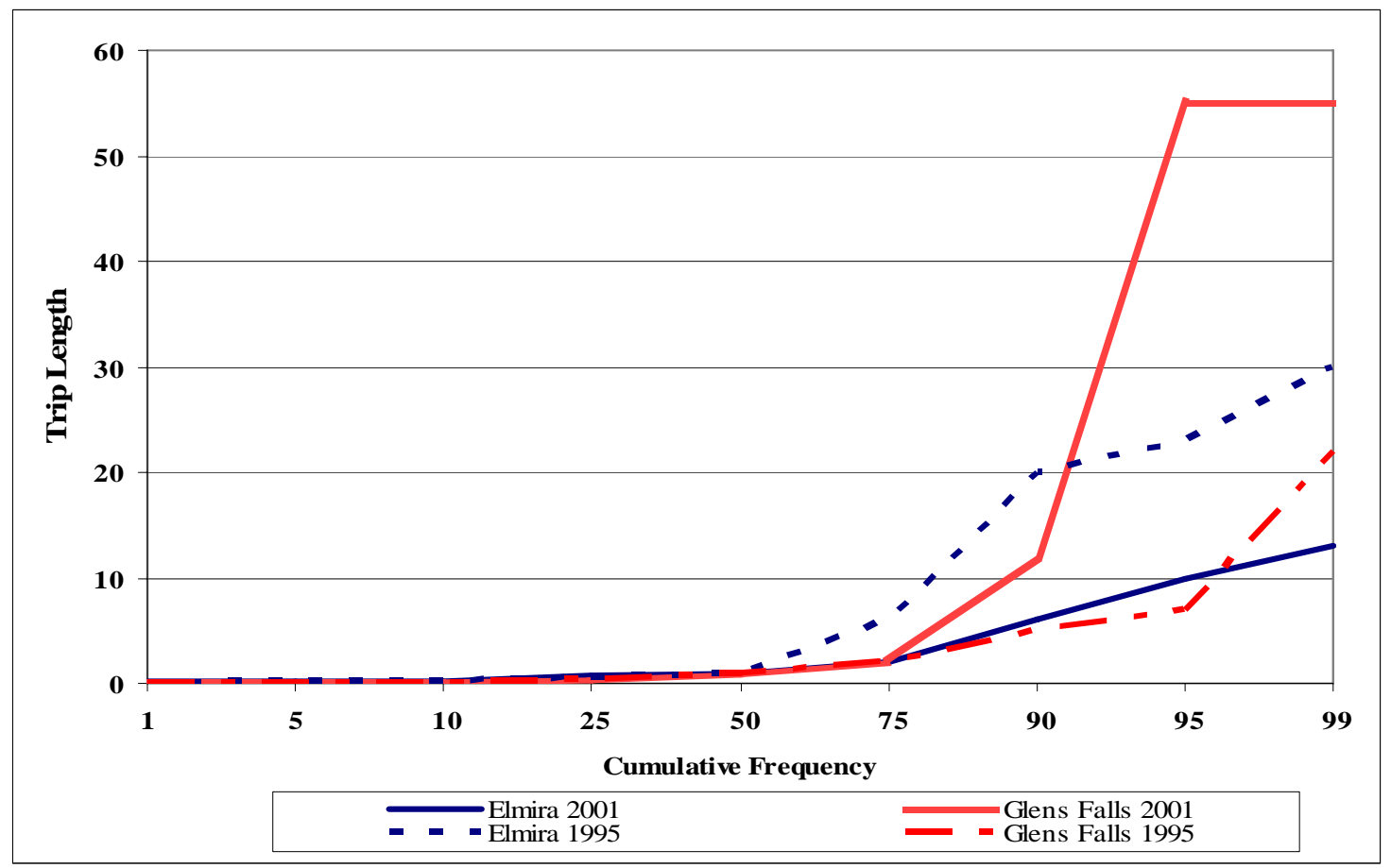

$6-21$ 
Mode choice among people in metropolitan areas who do not own a vehicle does not seem to follow any particular pattern. In small and medium-size MSAs, people who do not own a vehicle still rely heavily on private vehicles, accounting for almost half of all personal travel. As metropolitan size increases, the dependence on private vehicles declines and walking and public transit become more prominent, with a few exceptions. Residents in Poughkeepsie have similar patterns to those in small size MSAs. Almost half of the residents in NYC probably do not own a vehicle by choice and travel to places primarily by walking or by public transit. Outside NYC, residents in Newburgh are more inclined to walk to places than residents in other MPOs (Table 6.5a).

\subsection{Vehicle Travel}

Vehicle travel by residents in New York MPOs varies more widely than was observed in personal travel. Again, this variation in vehicle travel is primarily observed in NYC. Almost all drivers drive an average of 3 to 4 trips per day, with the exception of NYC drivers. NYC drivers only drive an average of 1/1/2 vehicle trips per day, whereas New York/Manhattan drivers drive on average less than 1 vehicle trip per day (Table 6.6).

Less driving by drivers in larger metropolitan areas results in fewer vehicle miles. On a per driver basis, NYC drivers drive an average of 12 miles per day, which is less than one-half of the mileage driven by drivers in other MPO areas (Table 6.6). Although New York/Manhattan drivers drive the fewest number of trips and the least amount of miles, their vehicle trips continue in 2001 to be the longest among all MPOs (Table 6.6 and Figure 6.9). Drivers living in New York/Manhattan drive more and longer in 2001 than in 1995. 
Table 6.6 Daily Vehicle Travel Statistics of New York State MPO Drivers by MSA Size 2001 NHTS and 1995 NPTS

\begin{tabular}{|c|c|c|c|c|c|c|}
\hline \multirow[b]{2}{*}{ MPO/MSA Size } & \multicolumn{2}{|c|}{$\begin{array}{c}\text { Daily Vehicle } \\
\text { Trips }\end{array}$} & \multicolumn{2}{|c|}{$\begin{array}{c}\text { Avg. Trip } \\
\text { Length (miles) }\end{array}$} & \multicolumn{2}{|c|}{$\begin{array}{l}\text { Daily } \\
\text { VMT }\end{array}$} \\
\hline & 2001 & 1995 & 2001 & 1995 & 2001 & 1995 \\
\hline \multicolumn{7}{|l|}{ Not in MSA } \\
\hline Ithaca & 3.25 & 3.07 & 8.3 & 8.51 & 26.51 & 26.05 \\
\hline \multicolumn{7}{|l|}{$<250,000$} \\
\hline Elmira & 3.36 & 3.78 & 8.91 & 8.66 & 29.91 & 32.67 \\
\hline Glens Falls & 3.24 & 3.94 & 10.04 & 8.08 & 32.34 & 31.7 \\
\hline \multicolumn{7}{|l|}{250,000 to 499,999} \\
\hline Binghamton & 3.41 & 3.54 & 8.73 & 8.03 & 29.07 & 28.32 \\
\hline Utica-Rome & 3.63 & 3.59 & 8.64 & 8.57 & 31.31 & 30.63 \\
\hline \multicolumn{7}{|l|}{500,000 to 999,999} \\
\hline Albany & 3.27 & 3.3 & 8.75 & 7.95 & 28.22 & 26.05 \\
\hline Syracuse & 3.21 & 3.65 & 8.47 & 8.34 & 26.85 & 30.28 \\
\hline \multicolumn{7}{|l|}{1 to 2.9 million } \\
\hline Buffalo & 3.43 & 3.61 & 7.85 & 7.46 & 26.69 & 26.79 \\
\hline Rochester & 3.43 & 3.66 & 8.26 & 8.49 & 28.07 & 30.54 \\
\hline \multicolumn{7}{|l|}{3 million } \\
\hline Newburgh & 3.32 & 3.14 & 12.08 & 10.79 & 39.93 & 33.68 \\
\hline Poughkeepsie & 3.35 & 3.55 & 9.85 & 10.54 & 32.66 & 37.23 \\
\hline \multicolumn{7}{|l|}{ NYMTC } \\
\hline Nassau/Suffolk & 3.07 & 3.45 & 8.59 & 7.98 & 25.73 & 27.12 \\
\hline $\begin{array}{l}\text { Putnam/Rockland/ } \\
\text { Westchester }\end{array}$ & 3.17 & 3.05 & 9.4 & 9.58 & 29.16 & 28.63 \\
\hline New York City & 1.57 & 1.67 & 7.91 & 8.54 & 11.86 & 13.86 \\
\hline - New York/ Manhattan & 0.75 & 0.66 & 15.59 & 11.45 & 11.1 & 7.45 \\
\hline - Rest of NYC & 1.77 & 1.97 & 7.1 & 8.24 & 12.06 & 15.74 \\
\hline
\end{tabular}


Figure 6.9 Vehicle Travel Statistics by New York State MPOs

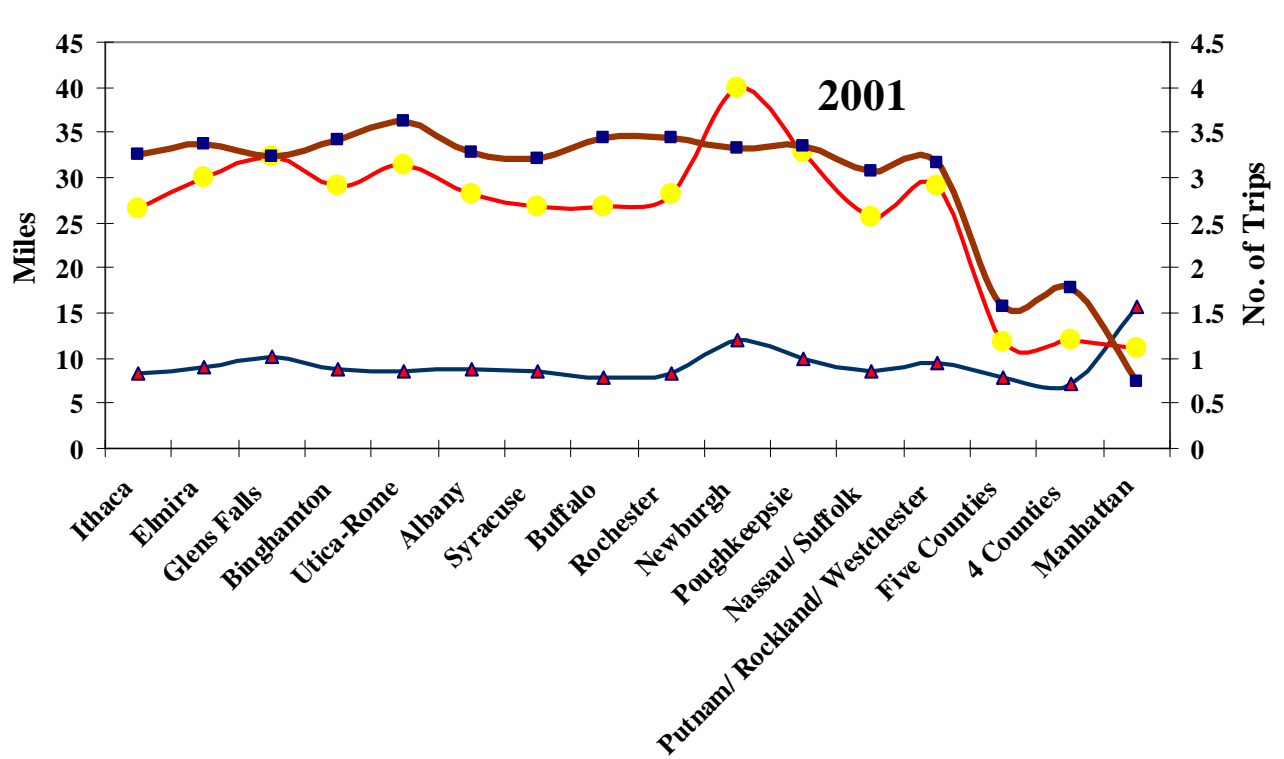

$\rightarrow$ Average Vehicle Trip Length (miles) (Y1) - Daily VMT (Y1) $\rightarrow$ Daily Vehicle Trips (Y2)

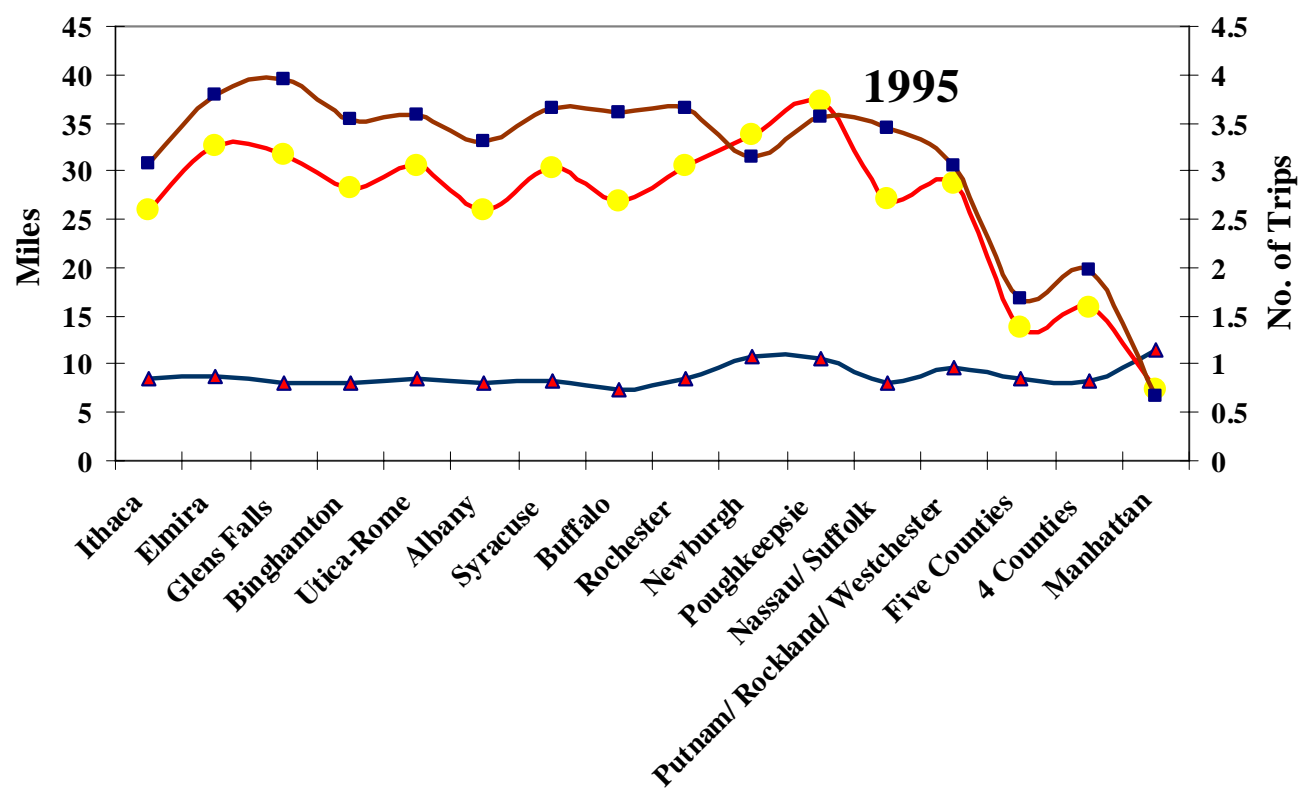

$\neg-$ Average Vehicle Trip Length (miles) (Y1) $-\_$Daily VMT (Y1) $\rightarrow$ Daily Vehicle Trips (Y2)

Source: Table 6.6 
Regardless of residential location, family and personal business is the primary reason to drive, followed by to- and from-work (Appendix C, Chapter 6, Table 5). This pattern resembles that in the rest of the nation. In 1995, New York/Manhattan residents spent an average of more than 80 minutes driving a day - the greatest amount of time among all drivers in NYS MPOs (Figure 6.10). By 2001, residents living in every large New York MPO (more than 3 million people) spend an average of at least 80 minutes driving a day, while the driving times for residents in most small and medium-size MPOs are approaching 80 minutes a day. Although spending the greatest amount of time driving, New York/Manhattan residents drive on average less than 12 miles per day. Even then, the 12-mile commute by New York/Manhattan residents was 50\% longer than their commutes in 1995.

\subsection{Commute Patterns}

Commutes by workers living in New York MPOs follow a pattern similar to that of the overall personal travel. There is not a notable difference among MPOs in the number of commute trips taken. However, the difference in the average miles commuted among MPOs seems to have widened in 2001 compared to 1995. For example, the difference between commutes by Elmira residents and commutes by Glens Falls residents increases from 2 miles in 1995 to 3.5 miles in 2001 (Tables 6.7a and 6.7 b).

In 1995, workers in large metro areas, NYC and Nassau and Suffolk counties, took fewer commute trips than other workers (Table 6.7b). This disparity narrows in 2001. Commute time and one-way commute distance were fairly consistent in 1995 across small and medium-size MPOs (in MSA with less than 3 million people), with Albany and Syracuse workers spending a little more time commuting than other MPOs (Figure 6.11). Although one-way commute distances for workers in NYC are about the same as those for workers in small and medium-size MPOs (with less than 3 million people), NYC residents spend almost twice as long commuting as workers in smaller MPOs. Furthermore, New York/Manhattan residents spend 50\% more time commuting in 2001 than in 1995, while their commutes are shorter in distance (Figure 6.12). 
Figure 6.10 Average Time Driving a Private Vehicle and Daily VMT New York State MPO
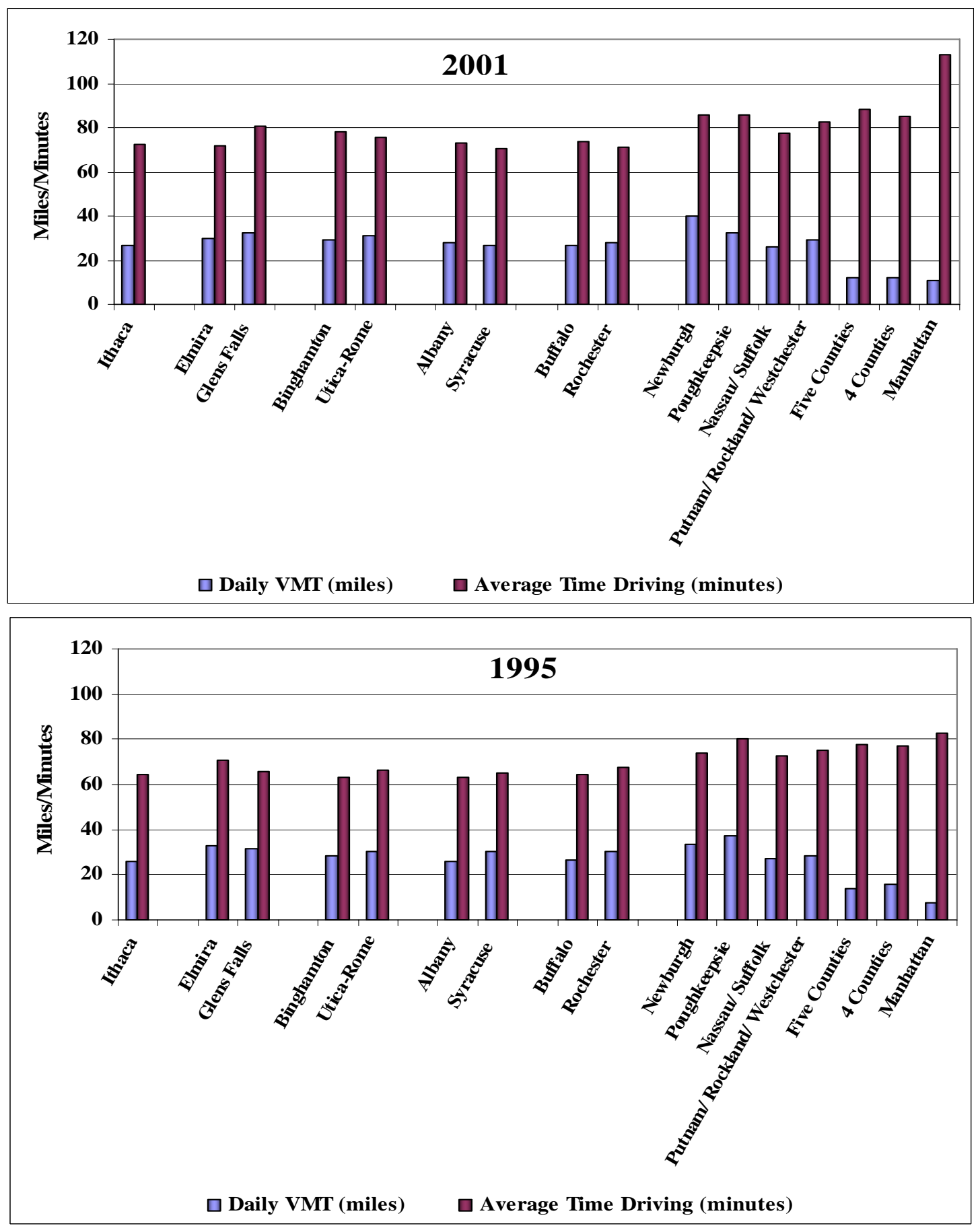

Source: Appendix C, Chapter 6, Table 5 
Table 6.7a Commute Statistics by Mode of Transportation New York State MPOs by MSA Size

2001 NHTS $^{a}$

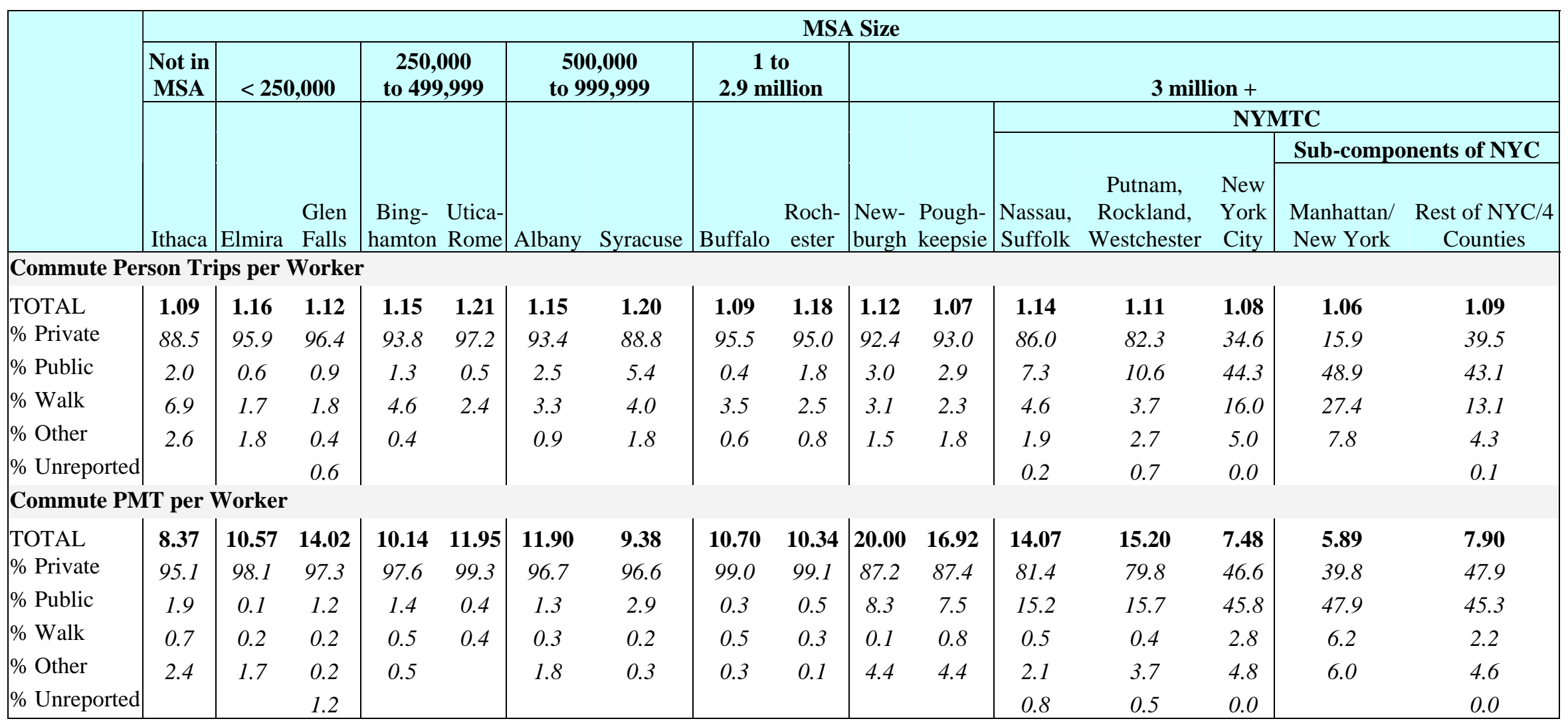

Note:

$\bar{a}$ All percents may not add to $100 \%$ due to rounding. 
Table 6.7b Commute Statistics by Mode of Transportation

New York State MPOs by MSA Size

1995 NPTS

\begin{tabular}{|c|c|c|c|c|c|c|c|c|c|c|c|c|c|c|c|c|}
\hline & \multicolumn{16}{|c|}{ MSA size } \\
\hline & \multirow{4}{*}{\begin{tabular}{|l} 
Not in \\
MSA \\
Ithaca \\
\end{tabular}} & \multicolumn{2}{|c|}{$<250,000$} & \multicolumn{2}{|c|}{$\begin{array}{c}250,000 \\
\text { to } 499,999\end{array}$} & \multicolumn{2}{|c|}{$\begin{array}{c}500,000 \\
\text { to } 999,999\end{array}$} & \multicolumn{2}{|c|}{$\begin{array}{c}1 \text { to } \\
2.9 \text { million }\end{array}$} & \multicolumn{7}{|c|}{3 million + } \\
\hline & & \multirow{3}{*}{ Elmira } & \multirow[b]{3}{*}{$\begin{array}{l}\text { Glen } \\
\text { Falls }\end{array}$} & \multirow[b]{3}{*}{$\begin{array}{c}\text { Bing- } \\
\text { hamton }\end{array}$} & \multirow[b]{3}{*}{$\begin{array}{l}\text { Utica- } \\
\text { Rome }\end{array}$} & \multirow[b]{3}{*}{ Albany } & \multirow[b]{3}{*}{ Syracuse } & \multirow[b]{3}{*}{ Buffalo } & \multirow[b]{3}{*}{$\begin{array}{l}\text { Roch- } \\
\text { ester }\end{array}$} & \multirow[b]{3}{*}{$\begin{array}{l}\text { New- } \\
\text { burgh }\end{array}$} & \multirow[b]{3}{*}{$\begin{array}{l}\text { Pough- } \\
\text { keepsie }\end{array}$} & \multicolumn{5}{|c|}{ NYMTC } \\
\hline & & & & & & & & & & & & \multirow[b]{2}{*}{\begin{tabular}{|l} 
Nassau, \\
Suffolk
\end{tabular}} & \multirow[b]{2}{*}{$\begin{array}{c}\text { Putnam, } \\
\text { Rockland, } \\
\text { Westchester }\end{array}$} & \multirow[b]{2}{*}{$\begin{array}{l}\text { New } \\
\text { York } \\
\text { City }\end{array}$} & \multicolumn{2}{|c|}{ Sub-components of NYC } \\
\hline & & & & & & & & & & & & & & & $\begin{array}{l}\text { Manhattan/ } \\
\text { New York }\end{array}$ & $\begin{array}{c}\text { Rest of NYC/4 } \\
\text { Counties }\end{array}$ \\
\hline \multicolumn{17}{|c|}{ Commute Person Trip per Person } \\
\hline TOTAL & $\mid 1.41$ & $\mid 1.43$ & 1.61 & 1.39 & 1.44 & 1.32 & 1.37 & 1.40 & 1.36 & 1.41 & 1.34 & 1.21 & 1.44 & 1.26 & 1.21 & 1.28 \\
\hline$\%$ Private & 81.6 & 95.1 & 93.8 & 90.7 & 93.8 & 90.2 & 94.9 & 90.7 & 93.4 & 90.1 & 93.3 & 85.9 & 83.3 & 34.9 & 14.9 & 39.9 \\
\hline$\%$ Public & 1.4 & 0.7 & 1.2 & 2.2 & 0.0 & 4.6 & 1.5 & 2.9 & 1.5 & 2.1 & 1.5 & 8.3 & 9.7 & 43.7 & 43.8 & 44.5 \\
\hline$\%$ Walk & 8.5 & 2.8 & 1.9 & 3.6 & 1.4 & 2.3 & 1.5 & 2.9 & 1.5 & 2.1 & 2.2 & 2.5 & 3.5 & 13.5 & 26.5 & 8.6 \\
\hline$\%$ Other & 2.8 & 0.0 & 1.9 & 0.7 & 2.1 & 0.0 & 0.0 & 1.4 & 1.5 & 1.4 & 2.2 & 1.7 & 0.7 & 5.6 & 10.7 & 3.1 \\
\hline$\%$ Unreported & 5.7 & 1.4 & 1.2 & 2.9 & 2.8 & 3.0 & 2.2 & 2.1 & 2.2 & 4.3 & 0.7 & 1.7 & 2.8 & 2.4 & 4.1 & 3.9 \\
\hline \multicolumn{17}{|c|}{ Commute PMT per Person } \\
\hline TOTAL & | 12.97 & $\mid \begin{array}{l}14.34 \\
\end{array}$ & 16.42 & 15.01 & 15.00 & 13.67 & 15.08 & 13.50 & 12.01 & | 22.54 & 19.74 & 16.07 & 18.41 & 10.70 & 8.52 & 11.42 \\
\hline$\%$ Private & 96.0 & 99.2 & 91.0 & 97.6 & 97.6 & 95.0 & 99.2 & 96.6 & 97.2 & 92.1 & 93.2 & 81.6 & 79.1 & 47.3 & 34.7 & 50.7 \\
\hline$\%$ Public & 0.6 & 0.1 & 5.2 & 1.0 & 0.1 & 3.7 & 0.5 & 2.4 & 0.6 & 6.3 & 5.4 & 16.9 & 17.4 & 42.2 & 33.0 & 44.3 \\
\hline$\%$ Walk & 0.9 & 0.2 & 0.2 & 0.2 & 0.1 & 0.2 & 0.1 & 0.2 & 0.1 & 0.0 & 0.1 & 0.1 & 0.1 & 1.7 & 4.5 & 1.1 \\
\hline$\%$ Other & 1.2 & 0.1 & 2.2 & 0.1 & 1.9 & 0.1 & & 0.4 & 1.8 & 0.9 & 1.2 & 0.5 & 2.5 & 8.1 & 27.2 & 3.4 \\
\hline$\%$ Unreported & 1.4 & 0.4 & 1.4 & 1.1 & 0.3 & 1.0 & 0.2 & 0.4 & 0.3 & 0.7 & 0.2 & 0.9 & 0.9 & 0.7 & 0.6 & 0.5 \\
\hline
\end{tabular}

Note:

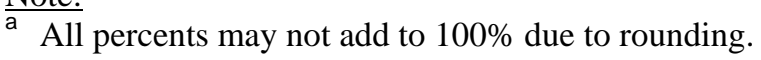


Figure 6.11 Average Commute Length and Commute Time New York State MPO

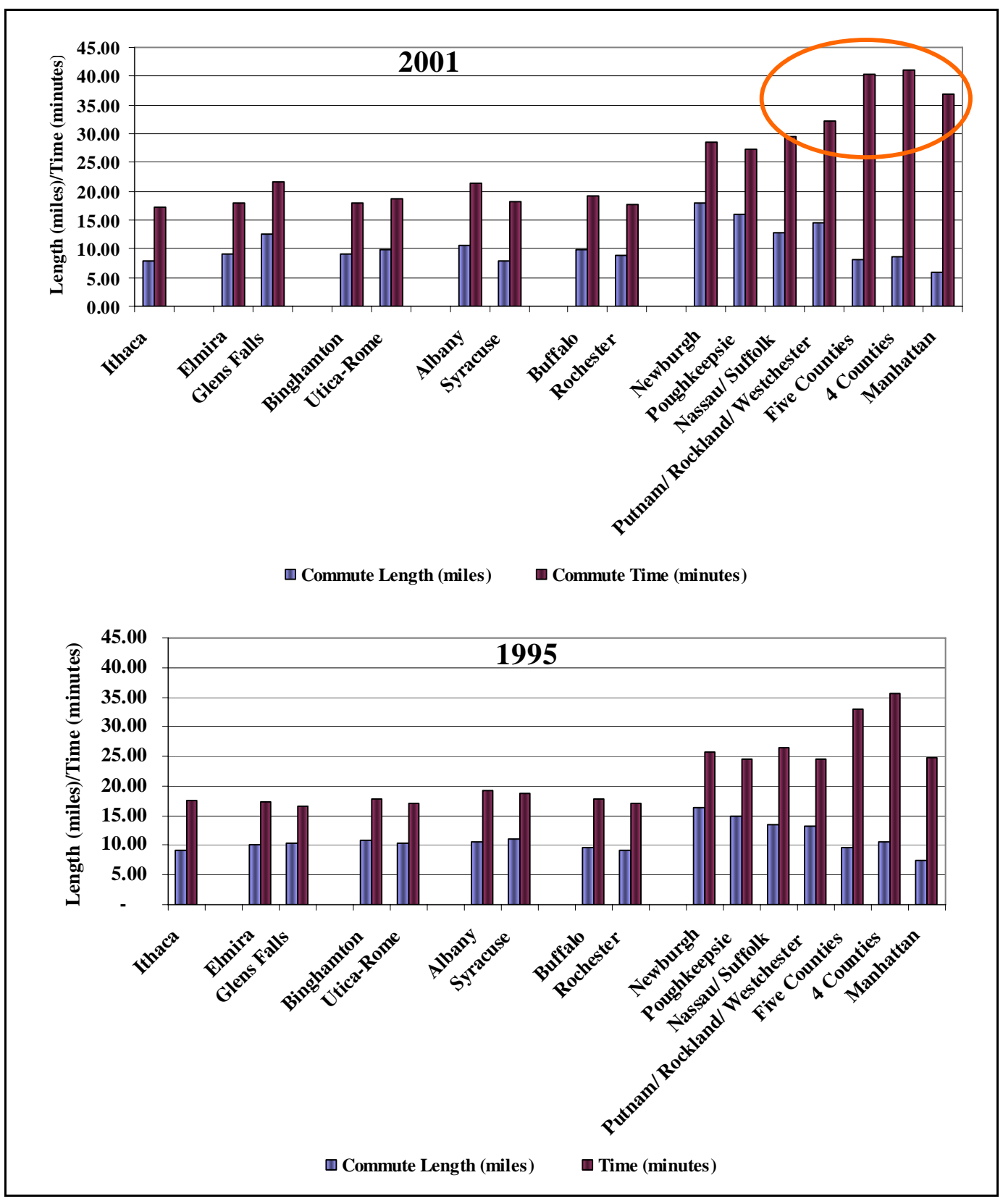

Source: Appendix C, Chapter 6, Table 7 
Figure 6.12 Percent Changes in Commute Travel Statistics from 1995 to 2001 New York MPOs

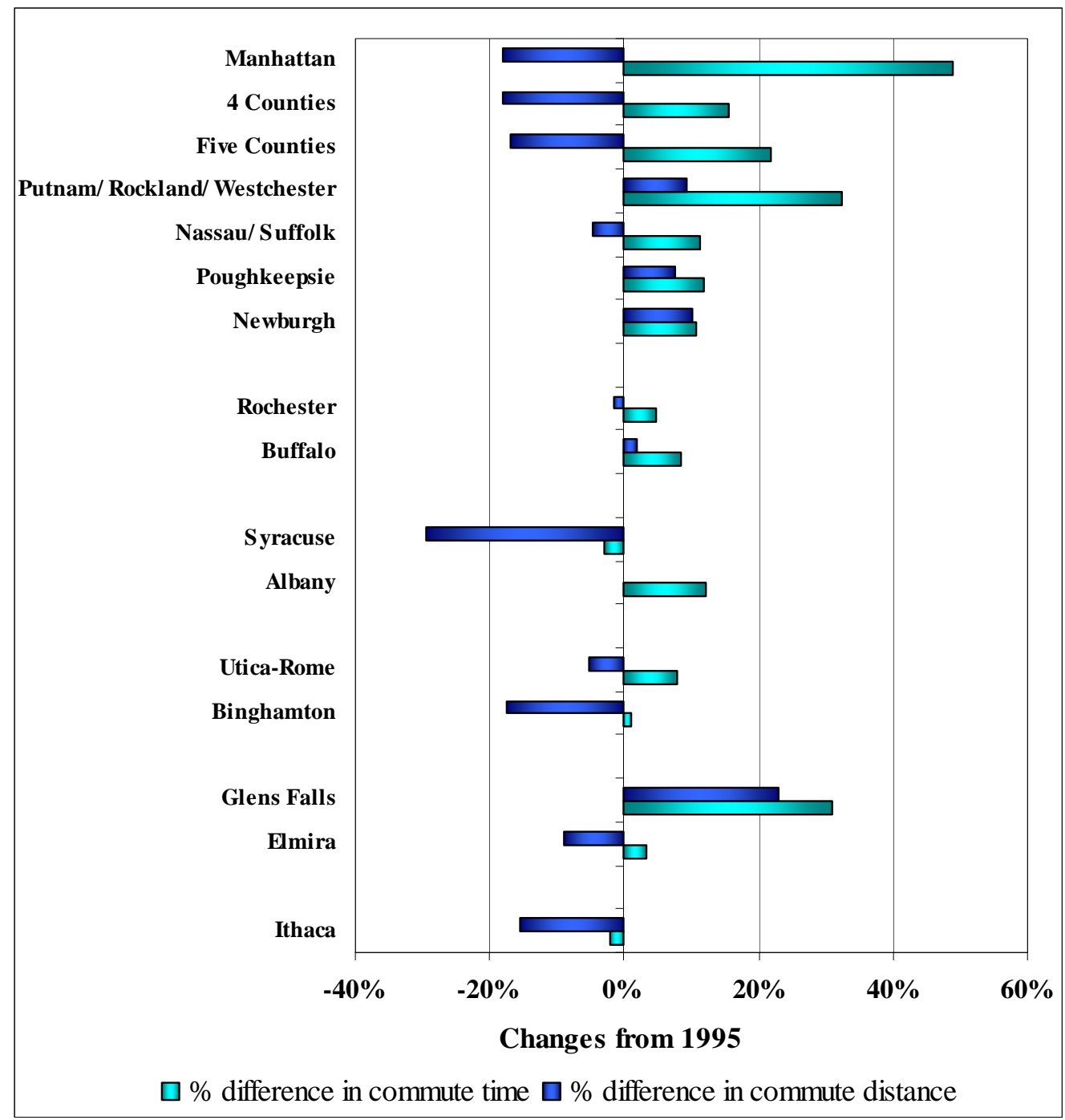

Source: Appendix C, Chapter 6, Table 7

In small and medium-size MPOs (in MSAs with less than 3 million people), 89\%-97\% of commutes are in private vehicles (Appendix C, Chapter 6, Table 6). Typically, one in every 6 such trips is car-pooled. This pattern extends to Ithaca and to some but not all large MPOs (with more than 3 million population). Similar to personal travel patterns, NYC is in a category by 
itself with respect to modes used for commutes. Only 35\% of commutes in NYC are by cars while $30 \%$ are by subway and $16 \%$ are by walking. These mode shares are relatively the same as in 1995. Separating New York/Manhattan from the rest of NYC reveals more distinct commute patterns, as discussed further in Chapter 4. Walking continues to be a significantly more common mode for commutes in New York/Manhattan than in the remaining four counties in NYC, amounting to $27 \%$ of all commutes.

\subsection{Summary}

From the standpoint of personal travel, there is little difference among New York MPOs when compared to other MPOs with similar population size. However, this is not true with respect to vehicle ownership, vehicle travel, and commutes. The vehicle travel characteristics observed in this chapter show some distinct patterns among NYS MPOs. Almost all comparisons suggest that NYS MPOs can be categorized into three distinctive groups regardless of the size of the MSA within which an MPO is located. The first group consists of New York/Manhattan, the second group consists of the remaining four counties of NYC, and the last group consists of all of the remaining MPOs and the rest of the NYMTC area outside NYC (i.e., Nassau and Suffolk, and Putnam, Rockland, and Westchester). The second group has travel patterns somewhere between those of the first and the third groups. When data for New York/Manhattan residents are combined with those for the rest of the NYC, the unique travel characteristics of New York/Manhattan residents are obscured. Therefore, any comparisons in travel characteristics among MPOs should be made with caution.

Similar to 1995, seven out of every 10 households in New York/Manhattan do not own a vehicle in 2001. The decision made by Manhattan residents not to own a vehicle was probably due to the high cost of owning a vehicle (e.g., maintenance, parking, and insurance). While households in MPOs outside NYC do not own a vehicle largely due to income constraints, many households in New York/Manhattan do not own a vehicle by choice. One in every four zerovehicle households in New York/Manhattan is below the poverty line (with a household income 
less than \$20,000) whereas at least 2 in every 3 zero-vehicle households in some MPOs are in poverty. Our analysis results suggest that the mobility of zero-vehicle households in New York/Manhattan is by no means deterred by the lack of a vehicle. Most of their daily travel is met by walking or by public transit.

In conjunction with the lower vehicle ownership, the driver rates of NYC residents are at least 20\% lower for men and over 30\% lower for women than those in MPOs elsewhere. These gaps are not narrowing between 1995 and 2001 in any meaningful way. However, men and women in NYC do not take fewer trips in proportion to the lower driver rates. This again indicates that owning a vehicle or being a driver in NYC is less important for meeting households' mobility needs than anywhere else in NYS. 
APPENDIX A

\section{GLOSSARY OF TERMS}


2001 New York NHTS: A Comparison Study

This page intentionally left blank. 


\section{GLOSSARY OF TERMS}

This glossary provides the most commonly used terms in the NHTS and definitions of those terms. These definitions are provided to assist the user in the interpretation of the NHTS data.

Adult

Block Group

Census Region and
Division
For NHTS, this is defined as a person 18 years or older.

A subdivision of a Census tract that averages 1000 to 1100 people, and approximately 400-500 housing units. The source used for the 2001 NHTS was GDT Dynamap 2000 (from Census 2000 TIGER/Line files).

The Census Bureau divides the states into four regions and nine divisions. Note that the divisions are wholly contained within a region, i.e., region lines do not split division lines. The regions and their component divisions are:

\section{Northeast Region:}

- New England Division: Connecticut, Maine, Massachusetts, New Hampshire, Rhode Island, Vermont

- Middle Atlantic Division: New Jersey, New York, Pennsylvania North Central Region:

- East North Central Division: Illinois, Indiana, Michigan, Ohio, Wisconsin

- West North Central Division: Iowa, Kansas, Minnesota, Missouri, Nebraska, North Dakota, South Dakota

\section{South Region:}

- South Atlantic Division: Delaware, Florida, Georgia, Maryland, North Carolina, South Carolina, Virginia, West Virginia

- East South Central Division: Alabama, Kentucky, Mississippi, Tennessee

- West South Central Division: Arkansas, Louisiana, Oklahoma, Texas

\section{West Region:}

- Mountain Division: Arizona, Colorado, Idaho, Montana, Nevada, New Mexico, Utah, Wyoming

- Pacific Division: Alaska, California, Hawaii, Oregon, Washington Puerto Rico.

For the 2001 NHTS the source used for the 2000 Census Region was: http://www.census.gov/geo/www/cob/rg2000.html. The source used for the 2000 Census Division was: http://www.census.gov/geo/www/cob/dv2000.html. 
Census Tract

Child

\section{Consolidated Metropolitan Statistical Area (CMSA)}

\section{Destination}

Driver

Employed

Education Level

Household
A small subdivision of a county, containing approximately 4,000 persons. Tracts can range in population from 2,500 to 8,000. The geographic size of the tract may vary considerably, depending on population density. Tracts were designed to be homogeneous in regard to population characteristics, economic status and living conditions when they were first delineated. Since the first tracts were delineated for the 1890 Census, today's tracts may be far from homogeneous. The source used for the 2001 NHTS was GDT Dynamap 2000 (from Census 2000 TIGER/Line files).

A child is normally defined as a person under the age of 18 . An exception to this is for life cycle, where a child can be anyone through the age of 21 who is listed as a child to the household respondent.

A large metropolitan complex of 1 million or more population, containing two or more identifiable component parts designated as primary metropolitan statistical areas (PMSAs). For example, the New York-Northern New JerseyLong Island CMSA is composed of the following fourteen PMSAs: Bridgeport, Danbury, Dutchess County, Jersey City, Middlesex-Somerset-Hunterdon, Monmouth-Ocean, Nassau-Suffolk, New Haven-Meriden, New York, Newark, Newburgh, Stamford-Norwalk, Trenton, Waterbury.

For travel day trips, the destination is the point at which there is a break in travel, except if the break is only to change vehicles or means of transport.

For travel period trips, the destination is the farthest point of travel.

A driver is a person who operates a motorized vehicle. If more than one person drives on a single trip, the person who drives the most miles is classified as the principal driver.

A person is considered employed if (s)he worked for pay, either full time or part time, during the week before the interview. This includes persons who work at home or persons who have more than one job.

The number of years of regular schooling completed in graded public, private, or parochial schools, or in colleges, universities, or professional schools, whether day school or night school. Regular schooling advances a person toward an elementary or high school diploma, or a college, university, or professional school degree.

A group of persons whose usual place of residence is a specific housing unit; these persons may or may not be related to each other. The total of all U.S. households represents the total civilian non-institutionalized population. A household does not include group quarters (i.e., 10 or more persons living together, none of whom are related).

\section{A - 4}


Household Income

Household Members

Household Vehicle

Journey-to-Work Trips (Commute trips)

\section{Means of Transportation}

Household income is the money earned by all family members in a household, including those temporarily absent. Annual income consisted of the income earned 12 months preceding the interview. Household income includes monies from all sources, such as wages and salary, commissions, tips, cash bonuses, income from a business or farm, pensions, dividends, interest, unemployment or workmen's compensation, social security, veterans' payments, rent received from owned property (minus the operating costs), public assistance payments, regular gifts of money from friends or relatives not living in the household, alimony, child support, and other kinds of periodic money income other than earnings. Household income excludes in-kind income such as room and board, insurance payments, lump-sum inheritances, occasional gifts of money from persons not living in the same household, withdrawal of savings from banks, tax refunds, and the proceeds of the sale of one's house, car, or other personal property.

Household members include all people, whether present or temporarily absent, whose usual place of residence is in the sample unit. Household members also include people staying in the sample unit who have no other usual place of residence elsewhere.

A household vehicle is a motorized vehicle that is owned, leased, rented or company-owned and available to be used regularly by household members during the two-week travel period. Household vehicles include vehicles used solely for business purposes or business-owned vehicles, so long as they are driven home and can be used for the home to work trip, (e.g., taxicabs, police cars, etc.). Household vehicles include all vehicles that were owned or available for use by members of the household during the travel period, even though a vehicle may have been sold before the interview. Vehicles excluded from household vehicles are those which were not working and were not expected to be working within 60 days, and vehicles that were purchased or received after the designated travel day.

Includes travel to and from a place where one reports for work. Does not include any other work-related travel. Does not include any trips for persons who work at home.

A mode of travel used for going from one place (origin) to another (destination). A means of transportation includes private and public transit modes, as well as walking.

The following transportation modes, grouped by major mode, are included in the NHTS data.

\section{Private Vehicle}


1. Car - A privately owned and/or operated licensed motorized vehicle including cars and station wagons. Leased and rented cars are included if they are privately operated and not used for picking up passengers in return for fare.

2. Van - privately owned and/or operated van or minivan designed to carry 5 to 13 passengers, or to haul cargo.

3. Sport Utility Vehicle - A privately owned and/or operated vehicle that is a hybrid of design elements from a van, a pickup truck and a station wagon. Examples include a Chevrolet Blazer, Ford Bronco, Jeep Cherokee, or Nissan Pathfinder.

4. Pickup Truck - A pickup truck is a motorized vehicle, privately owned and/or operated, with an enclosed cab that usually accommodates 2-3 passengers, and an open cargo area in the rear. Later model pickups often have a back seat that allows for total seating of 4 - 6 passengers. Pickup trucks usually have the same size of wheel-base as a full-size station wagon. This category also includes pickups with campers.

5. Other Truck - This category consists of all trucks other than pickup trucks (i.e., dump trucks, trailer trucks, etc.).

6. RV or Motor Home - An RV or motor home includes a self-powered recreational vehicle that is operated as a unit without being towed by another vehicle (e.g., a Winnebago motor home).

7. Motorcycle - This category includes large, medium, and small motorcycles and mopeds.

\section{Public Transportation}

10. Local public transit buses (mass transit buses that are available to the general public).

11. Commuter buses.

16. Commuter train.

17. Subway/Elevated rail (also known as rail rapid transit is a high capacity system operated on a fixed rail or guide way system on a private right of way).

18. Street car/Trolley (vehicles that run on a fixed rail system powered by electricity obtained from an overhead power distribution system.)

\section{Other Modes}

8. Commercial/Charter Airplane (airplanes that are available for use by the general public in exchange for a fare).

9. Private/Corporate Airplanes

12. School Buses.

13. Charter/Tour buses (privately owned buses that are either rented by a group or are available to the public for a fee for sightseeing).

14. City to City buses (buses that run from one center to the other).

15. Amtrak/Intercity Train (heavy passenger rail that runs from one urban center to another).

19. Ship/Cruise Ships.

$$
\text { A - } 6
$$


Metropolitan Statistical Area (MSA)

Motorized Vehicle

New York State
Metro Area

Occupancy

Origin

Overlap Trip
20. Passenger Line/Ferry.

21. Sailboat/Motorboat/Yacht.

22. Taxicab - Includes the use of a taxicab by a passenger for fare. The taxi category does not include rental cars if they are privately operated.

23. Limousine - Includes the use of a limousine by passenger for fare. The limousine category does not include rental cars if they are privately operated.

24. Hotel/Airport Shuttle - This includes privately operated shuttle buses that are operated between a limited number of points for a fare.

25. Bicycle - This category includes bicycles of all speeds and sizes that do not have a motor.

26. Walk. - This category includes walking and jogging.

91. Other - Includes any types of transportation not previously listed, e.g. skate boards.

Except in the New England States, a Metropolitan Statistical Area is a county or group of contiguous counties which contains at least one city of 50,000 inhabitants or more, or "twin cities" with a combined population of at least 50,000 . In addition, contiguous counties are included in an MSA if, according to certain criteria, they are socially and economically integrated with the central city. In the New England States, MSA's consist of towns and cities instead of counties. The source used for the 2001 NHTS was 1999 Metropolitan Areas: Cartographic Boundary Files. File ma99_99.shp from http://www.census.gov/geo/www/cob/ma1999.html.

Motorized vehicles are all vehicles that are licensed for highway driving. Snow mobiles and minibikes are specifically excluded.

The New York State Metro area includes the following three areas: (1) Nassau, Suffolk; (2) New York City, (which includes the following counties: Bronx, Kings, Queens, New York, and Richmond); and (3) Putnam, Rockland, and Westchester.

Occupancy is the number of persons, including driver and passenger(s) in a vehicle. NHTS occupancy rates are generally defined as person miles divided by vehicle miles.

Origin is the starting point of a trip.

A travel period trip that occurs on travel day, and is thus collected in both portions of the NHTS questionnaire. To ensure that this trip is not counted twice, eliminate overlap trips from travel day data when travel day and travel period data will be added together. 
Passenger

Person Miles of Travel (PMT)

Person Trip

POV

Seasonal Variation

Travel Day

Travel Day Trip

Travel Day Trip Purpose
For a specific trip, a passenger is any occupant of a motorized vehicle, other than the driver.

PMT is a primary measure of person travel. When one person travels one mile, one person mile of travel results. Where 2 or more persons travel together in the same vehicle, each person makes the same number of person miles as the vehicle miles. Therefore, four persons traveling 5 miles in the same vehicle results in 20 person miles $(4 \times 5=20)$.

A person trip is a trip by one or more persons in any mode of transportation. Each person is considered as making one person trip. For example, four persons traveling together in one auto are counted as four person trips.

A privately-owned vehicle or privately-operated vehicle. Either way, the intent here is that this is not a vehicle available to the public for a fee, such as a bus, subway, taxi, etc.

Season is defined as:

Winter: December through February;

Spring: March through May;

Summer: June through August;

Fall: September through November.

A travel day is a 24-hour period from 4:00 a.m. to 3:59 a.m. designated as the reference period for studying trips and travel by members of a sampled household.

A travel day trip is defined as any time the respondent went from one address to another by private motor vehicle, public transportation, bicycle, walking, or other means. However, a separate trip is not counted in two instances:

1. When the sole purpose for the trip is to get to another vehicle or mode of transportation in order to continue to the destination.

2. Travel within a shopping center, mall or shopping areas of 4-5 blocks is to be considered as travel to one destination.

A trip purpose is the main reason that motivates a trip. There are 36 travel day trip purposes used in the 2001 NHTS.

For the 2001 Survey, trip purposes were collected using a From-To approach. For each trip, the origin and destination are on the file in generic terms, e.g. from work to shopping. The 36 trip reasons are defined as follows, and shown with their coded trip purpose number. 
1. To Home - Travel to home after leaving for some reason.

11. Go to Work - The first trip to the work location on travel day.

12. Return to Work - A trip to work that is not the first trip to work on the travel day.

13. Attend Business Meeting/Trip - A work related trip whose purpose is to attend a business meeting.

14. Other Work Related - A work related trip whose purpose is not specifically to attend a business meeting.

20. Other School/Religious Activity - School and religious activities not covered by categories 21 through 23 below.

21. Go to School as a Student - A trip whose purpose is to go to school as a student.

22. Go to Religious Activity - A trip whose purpose is to go to a place to attend a religious activity.

23. Go to Library, School Related - A trip whose purpose is to go to the library as part of a school related activity.

24. Go to Daycare - A trip whose purpose is to attend day care.

30. Medical/Dental Services - A trip made for medical, dental, or mental health treatment, or other related professional services.

40. Shopping/Errands - Shopping/errand trips not covered by categories 41 through 43 below.

Buy Goods, (e.g., groceries/clothing/hardware store) - A shopping trip

41. whose purpose is to purchase commodities for use or consumption elsewhere. This purpose also includes window-shopping and trip made to shop even if nothing is purchased.

Buy Services, (e.g., video rentals/dry cleaning/post office/car

42. service/bank) - The category includes the purchase of services other than medical/dental or other professional services.

43. Buy Gas - A trip made specifically to get gas.

50. Social/Recreational - Includes social and recreational trips not covered by categories 51 through 55 below.

51. Go to the Gym/Exercise/Play Sports - A trip made for exercise or to participate in a sport. 
52. Rest or Relaxation/Vacation.

53. Visit Friends/Relatives - The social/recreational trip whose purpose is to visit with family and friends.

54. Go out/Hang out, Entertainment/Theater/Sports Event/Go to Bar - The purpose of the trip is entertainment or hanging out with friends.

55. Visit Public Place, Historical Site/Museum/Park/Library.

60. Family Personal Business/Obligations - A trip for personal business not covered by categories 61 through 65 below.

61. Use Professional Services, Attorney/Accountant - A trip made for professional services other than for medical/dental purposes.

62. Attend Funeral/Wedding - A personal trip to attend a funeral or a wedding.

63. Use Personal Services, Grooming/Haircut/Nails - A trip for personal services such as to a hairdresser.

64. Pet Care, Walk the dog/Vet visits.

Attend Meeting, PTA/Home Owners Association/Local Government -

65. The purpose of the trip is to attend a non-work related meeting, such as a community meeting.

Transport Someone - Trips with a passenger that are related to picking

70. up or dropping off someone but not covered by categories 71 through 73 below.

71. Pickup Someone.

72. Take and Wait - A trip made to take someone to a destination and then wait with them at the destination and return together.

73. Drop Someone Off.

80. Meals - A trip whose purpose is to eat or get a meal but not covered by categories 81 through 83 below.

81. Social Event - A trip whose purpose is to eat a meal at a social event.

82. Get/Eat Meal - A trip whose purpose is to get and eat a meal but not at a social event.

83. Coffee/Ice Cream/Snacks - A trip whose purpose is to get/eat a snack or drink, something less than a meal. 
91. Other - A trip purpose not covered by categories above.

\section{Travel Period}

Travel Period Trip

Trip Purpose
A travel period consists of a four-week period ending with the travel day.

A travel period trip is a trip where the farthest destination is at least 50 miles from home. The outgoing portion of this trip can take place at any time, but the return must be within the four-week travel period. The four-week travel period ends on and includes the assigned travel day.

A trip purpose is the main reason that motivates a trip. For purposes of this survey, there are 11 trip reasons. For travel day trips, if there is more than one reason, and the reasons do not involve different destinations, then only the main reason is chosen. If there are two or more reasons, and they each involve different destinations, then each reason is classified as a separate trip. For travel period trips, if there is more than one reason, the primary reason is collected. The 11 trip reasons (grouped into the four major purposes) are defined as follows:

\section{Earning A Living:}

- To or From Work - Travel to a place where one reports for work; excluding work-related travel Middle Atlantic Division: New Jersey, New York, Pennsylvania.

- Work-Related Business - Trips related to business activities; excluding travel to the place of work. Example: a plumber drives to a wholesale dealer to purchase supplies for his business, or a company executive travels from his office to another firm to attend a business meeting. Business, out-of-town trips, and professional conventions are included.

Family and Personal Business:

- Shopping - Shopping includes "window-shopping" and purchases of commodities such as groceries, furniture, clothing, etc. for use or consumption elsewhere.

- Doctor/Dentist - This category includes trips made for medical, dental, or psychiatric treatment, or other related professional services.

- Other Family or Personal Business - This category includes the purchase of services such as cleaning garments, servicing an automobile, haircuts, banking, legal services, etc.

\section{School or Church:}

- School/Church - This category includes trips to school, college or university for class(es), or to PTA meetings, seminars, etc., or to church services or to participate in other religious activities.

- Social activities that take place at a church or school, but cannot be classified as religious or educational are not included in this category.

$$
\text { A - } 11
$$




\section{Social and Recreational:}

- Vacation - This category is for trips reported by the respondent as "vacation."

- Visit Friends or Relatives - Trips which are specifically designated to visit friends or relatives.

- Pleasure Driving - Driving trips made with no other purpose listed but to "go for a drive" with no destination in mind.

- Other Social or Recreational - Trips taken to enjoy some form of social activity involving friends or acquaintances. This category includes trips for general entertainment or recreation (both as observer and as participant).

Urbanized Area

Vehicle

Vehicle Miles of Travel (VMT)

Vehicle Occupancy
An urbanized area consists of the built up area surrounding a central core (or central city), with a population density of at least 1,000 persons per square mile. Urbanized areas do not follow jurisdictional boundaries, thus it is common for the urbanized area boundary to divide a town.

For the 2001 NHTS, Urban Areas were calculated two ways.

1. Variable URBAN uses the 2000 Urbanized Areas: Cartographic Boundary Files. File ua00_d00.shp from http://www.census.gov/geo/www/cob/ua2000.html. Two codes are used: $0=$ Not in Urban Area, $1=$ in Urban Area.

2. Variable URBAN1 uses the 2000 Urbanized Areas: Cartographic Boundary Files. File ua00_d00.shp from http://www.census.gov/geo/www/cob/ua2000.html. Three codes are used: $0=$ Not in Urban Area, $1=$ in Urban Cluster, $2=$ in Urban Area, $3=$ in area surrounded by urban areas.

In the 2001 NHTS, the term vehicle includes autos, passenger vans, sport utility vehicles, pickups and other light trucks, RV's, motorcycles and mopeds owned or available to the household.

VMT is a unit to measure vehicle travel made by a private vehicle, such as an automobile, van, pickup truck, or motorcycle. Each mile traveled is counted as one vehicle mile regardless of the number of persons in the vehicle.

Vehicle occupancy is the number of persons, including driver and passenger(s) in a vehicle; also includes persons who did not complete a whole trip. NHTS occupancy rates are generally calculated as person miles divided by vehicle miles.

A trip by a single privately-operated vehicle (POV) regardless of the number of persons in the vehicle. 
Vehicle Type

Weekday

Weekend

Work-Related Travel (WR)

Worker
For purposes of the 2001 NHTS, one of the following:

1. Automobile (including station wagon)

2. Van

3. Sport Utility Vehicle

4. Pickup Truck (including pickup with camper)

5. Other Truck

6. RV or Motor Home

7. Motorcycle

8. Other

Weekday is defined as the time between 12:01 a.m. Monday and 6:00 p.m. Friday. This was done because Friday evening is considered the start of the weekend.

Weekend is defined as the time between 6:01 p.m. Friday and midnight Sunday.

These are trips related to business activities except travel to the place of work: for example, a plumber drives to a wholesale dealer to purchase supplies for his business or a company executive travels from his office to another firm to attend a business meeting. Business, out-of-town trips, and professional conventions are also included.

See “Employed.” 
2001 New York NHTS: A Comparison Study

This page intentionally left blank.

A - 14 


\section{APPENDIX B}

\section{MAPS OF NEW YORK STATE AREA}




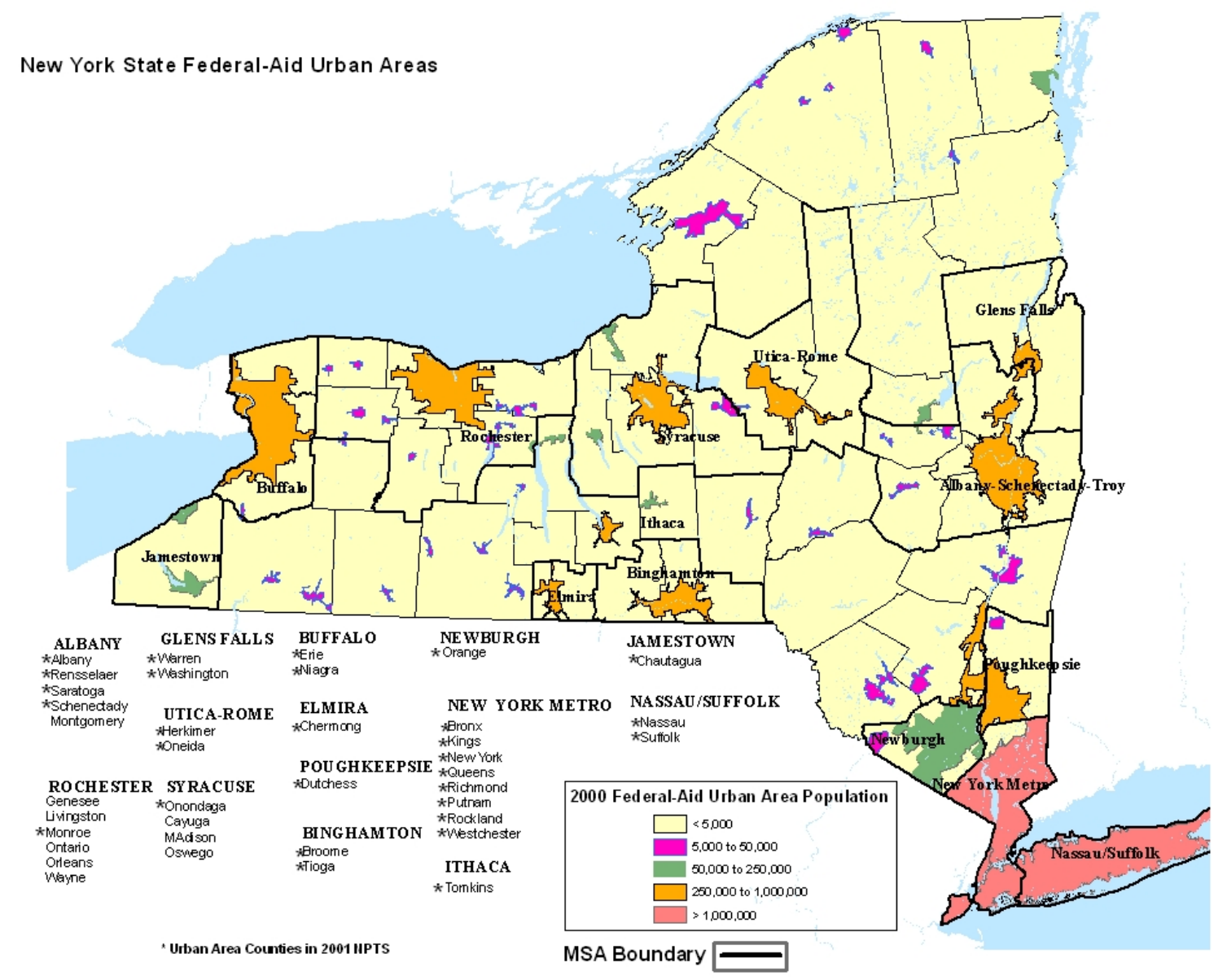

B - 3 


\section{New York State}

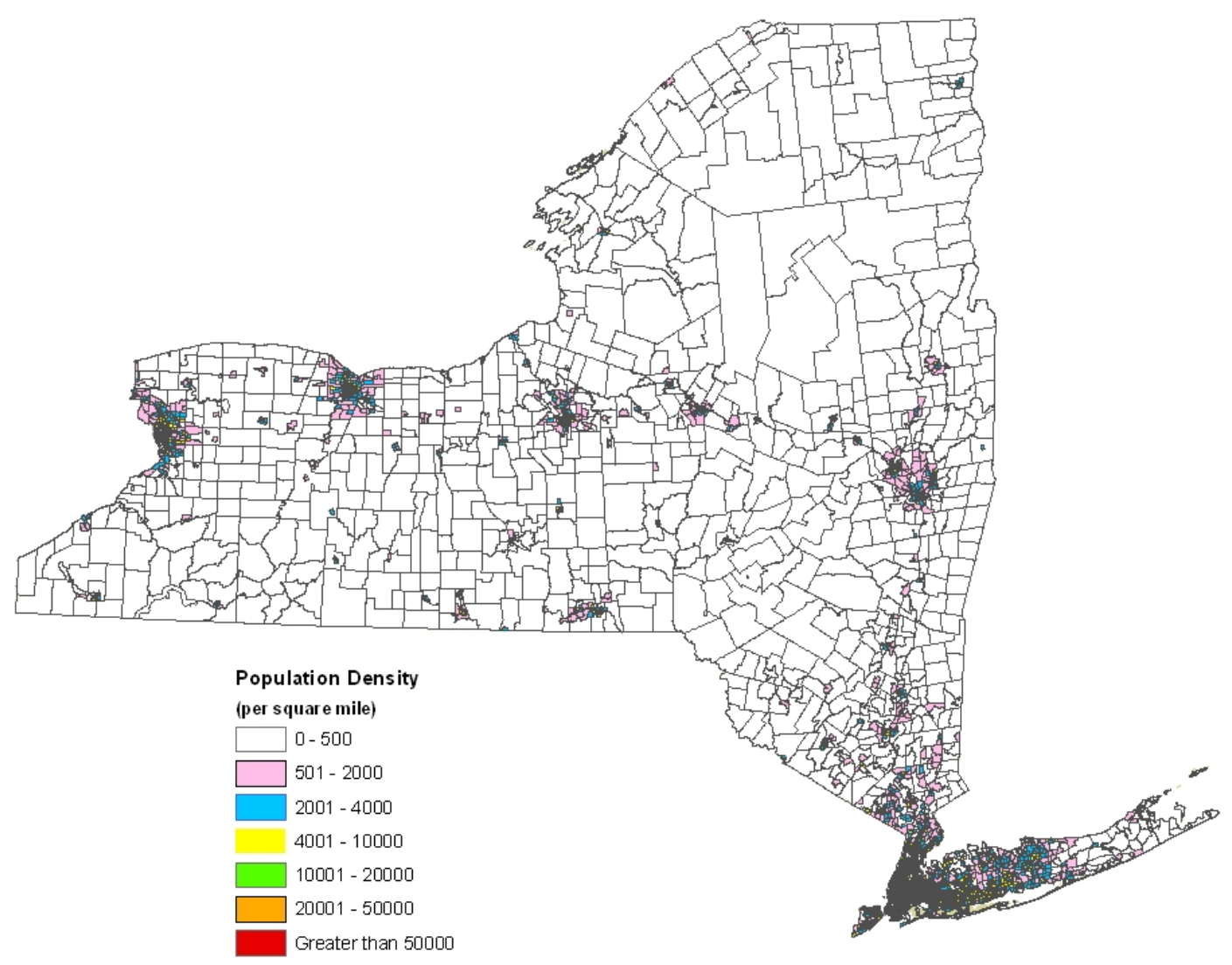

B - 4 
ITHACA -ELMIRA-BINGHAMTON

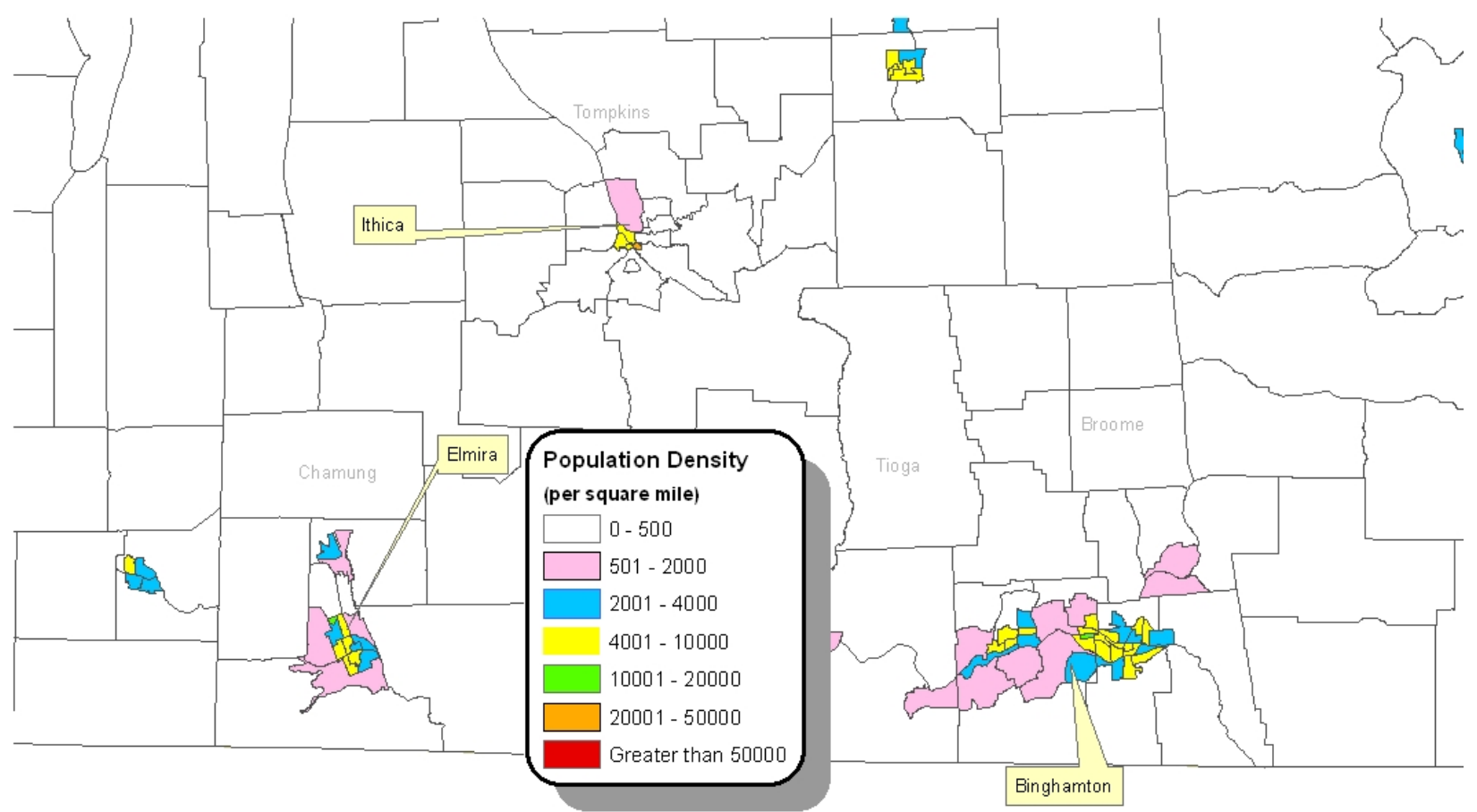

B - 5 


\section{CAPITAL DISTRICT AND GLENS FALLS}

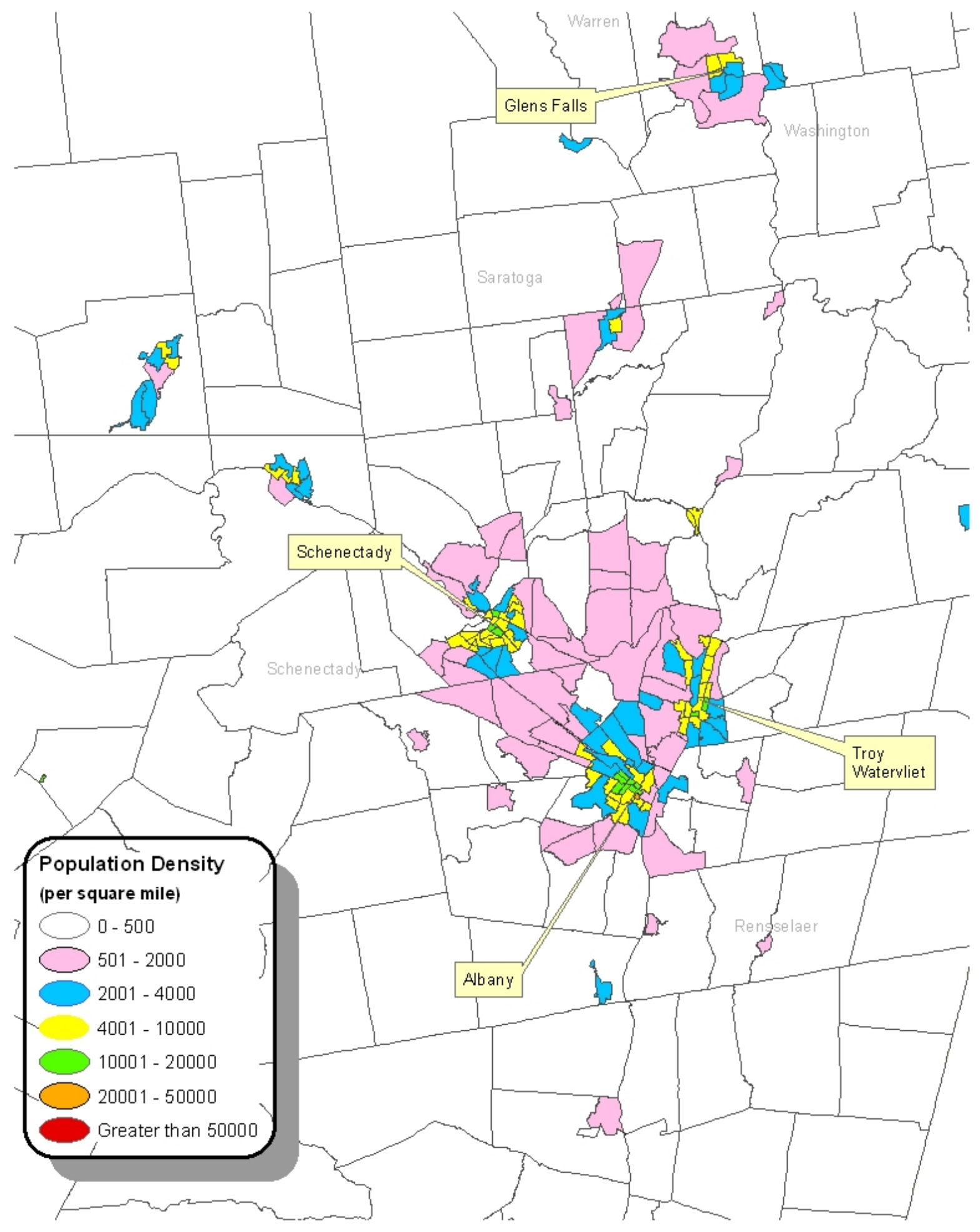




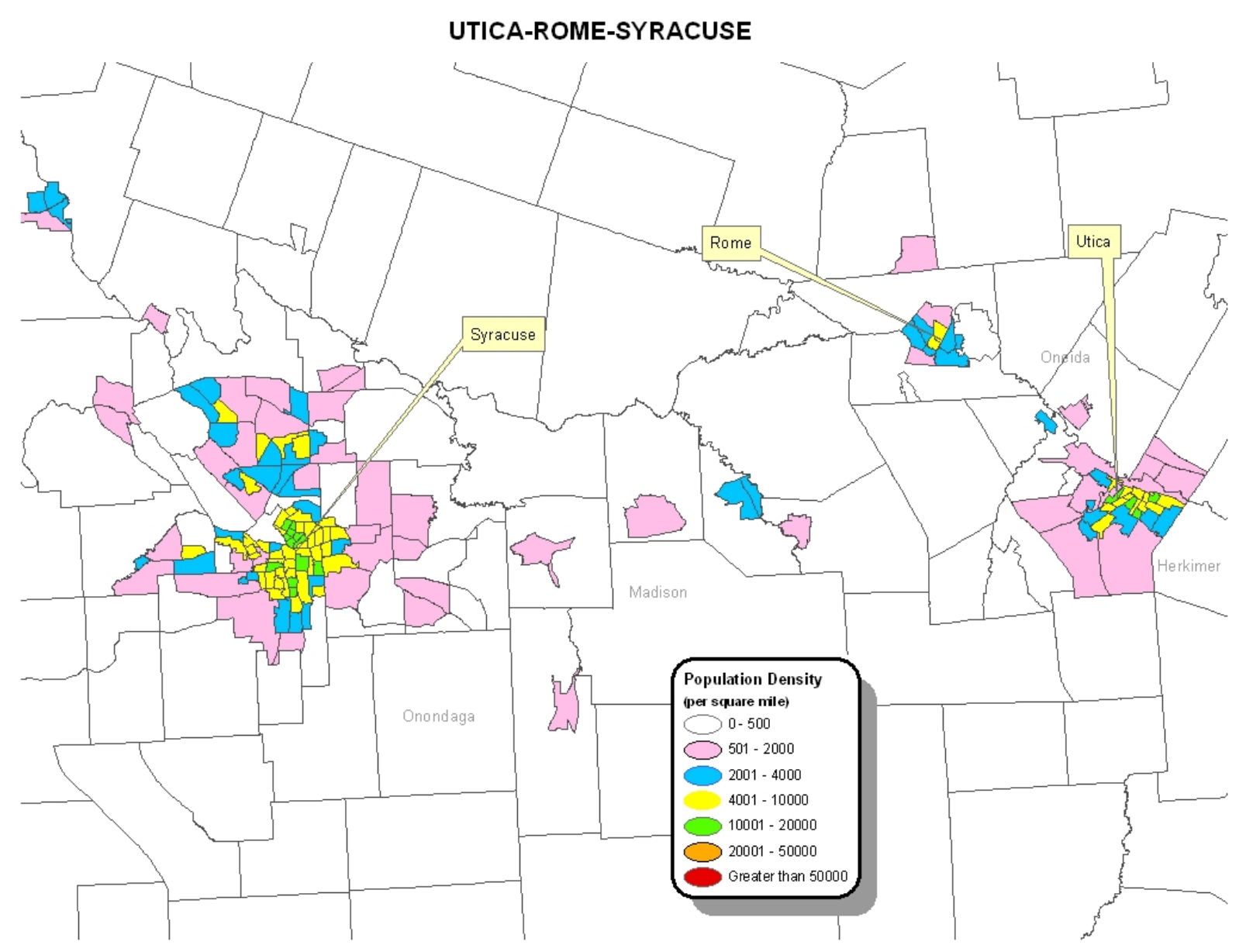

B - 7 


\section{BUFFALO}

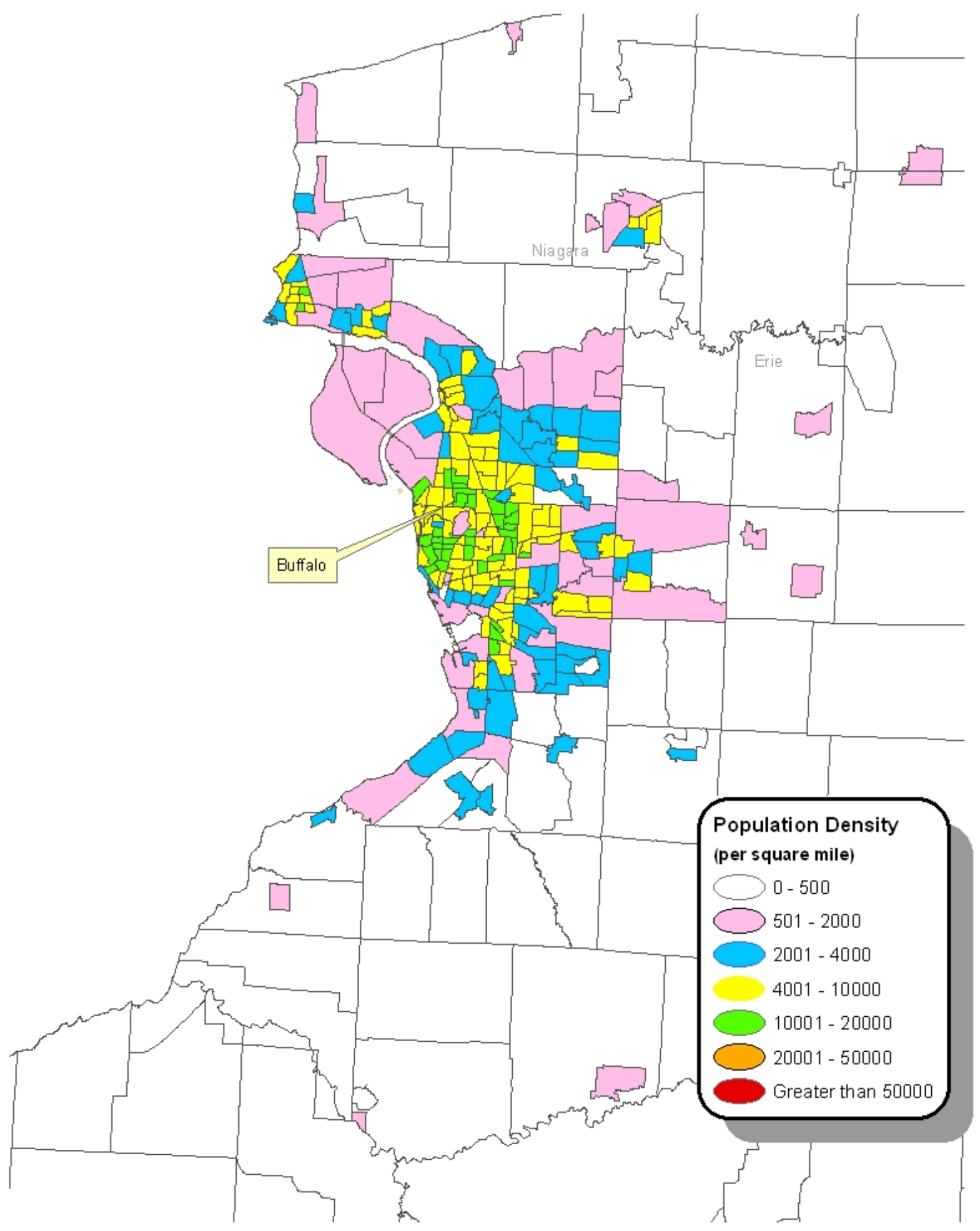




\section{NASSAU/SUFFOLK}

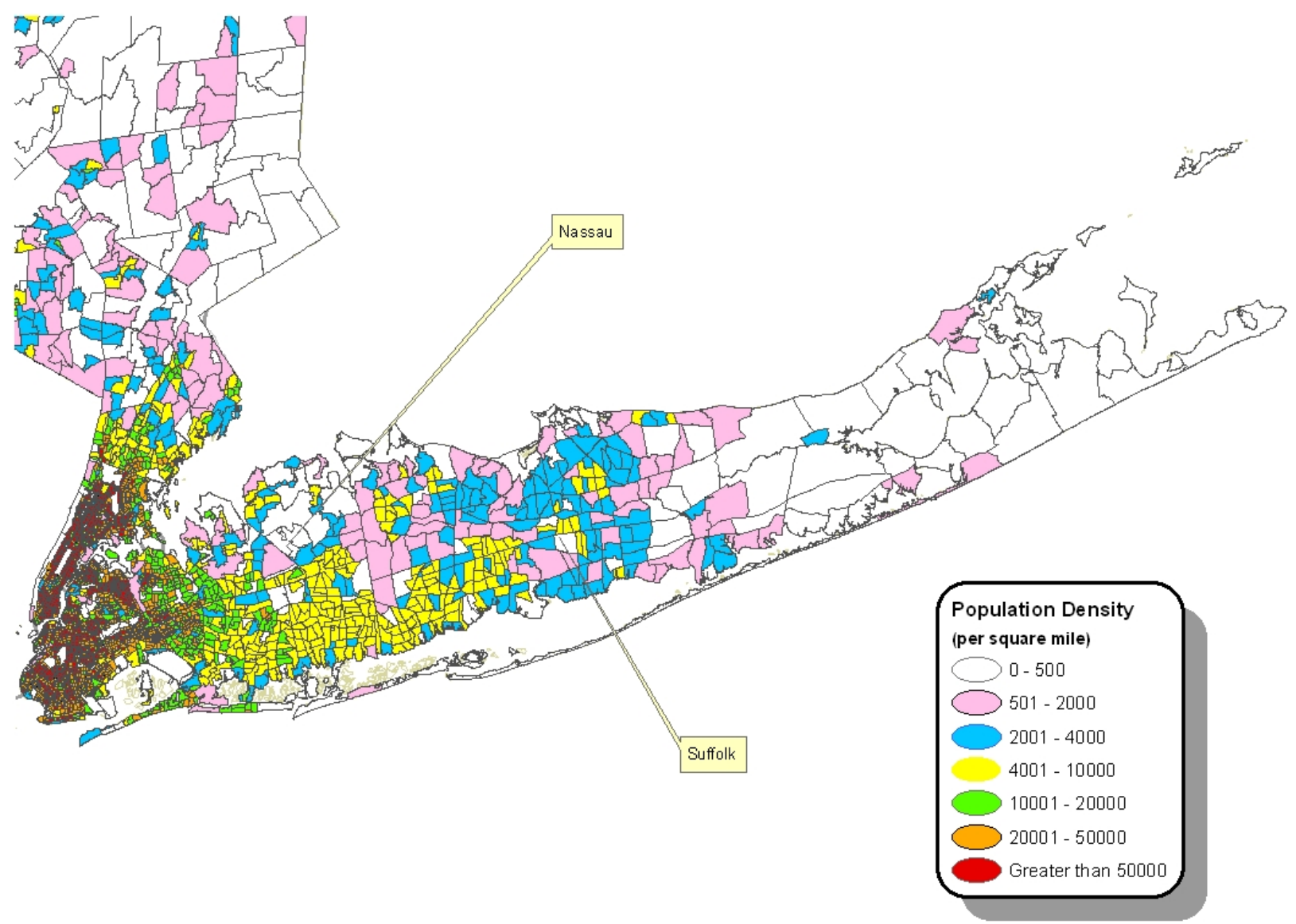

B - 9 


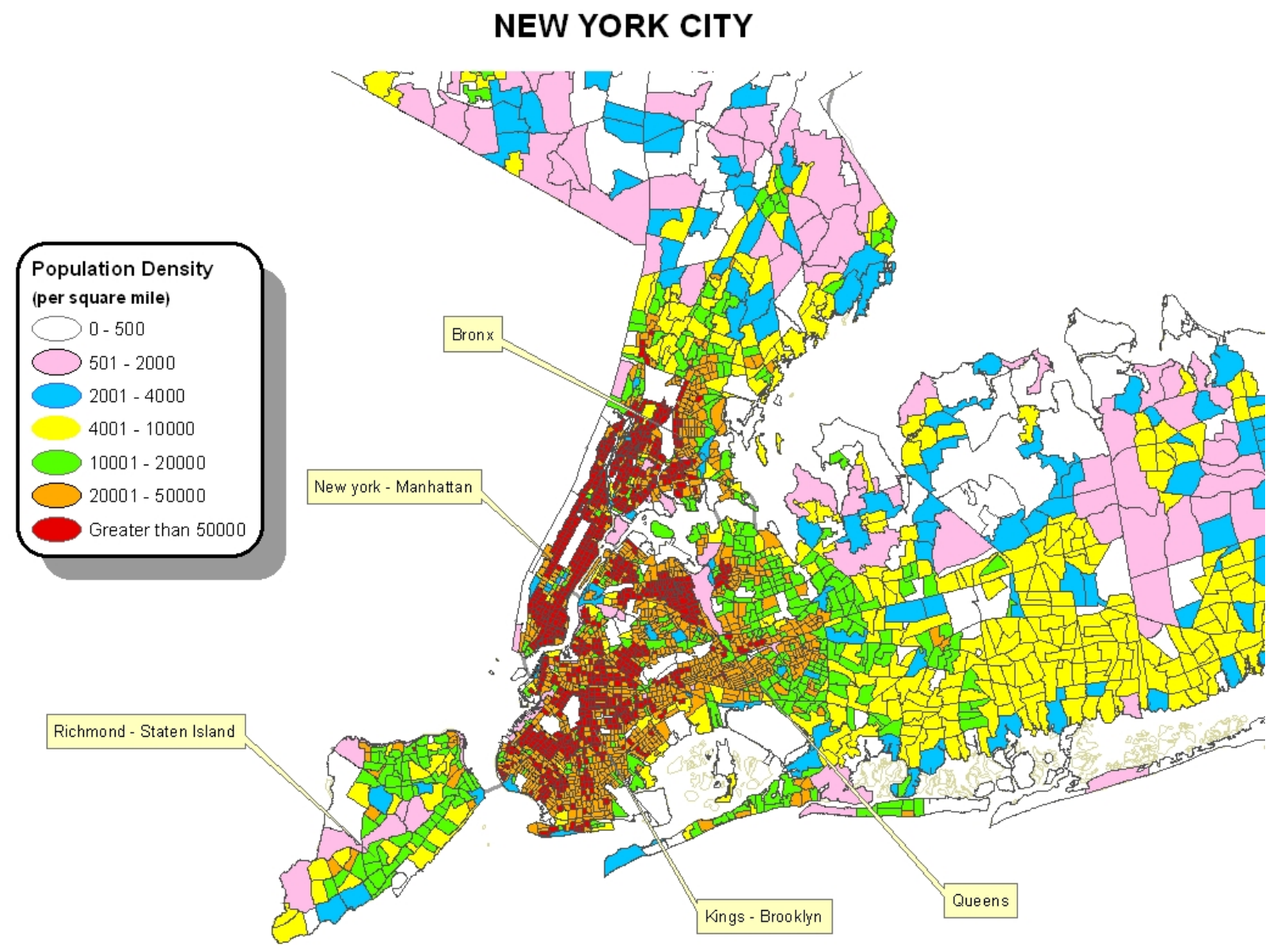

B - 10 
POUGHKEEPSIE - NEWBURGH - WHITE PLAINS

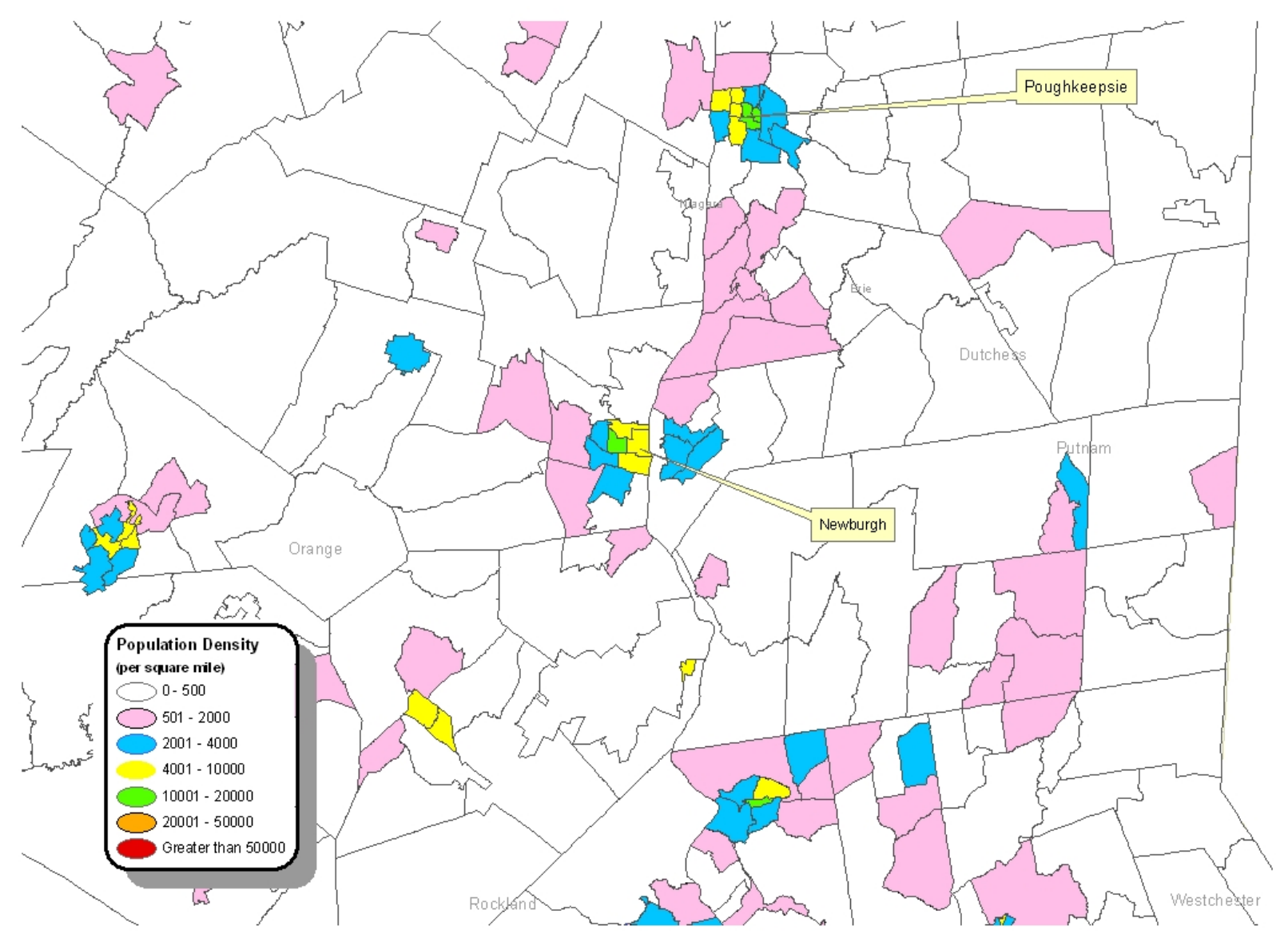

B - 11 


\section{ROCHESTER}

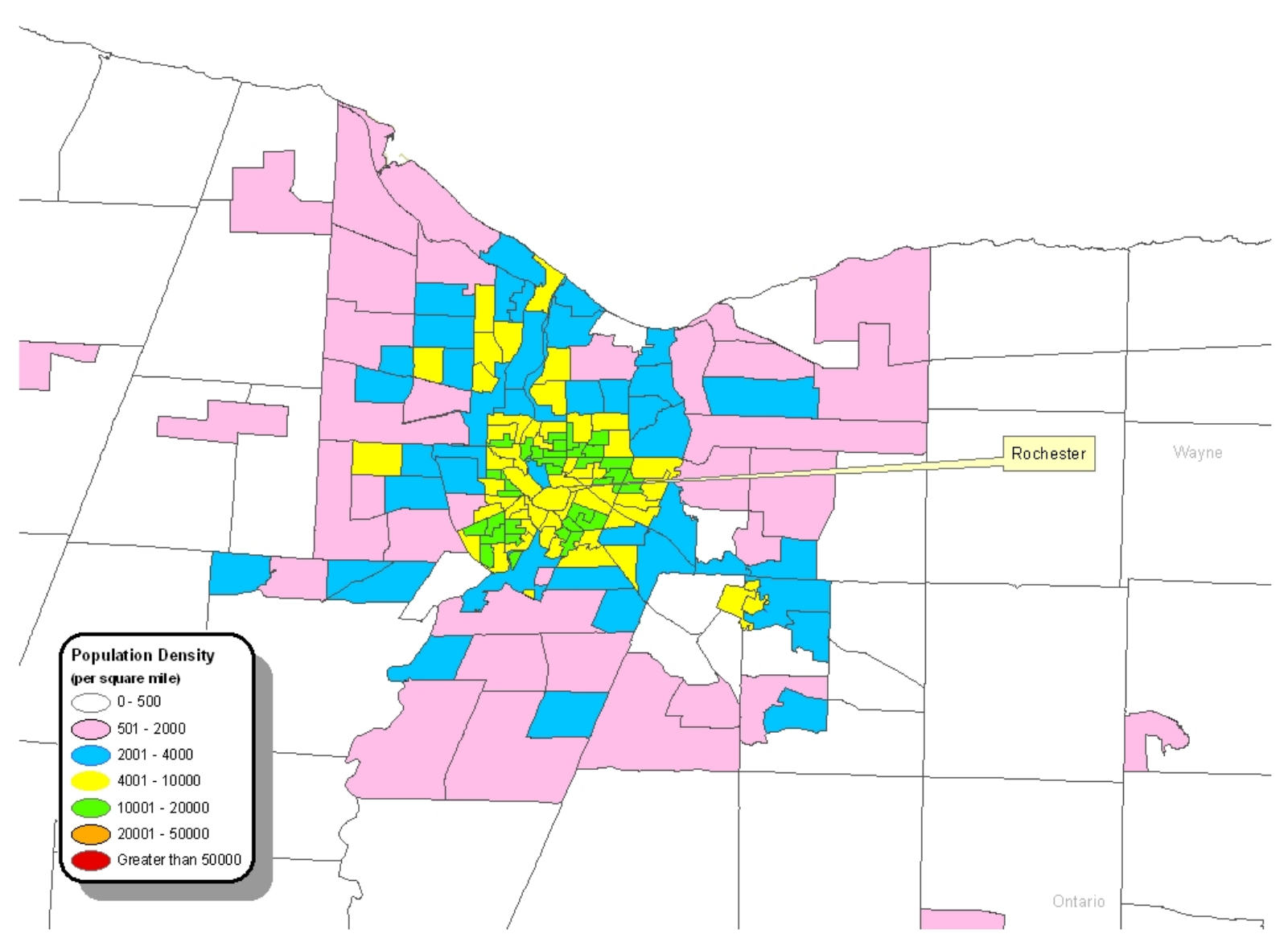




\section{APPENDIX C}

\section{SUPPLEMENTARY TRAVEL TABLES BY CHAPTER}




\section{Accompanying Notes for Tables in Appendix C}

口 All totals could include some unreported characteristics.

ㅁ Empty cells indicate no data available. Values of 0.0 indicate data available, but less than 0.1 .

a A highlighted cell indicates a sample size of 5 or less.

口 Daily trip or mile-per-person rates include all persons 5 or older. This also includes persons not traveling on their travel day.

- Weekday is defined as the time between 12:01 a.m. Monday and 6:00 p.m. Friday. Weekend is defined as the time between 6:01 p.m. Friday and midnight Sunday.

․ Number of workers includes those who work at home.

- Commute trips do not include those who work at home.

a All average trip lengths are calculated using only those records with trip mileage information present.

$\square \quad$ All calculations of average time spent driving do not include any persons who did not take a trip on their travel day. They also do not include any driving done in a segmented trip.

口 All calculations of average commute travel time do include time spent waiting for transportation.

口 All calculations of average commute speed do not include time spent waiting for transportation. For the sake of consistency with 1995 data, they also do not include any segmented trips, which eliminates nearly all data points in 2001 statistics. All calculations for the miles per hour (mph) are based on estimates of miles and minutes given by the respondent. Therefore, any mph estimate for walking that is greater than 5 might be attributable to self-reporting bias.

口 1995 numbers are based on the revised sample expansion factors where applicable (households and per household statistics).

$$
\text { C - } 3
$$


all "Driver Rates" are computed using NPTS/NHTS data, and do not take into account NYDMV licensing rates.

口 Any increases in walk trips from 1995 to 2001 may be due, at least in part, to multiple prompts in the 2001 survey for walk trips.

口 In Chapters 2 and 3, 1995 income has been adjusted to 2001 Dollars for all tables excluding vehicle occupancy. Statistics by household income for 1995 are unavailable in 2001 Dollar terms for tables in Chapters 4-6.

Chapter 5 includes only households and travel by households outside MPOs and in areas with less than 1,000 persons per square mile in an individual block group level. Statistics are presented by population density determined at the census tract level in order to allow comparisons with previous chapters.

口 The "Other" category for statistics by the extended mode categorization (9 categories) contains Airplane, Taxicab, Bicycle, School Bus, and Other Non-POVs in 1995. In 2001, these modes were added to the previously listed modes: Commuter, Charter/tour, and city-to-city buses, Ship/cruise, Passenger line/ferry, Sailboat/motorboat/yacht, Limousine, and Hotel/airport shuttle.

口 The "Other" category for statistics by the abbreviated mode categorization (Private, Public, Walk, Other, and Unreported) contains those modes used in the extended mode categorization, plus Amtrak.

"Other POV" was not an available mode category in the 2001 survey.

The "Other" category for statistics by trip purpose simply is data found in the "Other" category of the WHYTRP90 variable. 


\begin{tabular}{|c|c|c|c|c|}
\hline & New York State & $\begin{array}{c}5 \\
\text { Remainder of } \\
\text { U.S. }\end{array}$ & New York State & $\begin{array}{c}1 \\
\text { Remainder of } \\
\text { U.S. }\end{array}$ \\
\hline \multicolumn{5}{|l|}{ General Statistics } \\
\hline Households (000) & 6,848 & 92,858 & 7,183 & 100,182 \\
\hline Drivers (000) & 10,469 & 165,861 & 11,167 & 179,258 \\
\hline Workers (000) & 8,775 & 122,922 & 9,645 & 135,627 \\
\hline Vehicles (000) & 7,922 & 168,145 & 9,545 & 193,041 \\
\hline Workers per Household & 1.28 & 1.32 & 1.34 & 1.35 \\
\hline Vehicles per Household & 1.16 & 1.81 & 1.33 & 1.93 \\
\hline Vehicles per Driver & 0.76 & 1.01 & 0.85 & 1.08 \\
\hline Daily PMT per Person & 28.86 & 39.40 & 29.4 & 41.03 \\
\hline Daily VMT per Driver & 25.01 & 32.59 & 23.36 & 33.31 \\
\hline Daily Commute PMT per Worker & 13.97 & 16.08 & 10.79 & 13.78 \\
\hline \multicolumn{5}{|c|}{ Distribution of Households by Household Vehicle Count } \\
\hline ALL & $100 \%$ & $100 \%$ & $100 \%$ & $100 \%$ \\
\hline 0 vehicles & $26.8 \%$ & $6.9 \%$ & $26.5 \%$ & $6.8 \%$ \\
\hline 1 vehicle & $32.8 \%$ & $32.4 \%$ & $33.2 \%$ & $31.3 \%$ \\
\hline 2 vehicles & $29.7 \%$ & $41.1 \%$ & $27.2 \%$ & $37.9 \%$ \\
\hline 3 vehicles & $7.8 \%$ & $14.4 \%$ & $9.3 \%$ & $15.4 \%$ \\
\hline $4+$ vehicles & $2.9 \%$ & $5.3 \%$ & $3.9 \%$ & $8.6 \%$ \\
\hline \multicolumn{5}{|c|}{ Distribution of Households by Household Income (2001 Dollars) } \\
\hline ALL & $100 \%$ & $100 \%$ & $100 \%$ & $100 \%$ \\
\hline$<\$ 10,000$ Households & $7.1 \%$ & $6.5 \%$ & $9.2 \%$ & $8.7 \%$ \\
\hline$\$ 10$ to $\$ 20,000$ Households & $11.1 \%$ & $11.7 \%$ & $12.2 \%$ & $12.1 \%$ \\
\hline$\$ 20$ to $\$ 30,000$ Households & $11.5 \%$ & $12.7 \%$ & $12.2 \%$ & $13.3 \%$ \\
\hline$\$ 30$ to $\$ 40,000$ Households & $10.7 \%$ & $12.2 \%$ & $11.3 \%$ & $12.8 \%$ \\
\hline$\$ 40$ to $\$ 50,000$ Households & $9.2 \%$ & $10.5 \%$ & $9.2 \%$ & $10.3 \%$ \\
\hline$\$ 50$ to $\$ 60,000$ Households & $7.4 \%$ & $8.2 \%$ & $7.4 \%$ & $8.3 \%$ \\
\hline$\$ 60$ to $\$ 70,000$ Households & $5.6 \%$ & $5.9 \%$ & $5.6 \%$ & $6.0 \%$ \\
\hline$\$ 70$ to $\$ 80,000$ Households & $4.2 \%$ & $4.2 \%$ & $4.9 \%$ & $5.1 \%$ \\
\hline$\$ 80,000+$ Households & $13.7 \%$ & $11.7 \%$ & $17.7 \%$ & $15.4 \%$ \\
\hline Unreported Households & $19.5 \%$ & $16.5 \%$ & $10.3 \%$ & $8.1 \%$ \\
\hline \multicolumn{5}{|l|}{ Driver Rate } \\
\hline$\%$ Female Drivers/Female 16+ & $68.4 \%$ & $86.6 \%$ & $71.1 \%$ & $87.7 \%$ \\
\hline$\%$ Male Drivers/Male 16+ & $84.1 \%$ & $93.2 \%$ & $83.5 \%$ & $93.3 \%$ \\
\hline
\end{tabular}


Chapter 2: Table 2

Comparison of NY State Data to the Rest of the United States

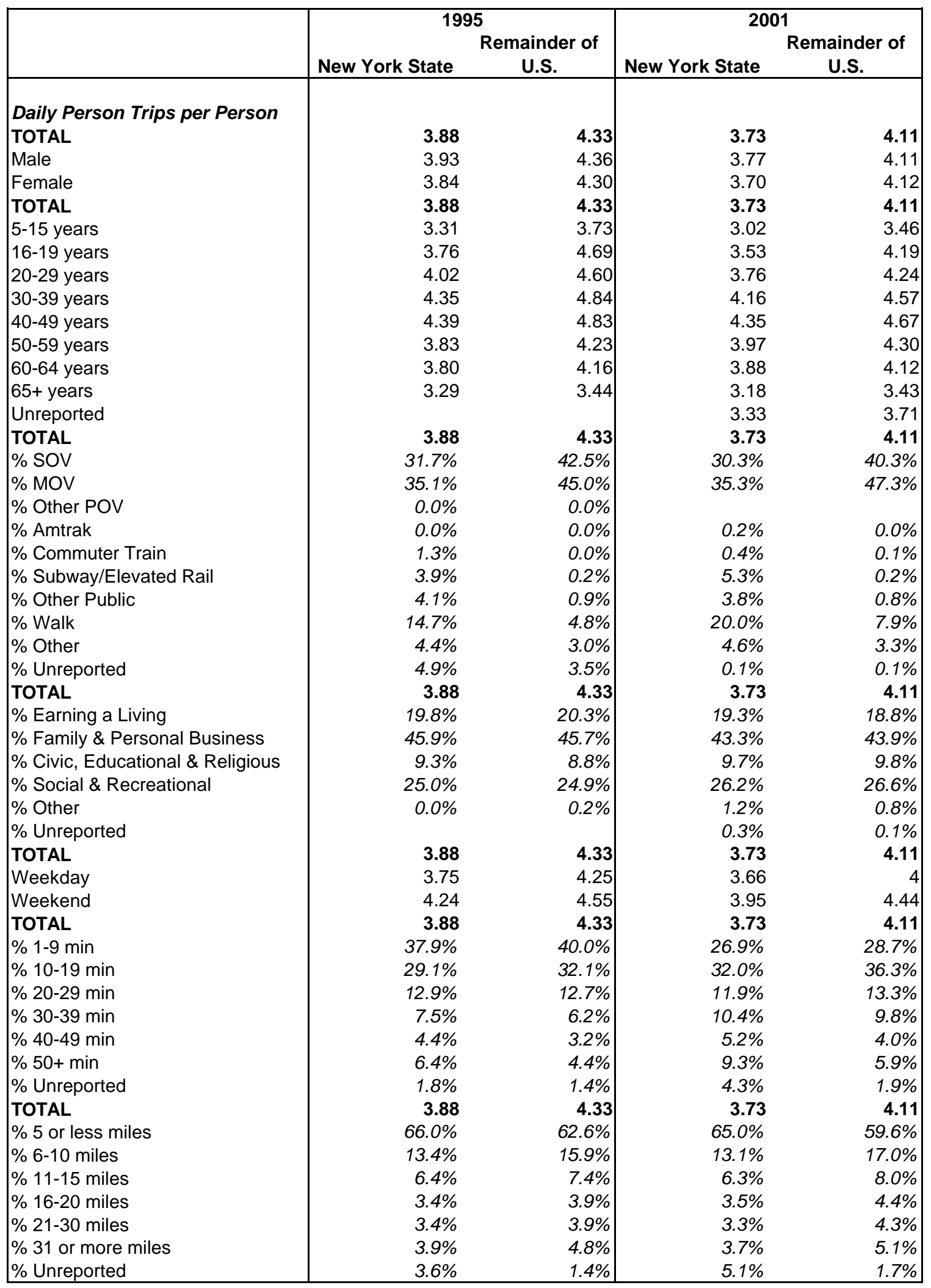




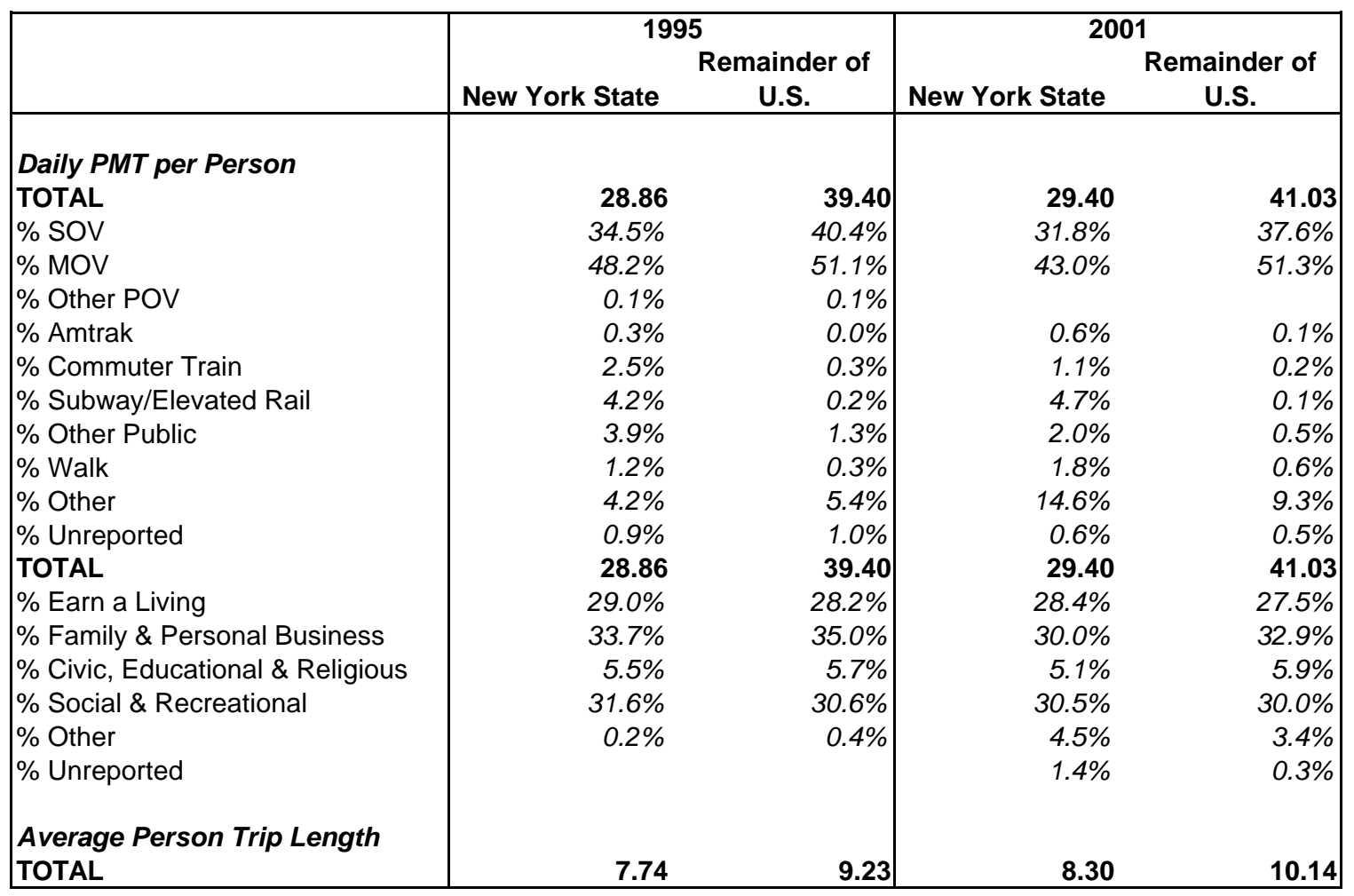




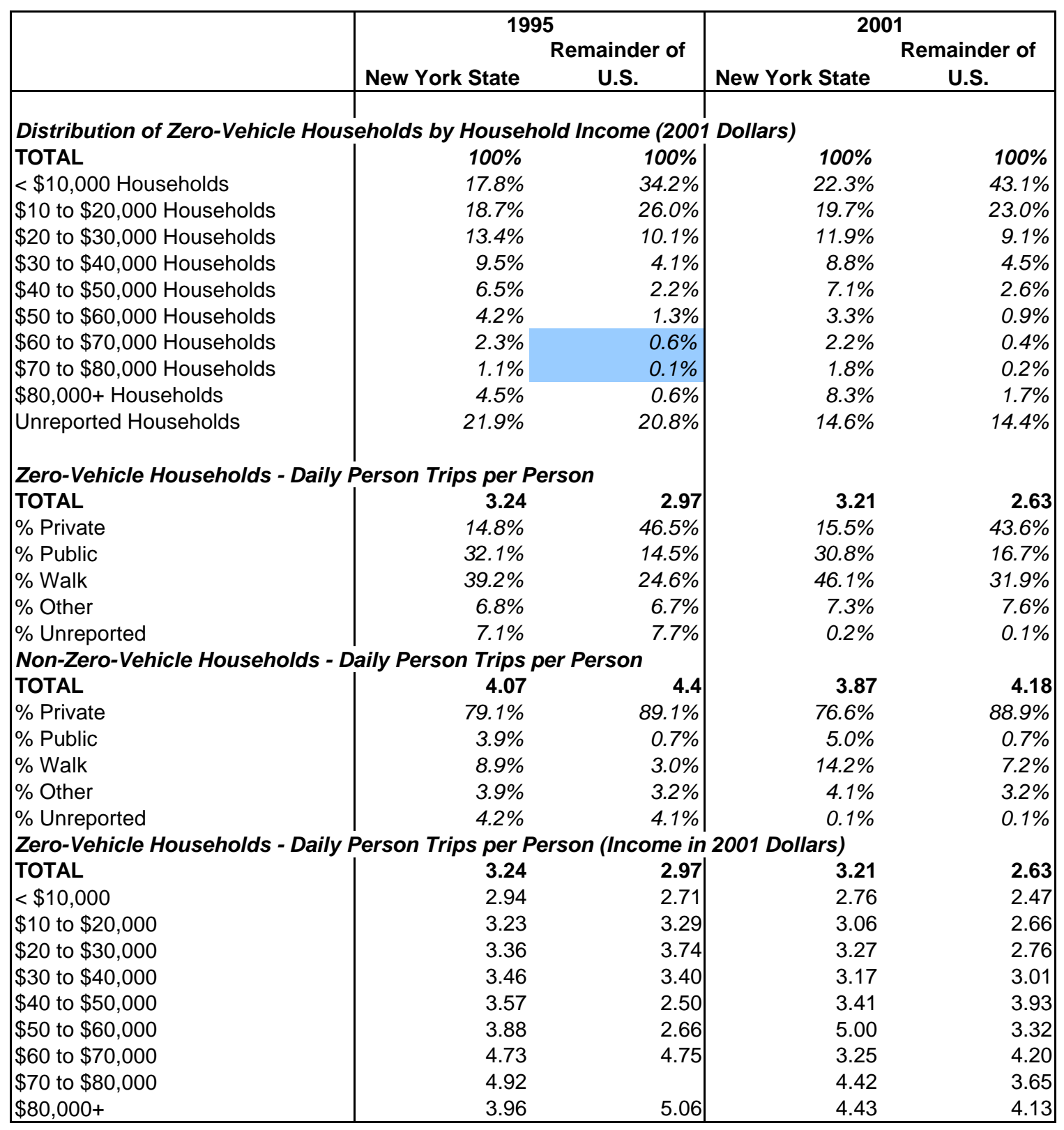




\begin{tabular}{|c|c|c|c|c|}
\hline & New York State & $\begin{array}{l}\text { lainder of } \\
\text { U.S. }\end{array}$ & New York State & $\begin{array}{l}\text { Remainder of } \\
\text { U.S. }\end{array}$ \\
\hline \multicolumn{5}{|c|}{ Zero-Vehicle Households - Daily PMT per Person (Income in 2001 Dollars) } \\
\hline TOTAL & 15.01 & 13.61 & 16.82 & 18.56 \\
\hline$\%$ Private & $39.4 \%$ & $68.7 \%$ & $20.0 \%$ & $56.6 \%$ \\
\hline$\%$ Public & $45.5 \%$ & $21.6 \%$ & $30.6 \%$ & $10.6 \%$ \\
\hline$\%$ Walk & $5.3 \%$ & $5.3 \%$ & $5.8 \%$ & $3.0 \%$ \\
\hline$\%$ Other & $9.0 \%$ & $3.0 \%$ & $43.6 \%$ & $29.6 \%$ \\
\hline$\%$ Unreported & $0.8 \%$ & $1.4 \%$ & $0.1 \%$ & $0.1 \%$ \\
\hline TOTAL & 15.01 & 13.61 & 16.82 & 18.56 \\
\hline$<\$ 10,000$ & 12.51 & 12.19 & 9.58 & 9.50 \\
\hline$\$ 10$ to $\$ 20,000$ & 13.70 & 14.59 & 9.03 & 10.26 \\
\hline$\$ 20$ to $\$ 30,000$ & 15.40 & 15.46 & 13.8 & 37.43 \\
\hline$\$ 30$ to $\$ 40,000$ & 17.76 & 17.80 & 12.42 & 21.42 \\
\hline$\$ 40$ to $\$ 50,000$ & 19.53 & 19.42 & 14.44 & 154.95 \\
\hline$\$ 50$ to $\$ 60,000$ & 19.65 & 17.48 & 14.78 & 10.71 \\
\hline$\$ 60$ to $\$ 70,000$ & 18.11 & 12.54 & 31.07 & 40.32 \\
\hline$\$ 70$ to $\$ 80,000$ & 19.23 & & 17.48 & 81.42 \\
\hline$\$ 80,000_{+}$ & 17.48 & 41.84 & 77.47 & 52.45 \\
\hline
\end{tabular}




\begin{tabular}{|c|c|c|c|c|}
\hline & New York State & $\begin{array}{l}5 \\
\text { Remainder of } \\
\text { U.S. }\end{array}$ & New York State & $\begin{array}{l}\text { Remainder of } \\
\text { U.S. }\end{array}$ \\
\hline \multicolumn{5}{|l|}{ Daily Vehicle Trips per Driver } \\
\hline TOTAL & 2.88 & 3.61 & 2.67 & 3.40 \\
\hline$\%$ Earning a Living & $26.7 \%$ & $27.4 \%$ & $25.5 \%$ & $26.2 \%$ \\
\hline$\%$ Family \& Personal Business & $51.0 \%$ & $49.9 \%$ & $49.0 \%$ & $48.0 \%$ \\
\hline$\%$ Civic, Educational \& Religious & $3.8 \%$ & $4.2 \%$ & $4.1 \%$ & $4.9 \%$ \\
\hline$\%$ Social \& Recreational & $18.4 \%$ & $18.3 \%$ & $20.6 \%$ & $20.3 \%$ \\
\hline$\%$ Other & $0.0 \%$ & $0.1 \%$ & $0.6 \%$ & $0.5 \%$ \\
\hline$\%$ Unreported & & & $0.2 \%$ & $0.1 \%$ \\
\hline TOTAL & 2.88 & 3.61 & 2.67 & 3.40 \\
\hline$\% 1-9 \min$ & $39.6 \%$ & $40.2 \%$ & $30.1 \%$ & $29.9 \%$ \\
\hline$\% 10-19 \min$ & $31.3 \%$ & $33.0 \%$ & $35.9 \%$ & $37.3 \%$ \\
\hline$\% 20-29 \mathrm{~min}$ & $13.5 \%$ & $13.3 \%$ & $13.3 \%$ & $13.7 \%$ \\
\hline$\% 30-39 \mathrm{~min}$ & $6.3 \%$ & $6.4 \%$ & $9.9 \%$ & $9.5 \%$ \\
\hline$\% 40-49 \mathrm{~min}$ & $3.8 \%$ & $3.3 \%$ & $4.2 \%$ & $4.0 \%$ \\
\hline$\% 50+\min$ & $4.9 \%$ & $3.9 \%$ & $6.0 \%$ & $5.1 \%$ \\
\hline$\%$ Unreported & $0.6 \%$ & $0.0 \%$ & $0.6 \%$ & $0.6 \%$ \\
\hline TOTAL & 2.88 & 3.61 & 2.67 & 3.40 \\
\hline$\% 5$ or less miles & $60.4 \%$ & $60.1 \%$ & $59.3 \%$ & $56.3 \%$ \\
\hline$\%$ 6-10 miles & $17.4 \%$ & $17.5 \%$ & $17.0 \%$ & $18.5 \%$ \\
\hline$\% 11-15$ miles & $8.3 \%$ & $8.3 \%$ & $8.4 \%$ & $9.1 \%$ \\
\hline$\% 16-20$ miles & $4.2 \%$ & $4.4 \%$ & $4.6 \%$ & $4.9 \%$ \\
\hline$\% 21-30$ miles & $4.2 \%$ & $4.4 \%$ & $4.3 \%$ & $4.9 \%$ \\
\hline$\% 31$ or more miles & $4.5 \%$ & $4.7 \%$ & $4.6 \%$ & $5.3 \%$ \\
\hline$\%$ Unreported & $1.0 \%$ & $0.6 \%$ & $1.9 \%$ & $1.0 \%$ \\
\hline TOTAL & 2.88 & 3.61 & 2.67 & 3.40 \\
\hline Weekday & 2.85 & 3.70 & 2.68 & 3.46 \\
\hline Weekend & 3.00 & 3.43 & 2.68 & 3.26 \\
\hline \multicolumn{5}{|l|}{ Daily PMT per Driver } \\
\hline TOTAL & 25.01 & 32.59 & 23.36 & 33.31 \\
\hline \% Earn a Living & $37.0 \%$ & $37.8 \%$ & $34.8 \%$ & $35.5 \%$ \\
\hline \% Family \& Personal Business & $35.1 \%$ & $35.5 \%$ & $34.8 \%$ & $35.3 \%$ \\
\hline$\%$ Civic, Educational \& Religious & $2.8 \%$ & $3.8 \%$ & $3.3 \%$ & $3.8 \%$ \\
\hline$\%$ Social \& Recreational & $24.8 \%$ & $22.7 \%$ & $26.1 \%$ & $24.4 \%$ \\
\hline$\%$ Other & $0.2 \%$ & $0.1 \%$ & $0.8 \%$ & $0.8 \%$ \\
\hline$\%$ Unreported & & & $0.3 \%$ & $0.2 \%$ \\
\hline \multicolumn{5}{|l|}{ Average Vehicle Trip Length } \\
\hline TOTAL & 8.78 & 9.07 & 8.92 & 9.91 \\
\hline \multicolumn{5}{|l|}{ \% Vehicle Trips/Person Trips } \\
\hline TOTAL & 46.29 & 61.59 & 45.92 & 61.59 \\
\hline$\%$ VMT/PMT & & & & \\
\hline TOTAL & 53.97 & 61.00 & 51.00 & 60.59 \\
\hline
\end{tabular}




\begin{tabular}{|c|c|c|c|c|}
\hline & New York State & $\begin{array}{l}5 \\
\text { Remainder of } \\
\text { U.S. } \\
\end{array}$ & New York State & $\begin{array}{l}\text { Remainder of } \\
\text { U.S. }\end{array}$ \\
\hline \multicolumn{5}{|l|}{ Daily Commute Trips per Worker } \\
\hline$\%$ SOV & $56.5 \%$ & $75.7 \%$ & $55.3 \%$ & $77.7 \%$ \\
\hline$\% \mathrm{MOV}$ & $13.0 \%$ & $16.4 \%$ & $12.6 \%$ & $16.4 \%$ \\
\hline$\%$ Other POV & $0.0 \%$ & $0.0 \%$ & & \\
\hline$\%$ Amtrak & $0.0 \%$ & $0.0 \%$ & $0.7 \%$ & $0.1 \%$ \\
\hline$\%$ Commuter Train & $3.1 \%$ & $0.7 \%$ & $1.8 \%$ & $0.3 \%$ \\
\hline$\%$ Subway/Elevated Rail & $9.9 \%$ & $0.7 \%$ & $12.8 \%$ & $0.5 \%$ \\
\hline$\%$ Other Public & $5.3 \%$ & $1.4 \%$ & $5.5 \%$ & $1.6 \%$ \\
\hline$\%$ Walk & $6.1 \%$ & $2.1 \%$ & $8.7 \%$ & $2.4 \%$ \\
\hline$\%$ Other & $2.3 \%$ & $1.4 \%$ & $2.4 \%$ & $0.9 \%$ \\
\hline$\%$ Unreported & $3.8 \%$ & $1.6 \%$ & $0.1 \%$ & $0.1 \%$ \\
\hline TOTAL & 1.31 & 1.40 & 1.12 & 1.15 \\
\hline$\% 1-6 \mathrm{am}$ & $4.5 \%$ & $5.7 \%$ & $4.9 \%$ & $6.2 \%$ \\
\hline$\% 6-9$ am & $29.3 \%$ & $28.6 \%$ & $30.9 \%$ & $30.1 \%$ \\
\hline$\% 9$ am-1 pm & $12.0 \%$ & $12.9 \%$ & $11.0 \%$ & $11.5 \%$ \\
\hline$\% 1-4 \mathrm{pm}$ & $14.3 \%$ & $15.0 \%$ & $13.8 \%$ & $14.3 \%$ \\
\hline$\% 4-7$ pm & $25.6 \%$ & $26.4 \%$ & $26.2 \%$ & $25.5 \%$ \\
\hline$\% 7-10 \mathrm{pm}$ & $9.0 \%$ & $7.1 \%$ & $8.5 \%$ & $8.1 \%$ \\
\hline$\% 10 \mathrm{pm}-1 \mathrm{am}$ & $5.3 \%$ & $4.3 \%$ & $4.7 \%$ & $4.3 \%$ \\
\hline$\%$ Unreported & & & $0.1 \%$ & $0.1 \%$ \\
\hline \multicolumn{5}{|l|}{ Daily Commute PMT per Worker } \\
\hline TOTAL & 13.97 & 16.08 & 10.79 & 13.78 \\
\hline$\%$ SOV & $62.5 \%$ & $76.8 \%$ & $64.7 \%$ & $77.7 \%$ \\
\hline$\% \mathrm{MOV}$ & $15.0 \%$ & $17.2 \%$ & $12.8 \%$ & $16.1 \%$ \\
\hline$\%$ Other POV & $0.1 \%$ & $0.1 \%$ & & \\
\hline$\%$ Amtrak & $0.0 \%$ & $0.1 \%$ & $1.0 \%$ & $0.3 \%$ \\
\hline$\%$ Commuter Train & $5.9 \%$ & $0.7 \%$ & $4.5 \%$ & $0.7 \%$ \\
\hline \% Subway/Elevated Rail & $8.4 \%$ & $0.4 \%$ & $10.9 \%$ & $0.5 \%$ \\
\hline$\%$ Other Public & $3.7 \%$ & $1.5 \%$ & $2.7 \%$ & $1.0 \%$ \\
\hline$\%$ Walk & $0.6 \%$ & $0.1 \%$ & $1.1 \%$ & $0.2 \%$ \\
\hline$\%$ Other & $3.1 \%$ & $2.2 \%$ & $2.1 \%$ & $3.5 \%$ \\
\hline$\%$ Unreported & $0.7 \%$ & $0.9 \%$ & $0.2 \%$ & $0.1 \%$ \\
\hline TOTAL & 13.97 & 16.08 & 10.79 & 13.78 \\
\hline$\% 1-6$ am & $6.4 \%$ & $8.6 \%$ & $7.7 \%$ & $9.6 \%$ \\
\hline$\%$ 6-9 am & $30.8 \%$ & $29.0 \%$ & $33.0 \%$ & $31.9 \%$ \\
\hline$\% 9$ am-1 pm & $10.3 \%$ & $9.5 \%$ & $8.6 \%$ & $8.4 \%$ \\
\hline$\% 1-4 \mathrm{pm}$ & $13.6 \%$ & $14.6 \%$ & $12.9 \%$ & $13.1 \%$ \\
\hline$\% 4-7 \mathrm{pm}$ & $26.1 \%$ & $26.5 \%$ & $25.9 \%$ & $24.2 \%$ \\
\hline$\% 7-10 \mathrm{pm}$ & $8.0 \%$ & $7.6 \%$ & $7.5 \%$ & $8.7 \%$ \\
\hline$\% 10 \mathrm{pm}-1 \mathrm{am}$ & $4.7 \%$ & $4.2 \%$ & $4.3 \%$ & $4.1 \%$ \\
\hline$\%$ Unreported & & & $0.1 \%$ & $0.1 \%$ \\
\hline
\end{tabular}




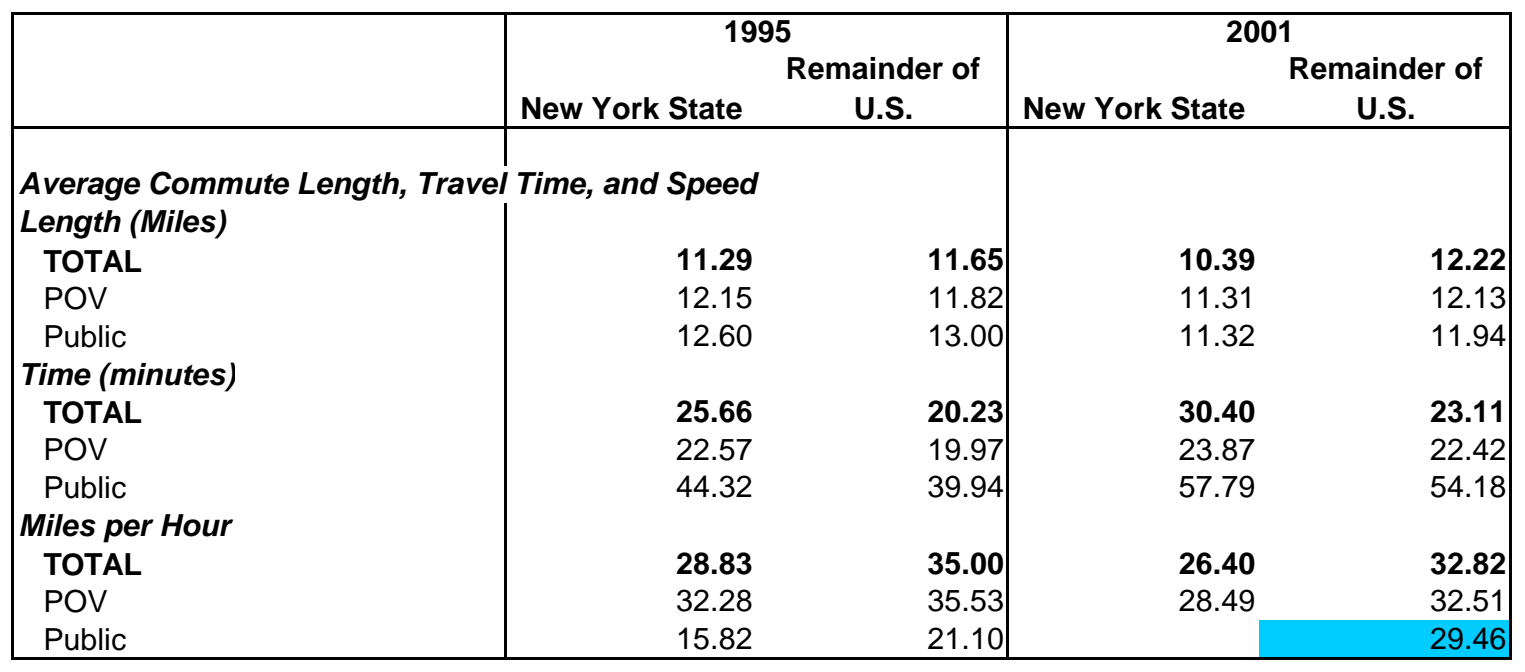




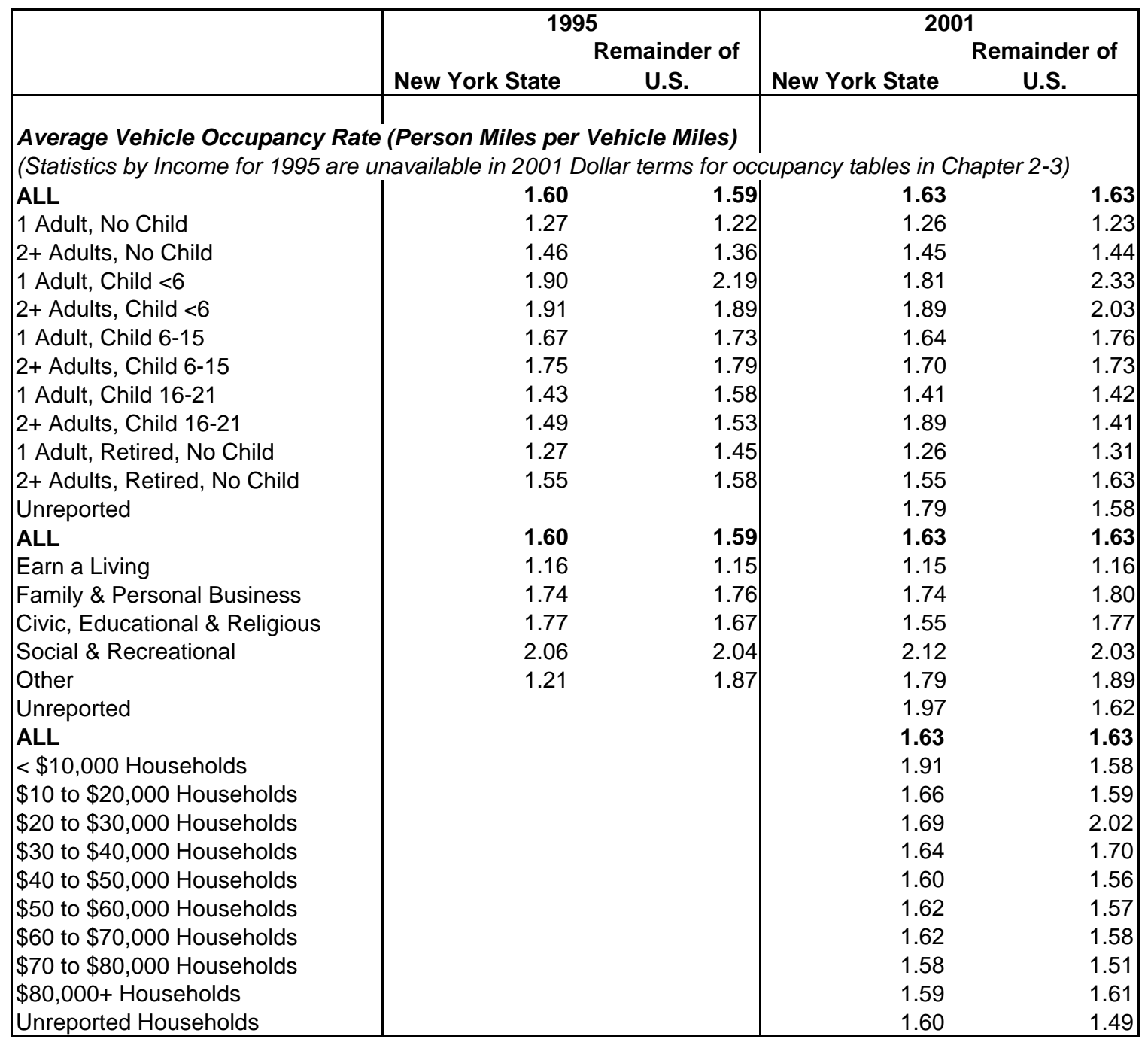


Chapter 3: Table 1

Influence of NY State Metropolitan Data on Overall NY Travel Patterns

\begin{tabular}{|c|c|c|c|c|c|c|c|c|}
\hline & \multicolumn{4}{|c|}{1995} & \multicolumn{4}{|c|}{2001} \\
\hline & $\begin{array}{c}\text { New York } \\
\text { City }\end{array}$ & $\begin{array}{c}\text { Remainder } \\
\text { NY State }\end{array}$ & $\begin{array}{c}\text { Remainder } \\
\text { of U.S. }\end{array}$ & $\%$ NYC of NYS & $\begin{array}{c}\text { New York } \\
\text { City }\end{array}$ & $\begin{array}{c}\text { Remainder } \\
\text { NY State }\end{array}$ & $\begin{array}{c}\text { Remainder } \\
\text { of U.S. }\end{array}$ & $\%$ NYC of NYS \\
\hline \multicolumn{9}{|l|}{ General Statistics } \\
\hline Households (000) & 2,920 & 3,928 & 92,858 & $42.6 \%$ & 3,076 & 4,108 & 100,182 & $42.8 \%$ \\
\hline Persons (000) & 6,792 & 10,015 & 224,868 & $40.4 \%$ & 7,928 & 10,708 & 258,568 & $42.5 \%$ \\
\hline Persons 5+ $(000)$ & & & & & 7,439 & 9,955 & 240,182 & $42.8 \%$ \\
\hline Drivers $(000)$ & 3,218 & 7,251 & 165,861 & $30.7 \%$ & 3,779 & 7,388 & 179,258 & $33.8 \%$ \\
\hline Workers $(000)$ & 3,404 & 5,371 & 122,922 & $38.8 \%$ & 4,045 & 5,601 & 135,627 & $41.9 \%$ \\
\hline Vehicles $(000)$ & 1,600 & 6,322 & 168,145 & $20.2 \%$ & 2,085 & 7,461 & 193,041 & $21.8 \%$ \\
\hline 0 -vehicle households $(000)$ & 1,544 & 291 & 6,368 & $84.1 \%$ & 1,587 & 314 & 6,815 & $83.5 \%$ \\
\hline Workers per $\mathrm{HH}$ & 1.17 & 1.37 & 1.32 & & 1.32 & 1.36 & 1.35 & \\
\hline Vehicles per HH & 0.55 & 1.61 & 1.81 & & 0.68 & 1.82 & 1.93 & \\
\hline Vehicles per $\mathrm{Dr}$ & 0.50 & 0.87 & 1.01 & & 0.55 & 1.01 & 1.08 & \\
\hline \multicolumn{9}{|c|}{ Distribution of Households by Household } \\
\hline ALL & $100 \%$ & $100 \%$ & $100 \%$ & & $100 \%$ & $100 \%$ & $100 \%$ & \\
\hline 0 vehicles & $52.9 \%$ & $7.4 \%$ & $6.9 \%$ & & $51.6 \%$ & $7.6 \%$ & $6.8 \%$ & \\
\hline 1 vehicle & $33.8 \%$ & $32.1 \%$ & $32.4 \%$ & & $33.7 \%$ & $32.8 \%$ & $31.3 \%$ & \\
\hline 2 vehicles & $11.2 \%$ & $43.3 \%$ & $41.1 \%$ & & $11.3 \%$ & $39.0 \%$ & $37.9 \%$ & \\
\hline 3 vehicles & $1.6 \%$ & $12.4 \%$ & $14.4 \%$ & & $2.7 \%$ & $14.3 \%$ & $15.4 \%$ & \\
\hline $4+$ vehicles & $0.5 \%$ & $4.7 \%$ & $5.3 \%$ & & $0.7 \%$ & $6.3 \%$ & $8.6 \%$ & \\
\hline \multicolumn{9}{|c|}{ Distribution of Households by Household Income (2001 Dollars) } \\
\hline ALL & $100 \%$ & $100 \%$ & $100 \%$ & & $100 \%$ & $100 \%$ & $100 \%$ & \\
\hline$<\$ 10,000$ Households & $9.6 \%$ & $5.3 \%$ & $6.5 \%$ & & $12.5 \%$ & $6.7 \%$ & $8.7 \%$ & \\
\hline$\$ 10$ to $\$ 20,000$ Households & $12.6 \%$ & $9.9 \%$ & $11.7 \%$ & & $12.9 \%$ & $11.7 \%$ & $12.1 \%$ & \\
\hline$\$ 20$ to $\$ 30,000$ Households & $12.3 \%$ & $10.9 \%$ & $12.7 \%$ & & $12.3 \%$ & $12.0 \%$ & $13.3 \%$ & \\
\hline$\$ 30$ to $\$ 40,000$ Households & $10.8 \%$ & $10.7 \%$ & $12.2 \%$ & & $11.1 \%$ & $11.5 \%$ & $12.8 \%$ & \\
\hline$\$ 40$ to $\$ 50,000$ Households & $8.6 \%$ & $9.7 \%$ & $10.5 \%$ & & $8.5 \%$ & $9.8 \%$ & $10.3 \%$ & \\
\hline$\$ 50$ to $\$ 60,000$ Households & $6.3 \%$ & $8.2 \%$ & $8.2 \%$ & & $6.7 \%$ & $7.8 \%$ & $8.3 \%$ & \\
\hline$\$ 60$ to $\$ 70,000$ Households & $4.5 \%$ & $6.4 \%$ & $5.9 \%$ & & $4.7 \%$ & $6.2 \%$ & $6.0 \%$ & \\
\hline$\$ 70$ to $\$ 80,000$ Households & $3.3 \%$ & $4.8 \%$ & $4.2 \%$ & & $3.8 \%$ & $5.8 \%$ & $5.1 \%$ & \\
\hline$\$ 80,000+$ Households & $11.6 \%$ & $15.3 \%$ & $11.7 \%$ & & $15.6 \%$ & $19.2 \%$ & $15.4 \%$ & \\
\hline Unreported & $20.5 \%$ & $18.8 \%$ & $16.5 \%$ & & $11.9 \%$ & $9.1 \%$ & $8.1 \%$ & \\
\hline \multicolumn{9}{|l|}{ Driver Rate } \\
\hline$\%$ Female Drivers/Female $16+$ & $44.5 \%$ & $85.9 \%$ & $86.6 \%$ & & $49.7 \%$ & $87.8 \%$ & $87.7 \%$ & \\
\hline$\%$ Male Drivers/Male $16+$ & $71.4 \%$ & $92.4 \%$ & $93.2 \%$ & & $71.5 \%$ & $92.5 \%$ & $93.3 \%$ & \\
\hline
\end{tabular}


Chapter 3: Table 2

Influence of NY State Metropolitan Data on Overall NY Travel Patterns

\begin{tabular}{|c|c|c|c|c|c|c|}
\hline & \multicolumn{3}{|c|}{1995} & \multicolumn{3}{|c|}{2001} \\
\hline & $\begin{array}{c}\text { New York } \\
\text { City }\end{array}$ & $\begin{array}{l}\text { Remainder } \\
\text { NY State }\end{array}$ & $\begin{array}{c}\text { Remainder } \\
\text { of U.S. }\end{array}$ & $\begin{array}{c}\text { New York } \\
\text { City }\end{array}$ & $\begin{array}{c}\text { Remainder } \\
\text { NY State }\end{array}$ & $\begin{array}{c}\text { Remainder } \\
\text { of U.S. }\end{array}$ \\
\hline \multicolumn{7}{|c|}{ Daily Person Trips per Person } \\
\hline TOTAL & 3.58 & 4.08 & 4.33 & 3.44 & 3.95 & 4.11 \\
\hline Male & 3.63 & 4.12 & 4.36 & 3.54 & 3.93 & 4.11 \\
\hline Female & 3.54 & 4.05 & 4.30 & 3.35 & 3.97 & 4.12 \\
\hline TOTAL & 3.58 & 4.08 & 4.33 & 3.44 & 3.95 & 4.11 \\
\hline $0-4$ years & & & & 2.67 & 2.61 & 3.22 \\
\hline $5-15$ years & 3.09 & 3.44 & 3.73 & 2.71 & 3.21 & 3.46 \\
\hline $16-19$ years & 3.18 & 4.22 & 4.69 & 3.08 & 3.97 & 4.19 \\
\hline 20-34 years & 3.96 & 4.29 & 4.67 & 3.77 & 3.98 & 4.30 \\
\hline $35-54$ years & 3.84 & 4.55 & 4.75 & 3.89 & 4.47 & 4.64 \\
\hline $55-64$ years & 3.28 & 4.15 & 4.19 & 3.66 & 4.18 & 4.13 \\
\hline $65+$ years & 2.95 & 3.46 & 3.44 & 2.57 & 3.56 & 3.43 \\
\hline Unreported & & & & 3.03 & 3.61 & 3.71 \\
\hline TOTAL & 3.58 & 4.08 & 4.33 & 3.44 & 3.95 & 4.11 \\
\hline$\%$ SOV & $14.0 \%$ & $42.4 \%$ & $42.5 \%$ & $14.1 \%$ & $40.8 \%$ & $40.3 \%$ \\
\hline$\% \mathrm{MOV}$ & $21.8 \%$ & $43.1 \%$ & $45.0 \%$ & $21.9 \%$ & $44.1 \%$ & $47.3 \%$ \\
\hline$\%$ Other POV & $0.0 \%$ & $0.0 \%$ & $0.0 \%$ & & & \\
\hline$\%$ Amtrak & $0.0 \%$ & $0.0 \%$ & $0.0 \%$ & $0.4 \%$ & $0.1 \%$ & $0.0 \%$ \\
\hline$\%$ Commuter Train & $2.5 \%$ & $0.5 \%$ & $0.0 \%$ & $0.4 \%$ & $0.4 \%$ & $0.1 \%$ \\
\hline$\%$ Subway & $10.3 \%$ & $0.2 \%$ & $0.2 \%$ & $13.0 \%$ & $0.3 \%$ & $0.2 \%$ \\
\hline$\%$ Other Public Transit & $9.2 \%$ & $1.0 \%$ & $0.9 \%$ & $8.7 \%$ & $0.6 \%$ & $0.8 \%$ \\
\hline$\%$ Walk & $31.0 \%$ & $4.9 \%$ & $4.8 \%$ & $36.8 \%$ & $9.1 \%$ & $7.9 \%$ \\
\hline$\%$ Other & $5.0 \%$ & $4.2 \%$ & $3.0 \%$ & $4.6 \%$ & $4.6 \%$ & $3.3 \%$ \\
\hline$\%$ Unreported & $6.1 \%$ & $3.7 \%$ & $3.5 \%$ & $0.1 \%$ & $0.1 \%$ & $0.1 \%$ \\
\hline TOTAL & 3.58 & 4.08 & 4.33 & 3.44 & 3.95 & 4.11 \\
\hline$\%$ Earn a Living & $19.6 \%$ & $20.0 \%$ & $20.3 \%$ & $20.1 \%$ & $18.8 \%$ & $18.8 \%$ \\
\hline$\%$ Fam/Per Bus & $45.8 \%$ & $45.9 \%$ & $45.7 \%$ & $42.7 \%$ & $43.7 \%$ & $43.9 \%$ \\
\hline$\%$ Civ, Ed \& Rel & $10.6 \%$ & $8.5 \%$ & $8.8 \%$ & $11.1 \%$ & $8.8 \%$ & $9.8 \%$ \\
\hline$\%$ Social \& Recreational & $24.0 \%$ & $25.4 \%$ & $24.9 \%$ & $24.6 \%$ & $27.3 \%$ & $26.6 \%$ \\
\hline$\%$ Other & $0.0 \%$ & $0.2 \%$ & $0.2 \%$ & $1.3 \%$ & $1.1 \%$ & $0.8 \%$ \\
\hline$\%$ Unreported & & & & $0.3 \%$ & $0.3 \%$ & $0.1 \%$ \\
\hline TOTAL & 3.58 & 4.08 & 4.33 & 3.44 & 3.95 & 4.11 \\
\hline Weekday & 3.45 & 3.96 & 4.25 & 3.41 & 3.84 & 4.00 \\
\hline Weekend & 3.94 & 4.44 & 4.55 & 3.53 & 4.26 & 4.44 \\
\hline TOTAL & 3.58 & 4.08 & 4.33 & 3.44 & 3.95 & 4.11 \\
\hline$\% 1-9 \min$ & $32.7 \%$ & $40.9 \%$ & $40.0 \%$ & $21.6 \%$ & $30.4 \%$ & $28.7 \%$ \\
\hline$\% 10-19 \min$ & $26.0 \%$ & $31.1 \%$ & $32.1 \%$ & $27.9 \%$ & $34.6 \%$ & $36.3 \%$ \\
\hline$\% 20-29 \min$ & $13.1 \%$ & $12.5 \%$ & $12.7 \%$ & $10.3 \%$ & $13.0 \%$ & $13.3 \%$ \\
\hline$\% 30-39 \mathrm{~min}$ & $9.5 \%$ & $6.1 \%$ & $6.2 \%$ & $12.2 \%$ & $9.2 \%$ & $9.8 \%$ \\
\hline$\%$ 40-49 min & $6.7 \%$ & $3.2 \%$ & $3.2 \%$ & $7.2 \%$ & $3.8 \%$ & $4.0 \%$ \\
\hline$\% 50+\min$ & $9.2 \%$ & $4.9 \%$ & $4.4 \%$ & $13.7 \%$ & $6.5 \%$ & $5.9 \%$ \\
\hline$\%$ Unreported & $2.8 \%$ & $1.2 \%$ & $1.4 \%$ & $7.0 \%$ & $2.5 \%$ & $1.9 \%$ \\
\hline TOTAL & 3.58 & 4.08 & 4.33 & 3.44 & 3.95 & 4.11 \\
\hline$\% 5$ or less miles & $72.1 \%$ & $62.3 \%$ & $62.6 \%$ & $70.2 \%$ & $61.7 \%$ & $59.6 \%$ \\
\hline$\%$ 6-10 miles & $8.7 \%$ & $16.2 \%$ & $15.9 \%$ & $9.2 \%$ & $15.6 \%$ & $17.0 \%$ \\
\hline$\% 11-15$ miles & $5.0 \%$ & $7.4 \%$ & $7.4 \%$ & $4.4 \%$ & $7.5 \%$ & $8.0 \%$ \\
\hline$\% 16-20$ miles & $2.2 \%$ & $3.9 \%$ & $3.9 \%$ & $2.6 \%$ & $4.1 \%$ & $4.4 \%$ \\
\hline$\%$ 21-30 miles & $2.5 \%$ & $3.9 \%$ & $3.9 \%$ & $1.9 \%$ & $4.2 \%$ & $4.3 \%$ \\
\hline$\% 31$ or more miles & $2.2 \%$ & $4.7 \%$ & $4.9 \%$ & $1.9 \%$ & $5.0 \%$ & $5.1 \%$ \\
\hline$\%$ Unreported & $7.3 \%$ & $1.7 \%$ & $1.4 \%$ & $9.9 \%$ & $2.0 \%$ & $1.7 \%$ \\
\hline
\end{tabular}


Chapter 3: Table 3

Influence of NY State Metropolitan Data on Overall NY Travel Patterns

\begin{tabular}{|c|c|c|c|c|c|c|}
\hline & \multicolumn{3}{|c|}{1995} & \multicolumn{3}{|c|}{2001} \\
\hline & $\begin{array}{c}\text { New York } \\
\text { City }\end{array}$ & $\begin{array}{c}\text { Remainder } \\
\text { NY State }\end{array}$ & $\begin{array}{l}\text { Remainder } \\
\text { of U.S. }\end{array}$ & $\begin{array}{c}\text { New York } \\
\text { City }\end{array}$ & $\begin{array}{c}\text { Remainder } \\
\text { NY State }\end{array}$ & $\begin{array}{l}\text { Remainder } \\
\text { of U.S. }\end{array}$ \\
\hline Daily PMT per Person & & & & & & \\
\hline TOTAL & 19.08 & 35.5 & 39.4 & 21.11 & 35.6 & 41.03 \\
\hline$\%$ SOV & $20.5 \%$ & $39.6 \%$ & $40.4 \%$ & $16.5 \%$ & $38.6 \%$ & $37.6 \%$ \\
\hline$\%$ MOV & $38.9 \%$ & $51.5 \%$ & $51.1 \%$ & $28.2 \%$ & $49.5 \%$ & $51.3 \%$ \\
\hline$\%$ Other POV & $0.3 \%$ & $0.0 \%$ & $0.1 \%$ & & & \\
\hline$\%$ Amtrak & $0.3 \%$ & $0.3 \%$ & $0.0 \%$ & $1.0 \%$ & $0.4 \%$ & $0.1 \%$ \\
\hline$\%$ Commuter Train & $5.0 \%$ & $1.6 \%$ & $0.3 \%$ & $0.6 \%$ & $1.3 \%$ & $0.2 \%$ \\
\hline \% Subway & $14.8 \%$ & $0.3 \%$ & $0.2 \%$ & $14.2 \%$ & $0.4 \%$ & $0.1 \%$ \\
\hline$\%$ Other Public Transit & $9.2 \%$ & $2.0 \%$ & $1.3 \%$ & $5.4 \%$ & $0.4 \%$ & $0.5 \%$ \\
\hline$\%$ Walk & $3.5 \%$ & $0.3 \%$ & $0.3 \%$ & $3.9 \%$ & $0.8 \%$ & $0.6 \%$ \\
\hline$\%$ Other & $6.6 \%$ & $3.3 \%$ & $5.4 \%$ & $29.1 \%$ & $8.1 \%$ & $9.3 \%$ \\
\hline$\%$ Unreported & $0.8 \%$ & $1.0 \%$ & $1.0 \%$ & $0.9 \%$ & $0.4 \%$ & $0.5 \%$ \\
\hline TOTAL & 19.08 & 35.5 & 39.4 & 21.11 & 35.6 & 41.03 \\
\hline$\%$ Earn a Living & $31.2 \%$ & $28.2 \%$ & $28.2 \%$ & $34.2 \%$ & $25.9 \%$ & $27.5 \%$ \\
\hline$\%$ Fam/Per Bus & $32.2 \%$ & $34.2 \%$ & $35.0 \%$ & $23.6 \%$ & $32.9 \%$ & $32.9 \%$ \\
\hline$\%$ Civ, Ed \& Rel & $6.7 \%$ & $5.1 \%$ & $5.7 \%$ & $5.3 \%$ & $5.1 \%$ & $5.9 \%$ \\
\hline \% Social \& Recreational & $30.0 \%$ & $32.2 \%$ & $30.6 \%$ & $24.3 \%$ & $33.3 \%$ & $30.0 \%$ \\
\hline$\%$ Other & $0.0 \%$ & $0.3 \%$ & $0.4 \%$ & $9.1 \%$ & $2.4 \%$ & $3.4 \%$ \\
\hline$\%$ Unreported & & & & $3.6 \%$ & $0.5 \%$ & $0.3 \%$ \\
\hline $\begin{array}{l}\text { Average Person Trip Length } \\
\text { TOTAL }\end{array}$ & 5.74 & 8.86 & 9.23 & 6.82 & 9.18 & 10.14 \\
\hline
\end{tabular}


Chapter 3: Table 4

Influence of NY State Metropolitan Data on Overall NY Travel Patterns

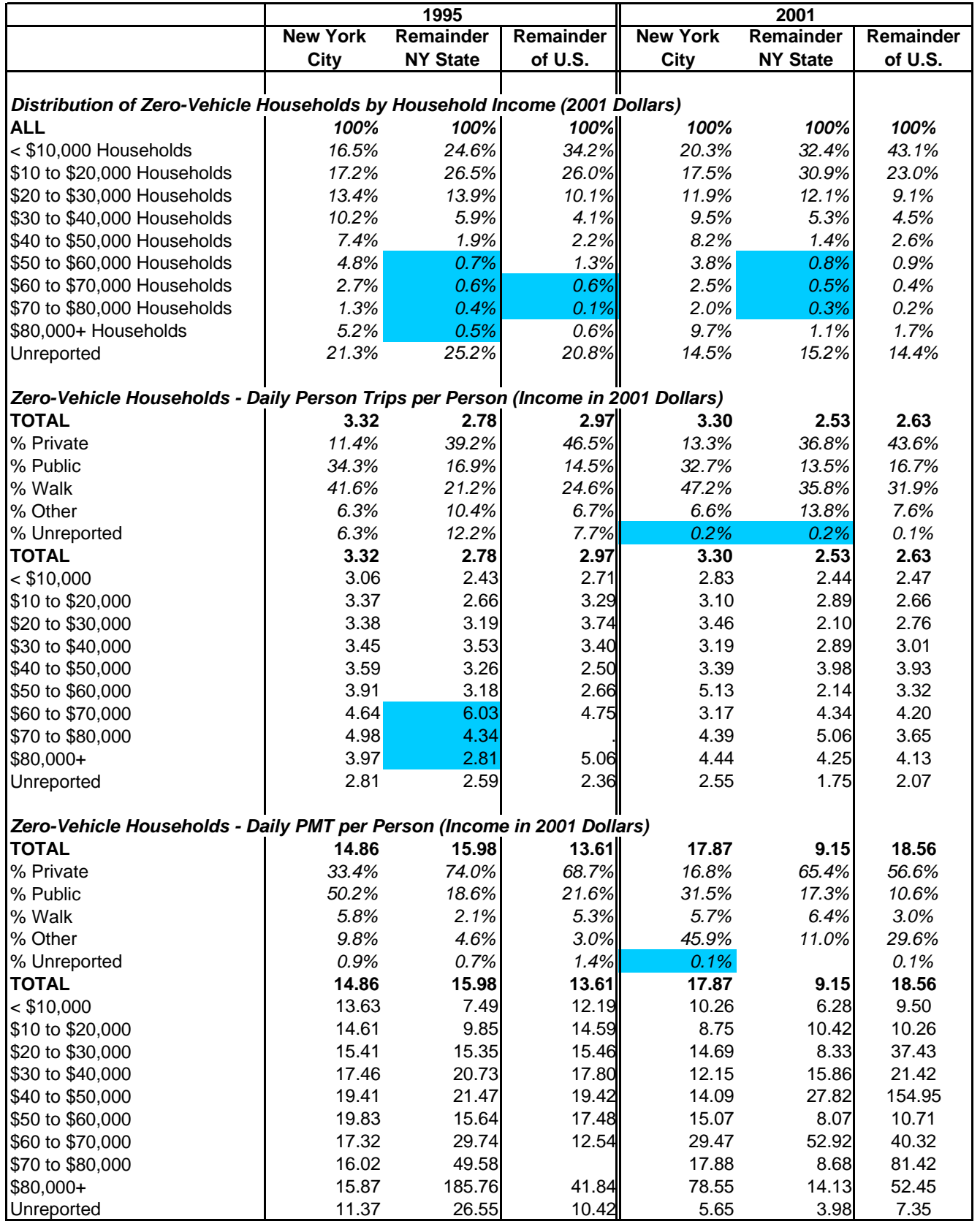


Chapter 3: Table 5

Influence of NY State Metropolitan Data on Overall NY Travel Patterns

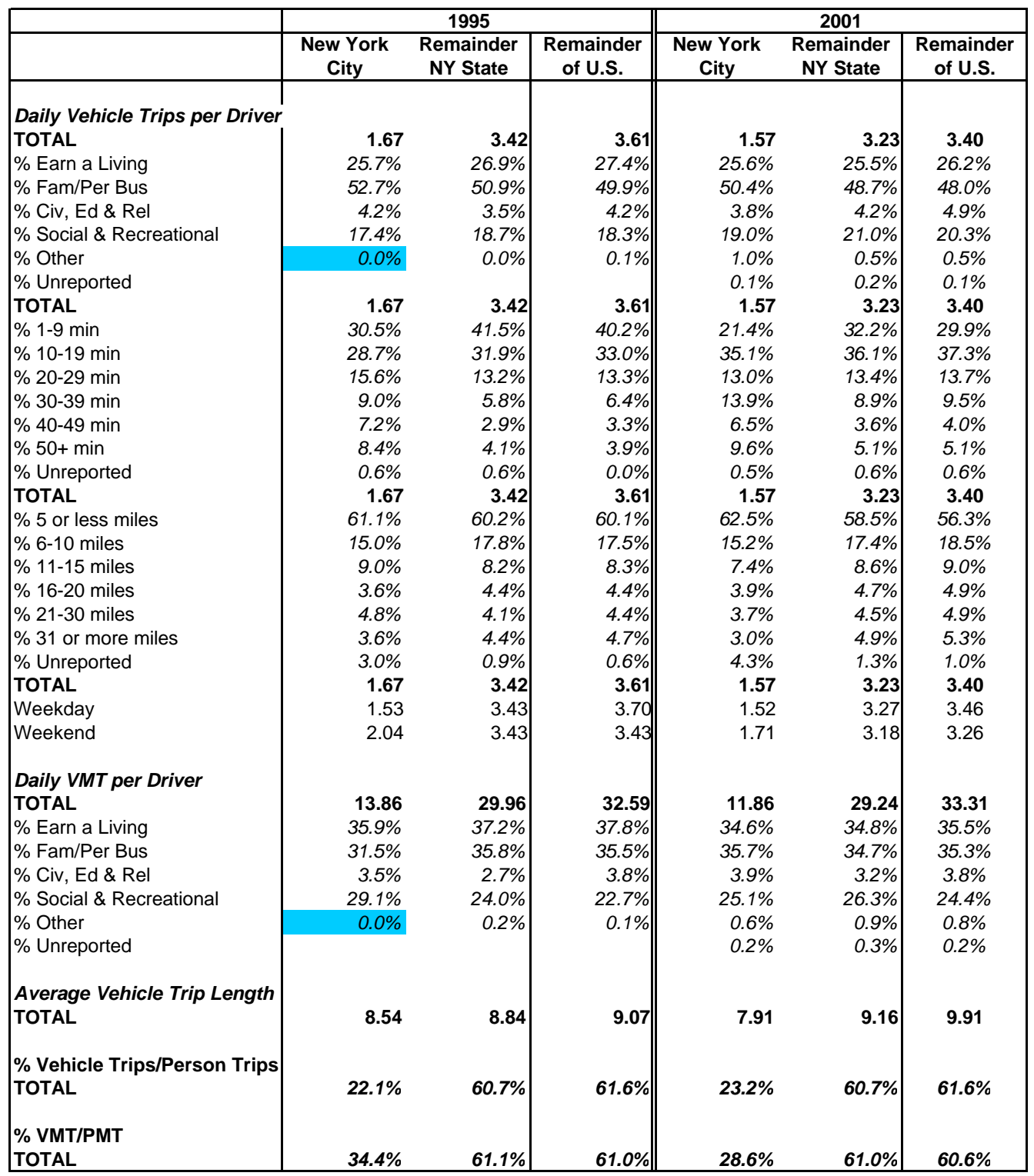


Chapter 3: Table 6

Influence of NY State Metropolitan Data on Overall NY Travel Patterns

\begin{tabular}{|c|c|c|c|c|c|c|}
\hline & \multicolumn{3}{|c|}{1995} & \multicolumn{3}{|c|}{2001} \\
\hline & $\begin{array}{c}\text { New York } \\
\text { City }\end{array}$ & $\begin{array}{c}\text { Remainder } \\
\text { NY State }\end{array}$ & $\begin{array}{c}\text { Remainder } \\
\text { of U.S. }\end{array}$ & $\begin{array}{c}\text { New York } \\
\text { City }\end{array}$ & $\begin{array}{c}\text { Remainder } \\
\text { NY State }\end{array}$ & $\begin{array}{c}\text { Remainder } \\
\text { of U.S. }\end{array}$ \\
\hline \multicolumn{7}{|c|}{ Daily Commute Trips per Worker } \\
\hline TOTAL & 1.26 & 1.34 & 1.40 & 1.08 & 1.14 & 1.15 \\
\hline$\%$ SOV & $25.4 \%$ & $75.4 \%$ & $75.7 \%$ & $25.0 \%$ & $76.1 \%$ & $77.7 \%$ \\
\hline$\% \mathrm{MOV}$ & $9.5 \%$ & $14.9 \%$ & $16.4 \%$ & $9.7 \%$ & $14.7 \%$ & $16.4 \%$ \\
\hline$\%$ Other POV & $0.0 \%$ & $0.0 \%$ & $0.0 \%$ & & & \\
\hline$\%$ Amtrak & $0.0 \%$ & $0.0 \%$ & $0.0 \%$ & $1.2 \%$ & $0.4 \%$ & $0.1 \%$ \\
\hline$\%$ Commuter Train & $5.6 \%$ & $2.2 \%$ & $0.7 \%$ & $1.4 \%$ & $2.1 \%$ & $0.3 \%$ \\
\hline$\%$ Subway & $26.2 \%$ & $0.7 \%$ & $0.7 \%$ & $30.3 \%$ & $0.7 \%$ & $0.5 \%$ \\
\hline$\%$ Other Public Transit & $11.9 \%$ & $1.5 \%$ & $1.4 \%$ & $12.2 \%$ & $1.0 \%$ & $1.6 \%$ \\
\hline$\%$ Walk & $13.5 \%$ & $2.2 \%$ & $2.1 \%$ & $16.0 \%$ & $3.8 \%$ & $2.4 \%$ \\
\hline$\%$ Other & $5.6 \%$ & $1.5 \%$ & $1.4 \%$ & $4.2 \%$ & $1.2 \%$ & $0.9 \%$ \\
\hline$\%$ Unreported & $2.4 \%$ & $1.5 \%$ & $1.6 \%$ & $0.0 \%$ & $0.2 \%$ & $0.1 \%$ \\
\hline TOTAL & 1.26 & 1.34 & 1.40 & 1.08 & 1.14 & 1.15 \\
\hline$\% 1-6$ am & $3.2 \%$ & $4.5 \%$ & $5.7 \%$ & $5.0 \%$ & $4.8 \%$ & $6.2 \%$ \\
\hline$\% 6-9$ am & $31.7 \%$ & $28.4 \%$ & $28.6 \%$ & $31.4 \%$ & $30.5 \%$ & $30.1 \%$ \\
\hline$\% 9$ am-1 pm & $9.5 \%$ & $13.4 \%$ & $12.9 \%$ & $10.1 \%$ & $11.7 \%$ & $11.5 \%$ \\
\hline$\% 1-4 \mathrm{pm}$ & $11.9 \%$ & $16.4 \%$ & $15.0 \%$ & $11.0 \%$ & $15.6 \%$ & $14.3 \%$ \\
\hline$\%$ 4-7 pm & $26.2 \%$ & $25.4 \%$ & $26.4 \%$ & $26.9 \%$ & $25.7 \%$ & $25.5 \%$ \\
\hline$\% 7-10 \mathrm{pm}$ & $11.9 \%$ & $6.7 \%$ & $7.1 \%$ & $10.4 \%$ & $7.2 \%$ & $8.1 \%$ \\
\hline$\% 10 \mathrm{pm}-1 \mathrm{am}$ & $5.6 \%$ & $4.5 \%$ & $4.3 \%$ & $5.1 \%$ & $4.4 \%$ & $4.3 \%$ \\
\hline$\%$ Unreported & $0.0 \%$ & $0.7 \%$ & $0.0 \%$ & $0.1 \%$ & $0.1 \%$ & $0.1 \%$ \\
\hline \multicolumn{7}{|c|}{ Daily Commute PMT per Worker } \\
\hline TOTAL & 10.70 & 16.04 & 16.08 & 7.48 & 13.18 & 13.78 \\
\hline$\%$ SOV & $33.6 \%$ & $74.8 \%$ & $76.8 \%$ & $33.5 \%$ & $77.4 \%$ & $77.7 \%$ \\
\hline$\% \mathrm{MOV}$ & $13.7 \%$ & $15.5 \%$ & $17.2 \%$ & $13.0 \%$ & $12.8 \%$ & $16.1 \%$ \\
\hline$\%$ Other POV & $0.2 \%$ & $0.0 \%$ & $0.1 \%$ & & & \\
\hline$\%$ Amtrak & $0.0 \%$ & $0.1 \%$ & $0.1 \%$ & $1.4 \%$ & $0.9 \%$ & $0.3 \%$ \\
\hline$\%$ Commuter Train & $6.6 \%$ & $5.5 \%$ & $0.7 \%$ & $2.3 \%$ & $5.3 \%$ & $0.7 \%$ \\
\hline \% Subway & $26.2 \%$ & $0.9 \%$ & $0.4 \%$ & $35.1 \%$ & $1.0 \%$ & $0.5 \%$ \\
\hline$\%$ Other Public Transit & $9.2 \%$ & $1.4 \%$ & $1.5 \%$ & $7.7 \%$ & $0.6 \%$ & $1.0 \%$ \\
\hline$\%$ Walk & $1.7 \%$ & $0.1 \%$ & $0.1 \%$ & $2.8 \%$ & $0.4 \%$ & $0.2 \%$ \\
\hline$\%$ Other & $8.1 \%$ & $0.9 \%$ & $2.2 \%$ & $4.1 \%$ & $1.3 \%$ & $3.5 \%$ \\
\hline$\%$ Unreported & $0.7 \%$ & $0.9 \%$ & $0.9 \%$ & $0.0 \%$ & $0.3 \%$ & $0.1 \%$ \\
\hline TOTAL & 10.70 & 16.04 & 16.08 & 7.48 & 13.18 & 13.78 \\
\hline$\% 1-6$ am & $4.9 \%$ & $7.2 \%$ & $8.6 \%$ & $7.6 \%$ & $7.8 \%$ & $9.6 \%$ \\
\hline$\%$ 6-9 am & $32.8 \%$ & $29.9 \%$ & $29.0 \%$ & $33.1 \%$ & $33.0 \%$ & $31.9 \%$ \\
\hline$\% 9$ am-1 pm & $7.1 \%$ & $11.7 \%$ & $9.5 \%$ & $7.6 \%$ & $9.0 \%$ & $8.4 \%$ \\
\hline$\% 1-4 \mathrm{pm}$ & $10.8 \%$ & $14.8 \%$ & $14.6 \%$ & $9.6 \%$ & $14.3 \%$ & $13.1 \%$ \\
\hline$\% 4-7$ pm & $27.8 \%$ & $25.3 \%$ & $26.5 \%$ & $27.7 \%$ & $25.1 \%$ & $24.2 \%$ \\
\hline$\% 7-10 \mathrm{pm}$ & $11.4 \%$ & $6.6 \%$ & $7.6 \%$ & $9.0 \%$ & $6.9 \%$ & $8.7 \%$ \\
\hline$\% 10 \mathrm{pm}-1 \mathrm{am}$ & $5.2 \%$ & $4.6 \%$ & $4.2 \%$ & $5.5 \%$ & $3.8 \%$ & $4.1 \%$ \\
\hline$\%$ Unreported & & & & $0.0 \%$ & $0.2 \%$ & $0.1 \%$ \\
\hline
\end{tabular}




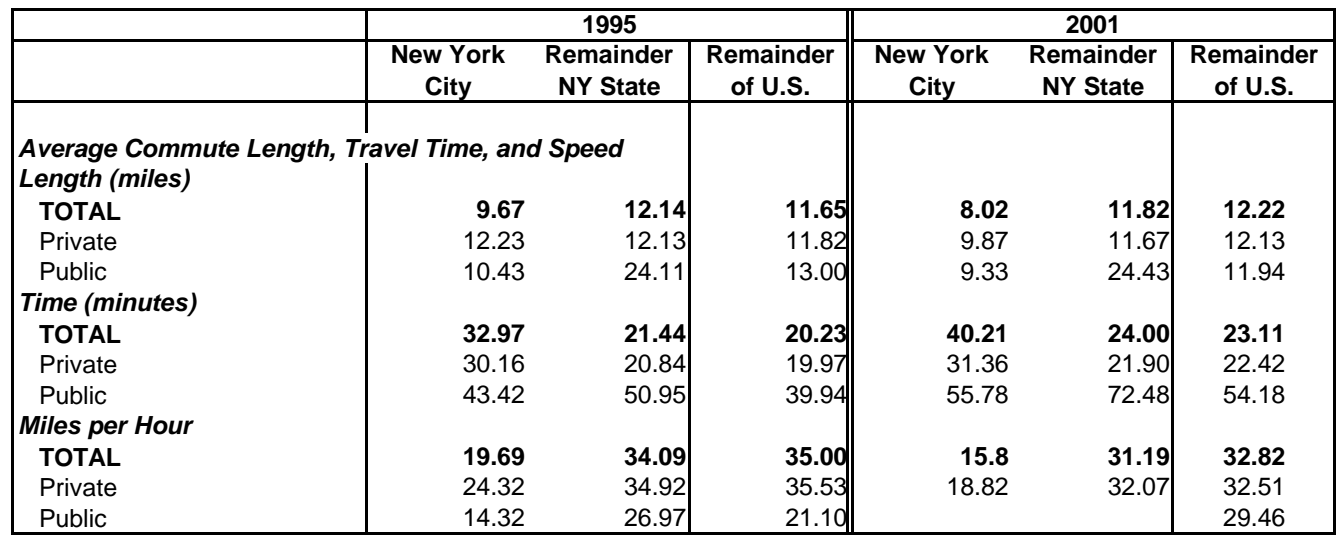


Chapter 3: Table 8

Influence of NY State Metropolitan Data on Overall NY Travel Patterns

\begin{tabular}{|c|c|c|c|c|c|c|}
\hline & & 1995 & & & 2001 & \\
\hline & $\begin{array}{c}\text { New York } \\
\text { City }\end{array}$ & $\begin{array}{c}\text { Remainder } \\
\text { NY State }\end{array}$ & $\begin{array}{c}\text { Remainder } \\
\text { of U.S. }\end{array}$ & $\begin{array}{c}\text { New York } \\
\text { City }\end{array}$ & $\begin{array}{c}\text { Remainder } \\
\text { NY State }\end{array}$ & $\begin{array}{c}\text { Remainder } \\
\text { of U.S. }\end{array}$ \\
\hline $\begin{array}{l}\text { Average Vehicle Occupanc } \\
\text { (Statistics by Income for } 199\end{array}$ & $\begin{array}{l}\text { Tate (Person } \\
\text { e unavailable }\end{array}$ & $\begin{array}{l}\text { Miles per Veh } \\
\text { in } 2001 \text { Dollar }\end{array}$ & $\begin{array}{l}\text { cle Mile) } \\
\text { terms for vehic }\end{array}$ & occupancy & ables in Chapt & $2-3)$ \\
\hline ALL & $1.7 \mathrm{c}$ & 1.56 & 1.59 & 1.68 & 1.62 & 1.63 \\
\hline 1 Adult, No Child & $1.1 \mathrm{c}$ & 1.28 & 1.22 & 1.62 & 1.19 & 1.23 \\
\hline 2+ Adults, No Child & 1.70 & 1.40 & 1.36 & 1.66 & 1.40 & 1.44 \\
\hline 1 Adult, Child $<6$ & 1.91 & 1.90 & 2.19 & 1.89 & 1.80 & 2.33 \\
\hline $2+$ Adults, Child $<6$ & 2.16 & 1.85 & 1.89 & 1.70 & 1.94 & 2.03 \\
\hline 1 Adult, Child 6-15 & 1.80 & 1.59 & 1.73 & 1.76 & 1.63 & 1.76 \\
\hline $2+$ Adults, Child 6-15 & 1.96 & 1.71 & 1.79 & 1.86 & 1.67 & 1.73 \\
\hline 1 Adult, Child 16-21 & 1.57 & 1.42 & 1.58 & 1.18 & 1.42 & 1.42 \\
\hline 2+ Adults, Child 16-21 & $1.8 \mathrm{~s}$ & 1.44 & 1.53 & 1.44 & 1.96 & 1.41 \\
\hline 1 Adult, Retired, No Child & 1.37 & 1.25 & 1.45 & 1.30 & 1.25 & 1.31 \\
\hline 2+ Adults, Retired, No Child & 1.51 & 1.56 & 1.58 & 1.57 & 1.55 & 1.63 \\
\hline Unreported & & & & 1.79 & 1.79 & 1.58 \\
\hline ALL & $1.7 \mathrm{c}$ & 1.56 & 1.59 & 1.68 & 1.62 & 1.63 \\
\hline Earn a Living & 1.32 & 1.12 & 1.15 & 1.26 & 1.13 & 1.16 \\
\hline Fam/Pers Bus & 1.84 & 1.72 & 1.76 & 1.86 & 1.72 & 1.80 \\
\hline Civ, Ed, \& Rel & 1.76 & 1.77 & 1.67 & 1.69 & 1.51 & 1.77 \\
\hline Soc and $\mathrm{Rec}$ & 2.31 & 2.00 & 2.04 & 1.99 & 2.14 & 2.03 \\
\hline Other & $1.8 \subseteq$ & 1.21 & 1.87 & 1.84 & 1.78 & 1.89 \\
\hline Unreported & & & & 1.09 & 2.12 & 1.62 \\
\hline ALL & & & & 1.68 & 1.62 & 1.63 \\
\hline$<\$ 10,000$ Households & & & & 1.20 & 1.62 & 1.91 \\
\hline$\$ 10$ to $\$ 20,000$ Households & & & & 1.51 & 1.60 & 1.66 \\
\hline$\$ 20$ to $\$ 30,000$ Households & & & & 1.94 & 2.04 & 1.69 \\
\hline$\$ 30$ to $\$ 40,000$ Households & & & & 1.66 & 1.71 & 1.64 \\
\hline$\$ 40$ to $\$ 50,000$ Households & & & & 1.90 & 1.47 & 1.60 \\
\hline$\$ 50$ to $\$ 60,000$ Households & & & & 1.55 & 1.57 & 1.62 \\
\hline$\$ 60$ to $\$ 70,000$ Households & & & & 1.35 & 1.64 & 1.62 \\
\hline$\$ 70$ to $\$ 80,000$ Households & & & & 1.70 & 1.48 & 1.58 \\
\hline$\$ 80,000+$ Households & & & & 1.73 & 1.58 & 1.59 \\
\hline Unreported Households & & & & 1.42 & 1.50 & 1.60 \\
\hline
\end{tabular}




\begin{tabular}{|c|c|c|c|c|c|c|c|c|c|c|c|c|c|c|}
\hline \multicolumn{15}{|c|}{ Population Density (census tract) } \\
\hline & \multicolumn{2}{|c|}{$<500$} & \multicolumn{2}{|c|}{$500-2,000$} & \multicolumn{2}{|c|}{$2,000-4,000$} & \multicolumn{2}{|c|}{$4,000-10,000$} & \multicolumn{2}{|c|}{$10,000-20,000$} & \multicolumn{2}{|c|}{$20,000-50,000$} & \multicolumn{2}{|c|}{$50,000+$} \\
\hline & NY State & U.S. & NY State & U.S. & NY State & U.S. & NY State & U.S. & NY State & U.S. & NY State & U.S. & NY State & U.S. \\
\hline \multicolumn{15}{|l|}{ General Statistics } \\
\hline Households (000) & $\begin{array}{r}530 \\
1054\end{array}$ & & $\begin{array}{r}738 \\
1407\end{array}$ & $\begin{array}{l}16,937 \\
32 ? 76\end{array}$ & 664 & $\begin{array}{l}17,589 \\
30,838\end{array}$ & $\begin{array}{l}1,028 \\
1784\end{array}$ & $\begin{array}{l}21,471 \\
36,639\end{array}$ & $\begin{array}{r}635 \\
1087\end{array}$ & $\begin{array}{l}5,839 \\
9083\end{array}$ & $\begin{array}{l}1,002 \\
1,279\end{array}$ & 2,337 & $\begin{array}{l}1,720 \\
1812\end{array}$ & $\begin{array}{l}188 \\
17 ?\end{array}$ \\
\hline Drivers (000) & 1,054 & 29,421 & 1,407 & 32,276 & 1,192 & 30,838 & 1,784 & 36,639 & 1,087 & 9,083 & 1,279 & 3,103 & 1,812 & \\
\hline Workers $(000)$ & 756 & 21,618 & 1,046 & 23,912 & 882 & 23,264 & 1,428 & 28,955 & 953 & 8,173 & 1,280 & 2,972 & 2,170 & 206 \\
\hline Vehicles (000) & 1,105 & 33,711 & 1,445 & 34,264 & 1,174 & 32,514 & 1,707 & 36,671 & 868 & 8,473 & 779 & 2,597 & 806 & 104 \\
\hline Workers per Household & 1.42 & 1.46 & 1.42 & 1.41 & 1.33 & 1.32 & 1.39 & 1.35 & 1.50 & 1.40 & 1.28 & 1.27 & 1.26 & 1.10 \\
\hline Vehicles per Household & 2.08 & 2.28 & 1.96 & 2.02 & 1.77 & 1.85 & 1.66 & 1.71 & 1.37 & 1.45 & 0.78 & 1.11 & 0.47 & 0.55 \\
\hline Vehicles per Driver & 1.05 & 1.15 & 1.03 & 1.06 & 0.98 & 1.05 & 0.96 & 1.00 & 0.80 & 0.93 & 0.61 & 0.84 & 0.44 & 0.60 \\
\hline \multicolumn{15}{|c|}{ Distribution of Households by Household Vehicle Count } \\
\hline ALL & $100 \%$ & $100 \%$ & $100 \%$ & $100 \%$ & $100 \%$ & $100 \%$ & $100 \%$ & $100 \%$ & $100 \%$ & $100 \%$ & $100 \%$ & $100 \%$ & $100 \%$ & $100 \%$ \\
\hline 0 vehicles & $4.0 \%$ & $3.3 \%$ & $3.2 \%$ & $3.5 \%$ & $7.5 \%$ & $5.6 \%$ & $10.2 \%$ & $8.7 \%$ & $21.8 \%$ & $15.6 \%$ & $45.0 \%$ & $28.1 \%$ & $61.5 \%$ & $50.7 \%$ \\
\hline 1 vehicle & $24.0 \%$ & $22.9 \%$ & $30.2 \%$ & $28.4 \%$ & $33.7 \%$ & $34.0 \%$ & $35.6 \%$ & $37.1 \%$ & $38.2 \%$ & $41.8 \%$ & $36.6 \%$ & $42.1 \%$ & $32.5 \%$ & $43.3 \%$ \\
\hline 2 vehicles & $45.0 \%$ & $39.9 \%$ & $44.1 \%$ & $43.1 \%$ & $40.7 \%$ & $39.2 \%$ & $37.4 \%$ & $36.6 \%$ & $26.5 \%$ & $30.1 \%$ & $15.2 \%$ & $22.5 \%$ & $5.2 \%$ & $6.0 \%$ \\
\hline 3 vehicles & $18.0 \%$ & $20.1 \%$ & $15.9 \%$ & $16.3 \%$ & $12.9 \%$ & $15.3 \%$ & $12.6 \%$ & $12.4 \%$ & $10.2 \%$ & $8.3 \%$ & $2.5 \%$ & $5.6 \%$ & $0.6 \%$ & \\
\hline 4+ vehicles & $9.0 \%$ & $13.8 \%$ & $6.7 \%$ & $8.6 \%$ & $5.3 \%$ & $6.0 \%$ & $4.3 \%$ & $5.2 \%$ & $3.3 \%$ & $4.2 \%$ & $0.8 \%$ & $1.8 \%$ & $0.3 \%$ & \\
\hline \multicolumn{15}{|c|}{ Distribution of Households by Household Income } \\
\hline ALL & $100 \%$ & $100 \%$ & $100 \%$ & $100 \%$ & $100 \%$ & $100 \%$ & $100 \%$ & $100 \%$ & $100 \%$ & $100 \%$ & $100 \%$ & $100 \%$ & $100 \%$ & $100 \%$ \\
\hline$<\$ 10,000$ & $4.5 \%$ & $6.2 \%$ & $4.2 \%$ & $5.6 \%$ & $5.8 \%$ & $6.7 \%$ & $6.9 \%$ & $10.1 \%$ & $11.2 \%$ & $13.5 \%$ & $13.5 \%$ & $14.0 \%$ & $13.1 \%$ & $10.8 \%$ \\
\hline$\$ 10$ to $\$ 20,000$ & $9.1 \%$ & $11.5 \%$ & $6.7 \%$ & $8.5 \%$ & $9.7 \%$ & $9.9 \%$ & $11.4 \%$ & $11.9 \%$ & $10.8 \%$ & $14.1 \%$ & $13.4 \%$ & $17.1 \%$ & $14.3 \%$ & $40.0 \%$ \\
\hline$\$ 20$ to $\$ 30,000$ & $12.8 \%$ & $12.9 \%$ & $9.4 \%$ & $11.3 \%$ & $10.2 \%$ & $12.0 \%$ & $9.9 \%$ & $13.1 \%$ & $12.2 \%$ & $12.8 \%$ & $12.4 \%$ & $16.7 \%$ & $13.1 \%$ & $9.2 \%$ \\
\hline$\$ 30$ to $\$ 40,000$ & $12.6 \%$ & $13.4 \%$ & $9.3 \%$ & $11.2 \%$ & $10.6 \%$ & $12.3 \%$ & $10.6 \%$ & $12.7 \%$ & $11.7 \%$ & $12.7 \%$ & $12.5 \%$ & $14.8 \%$ & $10.1 \%$ & $4.3 \%$ \\
\hline$\$ 40$ to $\$ 50,000$ & $10.6 \%$ & $10.3 \%$ & $9.4 \%$ & $10.8 \%$ & $6.6 \%$ & $9.8 \%$ & $11.0 \%$ & $10.0 \%$ & $9.5 \%$ & $8.5 \%$ & $8.9 \%$ & $7.8 \%$ & $7.8 \%$ & $4.7 \%$ \\
\hline$\$ 50$ to $\$ 60,000$ & $8.6 \%$ & $8.9 \%$ & $8.4 \%$ & $8.7 \%$ & $5.9 \%$ & $8.9 \%$ & $8.0 \%$ & $8.1 \%$ & $7.5 \%$ & $6.4 \%$ & $6.9 \%$ & $4.3 \%$ & $6.4 \%$ & $3.8 \%$ \\
\hline$\$ 60$ to $\$ 70,000$ & $7.1 \%$ & $7.1 \%$ & $9.0 \%$ & $6.7 \%$ & $5.7 \%$ & $6.1 \%$ & $5.2 \%$ & $5.9 \%$ & $6.6 \%$ & $5.8 \%$ & $3.3 \%$ & $2.6 \%$ & $4.8 \%$ & $1.5 \%$ \\
\hline$\$ 70$ to $\$ 80,000$ & $6.0 \%$ & $5.7 \%$ & $7.8 \%$ & $6.3 \%$ & $7.5 \%$ & $6.6 \%$ & $6.3 \%$ & $5.1 \%$ & $3.8 \%$ & $3.2 \%$ & $3.3 \%$ & $3.6 \%$ & $3.6 \%$ & $8.7 \%$ \\
\hline$\$ 80,000+$ & $21.4 \%$ & $16.8 \%$ & $26.9 \%$ & $22.6 \%$ & $27.3 \%$ & $18.8 \%$ & $20.2 \%$ & $14.6 \%$ & $18.8 \%$ & $13.9 \%$ & $12.9 \%$ & $9.9 \%$ & $14.7 \%$ & $12.5 \%$ \\
\hline Unreported & $7.2 \%$ & $7.3 \%$ & $9.0 \%$ & $8.2 \%$ & $10.8 \%$ & $8.9 \%$ & $10.5 \%$ & $8.6 \%$ & $8.0 \%$ & $9.1 \%$ & $12.9 \%$ & $9.2 \%$ & $12.1 \%$ & $4.5 \%$ \\
\hline \multirow{3}{*}{$\begin{array}{l}\text { Driver Rate } \\
\% \text { Male Drivers/Male } 16+ \\
\% \text { Female Drivers/Female } 16+\end{array}$} & & & & & & & & & & & & & & \\
\hline & $94.22 \%$ & $95.39 \%$ & $95.77 \%$ & $95.12 \%$ & $95.34 \%$ & $93.71 \%$ & $89.21 \%$ & $91.67 \%$ & $82.07 \%$ & $86.44 \%$ & $73.96 \%$ & $80.51 \%$ & $66.72 \%$ & $66.03 \%$ \\
\hline & $93.00 \%$ & $91.12 \%$ & $92.04 \%$ & $92.12 \%$ & $87.52 \%$ & $88.99 \%$ & $84.06 \%$ & $84.75 \%$ & $71.17 \%$ & $72.20 \%$ & $54.08 \%$ & $64.97 \%$ & $41.88 \%$ & $56.60 \%$ \\
\hline
\end{tabular}




\begin{tabular}{|c|c|c|c|c|c|c|c|c|c|c|c|c|c|c|}
\hline \multicolumn{15}{|c|}{ Population Density (census tract) } \\
\hline & \multicolumn{2}{|c|}{$<500$} & \multicolumn{2}{|c|}{$500-2,000$} & \multicolumn{2}{|c|}{$2,000-4,000$} & \multicolumn{2}{|c|}{$4,000-10,000$} & \multicolumn{2}{|c|}{$10,000-20,000$} & \multicolumn{2}{|c|}{$20,000-50,000$} & \multicolumn{2}{|c|}{$50,000+$} \\
\hline & NY State & U.S. & NY State & U.S. & NY State & U.S. & NY State & U.S. & NY State & U.S. & NY State & U.S. & NY State & U.S. \\
\hline \multicolumn{15}{|l|}{ General Statistics } \\
\hline Households (000) & 568 & 14,723 & 727 & 15,721 & 601 & 15,126 & 994 & 19,726 & 617 & 5,230 & 978 & 1,962 & 1,528 & 83 \\
\hline Drivers $(000)$ & 1,076 & 28,148 & 1,422 & 29,804 & 1,141 & 27,253 & 1,781 & 34,019 & 903 & 7,741 & 1,174 & 2,387 & 1,428 & 92 \\
\hline Workers $(000)$ & 796 & 20,355 & 1,007 & 22,007 & 834 & 20,532 & 1,397 & 26,000 & 792 & 6,189 & 1,137 & 2,337 & 1,713 & 98 \\
\hline Vehicles (000) & 995 & 30,649 & 1,283 & 30,706 & 971 & 27,071 & 1,444 & 32,278 & 664 & 6,772 & 679 & 1,767 & 496 & 55 \\
\hline Workers per Household & 1.40 & 1.38 & 1.39 & 1.40 & 1.39 & 1.36 & 1.41 & 1.32 & 1.28 & 1.18 & 1.16 & 1.19 & 1.12 & 1.18 \\
\hline Vehicles per Household & 1.75 & 2.08 & 1.76 & 1.95 & 1.62 & 1.79 & 1.45 & 1.64 & 1.08 & 1.29 & 0.69 & 0.90 & 0.32 & 0.66 \\
\hline Vehicles per Driver & 0.92 & 1.09 & 0.90 & 1.03 & 0.85 & 0.99 & 0.81 & 0.95 & 0.73 & 0.87 & 0.58 & 0.74 & 0.35 & 0.60 \\
\hline \multicolumn{15}{|c|}{ Distribution of Households by Household Vehicle Count } \\
\hline ALL & $100 \%$ & $100 \%$ & $100 \%$ & $100 \%$ & $100 \%$ & $100 \%$ & $100 \%$ & $100 \%$ & $100 \%$ & $100 \%$ & $100 \%$ & $100 \%$ & $100 \%$ & $100 \%$ \\
\hline 0 vehicles & $4.2 \%$ & $3.4 \%$ & $2.8 \%$ & $3.2 \%$ & $6.1 \%$ & $6.1 \%$ & $11.3 \%$ & $8.3 \%$ & $21.9 \%$ & $18.5 \%$ & $42.2 \%$ & $35.3 \%$ & $68.2 \%$ & $47.1 \%$ \\
\hline 1 vehicle & $26.8 \%$ & $23.1 \%$ & $28.1 \%$ & $28.8 \%$ & $32.1 \%$ & $33.7 \%$ & $36.1 \%$ & $38.6 \%$ & $43.0 \%$ & $45.1 \%$ & $39.2 \%$ & $43.9 \%$ & $27.2 \%$ & $40.4 \%$ \\
\hline 2 vehicles & $48.1 \%$ & $46.4 \%$ & $48.8 \%$ & $46.4 \%$ & $43.4 \%$ & $42.3 \%$ & $39.5 \%$ & $38.6 \%$ & $28.5 \%$ & $28.0 \%$ & $15.2 \%$ & $16.6 \%$ & $4.3 \%$ & $12.1 \%$ \\
\hline 3 vehicles & $15.5 \%$ & $19.6 \%$ & $14.1 \%$ & $16.0 \%$ & $13.8 \%$ & $12.8 \%$ & $8.8 \%$ & $11.0 \%$ & $5.4 \%$ & $6.4 \%$ & $2.9 \%$ & $3.9 \%$ & $0.3 \%$ & $0.4 \%$ \\
\hline $4+$ vehicles & $5.4 \%$ & $7.5 \%$ & $6.3 \%$ & $5.7 \%$ & $4.6 \%$ & $5.1 \%$ & $4.4 \%$ & $3.5 \%$ & $1.1 \%$ & $2.1 \%$ & $0.6 \%$ & $0.3 \%$ & $0.1 \%$ & $0.0 \%$ \\
\hline \multicolumn{15}{|l|}{ Driver Rate } \\
\hline$\%$ Male Drivers/Male $16+$ & $94.66 \%$ & $95.78 \%$ & $95.43 \%$ & $95.19 \%$ & $93.99 \%$ & $93.44 \%$ & $90.40 \%$ & $92.02 \%$ & $82.15 \%$ & $85.00 \%$ & $75.27 \%$ & $73.40 \%$ & $64.78 \%$ & $74.71 \%$ \\
\hline$\%$ Female Drivers/Female 16+ & $89.74 \%$ & $90.99 \%$ & $90.38 \%$ & $91.15 \%$ & $88.71 \%$ & $86.87 \%$ & $80.31 \%$ & $84.22 \%$ & $64.69 \%$ & $70.99 \%$ & $49.23 \%$ & $58.72 \%$ & $36.64 \%$ & $55.61 \%$ \\
\hline
\end{tabular}




\begin{tabular}{|c|c|c|c|c|c|c|c|c|c|c|c|c|c|c|}
\hline \multicolumn{15}{|c|}{ Population Density (census tract) } \\
\hline & \multicolumn{2}{|c|}{$<500$} & \multicolumn{2}{|c|}{$500-2,000$} & \multicolumn{2}{|c|}{$2,000-4,000$} & \multicolumn{2}{|c|}{$4,000-10,000$} & \multicolumn{2}{|c|}{$10,000-20,000$} & \multicolumn{2}{|c|}{$20,000-50,000$} & \multicolumn{2}{|c|}{$50,000+$} \\
\hline & NY State & U.S. & NY State & U.S. & NY State & U.S. & NY State & U.S. & NY State & U.S. & NY State & U.S. & NY State & U.S. \\
\hline Daily Person Trips per Person & & & & & & & & & & & & & & \\
\hline TOTAL & 3.80 & 4.01 & 4.10 & 4.33 & 4.11 & 4.31 & 3.93 & 4.11 & 3.42 & 3.74 & 3.51 & 3.58 & 3.40 & 3.57 \\
\hline Male & 3.74 & 4.02 & 4.05 & 4.30 & 4.06 & 4.25 & 3.90 & 4.09 & 3.46 & 3.88 & 3.76 & 3.82 & 3.46 & 3.83 \\
\hline Female & 3.86 & 4.01 & 4.14 & 4.37 & 4.16 & 4.36 & 3.95 & 4.13 & 3.39 & 3.61 & 3.28 & 3.35 & 3.34 & 2.89 \\
\hline TOTAL & 3.80 & 4.01 & 4.10 & 4.33 & 4.11 & 4.31 & 3.93 & 4.11 & 3.42 & 3.74 & 3.51 & 3.58 & 3.40 & 3.57 \\
\hline $0-4$ years & 2.84 & 3.12 & 2.78 & 3.53 & 2.83 & 3.35 & 2.44 & 3.05 & 2.31 & 2.94 & 2.84 & 3.30 & 2.72 & \\
\hline $5-15$ years & 3.07 & 3.42 & 3.27 & 3.74 & 3.47 & 3.45 & 3.00 & 3.43 & 2.71 & 3.06 & 2.83 & 3.16 & 2.63 & 0.67 \\
\hline $16-19$ years & 3.44 & 4.04 & 4.13 & 4.52 & 4.23 & 4.38 & 3.88 & 4.11 & 3.13 & 3.31 & 3.49 & 3.60 & 2.83 & \\
\hline 20-34 years & 3.79 & 4.28 & 4.14 & 4.53 & 4.04 & 4.49 & 3.98 & 4.28 & 3.66 & 4.01 & 3.73 & 3.87 & 3.85 & 3.91 \\
\hline $35-54$ years & 4.25 & 4.42 & 4.62 & 4.80 & 4.40 & 4.94 & 4.52 & 4.67 & 4.02 & 4.25 & 4.17 & 4.15 & 3.72 & 2.97 \\
\hline $55-64$ years & 3.99 & 4.09 & 4.36 & 4.36 & 4.51 & 4.32 & 4.12 & 4.09 & 3.11 & 3.62 & 4.23 & 3.59 & 3.46 & 4.90 \\
\hline $65+$ years & 3.65 & 3.37 & 3.61 & 3.70 & 4.05 & 3.65 & 3.60 & 3.41 & 2.73 & 2.75 & 2.33 & 2.04 & 2.67 & 0.06 \\
\hline Unreported & 3.83 & 3.36 & 3.88 & 3.62 & 4.16 & 3.93 & 3.28 & 3.86 & 3.64 & 4.03 & 2.66 & 2.05 & 2.98 & 3.47 \\
\hline TOTAL & 3.80 & 4.01 & 4.10 & 4.33 & 4.11 & 4.31 & 3.93 & 4.11 & 3.42 & 3.74 & 3.51 & 3.58 & 3.40 & 3.57 \\
\hline$\%$ POV & $86.4 \%$ & $90.5 \%$ & $87.3 \%$ & $89.8 \%$ & $86.2 \%$ & $89.0 \%$ & $80.6 \%$ & $86.0 \%$ & $67.1 \%$ & $75.6 \%$ & $45.1 \%$ & $65.4 \%$ & $23.6 \%$ & $35.2 \%$ \\
\hline$\%$ Public & $1.3 \%$ & $0.1 \%$ & $0.7 \%$ & $0.4 \%$ & $1.6 \%$ & $0.8 \%$ & $3.0 \%$ & $1.7 \%$ & $9.3 \%$ & $4.9 \%$ & $18.2 \%$ & $9.8 \%$ & $26.9 \%$ & $25.7 \%$ \\
\hline$\%$ Walk & $7.2 \%$ & $5.5 \%$ & $7.3 \%$ & $5.9 \%$ & $7.7 \%$ & $7.5 \%$ & $11.6 \%$ & $9.7 \%$ & $19.3 \%$ & $16.3 \%$ & $32.4 \%$ & $20.5 \%$ & $43.9 \%$ & $35.2 \%$ \\
\hline$\%$ Other & $5.0 \%$ & $3.8 \%$ & $4.6 \%$ & $3.8 \%$ & $4.4 \%$ & $2.6 \%$ & $4.7 \%$ & $2.6 \%$ & $4.1 \%$ & $3.3 \%$ & $4.3 \%$ & $4.1 \%$ & $5.5 \%$ & $3.8 \%$ \\
\hline$\%$ Unreported & $0.1 \%$ & $0.1 \%$ & $0.1 \%$ & $0.1 \%$ & $0.1 \%$ & $0.1 \%$ & $0.1 \%$ & $0.1 \%$ & $0.2 \%$ & $0.0 \%$ & $0.1 \%$ & $0.1 \%$ & $0.1 \%$ & \\
\hline TOTAL & 3.80 & 4.01 & 4.10 & 4.33 & 4.11 & 4.31 & 3.93 & 4.11 & 3.42 & 3.74 & 3.51 & 3.58 & 3.40 & 3.57 \\
\hline$\%$ SOV & $42.1 \%$ & $41.8 \%$ & $44.2 \%$ & $40.8 \%$ & $39.9 \%$ & $42.4 \%$ & $39.0 \%$ & $39.0 \%$ & $32.5 \%$ & $33.7 \%$ & $18.2 \%$ & $27.5 \%$ & $8.0 \%$ & $22.0 \%$ \\
\hline$\%$ MOV & $44.2 \%$ & $48.7 \%$ & $43.0 \%$ & $49.0 \%$ & $46.3 \%$ & $46.7 \%$ & $41.6 \%$ & $47.0 \%$ & $34.6 \%$ & $41.9 \%$ & $26.8 \%$ & $37.9 \%$ & $15.6 \%$ & $13.3 \%$ \\
\hline$\%$ Amtrak & $0.0 \%$ & $0.0 \%$ & $0.1 \%$ & $0.0 \%$ & $0.1 \%$ & $0.1 \%$ & $0.2 \%$ & $0.0 \%$ & $0.5 \%$ & $0.1 \%$ & $0.3 \%$ & & $0.4 \%$ & \\
\hline$\%$ Commuter Train & $0.2 \%$ & $0.0 \%$ & $0.2 \%$ & $0.0 \%$ & $0.6 \%$ & $0.1 \%$ & $0.9 \%$ & $0.2 \%$ & $0.4 \%$ & $0.1 \%$ & $0.5 \%$ & $0.2 \%$ & $0.4 \%$ & \\
\hline$\%$ Subway/El Rail & $0.4 \%$ & $0.0 \%$ & $0.3 \%$ & $0.1 \%$ & $0.5 \%$ & $0.1 \%$ & $0.8 \%$ & $0.2 \%$ & $4.8 \%$ & $0.8 \%$ & $10.0 \%$ & $1.7 \%$ & $16.1 \%$ & $5.3 \%$ \\
\hline$\%$ Other Public & $0.7 \%$ & $0.1 \%$ & $0.1 \%$ & $0.2 \%$ & $0.5 \%$ & $0.5 \%$ & $1.2 \%$ & $1.3 \%$ & $4.0 \%$ & $3.9 \%$ & $7.4 \%$ & $7.7 \%$ & $10.3 \%$ & $20.4 \%$ \\
\hline$\%$ Walk & $7.2 \%$ & $5.5 \%$ & $7.3 \%$ & $5.9 \%$ & $7.7 \%$ & $7.5 \%$ & $11.6 \%$ & $9.7 \%$ & $19.3 \%$ & $16.3 \%$ & $32.4 \%$ & $20.5 \%$ & $43.9 \%$ & $35.2 \%$ \\
\hline$\%$ Other & $5.1 \%$ & $3.8 \%$ & $4.6 \%$ & $3.8 \%$ & $4.4 \%$ & $2.6 \%$ & $4.7 \%$ & $2.6 \%$ & $3.7 \%$ & $3.4 \%$ & $4.3 \%$ & $4.3 \%$ & $5.2 \%$ & $3.8 \%$ \\
\hline$\%$ Unreported & $0.1 \%$ & $0.1 \%$ & $0.1 \%$ & $0.1 \%$ & $0.1 \%$ & $0.1 \%$ & $0.1 \%$ & $0.1 \%$ & $0.2 \%$ & $0.0 \%$ & $0.1 \%$ & $0.1 \%$ & $0.1 \%$ & \\
\hline TOTAL & 3.80 & 4.01 & 4.10 & 4.33 & 4.11 & 4.31 & 3.93 & 4.11 & 3.42 & 3.74 & 3.51 & 3.58 & 3.40 & 3.57 \\
\hline \% Earn a Living & $19.0 \%$ & $19.2 \%$ & $18.8 \%$ & $17.9 \%$ & $18.8 \%$ & $18.6 \%$ & $18.3 \%$ & $18.7 \%$ & $22.4 \%$ & $20.6 \%$ & $19.2 \%$ & $22.4 \%$ & $19.9 \%$ & $14.8 \%$ \\
\hline$\%$ Family \& Personal Business & $42.3 \%$ & $43.5 \%$ & $43.3 \%$ & $43.5 \%$ & $44.4 \%$ & $44.0 \%$ & $44.6 \%$ & $44.7 \%$ & $40.1 \%$ & $43.1 \%$ & $45.8 \%$ & $41.6 \%$ & $41.3 \%$ & $50.4 \%$ \\
\hline$\%$ Civic, Educational \& Religious & $9.0 \%$ & $10.4 \%$ & $8.3 \%$ & $9.6 \%$ & $7.6 \%$ & $9.4 \%$ & $9.8 \%$ & $9.4 \%$ & $11.5 \%$ & $8.8 \%$ & $10.5 \%$ & $9.8 \%$ & $11.2 \%$ & $6.1 \%$ \\
\hline \% Social \& Recreational & $28.3 \%$ & $26.0 \%$ & $28.2 \%$ & $28.0 \%$ & $28.3 \%$ & $27.0 \%$ & $25.2 \%$ & $26.5 \%$ & $24.3 \%$ & $26.6 \%$ & $22.4 \%$ & $25.0 \%$ & $26.5 \%$ & $26.6 \%$ \\
\hline$\%$ Other & $1.0 \%$ & $0.8 \%$ & $1.1 \%$ & $0.9 \%$ & $0.7 \%$ & $0.9 \%$ & $1.6 \%$ & $0.7 \%$ & $1.6 \%$ & $0.8 \%$ & $1.7 \%$ & $1.2 \%$ & $1.1 \%$ & \\
\hline$\%$ Unreported & $0.3 \%$ & $0.1 \%$ & $0.3 \%$ & $0.1 \%$ & $0.2 \%$ & $0.1 \%$ & $0.4 \%$ & $0.1 \%$ & $0.1 \%$ & $0.2 \%$ & $0.5 \%$ & $0.0 \%$ & $0.1 \%$ & $2.2 \%$ \\
\hline TOTAL & 3.80 & 4.01 & 4.10 & 4.33 & 4.11 & 4.31 & 3.93 & 4.11 & 3.42 & 3.74 & 3.51 & 3.58 & 3.40 & 3.57 \\
\hline Weekday & 3.71 & 3.95 & 4.01 & 4.27 & 4.01 & 4.17 & 3.78 & 3.92 & 3.34 & 3.48 & 3.50 & 3.53 & 3.30 & 4.08 \\
\hline Weekend & 4.06 & 4.20 & 4.36 & 4.54 & 4.40 & 4.68 & 4.32 & 4.62 & 3.66 & 4.43 & 3.56 & 3.73 & 3.68 & 2.34 \\
\hline
\end{tabular}




\begin{tabular}{|c|c|c|c|c|c|c|c|c|c|c|c|c|c|c|}
\hline \multicolumn{15}{|c|}{ Population Density (census tract) } \\
\hline & \multicolumn{2}{|c|}{$<500$} & \multicolumn{2}{|c|}{$500-2,000$} & \multicolumn{2}{|c|}{$2,000-4,000$} & \multicolumn{2}{|c|}{$4,000-10,000$} & \multicolumn{2}{|c|}{$10,000-20,000$} & \multicolumn{2}{|c|}{$20,000-50,000$} & \multicolumn{2}{|c|}{$50,000+$} \\
\hline & NY State & U.S. & NY State & U.S. & NY State & U.S. & NY State & U.S. & NY State & U.S. & NY State & U.S. & NY State & U.S. \\
\hline Daily Person Trips per Person & & & & & & & & & & & & & & \\
\hline $\begin{array}{l}\text { TOTAL } \\
\text { Male }\end{array}$ & $\begin{array}{l}4.06 \\
4.07\end{array}$ & $\begin{array}{l}4.17 \\
4.18\end{array}$ & $\begin{array}{l}4.24 \\
4.24\end{array}$ & $\begin{array}{l}4.36 \\
4.39\end{array}$ & $\begin{array}{l}4.34 \\
4.44\end{array}$ & $\begin{array}{l}4.45 \\
4.49\end{array}$ & $\begin{array}{l}4.01 \\
4.09\end{array}$ & $\begin{array}{l}4.36 \\
4.38\end{array}$ & $\begin{array}{l}3.62 \\
3.60\end{array}$ & $\begin{array}{l}4.03 \\
4.08\end{array}$ & $\begin{array}{l}3.76 \\
3.71\end{array}$ & $\begin{array}{l}4.09 \\
4.47\end{array}$ & $\begin{array}{l}3.46 \\
3.55\end{array}$ & $\begin{array}{l}3.50 \\
3.26\end{array}$ \\
\hline Female & 4.06 & 4.15 & 4.25 & 4.33 & 4.24 & 4.42 & 3.93 & 4.33 & 3.63 & 3.99 & 3.82 & 3.78 & 3.38 & 3.83 \\
\hline TOTAL & 4.06 & 4.17 & 4.24 & 4.36 & 4.34 & 4.45 & 4.01 & 4.36 & 3.62 & 4.03 & 3.76 & 4.09 & 3.46 & 3.50 \\
\hline $5-15$ years & 3.62 & 3.58 & 3.72 & 3.76 & 3.37 & 3.74 & 3.38 & 3.86 & 2.96 & 3.14 & 3.19 & 3.13 & 3.03 & 2.00 \\
\hline $16-19$ years & 4.16 & 4.74 & 4.43 & 4.82 & 4.47 & 4.79 & 4.31 & 4.48 & 3.23 & 4.19 & 3.38 & 4.35 & 3.01 & \\
\hline 20-34 years & 3.95 & 4.55 & 4.28 & 4.57 & 4.50 & 4.85 & 4.38 & 4.69 & 4.01 & 4.55 & 4.03 & 4.43 & 3.93 & 3.80 \\
\hline $35-54$ years & 4.49 & 4.51 & 4.68 & 4.89 & 4.77 & 4.84 & 4.49 & 4.68 & 4.11 & 4.31 & 4.13 & 4.60 & 3.62 & 4.15 \\
\hline $55-64$ years & 4.18 & 4.18 & 4.65 & 4.17 & 4.63 & 4.44 & 3.70 & 4.21 & 3.59 & 3.92 & 3.22 & 4.24 & 3.06 & \\
\hline $65+$ years & 3.60 & 3.21 & 3.58 & 3.47 & 3.99 & 3.57 & 3.19 & 3.57 & 2.85 & 3.21 & 3.55 & 2.80 & 2.42 & 3.34 \\
\hline TOTAL & 4.06 & 4.17 & 4.24 & 4.36 & 4.34 & 4.45 & 4.01 & 4.36 & 3.62 & 4.03 & 3.76 & 4.09 & 3.46 & 3.50 \\
\hline$\%$ POV & $87.7 \%$ & $90.6 \%$ & $86.8 \%$ & $89.7 \%$ & $86.4 \%$ & $88.5 \%$ & $81.8 \%$ & $86.0 \%$ & $69.1 \%$ & $75.2 \%$ & $41.8 \%$ & $57.2 \%$ & $23.4 \%$ & $45.4 \%$ \\
\hline$\%$ Public & $1.0 \%$ & $0.2 \%$ & $0.9 \%$ & $0.5 \%$ & $1.6 \%$ & $1.1 \%$ & $3.0 \%$ & $1.8 \%$ & $10.2 \%$ & $6.5 \%$ & $18.6 \%$ & $10.5 \%$ & $27.7 \%$ & $20.3 \%$ \\
\hline$\%$ Walk & $3.9 \%$ & $2.4 \%$ & $4.5 \%$ & $3.0 \%$ & $4.1 \%$ & $4.7 \%$ & $7.2 \%$ & $6.2 \%$ & $12.4 \%$ & $11.7 \%$ & $30.3 \%$ & $22.7 \%$ & $36.1 \%$ & $28.9 \%$ \\
\hline$\%$ Other & $4.4 \%$ & $3.6 \%$ & $4.2 \%$ & $3.7 \%$ & $4.1 \%$ & $2.7 \%$ & $3.7 \%$ & $2.3 \%$ & $3.0 \%$ & $2.2 \%$ & $4.0 \%$ & $3.4 \%$ & $6.4 \%$ & $1.4 \%$ \\
\hline \% Unreported & $3.0 \%$ & $3.1 \%$ & $3.5 \%$ & $3.2 \%$ & $3.7 \%$ & $2.9 \%$ & $4.2 \%$ & $3.7 \%$ & $5.2 \%$ & $4.5 \%$ & $5.3 \%$ & $6.1 \%$ & $6.4 \%$ & $4.0 \%$ \\
\hline TOTAL & 4.06 & 4.17 & 4.24 & 4.36 & 4.34 & 4.45 & 4.01 & 4.36 & 3.62 & 4.03 & 3.76 & 4.09 & 3.46 & 3.50 \\
\hline$\%$ SOV & $43.1 \%$ & $43.4 \%$ & $41.7 \%$ & $42.9 \%$ & $46.8 \%$ & $44.3 \%$ & $39.7 \%$ & $42.0 \%$ & $32.0 \%$ & $36.7 \%$ & $18.4 \%$ & $23.2 \%$ & $7.2 \%$ & $25.4 \%$ \\
\hline$\%$ MOV & $44.6 \%$ & $47.0 \%$ & $45.0 \%$ & $46.8 \%$ & $39.4 \%$ & $44.3 \%$ & $42.1 \%$ & $44.0 \%$ & $37.0 \%$ & $38.5 \%$ & $23.1 \%$ & $34.0 \%$ & $16.2 \%$ & $20.0 \%$ \\
\hline$\%$ Other POV & $0.0 \%$ & $0.2 \%$ & $0.0 \%$ & $0.0 \%$ & $0.2 \%$ & $0.0 \%$ & $0.0 \%$ & $0.0 \%$ & $0.0 \%$ & $0.0 \%$ & $0.3 \%$ & $0.0 \%$ & $0.0 \%$ & \\
\hline$\%$ Amtrak & $0.0 \%$ & $0.0 \%$ & $0.0 \%$ & $0.0 \%$ & $0.0 \%$ & $0.0 \%$ & $0.0 \%$ & $0.0 \%$ & & $0.0 \%$ & $0.0 \%$ & & $0.0 \%$ & \\
\hline$\%$ Commuter Train & $0.2 \%$ & $0.0 \%$ & $0.5 \%$ & $0.0 \%$ & $0.7 \%$ & $0.2 \%$ & $0.7 \%$ & $0.2 \%$ & $0.8 \%$ & $0.5 \%$ & $1.9 \%$ & $0.5 \%$ & $3.5 \%$ & $0.6 \%$ \\
\hline \% Subway/El Rail & $0.2 \%$ & $0.0 \%$ & $0.0 \%$ & $0.0 \%$ & $0.2 \%$ & $0.0 \%$ & $0.7 \%$ & $0.0 \%$ & $3.0 \%$ & $1.0 \%$ & $8.2 \%$ & $1.7 \%$ & $13.3 \%$ & $6.9 \%$ \\
\hline \% Other Public & $0.5 \%$ & $0.2 \%$ & $0.5 \%$ & $0.5 \%$ & $0.7 \%$ & $0.9 \%$ & $1.5 \%$ & $1.6 \%$ & $6.4 \%$ & $5.0 \%$ & $8.5 \%$ & $8.3 \%$ & $11.0 \%$ & $12.9 \%$ \\
\hline$\%$ Walk & $3.9 \%$ & $2.4 \%$ & $4.5 \%$ & $3.0 \%$ & $4.1 \%$ & $4.7 \%$ & $7.2 \%$ & $6.2 \%$ & $12.4 \%$ & $11.7 \%$ & $30.3 \%$ & $22.7 \%$ & $36.1 \%$ & $28.9 \%$ \\
\hline$\%$ Other & $4.4 \%$ & $3.6 \%$ & $4.2 \%$ & $3.7 \%$ & $4.1 \%$ & $2.7 \%$ & $3.7 \%$ & $2.3 \%$ & $3.0 \%$ & $2.2 \%$ & $4.0 \%$ & $3.4 \%$ & $6.4 \%$ & $1.4 \%$ \\
\hline$\%$ Unreported & $3.0 \%$ & $3.1 \%$ & $3.5 \%$ & $3.2 \%$ & $3.7 \%$ & $2.9 \%$ & $4.2 \%$ & $3.7 \%$ & $5.2 \%$ & $4.5 \%$ & $5.3 \%$ & $6.1 \%$ & $6.4 \%$ & $4.0 \%$ \\
\hline TOTAL & 4.06 & 4.17 & 4.24 & 4.36 & 4.34 & 4.45 & 4.01 & 4.36 & 3.62 & 4.03 & 3.76 & 4.09 & 3.46 & 3.50 \\
\hline \% Earn a Living & $20.4 \%$ & $20.7 \%$ & $19.1 \%$ & $19.7 \%$ & $19.3 \%$ & $20.9 \%$ & $20.1 \%$ & $20.0 \%$ & $22.3 \%$ & $19.8 \%$ & $17.8 \%$ & $19.1 \%$ & $20.6 \%$ & $29.1 \%$ \\
\hline \% Fam/Per Bus & $45.7 \%$ & $45.9 \%$ & $45.0 \%$ & $45.5 \%$ & $47.4 \%$ & $45.4 \%$ & $46.9 \%$ & $47.2 \%$ & $46.6 \%$ & $45.0 \%$ & $47.7 \%$ & $46.6 \%$ & $43.8 \%$ & $35.0 \%$ \\
\hline \% Civ, Ed, \& Rel & $7.9 \%$ & $8.7 \%$ & $8.5 \%$ & $9.2 \%$ & $8.0 \%$ & $8.5 \%$ & $9.0 \%$ & $8.0 \%$ & $9.1 \%$ & $10.1 \%$ & $10.6 \%$ & $9.3 \%$ & $10.7 \%$ & $6.6 \%$ \\
\hline$\%$ Soc and Rec & $25.8 \%$ & $24.8 \%$ & $27.4 \%$ & $25.4 \%$ & $25.1 \%$ & $24.9 \%$ & $24.1 \%$ & $24.5 \%$ & $22.0 \%$ & $24.8 \%$ & $23.9 \%$ & $25.0 \%$ & $24.9 \%$ & $29.3 \%$ \\
\hline$\%$ Other & $0.2 \%$ & $0.0 \%$ & $0.0 \%$ & $0.2 \%$ & $0.2 \%$ & $0.2 \%$ & $0.0 \%$ & $0.2 \%$ & $0.0 \%$ & $0.2 \%$ & $0.0 \%$ & $0.0 \%$ & $0.0 \%$ & \\
\hline TOTAL & 4.06 & 4.17 & 4.24 & 4.36 & 4.34 & 4.45 & 4.01 & 4.36 & 3.62 & 4.03 & 3.76 & 4.09 & 3.46 & 3.50 \\
\hline Weekday & 3.97 & 4.12 & 4.30 & 4.25 & 4.13 & 4.44 & 3.74 & 4.25 & 3.31 & 3.75 & 3.48 & 3.87 & 3.47 & 3.81 \\
\hline Weekend & 4.34 & 4.32 & 4.13 & 4.70 & 4.90 & 4.54 & 4.70 & 4.67 & 4.42 & 4.79 & 4.50 & 4.66 & 3.46 & 2.75 \\
\hline
\end{tabular}


Chapter 4: Table 3

Urban Travel and Population Density, 2001

\begin{tabular}{|c|c|c|c|c|c|c|c|c|c|c|c|c|c|c|}
\hline \multicolumn{15}{|c|}{ Population Density (census tract) } \\
\hline & \multicolumn{2}{|c|}{$<500$} & \multicolumn{2}{|c|}{$500-2,000$} & \multicolumn{2}{|c|}{$2,000-4,000$} & \multicolumn{2}{|c|}{$4,000-10,000$} & \multicolumn{2}{|c|}{$10,000-20,000$} & \multicolumn{2}{|c|}{$20,000-50,000$} & \multicolumn{2}{|c|}{$50,000+$} \\
\hline & NY State & U.S. & NY State & U.S. & NY State & U.S. & NY State & U.S. & NY State & U.S. & NY State & U.S. & NY State & U.S. \\
\hline Daily Person Trips per Person & 3.80 & 4.01 & 4.10 & 4.33 & 4.11 & 4.31 & 3,93 & 4.11 & 3.42 & 3.74 & 3,51 & 358 & 3,40 & 3.57 \\
\hline$\% 1-9 \min$ & $27.6 \%$ & $26.1 \%$ & $29.8 \%$ & $28.3 \%$ & $31.2 \%$ & $29.5 \%$ & $31.1 \%$ & $28.3 \%$ & $22.7 \%$ & $23.0 \%$ & $23.1 \%$ & $20.2 \%$ & $20.6 \%$ & $17.9 \%$ \\
\hline$\% 10-19 \min$ & $33.5 \%$ & $35.5 \%$ & $37.0 \%$ & $38.1 \%$ & $35.5 \%$ & $38.0 \%$ & $34.1 \%$ & $37.2 \%$ & $33.0 \%$ & $35.7 \%$ & $30.5 \%$ & $33.6 \%$ & $25.8 \%$ & $21.5 \%$ \\
\hline$\%$ 20-29 min & $14.8 \%$ & $14.8 \%$ & $13.7 \%$ & $13.8 \%$ & $12.0 \%$ & $13.3 \%$ & $12.5 \%$ & $13.6 \%$ & $12.1 \%$ & $13.0 \%$ & $9.5 \%$ & $12.9 \%$ & $10.5 \%$ & $14.2 \%$ \\
\hline$\%$ 30-39 min & $11.3 \%$ & $11.4 \%$ & $8.2 \%$ & $9.3 \%$ & $8.9 \%$ & $8.8 \%$ & $8.3 \%$ & $9.8 \%$ & $11.3 \%$ & $11.6 \%$ & $11.7 \%$ & $15.1 \%$ & $12.9 \%$ & $20.3 \%$ \\
\hline$\%$ 40-49 min & $4.4 \%$ & $4.6 \%$ & $3.6 \%$ & $3.9 \%$ & $3.5 \%$ & $3.6 \%$ & $3.4 \%$ & $3.7 \%$ & $4.6 \%$ & $4.8 \%$ & $6.6 \%$ & $5.2 \%$ & $8.2 \%$ & $5.6 \%$ \\
\hline$\% 50+\min$ & $6.2 \%$ & $6.1 \%$ & $6.0 \%$ & $5.1 \%$ & $6.6 \%$ & $5.0 \%$ & $7.4 \%$ & $5.3 \%$ & $11.6 \%$ & $8.5 \%$ & $13.1 \%$ & $8.6 \%$ & $13.6 \%$ & $11.5 \%$ \\
\hline$\%$ Unreported & $2.2 \%$ & $1.5 \%$ & $1.6 \%$ & $1.6 \%$ & $2.4 \%$ & $1.8 \%$ & $3.2 \%$ & $2.0 \%$ & $4.6 \%$ & $3.4 \%$ & $5.6 \%$ & $4.5 \%$ & $8.4 \%$ & $9.0 \%$ \\
\hline TOTAL & 3.80 & 4.01 & 4.10 & 4.33 & 4.11 & 4.31 & 3.93 & 4.11 & 3.42 & 3.74 & 3.51 & 3.58 & 3.40 & 3.57 \\
\hline$\% 5$ or less miles & $52.1 \%$ & $49.5 \%$ & $61.5 \%$ & $59.0 \%$ & $64.6 \%$ & $63.1 \%$ & $67.7 \%$ & $64.6 \%$ & $64.7 \%$ & $64.7 \%$ & $72.9 \%$ & $66.1 \%$ & $70.7 \%$ & $68.5 \%$ \\
\hline$\%$ 6-10 miles & $20.5 \%$ & $20.5 \%$ & $16.7 \%$ & $18.9 \%$ & $15.4 \%$ & $16.7 \%$ & $13.3 \%$ & $15.9 \%$ & $12.6 \%$ & $13.7 \%$ & $9.1 \%$ & $13.1 \%$ & $8.0 \%$ & $5.8 \%$ \\
\hline$\% 11-15$ miles & $9.5 \%$ & $10.7 \%$ & $7.6 \%$ & $8.3 \%$ & $6.5 \%$ & $7.0 \%$ & $5.5 \%$ & $6.9 \%$ & $8.4 \%$ & $6.6 \%$ & $4.2 \%$ & $5.5 \%$ & $3.2 \%$ & $3.5 \%$ \\
\hline$\% 16-20$ miles & $5.9 \%$ & $6.1 \%$ & $4.4 \%$ & $4.1 \%$ & $3.4 \%$ & $3.8 \%$ & $2.8 \%$ & $3.6 \%$ & $3.6 \%$ & $3.1 \%$ & $2.7 \%$ & $3.9 \%$ & $2.0 \%$ & $4.3 \%$ \\
\hline$\% 21-30$ miles & $5.4 \%$ & $5.9 \%$ & $3.4 \%$ & $4.2 \%$ & $3.7 \%$ & $3.8 \%$ & $3.7 \%$ & $3.1 \%$ & $2.7 \%$ & $3.3 \%$ & $1.7 \%$ & $3.3 \%$ & $1.8 \%$ & $1.0 \%$ \\
\hline$\% 31$ or more miles & $5.6 \%$ & $6.1 \%$ & $4.9 \%$ & $4.6 \%$ & $5.0 \%$ & $4.0 \%$ & $3.9 \%$ & $3.8 \%$ & $2.6 \%$ & $3.5 \%$ & $1.6 \%$ & $3.5 \%$ & $1.9 \%$ & $2.3 \%$ \\
\hline \% Unreported & $1.0 \%$ & $1.2 \%$ & $1.6 \%$ & $1.0 \%$ & $1.5 \%$ & $1.6 \%$ & $3.2 \%$ & $2.1 \%$ & $5.4 \%$ & $5.1 \%$ & $7.8 \%$ & $4.7 \%$ & $12.4 \%$ & $14.6 \%$ \\
\hline Daily PMT per Person & & & & & & & & & & & & & & \\
\hline TOTAL & 40.12 & 44.65 & 37.78 & 42.51 & 35.05 & 39.00 & 28.31 & 36.12 & 23.75 & 33.53 & 24.84 & 30.69 & 18.51 & 24.49 \\
\hline \% POV & $91.8 \%$ & $93.9 \%$ & $86.2 \%$ & $88.1 \%$ & $88.8 \%$ & $90.3 \%$ & $84.2 \%$ & $85.8 \%$ & $79.2 \%$ & $69.6 \%$ & $37.2 \%$ & $67.0 \%$ & $42.4 \%$ & $80.3 \%$ \\
\hline$\%$ Public & $1.9 \%$ & $0.2 \%$ & $1.4 \%$ & $0.6 \%$ & $3.3 \%$ & $0.7 \%$ & $5.5 \%$ & $1.6 \%$ & $12.3 \%$ & $3.3 \%$ & $15.2 \%$ & $5.8 \%$ & $25.3 \%$ & $16.2 \%$ \\
\hline \% Walk & $0.6 \%$ & $0.4 \%$ & $0.7 \%$ & $0.5 \%$ & $0.7 \%$ & $0.6 \%$ & $1.3 \%$ & $0.8 \%$ & $2.2 \%$ & $1.2 \%$ & $3.4 \%$ & $1.5 \%$ & $4.9 \%$ & $2.8 \%$ \\
\hline$\%$ Other & $5.7 \%$ & $5.4 \%$ & $11.6 \%$ & $10.7 \%$ & $7.1 \%$ & $6.2 \%$ & $7.2 \%$ & $11.7 \%$ & $6.1 \%$ & $25.9 \%$ & $44.3 \%$ & $25.7 \%$ & $25.6 \%$ & $0.7 \%$ \\
\hline$\%$ Unreported & $0.0 \%$ & $0.2 \%$ & $0.1 \%$ & $0.1 \%$ & $0.2 \%$ & $2.2 \%$ & $1.8 \%$ & $0.1 \%$ & $0.2 \%$ & $0.0 \%$ & $0.0 \%$ & $0.0 \%$ & $1.9 \%$ & \\
\hline TOTAL & 40.12 & 44.65 & 37.78 & 42.51 & 35.05 & 39.00 & 28.31 & 36.12 & 23.75 & 33.53 & 24.84 & 30.69 & 18.51 & 24.49 \\
\hline$\%$ SOV & $42.5 \%$ & $40.3 \%$ & $41.5 \%$ & $38.5 \%$ & $39.7 \%$ & $39.6 \%$ & $36.8 \%$ & $36.6 \%$ & $31.4 \%$ & $27.8 \%$ & $16.3 \%$ & $24.4 \%$ & $13.0 \%$ & $22.0 \%$ \\
\hline$\% \mathrm{MOV}$ & $49.3 \%$ & $53.7 \%$ & $44.8 \%$ & $49.6 \%$ & $49.0 \%$ & $50.7 \%$ & $47.4 \%$ & $49.3 \%$ & $47.9 \%$ & $41.7 \%$ & $20.9 \%$ & $42.6 \%$ & $29.4 \%$ & $58.4 \%$ \\
\hline$\%$ Amtrak & $0.6 \%$ & $0.0 \%$ & $0.4 \%$ & $0.0 \%$ & $0.2 \%$ & $0.0 \%$ & $0.6 \%$ & $0.2 \%$ & $0.9 \%$ & $0.4 \%$ & $0.2 \%$ & & $1.7 \%$ & \\
\hline$\%$ Commuter Train & $0.7 \%$ & $0.1 \%$ & $0.7 \%$ & $0.2 \%$ & $2.2 \%$ & $0.1 \%$ & $2.9 \%$ & $0.5 \%$ & $1.4 \%$ & $0.3 \%$ & $0.9 \%$ & $0.2 \%$ & $0.5 \%$ & \\
\hline \% Subway/El Rail & $0.5 \%$ & $0.0 \%$ & $0.3 \%$ & $0.2 \%$ & $0.5 \%$ & $0.1 \%$ & $1.5 \%$ & $0.2 \%$ & $6.9 \%$ & $0.7 \%$ & $9.8 \%$ & $1.1 \%$ & $18.2 \%$ & $3.7 \%$ \\
\hline \% Other Public & $0.6 \%$ & $0.1 \%$ & $0.2 \%$ & $0.2 \%$ & $0.4 \%$ & $0.4 \%$ & $1.0 \%$ & $1.0 \%$ & $3.5 \%$ & $2.3 \%$ & $4.1 \%$ & $3.9 \%$ & $6.5 \%$ & $12.4 \%$ \\
\hline$\%$ Walk & $0.6 \%$ & $0.4 \%$ & $0.7 \%$ & $0.5 \%$ & $0.7 \%$ & $0.6 \%$ & $1.3 \%$ & $0.8 \%$ & $2.2 \%$ & $1.2 \%$ & $3.4 \%$ & $1.5 \%$ & $4.9 \%$ & $2.8 \%$ \\
\hline$\%$ Other & $5.2 \%$ & $5.4 \%$ & $11.4 \%$ & $10.7 \%$ & $7.1 \%$ & $6.2 \%$ & $6.8 \%$ & $11.6 \%$ & $5.7 \%$ & $25.5 \%$ & $44.5 \%$ & $26.3 \%$ & $24.1 \%$ & $0.7 \%$ \\
\hline$\%$ Unreported & $0.0 \%$ & $0.2 \%$ & $0.1 \%$ & $0.1 \%$ & $0.2 \%$ & $2.2 \%$ & $1.8 \%$ & $0.1 \%$ & $0.2 \%$ & $0.0 \%$ & $0.0 \%$ & $0.0 \%$ & $1.9 \%$ & \\
\hline TOTAL & 40.12 & 44.65 & 37.78 & 42.51 & 35.05 & 39.00 & 28.31 & 36.12 & 23.75 & 33.53 & 24.84 & 30.69 & 18.51 & 24.49 \\
\hline$\%$ Earn a Living & $27.2 \%$ & $27.1 \%$ & $27.1 \%$ & $28.8 \%$ & $29.6 \%$ & $25.3 \%$ & $28.8 \%$ & $29.0 \%$ & $29.9 \%$ & $41.6 \%$ & $45.9 \%$ & $25.0 \%$ & $24.3 \%$ & $20.5 \%$ \\
\hline \% Family \& Personal Business & $32.6 \%$ & $33.8 \%$ & $30.5 \%$ & $32.2 \%$ & $29.4 \%$ & $32.7 \%$ & $31.8 \%$ & $30.8 \%$ & $31.1 \%$ & $27.2 \%$ & $20.6 \%$ & $23.6 \%$ & $24.5 \%$ & $19.5 \%$ \\
\hline$\%$ Civic, Educational \& Religious & $6.0 \%$ & $7.1 \%$ & $5.5 \%$ & $6.2 \%$ & $4.2 \%$ & $5.1 \%$ & $5.0 \%$ & $4.9 \%$ & $7.0 \%$ & $4.2 \%$ & $4.4 \%$ & $4.7 \%$ & $5.0 \%$ & $1.1 \%$ \\
\hline \% Social \& Recreational & $32.0 \%$ & $29.8 \%$ & $31.6 \%$ & $29.8 \%$ & $34.7 \%$ & $31.4 \%$ & $32.5 \%$ & $30.5 \%$ & $30.0 \%$ & $25.5 \%$ & $13.8 \%$ & $26.4 \%$ & $32.3 \%$ & $57.9 \%$ \\
\hline$\%$ Other & $1.6 \%$ & $1.7 \%$ & $4.7 \%$ & $2.7 \%$ & $1.5 \%$ & $5.4 \%$ & $1.7 \%$ & $4.7 \%$ & $1.9 \%$ & $1.3 \%$ & $8.9 \%$ & $20.4 \%$ & $11.5 \%$ & \\
\hline$\%$ Unreported & $0.7 \%$ & $0.4 \%$ & $0.6 \%$ & $0.2 \%$ & $0.7 \%$ & $0.2 \%$ & $0.2 \%$ & $0.3 \%$ & $0.1 \%$ & $0.2 \%$ & $6.5 \%$ & $0.0 \%$ & $2.5 \%$ & $1.0 \%$ \\
\hline $\begin{array}{l}\text { Average Person Trip Length } \\
\text { TOTAL }\end{array}$ & 11.32 & 11.55 & 9.95 & 9.73 & 8.16 & 8.66 & 7.02 & 8.22 & 7.17 & 8.40 & 7.52 & 7.86 & 8.60 & 6.60 \\
\hline
\end{tabular}


Chapter 4: Table 3

Urban Travel and Population Density, 1995

\begin{tabular}{|c|c|c|c|c|c|c|c|c|c|c|c|c|c|c|}
\hline \multicolumn{15}{|c|}{ Population Density (census tract) } \\
\hline & \multicolumn{2}{|c|}{$<500$} & \multicolumn{2}{|c|}{$500-2,000$} & \multicolumn{2}{|c|}{$2,000-4,000$} & \multicolumn{2}{|c|}{$4,000-10,000$} & \multicolumn{2}{|c|}{$10,000-20,000$} & \multicolumn{2}{|c|}{$20,000-50,000$} & \multicolumn{2}{|c|}{$50,000+$} \\
\hline & NY State & U.S. & NY State & U.S. & NY State & U.S. & NY State & U.S. & NY State & U.S. & NY State & U.S. & NY State & U.S. \\
\hline $\begin{array}{l}\text { Daily Person Trips per Person } \\
\text { TOTAL }\end{array}$ & 4.06 & 4.17 & 4.24 & 4.36 & 4.34 & 4.45 & 4.01 & 4.36 & 3,62 & 4.03 & 376 & 4.09 & 3.46 & 350 \\
\hline$\% 1-9 \min$ & $39.2 \%$ & $36.0 \%$ & $40.3 \%$ & $39.2 \%$ & $41.9 \%$ & $40.4 \%$ & $40.4 \%$ & $40.1 \%$ & $37.3 \%$ & $35.5 \%$ & $33.5 \%$ & $31.3 \%$ & $31.5 \%$ & $34.9 \%$ \\
\hline$\% 10-19 \min$ & $30.8 \%$ & $32.1 \%$ & $32.1 \%$ & $33.7 \%$ & $31.6 \%$ & $33.0 \%$ & $31.7 \%$ & $32.8 \%$ & $29.8 \%$ & $33.5 \%$ & $26.6 \%$ & $32.5 \%$ & $25.1 \%$ & $25.7 \%$ \\
\hline$\% 20-29 \min$ & $13.8 \%$ & $14.6 \%$ & $13.7 \%$ & $12.8 \%$ & $12.2 \%$ & $12.8 \%$ & $12.0 \%$ & $13.1 \%$ & $11.9 \%$ & $13.9 \%$ & $13.6 \%$ & $14.7 \%$ & $13.6 \%$ & $13.4 \%$ \\
\hline$\% 30-39 \min$ & $7.6 \%$ & $7.4 \%$ & $6.1 \%$ & $6.0 \%$ & $5.3 \%$ & $5.8 \%$ & $5.7 \%$ & $6.2 \%$ & $6.6 \%$ & $8.4 \%$ & $8.5 \%$ & $9.0 \%$ & $10.4 \%$ & $9.4 \%$ \\
\hline$\% 40-49 \min$ & $3.2 \%$ & $3.8 \%$ & $2.6 \%$ & $3.4 \%$ & $2.8 \%$ & $2.7 \%$ & $3.2 \%$ & $3.0 \%$ & $4.1 \%$ & $3.7 \%$ & $5.9 \%$ & $5.4 \%$ & $7.5 \%$ & $7.7 \%$ \\
\hline$\% 50+\min$ & $4.2 \%$ & $4.8 \%$ & $4.5 \%$ & $3.9 \%$ & $4.8 \%$ & $4.0 \%$ & $5.2 \%$ & $3.7 \%$ & $8.0 \%$ & $4.2 \%$ & $9.3 \%$ & $5.4 \%$ & $8.7 \%$ & $6.3 \%$ \\
\hline$\%$ Unreported & $1.2 \%$ & $1.2 \%$ & $0.7 \%$ & $0.9 \%$ & $1.4 \%$ & $1.1 \%$ & $1.7 \%$ & $1.1 \%$ & $2.2 \%$ & $0.7 \%$ & $2.7 \%$ & $1.7 \%$ & $3.2 \%$ & $2.6 \%$ \\
\hline TOTAL & 4.06 & 4.17 & 4.24 & 4.36 & 4.34 & 4.45 & 4.01 & 4.36 & 3.62 & 4.03 & 3.76 & 4.09 & 3.46 & 3.50 \\
\hline$\% 5$ or less miles & $54.2 \%$ & $52.5 \%$ & $61.1 \%$ & $61.0 \%$ & $66.4 \%$ & $65.4 \%$ & $67.6 \%$ & $67.4 \%$ & $68.2 \%$ & $69.2 \%$ & $70.7 \%$ & $72.1 \%$ & $73.7 \%$ & $77.1 \%$ \\
\hline$\% 6-10$ miles & $20.7 \%$ & $19.7 \%$ & $17.7 \%$ & $17.9 \%$ & $14.5 \%$ & $15.7 \%$ & $13.7 \%$ & $14.7 \%$ & $11.6 \%$ & $13.4 \%$ & $9.6 \%$ & $11.2 \%$ & $7.2 \%$ & $12.0 \%$ \\
\hline$\% 11-15$ miles & $9.6 \%$ & $10.1 \%$ & $8.0 \%$ & $7.6 \%$ & $6.5 \%$ & $6.7 \%$ & $6.0 \%$ & $6.4 \%$ & $5.8 \%$ & $6.2 \%$ & $5.1 \%$ & $4.6 \%$ & $4.3 \%$ & $3.4 \%$ \\
\hline$\% 16-20$ miles & $5.4 \%$ & $5.8 \%$ & $3.8 \%$ & $3.9 \%$ & $3.0 \%$ & $3.6 \%$ & $3.0 \%$ & $3.4 \%$ & $3.0 \%$ & $3.0 \%$ & $3.2 \%$ & $2.4 \%$ & $1.7 \%$ & $2.9 \%$ \\
\hline$\% 21-30$ miles & $4.4 \%$ & $5.3 \%$ & $3.3 \%$ & $3.9 \%$ & $3.7 \%$ & $3.4 \%$ & $3.2 \%$ & $3.0 \%$ & $3.6 \%$ & $3.0 \%$ & $2.1 \%$ & $2.4 \%$ & $2.3 \%$ & $1.7 \%$ \\
\hline$\% 31$ or more miles & $4.4 \%$ & $5.8 \%$ & $4.5 \%$ & $4.8 \%$ & $4.6 \%$ & $4.0 \%$ & $3.5 \%$ & $3.4 \%$ & $2.8 \%$ & $2.7 \%$ & $1.9 \%$ & $2.7 \%$ & $2.6 \%$ & $3.1 \%$ \\
\hline$\%$ Unreported & $1.2 \%$ & $0.8 \%$ & $1.7 \%$ & $0.9 \%$ & $1.4 \%$ & $1.1 \%$ & $3.0 \%$ & $1.6 \%$ & $5.0 \%$ & $2.5 \%$ & $7.4 \%$ & $4.4 \%$ & $8.1 \%$ & \\
\hline \multicolumn{15}{|l|}{ Daily PMT per Person } \\
\hline TOTAL & 39.75 & 43.90 & 39.25 & 40.28 & 34.31 & 39.89 & 28.12 & 34.49 & 23.60 & 26.13 & 18.05 & 22.84 & 18.93 & 25.59 \\
\hline$\%$ POV & $90.8 \%$ & $94.7 \%$ & $92.7 \%$ & $92.5 \%$ & $91.3 \%$ & $88.2 \%$ & $87.3 \%$ & $90.1 \%$ & $83.0 \%$ & $84.5 \%$ & $63.0 \%$ & $78.8 \%$ & $51.2 \%$ & $84.4 \%$ \\
\hline$\%$ Public & $2.2 \%$ & $0.5 \%$ & $2.5 \%$ & $0.7 \%$ & $3.9 \%$ & $2.8 \%$ & $7.6 \%$ & $2.0 \%$ & $13.1 \%$ & $10.2 \%$ & $28.4 \%$ & $11.3 \%$ & $34.7 \%$ & $11.8 \%$ \\
\hline$\%$ Walk & $0.4 \%$ & $0.1 \%$ & $0.3 \%$ & $0.2 \%$ & $0.3 \%$ & $0.3 \%$ & $0.6 \%$ & $0.4 \%$ & $0.9 \%$ & $0.9 \%$ & $3.6 \%$ & $2.1 \%$ & $4.1 \%$ & $3.4 \%$ \\
\hline$\%$ Other & $5.8 \%$ & $4.0 \%$ & $3.6 \%$ & $5.9 \%$ & $3.3 \%$ & $6.9 \%$ & $3.2 \%$ & $6.6 \%$ & $2.1 \%$ & $2.9 \%$ & $4.4 \%$ & $7.5 \%$ & $9.1 \%$ & $0.2 \%$ \\
\hline$\%$ Unreported & $0.8 \%$ & $0.8 \%$ & $0.8 \%$ & $0.7 \%$ & $1.1 \%$ & $1.8 \%$ & $1.4 \%$ & $0.9 \%$ & $1.0 \%$ & $1.5 \%$ & $0.7 \%$ & $0.3 \%$ & $0.9 \%$ & $0.2 \%$ \\
\hline TOTAL & 39.75 & 43.90 & 39.25 & 40.28 & 34.31 & 39.89 & 28.12 & 34.49 & 23.60 & 26.13 & 18.05 & 22.84 & 18.93 & 25.59 \\
\hline$\%$ SOV & $42.4 \%$ & $42.7 \%$ & $37.1 \%$ & $41.4 \%$ & $43.7 \%$ & $38.4 \%$ & $38.9 \%$ & $41.1 \%$ & $34.1 \%$ & $40.1 \%$ & $26.1 \%$ & $31.8 \%$ & $12.8 \%$ & $16.0 \%$ \\
\hline$\% \mathrm{MOV}$ & $48.3 \%$ & $52.0 \%$ & $55.6 \%$ & $51.0 \%$ & $47.4 \%$ & $49.4 \%$ & $48.3 \%$ & $49.0 \%$ & $48.9 \%$ & $44.4 \%$ & $36.4 \%$ & $47.0 \%$ & $38.4 \%$ & $68.4 \%$ \\
\hline$\%$ Other POV & $0.0 \%$ & $0.1 \%$ & $0.0 \%$ & $0.0 \%$ & $0.3 \%$ & $0.4 \%$ & $0.0 \%$ & $0.1 \%$ & $0.0 \%$ & $0.0 \%$ & $0.4 \%$ & $0.0 \%$ & $0.1 \%$ & \\
\hline$\%$ Amtrak & $1.8 \%$ & $0.0 \%$ & $0.1 \%$ & $0.0 \%$ & $0.0 \%$ & $0.1 \%$ & $0.4 \%$ & $0.0 \%$ & & $0.1 \%$ & & & $0.2 \%$ & \\
\hline$\%$ Commuter Train & $0.7 \%$ & $0.1 \%$ & $1.5 \%$ & $0.2 \%$ & $2.7 \%$ & $0.5 \%$ & $3.3 \%$ & $0.4 \%$ & $2.2 \%$ & $0.7 \%$ & $3.0 \%$ & $0.6 \%$ & $7.4 \%$ & $1.5 \%$ \\
\hline \% Subway/El Rail & $0.2 \%$ & $0.0 \%$ & $0.1 \%$ & $0.1 \%$ & $0.1 \%$ & $0.2 \%$ & $1.4 \%$ & $0.1 \%$ & $3.9 \%$ & $1.2 \%$ & $16.1 \%$ & $1.9 \%$ & $16.6 \%$ & $6.5 \%$ \\
\hline \% Other Public & $1.3 \%$ & $0.3 \%$ & $0.9 \%$ & $0.4 \%$ & $1.1 \%$ & $2.1 \%$ & $2.9 \%$ & $1.4 \%$ & $6.9 \%$ & $8.3 \%$ & $9.3 \%$ & $8.8 \%$ & $10.7 \%$ & $3.7 \%$ \\
\hline$\%$ Walk & $0.4 \%$ & $0.1 \%$ & $0.3 \%$ & $0.2 \%$ & $0.3 \%$ & $0.3 \%$ & $0.6 \%$ & $0.4 \%$ & $0.9 \%$ & $0.9 \%$ & $3.6 \%$ & $2.1 \%$ & $4.1 \%$ & $3.4 \%$ \\
\hline$\%$ Other & $4.0 \%$ & $3.9 \%$ & $3.5 \%$ & $5.9 \%$ & $3.3 \%$ & $6.8 \%$ & $2.8 \%$ & $6.6 \%$ & $2.1 \%$ & $2.8 \%$ & $4.4 \%$ & $7.5 \%$ & $8.9 \%$ & $0.2 \%$ \\
\hline$\%$ Unreported & $0.8 \%$ & $0.8 \%$ & $0.8 \%$ & $0.7 \%$ & $1.1 \%$ & $1.8 \%$ & $1.4 \%$ & $0.9 \%$ & $1.0 \%$ & $1.5 \%$ & $0.7 \%$ & $0.3 \%$ & $0.9 \%$ & $0.2 \%$ \\
\hline TOTAL & 39.75 & 43.9 & 39.25 & 40.28 & 34.31 & 39.89 & 28.12 & 34.49 & 23.6 & 26.13 & 18.05 & 22.84 & 18.93 & 25.59 \\
\hline \% Earn a Living & $29.5 \%$ & $29.0 \%$ & $27.0 \%$ & $29.2 \%$ & $30.7 \%$ & $30.1 \%$ & $31.1 \%$ & $27.7 \%$ & $29.8 \%$ & $26.9 \%$ & $35.6 \%$ & $28.9 \%$ & $28.0 \%$ & $18.5 \%$ \\
\hline$\%$ Fam/Per Bus & $33.2 \%$ & $34.7 \%$ & $34.8 \%$ & $35.7 \%$ & $35.0 \%$ & $31.8 \%$ & $31.8 \%$ & $34.8 \%$ & $31.9 \%$ & $34.0 \%$ & $32.4 \%$ & $29.9 \%$ & $31.2 \%$ & $29.0 \%$ \\
\hline$\%$ Civ, Ed, \& Rel & $5.2 \%$ & $6.2 \%$ & $4.5 \%$ & $6.3 \%$ & $4.5 \%$ & $5.3 \%$ & $6.3 \%$ & $4.2 \%$ & $5.2 \%$ & $7.4 \%$ & $6.1 \%$ & $5.0 \%$ & $6.3 \%$ & $2.8 \%$ \\
\hline$\%$ Soc and Rec & $31.5 \%$ & $30.0 \%$ & $33.6 \%$ & $28.3 \%$ & $29.5 \%$ & $32.6 \%$ & $30.7 \%$ & $32.9 \%$ & $32.8 \%$ & $31.6 \%$ & $25.9 \%$ & $36.2 \%$ & $34.5 \%$ & $49.7 \%$ \\
\hline$\%$ Other & $0.7 \%$ & $0.1 \%$ & $0.2 \%$ & $0.6 \%$ & $0.3 \%$ & $0.3 \%$ & $0.1 \%$ & $0.1 \%$ & $0.0 \%$ & $0.0 \%$ & $0.0 \%$ & $0.0 \%$ & $0.0 \%$ & \\
\hline$\%$ Unreported & $0.0 \%$ & $0.0 \%$ & $0.0 \%$ & $0.0 \%$ & . & $0.0 \%$ & $0.0 \%$ & $0.2 \%$ & $0.3 \%$ & & & & & \\
\hline Average Person Trip L & & & & & & & & & & & & & & \\
\hline TOTAL & 9.91 & 10.66 & 9.41 & 9.33 & 8.02 & 9.06 & 7.23 & 8.05 & 6.85 & 6.64 & 5.18 & 5.83 & 5.95 & 7.31 \\
\hline
\end{tabular}

NOTE: Statistics by Household Income for 1995 are unavailable in 2001 Dollar terms for tables in Chapters 4-6. 


\begin{tabular}{|c|c|c|c|c|c|c|c|c|c|c|c|c|c|c|}
\hline \multicolumn{15}{|c|}{ Population Density (census tract) } \\
\hline & \multicolumn{2}{|c|}{$<500$} & \multirow{2}{*}{\multicolumn{2}{|c|}{\begin{tabular}{ll}
\multicolumn{2}{c}{$500-2,000$} \\
NY State U.S.
\end{tabular}}} & \multicolumn{2}{|c|}{$2,000-4,000$} & \multicolumn{2}{|c|}{$4,000-10,000$} & \multicolumn{2}{|c|}{$10,000-20,000$} & \multicolumn{2}{|c|}{$20,000-50,000$} & \multicolumn{2}{|c|}{$50,000+$} \\
\hline & NY State & U.S. & & & NY State & U.S. & NY State & U.S. & NY State & U.S. & NY State & U.S. & NY State & U.S. \\
\hline \multicolumn{15}{|c|}{ Distribution of Zero-Vehicle Households by Household Income } \\
\hline ALL & $100 \%$ & $100 \%$ & $100 \%$ & $100 \%$ & $100 \%$ & $100 \%$ & $100 \%$ & $100 \%$ & $100 \%$ & $100 \%$ & $100 \%$ & $100 \%$ & $100 \%$ & $100 \%$ \\
\hline$<\$ 10,000$ & $30.0 \%$ & $44.4 \%$ & $28.4 \%$ & $38.2 \%$ & $34.5 \%$ & $44.2 \%$ & $32.4 \%$ & $43.8 \%$ & $25.8 \%$ & $41.3 \%$ & $23.6 \%$ & $28.4 \%$ & $19.0 \%$ & $9.1 \%$ \\
\hline$\$ 10$ to $\$ 20,000$ & $26.6 \%$ & $17.3 \%$ & $17.0 \%$ & $23.7 \%$ & $19.8 \%$ & $21.9 \%$ & $32.4 \%$ & $23.7 \%$ & $22.0 \%$ & $26.5 \%$ & $17.4 \%$ & $20.1 \%$ & $17.8 \%$ & $71.5 \%$ \\
\hline$\$ 20$ to $\$ 30,000$ & $5.1 \%$ & $8.8 \%$ & $14.4 \%$ & $11.5 \%$ & $21.3 \%$ & $5.4 \%$ & $11.7 \%$ & $10.7 \%$ & $11.9 \%$ & $8.0 \%$ & $13.2 \%$ & $15.3 \%$ & $11.2 \%$ & $10.3 \%$ \\
\hline$\$ 30$ to $\$ 40,000$ & $10.6 \%$ & $3.3 \%$ & $12.2 \%$ & $3.6 \%$ & $2.1 \%$ & $3.5 \%$ & $5.5 \%$ & $3.2 \%$ & $6.9 \%$ & $7.5 \%$ & $11.3 \%$ & $12.0 \%$ & $8.8 \%$ & $3.9 \%$ \\
\hline$\$ 40$ to $\$ 50,000$ & $2.0 \%$ & $3.0 \%$ & $1.3 \%$ & $1.4 \%$ & $3.8 \%$ & $1.7 \%$ & $2.7 \%$ & $2.7 \%$ & $10.8 \%$ & $3.9 \%$ & $5.3 \%$ & $4.8 \%$ & $8.6 \%$ & $2.3 \%$ \\
\hline$\$ 50$ to $\$ 60,000$ & $0.4 \%$ & $0.0 \%$ & $2.1 \%$ & $0.5 \%$ & & $1.2 \%$ & $0.9 \%$ & $1.0 \%$ & $4.0 \%$ & $0.2 \%$ & $3.7 \%$ & $1.6 \%$ & $3.7 \%$ & \\
\hline$\$ 60$ to $\$ 70,000$ & $0.3 \%$ & $0.9 \%$ & $0.6 \%$ & $0.5 \%$ & $0.3 \%$ & $0.1 \%$ & & & $0.6 \%$ & $0.0 \%$ & $1.0 \%$ & $1.0 \%$ & $3.3 \%$ & $3.0 \%$ \\
\hline$\$ 70$ to $\$ 80,000$ & $7.5 \%$ & $0.2 \%$ & & $0.0 \%$ & & $0.5 \%$ & $0.8 \%$ & $0.2 \%$ & $2.0 \%$ & $0.3 \%$ & $0.4 \%$ & $0.0 \%$ & $2.5 \%$ & \\
\hline$\$ 80,000+$ & $7.1 \%$ & $4.1 \%$ & $1.1 \%$ & $2.6 \%$ & & $1.0 \%$ & $0.5 \%$ & $0.9 \%$ & $3.7 \%$ & $1.5 \%$ & $5.2 \%$ & $5.9 \%$ & $12.0 \%$ & \\
\hline Unreported & $10.5 \%$ & $18.0 \%$ & $22.9 \%$ & $17.9 \%$ & $18.1 \%$ & $20.6 \%$ & $13.2 \%$ & $13.8 \%$ & $12.4 \%$ & $10.8 \%$ & $19.0 \%$ & $10.9 \%$ & $13.2 \%$ & \\
\hline \multicolumn{15}{|c|}{ Zero-Vehicle Households - Daily Person Trips per Person } \\
\hline TOTAL & 2.97 & 2.32 & 2.21 & 2.78 & 2.05 & 2.94 & 2.95 & 2.45 & 2.84 & 2.55 & 3.31 & 2.80 & 3.32 & 3.23 \\
\hline$\%$ Private & $14.3 \%$ & $79.6 \%$ & $35.9 \%$ & $74.1 \%$ & $45.3 \%$ & $51.1 \%$ & $25.1 \%$ & $36.2 \%$ & $21.9 \%$ & $20.1 \%$ & $23.0 \%$ & $18.3 \%$ & $9.1 \%$ & \\
\hline$\%$ Public & $33.7 \%$ & $0.3 \%$ & $20.6 \%$ & $7.8 \%$ & $16.7 \%$ & $9.6 \%$ & $18.6 \%$ & $19.1 \%$ & $28.3 \%$ & $29.9 \%$ & $26.7 \%$ & $33.9 \%$ & $34.8 \%$ & $46.9 \%$ \\
\hline$\%$ Other & $6.0 \%$ & $4.4 \%$ & $4.0 \%$ & $4.4 \%$ & $16.1 \%$ & $5.7 \%$ & $13.8 \%$ & $8.3 \%$ & $8.2 \%$ & $7.6 \%$ & $6.5 \%$ & $8.3 \%$ & $6.7 \%$ & $5.6 \%$ \\
\hline$\%$ Walk & $46.0 \%$ & $15.4 \%$ & $39.5 \%$ & $13.6 \%$ & $21.9 \%$ & $33.5 \%$ & $42.5 \%$ & $36.3 \%$ & $41.7 \%$ & $42.3 \%$ & $43.6 \%$ & $39.5 \%$ & $49.1 \%$ & $47.6 \%$ \\
\hline$\%$ Unreported & & $0.3 \%$ & & $0.1 \%$ & & & $0.0 \%$ & $0.1 \%$ & & & $0.2 \%$ & & $0.3 \%$ & \\
\hline TOTAL & 2.97 & 2.32 & 2.21 & 2.78 & 2.05 & 2.94 & 2.95 & 2.45 & 2.84 & 2.55 & 3.31 & 2.80 & 3.32 & 3.23 \\
\hline Unreported & 1.45 & 2.09 & 1.73 & 1.50 & 1.81 & 2.03 & 2.12 & 2.14 & 2.20 & 1.71 & 2.22 & 2.84 & 2.72 & \\
\hline$<\$ 10,000$ & 3.30 & 2.07 & 1.41 & 2.54 & 2.05 & 2.83 & 3.22 & 2.31 & 2.55 & 2.77 & 2.75 & 2.20 & 2.86 & 3.50 \\
\hline$\$ 10$ to $\$ 20,000$ & 1.16 & 1.99 & 1.55 & 2.96 & 2.93 & 3.25 & 3.48 & 2.65 & 2.30 & 2.59 & 3.42 & 2.83 & 3.07 & 3.07 \\
\hline$\$ 20$ to $\$ 30,000$ & 2.04 & 2.13 & 2.78 & 4.09 & 1.06 & 3.16 & 1.95 & 2.39 & 2.55 & 2.18 & 3.56 & 2.41 & 3.65 & 2.00 \\
\hline$\$ 30$ to $\$ 40,000$ & 0.41 & 2.39 & 5.75 & 2.92 & 4.47 & 3.60 & 3.45 & 2.02 & 2.11 & 2.86 & 3.17 & 4.08 & 3.20 & 2.00 \\
\hline$\$ 40$ to $\$ 50,000$ & 5.57 & 5.13 & 1.35 & 1.85 & 5.62 & 4.31 & 3.01 & 3.81 & 3.33 & 3.48 & 4.58 & 3.83 & 3.05 & 4.93 \\
\hline$\$ 50$ to $\$ 60,000$ & 2.45 & 2.00 & & 4.98 & & 5.56 & 2.00 & 2.78 & 5.58 & 4.45 & 5.12 & 2.54 & 4.87 & \\
\hline$\$ 60$ to $\$ 70,000$ & 5.00 & 4.81 & 1.18 & & 1.95 & 4.04 & & & 1.24 & 3.00 & 4.03 & 2.03 & 3.14 & 8.00 \\
\hline$\$ 70$ to $\$ 80,000$ & 4.02 & 2.00 & & 6.49 & & 5.64 & 5.13 & 1.92 & 3.92 & 3.07 & 5.64 & 1.68 & 4.48 & \\
\hline$\$ 80,000+$ & 5.96 & 4.09 & 4.32 & 3.66 & & 2.28 & 4.05 & 5.02 & 2.47 & 3.83 & 4.45 & 4.00 & 4.45 & \\
\hline \multicolumn{15}{|c|}{ Zero-Vehicle Households - Daily PMT per Person } \\
\hline TOTAL & 12.63 & 27.15 & 9.08 & 25.59 & 8.04 & 11.21 & 9.26 & 26.92 & 12.51 & 8.73 & 30.29 & 9.54 & 12.97 & 7.53 \\
\hline$\%$ Private & $33.7 \%$ & $97.3 \%$ & $44.7 \%$ & $80.0 \%$ & $62.7 \%$ & $83.4 \%$ & $48.0 \%$ & $24.6 \%$ & $27.9 \%$ & $51.6 \%$ & $10.8 \%$ & $32.2 \%$ & $22.2 \%$ & \\
\hline$\%$ Public & $48.7 \%$ & $0.3 \%$ & $41.1 \%$ & $4.6 \%$ & $18.0 \%$ & $8.3 \%$ & $33.8 \%$ & $8.4 \%$ & $45.9 \%$ & $31.6 \%$ & $13.8 \%$ & $53.4 \%$ & $45.6 \%$ & $86.5 \%$ \\
\hline$\%$ Other & $2.9 \%$ & $1.7 \%$ & $9.0 \%$ & $14.7 \%$ & $14.4 \%$ & $2.7 \%$ & $9.9 \%$ & $64.8 \%$ & $19.4 \%$ & $9.1 \%$ & $71.6 \%$ & $4.7 \%$ & $24.7 \%$ & $2.9 \%$ \\
\hline$\%$ Walk & $14.7 \%$ & $0.7 \%$ & $5.3 \%$ & $0.6 \%$ & $4.8 \%$ & $5.6 \%$ & $8.3 \%$ & $2.2 \%$ & $6.7 \%$ & $7.7 \%$ & $3.8 \%$ & $9.7 \%$ & $7.5 \%$ & $10.6 \%$ \\
\hline$\%$ Unreported & & & & $0.0 \%$ & & & & $0.0 \%$ & & & & & $0.1 \%$ & \\
\hline
\end{tabular}




\begin{tabular}{|c|c|c|c|c|c|c|c|c|c|c|c|c|c|c|}
\hline \multicolumn{15}{|c|}{ Population Density (census tract) } \\
\hline & \multicolumn{2}{|c|}{$<500$} & \multicolumn{2}{|c|}{$500-2,000$} & \multicolumn{2}{|c|}{$2,000-4,000$} & \multicolumn{2}{|c|}{$4,000-10,000$} & \multicolumn{2}{|c|}{$10,000-20,000$} & \multicolumn{2}{|c|}{$20,000-50,000$} & \multicolumn{2}{|c|}{$50,000+$} \\
\hline & NY State & U.S. & NY State & U.S. & NY State & U.S. & NY State & U.S. & NY State & U.S. & NY State & U.S. & NY State & U.S. \\
\hline \multicolumn{15}{|c|}{ Zero-Vehicle Households - Daily Person Trips per Person } \\
\hline TOTAL & 3.82 & 2.45 & 2.36 & 2.56 & 3.27 & 2.71 & 2.91 & 3.01 & 2.84 & 3.14 & 3.40 & 3.62 & 3.29 & 3.05 \\
\hline$\%$ Private & $34.6 \%$ & $71.4 \%$ & $33.1 \%$ & $68.8 \%$ & $42.5 \%$ & $60.9 \%$ & $34.7 \%$ & $40.2 \%$ & $31.0 \%$ & $30.9 \%$ & $13.5 \%$ & $24.3 \%$ & $9.7 \%$ & $5.6 \%$ \\
\hline$\%$ Public & $13.4 \%$ & $1.2 \%$ & $12.7 \%$ & $7.4 \%$ & $16.5 \%$ & $8.9 \%$ & $19.9 \%$ & $16.6 \%$ & $29.9 \%$ & $25.2 \%$ & $32.1 \%$ & $24.3 \%$ & $35.3 \%$ & $42.0 \%$ \\
\hline$\%$ Other & $8.6 \%$ & $12.7 \%$ & $8.1 \%$ & $9.4 \%$ & $7.3 \%$ & $8.9 \%$ & $13.4 \%$ & $6.0 \%$ & $6.0 \%$ & $8.3 \%$ & $5.0 \%$ & $4.4 \%$ & $7.0 \%$ & $1.6 \%$ \\
\hline$\%$ Walk & $32.7 \%$ & $10.2 \%$ & $30.1 \%$ & $6.6 \%$ & $19.9 \%$ & $16.6 \%$ & $24.7 \%$ & $29.6 \%$ & $22.9 \%$ & $27.7 \%$ & $42.9 \%$ & $37.6 \%$ & $41.6 \%$ & $43.3 \%$ \\
\hline$\%$ Unreported & $10.7 \%$ & $4.5 \%$ & $16.1 \%$ & $7.8 \%$ & $13.8 \%$ & $4.8 \%$ & $7.2 \%$ & $7.6 \%$ & $10.2 \%$ & $8.0 \%$ & $6.5 \%$ & $9.4 \%$ & $6.4 \%$ & $7.5 \%$ \\
\hline \multicolumn{15}{|c|}{ Zero-Vehicle Households - Daily PMT per Person } \\
\hline TOTAL & 24.75 & 16.36 & 8.21 & 17.54 & 14.22 & 12.72 & 16.69 & 12.51 & 13.71 & 12.16 & 11.17 & 11.74 & 16.31 & 5.97 \\
\hline$\%$ Private & $61.5 \%$ & $89.0 \%$ & $71.0 \%$ & $88.8 \%$ & $57.9 \%$ & $66.0 \%$ & $59.9 \%$ & $70.2 \%$ & $64.8 \%$ & $32.3 \%$ & $19.5 \%$ & $42.2 \%$ & $37.0 \%$ & $16.9 \%$ \\
\hline$\%$ Public & $25.5 \%$ & $2.4 \%$ & $14.6 \%$ & $6.0 \%$ & $22.7 \%$ & $18.7 \%$ & $20.4 \%$ & $20.8 \%$ & $27.1 \%$ & $54.2 \%$ & $69.3 \%$ & $44.2 \%$ & $46.2 \%$ & $66.3 \%$ \\
\hline$\%$ Walk & $5.8 \%$ & $0.9 \%$ & $5.8 \%$ & $0.8 \%$ & $3.0 \%$ & $1.8 \%$ & $2.6 \%$ & $4.1 \%$ & $2.8 \%$ & $4.3 \%$ & $7.1 \%$ & $6.6 \%$ & $5.5 \%$ & $14.9 \%$ \\
\hline$\%$ Other & $1.9 \%$ & $6.8 \%$ & $6.5 \%$ & $4.0 \%$ & $15.5 \%$ & $12.7 \%$ & $16.8 \%$ & $3.9 \%$ & $5.0 \%$ & $4.9 \%$ & $3.1 \%$ & $5.9 \%$ & $10.6 \%$ & $0.8 \%$ \\
\hline$\%$ Unreported & $5.3 \%$ & $0.9 \%$ & $2.1 \%$ & $0.3 \%$ & $0.8 \%$ & $0.9 \%$ & $0.4 \%$ & $1.0 \%$ & $0.4 \%$ & $4.3 \%$ & $1.0 \%$ & $1.1 \%$ & $0.7 \%$ & $1.0 \%$ \\
\hline
\end{tabular}




\begin{tabular}{|c|c|c|c|c|c|c|c|c|c|c|c|c|c|c|}
\hline \multicolumn{15}{|c|}{ Population Density (census tract) } \\
\hline & \multicolumn{2}{|c|}{$<500$} & \multicolumn{2}{|c|}{$500-2,000$} & \multicolumn{2}{|c|}{$2,000-4,000$} & \multicolumn{2}{|c|}{$4,000-10,000$} & \multicolumn{2}{|c|}{$10,000-20,000$} & \multicolumn{2}{|c|}{$20,000-50,000$} & \multicolumn{2}{|c|}{$50,000+$} \\
\hline & NY State & U.S. & NY State & U.S. & NY State & U.S. & NY State & U.S. & NY State & U.S. & NY State & U.S. & NY State & U.S. \\
\hline \multicolumn{15}{|c|}{ Zero-Vehicle Households - Daily PMT per Person } \\
\hline TOTAL & 12.63 & 27.15 & 9.08 & 25.59 & 8.04 & 11.21 & 9.26 & 26.92 & 12.51 & 8.73 & 30.29 & 9.54 & 12.97 & 7.53 \\
\hline Unreported & 8.96 & 11.72 & 9.02 & 8.69 & 1.09 & 8.85 & 3.23 & 6.60 & 8.42 & 2.27 & 5.18 & 2.82 & 5.91 & \\
\hline$<\$ 10,000$ & 14.90 & 29.80 & 4.48 & 10.91 & 5.51 & 6.97 & 7.62 & 6.50 & 8.09 & 4.30 & 8.21 & 10.48 & 11.14 & 3.61 \\
\hline$\$ 10$ to $\$ 20,000$ & 7.18 & 8.68 & 3.14 & 25.25 & 7.51 & 10.87 & 11.32 & 10.22 & 14.10 & 9.01 & 4.42 & 5.91 & 9.07 & 8.14 \\
\hline$\$ 20$ to $\$ 30,000$ & 6.70 & 41.27 & 6.68 & 61.83 & 4.42 & 12.55 & 6.92 & 49.15 & 6.34 & 8.85 & 9.05 & 6.11 & 19.12 & 8.00 \\
\hline$\$ 30$ to $\$ 40,000$ & 22.69 & 10.43 & 24.82 & 16.31 & 34.44 & 18.70 & 26.69 & 8.10 & 7.32 & 34.49 & 19.70 & 20.31 & 7.54 & \\
\hline$\$ 40$ to $\$ 50,000$ & 30.57 & 106.05 & & 34.09 & 27.08 & 35.38 & 8.46 & 476.56 & 20.48 & 17.12 & 8.81 & 15.74 & 14.13 & 9.48 \\
\hline$\$ 50$ to $\$ 60,000$ & 1.61 & 20.51 & & 43.75 & & 12.46 & & 9.34 & 14.80 & 14.04 & 19.72 & 14.40 & 11.64 & \\
\hline$\$ 60$ to $\$ 70,000$ & 10.00 & 51.69 & 23.54 & & 107.07 & 12.90 & & & 16.11 & 60.00 & 22.64 & 6.68 & 29.92 & 7.33 \\
\hline$\$ 70$ to $\$ 80,000$ & 16.09 & 52.00 & & 14.16 & & 163.42 & 8.98 & 3.98 & 13.48 & 9.92 & 16.61 & 28.40 & 19.54 & \\
\hline$\$ 80,000+$ & 13.32 & 44.63 & 47.20 & 104.24 & & 12.61 & 7.80 & 77.66 & 10.21 & 5.77 & 359.98 & 13.97 & 19.07 & \\
\hline \multicolumn{15}{|c|}{ Non-Zero-Vehicle Households - Daily Person Trips per Person } \\
\hline TOTAL & 3.82 & 4.04 & 4.12 & 4.37 & 4.22 & 4.35 & 4.00 & 4.20 & 3.55 & 3.89 & 3.62 & 3.78 & 3.48 & 4.11 \\
\hline$\%$ Private & $87.6 \%$ & $90.6 \%$ & $87.6 \%$ & $90.0 \%$ & $87.2 \%$ & $89.8 \%$ & $83.8 \%$ & $87.5 \%$ & $74.8 \%$ & $80.3 \%$ & $56.6 \%$ & $74.5 \%$ & $38.9 \%$ & $78.0 \%$ \\
\hline$\%$ Public & $0.8 \%$ & $0.1 \%$ & $0.6 \%$ & $0.3 \%$ & $1.3 \%$ & $0.6 \%$ & $2.1 \%$ & $1.2 \%$ & $6.0 \%$ & $2.8 \%$ & $13.7 \%$ & $5.1 \%$ & $18.6 \%$ & \\
\hline \% Walk & $6.6 \%$ & $5.4 \%$ & $7.1 \%$ & $5.8 \%$ & $7.4 \%$ & $7.0 \%$ & $9.8 \%$ & $8.9 \%$ & $15.5 \%$ & $14.1 \%$ & $26.5 \%$ & $16.9 \%$ & $38.3 \%$ & $20.3 \%$ \\
\hline$\%$ Other & $5.0 \%$ & $3.8 \%$ & $4.6 \%$ & $3.7 \%$ & $4.1 \%$ & $2.5 \%$ & $4.2 \%$ & $2.4 \%$ & $3.4 \%$ & $2.9 \%$ & $3.1 \%$ & $3.3 \%$ & $4.2 \%$ & $1.7 \%$ \\
\hline$\%$ Unreported & $0.1 \%$ & $0.1 \%$ & $0.1 \%$ & $0.1 \%$ & $0.1 \%$ & $0.1 \%$ & $0.1 \%$ & $0.1 \%$ & $0.2 \%$ & $0.0 \%$ & $0.1 \%$ & $0.1 \%$ & $0.0 \%$ & \\
\hline \multicolumn{15}{|c|}{ Non-Zero-Vehicle Households - Daily PMT per Person } \\
\hline TOTAL & 40.74 & 45.00 & 38.16 & 42.84 & 36.39 & 39.88 & 29.78 & 36.62 & 26.16 & 36.73 & 21.73 & 36.22 & 24.66 & 50.78 \\
\hline$\%$ Private & $92.2 \%$ & $93.9 \%$ & $86.4 \%$ & $88.2 \%$ & $89.0 \%$ & $90.4 \%$ & $85.0 \%$ & $88.2 \%$ & $84.5 \%$ & $70.1 \%$ & $58.2 \%$ & $69.4 \%$ & $54.1 \%$ & $98.8 \%$ \\
\hline$\%$ Public & $1.5 \%$ & $0.1 \%$ & $1.3 \%$ & $0.5 \%$ & $3.1 \%$ & $0.6 \%$ & $4.8 \%$ & $1.4 \%$ & $8.9 \%$ & $2.4 \%$ & $16.3 \%$ & $2.6 \%$ & $13.4 \%$ & \\
\hline$\%$ Walk & $0.5 \%$ & $0.3 \%$ & $0.6 \%$ & $0.5 \%$ & $0.7 \%$ & $0.5 \%$ & $1.2 \%$ & $0.7 \%$ & $1.7 \%$ & $1.0 \%$ & $3.0 \%$ & $0.9 \%$ & $3.3 \%$ & $1.0 \%$ \\
\hline$\%$ Other & $5.7 \%$ & $5.5 \%$ & $11.6 \%$ & $10.6 \%$ & $7.0 \%$ & $6.2 \%$ & $7.1 \%$ & $9.6 \%$ & $4.7 \%$ & $26.4 \%$ & $22.5 \%$ & $27.1 \%$ & $26.2 \%$ & $0.2 \%$ \\
\hline$\%$ Unreported & $0.0 \%$ & $0.2 \%$ & $0.1 \%$ & $0.1 \%$ & $0.2 \%$ & $2.3 \%$ & $1.9 \%$ & $0.1 \%$ & $0.2 \%$ & $0.0 \%$ & $0.0 \%$ & $0.0 \%$ & $2.9 \%$ & \\
\hline \multicolumn{15}{|l|}{ Average Person Trip Length } \\
\hline ALL & 10.66 & 11.27 & 9.36 & 9.90 & 8.65 & 9.20 & 7.45 & 8.97 & 7.34 & 9.44 & 7.68 & 9.00 & 6.22 & 8.03 \\
\hline Zero Vehicle HHs & 4.37 & 12.36 & 4.30 & 10.09 & 4.88 & 4.16 & 3.62 & 12.30 & 5.31 & 4.03 & 10.34 & 3.94 & 4.57 & 3.18 \\
\hline Non-Zero Vehicle HHs & 10.77 & 11.26 & 9.40 & 9.90 & 8.72 & 9.30 & 7.64 & 8.88 & 7.64 & 9.85 & 6.38 & 9.88 & 7.88 & 12.35 \\
\hline
\end{tabular}




\begin{tabular}{|c|c|c|c|c|c|c|c|c|c|c|c|c|c|c|}
\hline \multicolumn{15}{|c|}{ Population Density (census tract) } \\
\hline & \multicolumn{2}{|c|}{$<500$} & \multicolumn{2}{|c|}{$500-2,000$} & \multicolumn{2}{|c|}{$2,000-4,000$} & \multicolumn{2}{|c|}{$4,000-10,000$} & \multicolumn{2}{|c|}{$10,000-20,000$} & \multicolumn{2}{|c|}{$20,000-50,000$} & \multicolumn{2}{|c|}{$50,000+$} \\
\hline & NY State & U.S. & NY State & U.S. & NY State & U.S. & NY State & U.S. & NY State & U.S. & NY State & U.S. & NY State & U.S. \\
\hline \multicolumn{15}{|c|}{ Non-Zero-Vehicle Households - Daily Person Trips per Person } \\
\hline TOTAL & 4.07 & 4.21 & 4.28 & 4.40 & 4.38 & 4.53 & 4.10 & 4.44 & 3.77 & 4.20 & 4.00 & 4.28 & 3.75 & 3.81 \\
\hline$\%$ Private & $88.9 \%$ & $91.0 \%$ & $87.4 \%$ & $90.0 \%$ & $87.9 \%$ & $89.2 \%$ & $84.9 \%$ & $88.1 \%$ & $75.1 \%$ & $81.2 \%$ & $57.5 \%$ & $68.5 \%$ & $44.3 \%$ & $67.7 \%$ \\
\hline$\%$ Public & $0.7 \%$ & $0.2 \%$ & $0.9 \%$ & $0.5 \%$ & $0.9 \%$ & $0.9 \%$ & $2.2 \%$ & $1.1 \%$ & $7.2 \%$ & $3.6 \%$ & $11.0 \%$ & $5.8 \%$ & $16.0 \%$ & $8.4 \%$ \\
\hline$\%$ Walk & $3.2 \%$ & $2.1 \%$ & $4.2 \%$ & $3.0 \%$ & $3.7 \%$ & $4.4 \%$ & $6.3 \%$ & $5.2 \%$ & $10.9 \%$ & $9.3 \%$ & $23.3 \%$ & $17.5 \%$ & $27.5 \%$ & $21.0 \%$ \\
\hline$\%$ Other & $4.4 \%$ & $3.6 \%$ & $4.2 \%$ & $3.6 \%$ & $4.1 \%$ & $2.6 \%$ & $3.2 \%$ & $2.0 \%$ & $2.4 \%$ & $1.4 \%$ & $3.5 \%$ & $3.0 \%$ & $5.6 \%$ & $1.3 \%$ \\
\hline$\%$ Unreported & $2.7 \%$ & $3.1 \%$ & $3.3 \%$ & $3.0 \%$ & $3.4 \%$ & $2.9 \%$ & $3.4 \%$ & $3.6 \%$ & $4.5 \%$ & $4.5 \%$ & $4.8 \%$ & $5.1 \%$ & $6.7 \%$ & $1.6 \%$ \\
\hline \multicolumn{15}{|c|}{ Non-Zero-Vehicle Households - Daily PMT per Person } \\
\hline TOTAL & 40.17 & 44.53 & 39.89 & 40.74 & 35.12 & 41.04 & 29.10 & 35.88 & 25.54 & 28.71 & 22.56 & 27.37 & 23.46 & 39.41 \\
\hline$\%$ Private & $91.3 \%$ & $94.7 \%$ & $92.8 \%$ & $92.5 \%$ & $91.9 \%$ & $88.5 \%$ & $88.6 \%$ & $90.5 \%$ & $84.9 \%$ & $88.6 \%$ & $77.1 \%$ & $85.2 \%$ & $68.4 \%$ & $91.6 \%$ \\
\hline$\%$ Public & $1.8 \%$ & $0.4 \%$ & $2.5 \%$ & $0.7 \%$ & $3.6 \%$ & $2.6 \%$ & $6.9 \%$ & $1.6 \%$ & $11.6 \%$ & $6.8 \%$ & $15.2 \%$ & $5.5 \%$ & $20.7 \%$ & $6.0 \%$ \\
\hline$\%$ Walk & $0.3 \%$ & $0.1 \%$ & $0.3 \%$ & $0.2 \%$ & $0.3 \%$ & $0.3 \%$ & $0.4 \%$ & $0.3 \%$ & $0.7 \%$ & $0.7 \%$ & $2.5 \%$ & $1.2 \%$ & $2.3 \%$ & $2.2 \%$ \\
\hline$\%$ Other & $5.9 \%$ & $4.0 \%$ & $3.6 \%$ & $5.9 \%$ & $3.1 \%$ & $6.8 \%$ & $2.5 \%$ & $6.7 \%$ & $1.8 \%$ & $2.7 \%$ & $4.7 \%$ & $7.8 \%$ & $7.4 \%$ & $0.1 \%$ \\
\hline$\%$ Unreported & $0.7 \%$ & $0.8 \%$ & $0.9 \%$ & $0.7 \%$ & $1.1 \%$ & $1.8 \%$ & $1.5 \%$ & $0.8 \%$ & $1.0 \%$ & $1.2 \%$ & $0.5 \%$ & $0.2 \%$ & $1.1 \%$ & $0.1 \%$ \\
\hline \multicolumn{15}{|l|}{ Average Person Trip Length } \\
\hline ALL & 9.91 & 10.66 & 9.41 & 9.33 & 8.02 & 9.06 & 7.23 & 8.05 & 6.85 & 6.64 & 5.18 & 5.83 & 5.95 & 7.31 \\
\hline Zero-Vehicle HHs & 6.72 & 7.08 & 3.58 & 7.25 & 4.78 & 4.85 & 6.13 & 4.40 & 5.38 & 4.09 & 3.69 & 3.63 & 5.49 & 1.95 \\
\hline Non-Zero Veh HHs & 9.99 & 10.70 & 9.47 & 9.35 & 8.11 & 9.16 & 7.29 & 8.20 & 7.06 & 6.99 & 5.96 & 6.53 & 6.64 & 10.33 \\
\hline
\end{tabular}




\begin{tabular}{|c|c|c|c|c|c|c|c|c|c|c|c|c|c|c|}
\hline \multicolumn{15}{|c|}{ Population Density (census tract) } \\
\hline & \multicolumn{2}{|c|}{$<500$} & \multicolumn{2}{|c|}{$500-2,000$} & \multicolumn{2}{|c|}{$2,000-4,000$} & \multicolumn{2}{|c|}{$4,000-10,000$} & \multicolumn{2}{|c|}{$10,000-20,000$} & \multicolumn{2}{|c|}{$20,000-50,000$} & \multicolumn{2}{|c|}{$50,000+$} \\
\hline & NY State & U.S. & NY State & U.S. & NY State & U.S. & NY State & U.S. & NY State & U.S. & NY State & U.S. & NY State & U.S. \\
\hline Daily Vehicle Trips per Driver & & & & & & & & & & & & & & \\
\hline TOTAL & 3.10 & 3.35 & 3.39 & 3.56 & 3.33 & 3.62 & 3.21 & 3.38 & 2.47 & 2.93 & 1.99 & 2.52 & 1.03 & 1.75 \\
\hline \% Earn a Living & $26.8 \%$ & & $25.4 \%$ & $25.4 \%$ & $25.5 \%$ & $25.8 \%$ & $24.2 \%$ & $25.7 \%$ & $25.9 \%$ & $28.5 \%$ & $23.0 \%$ & $28.4 \%$ & $28.1 \%$ & $14.8 \%$ \\
\hline \% Family \& Personal Business & $47.4 \%$ & $47.5 \%$ & $48.9 \%$ & $48.5 \%$ & $48.5 \%$ & $48.2 \%$ & $49.6 \%$ & $48.9 \%$ & $47.9 \%$ & $45.8 \%$ & $55.1 \%$ & $43.8 \%$ & $44.9 \%$ & $61.3 \%$ \\
\hline$\%$ Civic, Educational \& Religious & $3.9 \%$ & $4.9 \%$ & $4.2 \%$ & $4.7 \%$ & $3.5 \%$ & $5.0 \%$ & $5.0 \%$ & $4.7 \%$ & $5.6 \%$ & $4.0 \%$ & $3.8 \%$ & $4.9 \%$ & $2.6 \%$ & $0.1 \%$ \\
\hline$\%$ Social \& Recreational & $21.2 \%$ & $19.7 \%$ & $20.8 \%$ & $20.9 \%$ & $22.1 \%$ & $20.4 \%$ & $20.4 \%$ & $20.3 \%$ & $20.0 \%$ & $21.1 \%$ & $16.2 \%$ & $22.5 \%$ & $23.7 \%$ & $20.7 \%$ \\
\hline$\%$ Other & $0.5 \%$ & $0.5 \%$ & $0.6 \%$ & $0.5 \%$ & $0.4 \%$ & $0.5 \%$ & $0.7 \%$ & $0.5 \%$ & $0.6 \%$ & $0.5 \%$ & $1.7 \%$ & $0.4 \%$ & $0.6 \%$ & \\
\hline$\%$ Unreported & $0.3 \%$ & $0.1 \%$ & $0.1 \%$ & $0.1 \%$ & $0.1 \%$ & $0.1 \%$ & $0.2 \%$ & $0.1 \%$ & $0.0 \%$ & $0.1 \%$ & $0.1 \%$ & $0.0 \%$ & $0.1 \%$ & $3.2 \%$ \\
\hline TOTAL & 3.10 & 3.35 & 3.39 & 3.56 & 3.33 & 3.62 & 3.21 & 3.38 & 2.47 & 2.93 & 1.99 & 2.52 & 1.03 & 1.75 \\
\hline Weekday & 3.21 & 3.46 & 3.43 & 3.69 & 3.41 & 3.68 & 3.18 & 3.36 & 2.42 & 2.84 & 1.84 & 2.44 & 0.96 & 1.83 \\
\hline Weekend & 2.86 & 3.10 & 3.31 & 3.27 & 3.18 & 3.49 & 3.32 & 3.44 & 2.63 & 3.19 & 2.39 & 2.72 & 1.22 & 1.56 \\
\hline TOTAL & 3.10 & 3.35 & 3.39 & 3.56 & 3.33 & 3.62 & 3.21 & 3.38 & 2.47 & 2.93 & 1.99 & 2.52 & 1.03 & 1.75 \\
\hline$\% 1-9 \min$ & $28.3 \%$ & $26.9 \%$ & $31.0 \%$ & $29.1 \%$ & $32.8 \%$ & $30.2 \%$ & $34.2 \%$ & $28.9 \%$ & $24.8 \%$ & $25.3 \%$ & $24.3 \%$ & $21.0 \%$ & $13.7 \%$ & $21.6 \%$ \\
\hline$\% 10-19 \min$ & $35.7 \%$ & $36.2 \%$ & $38.3 \%$ & $38.6 \%$ & $36.8 \%$ & $39.1 \%$ & $36.0 \%$ & $38.2 \%$ & $37.0 \%$ & $37.8 \%$ & $38.6 \%$ & $37.5 \%$ & $31.8 \%$ & $31.1 \%$ \\
\hline$\% 20-29 \min$ & $15.4 \%$ & $15.1 \%$ & $13.7 \%$ & $14.1 \%$ & $12.7 \%$ & $13.7 \%$ & $13.2 \%$ & $14.6 \%$ & $13.7 \%$ & $14.1 \%$ & $11.7 \%$ & $14.0 \%$ & $14.6 \%$ & $18.5 \%$ \\
\hline$\%$ 30-39 min & $10.7 \%$ & $11.0 \%$ & $8.3 \%$ & $9.1 \%$ & $8.5 \%$ & $8.5 \%$ & $7.7 \%$ & $9.8 \%$ & $11.5 \%$ & $11.5 \%$ & $12.5 \%$ & $15.3 \%$ & $17.8 \%$ & $10.6 \%$ \\
\hline$\% 40-49 \min$ & $4.1 \%$ & $4.5 \%$ & $3.5 \%$ & $3.9 \%$ & $3.2 \%$ & $3.7 \%$ & $3.2 \%$ & $3.6 \%$ & $5.1 \%$ & $5.1 \%$ & $5.4 \%$ & $5.6 \%$ & $8.2 \%$ & $9.5 \%$ \\
\hline$\% 50+\min$ & $5.0 \%$ & $5.7 \%$ & $4.7 \%$ & $4.6 \%$ & $5.4 \%$ & $4.2 \%$ & $5.0 \%$ & $4.4 \%$ & $7.2 \%$ & $5.7 \%$ & $6.9 \%$ & $6.1 \%$ & $13.5 \%$ & $8.7 \%$ \\
\hline$\%$ Unreported & $0.7 \%$ & $0.5 \%$ & $0.5 \%$ & $0.6 \%$ & $0.7 \%$ & $0.6 \%$ & $0.6 \%$ & $0.5 \%$ & $0.6 \%$ & $0.6 \%$ & $0.5 \%$ & $0.5 \%$ & $0.3 \%$ & \\
\hline TOTAL & 3.10 & 3.35 & 3.39 & 3.56 & 3.33 & 3.62 & 3.21 & 3.38 & 2.47 & 2.93 & 1.99 & 2.52 & 1.03 & 1.75 \\
\hline$\% 5$ or less miles & $48.3 \%$ & $46.4 \%$ & $58.1 \%$ & $56.2 \%$ & $61.8 \%$ & $60.0 \%$ & $65.7 \%$ & $60.5 \%$ & $61.4 \%$ & $58.5 \%$ & $68.1 \%$ & $58.9 \%$ & $55.8 \%$ & $69.5 \%$ \\
\hline$\%$ 6-10 miles & $21.7 \%$ & $21.5 \%$ & $18.1 \%$ & $19.8 \%$ & $17.1 \%$ & $18.5 \%$ & $15.2 \%$ & $17.9 \%$ & $15.6 \%$ & $17.1 \%$ & $14.2 \%$ & $17.4 \%$ & $16.8 \%$ & $11.9 \%$ \\
\hline$\% 11-15$ miles & $10.8 \%$ & $11.6 \%$ & $9.0 \%$ & $9.2 \%$ & $7.5 \%$ & $8.0 \%$ & $6.4 \%$ & $8.2 \%$ & $10.4 \%$ & $8.5 \%$ & $5.4 \%$ & $7.4 \%$ & $7.1 \%$ & $3.2 \%$ \\
\hline$\% 16-20$ miles & $6.9 \%$ & $6.7 \%$ & $4.9 \%$ & $4.7 \%$ & $4.2 \%$ & $4.1 \%$ & $3.2 \%$ & $4.2 \%$ & $4.3 \%$ & $4.2 \%$ & $3.2 \%$ & $5.9 \%$ & $3.8 \%$ & $9.5 \%$ \\
\hline$\% 21-30$ miles & $6.0 \%$ & $6.5 \%$ & $3.9 \%$ & $4.7 \%$ & $3.8 \%$ & $4.3 \%$ & $3.6 \%$ & $3.9 \%$ & $3.2 \%$ & $4.4 \%$ & $2.5 \%$ & $4.3 \%$ & $5.0 \%$ & $3.6 \%$ \\
\hline$\% 31$ or more miles & $5.7 \%$ & $6.4 \%$ & $4.7 \%$ & $4.8 \%$ & $4.9 \%$ & $4.0 \%$ & $3.7 \%$ & $4.0 \%$ & $2.7 \%$ & $4.0 \%$ & $2.6 \%$ & $4.1 \%$ & $4.6 \%$ & $2.4 \%$ \\
\hline$\%$ Unreported & $0.7 \%$ & $0.8 \%$ & $1.3 \%$ & $0.6 \%$ & $0.7 \%$ & $1.0 \%$ & $2.3 \%$ & $1.4 \%$ & $2.5 \%$ & $3.3 \%$ & $4.1 \%$ & $1.9 \%$ & $7.0 \%$ & \\
\hline \multicolumn{15}{|l|}{ Daily VMT per Driver } \\
\hline TOTAL & $\mathbf{3 3 . 7 0}$ & 37.92 & 30.22 & 33.80 & 28.76 & 32.01 & 23.12 & 29.30 & 19.46 & 23.22 & 12.21 & 20.37 & 10.08 & 11.88 \\
\hline$\%$ Earn a Living & $36.2 \%$ & $37.7 \%$ & $36.2 \%$ & $34.8 \%$ & $38.3 \%$ & $34.4 \%$ & $35.6 \%$ & $36.2 \%$ & $32.7 \%$ & $37.3 \%$ & $32.8 \%$ & $31.9 \%$ & $32.2 \%$ & $38.7 \%$ \\
\hline$\%$ Family \& Personal Business & $34.3 \%$ & $35.0 \%$ & $34.5 \%$ & $34.9 \%$ & $31.7 \%$ & $35.5 \%$ & $32.1 \%$ & $33.4 \%$ & $34.0 \%$ & $35.9 \%$ & $40.9 \%$ & $29.5 \%$ & $34.9 \%$ & $43.3 \%$ \\
\hline$\%$ Civic, Educational \& Religious & $2.9 \%$ & $4.1 \%$ & $3.4 \%$ & $3.7 \%$ & $3.1 \%$ & $3.6 \%$ & $3.5 \%$ & $3.5 \%$ & $6.0 \%$ & $3.6 \%$ & $2.6 \%$ & $5.0 \%$ & $2.1 \%$ & $0.0 \%$ \\
\hline \% Social \& Recreational & $25.6 \%$ & $22.3 \%$ & $24.3 \%$ & $25.3 \%$ & $26.3 \%$ & $25.4 \%$ & $28.0 \%$ & $26.2 \%$ & $26.4 \%$ & $22.4 \%$ & $22.7 \%$ & $33.1 \%$ & $30.0 \%$ & $14.3 \%$ \\
\hline$\%$ Other & $0.9 \%$ & $0.6 \%$ & $0.9 \%$ & $1.2 \%$ & $0.5 \%$ & $1.1 \%$ & $0.7 \%$ & $0.6 \%$ & $0.9 \%$ & $0.6 \%$ & $0.8 \%$ & $0.5 \%$ & $0.5 \%$ & \\
\hline$\%$ Unreported & $0.2 \%$ & $0.3 \%$ & $0.6 \%$ & $0.1 \%$ & $0.1 \%$ & $0.1 \%$ & $0.1 \%$ & $0.2 \%$ & $0.1 \%$ & $0.1 \%$ & $0.2 \%$ & $0.0 \%$ & $0.3 \%$ & $3.7 \%$ \\
\hline Average Vehicle Trip Length & & & & & & & & & & & & & & \\
\hline TOTAL & 10.95 & 11.42 & 9.03 & 9.55 & 8.69 & 8.94 & 7.37 & 8.81 & 8.07 & 8.19 & 6.40 & 8.25 & 10.50 & 6.78 \\
\hline \multicolumn{15}{|c|}{ Average Time Driving a POV (persons who drove on travel day only) } \\
\hline TOTAL & 78.76 & 84.74 & 76.13 & 81.31 & 79.37 & 79.32 & 74.22 & 80.43 & 81.01 & $\mathbf{7 7 . 6 4}$ & 84.66 & 81.51 & 97.22 & 113.02 \\
\hline
\end{tabular}




\begin{tabular}{|c|c|c|c|c|c|c|c|c|c|c|c|c|c|c|}
\hline \multicolumn{15}{|c|}{ Population Density (census tract) } \\
\hline & \multicolumn{2}{|c|}{$<500$} & \multicolumn{2}{|c|}{$500-2,000$} & \multicolumn{2}{|c|}{$2,000-4,000$} & \multicolumn{2}{|c|}{$4,000-10,000$} & \multicolumn{2}{|c|}{$10,000-20,000$} & \multicolumn{2}{|c|}{$20,000-50,000$} & \multicolumn{2}{|c|}{$50,000+$} \\
\hline & NY State & U.S. & NY State & U.S. & NY State & U.S. & NY State & U.S. & NY State & U.S. & NY State & U.S. & NY State & U.S. \\
\hline \multicolumn{15}{|l|}{ Daily Vehicle Trips per Driver } \\
\hline TOTAL & 3.39 & 3.53 & 3.47 & 3.65 & 3.67 & 3.77 & 3.31 & 3.58 & 2.80 & 3.23 & 1.95 & 2.69 & 1.07 & 1.79 \\
\hline$\%$ Earn a Living & $27.9 \%$ & $28.2 \%$ & $26.2 \%$ & $27.2 \%$ & $24.5 \%$ & $27.9 \%$ & $26.1 \%$ & $26.5 \%$ & $28.5 \%$ & $25.7 \%$ & $22.6 \%$ & $26.8 \%$ & $31.8 \%$ & $29.1 \%$ \\
\hline$\%$ Fam/Per Bus & $50.0 \%$ & $49.9 \%$ & $51.3 \%$ & $50.8 \%$ & $52.2 \%$ & $49.6 \%$ & $51.8 \%$ & $51.1 \%$ & $50.5 \%$ & $49.2 \%$ & $54.4 \%$ & $47.2 \%$ & $47.7 \%$ & $48.6 \%$ \\
\hline$\%$ Civ, Ed, \& Rel & $2.9 \%$ & $4.0 \%$ & $4.0 \%$ & $3.8 \%$ & $3.8 \%$ & $4.5 \%$ & $3.6 \%$ & $3.9 \%$ & $3.9 \%$ & $5.3 \%$ & $5.1 \%$ & $5.2 \%$ & $3.7 \%$ & \\
\hline$\%$ Soc and Rec & $18.8 \%$ & $17.9 \%$ & $18.4 \%$ & $18.1 \%$ & $19.6 \%$ & $18.0 \%$ & $18.5 \%$ & $18.4 \%$ & $17.1 \%$ & $19.8 \%$ & $17.9 \%$ & $20.8 \%$ & $16.8 \%$ & $22.3 \%$ \\
\hline$\%$ Other & $0.3 \%$ & $0.0 \%$ & $0.0 \%$ & $0.0 \%$ & $0.0 \%$ & $0.0 \%$ & $0.0 \%$ & $0.0 \%$ & $0.0 \%$ & $0.0 \%$ & $0.0 \%$ & & & \\
\hline TOTAL & 3.39 & 3.53 & 3.47 & 3.65 & 3.67 & 3.77 & 3.31 & 3.58 & 2.80 & 3.23 & 1.95 & & 1.07 & 1.79 \\
\hline Weekday & 3.45 & 3.66 & 3.61 & 3.70 & 3.61 & 3.91 & 3.18 & 3.60 & 2.53 & 3.05 & 1.73 & 2.48 & 1.04 & 1.85 \\
\hline Weekend & 3.26 & 3.23 & 3.16 & 3.55 & 3.86 & 3.44 & 3.66 & 3.56 & 3.52 & 3.70 & 2.52 & 3.24 & 1.15 & 1.67 \\
\hline TOTAL & 3.39 & 3.53 & 3.47 & 3.65 & 3.67 & 3.77 & 3.31 & 3.58 & 2.80 & 3.23 & 1.95 & 2.69 & 1.07 & 1.79 \\
\hline$\% 1-9 \min$ & $39.8 \%$ & $35.4 \%$ & $39.2 \%$ & $38.6 \%$ & $42.8 \%$ & $40.6 \%$ & $42.6 \%$ & $39.4 \%$ & $37.1 \%$ & $34.4 \%$ & $31.8 \%$ & $28.6 \%$ & $23.4 \%$ & $40.6 \%$ \\
\hline$\% 10-19 \min$ & $31.3 \%$ & $32.9 \%$ & $33.4 \%$ & $34.2 \%$ & $31.6 \%$ & $33.7 \%$ & $32.0 \%$ & $33.5 \%$ & $33.6 \%$ & $35.3 \%$ & $30.3 \%$ & $33.1 \%$ & $23.4 \%$ & $24.4 \%$ \\
\hline$\%$ 20-29 min & $14.5 \%$ & $15.3 \%$ & $14.1 \%$ & $13.4 \%$ & $13.1 \%$ & $13.3 \%$ & $12.7 \%$ & $14.0 \%$ & $13.6 \%$ & $14.9 \%$ & $16.4 \%$ & $17.5 \%$ & $18.7 \%$ & $18.3 \%$ \\
\hline$\% 30-39 \mathrm{~min}$ & $7.1 \%$ & $7.6 \%$ & $5.8 \%$ & $6.3 \%$ & $5.7 \%$ & $5.8 \%$ & $5.1 \%$ & $6.1 \%$ & $5.4 \%$ & $8.4 \%$ & $8.7 \%$ & $9.7 \%$ & $10.3 \%$ & $6.7 \%$ \\
\hline$\% 40-49 \mathrm{~min}$ & $3.2 \%$ & $3.7 \%$ & $3.2 \%$ & $3.6 \%$ & $2.7 \%$ & $2.9 \%$ & $2.7 \%$ & $3.1 \%$ & $4.3 \%$ & $3.4 \%$ & $6.2 \%$ & $5.6 \%$ & $10.3 \%$ & \\
\hline$\% 50+\min$ & $3.8 \%$ & $4.5 \%$ & $4.0 \%$ & $3.6 \%$ & $4.1 \%$ & $3.2 \%$ & $4.2 \%$ & $3.4 \%$ & $5.7 \%$ & $3.4 \%$ & $6.2 \%$ & $5.2 \%$ & $13.1 \%$ & $10.0 \%$ \\
\hline$\%$ Unreported & $0.3 \%$ & $0.6 \%$ & $0.3 \%$ & $0.3 \%$ & $0.0 \%$ & $0.5 \%$ & $0.6 \%$ & $0.6 \%$ & $0.4 \%$ & $0.3 \%$ & $0.5 \%$ & $0.4 \%$ & $0.9 \%$ & \\
\hline TOTAL & 3.39 & 3.53 & 3.47 & 3.65 & 3.67 & 3.77 & 3.31 & 3.58 & 2.80 & 3.23 & 1.95 & 2.69 & 1.07 & 1.79 \\
\hline$\% 5$ or less miles & $51.6 \%$ & $50.1 \%$ & $57.6 \%$ & $58.6 \%$ & $65.4 \%$ & $63.4 \%$ & $65.9 \%$ & $63.7 \%$ & $63.9 \%$ & $64.1 \%$ & $62.6 \%$ & $59.9 \%$ & $55.1 \%$ & $62.8 \%$ \\
\hline$\% 6-10$ miles & $21.5 \%$ & $20.4 \%$ & $19.6 \%$ & $18.9 \%$ & $15.5 \%$ & $17.2 \%$ & $15.7 \%$ & $17.0 \%$ & $15.4 \%$ & $16.7 \%$ & $14.9 \%$ & $18.6 \%$ & $16.8 \%$ & $16.1 \%$ \\
\hline$\% 11-15$ miles & $10.6 \%$ & $11.3 \%$ & $8.9 \%$ & $8.5 \%$ & $6.8 \%$ & $7.4 \%$ & $6.9 \%$ & $7.5 \%$ & $7.5 \%$ & $7.4 \%$ & $7.7 \%$ & $8.2 \%$ & $11.2 \%$ & $8.3 \%$ \\
\hline$\% 16-20$ miles & $6.2 \%$ & $5.9 \%$ & $4.3 \%$ & $4.4 \%$ & $3.5 \%$ & $4.2 \%$ & $3.3 \%$ & $3.9 \%$ & $3.9 \%$ & $3.7 \%$ & $4.6 \%$ & $4.1 \%$ & $1.9 \%$ & $5.0 \%$ \\
\hline$\% 21-30$ miles & $5.0 \%$ & $5.9 \%$ & $3.7 \%$ & $4.7 \%$ & $4.1 \%$ & $3.7 \%$ & $3.3 \%$ & $3.4 \%$ & $4.3 \%$ & $3.7 \%$ & $3.6 \%$ & $4.1 \%$ & $6.5 \%$ & $2.8 \%$ \\
\hline$\% 31$ or more miles & $4.4 \%$ & $5.7 \%$ & $4.6 \%$ & $4.7 \%$ & $4.4 \%$ & $3.7 \%$ & $3.0 \%$ & $3.6 \%$ & $2.9 \%$ & $2.8 \%$ & $2.6 \%$ & $3.3 \%$ & $5.6 \%$ & $5.0 \%$ \\
\hline$\%$ Unreported & $0.6 \%$ & $0.6 \%$ & $1.2 \%$ & $0.3 \%$ & $0.3 \%$ & $0.3 \%$ & $1.8 \%$ & $0.8 \%$ & $2.1 \%$ & $1.5 \%$ & $4.1 \%$ & $1.9 \%$ & $2.8 \%$ & $0.0 \%$ \\
\hline \multicolumn{15}{|l|}{ Daily VMT per Driver } \\
\hline TOTAL & 33.21 & 37.19 & 32.04 & 33.74 & 28.89 & 31.19 & 23.22 & 28.28 & 20.81 & 23.04 & 13.37 & 20.65 & 12.12 & 20.35 \\
\hline \% Earn a Living & $38.8 \%$ & $39.7 \%$ & $35.5 \%$ & $38.7 \%$ & $37.2 \%$ & $38.4 \%$ & $41.2 \%$ & $36.6 \%$ & $36.9 \%$ & $34.4 \%$ & $35.4 \%$ & $34.7 \%$ & $34.9 \%$ & $16.6 \%$ \\
\hline$\%$ Fam/Per Bus & $34.2 \%$ & $36.1 \%$ & $37.1 \%$ & $35.7 \%$ & $34.5 \%$ & $34.0 \%$ & $33.6 \%$ & $35.6 \%$ & $34.2 \%$ & $34.6 \%$ & $37.1 \%$ & $32.6 \%$ & $24.2 \%$ & $48.2 \%$ \\
\hline$\%$ Civ, Ed, \& Rel & $2.3 \%$ & $4.0 \%$ & $2.9 \%$ & $3.7 \%$ & $2.5 \%$ & $3.9 \%$ & $3.1 \%$ & $2.9 \%$ & $2.1 \%$ & $5.4 \%$ & $5.9 \%$ & $4.3 \%$ & $1.5 \%$ & \\
\hline$\%$ Soc and Rec & $24.0 \%$ & $20.1 \%$ & $24.4 \%$ & $21.5 \%$ & $25.8 \%$ & $23.6 \%$ & $22.0 \%$ & $24.7 \%$ & $26.4 \%$ & $25.6 \%$ & $21.6 \%$ & $28.3 \%$ & $39.4 \%$ & $35.2 \%$ \\
\hline$\%$ Other & $0.8 \%$ & $0.1 \%$ & $0.1 \%$ & $0.3 \%$ & $0.0 \%$ & $0.1 \%$ & $0.1 \%$ & $0.1 \%$ & $0.0 \%$ & $0.0 \%$ & $0.0 \%$ & & & \\
\hline$\%$ Unreported & $0.0 \%$ & $0.0 \%$ & $0.0 \%$ & $0.0 \%$ & . & $0.0 \%$ & $0.0 \%$ & $0.0 \%$ & $0.5 \%$ & & & & & \\
\hline $\begin{array}{l}\text { Average Vehicle Trip Length } \\
\text { TOTAL }\end{array}$ & 9.85 & 10.61 & 9.35 & 9.29 & 7.90 & 8.32 & 7.12 & 7.97 & 7.58 & 7.24 & 7.11 & 7.86 & 11.68 & 11.34 \\
\hline \multicolumn{15}{|c|}{ Average Time Driving a POV (persons who drove on travel day only) } \\
\hline TOTAL & 69.85 & 77.11 & 71.47 & 74.00 & 70.84 & 71.46 & 67.94 & 70.63 & 69.79 & 71.46 & 72.28 & 79.40 & 89.71 & 86.19 \\
\hline
\end{tabular}




\begin{tabular}{|c|c|c|c|c|c|c|c|c|c|c|c|c|c|c|}
\hline \multicolumn{15}{|c|}{ Population Density (census tract) } \\
\hline & \multirow{2}{*}{\multicolumn{2}{|c|}{$\begin{array}{c}\text { NY State }^{<500} \text { U.S. } \\
\text { N. }\end{array}$}} & \multirow{2}{*}{\multicolumn{2}{|c|}{\begin{tabular}{ll}
\multicolumn{2}{c}{$500-2,000$} \\
NY State U.S.
\end{tabular}}} & \multirow{2}{*}{\multicolumn{2}{|c|}{\begin{tabular}{|c|}
\multicolumn{2}{c|}{$2,000-4,000$} \\
NY State $\quad$ U.S.
\end{tabular}}} & \multirow{2}{*}{\multicolumn{2}{|c|}{$\begin{array}{cc}4,000-10,000 \\
\text { NY State U. }\end{array}$}} & \multicolumn{2}{|c|}{$10,000-20,000$} & \multicolumn{2}{|c|}{$20,000-50,000$} & \multicolumn{2}{|c|}{$50,000+$} \\
\hline & & U.S. & & & & & & U.S. & NY State & U.S. & NY State & U.S. & NY State & U.S. \\
\hline \multicolumn{15}{|c|}{ Daily Commute Person Trips per Person } \\
\hline TOTAL & 1.12 & 1.13 & 1.17 & 1.15 & 1.20 & 1.18 & 1.09 & 1.13 & 1.19 & 1.11 & 1.05 & 1.21 & 1.05 & 0.59 \\
\hline$\%$ SOV & $80.3 \%$ & $81.3 \%$ & $81.2 \%$ & $81.2 \%$ & $73.9 \%$ & $81.0 \%$ & $71.2 \%$ & $73.5 \%$ & $50.1 \%$ & $64.9 \%$ & $33.7 \%$ & $47.1 \%$ & $13.8 \%$ & $23.3 \%$ \\
\hline$\% \mathrm{MOV}$ & $13.8 \%$ & $16.7 \%$ & $12.9 \%$ & $16.1 \%$ & $15.7 \%$ & $14.7 \%$ & $13.2 \%$ & $17.6 \%$ & $14.1 \%$ & $17.1 \%$ & $9.5 \%$ & $18.9 \%$ & $9.7 \%$ & $4.5 \%$ \\
\hline$\%$ Amtrak & $0.1 \%$ & & $0.2 \%$ & $0.0 \%$ & $0.1 \%$ & $0.1 \%$ & $0.9 \%$ & $0.1 \%$ & $2.0 \%$ & $0.3 \%$ & $0.7 \%$ & & $1.3 \%$ & \\
\hline$\%$ Commuter Train & $0.7 \%$ & $0.1 \%$ & $1.0 \%$ & $0.2 \%$ & $3.0 \%$ & $0.3 \%$ & $4.5 \%$ & $0.9 \%$ & $1.6 \%$ & $0.3 \%$ & $3.2 \%$ & $1.1 \%$ & $0.8 \%$ & \\
\hline \% Subway/El Rail & $1.8 \%$ & $0.0 \%$ & $0.4 \%$ & $0.3 \%$ & $1.4 \%$ & $0.3 \%$ & $2.8 \%$ & $0.5 \%$ & $12.5 \%$ & $3.1 \%$ & $23.8 \%$ & $4.9 \%$ & $36.4 \%$ & $27.3 \%$ \\
\hline$\%$ Other Public & $0.3 \%$ & $0.1 \%$ & $0.4 \%$ & $0.3 \%$ & $1.0 \%$ & $1.1 \%$ & $1.7 \%$ & $2.7 \%$ & $8.1 \%$ & $7.5 \%$ & $9.2 \%$ & $12.4 \%$ & $14.5 \%$ & $44.9 \%$ \\
\hline$\%$ Walk & $2.1 \%$ & $1.3 \%$ & $2.9 \%$ & $1.1 \%$ & $3.4 \%$ & $1.9 \%$ & $4.3 \%$ & $3.3 \%$ & $8.8 \%$ & $5.3 \%$ & $16.2 \%$ & $10.4 \%$ & $18.3 \%$ & \\
\hline$\%$ Other & $0.8 \%$ & $0.4 \%$ & $1.0 \%$ & $0.7 \%$ & $1.3 \%$ & $0.6 \%$ & $1.4 \%$ & $1.1 \%$ & $2.3 \%$ & $1.5 \%$ & $3.7 \%$ & $5.0 \%$ & $5.2 \%$ & \\
\hline$\%$ Unreported & $0.0 \%$ & $0.2 \%$ & & $0.1 \%$ & $0.2 \%$ & $0.0 \%$ & $0.1 \%$ & $0.1 \%$ & $0.5 \%$ & $0.0 \%$ & $0.0 \%$ & $0.3 \%$ & & \\
\hline TOTAL & 1.12 & 1.13 & 1.17 & 1.15 & 1.20 & 1.18 & 1.09 & 1.13 & 1.19 & 1.11 & 1.05 & 1.21 & 1.05 & 0.59 \\
\hline$\% 1-6$ am & $5.6 \%$ & $6.7 \%$ & $4.2 \%$ & $5.4 \%$ & $4.2 \%$ & $5.5 \%$ & $4.3 \%$ & $6.2 \%$ & $5.3 \%$ & $6.3 \%$ & $5.1 \%$ & $7.4 \%$ & $4.4 \%$ & \\
\hline$\% 6-9 \mathrm{am}$ & $32.3 \%$ & $30.6 \%$ & $31.1 \%$ & $30.8 \%$ & $30.2 \%$ & $30.3 \%$ & $30.8 \%$ & $30.2 \%$ & $29.9 \%$ & $30.0 \%$ & $33.4 \%$ & $30.5 \%$ & $30.5 \%$ & $40.9 \%$ \\
\hline$\% 9$ am-1 pm & $9.9 \%$ & $10.7 \%$ & $11.7 \%$ & $12.3 \%$ & $12.3 \%$ & $12.0 \%$ & $10.7 \%$ & $11.1 \%$ & $10.4 \%$ & $8.5 \%$ & $10.0 \%$ & $8.6 \%$ & $11.2 \%$ & \\
\hline$\% 1-4 \mathrm{pm}$ & $15.1 \%$ & $13.8 \%$ & $15.2 \%$ & $13.4 \%$ & $16.2 \%$ & $14.3 \%$ & $14.1 \%$ & $14.8 \%$ & $13.0 \%$ & $14.0 \%$ & $12.4 \%$ & $15.7 \%$ & $9.9 \%$ & $5.2 \%$ \\
\hline$\%$ 4-7 pm & $24.9 \%$ & $25.6 \%$ & $25.5 \%$ & $26.1 \%$ & $25.3 \%$ & $25.3 \%$ & $28.5 \%$ & $25.6 \%$ & $27.7 \%$ & $26.1 \%$ & $23.6 \%$ & $25.5 \%$ & $28.1 \%$ & $46.6 \%$ \\
\hline$\% 7-10 \mathrm{pm}$ & $7.6 \%$ & $8.2 \%$ & $7.6 \%$ & $8.4 \%$ & $8.3 \%$ & $8.7 \%$ & $7.1 \%$ & $7.6 \%$ & $6.3 \%$ & $8.6 \%$ & $11.1 \%$ & $6.6 \%$ & $11.5 \%$ & $7.3 \%$ \\
\hline$\% 10 \mathrm{pm}-1 \mathrm{am}$ & $4.5 \%$ & $4.4 \%$ & $4.7 \%$ & $3.6 \%$ & $3.5 \%$ & $3.8 \%$ & $4.5 \%$ & $4.4 \%$ & $7.0 \%$ & $6.5 \%$ & $4.5 \%$ & $5.8 \%$ & $4.5 \%$ & \\
\hline$\%$ Unreported & $0.1 \%$ & $0.1 \%$ & & $0.0 \%$ & & $0.1 \%$ & $0.1 \%$ & $0.1 \%$ & $0.5 \%$ & $0.1 \%$ & & & & \\
\hline \multicolumn{15}{|c|}{ Daily Commute PMT per Person } \\
\hline TOTAL & 15.55 & 16.66 & 14.07 & 14.10 & 14.75 & 12.71 & 11.28 & 12.57 & 10.76 & 10.44 & 7.51 & 8.81 & 6.20 & 6.33 \\
\hline$\%$ SOV & $78.6 \%$ & $81.1 \%$ & $82.0 \%$ & $78.2 \%$ & $70.2 \%$ & $79.5 \%$ & $70.2 \%$ & $72.2 \%$ & $53.2 \%$ & $70.3 \%$ & $42.5 \%$ & $54.3 \%$ & $20.2 \%$ & $28.7 \%$ \\
\hline$\% \mathrm{MOV}$ & $14.2 \%$ & $16.0 \%$ & $11.1 \%$ & $14.8 \%$ & $16.8 \%$ & $13.9 \%$ & $9.4 \%$ & $16.5 \%$ & $13.8 \%$ & $15.1 \%$ & $7.9 \%$ & $30.4 \%$ & $18.2 \%$ & $9.6 \%$ \\
\hline$\%$ Amtrak & $0.7 \%$ & & $0.9 \%$ & $0.1 \%$ & $0.6 \%$ & $0.1 \%$ & $1.8 \%$ & $0.7 \%$ & $2.8 \%$ & $2.3 \%$ & $0.9 \%$ & & $1.1 \%$ & \\
\hline$\%$ Commuter Train & $2.7 \%$ & $0.2 \%$ & $2.8 \%$ & $0.7 \%$ & $8.2 \%$ & $0.4 \%$ & $10.6 \%$ & $2.0 \%$ & $4.4 \%$ & $1.5 \%$ & $5.7 \%$ & $1.0 \%$ & $1.0 \%$ & \\
\hline \% Subway/El Rail & $1.0 \%$ & $0.0 \%$ & $0.9 \%$ & $0.4 \%$ & $1.0 \%$ & $0.4 \%$ & $4.3 \%$ & $0.5 \%$ & $17.0 \%$ & $3.2 \%$ & $30.4 \%$ & $4.3 \%$ & $41.7 \%$ & $21.4 \%$ \\
\hline \% Other Public & $0.2 \%$ & $0.1 \%$ & $0.4 \%$ & $0.3 \%$ & $0.8 \%$ & $1.0 \%$ & $1.0 \%$ & $1.7 \%$ & $5.4 \%$ & $4.8 \%$ & $5.9 \%$ & $7.0 \%$ & $9.3 \%$ & $40.3 \%$ \\
\hline$\%$ Walk & $0.4 \%$ & $0.1 \%$ & $0.2 \%$ & $0.1 \%$ & $0.2 \%$ & $0.2 \%$ & $0.8 \%$ & $0.3 \%$ & $1.2 \%$ & $0.5 \%$ & $2.7 \%$ & $1.2 \%$ & $3.6 \%$ & \\
\hline$\%$ Other & $2.0 \%$ & $2.1 \%$ & $1.7 \%$ & $5.3 \%$ & $1.5 \%$ & $4.5 \%$ & $1.4 \%$ & $6.1 \%$ & $2.0 \%$ & $2.4 \%$ & $4.0 \%$ & $1.8 \%$ & $5.0 \%$ & \\
\hline$\%$ Unreported & $0.1 \%$ & $0.4 \%$ & & $0.1 \%$ & $0.8 \%$ & $0.0 \%$ & $0.5 \%$ & $0.1 \%$ & $0.2 \%$ & $0.0 \%$ & $0.1 \%$ & & & \\
\hline TOTAL & 15.55 & 16.66 & 14.07 & 14.10 & 14.75 & 12.71 & 11.28 & 12.57 & 10.76 & 10.44 & 7.51 & 8.81 & 6.20 & 6.33 \\
\hline$\% 1-6 \mathrm{am}$ & $7.6 \%$ & $9.8 \%$ & $5.9 \%$ & $7.5 \%$ & $9.1 \%$ & $7.1 \%$ & $8.0 \%$ & $9.4 \%$ & $9.0 \%$ & $8.3 \%$ & $6.5 \%$ & $17.7 \%$ & $5.6 \%$ & \\
\hline$\% 6-9 \mathrm{am}$ & $34.4 \%$ & $32.2 \%$ & $35.2 \%$ & $35.6 \%$ & $32.5 \%$ & $35.2 \%$ & $31.0 \%$ & $30.9 \%$ & $32.5 \%$ & $28.8 \%$ & $34.1 \%$ & $27.5 \%$ & $33.0 \%$ & $47.6 \%$ \\
\hline$\% 9$ am-1 pm & $6.6 \%$ & $7.8 \%$ & $8.3 \%$ & $8.8 \%$ & $9.0 \%$ & $9.5 \%$ & $10.8 \%$ & $7.9 \%$ & $8.4 \%$ & $7.8 \%$ & $8.0 \%$ & $7.5 \%$ & $8.7 \%$ & \\
\hline$\% 1-4 \mathrm{pm}$ & $14.2 \%$ & $13.2 \%$ & $14.7 \%$ & $11.7 \%$ & $15.2 \%$ & $12.5 \%$ & $11.4 \%$ & $12.5 \%$ & $11.9 \%$ & $16.2 \%$ & $10.5 \%$ & $14.6 \%$ & $8.1 \%$ & $1.9 \%$ \\
\hline$\%$ 4-7 pm & $25.6 \%$ & $25.2 \%$ & $24.1 \%$ & $24.1 \%$ & $24.6 \%$ & $24.0 \%$ & $27.8 \%$ & $24.1 \%$ & $25.9 \%$ & $23.2 \%$ & $21.5 \%$ & $22.9 \%$ & $31.3 \%$ & $48.0 \%$ \\
\hline$\% 7-10$ pm & $7.2 \%$ & $7.8 \%$ & $7.8 \%$ & $8.9 \%$ & $7.1 \%$ & $8.1 \%$ & $6.5 \%$ & $11.1 \%$ & $5.2 \%$ & $9.5 \%$ & $13.9 \%$ & $5.3 \%$ & $9.0 \%$ & $2.5 \%$ \\
\hline$\% 10 \mathrm{pm}-1 \mathrm{am}$ & $4.4 \%$ & $3.9 \%$ & $4.0 \%$ & $3.3 \%$ & $2.5 \%$ & $3.5 \%$ & $4.0 \%$ & $4.1 \%$ & $7.1 \%$ & $6.3 \%$ & $5.5 \%$ & $4.6 \%$ & $4.2 \%$ & \\
\hline$\%$ Unreported & $0.0 \%$ & $0.2 \%$ & & $0.0 \%$ & & $0.1 \%$ & $0.6 \%$ & $0.0 \%$ & $0.0 \%$ & & & & & \\
\hline
\end{tabular}




\begin{tabular}{|c|c|c|c|c|c|c|c|c|c|c|c|c|c|c|}
\hline \multicolumn{15}{|c|}{ Population Density (census tract) } \\
\hline & \multicolumn{2}{|c|}{$<500$} & \multicolumn{2}{|c|}{$500-2,000$} & \multirow{2}{*}{\multicolumn{2}{|c|}{\begin{tabular}{|c|}
\multicolumn{2}{|c|}{$2,000-4,000$} \\
NY State $\quad$ U.S.
\end{tabular}}} & \multirow{2}{*}{\multicolumn{2}{|c|}{\begin{tabular}{ll}
\multicolumn{2}{c}{$4,000-10,000$} \\
NY State U.S.
\end{tabular}}} & \multicolumn{2}{|c|}{$10,000-20,000$} & \multicolumn{2}{|c|}{$20,000-50,000$} & \multicolumn{2}{|c|}{$50,000+$} \\
\hline & NY State & U.S. & NY State & U.S. & & & & & NY State & U.S. & NY State & U.S. & NY State & U.S. \\
\hline \multicolumn{15}{|c|}{ Daily Commute Person Trips per Person } \\
\hline TOTAL & 1.32 & 1.35 & 1.34 & 1.36 & 1.34 & 1.44 & 1.29 & 1.36 & 1.37 & 1.35 & 1.19 & 1.36 & 1.32 & 1.34 \\
\hline$\%$ SOV & $78.2 \%$ & $79.3 \%$ & $78.2 \%$ & $80.0 \%$ & $78.9 \%$ & $77.2 \%$ & $67.7 \%$ & $73.2 \%$ & $50.7 \%$ & $63.7 \%$ & $32.2 \%$ & $46.3 \%$ & $16.0 \%$ & $30.1 \%$ \\
\hline$\% \mathrm{MOV}$ & $15.8 \%$ & $17.0 \%$ & $14.3 \%$ & $15.6 \%$ & $11.3 \%$ & $15.2 \%$ & $14.6 \%$ & $16.7 \%$ & $15.9 \%$ & $15.6 \%$ & $9.3 \%$ & $12.7 \%$ & $6.9 \%$ & $5.1 \%$ \\
\hline$\%$ Other POV & & $0.0 \%$ & $0.0 \%$ & $0.0 \%$ & $0.0 \%$ & $0.0 \%$ & $0.0 \%$ & $0.0 \%$ & & & & & $0.0 \%$ & \\
\hline$\%$ Amtrak & & $0.0 \%$ & & $0.0 \%$ & $0.0 \%$ & $0.0 \%$ & $0.0 \%$ & $0.0 \%$ & & & & & & \\
\hline$\%$ Commuter Train & $0.8 \%$ & $0.0 \%$ & $1.5 \%$ & $0.0 \%$ & $2.3 \%$ & $0.7 \%$ & $3.8 \%$ & $0.7 \%$ & $2.2 \%$ & $1.5 \%$ & $5.9 \%$ & $1.5 \%$ & $6.9 \%$ & $2.2 \%$ \\
\hline \% Subway/El Rail & $0.0 \%$ & $0.0 \%$ & $0.0 \%$ & $0.0 \%$ & $0.0 \%$ & $0.7 \%$ & $2.3 \%$ & $0.7 \%$ & $8.0 \%$ & $3.0 \%$ & $23.7 \%$ & $4.5 \%$ & $31.3 \%$ & $14.0 \%$ \\
\hline \% Other Public & $0.8 \%$ & $0.0 \%$ & $0.8 \%$ & $0.7 \%$ & $1.5 \%$ & $1.4 \%$ & $3.8 \%$ & $2.9 \%$ & $9.4 \%$ & $6.7 \%$ & $11.9 \%$ & $17.9 \%$ & $13.0 \%$ & $25.0 \%$ \\
\hline$\%$ Walk & $0.8 \%$ & $0.7 \%$ & $1.5 \%$ & $0.7 \%$ & $1.5 \%$ & $1.4 \%$ & $3.8 \%$ & $2.9 \%$ & $7.2 \%$ & $4.4 \%$ & $10.2 \%$ & $11.2 \%$ & $16.8 \%$ & $21.3 \%$ \\
\hline$\%$ Other & $0.8 \%$ & $0.7 \%$ & $1.5 \%$ & $1.5 \%$ & $1.5 \%$ & $1.4 \%$ & $1.5 \%$ & $0.7 \%$ & $3.6 \%$ & $1.5 \%$ & $3.4 \%$ & $3.0 \%$ & $6.1 \%$ & $2.2 \%$ \\
\hline$\%$ Unreported & $3.0 \%$ & $2.2 \%$ & $2.3 \%$ & $1.5 \%$ & $3.0 \%$ & $2.1 \%$ & $2.3 \%$ & $2.2 \%$ & $2.9 \%$ & $3.7 \%$ & $3.4 \%$ & $3.0 \%$ & $3.1 \%$ & $0.0 \%$ \\
\hline TOTAL & 1.32 & 1.35 & 1.34 & 1.36 & 1.34 & 1.44 & 1.29 & 1.36 & 1.37 & 1.35 & 1.19 & 1.36 & 1.32 & 1.34 \\
\hline$\% 1-6$ am & $4.5 \%$ & $5.9 \%$ & $3.7 \%$ & $5.1 \%$ & $4.5 \%$ & $4.8 \%$ & $4.7 \%$ & $5.9 \%$ & $3.6 \%$ & $6.7 \%$ & $3.3 \%$ & $4.4 \%$ & $3.8 \%$ & $2.2 \%$ \\
\hline$\%$ 6-9 am & $30.1 \%$ & $29.6 \%$ & $29.9 \%$ & $28.7 \%$ & $28.6 \%$ & $28.3 \%$ & $28.1 \%$ & $28.7 \%$ & $31.2 \%$ & $28.9 \%$ & $33.3 \%$ & $28.7 \%$ & $30.3 \%$ & $40.3 \%$ \\
\hline$\% 9 \mathrm{am}-1 \mathrm{pm}$ & $12.8 \%$ & $11.9 \%$ & $13.4 \%$ & $12.5 \%$ & $14.3 \%$ & $13.1 \%$ & $13.3 \%$ & $12.5 \%$ & $11.6 \%$ & $11.1 \%$ & $8.3 \%$ & $13.2 \%$ & $10.6 \%$ & $10.4 \%$ \\
\hline$\% 1-4 \mathrm{pm}$ & $14.3 \%$ & $14.8 \%$ & $14.9 \%$ & $15.4 \%$ & $13.5 \%$ & $13.8 \%$ & $16.4 \%$ & $14.7 \%$ & $18.1 \%$ & $15.6 \%$ & $12.5 \%$ & $12.5 \%$ & $10.6 \%$ & $5.2 \%$ \\
\hline$\% 4-7 \mathrm{pm}$ & $27.8 \%$ & $27.4 \%$ & $26.9 \%$ & $27.2 \%$ & $25.6 \%$ & $27.6 \%$ & $25.8 \%$ & $26.5 \%$ & $21.7 \%$ & $23.0 \%$ & $26.7 \%$ & $26.5 \%$ & $26.5 \%$ & $29.9 \%$ \\
\hline$\%$ 7-10 pm & $6.8 \%$ & $6.7 \%$ & $6.7 \%$ & $6.6 \%$ & $9.0 \%$ & $7.6 \%$ & $7.0 \%$ & $7.4 \%$ & $8.7 \%$ & $8.9 \%$ & $8.3 \%$ & $10.3 \%$ & $13.6 \%$ & $3.7 \%$ \\
\hline$\% 10 \mathrm{pm}-1 \mathrm{am}$ & $3.8 \%$ & $3.7 \%$ & $4.5 \%$ & $4.4 \%$ & $4.5 \%$ & $4.8 \%$ & $4.7 \%$ & $4.4 \%$ & $5.1 \%$ & $5.9 \%$ & $7.5 \%$ & $4.4 \%$ & $4.5 \%$ & $8.2 \%$ \\
\hline \multicolumn{15}{|c|}{ Daily Commute PMT per Person } \\
\hline TOTAL & 17.92 & 19.56 & 17.07 & 17.21 & 16.40 & 16.07 & 13.92 & 13.47 & 11.84 & 12.01 & 11.47 & 10.97 & 9.65 & 6.49 \\
\hline$\%$ SOV & $77.7 \%$ & $80.0 \%$ & $73.4 \%$ & $77.0 \%$ & $74.4 \%$ & $75.4 \%$ & $69.5 \%$ & $77.9 \%$ & $60.7 \%$ & $69.4 \%$ & $37.2 \%$ & $60.6 \%$ & $23.1 \%$ & $42.5 \%$ \\
\hline$\%$ MOV & $15.6 \%$ & $17.1 \%$ & $18.7 \%$ & $17.7 \%$ & $14.5 \%$ & $13.1 \%$ & $10.9 \%$ & $16.1 \%$ & $11.1 \%$ & $18.6 \%$ & $15.7 \%$ & $12.8 \%$ & $12.8 \%$ & $2.6 \%$ \\
\hline$\%$ Other POV & & $0.1 \%$ & $0.0 \%$ & $0.0 \%$ & $0.6 \%$ & $0.2 \%$ & & $0.1 \%$ & & & & & & \\
\hline$\%$ Amtrak & & $0.0 \%$ & & $0.1 \%$ & & $0.0 \%$ & $0.2 \%$ & $0.1 \%$ & & & & & & \\
\hline$\%$ Commuter Train & $2.3 \%$ & $0.1 \%$ & $4.8 \%$ & $0.8 \%$ & $7.6 \%$ & $1.4 \%$ & $10.9 \%$ & $1.3 \%$ & $6.2 \%$ & $2.1 \%$ & $3.9 \%$ & $1.7 \%$ & $10.7 \%$ & $8.6 \%$ \\
\hline \% Subway/El Rail & $0.1 \%$ & $0.1 \%$ & $0.2 \%$ & $0.1 \%$ & $0.4 \%$ & $0.6 \%$ & $4.2 \%$ & $0.5 \%$ & $10.0 \%$ & $2.2 \%$ & $30.0 \%$ & $3.8 \%$ & $27.4 \%$ & $24.9 \%$ \\
\hline$\%$ Other Public & $0.9 \%$ & $0.8 \%$ & $1.2 \%$ & $0.6 \%$ & $0.7 \%$ & $1.5 \%$ & $2.8 \%$ & $2.2 \%$ & $8.1 \%$ & $5.5 \%$ & $8.3 \%$ & $18.8 \%$ & $9.5 \%$ & $12.1 \%$ \\
\hline$\%$ Walk & $0.1 \%$ & $0.1 \%$ & $0.1 \%$ & $0.1 \%$ & $0.1 \%$ & $0.1 \%$ & $0.2 \%$ & $0.2 \%$ & $0.7 \%$ & $0.4 \%$ & $1.0 \%$ & $0.9 \%$ & $2.7 \%$ & $8.8 \%$ \\
\hline$\%$ Other & $2.1 \%$ & $0.9 \%$ & $1.0 \%$ & $2.8 \%$ & $0.2 \%$ & $6.8 \%$ & $1.1 \%$ & $0.4 \%$ & $1.8 \%$ & $0.8 \%$ & $3.7 \%$ & $1.2 \%$ & $13.6 \%$ & $0.5 \%$ \\
\hline$\%$ Unreported & $1.2 \%$ & $1.0 \%$ & $0.5 \%$ & $0.9 \%$ & $1.3 \%$ & $1.0 \%$ & $0.3 \%$ & $1.0 \%$ & $1.4 \%$ & $1.0 \%$ & $0.2 \%$ & $0.2 \%$ & $0.2 \%$ & \\
\hline TOTAL & 17.92 & 19.56 & 17.07 & 17.21 & 16.40 & 16.07 & 13.92 & 13.47 & 11.84 & 12.01 & 11.47 & 10.97 & 9.65 & 6.49 \\
\hline$\% 1-6$ am & $5.6 \%$ & $10.7 \%$ & $6.7 \%$ & $7.7 \%$ & $8.6 \%$ & $6.3 \%$ & $7.1 \%$ & $8.2 \%$ & $4.1 \%$ & $8.1 \%$ & $4.2 \%$ & $8.7 \%$ & $5.0 \%$ & $0.2 \%$ \\
\hline$\%$ 6-9 am & $31.5 \%$ & $29.1 \%$ & $30.7 \%$ & $30.0 \%$ & $29.5 \%$ & $30.7 \%$ & $31.2 \%$ & $28.7 \%$ & $32.0 \%$ & $31.4 \%$ & $35.8 \%$ & $27.7 \%$ & $30.6 \%$ & $36.9 \%$ \\
\hline$\% 9 \mathrm{am}-1 \mathrm{pm}$ & $10.3 \%$ & $7.6 \%$ & $14.1 \%$ & $10.5 \%$ & $12.9 \%$ & $9.8 \%$ & $10.9 \%$ & $9.3 \%$ & $9.5 \%$ & $9.9 \%$ & $5.4 \%$ & $16.0 \%$ & $7.9 \%$ & $11.2 \%$ \\
\hline$\% 1-4 \mathrm{pm}$ & $14.1 \%$ & $14.9 \%$ & $13.2 \%$ & $14.2 \%$ & $12.6 \%$ & $13.2 \%$ & $14.4 \%$ & $14.6 \%$ & $18.7 \%$ & $15.4 \%$ & $9.6 \%$ & $8.1 \%$ & $9.3 \%$ & $7.1 \%$ \\
\hline$\%$ 4-7 pm & $28.1 \%$ & $27.9 \%$ & $24.9 \%$ & $25.7 \%$ & $22.8 \%$ & $27.4 \%$ & $26.4 \%$ & $27.4 \%$ & $22.4 \%$ & $20.5 \%$ & $24.9 \%$ & $24.2 \%$ & $32.4 \%$ & $27.2 \%$ \\
\hline$\% 7-10 \mathrm{pm}$ & $6.2 \%$ & $6.6 \%$ & $6.6 \%$ & $7.4 \%$ & $9.2 \%$ & $8.4 \%$ & $5.6 \%$ & $7.3 \%$ & $4.9 \%$ & $8.3 \%$ & $14.8 \%$ & $9.8 \%$ & $11.0 \%$ & $8.9 \%$ \\
\hline$\% 10 \mathrm{pm}-1 \mathrm{am}$ & $4.1 \%$ & $3.2 \%$ & $3.8 \%$ & $4.6 \%$ & $4.4 \%$ & $4.3 \%$ & $4.4 \%$ & $4.4 \%$ & $8.4 \%$ & $6.4 \%$ & $5.3 \%$ & $5.5 \%$ & $4.0 \%$ & $8.4 \%$ \\
\hline
\end{tabular}


Chapter 4: Table 8

Urban Travel and Population Density, 2001

\begin{tabular}{|c|c|c|c|c|c|c|c|c|c|c|c|c|c|c|}
\hline \multicolumn{15}{|c|}{ Population Density (census tract) } \\
\hline & \multicolumn{2}{|c|}{$<500$} & \multicolumn{2}{|c|}{$500-2,000$} & \multicolumn{2}{|c|}{$2,000-4,000$} & \multicolumn{2}{|c|}{$4,000-10,000$} & \multicolumn{2}{|c|}{$10,000-20,000$} & \multicolumn{2}{|c|}{$20,000-50,000$} & \multicolumn{2}{|c|}{$50,000+$} \\
\hline & NY State & U.S. & NY State & U.S. & NY State & U.S. & NY State & U.S. & NY State & U.S. & NY State & U.S. & NY State & U.S. \\
\hline \multicolumn{15}{|c|}{$\begin{array}{l}\text { Average Commute Length, Travel Time, and Speed } \\
\text { Length (miles) }\end{array}$} \\
\hline TOTAL & 14.00 & 14.96 & 12.19 & 12.33 & 12.52 & 10.92 & 10.75 & 11.36 & 9.94 & 10.08 & 8.16 & 7.84 & 7.04 & 10.79 \\
\hline Private & 13.81 & 14.83 & 12.05 & 11.79 & 12.03 & 10.61 & 10.00 & 10.99 & 9.92 & 10.47 & 8.89 & 9.70 & 10.45 & 14.88 \\
\hline Public & 19.98 & 22.56 & 29.95 & 23.30 & 27.01 & 14.76 & 21.93 & 12.83 & 13.95 & 9.22 & 11.04 & 6.17 & 7.76 & 9.22 \\
\hline Other & 47.27 & 104.50 & 24.74 & 102.39 & 12.69 & 80.81 & 14.08 & 73.82 & 11.04 & 31.86 & 7.43 & 3.02 & 6.80 & \\
\hline Walk & 2.91 & 0.83 & 0.93 & 0.78 & 0.91 & 1.11 & 1.94 & 0.87 & 1.26 & 0.89 & 1.25 & 0.83 & 1.22 & \\
\hline \multicolumn{15}{|c|}{ Time (minutes) } \\
\hline TOTAL & 24.79 & 24.41 & 23.77 & 22.46 & 25.86 & 21.89 & 26.86 & 24.04 & 36.11 & 27.88 & 37.65 & 26.77 & 40.47 & 48.64 \\
\hline Private & 23.56 & 24.24 & 22.27 & 22.10 & 23.27 & 21.25 & 21.95 & 22.82 & 25.95 & 25.87 & 28.13 & 23.95 & 35.47 & 35.95 \\
\hline Public & 57.97 & 106.73 & 74.46 & 61.94 & 71.18 & 56.26 & 77.46 & 59.47 & 71.98 & 48.46 & 58.02 & 43.97 & 51.16 & 55.11 \\
\hline Other & 67.52 & 74.73 & 52.86 & 57.97 & 32.74 & 56.35 & 53.63 & 39.13 & 42.48 & 40.71 & 32.43 & 32.13 & 37.50 & \\
\hline Walk & 12.59 & 8.91 & 33.23 & 15.15 & 14.52 & 13.02 & 12.90 & 13.18 & 17.70 & 14.54 & 20.27 & 15.28 & 19.76 & \\
\hline \multicolumn{15}{|c|}{ Miles per Hour } \\
\hline TOTAL & 34.98 & 36.87 & 31.41 & 33.07 & 30.64 & 30.80 & 26.78 & 29.91 & 21.35 & 23.44 & 16.03 & 21.58 & 13.85 & 24.84 \\
\hline Private & 35.19 & 36.71 & 32.73 & 32.02 & 31.25 & 30.04 & 27.34 & 28.92 & 23.29 & 24.29 & 18.53 & 24.37 & 17.68 & 24.84 \\
\hline Public & & & & & & 34.29 & & 21.00 & & & & & & \\
\hline Other & 48.42 & 84.34 & 22.97 & 134.47 & 13.71 & 121.36 & 14.76 & 164.61 & 10.46 & 7.69 & 16.08 & 5.06 & 12.59 & \\
\hline Walk & 7.09 & 5.49 & 1.40 & 2.46 & 3.77 & 3.07 & 6.79 & 3.73 & 3.14 & 3.07 & 3.14 & 2.66 & 3.15 & \\
\hline
\end{tabular}




\begin{tabular}{|c|c|c|c|c|c|c|c|c|c|c|c|c|c|c|}
\hline \multicolumn{15}{|c|}{ Population Density (census tract) } \\
\hline & \multicolumn{2}{|c|}{$<500$} & \multicolumn{2}{|c|}{$500-2,000$} & \multicolumn{2}{|c|}{$2,000-4,000$} & \multicolumn{2}{|c|}{$4,000-10,000$} & \multicolumn{2}{|c|}{$10,000-20,000$} & \multicolumn{2}{|c|}{$20,000-50,000$} & \multicolumn{2}{|c|}{$50,000+$} \\
\hline & NY State & U.S. & NY State & U.S. & NY State & U.S. & NY State & U.S. & NY State & U.S. & NY State & U.S. & NY State & U.S. \\
\hline \multicolumn{15}{|c|}{$\begin{array}{l}\text { Average Commute Length, Travel Time and Speed } \\
\text { Length (miles) }\end{array}$} \\
\hline TOTAL & 13.66 & 14.64 & 12.92 & 12.77 & 12.38 & 11.27 & 11.12 & 10.07 & 9.17 & 9.11 & 11.02 & 8.60 & 8.49 & 4.84 \\
\hline Private & 13.44 & 14.73 & 12.80 & 12.71 & 12.29 & 10.67 & 10.74 & 10.41 & 9.57 & 10.02 & 12.96 & 10.61 & 11.88 & 6.18 \\
\hline Public & 38.32 & 38.67 & 35.01 & 20.24 & 27.13 & 20.44 & 20.86 & 11.24 & 12.97 & 8.32 & 12.99 & 8.72 & 8.89 & 5.36 \\
\hline Other & 41.18 & 17.50 & 11.32 & 22.61 & 2.82 & 71.95 & 7.51 & 8.49 & 4.67 & 5.39 & 10.17 & 4.16 & 16.61 & 1.00 \\
\hline Walk & 0.61 & 0.63 & 0.58 & 0.51 & 0.82 & 0.58 & 0.60 & 0.88 & 0.83 & 0.81 & 0.94 & 0.68 & 1.18 & 1.97 \\
\hline \multicolumn{15}{|l|}{ Time (minutes) } \\
\hline TOTAL & 21.39 & 23.01 & 22.24 & 21.03 & 23.13 & 19.54 & 23.60 & 20.29 & 25.75 & 21.44 & 34.64 & 27.43 & 31.55 & 24.99 \\
\hline Private & 21.25 & 22.77 & 21.71 & 20.90 & 22.02 & 19.12 & 21.60 & 19.83 & 22.70 & 21.01 & 29.63 & 26.13 & 30.76 & 18.07 \\
\hline Public & 55.72 & 67.45 & 60.88 & 48.73 & 60.38 & 46.46 & 50.32 & 39.15 & 46.31 & 33.28 & 49.94 & 36.85 & 39.39 & 35.84 \\
\hline Other & 37.95 & 56.84 & 35.40 & 24.83 & 11.80 & 36.82 & 24.93 & 39.77 & 23.33 & 19.48 & 29.48 & 52.54 & 23.23 & 5.00 \\
\hline Walk & 6.81 & 7.51 & 11.15 & 8.51 & 12.43 & 11.76 & 8.87 & 11.92 & 9.34 & 10.49 & 10.82 & 12.22 & 16.53 & 20.25 \\
\hline \multicolumn{15}{|l|}{ Miles per Hour } \\
\hline TOTAL & 37.98 & 38.22 & 34.71 & 36.53 & 32.72 & 34.88 & 28.40 & 30.35 & 22.02 & 26.66 & 22.13 & 19.86 & 17.79 & 13.50 \\
\hline Private & 37.94 & 38.81 & 35.37 & 36.46 & 33.48 & 33.47 & 29.84 & 31.50 & 25.30 & 28.61 & 26.25 & 24.36 & 23.17 & 20.51 \\
\hline Public & 30.71 & 39.65 & 37.73 & 27.07 & 30.72 & 34.98 & 21.85 & 17.09 & 14.99 & 15.51 & 17.63 & 11.42 & 12.32 & 10.98 \\
\hline Other & 65.10 & 18.42 & 19.19 & 55.04 & 13.76 & 117.25 & 15.75 & 11.16 & 12.35 & 16.59 & 20.70 & 4.75 & 42.90 & 12.00 \\
\hline Walk & 5.35 & 5.01 & 3.13 & 3.60 & 3.98 & 2.94 & 4.09 & 4.41 & 5.35 & 4.66 & 5.18 & 3.33 & 4.27 & 5.84 \\
\hline
\end{tabular}




\begin{tabular}{|c|c|c|c|c|c|c|c|c|c|c|c|c|c|c|}
\hline \multicolumn{15}{|c|}{ Population Density (census tract) } \\
\hline & \multicolumn{2}{|c|}{$<500$} & \multicolumn{2}{|c|}{$500-2,000$} & \multicolumn{2}{|c|}{$2,000-4,000$} & \multicolumn{2}{|c|}{$4,000-10,000$} & \multicolumn{2}{|c|}{$10,000-20,000$} & \multicolumn{2}{|c|}{$20,000-50,000$} & \multicolumn{2}{|c|}{$50,000+$} \\
\hline & NY State & U.S. & NY State & U.S. & NY State & U.S. & NY State & U.S. & NY State & U.S. & NY State & U.S. & NY State & U.S. \\
\hline \multicolumn{15}{|c|}{ Average Vehicle Occupancy (Person Miles per Vehicle Mile) } \\
\hline ALL & 1.52 & 1.62 & 1.52 & 1.63 & 1.61 & 1.60 & 1.58 & 1.62 & 2.06 & 1.65 & 1.70 & 1.74 & 1.68 & 1.16 \\
\hline 1 Adult, No Child & 1.15 & 1.18 & 1.19 & 1.27 & 1.20 & 1.25 & 1.15 & 1.21 & 1.42 & 1.26 & 1.29 & 1.06 & 1.78 & 1.09 \\
\hline 2+ Adults, No Child & 1.36 & 1.37 & 1.38 & 1.47 & 1.40 & 1.38 & 1.39 & 1.41 & 1.44 & 1.54 & 1.64 & 1.49 & 1.78 & 1.18 \\
\hline 1 Adult, Child <6 & 1.51 & 1.97 & 1.64 & 1.97 & 1.55 & 2.13 & 1.43 & 1.71 & 2.05 & 1.86 & 1.19 & 2.87 & 2.45 & 1.00 \\
\hline $2+$ Adults, Child $<6$ & 1.92 & 2.02 & 1.94 & 2.10 & 2.03 & 2.04 & 2.01 & 2.02 & 1.95 & 1.92 & 1.59 & 2.77 & 1.64 & 1.44 \\
\hline 1 Adult, Child 6-15 & 1.84 & 1.57 & 1.58 & 1.64 & 1.74 & 1.89 & 1.79 & 1.77 & 1.24 & 1.72 & 1.62 & 1.28 & 1.53 & \\
\hline 2+ Adults, Child 6-15 & 1.59 & 1.77 & 1.64 & 1.63 & 1.75 & 1.59 & 1.52 & 1.76 & 1.70 & 1.78 & 2.07 & 1.93 & 1.57 & 1.00 \\
\hline 1 Adult, Child 16-21 & 1.19 & 1.32 & 1.34 & 1.36 & 1.25 & 1.62 & 1.31 & 1.40 & 1.63 & 1.24 & 1.36 & 1.30 & 1.00 & \\
\hline 2+ Adults, Child 16-21 & 1.38 & 1.38 & 1.40 & 1.39 & 1.41 & 1.48 & 1.48 & 1.48 & 4.23 & 1.49 & 1.51 & 2.07 & 1.34 & \\
\hline 1 Adult, Retired, No Child & 1.14 & 1.34 & 1.34 & 1.31 & 1.18 & 1.31 & 1.28 & 1.26 & 1.07 & 1.37 & 1.71 & 1.27 & 1.08 & 1.26 \\
\hline 2+ Adults, Retired, No Child & 1.58 & 1.64 & 1.44 & 1.60 & 1.46 & 1.67 & 1.66 & 1.61 & 1.47 & 1.60 & 1.65 & 1.40 & 1.62 & \\
\hline Unreported & & 1.25 & 1.01 & 1.84 & 1.00 & & 1.94 & 1.65 & 1.55 & & & & & \\
\hline ALL & 1.52 & 1.62 & 1.52 & 1.63 & 1.61 & 1.60 & 1.58 & 1.62 & 2.06 & 1.65 & 1.70 & 1.74 & 1.68 & 1.16 \\
\hline Earn a Living & 1.11 & 1.17 & 1.11 & 1.13 & 1.20 & 1.15 & 1.09 & 1.16 & 1.24 & 1.11 & 1.18 & 1.16 & 1.29 & 1.16 \\
\hline Family \& Personal Business & 1.69 & 1.79 & 1.60 & 1.76 & 1.70 & 1.71 & 1.78 & 1.84 & 1.80 & 1.83 & 1.89 & 2.17 & 1.92 & 1.09 \\
\hline Civic, Educational \& Religious & 1.65 & 1.79 & 1.68 & 2.06 & 1.60 & 1.67 & 1.53 & 1.65 & 1.53 & 1.41 & 1.38 & 2.30 & 1.70 & 1.00 \\
\hline Social \& Recreational & 1.84 & 2.06 & 1.99 & 2.04 & 2.10 & 2.02 & 1.99 & 1.97 & 3.52 & 2.27 & 2.10 & 1.83 & 1.84 & 1.44 \\
\hline Other & 2.23 & 1.91 & 1.78 & 1.97 & 1.50 & 2.08 & 1.23 & 1.51 & 1.96 & 1.82 & 2.45 & 1.32 & 1.30 & \\
\hline Unreported & 1.31 & 1.80 & 2.16 & 1.33 & 3.03 & 2.05 & 2.14 & 1.50 & 1.31 & 1.00 & 1.00 & 1.14 & 1.00 & 1.00 \\
\hline
\end{tabular}




\begin{tabular}{|c|c|c|c|c|c|c|c|c|c|c|c|c|c|c|}
\hline \multicolumn{15}{|c|}{ Population Density (census tract) } \\
\hline & \multicolumn{2}{|c|}{$<500$} & \multicolumn{2}{|c|}{$500-2,000$} & \multicolumn{2}{|c|}{$2,000-4,000$} & \multicolumn{2}{|c|}{$4,000-10,000$} & \multicolumn{2}{|c|}{$10,000-20,000$} & \multicolumn{2}{|c|}{$20,000-50,000$} & \multicolumn{2}{|c|}{$50,000+$} \\
\hline & NY State & U.S. & NY State & U.S. & NY State & U.S. & NY State & U.S. & NY State & U.S. & NY State & U.S. & NY State & U.S. \\
\hline \multicolumn{15}{|c|}{ Average Vehicle Occupancy Rate (Person Miles per Vehicle Mile) } \\
\hline ALL & 1.50 & 1.56 & 1.62 & 1.59 & 1.53 & 1.62 & 1.58 & 1.55 & 1.70 & 1.57 & 1.54 & 1.66 & 2.05 & 1.74 \\
\hline Single Adult, No Child & 1.22 & 1.14 & 1.51 & 1.25 & 1.08 & 1.29 & 1.31 & 1.19 & 1.17 & 1.40 & 1.10 & 1.21 & 1.20 & 1.45 \\
\hline 2 or $>$ Adult, No Child & 1.36 & 1.34 & 1.38 & 1.31 & 1.49 & 1.40 & 1.32 & 1.32 & 1.50 & 1.29 & 1.62 & 1.45 & 2.01 & 1.79 \\
\hline Single Adult, Child $<6$ & 1.62 & 1.48 & 2.57 & 1.67 & 1.34 & 4.11 & 2.12 & 1.74 & 2.88 & 1.81 & 1.41 & & 1.36 & \\
\hline 2 or $>$ Adult, Child $<6$ & 1.69 & 1.79 & 2.00 & 1.91 & 1.74 & 1.88 & 1.91 & 1.89 & 1.97 & 1.87 & 1.67 & 1.80 & 2.54 & 1.00 \\
\hline Single Adult, Child 6-15 & 1.75 & 1.51 & 1.39 & 1.66 & 1.35 & 2.17 & 1.55 & 1.57 & 2.96 & 1.52 & 1.27 & 2.42 & 2.30 & \\
\hline 2 or > Adult, Child 6-15 & 1.67 & 1.83 & 1.64 & 1.74 & 1.85 & 1.80 & 1.78 & 1.84 & 1.94 & 1.84 & 1.90 & 2.15 & 2.06 & 1.57 \\
\hline Single Adult, Child $16-20$ & 1.07 & 1.67 & 1.80 & 1.55 & 1.21 & 1.94 & 1.51 & 1.42 & 1.55 & 1.06 & & 2.51 & 1.47 & \\
\hline 2 or $>$ Adult, Child $16-20$ & 1.37 & 1.37 & 1.40 & 1.44 & 1.19 & 1.49 & 1.63 & 1.63 & 1.69 & 1.29 & 1.31 & 2.42 & 2.47 & \\
\hline Single Adult, Retired & 1.19 & 1.29 & 1.06 & 1.82 & 1.20 & 1.42 & 1.15 & 1.20 & 1.44 & 1.32 & 1.41 & 1.02 & 1.50 & \\
\hline 2 or $>$ Adult, Retired & 1.46 & 1.50 & 1.66 & 1.61 & 1.49 & 1.49 & 1.58 & 1.54 & 1.69 & 2.02 & 1.43 & 2.20 & 1.73 & 2.00 \\
\hline ALL & 1.50 & 1.56 & 1.62 & 1.59 & 1.53 & 1.62 & 1.58 & 1.55 & 1.70 & 1.57 & 1.54 & 1.66 & 2.05 & 1.74 \\
\hline Earn a Living & 1.12 & 1.15 & 1.19 & 1.15 & 1.07 & 1.14 & 1.11 & 1.14 & 1.14 & 1.13 & 1.11 & 1.07 & 1.63 & 1.04 \\
\hline Fam/Per Bus & 1.63 & 1.70 & 1.72 & 1.76 & 1.70 & 1.80 & 1.75 & 1.71 & 1.86 & 1.74 & 1.64 & 2.04 & 2.04 & 1.88 \\
\hline Civ, Ed, \& Rel & 1.56 & 1.64 & 1.47 & 1.58 & 1.53 & 1.56 & 2.55 & 1.64 & 1.59 & 2.07 & 1.38 & 1.83 & 1.91 & \\
\hline Soc and Rec & 1.92 & 2.10 & 2.11 & 2.10 & 1.98 & 2.17 & 2.04 & 1.93 & 2.32 & 1.81 & 2.11 & 1.92 & 2.43 & 1.86 \\
\hline Other & 1.19 & 2.18 & 1.99 & 1.93 & 3.00 & 1.49 & 1.08 & 1.58 & 2.00 & 2.09 & 1.00 & & & \\
\hline
\end{tabular}


Definition of NYS RURAL: Outside MPO and Population Density $<1,000$ (Block Group) Definition of US RURAL: Outside NY and MSA with Population Density $<1,000$ (Block Group)

\begin{tabular}{|c|c|c|c|c|c|c|c|c|}
\hline & \multicolumn{4}{|c|}{1995} & \multicolumn{4}{|c|}{2001} \\
\hline & \multicolumn{8}{|c|}{ Population Density (census tract) } \\
\hline & \multicolumn{2}{|c|}{$<500$} & \multicolumn{2}{|c|}{500 to 2,000} & \multicolumn{2}{|c|}{$<500$} & \multicolumn{2}{|c|}{$500-2,000$} \\
\hline & NYS & U.S. & NYS & U.S. & NYS & U.S. & NYS & U.S. \\
\hline \multicolumn{9}{|l|}{ General Statistics } \\
\hline Households (000) & 564 & 13,421 & 24 & 1,278 & 607 & 14,504 & 27 & 1,414 \\
\hline Drivers (000) & 1,092 & 24,601 & 44 & 2,335 & 1,150 & 26,892 & 47 & 2,461 \\
\hline Workers $(000)$ & 775 & 17,056 & 34 & 1,609 & 828 & 19,033 & 39 & 1,733 \\
\hline Vehicles (000) & 1,013 & 26,995 & 44 & 2,369 & 1,261 & 32,596 & 48 & 2,805 \\
\hline Workers per Household & 1.37 & 1.27 & 1.41 & 1.26 & 1.36 & 1.31 & 1.44 & 1.23 \\
\hline Vehicles per Household & 1.80 & 2.01 & 1.84 & 1.85 & 2.08 & 2.25 & 1.79 & 1.98 \\
\hline Vehicles per Driver & 0.93 & 1.10 & 0.99 & 1.01 & 1.10 & 1.21 & 1.01 & 1.14 \\
\hline \multicolumn{9}{|c|}{ Distribution of Households by Household Vehicle Count } \\
\hline ALL & $100 \%$ & $100 \%$ & $100 \%$ & $100 \%$ & $100 \%$ & $100 \%$ & $100 \%$ & $100 \%$ \\
\hline 0 vehicles & $3.2 \%$ & $4.3 \%$ & $3.2 \%$ & $4.5 \%$ & $4.9 \%$ & $4.5 \%$ & $1.7 \%$ & $7.1 \%$ \\
\hline 1 vehicle & $30.7 \%$ & $27.7 \%$ & $35.3 \%$ & $33.5 \%$ & $27.6 \%$ & $24.4 \%$ & $44.6 \%$ & $26.7 \%$ \\
\hline 2 vehicles & $44.5 \%$ & $41.4 \%$ & $40.2 \%$ & $41.7 \%$ & $38.7 \%$ & $37.8 \%$ & $28.5 \%$ & $40.7 \%$ \\
\hline 3 vehicles & $16.4 \%$ & $19.2 \%$ & $8.9 \%$ & $14.9 \%$ & $18.4 \%$ & $18.8 \%$ & $23.4 \%$ & $16.0 \%$ \\
\hline 4+ vehicles & $5.2 \%$ & $7.4 \%$ & $12.4 \%$ & $5.5 \%$ & $10.5 \%$ & $14.5 \%$ & $1.8 \%$ & $9.6 \%$ \\
\hline \multicolumn{9}{|c|}{ 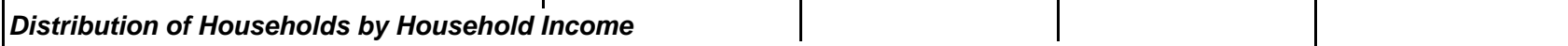 } \\
\hline \multicolumn{9}{|c|}{ (Statistics by Household Income for 1995 are unavailable in 2001 Dollar terms for tables in Chapters 4-6) } \\
\hline ALL & & & & & $100 \%$ & $100 \%$ & $100 \%$ & $100 \%$ \\
\hline$<\$ 10,000$ & & & & & $6.8 \%$ & $11.0 \%$ & $12.2 \%$ & $10.6 \%$ \\
\hline$\$ 10$ to $\$ 20,000$ & & & & & $16.2 \%$ & $15.3 \%$ & $14.6 \%$ & $16.7 \%$ \\
\hline$\$ 20$ to $\$ 30,000$ & & & & & $16.2 \%$ & $16.7 \%$ & $13.9 \%$ & $10.8 \%$ \\
\hline$\$ 30$ to $\$ 40,000$ & & & & & $14.2 \%$ & $14.0 \%$ & $23.3 \%$ & $17.1 \%$ \\
\hline$\$ 40$ to $\$ 50,000$ & & & & & $11.6 \%$ & $11.6 \%$ & $4.4 \%$ & $12.2 \%$ \\
\hline$\$ 50$ to $\$ 60,000$ & & & & & $8.9 \%$ & $8.6 \%$ & $4.6 \%$ & $9.7 \%$ \\
\hline$\$ 60$ to $\$ 70,000$ & & & & & $5.8 \%$ & $5.1 \%$ & $2.7 \%$ & $4.0 \%$ \\
\hline$\$ 70$ to $\$ 80,000$ & & & & & $3.9 \%$ & $3.4 \%$ & $3.4 \%$ & $2.8 \%$ \\
\hline$\$ 80,000+$ & & & & & $8.6 \%$ & $7.4 \%$ & $12.7 \%$ & $9.2 \%$ \\
\hline Unreported & & & & & $8.0 \%$ & $6.8 \%$ & $8.2 \%$ & $6.9 \%$ \\
\hline Average Annual Miles Driven per Driver & \multirow{4}{*}{\multicolumn{2}{|c|}{$\begin{array}{c}\text { All Rural NYS } \\
14,229 \\
17,578 \\
10,555\end{array}$}} & \multirow{4}{*}{\multicolumn{2}{|c|}{$\begin{array}{c}\text { All Rural U.S. } \\
15,310 \\
19,025 \\
11,234\end{array}$}} & \multirow{4}{*}{\multicolumn{2}{|c|}{$\begin{array}{c}\text { All Rural NYS } \\
14,515 \\
17,232 \\
11,255\end{array}$}} & \multirow{4}{*}{\multicolumn{2}{|c|}{$\begin{array}{c}\text { All Rural U.S. } \\
15,983 \\
19,976 \\
11,380\end{array}$}} \\
\hline ALL & & & & & & & & \\
\hline Male & & & & & & & & \\
\hline Female & & & & & & & & \\
\hline \multicolumn{9}{|l|}{ Driver Rate } \\
\hline$\%$ Male Drivers/Male $16+$ & $94.30 \%$ & $94.50 \%$ & $94.92 \%$ & $95.53 \%$ & $95.77 \%$ & $95.68 \%$ & $90.30 \%$ & $96.34 \%$ \\
\hline$\%$ Female Drivers/Female 16+ & $89.76 \%$ & $88.90 \%$ & $92.93 \%$ & $92.17 \%$ & $92.37 \%$ & $91.28 \%$ & $84.67 \%$ & $90.68 \%$ \\
\hline
\end{tabular}


Definition of NYS RURAL: Outside MPO and Population Density $<1,000$ (Block Group)

Definition of US RURAL: Outside NY and MSA with Population Density < 1,000 (Block Group)

\begin{tabular}{|c|c|c|c|c|c|c|c|c|}
\hline & \multicolumn{4}{|c|}{1995} & \multicolumn{4}{|c|}{2001} \\
\hline & \multicolumn{8}{|c|}{ Population Density (census tract) } \\
\hline & \multicolumn{2}{|c|}{$<500$} & \multicolumn{2}{|c|}{500 to 2,000} & \multicolumn{2}{|c|}{$<500$} & \multicolumn{2}{|c|}{$500-2,000$} \\
\hline & NYS & U.S. & NYS & U.S. & NYS & U.S. & NYS & U.S. \\
\hline Daily Person Trips per Person & & & & & & & & \\
\hline TOTAL & 3.91 & 4.25 & 3.80 & 4.71 & 3.88 & 3.93 & 4.33 & 4.39 \\
\hline Male & 3.92 & 4.27 & 3.97 & 4.46 & 3.85 & 3.92 & 4.39 & 4.47 \\
\hline Female & 3.91 & 4.23 & 3.58 & 4.97 & 3.92 & 3.94 & 4.26 & 4.32 \\
\hline TOTAL & 3.91 & 4.25 & 3.80 & 4.71 & 3.88 & 3.93 & 4.33 & 4.39 \\
\hline $0-4$ years & & & & & 2.40 & 3.02 & 3.50 & 3.93 \\
\hline $5-15$ years & 3.42 & 3.79 & 4.69 & 3.84 & 3.32 & 3.35 & 5.01 & 3.79 \\
\hline $16-19$ years & 3.73 & 4.74 & 5.24 & 5.39 & 4.37 & 4.17 & 2.51 & 3.65 \\
\hline 20-34 years & 4.34 & 4.55 & 3.53 & 5.22 & 3.98 & 4.02 & 2.61 & 4.80 \\
\hline $35-54$ years & 4.23 & 4.85 & 4.33 & 4.78 & 4.29 & 4.48 & 4.80 & 5.03 \\
\hline $55-64$ years & 4.05 & 3.89 & 1.91 & 4.84 & 4.18 & 3.88 & 3.75 & 4.84 \\
\hline $65+$ years & 3.18 & 3.21 & 2.33 & 4.48 & 3.14 & 3.28 & 4.17 & 3.43 \\
\hline TOTAL & 3.91 & 4.25 & 3.80 & 4.71 & 3.88 & 3.93 & 4.33 & 4.39 \\
\hline$\%$ SOV & $41.9 \%$ & $43.3 \%$ & $45.5 \%$ & $48.1 \%$ & $41.3 \%$ & $41.8 \%$ & $23.9 \%$ & $44.3 \%$ \\
\hline$\% \mathrm{MOV}$ & $45.8 \%$ & $47.1 \%$ & $46.6 \%$ & $43.4 \%$ & $46.9 \%$ & $48.3 \%$ & $67.4 \%$ & $46.9 \%$ \\
\hline$\%$ Other POV & $0.0 \%$ & $0.0 \%$ & & $0.2 \%$ & & & & \\
\hline$\%$ Amtrak & & & & & & & & $0.0 \%$ \\
\hline$\%$ Commuter Train & $0.0 \%$ & & & & $0.0 \%$ & & & \\
\hline \% Subway/El Rail & $0.0 \%$ & $0.0 \%$ & & & $0.1 \%$ & $0.0 \%$ & & $0.1 \%$ \\
\hline$\%$ Other Public & $0.5 \%$ & $0.2 \%$ & & $0.2 \%$ & $0.1 \%$ & $0.1 \%$ & & $0.1 \%$ \\
\hline$\%$ Walk & $2.6 \%$ & $2.8 \%$ & $3.9 \%$ & $2.8 \%$ & $7.1 \%$ & $5.7 \%$ & $5.5 \%$ & $5.3 \%$ \\
\hline$\%$ Other & $5.1 \%$ & $4.0 \%$ & $1.6 \%$ & $2.8 \%$ & $4.5 \%$ & $4.0 \%$ & $3.2 \%$ & $3.3 \%$ \\
\hline$\%$ Unreported & $4.1 \%$ & $2.6 \%$ & $2.4 \%$ & $2.5 \%$ & $0.0 \%$ & $0.1 \%$ & & $0.1 \%$ \\
\hline TOTAL & 3.91 & 4.25 & 3.80 & 4.71 & 3.88 & 3.93 & 4.33 & 4.39 \\
\hline$\%$ Earn a Living & $21.2 \%$ & $20.9 \%$ & $23.2 \%$ & $20.6 \%$ & $19.2 \%$ & $19.4 \%$ & $13.3 \%$ & $19.0 \%$ \\
\hline \% Family \& Personal Business & $44.8 \%$ & $44.2 \%$ & $42.1 \%$ & $46.9 \%$ & $43.9 \%$ & $44.1 \%$ & $48.7 \%$ & $41.7 \%$ \\
\hline$\%$ Civic, Educational \& Religious & $9.0 \%$ & $9.6 \%$ & $5.0 \%$ & $7.9 \%$ & $8.2 \%$ & $10.8 \%$ & $7.8 \%$ & $10.5 \%$ \\
\hline$\%$ Social \& Recreational & $25.1 \%$ & $24.9 \%$ & $29.5 \%$ & $24.6 \%$ & $27.6 \%$ & $24.7 \%$ & $30.2 \%$ & $27.6 \%$ \\
\hline$\%$ Other & $0.0 \%$ & $0.2 \%$ & & $0.0 \%$ & $0.7 \%$ & $0.7 \%$ & & $1.0 \%$ \\
\hline$\%$ Unreported & $0.0 \%$ & $0.0 \%$ & $0.2 \%$ & & $0.4 \%$ & $0.2 \%$ & & $0.1 \%$ \\
\hline TOTAL & 3.91 & 4.25 & 3.80 & 4.71 & 3.88 & 3.93 & 4.33 & 4.39 \\
\hline Weekday & 3.94 & 4.22 & 3.32 & 5.05 & 3.95 & 3.92 & 3.83 & 4.39 \\
\hline Weekend & 3.87 & 4.37 & 5.04 & 3.92 & 3.75 & 3.98 & 5.62 & 4.43 \\
\hline TOTAL & 3.91 & 4.25 & 3.80 & 4.71 & 3.88 & 3.93 & 4.33 & 4.39 \\
\hline$\% 1-9 \mathrm{~min}$ & $38.1 \%$ & $42.5 \%$ & $53.7 \%$ & $48.1 \%$ & $29.7 \%$ & $31.1 \%$ & $46.3 \%$ & $37.6 \%$ \\
\hline$\% 10-19 \mathrm{~min}$ & $29.7 \%$ & $29.6 \%$ & $21.3 \%$ & $31.4 \%$ & $31.7 \%$ & $32.2 \%$ & $21.2 \%$ & $36.4 \%$ \\
\hline$\% 20-29 \mathrm{~min}$ & $13.0 \%$ & $11.5 \%$ & $8.4 \%$ & $7.0 \%$ & $13.6 \%$ & $12.4 \%$ & $10.9 \%$ & $8.8 \%$ \\
\hline$\% 30-39 \mathrm{~min}$ & $7.9 \%$ & $6.1 \%$ & $5.8 \%$ & $3.2 \%$ & $10.9 \%$ & $10.2 \%$ & $10.1 \%$ & $6.9 \%$ \\
\hline$\% 40-49 \mathrm{~min}$ & $4.3 \%$ & $3.5 \%$ & $5.3 \%$ & $2.8 \%$ & $4.8 \%$ & $4.8 \%$ & $6.4 \%$ & $2.5 \%$ \\
\hline$\% 50+\min$ & $6.1 \%$ & $5.6 \%$ & $3.4 \%$ & $6.8 \%$ & $6.9 \%$ & $7.7 \%$ & $3.1 \%$ & $6.8 \%$ \\
\hline$\%$ Unreported & $0.8 \%$ & $1.2 \%$ & $2.1 \%$ & $0.8 \%$ & $2.4 \%$ & $1.7 \%$ & $2.2 \%$ & $0.9 \%$ \\
\hline TOTAL & 3.91 & 4.25 & 3.80 & 4.71 & 3.88 & 3.93 & 4.33 & 4.39 \\
\hline$\% 5$ or less miles & $51.4 \%$ & $57.1 \%$ & $68.2 \%$ & $70.4 \%$ & $50.6 \%$ & $52.0 \%$ & $66.2 \%$ & $68.8 \%$ \\
\hline$\%$ 6-10 miles & $19.4 \%$ & $17.0 \%$ & $9.5 \%$ & $11.1 \%$ & $18.1 \%$ & $16.7 \%$ & $10.4 \%$ & $10.9 \%$ \\
\hline$\% 11-15$ miles & $9.2 \%$ & $8.7 \%$ & $7.1 \%$ & $4.7 \%$ & $11.1 \%$ & $9.9 \%$ & $6.7 \%$ & $5.7 \%$ \\
\hline$\% 16-20$ miles & $5.9 \%$ & $4.7 \%$ & $2.1 \%$ & $2.1 \%$ & $5.8 \%$ & $5.8 \%$ & $6.1 \%$ & $3.4 \%$ \\
\hline$\% 21-30$ miles & $5.9 \%$ & $4.7 \%$ & $7.4 \%$ & $3.0 \%$ & $6.3 \%$ & $6.1 \%$ & $7.5 \%$ & $2.9 \%$ \\
\hline$\% 31$ or more miles & $7.2 \%$ & $7.1 \%$ & $5.8 \%$ & $7.9 \%$ & $6.9 \%$ & $8.5 \%$ & $3.0 \%$ & $6.7 \%$ \\
\hline$\%$ Unreported & $1.0 \%$ & $0.7 \%$ & $0.0 \%$ & $0.9 \%$ & $1.2 \%$ & $1.0 \%$ & $0.1 \%$ & $1.5 \%$ \\
\hline
\end{tabular}




\section{Chapter 5: Table 3}

Rural Travel

Definition of NYS RURAL: Outside MPO and Population Density $<1,000$ (Block Group)

Definition of US RURAL: Outside NY and MSA with Population Density $<1,000$ (Block Group)

\begin{tabular}{|c|c|c|c|c|c|c|c|c|}
\hline & \multicolumn{4}{|c|}{1995} & \multicolumn{4}{|c|}{2001} \\
\hline & \multicolumn{8}{|c|}{ Population Density (census tract) } \\
\hline & \multicolumn{2}{|c|}{$<500$} & \multicolumn{2}{|c|}{500 to 2,000} & \multicolumn{2}{|c|}{$<500$} & \multicolumn{2}{|c|}{$500-2,000$} \\
\hline & NYS & U.S. & NYS & U.S. & NYS & U.S. & NYS & U.S. \\
\hline \multicolumn{9}{|l|}{ Daily PMT per Person } \\
\hline TOTAL & 44.76 & 46.79 & 31.96 & 49.68 & 45.25 & 49.30 & 32.40 & 45.70 \\
\hline$\%$ SOV & $38.2 \%$ & $39.3 \%$ & $51.9 \%$ & $39.4 \%$ & $36.6 \%$ & $38.5 \%$ & $26.8 \%$ & $35.1 \%$ \\
\hline$\% \mathrm{MOV}$ & $54.7 \%$ & $55.0 \%$ & $37.8 \%$ & $56.7 \%$ & $52.8 \%$ & $55.5 \%$ & $71.0 \%$ & $52.9 \%$ \\
\hline$\%$ Other POV & $0.0 \%$ & $0.0 \%$ & & $0.0 \%$ & & & & \\
\hline$\%$ Amtrak & & & & & & & & $0.4 \%$ \\
\hline$\%$ Commuter Train & & & & & $0.0 \%$ & & & \\
\hline \% Subway/El Rail & $0.0 \%$ & $0.0 \%$ & & & $0.0 \%$ & $0.0 \%$ & & $0.0 \%$ \\
\hline$\%$ Other Public & $2.2 \%$ & $0.4 \%$ & & $0.0 \%$ & $0.1 \%$ & $0.1 \%$ & & $0.0 \%$ \\
\hline$\%$ Walk & $0.1 \%$ & $0.1 \%$ & $0.2 \%$ & $0.1 \%$ & $0.6 \%$ & $0.3 \%$ & $0.5 \%$ & $0.4 \%$ \\
\hline$\%$ Other & $3.8 \%$ & $4.4 \%$ & $1.5 \%$ & $1.1 \%$ & $9.9 \%$ & $5.5 \%$ & $1.7 \%$ & $11.2 \%$ \\
\hline$\%$ Unreported & $0.8 \%$ & $0.7 \%$ & $8.6 \%$ & $2.6 \%$ & & $0.2 \%$ & & $0.0 \%$ \\
\hline TOTAL & 44.76 & 46.79 & 31.96 & 49.68 & 45.25 & 49.30 & 32.40 & 45.70 \\
\hline \% Earn a Living & $25.8 \%$ & $26.5 \%$ & $31.7 \%$ & $28.3 \%$ & $21.2 \%$ & $25.2 \%$ & $19.1 \%$ & $21.8 \%$ \\
\hline \% Family \& Personal Business & $35.9 \%$ & $38.1 \%$ & $40.7 \%$ & $26.6 \%$ & $37.0 \%$ & $38.2 \%$ & $32.7 \%$ & $29.6 \%$ \\
\hline$\%$ Civic, Educational \& Religious & $6.5 \%$ & $7.1 \%$ & $1.3 \%$ & $3.2 \%$ & $5.1 \%$ & $7.1 \%$ & $3.5 \%$ & $5.3 \%$ \\
\hline$\%$ Social \& Recreational & $31.5 \%$ & $28.2 \%$ & $26.3 \%$ & $41.9 \%$ & $35.2 \%$ & $27.9 \%$ & $44.7 \%$ & $30.8 \%$ \\
\hline$\%$ Other & $0.3 \%$ & $0.2 \%$ & & $0.0 \%$ & $1.2 \%$ & $1.0 \%$ & & $12.4 \%$ \\
\hline$\%$ Unreported & & & & & $0.4 \%$ & $0.7 \%$ & & $0.1 \%$ \\
\hline \multicolumn{9}{|l|}{ Average Person Trip Length } \\
\hline TOTAL & 11.57 & 11.09 & 8.41 & 10.62 & 11.62 & 12.01 & 7.85 & 9.50 \\
\hline
\end{tabular}


Definition of NYS RURAL: Outside MPO and Population Density $<1,000$ (Block Group)

Definition of US RURAL: Outside NY and MSA with Population Density < 1,000 (Block Group)

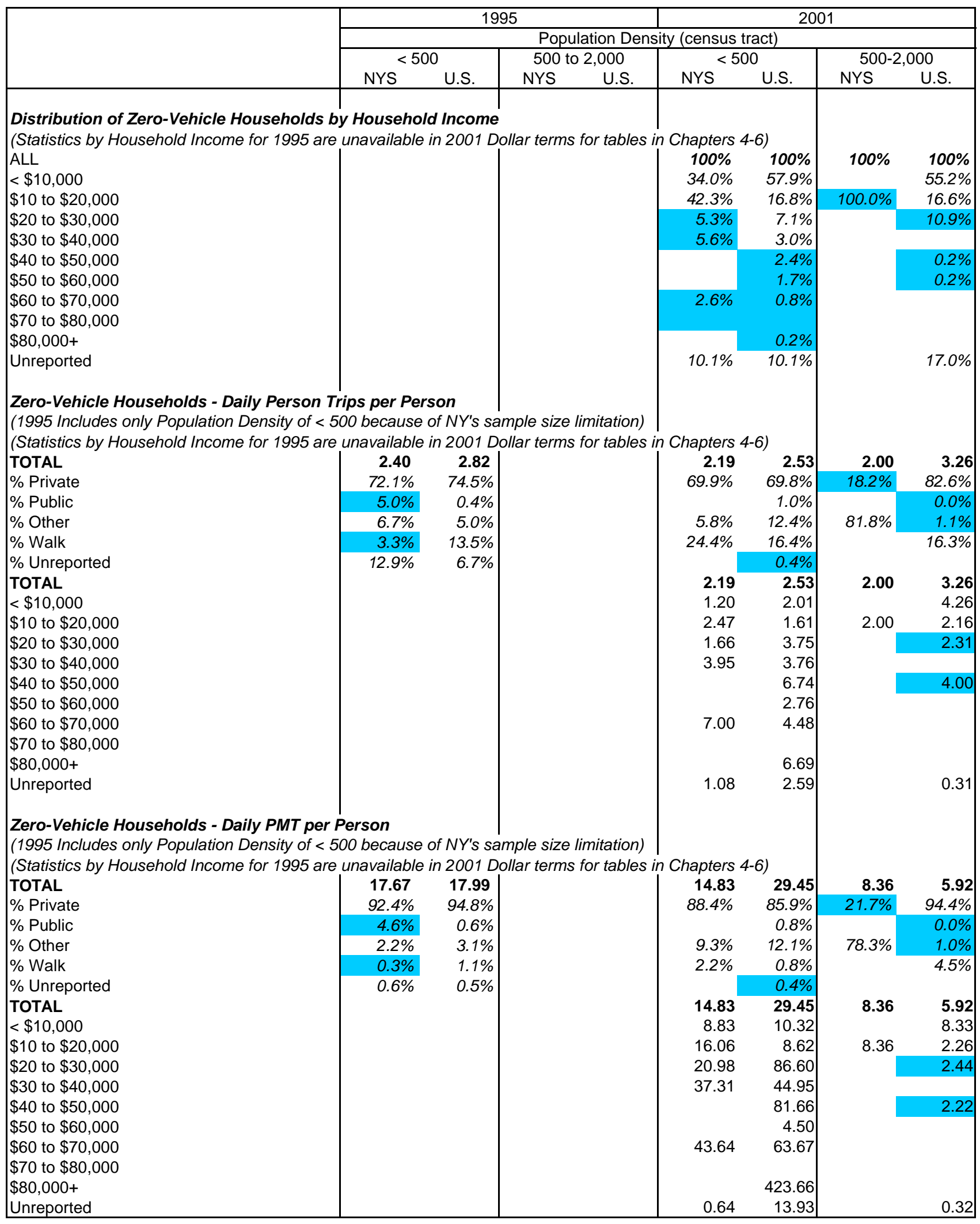


Definition of NYS RURAL: Outside MPO and Population Density $<1,000$ (Block Group)

Definition of US RURAL: Outside NY and MSA with Population Density $<1,000$ (Block Group)

\begin{tabular}{|c|c|c|c|c|c|c|c|c|}
\hline & \multicolumn{4}{|c|}{1995} & \multicolumn{4}{|c|}{2001} \\
\hline & \multicolumn{8}{|c|}{ Population Density (census tract) } \\
\hline & \multicolumn{2}{|c|}{$<500$} & \multicolumn{2}{|c|}{500 to 2,000} & \multicolumn{2}{|c|}{$<500$} & \multicolumn{2}{|c|}{$500-2,000$} \\
\hline & NYS & U.S. & NYS & U.S. & NYS & U.S. & NYS & U.S. \\
\hline Daily Vehicle Trips per Driver & & & & & & & & \\
\hline TOTAL & 3.29 & 3.57 & 3.18 & 4.08 & 3.11 & 3.25 & 3.24 & 3.62 \\
\hline$\%$ Earn a Living & $30.1 \%$ & $28.3 \%$ & $27.0 \%$ & $27.7 \%$ & $27.7 \%$ & $26.9 \%$ & $21.0 \%$ & $27.5 \%$ \\
\hline$\%$ Family \& Personal Business & $48.9 \%$ & $48.2 \%$ & $47.5 \%$ & $49.3 \%$ & $48.0 \%$ & $47.3 \%$ & $48.9 \%$ & $45.7 \%$ \\
\hline$\%$ Civic, Educational \& Religious & $3.3 \%$ & $4.8 \%$ & $1.6 \%$ & $4.2 \%$ & $3.5 \%$ & $5.6 \%$ & $2.4 \%$ & $6.2 \%$ \\
\hline$\%$ Social \& Recreational & $17.3 \%$ & $18.5 \%$ & $23.3 \%$ & $18.6 \%$ & $20.1 \%$ & $19.5 \%$ & $27.8 \%$ & $20.3 \%$ \\
\hline$\%$ Other & $0.0 \%$ & $0.0 \%$ & & & $0.4 \%$ & $0.5 \%$ & & $0.3 \%$ \\
\hline$\%$ Unreported & $0.3 \%$ & $0.3 \%$ & $0.6 \%$ & $0.2 \%$ & $0.3 \%$ & $0.1 \%$ & & $0.0 \%$ \\
\hline TOTAL & 3.29 & 3.57 & 3.18 & 4.08 & 3.11 & 3.25 & 3.24 & 3.62 \\
\hline Weekday & 3.50 & 3.69 & 2.99 & 4.56 & 3.28 & 3.39 & 2.76 & 3.89 \\
\hline Weekend & 2.80 & 3.29 & 3.66 & 2.90 & 2.71 & 2.92 & 4.46 & 2.99 \\
\hline TOTAL & 3.29 & 3.57 & 3.18 & 4.08 & 3.11 & 3.25 & 3.24 & 3.62 \\
\hline$\% 1-9 \min$ & $38.9 \%$ & $43.7 \%$ & $52.2 \%$ & $51.0 \%$ & $31.8 \%$ & $32.6 \%$ & $48.6 \%$ & $41.1 \%$ \\
\hline$\% 10-19 \min$ & $30.4 \%$ & $30.0 \%$ & $21.7 \%$ & $31.4 \%$ & $32.7 \%$ & $33.4 \%$ & $20.3 \%$ & $36.4 \%$ \\
\hline$\% 20-29 \mathrm{~min}$ & $13.1 \%$ & $11.5 \%$ & $10.7 \%$ & $6.1 \%$ & $13.8 \%$ & $12.5 \%$ & $11.1 \%$ & $8.0 \%$ \\
\hline$\% 30-39 \min$ & $7.6 \%$ & $5.9 \%$ & $6.9 \%$ & $3.2 \%$ & $11.0 \%$ & $9.6 \%$ & $10.8 \%$ & $6.1 \%$ \\
\hline$\% 40-49 \min$ & $4.0 \%$ & $3.4 \%$ & $5.0 \%$ & $2.2 \%$ & $4.3 \%$ & $4.4 \%$ & $4.6 \%$ & $2.2 \%$ \\
\hline$\% 50+\min$ & $5.5 \%$ & $4.8 \%$ & $3.1 \%$ & $5.9 \%$ & $5.9 \%$ & $6.7 \%$ & $3.7 \%$ & $5.6 \%$ \\
\hline$\%$ Unreported & $0.6 \%$ & $0.8 \%$ & $0.3 \%$ & $0.2 \%$ & $0.7 \%$ & $0.8 \%$ & $1.0 \%$ & $0.4 \%$ \\
\hline TOTAL & 3.29 & 3.57 & 3.18 & 4.08 & 3.11 & 3.25 & 3.24 & 3.62 \\
\hline$\% 5$ or less miles & $50.5 \%$ & $56.1 \%$ & $62.6 \%$ & $72.2 \%$ & $47.9 \%$ & $50.3 \%$ & $64.5 \%$ & $68.1 \%$ \\
\hline$\%$ 6-10 miles & $19.8 \%$ & $17.6 \%$ & $11.9 \%$ & $11.1 \%$ & $19.4 \%$ & $17.5 \%$ & $8.5 \%$ & $11.5 \%$ \\
\hline$\% 11-15$ miles & $9.7 \%$ & $8.9 \%$ & $9.7 \%$ & $4.2 \%$ & $11.8 \%$ & $10.4 \%$ & $8.1 \%$ & $6.3 \%$ \\
\hline$\% 16-20$ miles & $6.4 \%$ & $5.0 \%$ & $1.9 \%$ & $2.2 \%$ & $6.3 \%$ & $6.1 \%$ & $6.8 \%$ & $3.8 \%$ \\
\hline$\% 21-30$ miles & $6.1 \%$ & $5.3 \%$ & $8.8 \%$ & $2.7 \%$ & $7.2 \%$ & $6.5 \%$ & $8.0 \%$ & $3.5 \%$ \\
\hline$\% 31$ or more miles & $7.0 \%$ & $6.7 \%$ & $5.0 \%$ & $7.1 \%$ & $6.8 \%$ & $8.7 \%$ & $4.1 \%$ & $6.3 \%$ \\
\hline$\%$ Unreported & $0.6 \%$ & $0.3 \%$ & $0.0 \%$ & $0.5 \%$ & $0.6 \%$ & $0.6 \%$ & & $0.5 \%$ \\
\hline Daily VMT per Driver & & & & & & & & \\
\hline TOTAL & 37.84 & 38.31 & 28.08 & 39.69 & 34.94 & 40.51 & 27.12 & 33.74 \\
\hline$\%$ Earn a Living & $36.5 \%$ & $37.1 \%$ & $30.4 \%$ & $41.0 \%$ & $33.2 \%$ & $34.5 \%$ & $30.7 \%$ & $33.9 \%$ \\
\hline \% Family \& Personal Business & $37.5 \%$ & $36.5 \%$ & $48.6 \%$ & $28.4 \%$ & $37.6 \%$ & $38.1 \%$ & $25.6 \%$ & $34.7 \%$ \\
\hline$\%$ Civic, Educational \& Religious & $3.4 \%$ & $4.6 \%$ & $0.4 \%$ & $1.8 \%$ & $3.0 \%$ & $4.0 \%$ & $2.6 \%$ & $3.4 \%$ \\
\hline$\%$ Social \& Recreational & $22.2 \%$ & $21.7 \%$ & $20.6 \%$ & $28.8 \%$ & $24.9 \%$ & $22.5 \%$ & $41.2 \%$ & $26.3 \%$ \\
\hline$\%$ Other & $0.4 \%$ & $0.1 \%$ & & & $1.0 \%$ & $0.5 \%$ & & $1.8 \%$ \\
\hline$\%$ Unreported & & & & & $0.2 \%$ & $0.5 \%$ & & $0.0 \%$ \\
\hline Average Vehicle Trip Length & & & & & & & & \\
\hline TOTAL & 11.56 & 10.77 & 8.84 & 9.79 & 11.30 & 12.54 & 8.37 & 9.37 \\
\hline
\end{tabular}


Definition of NYS RURAL: Outside MPO and Population Density $<1,000$ (Block Group)

Definition of US RURAL: Outside NY and MSA with Population Density $<1,000$ (Block Group)

\begin{tabular}{|c|c|c|c|c|c|c|c|c|}
\hline & \multicolumn{4}{|c|}{1995} & \multicolumn{4}{|c|}{2001} \\
\hline & \multicolumn{8}{|c|}{ Population Density (census tract) } \\
\hline & \multicolumn{2}{|c|}{$<500$} & \multicolumn{2}{|c|}{500 to 2,000} & \multicolumn{2}{|c|}{$<500$} & \multicolumn{2}{|c|}{$500-2,000$} \\
\hline & NYS & U.S. & NYS & U.S. & NYS & U.S. & NYS & U.S. \\
\hline Daily Commute Person Trips per Worker & & & & & & & & \\
\hline TOTAL & 1.39 & 1.48 & 1.35 & 1.48 & 1.16 & 1.14 & 0.94 & 1.21 \\
\hline$\%$ SOV & $78.4 \%$ & $77.0 \%$ & $77.0 \%$ & $77.9 \%$ & $82.0 \%$ & $79.6 \%$ & $60.9 \%$ & $88.4 \%$ \\
\hline$\% \mathrm{MOV}$ & $18.0 \%$ & $17.6 \%$ & $9.6 \%$ & $18.8 \%$ & $14.2 \%$ & $17.1 \%$ & $29.0 \%$ & $11.1 \%$ \\
\hline$\%$ Other POV & $0.0 \%$ & $0.0 \%$ & & & & & & \\
\hline$\%$ Amtrak & $0.0 \%$ & & $0.0 \%$ & & & & & \\
\hline$\%$ Commuter Train & $0.0 \%$ & & $0.0 \%$ & & & & & \\
\hline \% Subway/El Rail & $0.0 \%$ & & & & & & & \\
\hline$\%$ Other Public & $0.7 \%$ & $0.0 \%$ & & & $0.2 \%$ & $0.2 \%$ & & $0.1 \%$ \\
\hline$\%$ Walk & $0.7 \%$ & $1.4 \%$ & $1.5 \%$ & & $3.0 \%$ & $2.3 \%$ & $10.1 \%$ & $0.1 \%$ \\
\hline$\%$ Other & $0.7 \%$ & $1.4 \%$ & $1.5 \%$ & $0.7 \%$ & $0.6 \%$ & $0.8 \%$ & & $0.3 \%$ \\
\hline$\%$ Unreported & $1.4 \%$ & $2.7 \%$ & $10.4 \%$ & $2.7 \%$ & $0.1 \%$ & $0.1 \%$ & & $0.0 \%$ \\
\hline TOTAL & 1.39 & 1.48 & 1.35 & 1.48 & 1.16 & 1.14 & 0.94 & 1.21 \\
\hline$\% 1-6$ am & $6.4 \%$ & $6.1 \%$ & $10.4 \%$ & $2.0 \%$ & $7.5 \%$ & $8.0 \%$ & $3.2 \%$ & $5.0 \%$ \\
\hline$\%$ 6-9 am & $26.4 \%$ & $27.0 \%$ & $28.1 \%$ & $27.7 \%$ & $30.1 \%$ & $29.1 \%$ & $33.1 \%$ & $29.4 \%$ \\
\hline$\% 9$ am-1 pm & $13.6 \%$ & $14.2 \%$ & $5.2 \%$ & $18.9 \%$ & $9.7 \%$ & $11.6 \%$ & $14.9 \%$ & $15.4 \%$ \\
\hline$\% 1-4 \mathrm{pm}$ & $17.1 \%$ & $16.9 \%$ & $23.0 \%$ & $15.5 \%$ & $18.3 \%$ & $14.8 \%$ & $14.4 \%$ & $15.2 \%$ \\
\hline$\%$ 4-7 pm & $24.3 \%$ & $25.7 \%$ & $17.8 \%$ & $24.3 \%$ & $23.7 \%$ & $24.5 \%$ & $25.1 \%$ & $23.5 \%$ \\
\hline$\% 7-10 \mathrm{pm}$ & $6.4 \%$ & $6.8 \%$ & $10.4 \%$ & $6.8 \%$ & $6.1 \%$ & $7.5 \%$ & $7.8 \%$ & $8.5 \%$ \\
\hline$\% 10 \mathrm{pm}-1 \mathrm{am}$ & $5.7 \%$ & $3.4 \%$ & $5.2 \%$ & $4.7 \%$ & $4.5 \%$ & $4.5 \%$ & $1.6 \%$ & $3.0 \%$ \\
\hline$\%$ Unreported & & & & & $0.1 \%$ & $0.0 \%$ & & \\
\hline Daily Commute PMT per Worker & & & & & & & & \\
\hline TOTAL & 19.56 & 18.68 & 16.01 & 16.14 & 14.63 & 15.74 & 11.37 & 12.21 \\
\hline$\%$ SOV & $77.5 \%$ & $76.0 \%$ & $67.6 \%$ & $73.0 \%$ & $88.6 \%$ & $80.1 \%$ & $66.8 \%$ & $89.5 \%$ \\
\hline$\% \mathrm{MOV}$ & $19.7 \%$ & $21.2 \%$ & $2.6 \%$ & $26.3 \%$ & $10.4 \%$ & $19.1 \%$ & $32.9 \%$ & $10.1 \%$ \\
\hline$\%$ Other POV & $0.1 \%$ & $0.0 \%$ & & & & & & \\
\hline$\%$ Amtrak & $0.0 \%$ & & $0.0 \%$ & & & & & \\
\hline$\%$ Commuter Train & $0.0 \%$ & & $0.0 \%$ & & & & & \\
\hline$\%$ Subway/El Rail & $0.1 \%$ & & & & & & & \\
\hline$\%$ Other Public & $0.7 \%$ & $0.3 \%$ & & & $0.5 \%$ & $0.2 \%$ & & $0.1 \%$ \\
\hline$\%$ Walk & $0.1 \%$ & $0.1 \%$ & $0.1 \%$ & & $0.2 \%$ & $0.1 \%$ & $0.3 \%$ & $0.0 \%$ \\
\hline$\%$ Other & $0.7 \%$ & $1.6 \%$ & $2.1 \%$ & $0.2 \%$ & $0.4 \%$ & $0.5 \%$ & & $0.3 \%$ \\
\hline$\%$ Unreported & $1.1 \%$ & $0.9 \%$ & $27.6 \%$ & $0.4 \%$ & & $0.1 \%$ & & $0.0 \%$ \\
\hline TOTAL & 19.56 & 18.68 & 16.01 & 16.14 & 14.63 & 15.74 & 11.37 & 12.21 \\
\hline$\% 1-6$ am & $8.5 \%$ & $10.4 \%$ & $20.4 \%$ & $3.3 \%$ & $10.3 \%$ & $13.0 \%$ & $0.9 \%$ & $7.4 \%$ \\
\hline$\%$ 6-9 am & $26.1 \%$ & $25.6 \%$ & $27.4 \%$ & $31.8 \%$ & $33.8 \%$ & $28.8 \%$ & $36.8 \%$ & $29.7 \%$ \\
\hline$\% 9$ am-1 pm & $11.5 \%$ & $8.9 \%$ & $2.7 \%$ & $11.1 \%$ & $6.7 \%$ & $7.3 \%$ & $7.1 \%$ & $16.1 \%$ \\
\hline$\% 1-4 \mathrm{pm}$ & $15.8 \%$ & $16.2 \%$ & $32.0 \%$ & $15.5 \%$ & $16.1 \%$ & $14.3 \%$ & $8.8 \%$ & $12.6 \%$ \\
\hline$\% 4-7 \mathrm{pm}$ & $26.6 \%$ & $26.9 \%$ & $10.4 \%$ & $23.7 \%$ & $24.3 \%$ & $24.4 \%$ & $38.1 \%$ & $20.3 \%$ \\
\hline$\%$ 7-10 pm & $6.2 \%$ & $7.8 \%$ & $6.8 \%$ & $11.6 \%$ & $4.9 \%$ & $7.5 \%$ & $7.8 \%$ & $10.7 \%$ \\
\hline$\% 10 \mathrm{pm}-1 \mathrm{am}$ & $5.3 \%$ & $4.2 \%$ & $0.3 \%$ & $2.9 \%$ & $3.8 \%$ & $4.7 \%$ & $0.4 \%$ & $3.1 \%$ \\
\hline$\%$ Unreported & & & & & $0.2 \%$ & $0.0 \%$ & & \\
\hline
\end{tabular}


Definition of NYS RURAL: Outside MPO and Population Density $<1,000$ (Block Group)

Definition of US RURAL: Outside NY and MSA with Population Density < 1,000 (Block Group)

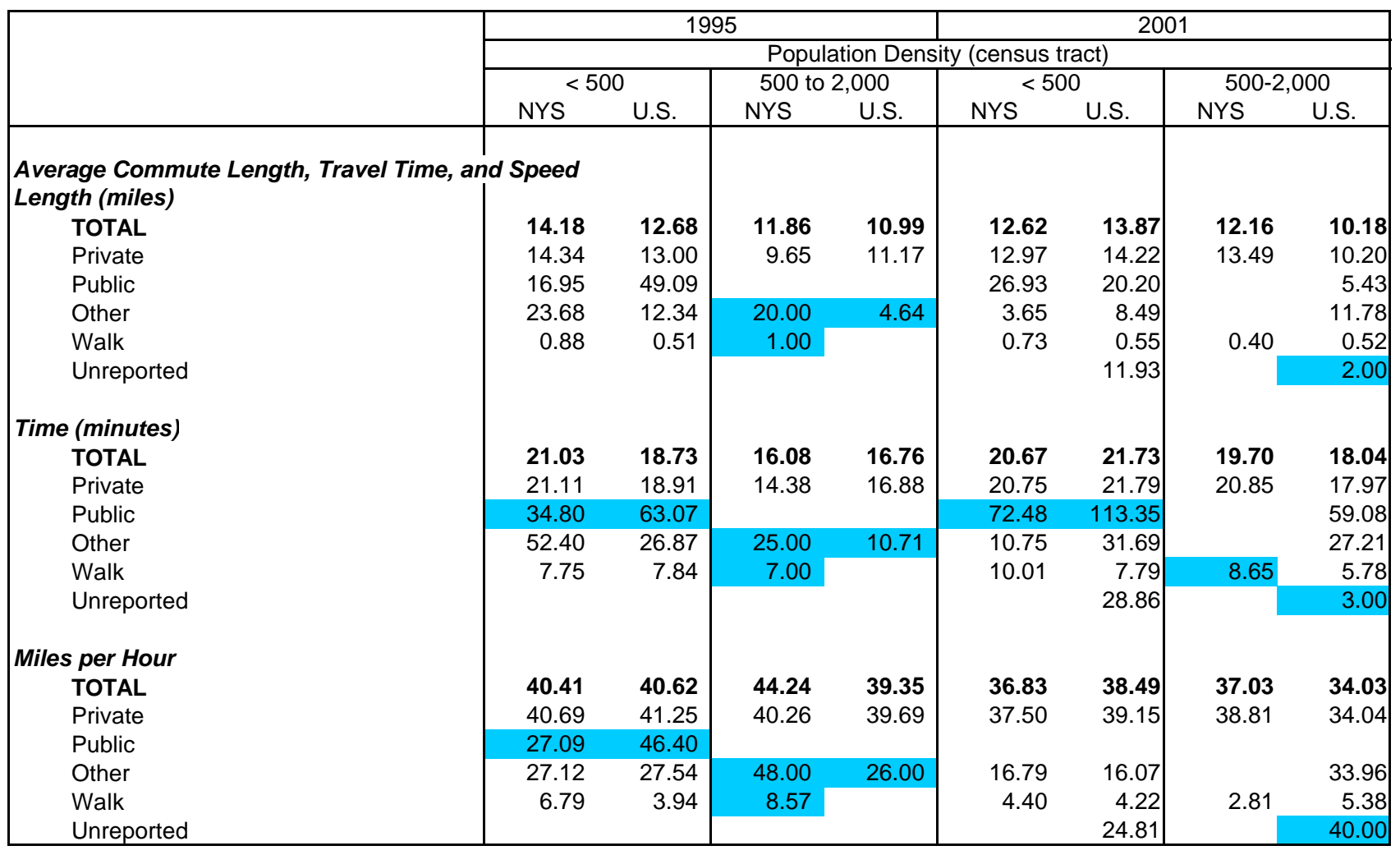


Definition of NYS RURAL: Outside MPO and Population Density $<1,000$ (Block Group) Definition of US RURAL: Outside NY and MSA with Population Density < 1,000 (Block Group)

\begin{tabular}{|c|c|c|c|c|c|c|c|c|}
\hline & \multicolumn{4}{|c|}{1995} & \multicolumn{4}{|c|}{2001} \\
\hline & \multicolumn{8}{|c|}{ Population Density (census tract) } \\
\hline & \multicolumn{2}{|c|}{$<500$} & \multicolumn{2}{|c|}{500 to 2,000} & \multicolumn{2}{|c|}{$<500$} & \multicolumn{2}{|c|}{$500-2,000$} \\
\hline & NYS & U.S. & NYS & U.S. & NYS & U.S. & NYS & U.S. \\
\hline \multicolumn{9}{|c|}{ Average Vehicle Occupancy (Person Miles per Vehicle Mile) } \\
\hline ALL & 1.57 & 1.63 & 1.34 & 1.74 & 1.60 & 1.64 & 2.05 & 1.67 \\
\hline 1 Adult, No Child & 1.30 & 1.16 & 1.01 & 1.51 & 1.21 & 1.23 & 1.36 & 1.06 \\
\hline 2+ Adults, No Child & 1.44 & 1.43 & 1.48 & 1.39 & 1.42 & 1.53 & 1.44 & 1.34 \\
\hline 1 Adult, Child $<6$ & 1.31 & 1.52 & & 3.55 & 1.80 & 2.23 & & 3.30 \\
\hline $2+$ Adults, Child $<6$ & 1.85 & 1.88 & 1.30 & 2.61 & 1.81 & 1.96 & 2.57 & 2.32 \\
\hline 1 Adult, Child 6-15 & 1.93 & 1.83 & & 1.12 & 1.56 & 1.94 & 1.74 & 1.64 \\
\hline 2+ Adults, Child 6-15 & 1.63 & 1.79 & 1.76 & 1.51 & 1.80 & 1.78 & 3.01 & 1.60 \\
\hline 1 Adult, Child 16-21 & 1.28 & 1.23 & & 1.78 & 1.57 & 1.39 & & 1.94 \\
\hline 2+ Adults, Child 16-21 & 1.43 & 1.71 & 1.14 & 1.80 & 1.62 & 1.34 & 1.51 & 1.39 \\
\hline 1 Adult, Retired, No Child & 1.54 & 1.49 & 1.98 & 1.00 & 1.35 & 1.30 & 1.00 & 1.28 \\
\hline 2+ Adults, Retired, No Child & 1.53 & 1.64 & 1.44 & 1.53 & 1.55 & 1.61 & 1.86 & 1.77 \\
\hline Unreported & & & & & & 1.08 & & \\
\hline ALL & 1.57 & 1.63 & 1.34 & 1.74 & 1.60 & 1.64 & 2.05 & 1.67 \\
\hline Earn a Living & 1.13 & 1.20 & 1.02 & 1.27 & 1.12 & 1.20 & 1.34 & 1.11 \\
\hline Family \& Personal Business & 1.79 & 1.79 & 1.36 & 1.98 & 1.74 & 1.80 & 2.35 & 1.93 \\
\hline Civic, Educational \& Religious & 1.88 & 1.82 & 1.73 & 1.51 & 1.35 & 1.76 & 2.34 & 1.83 \\
\hline Social \& Recreational & 1.88 & 2.03 & 1.77 & 2.19 & 2.03 & 2.00 & 2.37 & 1.95 \\
\hline Other & 1.00 & 1.83 & & & 1.81 & 1.76 & & 2.61 \\
\hline Unreported & & & & & 2.47 & 1.59 & & 1.17 \\
\hline
\end{tabular}




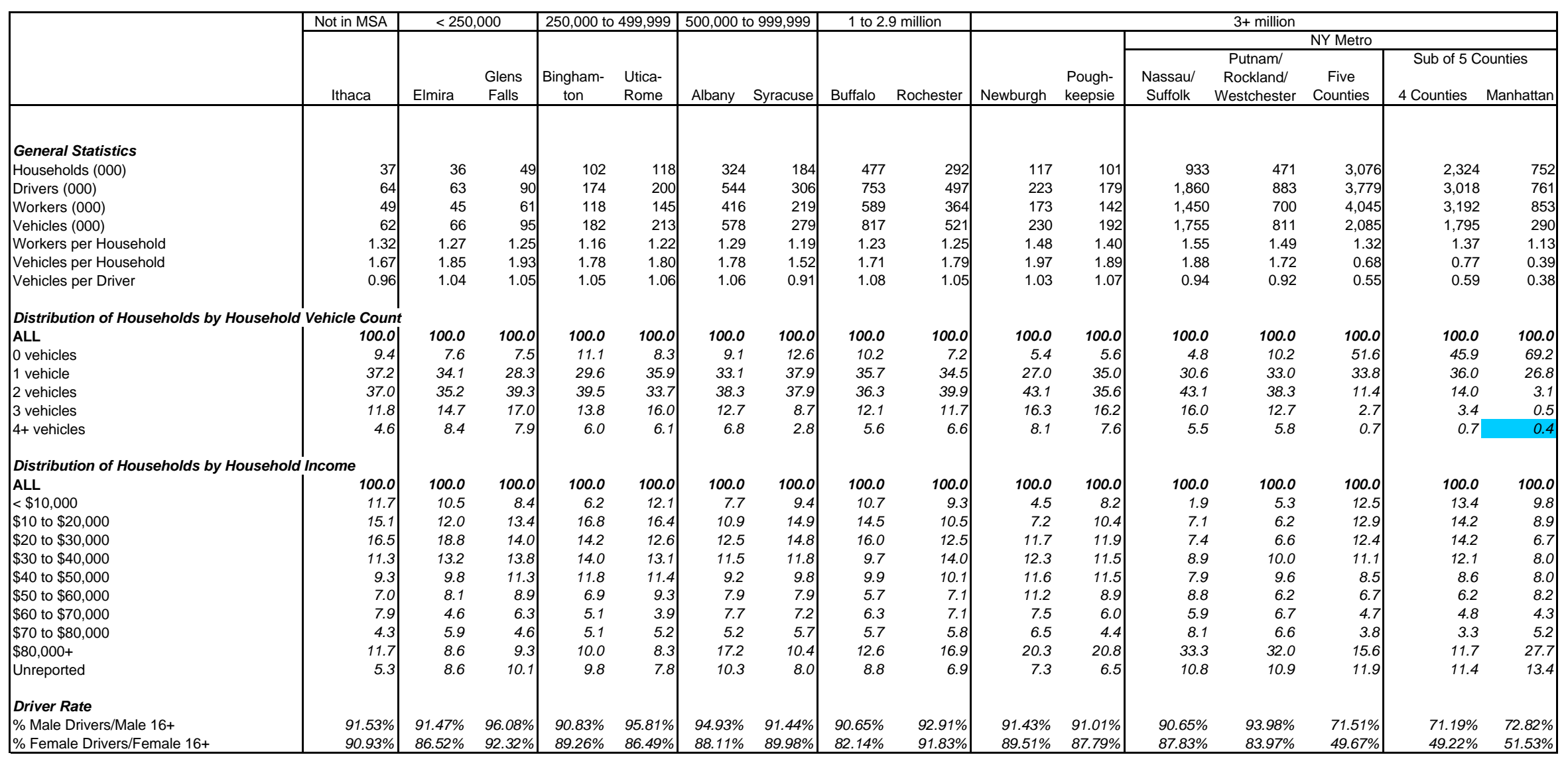




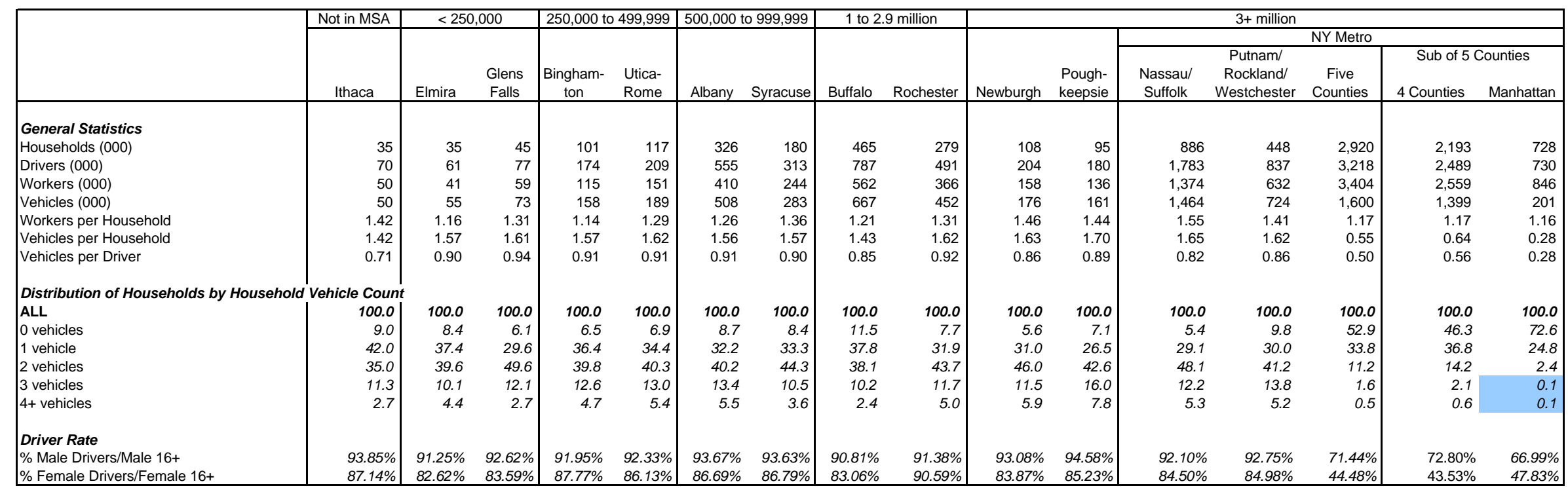


Chapter 6: Table 2

Comparison of Travel Patterns Among NY State MPOs, 2001

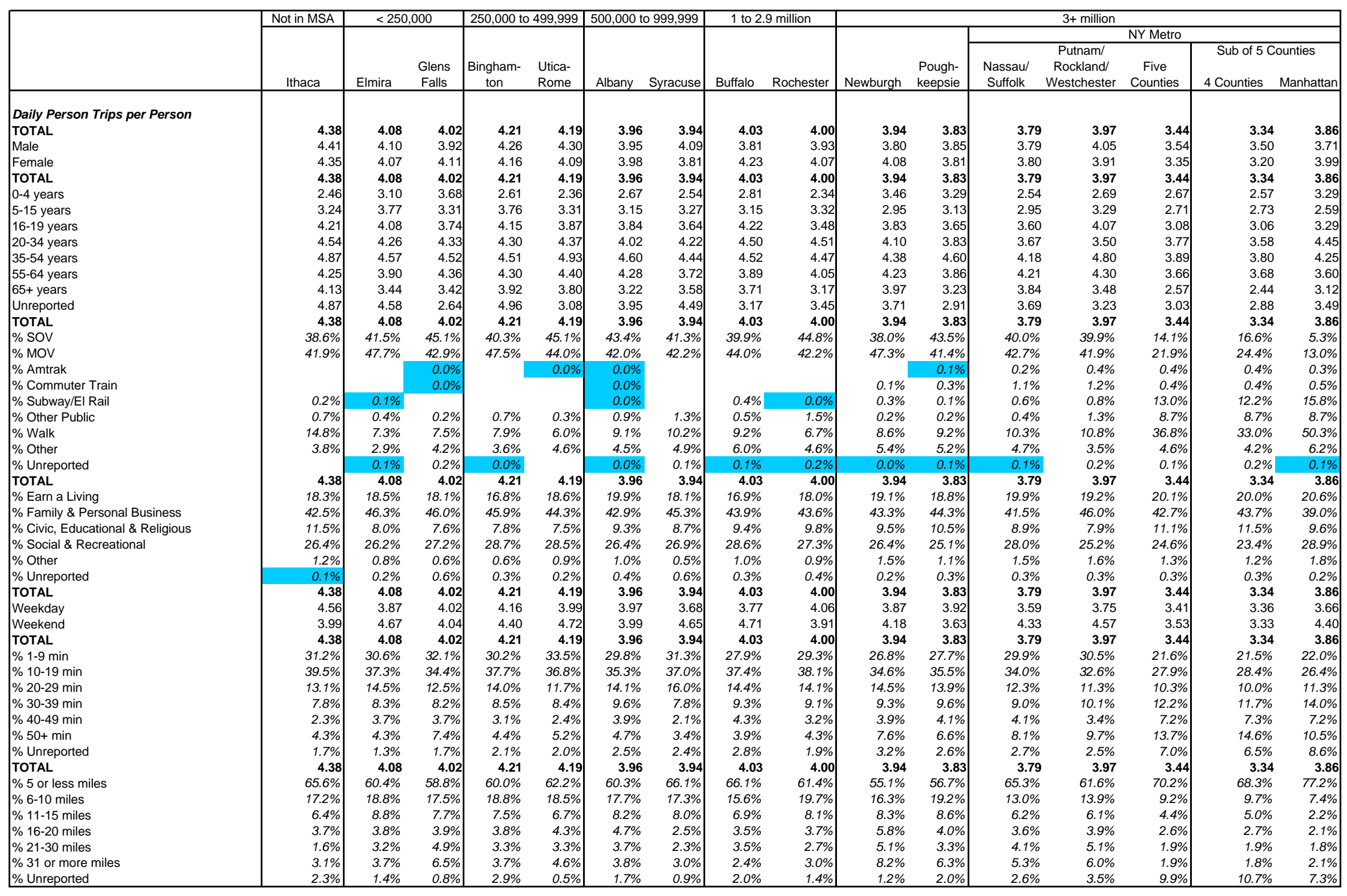




\begin{tabular}{|c|c|c|c|c|c|c|c|c|c|c|c|c|c|c|c|c|}
\hline & \multirow{3}{*}{\begin{tabular}{c|} 
Not in MSA \\
Ithaca \\
\end{tabular}} & \multicolumn{2}{|c|}{$<250,000$} & \multirow{3}{*}{\multicolumn{2}{|c|}{$\begin{array}{|cc|}250,000 \text { to } & 499,999 \\
& \\
\begin{array}{cc}\text { Bingham- } & \text { Utica- } \\
\text { ton } & \text { Rome }\end{array} \\
\end{array}$}} & \multirow{3}{*}{\multicolumn{2}{|c|}{\begin{tabular}{|l|}
500,000 to 999,999 \\
Albany Syracuse \\
\end{tabular}}} & \multirow{3}{*}{\multicolumn{2}{|c|}{\begin{tabular}{c|}
1 to 2.9 million \\
Buffalo Rochester
\end{tabular}}} & \multirow[b]{3}{*}{ Newburgh } & \multicolumn{6}{|c|}{$3+$ million } \\
\hline & & \multirow[b]{2}{*}{ Elmira } & \multirow[b]{2}{*}{$\begin{array}{l}\text { Glens } \\
\text { Falls }\end{array}$} & & & & & & & & & & & NY Metro & & \\
\hline & & & & & & & & & & & $\begin{array}{l}\text { Pough- } \\
\text { keepsie }\end{array}$ & $\begin{array}{l}\text { Nassau/ } \\
\text { Suffolk }\end{array}$ & $\begin{array}{c}\text { Putnam/ } \\
\text { Rockland/ } \\
\text { Westchester }\end{array}$ & $\begin{array}{c}\text { Five } \\
\text { Counties }\end{array}$ & $\begin{array}{l}\text { Sub of } 5 \mathrm{C} \\
4 \text { Counties }\end{array}$ & $\begin{array}{l}\text { Mounties } \\
\text { Manhattan }\end{array}$ \\
\hline \multicolumn{17}{|l|}{ Daily Person Trips per Person } \\
\hline TOTAL & 4.38 & 4.33 & 4.45 & 4.30 & 4.24 & 4.13 & 4.24 & 4.17 & 4.25 & 3.73 & 3.94 & 4.12 & 3.86 & 3.58 & 3.53 & 3.78 \\
\hline Male & 4.34 & 4.40 & 4.42 & 4.40 & 4.37 & 4.18 & 4.32 & 4.25 & 4.26 & 3.66 & 4.01 & 4.18 & 3.76 & 3.63 & 3.56 & 3.91 \\
\hline Female & 4.41 & 4.27 & 4.47 & 4.20 & 4.12 & 4.07 & 4.16 & 4.09 & 4.25 & 3.80 & 3.86 & 4.07 & 3.95 & 3.54 & 3.50 & 3.66 \\
\hline TOTAL & 4.38 & 4.33 & 4.45 & 4.30 & 4.24 & 4.13 & 4.24 & 4.17 & 4.25 & 3.73 & 3.94 & 4.12 & 3.86 & 3.58 & 3.53 & 3.78 \\
\hline $5-15$ years & 3.33 & 3.56 & 3.48 & 3.76 & 3.72 & 3.78 & 3.68 & 3.57 & 3.47 & 3.25 & 2.84 & 3.38 & 3.35 & 3.09 & 3.11 & 2.98 \\
\hline $16-19$ years & 4.95 & 5.25 & 4.51 & 4.04 & 4.28 & 4.22 & 5.23 & 4.09 & 5.10 & 3.84 & 4.56 & 4.29 & 3.57 & 3.18 & 3.26 & 2.58 \\
\hline 20-34 years & 4.73 & 4.54 & 4.50 & 4.93 & 3.99 & 4.19 & 4.32 & 4.63 & 4.53 & 3.64 & 4.17 & 4.31 & 3.83 & 3.96 & 3.85 & 4.31 \\
\hline $35-54$ years & 4.67 & 4.93 & 5.16 & 4.59 & 4.60 & 4.66 & 4.65 & 4.63 & 4.69 & 4.15 & 4.42 & 4.60 & 4.39 & 3.84 & 3.79 & 3.99 \\
\hline 55-64 years & 4.42 & 4.14 & 5.50 & 4.26 & 4.85 & 4.09 & 4.57 & 3.98 & 4.27 & 4.30 & 4.18 & 4.14 & 3.77 & 3.28 & 3.26 & 3.36 \\
\hline $65+$ years & 3.71 & 3.82 & 3.53 & 3.52 & 4.01 & 3.19 & 3.31 & 3.39 & 3.56 & 3.07 & 3.20 & 3.58 & 3.58 & 2.95 & 3.03 & 2.62 \\
\hline TOTAL & 4.38 & 4.33 & 4.45 & 4.30 & 4.24 & 4.13 & 4.24 & 4.17 & 4.25 & 3.73 & 3.94 & 4.12 & 3.86 & 3.58 & 3.53 & 3.78 \\
\hline$\%$ sov & $38.4 \%$ & $42.5 \%$ & $42.5 \%$ & $40.5 \%$ & $44.8 \%$ & $42.9 \%$ & $41.3 \%$ & $44.6 \%$ & $43.8 \%$ & $41.6 \%$ & $49.0 \%$ & $42.7 \%$ & $38.3 \%$ & $14.0 \%$ & $16.4 \%$ & $5.0 \%$ \\
\hline$\% \mathrm{MOV}$ & $40.0 \%$ & $46.0 \%$ & $43.6 \%$ & $46.7 \%$ & $41.7 \%$ & $42.6 \%$ & $47.4 \%$ & $40.3 \%$ & $43.5 \%$ & $42.4 \%$ & $40.6 \%$ & $41.7 \%$ & $42.7 \%$ & $21.8 \%$ & $24.6 \%$ & $12.4 \%$ \\
\hline$\%$ Other POV & $0.2 \%$ & $0.0 \%$ & $0.0 \%$ & $0.0 \%$ & $0.2 \%$ & $0.0 \%$ & & $0.0 \%$ & $0.0 \%$ & & $0.0 \%$ & $0.2 \%$ & $0.0 \%$ & $0.0 \%$ & $0.3 \%$ & \\
\hline$\%$ Amtrak & & & & & $0.0 \%$ & $0.0 \%$ & & & $0.0 \%$ & $0.0 \%$ & $0.0 \%$ & $0.0 \%$ & & $0.0 \%$ & $0.0 \%$ & $0.0 \%$ \\
\hline$\%$ Commuter Train & & & & & & $0.0 \%$ & & $0.0 \%$ & & $0.3 \%$ & $0.3 \%$ & $1.0 \%$ & $1.6 \%$ & $2.5 \%$ & $2.5 \%$ & $3.2 \%$ \\
\hline$\%$ Subway/El Rail & $0.0 \%$ & & & & & $0.0 \%$ & & $0.2 \%$ & & $0.0 \%$ & $0.3 \%$ & $0.5 \%$ & $0.3 \%$ & $10.3 \%$ & $9.3 \%$ & $13.5 \%$ \\
\hline$\%$ Other Public & $1.4 \%$ & $0.7 \%$ & $0.7 \%$ & $0.7 \%$ & $0.7 \%$ & $2.2 \%$ & $0.7 \%$ & $1.7 \%$ & $1.4 \%$ & $0.5 \%$ & $0.5 \%$ & $0.5 \%$ & $2.3 \%$ & $9.2 \%$ & $9.1 \%$ & $10.3 \%$ \\
\hline$\%$ Walk & $10.0 \%$ & $4.6 \%$ & $3.8 \%$ & $4.9 \%$ & $4.7 \%$ & $4.6 \%$ & $3.1 \%$ & $4.8 \%$ & $3.3 \%$ & $5.9 \%$ & $3.0 \%$ & $5.6 \%$ & $7.3 \%$ & $31.0 \%$ & $28.3 \%$ & $41.0 \%$ \\
\hline$\%$ Other & $4.6 \%$ & $3.2 \%$ & $5.8 \%$ & $4.0 \%$ & $4.2 \%$ & $3.6 \%$ & $3.8 \%$ & $3.6 \%$ & $4.0 \%$ & $5.1 \%$ & $3.8 \%$ & $4.4 \%$ & $4.1 \%$ & $5.0 \%$ & $3.7 \%$ & $8.7 \%$ \\
\hline$\%$ Unreported & $5.5 \%$ & $3.0 \%$ & $3.6 \%$ & $3.3 \%$ & $3.5 \%$ & $4.1 \%$ & $3.8 \%$ & $4.8 \%$ & $4.0 \%$ & $4.3 \%$ & $2.5 \%$ & $3.4 \%$ & $3.4 \%$ & $6.1 \%$ & $5.7 \%$ & $5.8 \%$ \\
\hline TOTAL & 4.38 & 4.33 & 4.45 & 4.30 & 4.24 & 4.13 & 4.24 & 4.17 & 4.25 & 3.73 & 3.94 & 4.12 & 3.86 & 3.58 & 3.53 & 3.78 \\
\hline$\%$ Earn a Living & $19.6 \%$ & $17.8 \%$ & $21.6 \%$ & $17.0 \%$ & $20.3 \%$ & $19.7 \%$ & $20.5 \%$ & $19.2 \%$ & $20.2 \%$ & $23.1 \%$ & $21.4 \%$ & $18.7 \%$ & $23.3 \%$ & $19.6 \%$ & $19.0 \%$ & $21.2 \%$ \\
\hline \% Family \& Personal Business & $44.5 \%$ & $49.0 \%$ & $44.8 \%$ & $46.7 \%$ & $46.0 \%$ & $45.5 \%$ & $47.5 \%$ & $47.4 \%$ & $46.0 \%$ & $45.3 \%$ & $47.8 \%$ & $47.6 \%$ & $41.3 \%$ & $45.8 \%$ & $46.9 \%$ & $42.4 \%$ \\
\hline \% Civic, Educational \& Religious & $11.4 \%$ & $7.9 \%$ & $9.5 \%$ & $9.1 \%$ & $8.7 \%$ & $7.5 \%$ & $7.5 \%$ & $7.2 \%$ & $8.0 \%$ & $9.1 \%$ & $7.6 \%$ & $9.0 \%$ & $9.3 \%$ & $10.6 \%$ & $11.4 \%$ & $7.4 \%$ \\
\hline$\%$ Social \& Recreational & $24.2 \%$ & $24.9 \%$ & $23.9 \%$ & $27.2 \%$ & $25.0 \%$ & $27.3 \%$ & $24.2 \%$ & $26.2 \%$ & $25.8 \%$ & $22.3 \%$ & $22.9 \%$ & $24.5 \%$ & $25.8 \%$ & $24.0 \%$ & $22.7 \%$ & $28.9 \%$ \\
\hline$\%$ Other & $0.2 \%$ & $0.5 \%$ & $0.2 \%$ & $0.0 \%$ & $0.0 \%$ & $0.0 \%$ & $0.2 \%$ & $0.0 \%$ & $0.0 \%$ & $0.3 \%$ & $0.3 \%$ & $0.2 \%$ & $0.3 \%$ & $0.0 \%$ & $0.0 \%$ & $0.0 \%$ \\
\hline TOTAL & 4.38 & 4.33 & 4.45 & 4.30 & 4.24 & 4.13 & 4.24 & 4.17 & 4.25 & 3.73 & 3.94 & 4.12 & 3.86 & 3.58 & 3.53 & 3.78 \\
\hline Weekday & 4.29 & 4.40 & 4.54 & 4.19 & 4.37 & 3.91 & 4.00 & 4.20 & 4.03 & 3.62 & 3.77 & 3.79 & 3.88 & 3.45 & 3.35 & 3.83 \\
\hline Weekend & 4.63 & 4.21 & 4.24 & 4.62 & 3.95 & 4.70 & 4.86 & 4.12 & 4.85 & 4.03 & 4.39 & 5.00 & 3.83 & 3.94 & 4.01 & 3.69 \\
\hline TOTAL & 4.38 & 4.33 & 4.45 & 4.30 & 4.24 & 4.13 & 4.24 & 4.17 & 4.25 & 3.73 & 3.94 & 4.12 & 3.86 & 3.58 & 3.53 & 3.78 \\
\hline$\% 1-9 \min$ & $41.6 \%$ & $43.0 \%$ & $45.8 \%$ & $42.8 \%$ & $44.1 \%$ & $38.7 \%$ & $42.0 \%$ & $43.2 \%$ & $39.3 \%$ & $40.8 \%$ & $36.0 \%$ & $40.5 \%$ & $38.1 \%$ & $32.7 \%$ & $32.9 \%$ & $31.5 \%$ \\
\hline$\% 10-19 \min$ & $34.9 \%$ & $32.6 \%$ & $29.0 \%$ & $33.5 \%$ & $32.8 \%$ & $33.9 \%$ & $31.8 \%$ & $32.6 \%$ & $33.6 \%$ & $29.8 \%$ & $32.7 \%$ & $30.3 \%$ & $30.6 \%$ & $26.0 \%$ & $25.5 \%$ & $28.0 \%$ \\
\hline$\% 20-29 \mathrm{~min}$ & $12.1 \%$ & $13.2 \%$ & $10.8 \%$ & $12.3 \%$ & $11.1 \%$ & $12.8 \%$ & $15.1 \%$ & $13.9 \%$ & $14.8 \%$ & $11.8 \%$ & $13.5 \%$ & $12.1 \%$ & $12.7 \%$ & $13.1 \%$ & $12.7 \%$ & $14.6 \%$ \\
\hline$\%$ 30-39 min & $4.8 \%$ & $5.1 \%$ & $5.8 \%$ & $4.9 \%$ & $3.8 \%$ & $7.0 \%$ & $5.7 \%$ & $5.3 \%$ & $5.2 \%$ & $7.0 \%$ & $6.3 \%$ & $6.3 \%$ & $6.5 \%$ & $9.5 \%$ & $8.8 \%$ & $11.6 \%$ \\
\hline$\% 40-49 \mathrm{~min}$ & $1.8 \%$ & $1.6 \%$ & $3.8 \%$ & $2.1 \%$ & $2.4 \%$ & $2.9 \%$ & $1.9 \%$ & $1.9 \%$ & $1.6 \%$ & $3.8 \%$ & $4.3 \%$ & $3.4 \%$ & $3.9 \%$ & $6.7 \%$ & $7.1 \%$ & $5.0 \%$ \\
\hline$\% 50+\min$ & $3.9 \%$ & $3.9 \%$ & $3.6 \%$ & $3.5 \%$ & $4.5 \%$ & $3.1 \%$ & $2.8 \%$ & $2.2 \%$ & $3.3 \%$ & $5.9 \%$ & $5.3 \%$ & $6.1 \%$ & $7.0 \%$ & $9.2 \%$ & $9.9 \%$ & $6.1 \%$ \\
\hline$\%$ Unreported & $0.9 \%$ & $0.7 \%$ & $1.1 \%$ & $0.9 \%$ & $1.4 \%$ & $1.5 \%$ & $0.7 \%$ & $1.0 \%$ & $2.1 \%$ & $1.1 \%$ & $1.8 \%$ & $1.2 \%$ & $1.3 \%$ & $2.8 \%$ & $3.1 \%$ & $3.2 \%$ \\
\hline TOTAL & 4.38 & 4.33 & 4.45 & 4.30 & 4.24 & 4.13 & 4.24 & 4.17 & 4.25 & 3.73 & 3.94 & 4.12 & 3.86 & 3.58 & 3.53 & 3.78 \\
\hline$\% 5$ or less miles & $67.4 \%$ & $63.7 \%$ & $63.4 \%$ & $63.7 \%$ & $63.4 \%$ & $62.0 \%$ & $61.8 \%$ & $67.4 \%$ & $59.8 \%$ & $60.6 \%$ & $57.6 \%$ & $65.0 \%$ & $58.8 \%$ & $72.1 \%$ & $69.4 \%$ & $81.2 \%$ \\
\hline$\%$ 6-10 miles & $16.2 \%$ & $17.3 \%$ & $16.2 \%$ & $17.7 \%$ & $17.2 \%$ & $18.2 \%$ & $18.2 \%$ & $16.3 \%$ & $19.5 \%$ & $15.3 \%$ & $19.0 \%$ & $13.6 \%$ & $15.8 \%$ & $8.7 \%$ & $9.3 \%$ & $6.1 \%$ \\
\hline$\% 11-15$ miles & $7.1 \%$ & $7.4 \%$ & $6.3 \%$ & $7.4 \%$ & $7.1 \%$ & $7.5 \%$ & $8.3 \%$ & $7.0 \%$ & $8.7 \%$ & $7.0 \%$ & $7.6 \%$ & $6.3 \%$ & $7.3 \%$ & $5.0 \%$ & $5.7 \%$ & $2.4 \%$ \\
\hline$\% 16-20$ miles & $3.0 \%$ & $3.5 \%$ & $4.5 \%$ & $2.8 \%$ & $3.5 \%$ & $4.1 \%$ & $4.7 \%$ & $3.4 \%$ & $3.5 \%$ & $4.3 \%$ & $3.8 \%$ & $3.4 \%$ & $4.1 \%$ & $2.2 \%$ & $2.8 \%$ & $0.8 \%$ \\
\hline$\% 21-30$ miles & $1.6 \%$ & $2.5 \%$ & $3.6 \%$ & $3.5 \%$ & $3.3 \%$ & $3.9 \%$ & $2.8 \%$ & $2.6 \%$ & $2.6 \%$ & $4.3 \%$ & $3.8 \%$ & $4.1 \%$ & $4.1 \%$ & $2.5 \%$ & $2.5 \%$ & $2.1 \%$ \\
\hline$\% 31$ or more miles & $3.4 \%$ & $4.6 \%$ & $4.9 \%$ & $3.5 \%$ & $4.5 \%$ & $2.9 \%$ & $3.1 \%$ & $1.9 \%$ & $3.5 \%$ & $6.7 \%$ & $6.6 \%$ & $4.9 \%$ & $5.4 \%$ & $2.2 \%$ & $2.3 \%$ & $2.4 \%$ \\
\hline$\%$ Unreported & $1.4 \%$ & $0.9 \%$ & $1.1 \%$ & $1.4 \%$ & $0.9 \%$ & $1.5 \%$ & $1.2 \%$ & $1.4 \%$ & $2.4 \%$ & $1.9 \%$ & $1.5 \%$ & $2.7 \%$ & $4.4 \%$ & $7.3 \%$ & $7.9 \%$ & $5.0 \%$ \\
\hline
\end{tabular}




\begin{tabular}{|c|c|c|c|c|c|c|c|c|c|c|c|c|c|c|c|c|}
\hline & \multirow{3}{*}{\begin{tabular}{c|} 
Not in MSA \\
Ithaca \\
\end{tabular}} & \multicolumn{2}{|c|}{$<250,000$} & \multirow{3}{*}{\multicolumn{2}{|c|}{$\begin{array}{|cc|}250,000 \text { to } & 499,999 \\
& \\
\begin{array}{c}\text { Bingham- } \\
\text { ton }\end{array} & \text { Utica- } \\
\end{array}$}} & \multirow{3}{*}{\multicolumn{2}{|c|}{$\begin{array}{l}500,000 \text { to } 999,999 \\
\text { Albany Syracuse } \\
\end{array}$}} & \multirow{3}{*}{\multicolumn{2}{|c|}{$\begin{array}{c}1 \text { to } 2.9 \text { million } \\
\text { Buffalo Rochester }\end{array}$}} & \multirow[b]{3}{*}{ Newburgh } & \multicolumn{6}{|c|}{$3+$ million } \\
\hline & & \multirow[b]{2}{*}{ Elmira } & \multirow[b]{2}{*}{$\begin{array}{c}\text { Glens } \\
\text { Falls }\end{array}$} & & & & & & & & & & & NY Metro & & \\
\hline & & & & & & & & & & & $\begin{array}{l}\text { Pough- } \\
\text { keepsie }\end{array}$ & $\begin{array}{c}\text { Nassau/ } \\
\text { Suffolk }\end{array}$ & $\begin{array}{c}\text { Putnam/ } \\
\text { Rockland// } \\
\text { Westchester }\end{array}$ & $\begin{array}{c}\text { Five } \\
\text { Counties }\end{array}$ & $\begin{array}{l}\text { Sub of } 5 \mathrm{Cc} \\
4 \text { Counties }\end{array}$ & $\begin{array}{l}\text { Sounties } \\
\text { Manhattan }\end{array}$ \\
\hline \multicolumn{17}{|l|}{ Daily PMT per Person } \\
\hline TOTAL & 35.19 & 35.54 & 39.93 & 35.95 & 36.19 & 34.21 & 30.44 & 29.16 & 33.49 & 45.54 & 38.93 & 31.95 & 36.50 & 21.11 & 18.80 & 30.84 \\
\hline$\%$ sov & $37.3 \%$ & $38.7 \%$ & $42.0 \%$ & $36.7 \%$ & $43.9 \%$ & $40.7 \%$ & $40.8 \%$ & $41.8 \%$ & $41.5 \%$ & $40.1 \%$ & $40.2 \%$ & $37.5 \%$ & $40.1 \%$ & $16.5 \%$ & $19.9 \%$ & $7.8 \%$ \\
\hline$\%$ MOV & $52.0 \%$ & $57.6 \%$ & $50.6 \%$ & $57.3 \%$ & $47.8 \%$ & $48.5 \%$ & $52.1 \%$ & $48.6 \%$ & $47.3 \%$ & $50.7 \%$ & $47.5 \%$ & $47.9 \%$ & $42.5 \%$ & $28.2 \%$ & $30.3 \%$ & $23.1 \%$ \\
\hline$\%$ Amtrak & & & $0.0 \%$ & & $2.1 \%$ & $0.5 \%$ & & & & & $0.7 \%$ & $0.6 \%$ & $1.1 \%$ & $1.0 \%$ & $0.8 \%$ & $1.5 \%$ \\
\hline$\%$ Commuter Train & & & $0.0 \%$ & & & $0.0 \%$ & & & & $0.5 \%$ & $1.8 \%$ & $3.6 \%$ & $3.6 \%$ & $0.6 \%$ & $0.6 \%$ & $0.6 \%$ \\
\hline$\%$ Subway/El Rail & $0.1 \%$ & $0.8 \%$ & & & & $0.0 \%$ & & $0.3 \%$ & $0.0 \%$ & $1.1 \%$ & $0.1 \%$ & $0.8 \%$ & $1.1 \%$ & $14.2 \%$ & $15.8 \%$ & $10.2 \%$ \\
\hline$\%$ Other Public & $0.5 \%$ & $0.1 \%$ & $0.1 \%$ & $0.8 \%$ & $0.2 \%$ & $0.6 \%$ & $0.8 \%$ & $0.1 \%$ & $1.0 \%$ & $0.4 \%$ & $0.1 \%$ & $0.5 \%$ & $0.7 \%$ & $5.4 \%$ & $6.0 \%$ & $4.0 \%$ \\
\hline$\%$ Walk & $1.4 \%$ & $0.7 \%$ & $0.6 \%$ & $0.9 \%$ & $0.6 \%$ & $0.8 \%$ & $0.8 \%$ & $1.1 \%$ & $0.6 \%$ & $0.5 \%$ & $0.7 \%$ & $1.1 \%$ & $1.0 \%$ & $3.9 \%$ & $3.7 \%$ & $4.4 \%$ \\
\hline$\%$ Other & $8.6 \%$ & $2.2 \%$ & $6.4 \%$ & $4.3 \%$ & $5.5 \%$ & $8.8 \%$ & $5.4 \%$ & $8.2 \%$ & $9.5 \%$ & $6.7 \%$ & $9.1 \%$ & $7.7 \%$ & $7.2 \%$ & $29.1 \%$ & $22.8 \%$ & $45.4 \%$ \\
\hline$\%$ Unreported & & $0.0 \%$ & $0.3 \%$ & & & & $0.0 \%$ & $0.1 \%$ & & & & $0.4 \%$ & $2.8 \%$ & $0.9 \%$ & $0.1 \%$ & $3.1 \%$ \\
\hline TOTAL & 35.19 & 35.54 & 39.93 & 35.95 & 36.19 & 34.21 & 30.44 & 29.16 & 33.49 & 45.54 & 38.93 & 31.95 & 36.50 & 21.11 & 18.80 & 30.84 \\
\hline$\%$ Earn a Living & $23.0 \%$ & $21.3 \%$ & $25.3 \%$ & $19.6 \%$ & $30.9 \%$ & $27.7 \%$ & $25.3 \%$ & $23.5 \%$ & $21.3 \%$ & $29.0 \%$ & $29.9 \%$ & $30.7 \%$ & $30.3 \%$ & $34.2 \%$ & $41.2 \%$ & $16.0 \%$ \\
\hline$\%$ Family \& F & $39.2 \%$ & $36.6 \%$ & $35.5 \%$ & $47.1 \%$ & $35.8 \%$ & $31.5 \%$ & $30.0 \%$ & $34.8 \%$ & $32.1 \%$ & $30.1 \%$ & $29.5 \%$ & $28.1 \%$ & $30.2 \%$ & $23.6 \%$ & $26.9 \%$ & $15.1 \%$ \\
\hline$\%$ Civic, Educational \& Religious & $8.0 \%$ & $5.8 \%$ & $5.5 \%$ & $5.6 \%$ & $5.7 \%$ & $6.0 \%$ & $4.9 \%$ & $5.7 \%$ & $8.0 \%$ & $4.8 \%$ & $6.8 \%$ & $3.9 \%$ & $4.4 \%$ & $5.3 \%$ & $6.4 \%$ & $2.4 \%$ \\
\hline \% Social \& Recreational & $26.2 \%$ & $35.5 \%$ & $31.7 \%$ & $27.4 \%$ & $26.7 \%$ & $30.8 \%$ & $39.0 \%$ & $32.3 \%$ & $34.9 \%$ & $30.0 \%$ & $32.8 \%$ & $35.6 \%$ & $30.4 \%$ & $24.3 \%$ & $21.5 \%$ & $31.3 \%$ \\
\hline \multirow{2}{*}{$\begin{array}{l}\% \text { Other } \\
\% \text { Unreported }\end{array}$} & $3.5 \%$ & $0.5 \%$ & $1.2 \%$ & $0.3 \%$ & $0.8 \%$ & $2.2 \%$ & $0.5 \%$ & $3.7 \%$ & $2.8 \%$ & $3.7 \%$ & $1.0 \%$ & $1.6 \%$ & $4.6 \%$ & $9.1 \%$ & $3.7 \%$ & $22.9 \%$ \\
\hline & $0.1 \%$ & $0.3 \%$ & $0.8 \%$ & $0.1 \%$ & $0.2 \%$ & $1.8 \%$ & $0.3 \%$ & $0.0 \%$ & $0.9 \%$ & $2.4 \%$ & $0.1 \%$ & $0.1 \%$ & $0.2 \%$ & $3.6 \%$ & $0.2 \%$ & $12.4 \%$ \\
\hline Average Person $T$ & 942 & 839 & 1004 & 8.67 & 8.65 & 925 & 8.48 & 8.47 & 891 & 1182 & 1068 & ?? & 1004 & 770 & 664 & 1193 \\
\hline
\end{tabular}




\begin{tabular}{|c|c|c|c|c|c|c|c|c|c|c|c|c|c|c|c|c|}
\hline & \multirow{3}{*}{$\begin{array}{c}\text { Not in MSA } \\
\text { Ithaca }\end{array}$} & \multicolumn{2}{|c|}{$<250,000$} & \multicolumn{2}{|c|}{\begin{tabular}{|l|}
250,000 to 499,999 \\
\end{tabular}} & \multirow{3}{*}{\multicolumn{2}{|c|}{$\begin{array}{l}500,000 \text { to } 999,999 \\
\text { Albany Syracuse }\end{array}$}} & \multirow{3}{*}{\multicolumn{2}{|c|}{$\begin{array}{c}1 \text { to } 2.9 \text { million } \\
\text { Buffalo Rochester }\end{array}$}} & \multirow[b]{3}{*}{ Newburgh } & \multicolumn{6}{|c|}{$3+$ million } \\
\hline & & \multirow[b]{2}{*}{ Elmira } & \multirow[b]{2}{*}{$\begin{array}{l}\text { Glens } \\
\text { Falls }\end{array}$} & \multirow[b]{2}{*}{$\begin{array}{c}\text { Bingham- } \\
\text { ton }\end{array}$} & \multirow[b]{2}{*}{$\begin{array}{l}\text { Utica- } \\
\text { Rome }\end{array}$} & & & & & & \multirow[b]{2}{*}{$\begin{array}{l}\text { Pough- } \\
\text { keepsie }\end{array}$} & \multicolumn{5}{|c|}{ NY Metro } \\
\hline & & & & & & & & & & & & $\begin{array}{l}\text { Nassau/ } \\
\text { Suffolk }\end{array}$ & $\begin{array}{c}\text { Putnam/ } \\
\text { Rockland/ } \\
\text { Westchester }\end{array}$ & $\begin{array}{c}\text { Five } \\
\text { Counties }\end{array}$ & $\begin{array}{r}\text { Sub of } 50 \\
4 \text { Counties }\end{array}$ & $\begin{array}{l}\text { Jounties } \\
\text { Manhattan }\end{array}$ \\
\hline \multicolumn{17}{|l|}{ Daily PMT per Person } \\
\hline $\begin{array}{l}\text { TOTAL } \\
\% \text { SOV }\end{array}$ & $\begin{array}{l}31.22 \\
46.5 \%\end{array}$ & $\begin{array}{l}39.67 \\
37.2 \%\end{array}$ & $\begin{array}{l}36.39 \\
38.9 \%\end{array}$ & $\begin{array}{l}34.43 \\
38.5 \%\end{array}$ & $\begin{array}{l}35.27 \\
41.8 \%\end{array}$ & $\begin{array}{l}33.84 \\
41.1 \%\end{array}$ & $\begin{array}{l}36.37 \\
35.4 \%\end{array}$ & $\begin{array}{l}28.54 \\
44.4 \%\end{array}$ & $\begin{array}{l}37.62 \\
34.3 \%\end{array}$ & $\begin{array}{l}\mathbf{3 4 . 4 3} \\
51.1 \%\end{array}$ & $\begin{array}{l}40.35 \\
49.9 \%\end{array}$ & $\begin{array}{l}\mathbf{3 3 . 4 7} \\
39.2 \%\end{array}$ & $\begin{array}{l}35.82 \\
36.6 \%\end{array}$ & $\begin{array}{l}19.08 \\
20.5 \%\end{array}$ & $\begin{array}{l}19.33 \\
21.9 \%\end{array}$ & $\begin{array}{l}\mathbf{1 8 . 1 3} \\
15.0 \%\end{array}$ \\
\hline$\%$ MOV & $46.2 \%$ & $58.2 \%$ & $50.9 \%$ & $57.6 \%$ & $54.1 \%$ & $48.3 \%$ & $57.9 \%$ & $50.7 \%$ & $57.0 \%$ & $40.6 \%$ & $42.9 \%$ & $48.6 \%$ & $50.6 \%$ & $38.9 \%$ & $41.2 \%$ & $29.8 \%$ \\
\hline$\%$ Other POV & $0.2 \%$ & $0.0 \%$ & $0.0 \%$ & & $0.1 \%$ & $0.0 \%$ & & $0.1 \%$ & $0.0 \%$ & & $0.0 \%$ & $0.1 \%$ & $0.1 \%$ & $0.3 \%$ & $0.3 \%$ & \\
\hline$\%$ Amtrak & & & & & $0.0 \%$ & & & & & $0.9 \%$ & $0.8 \%$ & $1.2 \%$ & & $0.3 \%$ & $0.2 \%$ & $0.4 \%$ \\
\hline$\%$ Commuter Train & & & & & & & & $0.0 \%$ & & $1.5 \%$ & $1.4 \%$ & $4.4 \%$ & $4.5 \%$ & $5.0 \%$ & $4.4 \%$ & $7.3 \%$ \\
\hline$\%$ Subway/EI Rail & $0.0 \%$ & & & & & $0.1 \%$ & & $0.2 \%$ & & $0.1 \%$ & $0.3 \%$ & $0.9 \%$ & $0.4 \%$ & $14.8 \%$ & $15.0 \%$ & $14.2 \%$ \\
\hline$\%$ Other Public & $1.2 \%$ & $2.6 \%$ & $2.8 \%$ & $1.1 \%$ & $0.2 \%$ & $2.7 \%$ & $2.0 \%$ & $1.5 \%$ & $2.4 \%$ & $1.5 \%$ & $0.5 \%$ & $1.9 \%$ & $3.4 \%$ & $9.2 \%$ & $9.5 \%$ & $7.9 \%$ \\
\hline \% Walk & $0.9 \%$ & $0.3 \%$ & $0.3 \%$ & $0.3 \%$ & $0.4 \%$ & $0.3 \%$ & $0.3 \%$ & $0.4 \%$ & $0.3 \%$ & $0.3 \%$ & $0.2 \%$ & $0.3 \%$ & $0.4 \%$ & $3.5 \%$ & $3.0 \%$ & $5.7 \%$ \\
\hline$\%$ Other & $4.0 \%$ & $1.3 \%$ & $6.6 \%$ & $1.9 \%$ & $2.9 \%$ & $5.6 \%$ & $4.0 \%$ & $2.0 \%$ & $4.0 \%$ & $3.4 \%$ & $3.7 \%$ & $2.3 \%$ & $3.2 \%$ & $6.6 \%$ & $3.7 \%$ & $18.4 \%$ \\
\hline$\%$ Unreported & $0.9 \%$ & $0.5 \%$ & $0.5 \%$ & $0.6 \%$ & $0.6 \%$ & $1.9 \%$ & $0.3 \%$ & $0.7 \%$ & $2.1 \%$ & $0.6 \%$ & $0.3 \%$ & $1.1 \%$ & $0.7 \%$ & $0.8 \%$ & $0.8 \%$ & $1.2 \%$ \\
\hline TOTAL & 31.22 & 39.67 & 36.39 & 34.43 & 35.27 & 33.84 & 36.37 & 28.54 & 37.62 & 34.43 & 40.35 & 33.47 & 35.82 & 19.08 & 19.33 & 18.13 \\
\hline$\%$ Earn a Living & $26.9 \%$ & $21.3 \%$ & $29.7 \%$ & $23.3 \%$ & $26.6 \%$ & $28.7 \%$ & $28.5 \%$ & $28.2 \%$ & $20.8 \%$ & $38.0 \%$ & $33.2 \%$ & $30.4 \%$ & $32.6 \%$ & $31.2 \%$ & $31.2 \%$ & $30.9 \%$ \\
\hline \% Family \& Personal Business & $36.8 \%$ & $40.6 \%$ & $34.0 \%$ & $36.1 \%$ & $40.7 \%$ & $34.7 \%$ & $34.7 \%$ & $32.9 \%$ & $41.1 \%$ & $30.4 \%$ & $30.3 \%$ & $33.3 \%$ & $24.9 \%$ & $32.2 \%$ & $31.9 \%$ & $33.3 \%$ \\
\hline \% Civic, Educational \& Religious & $6.5 \%$ & $4.2 \%$ & $8.4 \%$ & $5.2 \%$ & $5.3 \%$ & $4.0 \%$ & $4.9 \%$ & $4.6 \%$ & $4.9 \%$ & $5.3 \%$ & $4.5 \%$ & $5.2 \%$ & $4.4 \%$ & $6.7 \%$ & $7.1 \%$ & $4.9 \%$ \\
\hline$\%$ Social \& Recreational & $29.8 \%$ & $33.0 \%$ & $26.5 \%$ & $35.3 \%$ & $25.4 \%$ & $32.4 \%$ & $31.8 \%$ & $33.9 \%$ & $32.8 \%$ & $26.1 \%$ & $31.9 \%$ & $30.8 \%$ & $38.0 \%$ & $30.0 \%$ & $29.8 \%$ & $30.9 \%$ \\
\hline$\%$ Other & $0.1 \%$ & $0.9 \%$ & $1.4 \%$ & $0.1 \%$ & $2.0 \%$ & $0.1 \%$ & $0.1 \%$ & $0.0 \%$ & $0.4 \%$ & $0.1 \%$ & $0.1 \%$ & $0.4 \%$ & $0.1 \%$ & $0.0 \%$ & $0.0 \%$ & $0.0 \%$ \\
\hline$\%$ Unreported & & & $0.0 \%$ & & & $0.1 \%$ & $0.0 \%$ & $0.3 \%$ & & & & $0.0 \%$ & $0.0 \%$ & $0.0 \%$ & & \\
\hline \multicolumn{17}{|l|}{ Average Person Trip Length } \\
\hline TOTAL & 7.24 & 9.23 & 8.28 & 8.11 & 8.41 & 8.30 & 8.67 & 6.94 & 9.08 & 9.39 & 10.41 & 8.33 & 9.70 & 5.74 & 5.95 & 5.04 \\
\hline
\end{tabular}




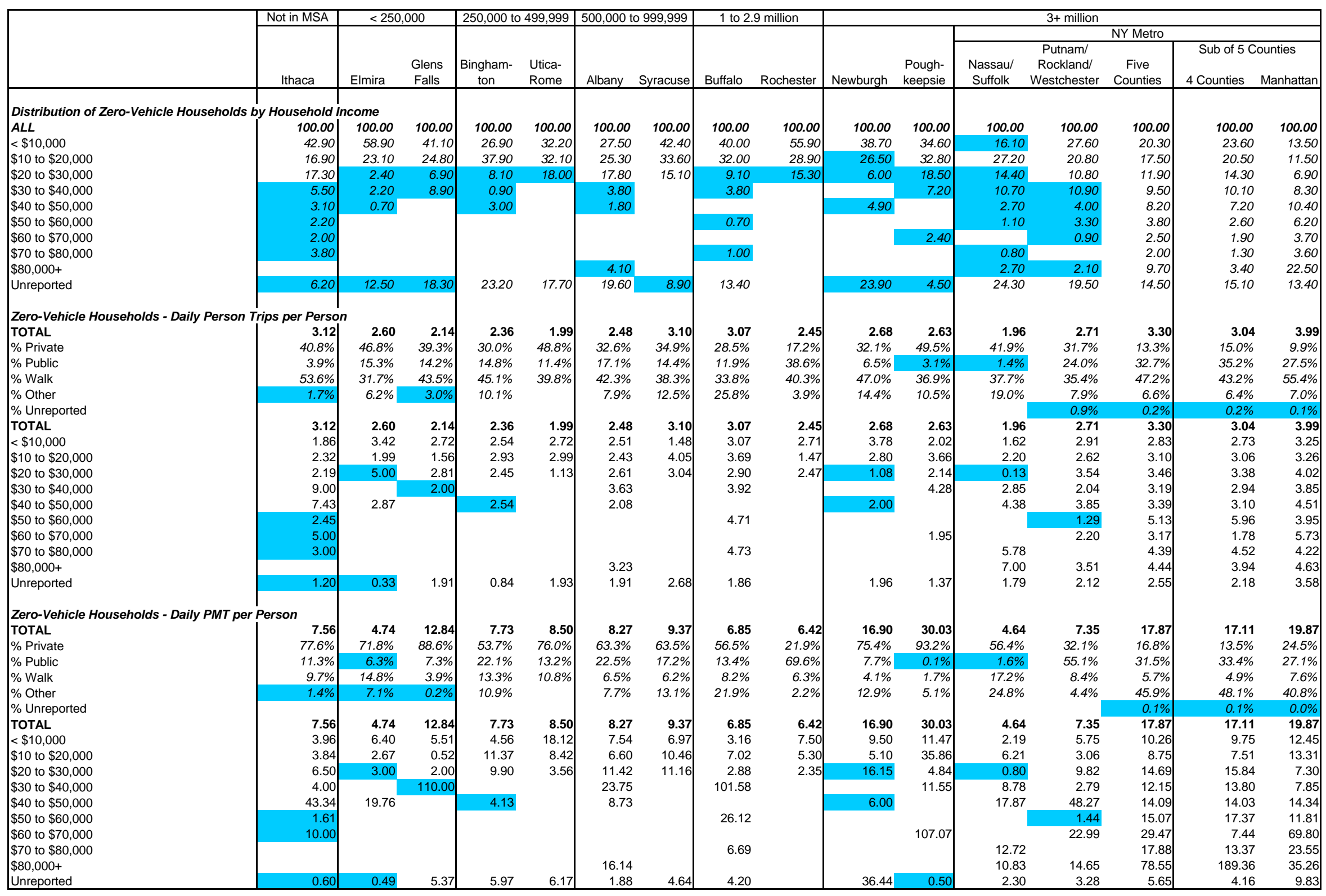




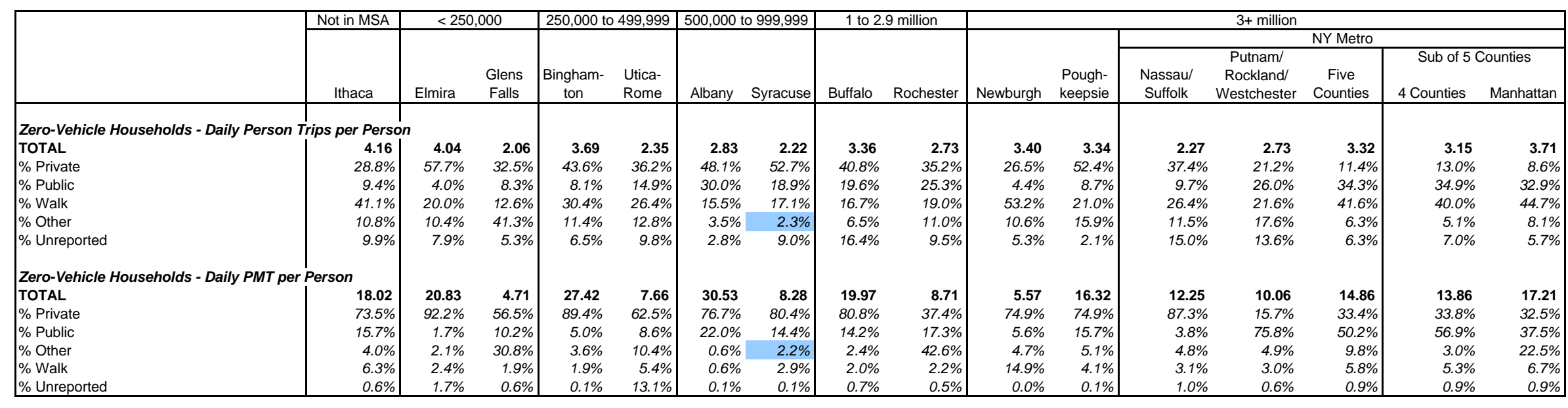




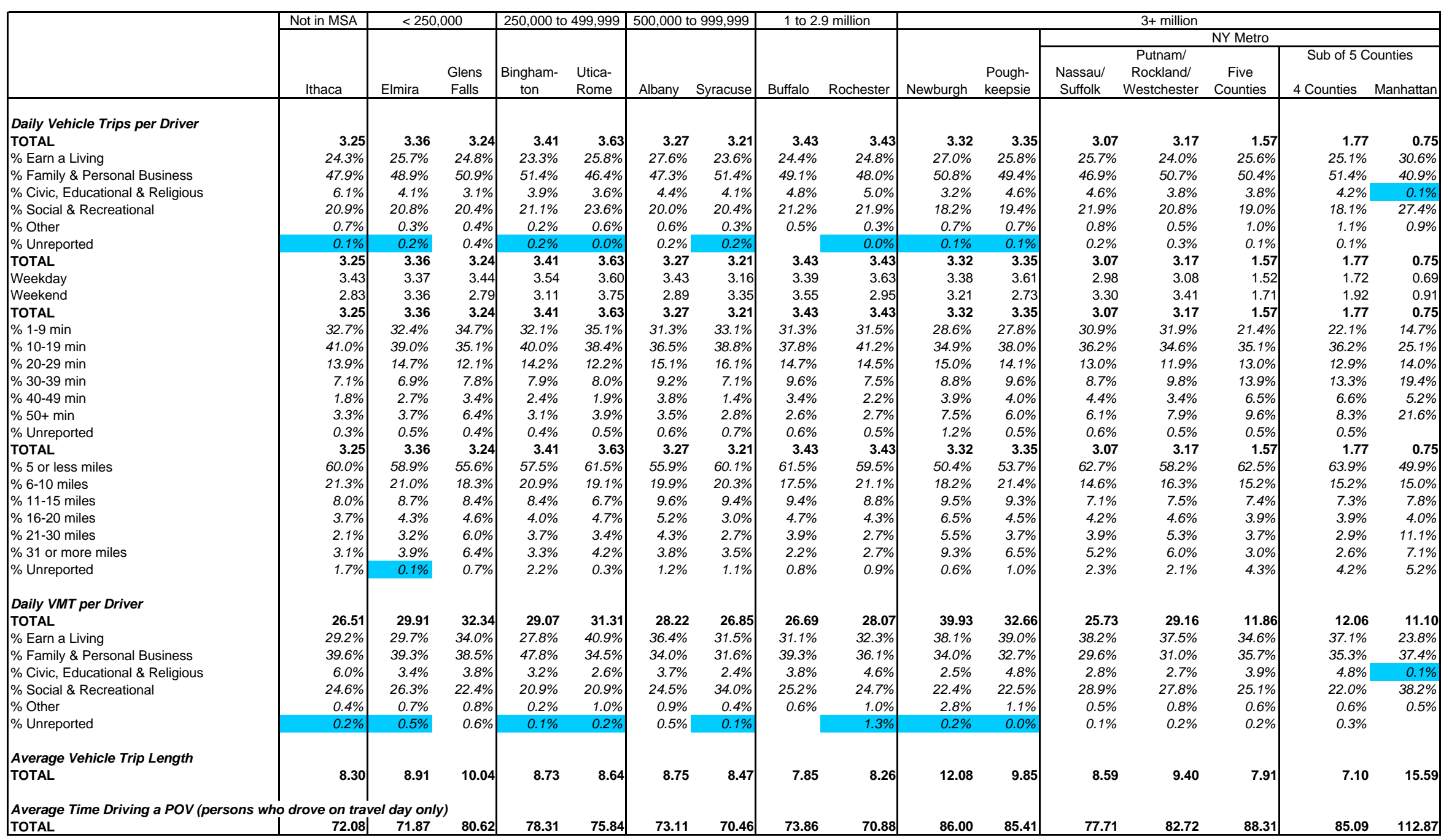




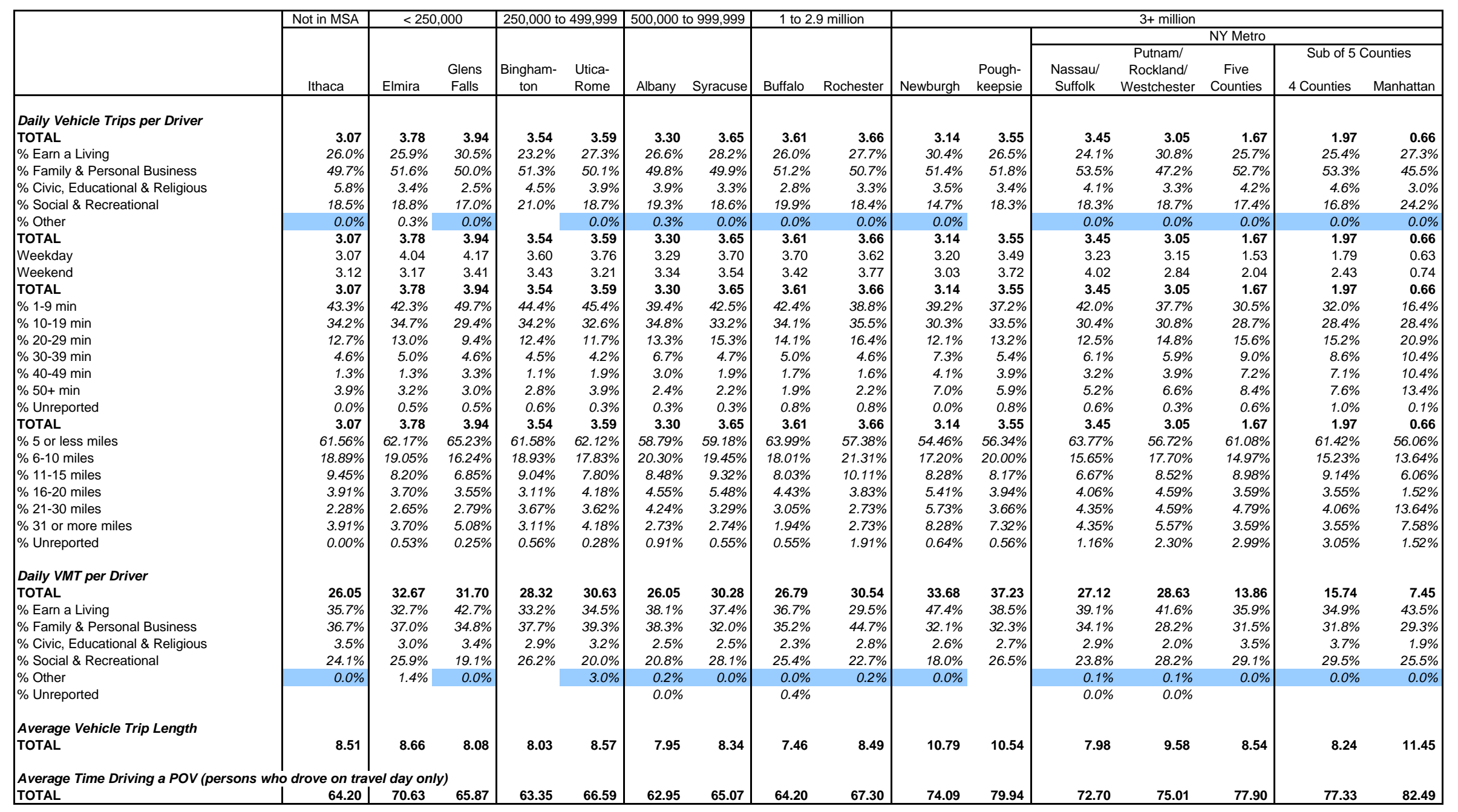




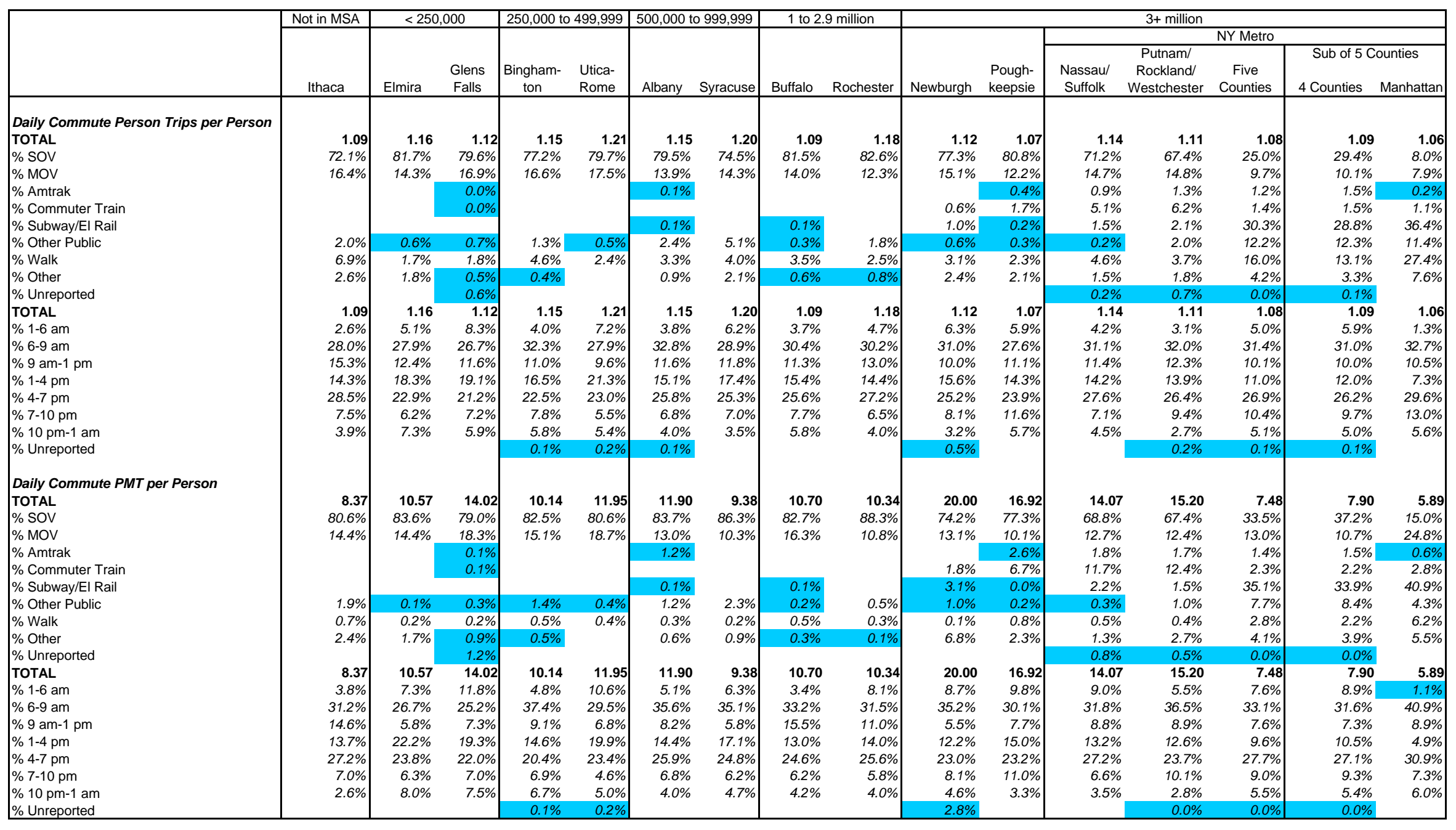




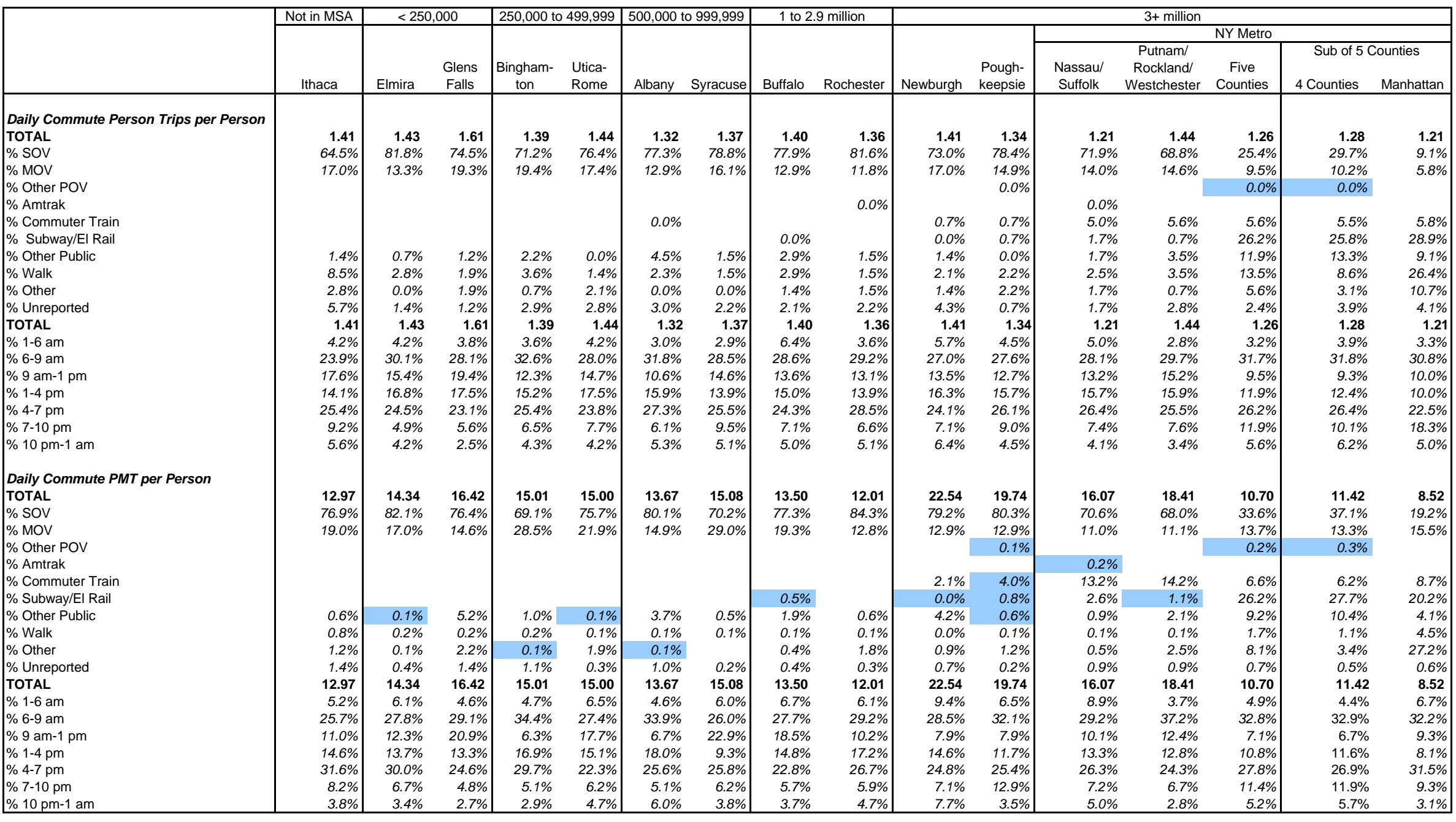




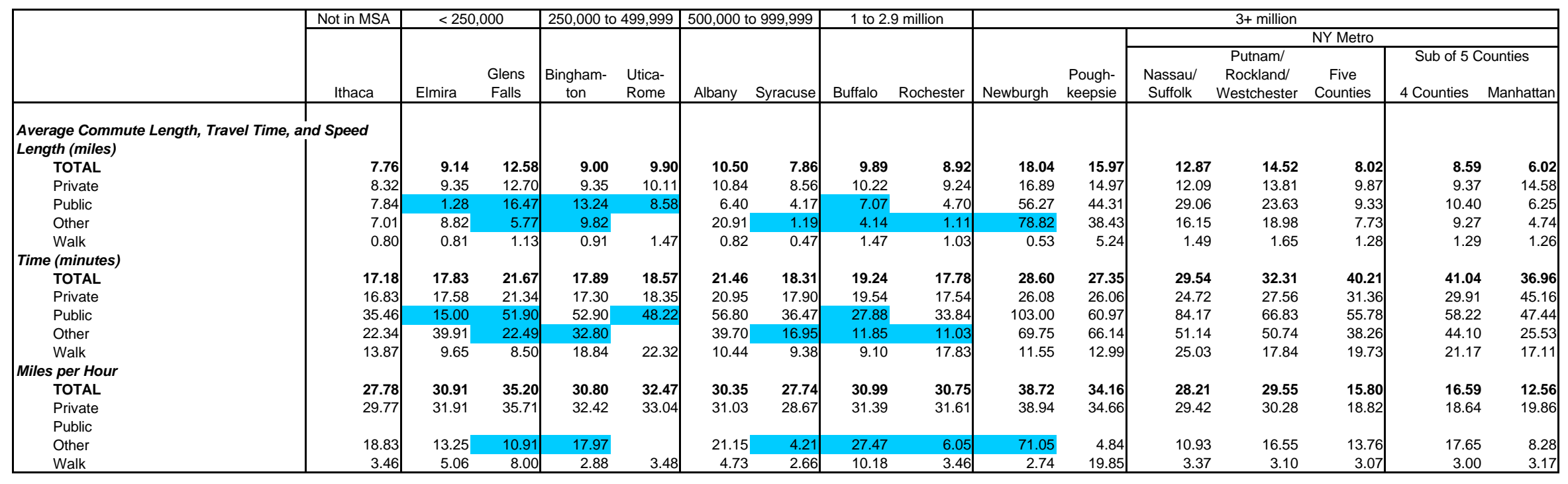




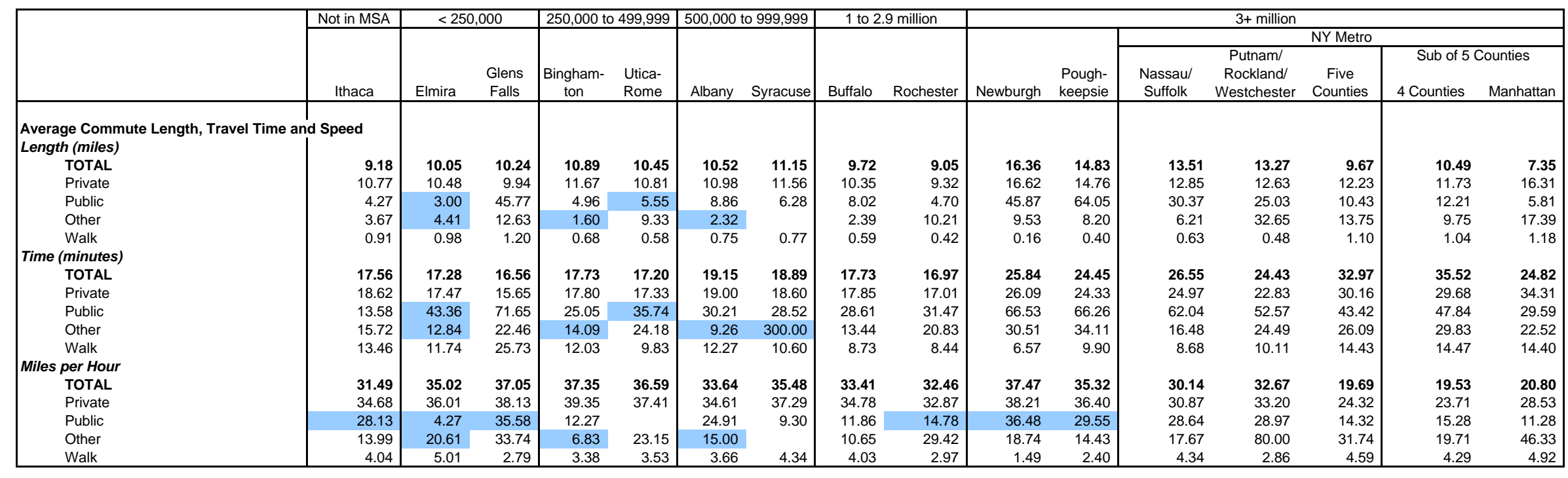




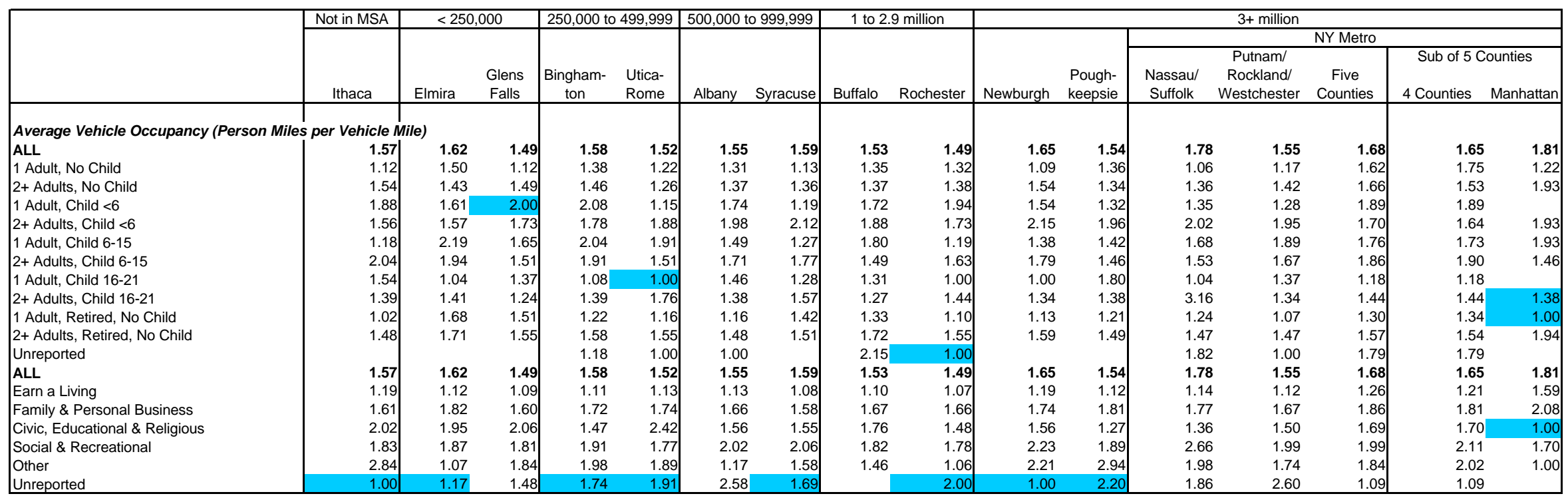




\begin{tabular}{|c|c|c|c|c|c|c|c|c|c|c|c|c|c|c|c|c|}
\hline & \multirow{3}{*}{$\begin{array}{c}\text { Not in MSA } \\
\text { Ithaca }\end{array}$} & \multicolumn{2}{|c|}{$<250,000$} & \multicolumn{2}{|c|}{250,000 to 499,999} & \multirow{2}{*}{\multicolumn{2}{|c|}{500,000 to 999,999}} & \multicolumn{2}{|c|}{1 to 2.9 million } & \multicolumn{7}{|c|}{$3+$ million } \\
\hline & & \multirow[b]{2}{*}{ Elmira } & \multirow[b]{2}{*}{$\begin{array}{l}\text { Glens } \\
\text { Falls }\end{array}$} & \multirow[b]{2}{*}{$\begin{array}{l}\text { Bingham- } \\
\text { ton }\end{array}$} & \multirow[b]{2}{*}{$\begin{array}{l}\text { Utica- } \\
\text { Rome }\end{array}$} & & & & & \multirow[b]{2}{*}{ Newburgh } & \multirow[b]{2}{*}{$\begin{array}{l}\text { Pough- } \\
\text { keepsie }\end{array}$} & \multicolumn{5}{|c|}{ NY Metro } \\
\hline & & & & & & Albany & Syracuse & Buffalo & Rochester & & & $\begin{array}{l}\text { Nassau/ } \\
\text { Suffolk }\end{array}$ & $\begin{array}{c}\text { Putnam/ } \\
\text { Rockland/ } \\
\text { Westchester }\end{array}$ & $\begin{array}{c}\text { Five } \\
\text { Counties }\end{array}$ & $\begin{array}{l}\text { Sub of } 50 \\
4 \text { Counties }\end{array}$ & $\begin{array}{l}\text { ounties } \\
\text { Manhattan }\end{array}$ \\
\hline \multicolumn{17}{|c|}{ Average Vehicle Occupancy Rate (Person Miles per Vehicle Mile) } \\
\hline ALL & 1.44 & 1.54 & 1.55 & 1.62 & 1.53 & 1.52 & 1.69 & 1.50 & 1.67 & 1.37 & 1.43 & 1.58 & 1.60 & 1.79 & 1.79 & 1.81 \\
\hline Single Adult, No Child & 1.16 & 1.16 & 1.42 & 1.23 & 1.27 & 1.22 & 1.63 & 1.08 & 1.13 & 1.06 & 1.05 & 1.39 & 1.27 & 1.19 & 1.13 & 1.32 \\
\hline 2 or $>$ Adult, No Child & 1.39 & 1.44 & 1.29 & 1.40 & 1.38 & 1.30 & 1.43 & 1.41 & 1.50 & 1.23 & 1.29 & 1.42 & 1.30 & 1.70 & 1.60 & 2.49 \\
\hline Single Adult, Child $<6$ & 1.45 & 1.69 & 2.17 & 1.17 & 1.48 & 1.35 & 2.95 & 2.14 & 1.18 & 1.53 & 1.01 & 2.01 & 2.49 & 1.91 & 3.17 & 1.36 \\
\hline 2 or $>$ Adult, Child $<6$ & 1.59 & 1.88 & 1.74 & 2.07 & 1.75 & 1.91 & 2.00 & 1.82 & 1.91 & 1.58 & 1.66 & 1.75 & 2.11 & 2.16 & 2.23 & 1.54 \\
\hline Single Adult, Child 6-15 & 1.55 & 2.09 & 1.57 & 1.94 & 1.44 & 1.61 & 1.35 & 1.57 & 1.95 & 1.57 & 1.26 & 1.30 & 1.47 & 1.80 & 1.80 & \\
\hline 2 or $>$ Adult, Child 6-15 & 1.72 & 1.49 & 1.65 & 1.77 & 1.92 & 1.67 & 1.79 & 1.74 & 1.89 & 1.39 & 1.43 & 1.88 & 1.56 & 1.96 & 1.96 & 1.85 \\
\hline Single Adult, Child $16-20$ & 1.01 & 1.00 & 1.61 & & 1.17 & 1.11 & 1.00 & 1.66 & 1.08 & 1.19 & 1.88 & 1.43 & 1.59 & 1.57 & 1.59 & 1.50 \\
\hline 2 or $>$ Adult, Child $16-20$ & 1.54 & 1.32 & 1.50 & 1.38 & 1.44 & 1.24 & 1.52 & 1.53 & 1.66 & 1.30 & 1.48 & 1.39 & 1.23 & 1.89 & 1.94 & 1.53 \\
\hline Single Adult, Retired & 1.01 & 1.43 & 1.14 & 1.02 & 1.20 & 1.10 & 1.16 & 1.10 & 1.35 & 1.08 & 1.06 & 1.17 & 1.17 & 1.37 & 1.37 & 1.50 \\
\hline 2 or $>$ Adult, Retired & 1.28 & 1.53 & 1.50 & 1.65 & 1.48 & 1.63 & 1.75 & 1.39 & 1.74 & 1.41 & 1.53 & 1.61 & 1.58 & 1.51 & 1.47 & 1.96 \\
\hline ALL & 1.44 & 1.54 & 1.55 & 1.62 & 1.53 & 1.52 & 1.69 & 1.50 & 1.67 & 1.37 & 1.43 & 1.58 & 1.60 & 1.79 & 1.79 & 1.81 \\
\hline Earn a Living & 1.10 & 1.11 & 1.13 & 1.26 & 1.12 & 1.12 & 1.15 & 1.19 & 1.08 & 1.09 & 1.08 & 1.10 & 1.12 & 1.32 & 1.23 & 1.83 \\
\hline Family \& Personal Business & 1.50 & 1.80 & 1.76 & 1.68 & 1.78 & 1.65 & 1.82 & 1.54 & 1.82 & 1.52 & 1.56 & 1.76 & 1.74 & 1.84 & 1.87 & 1.67 \\
\hline Civic, Educational \& Religious & 1.29 & 1.72 & 1.74 & 1.69 & 1.59 & 1.25 & 2.30 & 1.33 & 1.50 & 1.36 & 1.49 & 2.23 & 1.36 & 1.76 & 1.78 & 1.46 \\
\hline Social \& Recreational & 1.88 & 1.74 & 2.08 & 2.00 & 1.82 & 2.03 & 2.20 & 1.92 & 2.15 & 1.84 & 1.76 & 2.04 & 2.17 & 2.31 & 2.35 & 1.96 \\
\hline Other & 1.00 & 1.06 & 1.00 & & 1.00 & 1.26 & 2.00 & 2.00 & 2.00 & 1.27 & & 1.88 & 2.00 & 1.89 & 1.89 & \\
\hline
\end{tabular}





\section{APPENDIX D}

\section{STANDARD ERRORS FOR SELECTED TABLES AND FIGURES}


This page intentionally left blank. 
Table 2.2 Standard Errors for Personal Travel Statistics by Demographic Characteristics New York State vs. Rest of the United States (US) 1995 and 2001

\begin{tabular}{|l|c|c|c|c|}
\hline \multirow{2}{*}{ Weekday Person Trips/Person } & \multicolumn{2}{|c|}{1995} & \multicolumn{2}{c|}{2001} \\
\cline { 2 - 5 } Weekend Person Trips/Person & New York & Rest of US & New York & Rest of US \\
\hline & 0.03437 & 0.38174 & 0.03415 & 0.017299 \\
\hline
\end{tabular}

Figure 2.3 Standard Errors for Daily Person Trips by Age

New York State vs. Rest of the United States

\begin{tabular}{|l|c|c|c|c|}
\hline \multirow{2}{*}{} & \multicolumn{2}{|c|}{1995} & \multicolumn{2}{c|}{2001} \\
\cline { 2 - 5 } & New York & Rest of US & New York & Rest of US \\
\hline 5-15 years & 0.07511 & 0.04881 & 0.05884 & 0.03445 \\
16-19 years & 0.12283 & 0.08055 & 0.09776 & 0.06439 \\
20-34 years & 0.07537 & 0.05195 & 0.06801 & 0.03199 \\
35-54 years & 0.05957 & 0.03511 & 0.04634 & 0.02988 \\
55-64 years & 0.10251 & 0.06337 & 0.07286 & 0.0425 \\
65+ years & 0.08088 & 0.05943 & 0.07617 & 0.04433 \\
\hline
\end{tabular}

Table 2.6 Standard Errors for Commute Statistics New York State vs. Rest of the United States (US)

\begin{tabular}{|l|rr|rr|}
\hline & \multicolumn{2}{|c|}{1995} & \multicolumn{2}{c|}{2001} \\
& New York & Rest of US & New York & Rest of US \\
\hline Commute Trips per Worker & 0.018646 & 0.010897 & 0.015778 & 0.007026 \\
\hline
\end{tabular}


Figure 4.14 Standard Errors for Trip Length, Population Density and Vehicle Ownership New York State MPOs vs. MSAs Outside New York

\begin{tabular}{|l|c|c|c|c|}
\hline & $\begin{array}{c}\text { Without } \\
\text { Vehicles } \\
\text { - NYS }\end{array}$ & $\begin{array}{c}\text { Without } \\
\text { Vehicles - } \\
\text { Outside NYS }\end{array}$ & $\begin{array}{c}\text { With } \\
\text { Vehicles - } \\
\text { NYS }\end{array}$ & $\begin{array}{c}\text { With } \\
\text { Vehicles - } \\
\text { Outside NYS }\end{array}$ \\
\hline$<500$ & 0.8967 & 1.5774 & 0.3546 & 0.2321 \\
$500-2,000$ & 0.9703 & 0.9780 & 0.2781 & 0.1729 \\
$2,000-4,000$ & 1.4645 & 0.6600 & 0.4348 & 0.2695 \\
$4,000-10,000$ & 0.5549 & 0.6731 & 0.3706 & 0.2081 \\
$10,000-20,000$ & 0.7753 & 0.9221 & 0.8249 & 0.3741 \\
$20,000-50,000$ & 0.3737 & 0.6092 & 0.3936 & 0.5483 \\
$50,000+$ & 0.3129 & 2.1205 & 0.5684 & 8.2273 \\
\hline
\end{tabular}

Table 6.6 Standard Errors for Daily Vehicle Travel Statistics of New York State MPO Drivers by MSA Size 2001 NHTS and 1995 NPT

\begin{tabular}{|c|c|c|c|c|c|c|c|c|c|c|c|c|c|c|}
\hline & Ithaca & Elmira & $\begin{array}{l}\text { Glen } \\
\text { Falls }\end{array}$ & $\begin{array}{c}\text { Bing- } \\
\text { hamton }\end{array}$ & $\begin{array}{l}\text { Utica- } \\
\text { Rome }\end{array}$ & Albany & $\begin{array}{l}\text { Syra- } \\
\text { cuse }\end{array}$ & Buffalo & Rochester & $\begin{array}{l}\text { New- } \\
\text { burgh }\end{array}$ & $\begin{array}{l}\text { Pough- } \\
\text { keepsie }\end{array}$ & $\begin{array}{c}\text { Nassau, } \\
\text { Suffolk }\end{array}$ & $\begin{array}{c}\text { Putnam, } \\
\text { Rockland, } \\
\text { Westchester }\end{array}$ & $\begin{array}{l}\text { New } \\
\text { York } \\
\text { City }\end{array}$ \\
\hline $\begin{array}{l}\text { PMT per Person } \\
\text { (0-Veh HHs) - } 1995 \\
\text { PMT per Person } \\
(0-V e h H H s)-2001\end{array}$ & $\begin{array}{l}4.9655 \\
2.7507\end{array}$ & $\begin{array}{r}6.9628 \\
1.5706\end{array}$ & $\begin{array}{r}1.3708 \\
10.0433 \\
\end{array}$ & $\begin{array}{r}8.0423 \\
2.5321\end{array}$ & $\begin{array}{r}1.6002 \\
5.1332 \\
\end{array}$ & $\begin{array}{l}9.3523 \\
1.6097\end{array}$ & $\begin{array}{r}1.9030 \\
2.0714\end{array}$ & $\begin{array}{l}7.4268 \\
1.8735\end{array}$ & $\begin{array}{l}2.2266 \\
2.6669\end{array}$ & $\begin{array}{r}1.5528 \\
8.7078\end{array}$ & $\begin{array}{r}3.7394 \\
16.8197 \\
\end{array}$ & $\begin{array}{l}4.5521 \\
1.1420 \\
\end{array}$ & $\begin{array}{l}3.8280 \\
2.1738 \\
\end{array}$ & $\begin{array}{l}0.9976 \\
4.7921\end{array}$ \\
\hline
\end{tabular}

